\title{
exq!T
}

эчғnоs

$\not$ ไุ. 

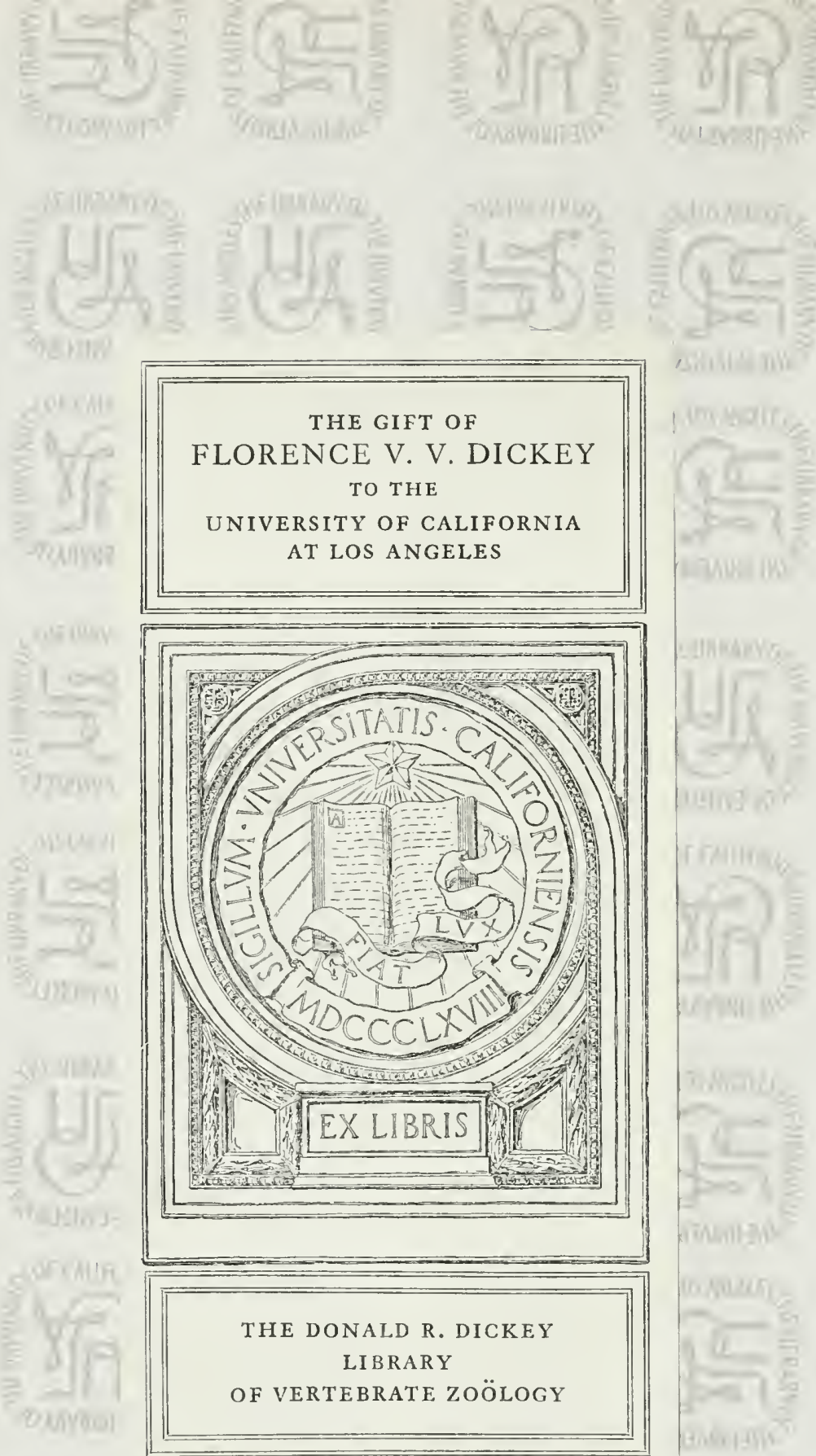

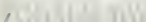
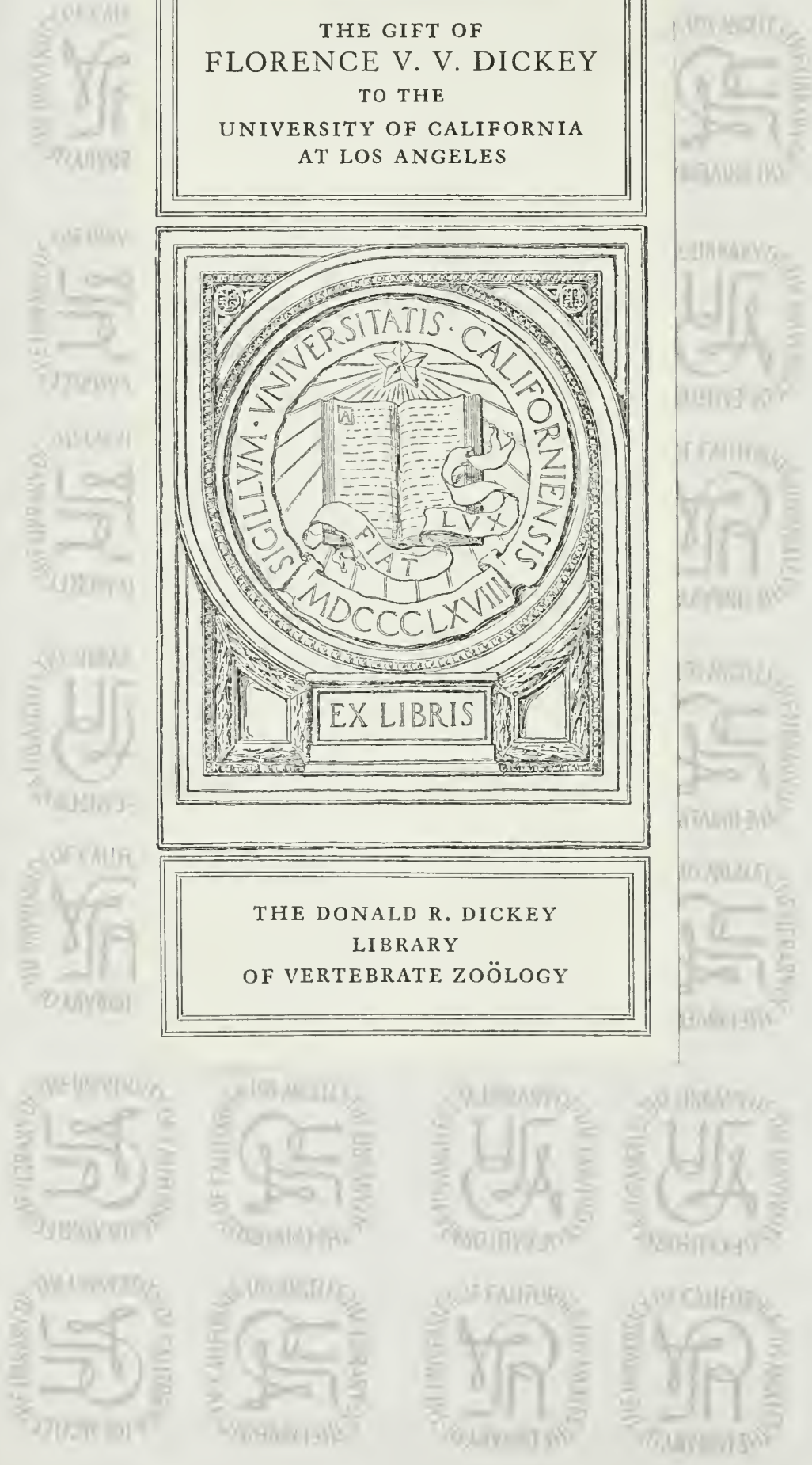


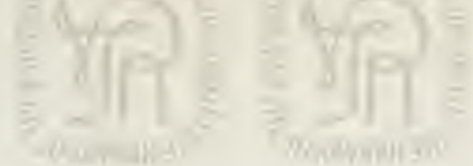

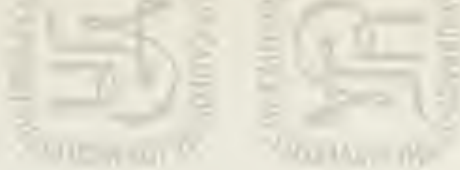
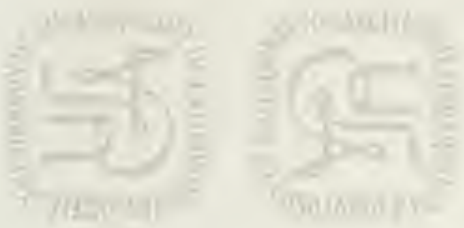

$\operatorname{cyc}(1)=0$
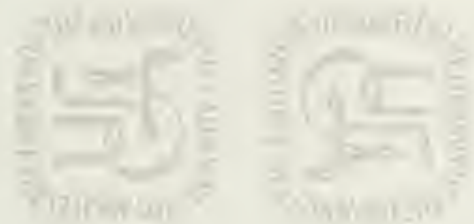

$=\sqrt{2}=$

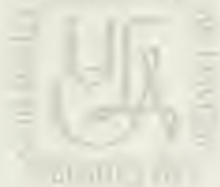

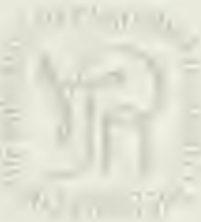

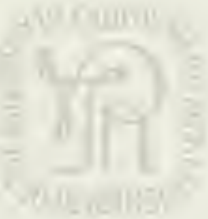

+11 11 , 1.
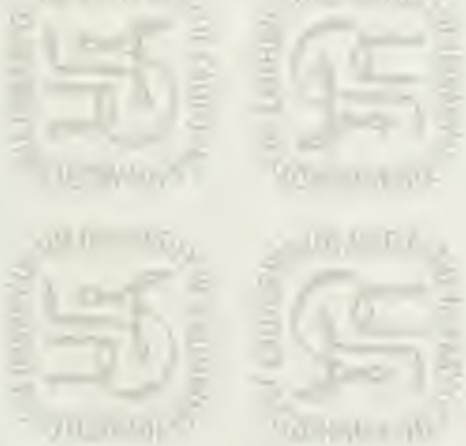

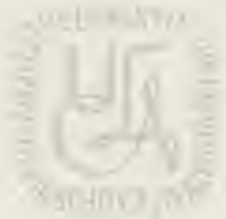

-1) Rhitur
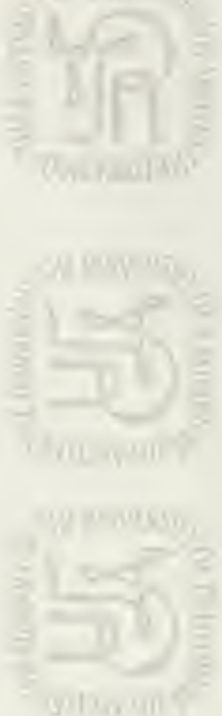

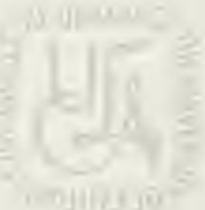

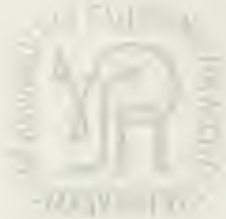

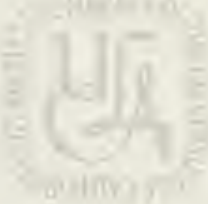
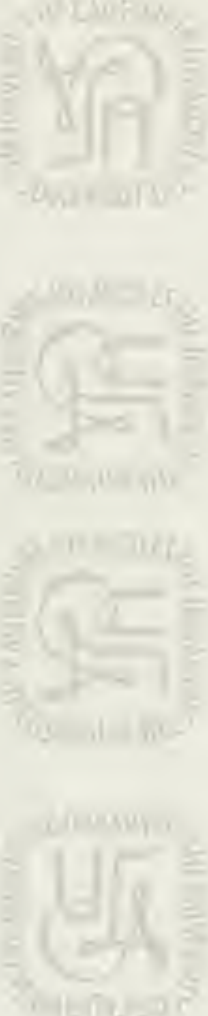

$=6$
$=0$
$=0$

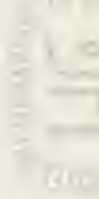

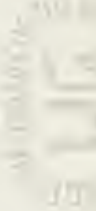

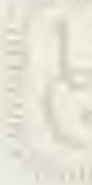

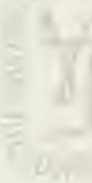
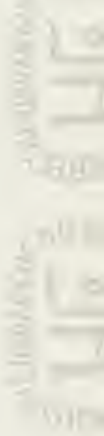

wi P Y
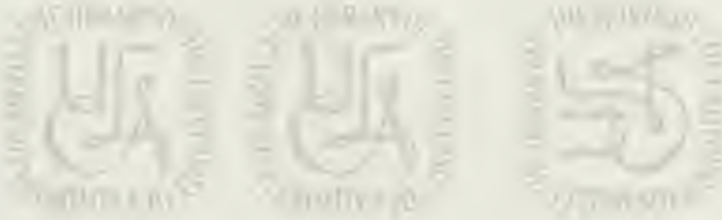

* II Ne if

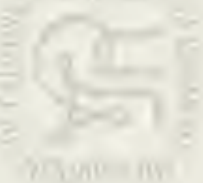

we biln

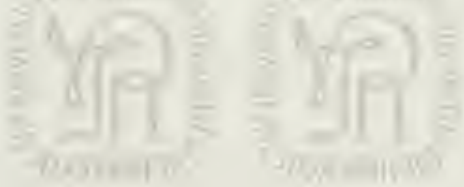

ant athones
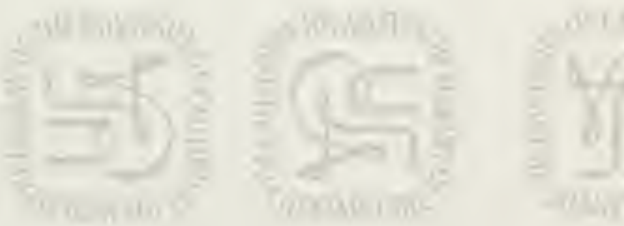




\title{
PROCEEDINGS
}

OF THE

FOURTH INTERNATIONAL CONGRESS

\author{
OF \\ ZOOLOGY
}

1898 
Il Ilonoon: C. J. CLAY AND SONS, CAMIRIDGE UNIVERSITI PRESS WAREHOUSE, AVE MARIA LANE.

ETlasgow: 263, ARGYLE STREET.

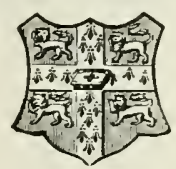

Ileipsig: F. A. BROCKHAUS. Reow gork: THE MACMILLAN COMPANY

bombat: E. SEYMOUR HALE. 


\title{
PROCEEDINGS
}

\author{
OF THE
}

\section{FOURTH INTERNATIONAL CONGRESS}

\author{
OF \\ ZOOLOGY
}

CAMBRIDGE, 22-27 AUGUST, 1898

EDITED BY

ADAM SEDGWICK, M.A., F.R.S.

ONE OF THE SECRETARIES OF THE FOURTH CONGRESS

\section{LONDON}

C. J. CLAY AND SONS

CAMBRIDGE UNIVERSITY PRESS WAREHOUSE

AVE MARIA LANE

I 899 



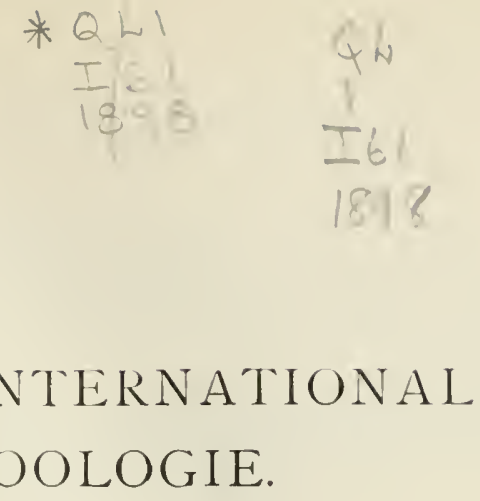

\section{COMITÉ PERMANENT}

INSTITUÉ EN I892 PAR LE CONGRÈS DE MOSCOU

LE deuxième Congrès international de zoologie, réuni à Moscou en I 892, a institué un Comité permanent, à l'exemple de ce qui avait lieu déjà pour le Congrès international d'anthropologie et d'archéologie préhistorique. Ce Comité a son siège permanent à Paris. Il est destiné à centraliser et à exécuter, dans l'intervalle des sessions du Congrès, toutes les affaires relatives au Congrès. Il comprend des Membres perpétuels et un Membre temporaire.

Sont de droit Membres perpétuels :

I $^{\circ}$. Les fondateurs du Congrès international de zoologie, MM. MilneEdwards, R. Blanchard, J. de Guerne, C. Schlumberger, L. Vaillant.

$2^{\circ}$. Les anciens présidents.

$3^{\circ}$. Le président du futur Congrès, quand il a été désigné au préalable.

$4^{\circ}$. Les présidents honoraires ayant été élus trois fois.

$5^{\circ}$. Les vice-présidents ayant été élus trois fois.

Est de droit Membre temporaire le Secrétaire général, pour toute la période qui va du Congrès pendant lequel il était en fonctions jusqu'au Congrès suivant.

Conformément à ces décisions, le Comité permanent s'est constitué en élisant un Président, un Secrétaire général et un Secrétaire. Voici quelle est sa constitution actuelle:

\section{Membres Perpétuels.}

\section{$\mathrm{I}^{\circ}$. Fondateurs du Congrès.}

Prof. A. Milne-Edwards (Paris), Président du Comité.

Prof. R. Blanchard (Paris), Sccrétaire général.

$\mathrm{B}^{\circ} \mathrm{J}$ J. de Guerne (Paris), Secrétaire.

C. Schlumberger (Paris).

Prof. 'Th. Studer (Berne), Vice-Président.

Prof. L. Vaillant (Paris), Vice-Président. 


\section{Anciens Présidents du Congrès.}

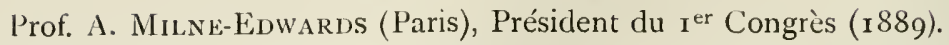

$\mathrm{C}^{\text {te }}$ Kapnist (Moscou), Président du $2^{\mathrm{e}}$ Congrès (1892), VicePrésident.

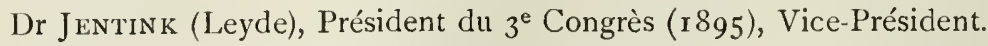

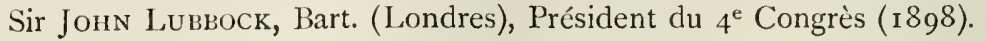

$3^{\circ}$. Président désigné du futur Congrès.

N......

$4^{\circ}$. Présidents honoraires ayant été élus trois fois.

N......

5. Vice-Présidents ayant été élus trois fois.

N......

Membre Temporaire.

Prof. F. Jeffreey Bell (Londres), Secrétaire général du $4^{e}$ Congrès.

\section{PRIX FONDÉS PAR LE CONGRÉS DE MOSCOU.}

Le deuxième Congrès international de zoologie, réuni à Moscou en 1892 , a fondé les deux prix suivants.

Prix DE S. M. L'Empereur Alexandre III.

Prix décerné par la Société Impériale des amis des sciences naturelles de Moscou, en mémoire des Congrès internationaux de 1892 et en l'honneur de S. M. l'Empereur Alexandre III.

\section{RÈGLEMENT.}

ARTICle $\mathrm{I}^{\mathrm{er}}$. Le Comité d'organisation des Congrès internationaux d'anthropologie et d'archéologie préhistorique, et de zoologie, réunis à Moscou en I 892, remet à la Société Impériale des amis des sciences naturelles la somme de 3500 roubles argent, pour constituer un capital perpétuel en souvenir de ces deux Congrès internationaux et de l'auguste bienveillance qui leur a été accordée par S. M. l'Empereur Alexandre III.

ARTiCle 2. Les intérêts de ce capital seront affectés à la création d'un prix en l'honneur de S. M. l'Empereur Alexandre III. Ce prix sera attribué alternativement au Congrès d'anthropologie et d'archéologie préhistorique et au Congrès de zoologie.

Article 3. La quotité du prix est égale au revenu du capital pendant deux ans. Au cas où il s'écoulerait plus de deux années entre deux Congrès consécutifs, les intérêts des années supplémentaires resteraient à la disposition de la Société des amis des sciences naturelles de Moscou, qui les consacrerait à des prix décernés dans sa séance annuelle du I5 octobre. 
Article 4. Si l'un des deux Congrès cesse d'exister, la part qui lui revient d'après les articles ci-dessus sera attribuée à la Société Impériale des amis des sciences naturelles, qui la consacrera également à des prix distribués dans sa séance annuelle.

ARTicle 5. Le prix attribué au Congrès d'anthropologie et d'archéologie préhistorique est décerné par une Commission spéciale nommée à cet effet par le Conseil permanent de ce Congrès. Le prix attribué au Congrès de zoologie est également décerné par une Commission spéciale nommée à cet effet par le Conseil permanent de ce Congrès.

ARTIClE 6. I.es prix peuvent consister en médailles ou en sommes d'argent.

ARTicle 7. Ils seront décernés en séance solennelle, pendant la session des Congrès.

Article 8. Le programme des prix sera élaboré par le Conseil permanent de chacun des deux Congrès.

Article 9. Ce Conseil permanent est en outre chargé de centraliser les travaux présentés, de désigner les savants ou les Commissions à l'examen desquels ils seront soumis et qui devront déposer un rapport écrit.

ARTicle ro. Tout savant est admis au concours, à la condition qu'il n'appartienne pas au pays dans lequel doit avoir lieu la prochaine session du Congrès.

Article rr. Le président du Congrès notifie immédiatement au président de la Société Impériale des amis des sciences naturelles le nom de la personne à laquelle le prix a été décerné.

\section{Prix DE S. M. L'EMPEREUR Nicolas II.}

Prix décerné par la Société Impériale des amis des sciences naturelles de Moscou en mémoire des Congrès internationaux de 1892 et en l'honneur de S. A. I. le Grand-Duc héritier Césarévitch Nicolas Alexandrovitch.

\section{RÈGLEMENT.}

ARTicle $\mathrm{I}^{\mathrm{er}}$. Le Comité d'organisation des Congrès internationaux d'anthropologie et d'archéologie préhistorique, et de zoologie, réunis à Moscou en 1892 , remet à la Société Impériale des amis des sciences naturelles la somme de 2000 roubles argent, pour constituer un capital perpétuel en souvenir du Congrès de zoologie et de l'auguste bienveillance qui lui a été accordée par S. A. I. le Grand-Duc héritier Nicolas Alexandrovitch.

ARTiCle 2. Les intérêts de ce capital seront affectés à la création d'un prix en l'honneur de S. A. I. le Grand-Duc héritier Césarévitch Nicolas Alexandrovitch. Ce prix sera attribué au Congrès de zoologie.

ARTIClE 3. La quotité du prix est égale au revenu du capital pendant deux ans. Au cas où il s'écoulerait plus de deux années entre deux Congrès consécutifs, les intérêts des années supplémentaires resteraient à la disposition de la Société des amis des sciences naturelles de Moscou, qui les consacrerait à des prix décernés dans sa séance annuelle dı I5 octobre. 
Article 4. Si le Congrès cesse d'exister, la part qui lui revient d'après les articles ci-dessus sera attribuée à la Société Impériale des amis des sciences naturelles, qui la consacrera également à des prix distribués dans sa séance annuelle.

Article 5. Le prix décerné par le Congrès de zoologie est décerné par une Commission spéciale nommée à cet effet par le Conseil permanent de ce Congrès.

ARTICLE 6. Les prix peuvent consister en médailles ou en sommes d'argent.

Article 7. Ils seront décernés en séance solennelle, pendant la session du Congrès.

Article 8. Le programme des prix sera élaboré par le Conseil permanent du Congrès.

ARTiCle 9. Ce Conseil permanent est en outre chargé de centraliser les travaux présentés, de désigner les savants ou les Commissions à l'examen desquels ils seront soumis et qui devront déposer un rapport écrit.

ARTIClE IO. Tout savant est admis au concours, à la condition qu'il n'appartienne pas au pays dans lequel doit avoir lieu la prochaine session du Congrès.

ARTicle it. Le président du Congrès notifie immédiatement au président de la Société Impériale des amis des sciences naturelles le nom de la personne à laquelle le prix a été décerné.

Conformément à ces décisions, le Comité permanent du Congrès a constitué une Commission internationale chargée d'élaborer le programme et les conditions du concours pour chacun des deux prix, et de juger ce concours. Cette Commission est composée comme suit.

COMMISSION INTERNATIONALE DES PRIX.

Prof. A. Milne-Edwards (Paris), Président.

Prof. R. Blanchard (Paris), Secrétaire.

Sir William Flower, K.C.B. (Londres).

Dr Jentink (Leyde).

Mr R. Bowdler Sharpe (Londres).

Prof. 'Th. STuder (Berne).

Prof. N. Zograf (Moscou).

\section{LISTE DES LAURÉATS DU CONGRES INTERNATIONAL DE ZOOLOGIE.}

Prix de S. M. L'Empereur Alexandre III.

1898. M. E. DE Pousargues (Paris).

Prix de S. M. L'EMpereur Nicolas II.

1895. Dr ScharfF (Dublin).

r898. Dr Fmile Hfcht (Nancy). 


\section{TABLE OF CONTENTS.}

PAGE

Permanent Committee and General Regulations of the International

Congress of Zoology . . . . . . . . . v-viii

Officers at the Cambridge Meeting . . . . . . . . I

Executive Committee . . . . . . . . . . 2

Committee of Patronage . . . . . . . . . . . 3

Delegates . . . . . . . . . . . 5

Reception Committee . . . . . . . . . 8

List of Members, Associates, and Societies which have subscribed to the

Congress . . . . . . . . . . . . 10

Regulations . . . . . . . . . . . . 29

Programme . . . . . . . . . . . . 30

Arrangements made by the Reception Committee . . . . . 34

Objects of Zoological Interest on view . . . . . . . 36

Honorary Degrees . . . . . . . . . . 39

Reception of the Congress by the Mayor of Cambridge . . . 4 I

\section{GENERAL MEETINGS OF THE CONGRESS.}

\section{TUESDAY, 23 August.}

President's Address . . . . . . . . . 43

Speech of the Vice-Chancellor . . . . . . . 47

Speeches of the Delegates . . . . . . . 47

Speech of the Chairman of the Reception Committee . . 50

Election of Vice-Presidents . . . . . . . 51

Election of Secretaries of Sections . . . . . . 52

Report on the Prizes, by Prof. R. Blanchard . . . . 52

Report on the Laws of Zoological Nomenclature, by Dr Stiles 54

Report on the transmission by post of specimens of Natural

History, by $\mathrm{Dr} \mathrm{Hoek}$. . . . . . 55 
2. WEDNESDAY, 24 August.

Letter from the German Ambassador

Telegram from University of Moscow . • . . 56

Discussion on the position of Sponges in the Animal Kingdom . $; 6$

Prof. Yves Delage . . . . . . . . 56

Mr E. A. Minchin . . . . . . . . 6I

Prof. Ernst Haeckel . . . . . . . . 64

Dr Vosmaer . . . . . . . . . . . 64

Mr Saville Kent . . . . . . . . . . 65

Prof. F. E. Schulze . . . . . . . . . 67

3. THURSDAY, 25 August.

Discussion on the Origin of Mammals.

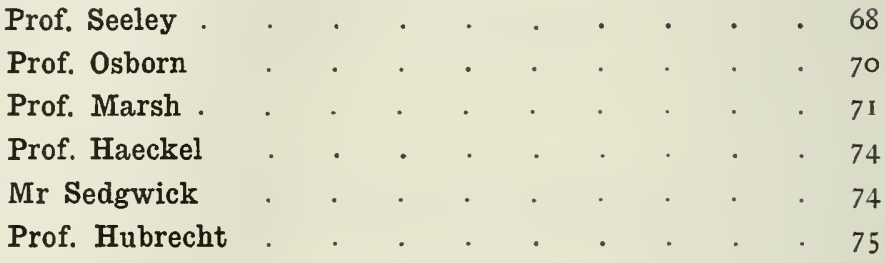

4. FRIDAY, 26 August.

Telegram from the Prince of Wales . . . . . 76

Prof. Haeckel.-Our Present Knowledge of the Descent of Man

Prof. Marey.-Du concours nécessaire de la physiologie et de l'anatomie comparée pour la connaissance de la locomotion animale . . . • . . . • • . . 77

Mr Duckworth.-Anthropoid Apes . . . . . . 78

M. E. Dubois.-The Brain-cast of Pithecanthropus erectus . 78

Prof. Macalister's remarks on a resolution as to the exploration of Trinil . . . . . . . . 95

5. SATURDAY, 27 August.

Concluding Proceedings . . . . . . . . 96

Next Meeting of the Congress . . . . . . 96

Votes of thanks . . . . . . . . . . 96

Committee of Terminology . . . . . . . 99

Concilium Bibliographicum . . . . . . . . 99 
SECTION A. GENERAL ZOOLOGY.

1. TUESDAY, 23 August.

Prof. Mitsukuri.-Zoological matters in Japan . . 101

Prof. Salensky.-Heteroblastie . . . . . . 111

Mr Stanley Gardiner.-Atolls (Plate 1) . . . . . 118

2. WEDNESDAY, 24 August.

Prof. Haeckel.-Phylogenetic Classification . . . . 124

Prof. L. v. Graff.-Geographical Distribution of Land Planarians . . . . . . . . . . . 124

Mr Bourne.-The Skeleton in Anthozoa . . . . 124

Prof. Apáthy.-Neurofibrillen und über ihre nervös leitende Natur . . . . . . . . . . . 125

3. THURSDAY, 25 August.

The Section did not meet.

4. FRIDAY, 26 August.

Prof. MacBride.-On the Origin of Echinoderms . . . 142

Sir Herbert Maxwell.--Recent Legislation on the Protection of Wild Birds in Great Britain . . . . . 148

Mr J. A. Harvie-Brown.-A Correct Colour-code . . . 155 


\section{SECTION B. VERTEBRATA.}

1. TUESDAY, 23 August.

M. Milne-Edwards.-Les Animaux éteints de Madagascar

Prof. Marsh.-The Value of Type Specimens . . . . 158

Dr Wolterstorff.-Urodelen der Alten Welt . . . . I6z

Dr van Bemmelen.-Reptilian affinities in the temporal region of the Monotreme-skull . . . . . . 162

Mr Graham Kerr.-An Exhibition illustrating the life-history of Lepidosiren . . . . . . . . . ${ }_{164}$

2. WEDNESDAY, 24 August.

Profs. Heymans and Van der Stricht.-Quelques données sur le système nerveux de l'Amphioxus . . . . . 165

Prof. Ewart.-Hybrids of Horse and Zebra . . . . 165

Prof. Kanthack, Mr Blandford and Mr Durham.--Tsetse disease in Mammals . . . . . . . . 166

Mr Saville-Kent.-Bipedal Locomotion among existing Lizards 168

\section{THURSDAY, 25 August.}

Prof. McIntosh.-Scientific Experiments to test the effects of Trawling in the Waters of Scotland . . . . . 170

4. FRIDAY, 26 August.

Prof. Hubrecht.-Haematopoietic Processes in the Placenta . 172

Prof. Osborn.-Pliohyrax Kruppii (Plate 2) . . . . 172

Prof. Osborn.-Restoration of Extinct Vertebrates . . . 174

M. Léon Vaillant.-De la structure spéciale des épines chez les Apogonini etc. . . . . . . . . . 174

Prof. Salensky.-Zur Entwickelungsgeschichte des Ichthyopterygiums . . . . . . . . . .

M. E. de Pousargues.-Présentation de planches coloriées du Rhinopithecus Bieti des deux sexes et à différents âges. I $\delta_{4}$

Prof. A. Carruccio.-Indications principales sur les Vertébrés de la nouvelle collection Régionale Romaine . . . I $\delta_{4}$

Prof. Ramsay Wright.-The so-called uterus masculınus of the Rabbit

Prof. H. Nitsche.-Ueber die Hirschgeweihe mit mehr als zwei Stangen, und die Hoerner der Wiederkaeuer im allgemeinen 


\section{SECTION C. INVERTEBRATA.}

1. TUESDAY, 23 August.

Prof. L. Plate.-Beiträge zur vergleichenden Anatomie der Chitonen. . . . . . . . . 188

Prof. L. Plate.-Chitonicium simplex, ein neuer Zellparasit • 194

Mr E. S. Goodrich.-New Type of Nephridium in Glycera . I96

Mr C. Rousselet.-Note on preserving Rotatoria . . . 197

2. WEDNESDAY, 24 August.

Prof. Pelseneer.-L'utilité de l'uniformité d'orientation des figures zoologiques

Prof. Pelseneer.-La condensation embryogénique chez un Nudibranche

Prof. Vejdorský.-Fertilisation of the Egg of Rhynchelmis . 200

Prof. Vejdorský.-New Integumentary Sense Organs of Rhynchobdellidae

Prof. Hickson.-Demonstration of the Medusae of Millepora .

3. THURSDAY, 25 August.

The section did not meet.

4. FRIDAY, 26 August.

Dr Zschokke.-Entozoen der aplacentalen Säugetiere 203

MM. Mesnil and Caullery.-Formes épitoques des Annélides, et en particulier des Cirratuliens; and . . . . 204

Demonstrations of the Monstrillidæ, Copepods parasitic on Annelids, and of Metschnikovella, parasitic in Gregarines

Prof. E. L. Mark. -A new type of Actinian . . . . Mr F. W. Harmer.-The range in time and space of Fusus (Neptunea) antiquns and its allies (Plate 3) . . .

E. Perrier and M. A. E. Malard.-Les relations à établir entre les différents Laboratoires maritimes pour l'étude de certaines questions de biologie générale des êtres marins . . . . . . . . . .

Prof. W. Schewiakoff.-A new method of staining cilia, flagella and other locomotor organs of Protozoa (with demonstration) .

M. Pierre Fauvel.-Les stades post-larvaires des Arénicoles .

Prof. L. Roule.-La structure de la larve Actinotroque des Phoronidiens . 


\section{SECTION D. ARTHROPODA.}

1. TUESDAY, 23 August.

Mr M. C. Piepers.-Evolution of Colour in Lepidoptera. . 232

M. Bordage.-Expériences sur la relation qui existe entre la couleur du Milieu et la couleur des Chrysalides de certains Lépidoptères . . • • • • • • • • 235

Dr Sharp.-Some points in the classification of Insecta Hexapoda . . . . . . . . . . 246

2. WEDNESDAY, 24 August.

M. A. Dollfus.-Sur la distribution géographique des lsopodes dans l'Afrique Septentrionale, du Sénégal à Obock . . 250

M. Ch. Janet.-Constitution morphologique de la Tête de l'Insecte . . . . . . . . . . 260

M. E. Olivier.-Les Lampyrides des Antilles . • • • 267

M. E.-L. Bouvier.-Les caractères externes des Péripates . 269

3. THURSDAY, 25 August.

The section did not meet.

4. FRIDAY, 26 August.

The section did not meet. 


\section{APPENDIX A.}

PAGE

J. Hartley Durrant. - Nomenclature of Lepidoptera : Correspondence relating to questions circulated by Sir George F. Hampson, Bart. .

\section{APPENDIX B.}

Prof. A. A. W. Hubrecht.-Ueber die Entwickelung der Placenta von Tarsius und Tupaja nebst Bemerkungen ueber deren Bedeutung als Haematopoietische Organe. (Plates 4-15) . . . . $3+3$

\section{APPENDIX C.}

Prof. H. F. Osborn.-Remarks at the discussion on the Origin of Mammals on Thursday, 25 August (see p. 70). 



\title{
INTERNATIONAL CONGRESS OF ZOOLOGY.
}

\author{
CAMBRIDGE MEETING. 1898.
}

OFFICERS.

Patron:

H.R.H. The Prince of Wales, K.G., LL.D.,' F.R.S.

\section{President:}

The Right Hon. Sir John Lubbock, Bart., M.P., LL.D., D.C.L., F.R.S.

\section{Vice-Presidents :}

Prof. Milne Edwards (Paris).

Dr Jentink (Leyden).

Prof. R. Collett (Christiania).

Prof. Haeckel (Jena).

Prof. von Graff (Graz).

Prof. R. Hertwig (München).

Prof. Marsh (Yale, New Haven).

Prof. Mitsukuri (Tōkyō).

Prof. Salensky (St Petersburg).

Prof. Vaillant (Paris). 
EXECUTIVE COMMITTEE.

\section{President :}

Right Hon. Sir John Lubbock, D.C.L., F.R.S.

\section{Vice-Presidents :}

The Vice-Chancellor of the University of Cambridge. Mr W. T. Blanford, LL.D., F.R.S.

Sir W. H. Flower, K.C.B., D.C.L., F.R.S.

President of the Linnean Society (Dr A. Giinther).

Professor E. Ray Lankester, LL.D., F.R.S.

Professor A. Newton, F.R.S.

Mr P. L. Sclater, F.R.S.

President of the Entomological Society (Dr R. Trimen). Sir William Turner, F.R.S.

Lord Walsingham, LL.D., F.R.S.

\section{Treasurers:}

Professor S. J. Hickson, F.R.S.

Mr P. L. Sclater.

\section{Secretaries:}

Professor F. Jeffrey Bell, M.A.

Mr G. C. Bourne, M.A.

Mr A. Sedgwick, M.A., F.R.S.

\section{Ordinary Mombers:}

Dr Gadow, F.R.S.

Mr F. D. Godman, F.R.S.

Lieut.-Colonel Godwin-Austen, F.R.S.

Sir George F. Hampson, Bart.

Dr S. F. Harmer.

Professor Howes, F.R.S.

Hon. W. Rothschild.

Mr H. Saunders.

Professor Seeley, F.R.S.

Dr D. Sharp, F.R.S.

Mr A. E. Shipley.

Professor C. Stewart, F.R.S.

Dr H. Woodward, F.R.S. 
COMMITTEE OF PATRONAGE.

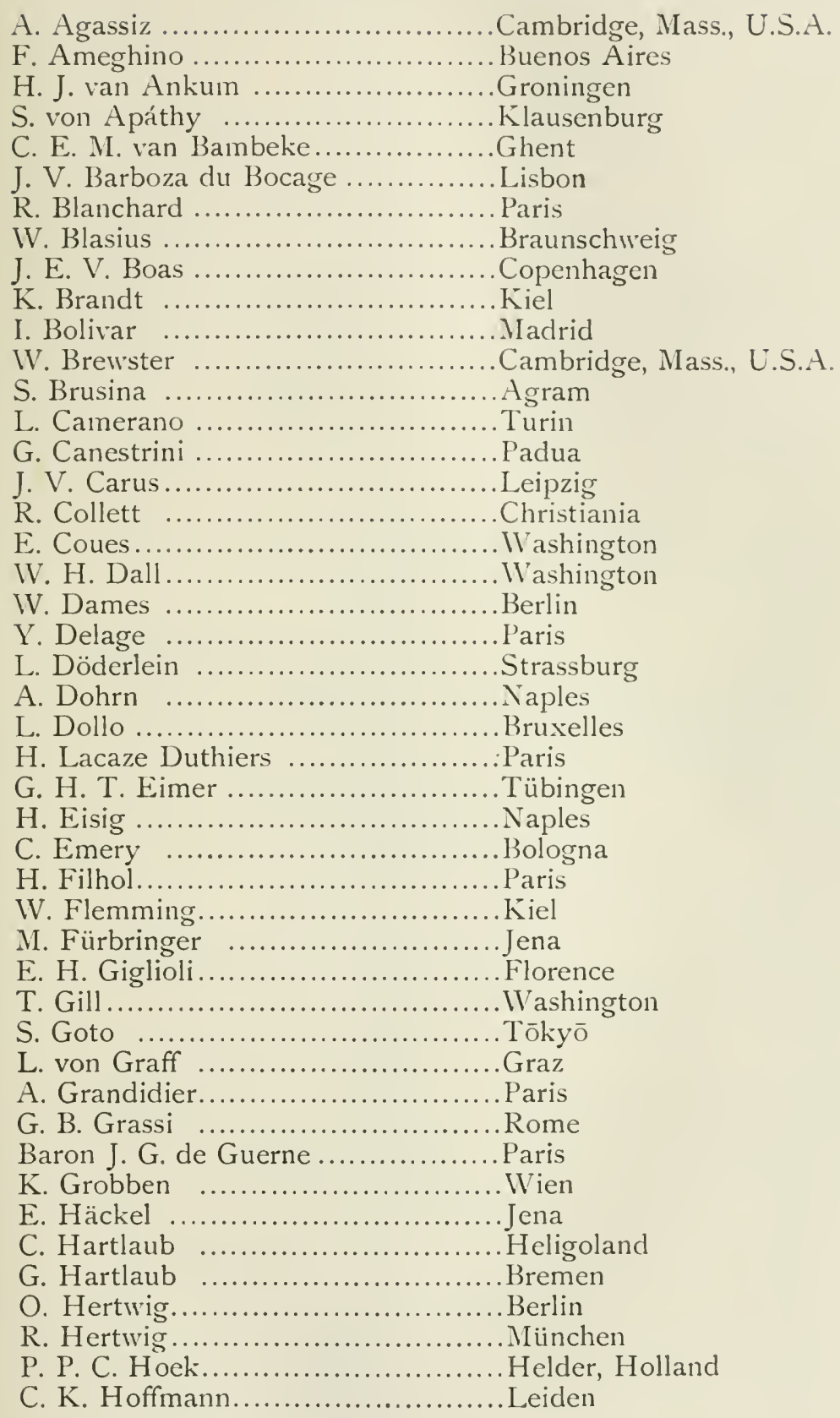


R. Horst .............................Leiden

L. O. Howard ......................Washington

A. A. W. Hubrecht ..................Utrecht

I. Ijima ............................ Tōkyō

C. Ishikawa $\ldots \ldots \ldots \ldots \ldots \ldots \ldots \ldots \ldots$ Tōkyō

F. A. Jentink ........................Leiden

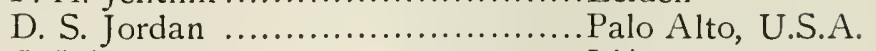

C. Julin $\ldots \ldots \ldots \ldots \ldots \ldots \ldots \ldots \ldots \ldots . . . \ldots$ Liége

C. Kerbert ........................... Amsterdam

R. Koehler ..........................Lyon

R. A. von Kölliker .................Würzburg

A. O. Kowalewsky ..................St Petersburg

K. M. F. Kraepelin ..................Hamburg

IV. Leche ............................ Stockholm

G. M. R. Levinsen....................Copenhagen

F. von Leydig .....................Würzburg

W. Lilljeborg ....................... Upsala

P. de Loriol le Fort ..................Genève

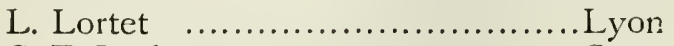

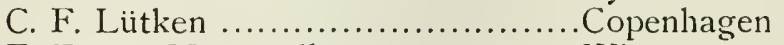

E. E. von Marenzeller ................Wien

A. F. Marion ........................... Marseille

E. L. Mark ........................... Cambridge, Mass., U.S.A.

O. C. Marsh .........................Newhaven, Conn., U.S.A

F. V. A. Meinert .....................Copenhagen

A. B. Meyer ............................Dresden

A. Milne-Edwards..................... Paris

C. H. Merriam ......................Washington

K. Mitsukuri ........................ Tōkyō

K. Möbius .......................... Berlin

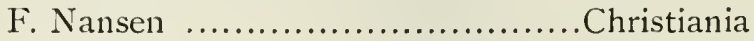

H. F. Osborn ....................... New York

E. Oustalet...........................Paris

A. S. Packard .........................Providence, R.I., U.S.A.

P. Pelseneer ..........................Ghent

E. Perrier ..............................Paris

F. Plateau ............................Ghent

A. Railliet ........................... Paris

A. Reichenow........................Berlin

M. G. Retzius........................Stockholm

R. Ridgway .........................Washington

G. O. Sars $\ldots \ldots \ldots \ldots \ldots \ldots \ldots \ldots \ldots \ldots$. Christiania

F. E. Schulze .......................... Berlin

W. B. Scott $\ldots \ldots \ldots \ldots \ldots \ldots \ldots \ldots \ldots \ldots$. Princeton, N.J., U.S.A.

R. W. Semon......................... Jena

H. Simroth ........................... Leipzig

J. W. Spengel......................Giessen

L. Stejneger ......................Washington 


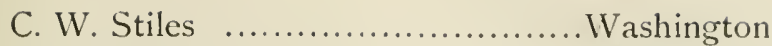

T. Studer ............................Berne

O. Taschenberg ........................ Halle

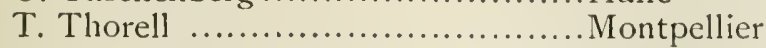

F. Todaro .......................... Rome

F. W. True.........................Washington

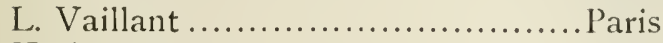

H. de Varigny .......................Paris

F. Vejdovský .......................Prague

G. C. J. Vosmaer ...................Utrecht

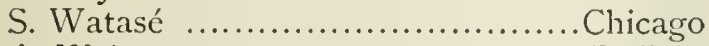

A. Weismann ......................... Freiburg i. Br.

R. Wiedersheim......................Freiburg i. Br.

E. B. Wilson ....................... New York

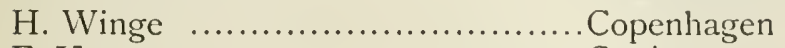

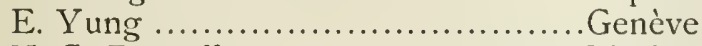

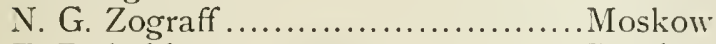

F. Zschokke .......................Basel

DELEGATES OF FOREIGN AND COLONIAL GOVERNMENTS.

Australia.

Prof. Bragg (S. Australia).

The Hon. Dr Cockburn (Agent-General: S. Australia).

Capt. A. F. H. Ferguson (New South Wales).

$\mathrm{Mr}$ J. H. Finlayson (S. Australia).

Prof. G. B. Howes (Victoria).

Mr W. Saville Kent (Queensland).

Mr W. H. D. Le Souëf (Victoria).

His Honour E. A. Stone (W. Australia).

AUstria.

Prof. Ludwig von Graff (Graz).

BELGIUM.

Prof. van Beneden (Liège).

Prof. Gilson (Louvain).

Prof. Lameere (Brussels).

M. Proost (Director-General at the Ministry of Agriculture and Public Works).

Mr O. Collett.

CEYLon.

FRANCE.

Prof. A. Milne-Edwards (Paris).

Prof. Barrois (Lille).

Prof. Bigot (Clermont).

Prof. Blanchard (Paris). 
M. Caullery (Lyons).

Prof. Cuénot (Nancy).

Prof Delage (Paris).

Prof. Filhol (Paris).

Prof. Girod (Clermont).

The Baron J. de Guerne (Paris).

M. Janet (Paris).

Prof. Joubin (Rennes).

M. Lambert (Nancy).

Prof. Lortet (Lyons).

Prof. Perrier (Paris).

Prof. Roule (Toulouse).

M. Schlumberger (Paris).

Prof. Vaillant (Paris).

GERMANY.

Prof. W. Blasius (Braunschweig).

Prof. Hertwig (Miinchen).

Prof. Kraepelin (Hamburg).

Prof. Möbius (Berlin).

Prof. F. E. Schulze (Berlin).

HUNGARY.

Prof. Stefan von Apáthy (Kolozsvár).

INDIA.

Mr H. M. Phipson (Bombay).

Mr R. C. Wroughton (Conservator of Forests: Bombay).

Mr R. B. Sányal (Calcutta).

ITALY.

Prof. Cav. C. A. Carruccio (Rome).

JAMAICA.

Sir Fielding Clarke (Chief Justice of Jamaica).

JAPAN.

Prof. K. Mitsukuri (Tōkyō).

NATAL.

Dr James Hyslop.

Dr Hoek.

NETHERLANDS.

Prof. Hubrecht.

New Zealand.

Prof. E. D. Brown (Auckland).

Dr James Hudson (Nelson). 
NORWAY.

Mr R. Collett (Christiania).

RUSSIA.

Prof. W. Salensky (St Petersburg).

Dr IV. Schewiakoff (St Petersburg).

SOUTII AFrica.

Dr R. Trimen (Capetown).

SWEDEN.

Prof. Théel (Stockholm).

SivitzerLand.

Prof. H. Blanc (Lausanne).

Prof. Zschokke (Basel).

TRINIDAD.

$\operatorname{Mr}$ H. Caracciolo (Port of Spain).

United States, Anerica.

Prof. E. L. Mark (Harvard).

Prof. O. C. Marsh (Yale).

Dr C. W. Stiles (Agricultural and Scientific Attaché of the U.S.A. Embassy at Berlin).

DELEGATES OF THOSE SOCIETIES WHICH ORGANIZED THE FIRST THREE INTERNATIONAL CONGRESSES OF ZOOLOGY.

Société Zoologique de France, Paris.

Prof. R. Blanchard (Paris).

M. A. Certes (Paris).

Dr L. Cuénot (Nancy).

M. Ph. Dautzenberg (Paris).

Prof. Delage (Paris).

Prof. Filhol (Paris).

M. J. Guiart (Paris).

M. Ch. Janet (Beauvais).

Prof. Joubin (Rennes).

Prof. Roule (Toulouse).

Société Impériale des AMis des Sciences Naturelles, DE L'Anthropologie et de l'Ethnographie, Moscow.

SOCiété NéERlandaise de Zoologie.

Dr F. A. Jentink (Leyden).

Prof. van Wijhe (Groningen). 


\section{RECEPTION COMMITTEE AT CAMBRIDGE.}

\section{Chairman:}

Alfred Newton, M.A., F.R.S., Magdalene College, Professor of Zoology and Comparative Anatomy.

Vice-Chairman:

A. Sedgwick, M.A., F.R.S., Trinity College, Reader in Animal Morphology.

\section{Trcasurers:}

J. W. Clark, M.A., Trinity College, Registrary of the University, formerly Superintendent of the University Museum of Zoology. Sydney J. Hickson, M.A. (D.Sc. Lond.), F.R.S., Downing College, Beyer Professor of Zoology in Owens College, Manchester.

\section{Secretaries:}

S. F. Harmer, Sc.D., F.R.S., King's College, Superintendent of the University Museum of Zoology.

Arthur E. Shipley, M.A., Christ's College, University Lecturer in Advanced Morphology of Invertebrates.

\section{Ordinary Members:}

Alex Hill, M.D., Master of Dozoning College and Vice-Chancellor of the University.

Alexander Peckover, Esq., LL.D., F.L.S., St John's College, Lord Lieutenant of the County.

Ernest T. Hooley, Esq., High Sheriff of the County.

S. R. Ginn, Esq., Mayor of Cambridge.

T. Clifford Allbutt, M.D., F.R.S., Gonville and Caius College, Regius Professor of Physic.

Richard Assheton, M.A., 'T'rinity College.

E. Barclay-Smith, M.A., M.D., Downing College.

IV. Bateson, M.A., F.R.S., St John's College.

Edward J. Bles (B.Sc. Lond.), King's College.

L. A. Borradaile, M.A., Selwyn College.

H. H. Brindley, M.A., St John's College.

A. H. Cooke, M.A., King's College, Honorary Curator of the $M^{c}$ Andrew Collection of Shells.

F. Darwin, M.A., M.B., F.R.S., Christ's College, University Reader in Botany.

G. H. Darwin, M.A., F.R.S., Trinity College, Plumian Professor of Astronomy.

Horace Darwin, M.A., Trinity College.

A. Deck, F.C.S., Alderman of Cambidge.

W. L. H. Duckworth, M.A., Jesus College. 
H. E. Durham, M.A., M.B., B.C., King's College.

A. H. Evans, M.A., Clare College.

John E. Foster, M.A., Trinity College.

M. Foster, M.A. (M.I). Lond.), Sec. R.S., Trinity College, Professor of Physiology'.

Hans Gadow, M.A. (Ph.D. Jena), F.R.S., King's College, Strickland Curator. University Lecturer in Advanced Morphology of Vertebrates.

J. Stanley Gardiner, B.A., Gonville and Caius College.

Walter Gardiner, M.A., F.R.S., Clare College.

W. H. Gaskell, M.D., F.R.S., Trinity Hall, Unizersity Lecturer in Advanced Pliysiology.

J. Reynolds Green, Sc.D., F.R.S., Trinity College.

O. F. F. Grünbaum, B.A., Trinity College.

F. H. H. Guillemard, M.A., M.D., Gonville and Caius College.

H. M. Gwatkin, M.A., Emmanuel College, Dixie Professor of Ecclesiastical History.

A. C. Haddon, Sc.D., Christ's College, Professor of Zoology in the Royal College of Science, Dublin.

N. Bishop Harman, B.A., St John's College.

Walter Heape, M.A., Trinity College.

Hubert Higgins, B.A., King's College, Funior Demonstrator of Anatomy.

T. McK. Hughes, M.A., F.R.S., Clare College, Woodwardian Professor of Geology.

A. A. Kanthack, M.A. (M.D. Lond.), St John's College, Professor of Pathology.

J. Graham Kerr, B.A., Christ's College, Demonstrator in Animal Morphology.

J. N. Langley, Sc.D., F.R.S., Trinity College, University Lecturer in Histology.

J. J. Lister, M.A., St John's College, Demonstrator of Comparative Anatomy.

A. Macalister, M.D., F.R.S., St John's College, Professor of Anatomy.

E. W. MacBride, M.A., St John's College, Professor of Zoology in the McGill University, Montreal.

J. E. Marr, M.A., F.R.S., St John's College, University Lecturer in Geology.

Edmund H. Parker, M.A., King's College.

IV. H. R. Rivers (M.D. Lond.), St John's College, University Lecturer in Physiological and Experimental Psychology.

A. C. Seward, M.A., St John's College, University Lecturer in Botany.

D. Sharp, M.A. (M.B. Edinb.), F.R.S., Curator in Zoology.

G. Elliot Smith (M.D. Sydney), St John's College.

I. L. Tuckett, M.A., Trinity College.

G. H. Verrall, Esq., Newmarket.

H. Marshall Ward, Sc.D., F.R.S., Sidney Sussex College, Professor of Botany.

Cecil Warburton, M.A., Christ's College.

J. H. Widdicombe, M.A., Downing College.

Arthur Willey (D.Sc. Lond.)., Balfour Student. 


\section{Accomnodation Sub-Committee.}

Officers of Reception Committee and

W. Bateson, St John's College.

E. J. Bles, King's College.

Dr Gadow, King's College.

Dr Gaskell, Trinity Hall.

A. P. Humphry, Trinity College.

Dr Langley, Trinity College.

J. J. Lister, St John's College.

J. E. Marr, St John's College.

Dr Sharp.

Finance Sub-Committee.

Officers of Reception Committee and

W. Bateson, St John's College.

H. Darwin, Trinity College.

J. E. Foster, Trinity College.

W. Heape, Trinity College.

J. J. Lister, St John's College.

E. H. Parker, King's College.

Entertainuents Sub-Commitee.

J. W. Clark, Trinity College.

J. J. Lister, St John's College.

Assignment of Rooms Sub-Commitee.

W. Bateson, St John's College.

J. J. Lister, St John's College.

\section{LIST OF MEMBERS, ASSOCIATES, AND SOCIETIES} WHICH SUBSCRIBED TO THE FUNDS OF THE CONGRESS.

THE list of names includes not only those who actually took part in the meeting, but also others who subscribed to the funds of the Congress.

The addresses in italics are those of residents in Cambridge or the Cambridge addresses of others who attended the Congress.

The names marked with an asterisk are those of Associates (see note, p. 34).

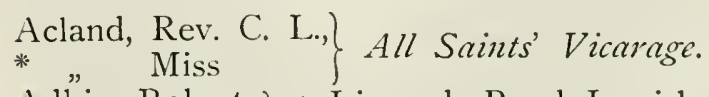

Adkin, Robert ) 4, Lingards Road, Lewisham. c/o G. H. Verrall, * „Mrs R. Esq., Sussex Lodge, Newmarket.

Aflalo, F. G., Sports Club, 8, St James' Square, London. 
Alcock, Miss R., Crofton Cottage, Newuhlam Croft.

Allbutt, T. Clifford, Chancer Rond.

Allen, E. J., The Laboratory, Citadel Hill, Plymouth. Sclauy'n College.

Allman, G. J., Ardmore, Parkestone, Dorset.

Anderson, John, 7I, Harrington Gardens, South Kensington.

Apáthy, Stefan v.

Richard John, Beech Hill, Newry, Ireland.

* „ Mme S. v.

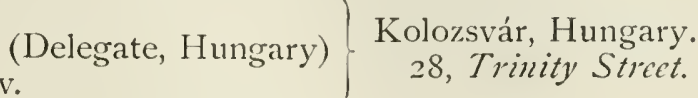

Aplin, O. V., Bloxham, near Banbury. Hoop Hotcl.

Arrigoni Degli Oddi, Conte Ettore (represents Società Italiana di Milano, Società Veneto-Trentina di Padova, R. Instituto

Veneto, Rivista Italiana, Accademia di Verona, Accademia di Acireale), R. Università, Padova. Trinity College.

Ascroft, Robert Lamb, II, Park Street, Lytham, Lancs. Clare College.

Assheton, Richard )

"Mrs R. $\}$ Birnam, Chancer Roud.

Babor, J. F., Prag, VII-748, Bohemia. St Fohn's College.

Baldwin, J. Mark $\}$ Princeton University, Princeton, N.J., U.S.A. * Mrs J. M. $\} \quad$ clo Prof. F. Ward, 6, Sclwyn Gardens.

Ball, Sir R. S., Observatory.

Bancroft, Frank W., Harvard University, Cambridge, Mass., U.S.A. 2, Pembroke St.

Bankes, Eustace R., The Rectory, Corfe Castle, Wareham.

Barclay \& Co., Cambridge.

Barclay-Smith, E., 57, Bateman Street.

Barrett, C. Golding, 39, Linden Grove, Nunhead.

Barrett-Hamilton, G. E. H., Savoy Mansions, Strand, London, IV.C. Trinity College.

Barrington, R. M., Fassaroe, Bray, Co. Wicklow. University Arms Hotcl.

Barrois, Th. (Delegate, France), 220, Rue Solferino, Lille.

Bassett-Smith, P: W. I I I 8, North Side, Clapham Common, London, * Miss $\}$ S.W. Hoop Hotel.

Bateson, W.

* ", Mrs W. $\}$ Noracich House, Panton Strcet.

Bather, F. A., British Museum (Natural History), Cromwell Road, London, S.W.

Beckwith, E. L., The Knoll, Eastbourne.

Bell, F. Jeffrey (Secretary to the General Committee), 35, Cambridge Street, Hyde Park, London, IV. Christ's College.

Bemmelen, J. F. van, Regentesselaan 96, 's Gravenhage. St Fohn's College.

Beneden, Ed. van (Delegate, Belgium), 5o, Quai des Pêcheurs, Liége. Benham, IV. B., University of Otago, Dunedin, New Zealand. 
Berg, Carlos, Museo Nacional, Buenos Aires, Argentina.

Bethune-Baker, G. T., I9, Clarendon Road, Edgbaston, Birmingham. Bevan, A. A., Trinity College.

Bidder, G. P., Ravensbury Park, Mitcham, Surrey. Trinity College. Bidwell, E., Fonnereau House, Twickenham, Middlesex. Clare College.

Bigot, A. (Delegate, France), Faculté des Sciences, Caen.

Birks, Edward) Birchcliffe, Broomhall Park, Sheffield. I4, King's * , Mrs E. $\}$ Parade.

Blanc, Edouard, 52, Rue de Varenne, Paris.

„ Henri(Delegate, Switzerland), Université, Lausanne. Clirist's College.

Blanchard, R. (Secretary to the Permanent Committee, Delegate, France; represents Société Zoologique de France)

" Mme

"Mlle

226, Boulevard St Germain, Paris. $c / 0$ Lady Humpliry,

Blandford, W. F., Peterhousc.

Blanford, W. T. I2, Bedford Gardens, London, W. King's * " Mrs W. T.j College.

Blasius, Wilh. (Delegate, Brunswick), I7, Gauss-Strasse, Braunschweig. Magdalene College.

Blathwayt, Lieut.-Col. L., Eagle House, Batheaston, Bath.

* „les, E. J. Mrs E. J. \} Neanham Lea, Grange Road.

Boas, J. E. V., Örstedsvej, 2 I, Copenhagen. St Fohn's College.

Bolsius, H. (S. J.), Collegium S. J., Oudenbosch, Holland.

Bolton Microscopical Society.

Bonand, Adolphe de, 74, Rue de Vaugirard, Paris. University Arms Hotel.

Bonhote, J. Lewis, 68, Lexham Gardens, Kensington.

Bonney, Rev. T. G., 23, Denning Road, Hampstead, London, N.W. Boquel, L., Trumpington Street.

Borgert, A., Universität, Bonn a. R. St John's College.

Borowikowsky, Serge, St. Petersburg. King's College.

Borradaile, I.. A., Selaunn College.

Bourne, G. C. (Secretary to the General Committee), New College, Oxford. Christ's College.

Bouskell, F., Market Bosworth, Nuneaton. IVicken, Cambs.

Bouvier, E. L. (represents Société Entomologique de France), 39, Rue Claude Bernard, Paris. Trinity College.

Bowes, Robert, I, Trinity Street.

Boycott, Mrs., 23, Lansdowne Crescent, Brighton. c/o Lady Humpliry, Grove Lodge.

Bradbury, J. B., 4, St Peter's Terrace.

Brady, G. S., Mowbray Villa, Sunderland.

Bragg, W. H. (Delegate, S. Australia), University, Adelaide, S. Australia. 6, Cherryhinton Road. 
Bridge, T. IV., Mason University College, Birmingham. Trinity Collegc. * Brindley, H. H. Mrs H. H. $\}$ 6, Richmond Road, Huntingdon Road.

Brölemann, H. W., 22, Rue Marignan, Paris.

Brown, Alexander, Marischal College, Aberdeen.

Brown, E. D. (Delegate, New Zealand), Auckland Institute, New Zealand.

Brusina, S. (represents South Slav Academy of Art and Science of Zagreb), Zagreb (= Agram), Croatia. Trinity College.

Buchanan, J. Y., Christ's College.

Buckley, T. E., Rossal, Inverness, N. B.

Buckton, G. B., Weycombe, Haslemere, Surrey.

Budgett, J. S., Trinity College. co Mrs Gall, Little Shelford, near Cambridsc.

Bund, J. W. Willis ) I 5, Old Square, Lincoln's Inn, London, IV.C. * " Miss $\} 28$, Trinity Strect.

Burne, R. H., I46, Gloucester Terrace, Hyde Park, London, IV.

*Burr, Malcolm, New College, Oxford. King's College.

Butler, G. W., Sandham, Chertsea, Surrey.

Butterfield, IV. Ruskin. 3, Stainsby Street, St Leonard's-on-Sea.

Caldwell, IV. H. I Pitliver, Dunfermline, N. B. c/o Dr Guille* "Mrs IV. H. $\}$ mard, Mill House, Trmmpington.

Calman, W. T., University College, Dundee. King's Collegc.

Caracciolo, H., (Delegate, Trinidad), Customs, Port of Spain, Trinidad. Clare College.

Carpenter, G. H. (represents Dublin Naturalists' Field Club), Science and Art Museum, Dublin. Emmanucl Collegc.

Carr, J. WV., University College, Nottingham. Emmanuel College. Carruccio, Cav. Antonio (Delegate, Italy. Represents R. Università di Roma, and Società Romana), R. Università, Roma. clo The Vice-Chancellor, The Lodge, Downing College.

Carver, E., West Road.

Caullery, M. (Delegate, France), Faculté des Sciences, Lyon. King's College.

Cave, C. J. P., Binsted, Herschel Road.

Certes, A. (represents Société Zoologique) 53, Rue de Varenne,

" Nme A. $\quad$ Ams Hotcl. de France),

Paris. University

Champion, G. C., Horsell, IVoking, Surrey. Clare College.

Chance, A. M., Lawnside, Edgbaston, Birmingham.

Chapman, A., South Bailey, Durham.

T. A., Betula, Reigate, Surrey.

Chaster, G. W., 42, Talbot Street, Southport.

Chawner, W., The Lodge, Emmanuel College.

Chester Society of Natural Science and Literature.

Chilton, Charles, I7, Melville Terrace, Edinburgh. I6, St Foln's Road. 
Clark, E. C., Nezunham House.

* " J. IV. (Treasurer) $\}$ Scroope House.

Clarke, Sir Ernest (represents Royal Agricultural Society), I3, Hanover Square, London.

Sir Fielding (Delegate, Jamaica) $\begin{aligned} & \text { Freltons, Danbury, } \\ & \text { Lady F. }\end{aligned}$
Chelmsford. Red
Lion Hotel.

IV. Eagle, Museum of Science and Art, Edinburgh.

Clay, C. J., West House, West Road.

Cockburn, Hon. Dr John A. (Delegate, S. Australia), Victoria Street, Westminster, S.W. Sidney Susscx College.

" Mrs $\quad$ Miss $\}$ University Arms Hotel.

Coffin, IV. H., 94, Cornwall Gardens, London, S.IV.

Collett, John, Binoya, 3, York Road, London, S.E.

" O. (Delegate, Ceylon), Ceylon. St Fohn's College.

" R. (Vicc-President; Delegate, Norway), Christiania. Magdalene College.

Collinge, WV. E., Mason University College, Birmingham. King's College.

Collins, F. Howard, Churchfield, Edgbaston, Birmingham.

Cooke, Rev. A. H., Willowbrook, Chaucer Road.

Corbett, IV. J., King's Collcge.

Cordeaux, John, Great Cotes House, R. S. O., Lincoln. St Fohn's College.

Cosmovici, Dr Leon C., Jassy. Sidney Sussex College.

Crick, Geo. C., British Museum (Natural History), Cromwell Road, London, S.W. Emmanuel College.

Crisp, Frank, 5, Lansdowne Road, Notting Hill, London, W.

Crowley, Philip, Waddon House, Croydon. Bull Hotcl.

Cuénot, L. (Delegate, France; represents Société Zoologique de France), 4, Rue de la Citadelle, Nancy. Trinity College.

Cunningham, D. J., Trinity College, Dublin.

" J. T., I, Addison Road, Plymouth.

" R. O., Queen's College, Belfast.

Dall, W. H., Smithsonian Institution, Washington, D.C., U.S.A.

Darwin, Francis, Wychfield, Huntingdon Road.

* " M. H.

* " Horace $\quad$ Hon. Mrs H.j The Orchard, Huntingdon Road.

Dautzenberg, Philippe (represents Société Zoologique de France),

2I3, Rue de l'Université, Paris. Hoop Hotcl.

Davies, H. R., Treborth, Bangor.

Davis, J. R. Ainsworth, University College, Aberystwyth. 
Dawson, G. M., Geological Survey of Canada, Sussex St, Ottawa, Canada.

Decattignies, Émile, Rue de Toul, Lille. St John's Collcge.

Deck, Alderman A., 9, King's Parade.

Delage, Yves

(Delegate, France; represents Société Zoologique de France)

* „ Mme Ýves

16, Rue du Marché, Sceaux

(Seine). 29, Trinity

Strect.

Denny, Alfred $\}$ University College, Sheffield. I4, King's Parade.

Dent, Hastings C., 20, Thurloe Square, London, S.IV.

Desaubliaux, Geo., 12, Rue de Seine, Paris. I4, King's Parade.

Devonshire, His Grace the Duke of (Chancellor of the Unirersity),

Devonshire House, Piccadilly, London, IV.

Distant, W. L., 4, Westbourne Terrace, Lower Addiscombe, Surrey.

Dixey, F. A., Wadham College, Oxford. Emmanucl College.

Dixon, A. Francis, University College, Cardiff.

Dohrn, Anton, Stazione Zoologica, Napoli. c/o IV. Heape, Esq., Heyrom, Chancer Road.

Dollfus, Adrien I 35, Rue Pierre Charron, Paris. c/o R. D. Mme A. ${ }^{2}$ Roberts, Esq., 4, Regent Street.

Doncaster, L., King's College.

Donisthorpe, Horace, 73, Cromwell Road, London, S.IV. King's College.

Dresser, H. E., Topclyffe Grange, Farnborough, R.S.O., Kent.

Druce, Herbert, 43, Circus Road, St John's IVood, London, N.IV.

Dublin Naturalists' Field Club.

Dubois, E., Sweelinckplein, I2, 's Gravenhage. Jesus Collegc.

Duckworth, IV. L. H., Jesis College.

Duppa-Crotch, W., Asgard, The Green, Richmond.

Durham, H. E.

Miss Florence M. $\}$, Parkside.

Durrant, John Hartley, Merton Hall, Thetford. Red Lion Hotcl.

Eaton, Rev. A. E., Woodlands, Seaton, Devon.

Ehlers, E., Universität, Göttingen. Christ's Collegc.

Elliot, Miss A. I. M., Sandecotes, Parkstone, Dorset. Newuliam College.

Elwes, H. J., Colesborne Park, Andoversford, R.S.O., Gloucestershire.

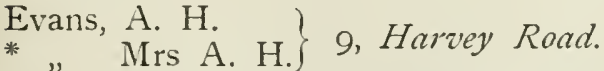

" Henry, Jura Forest, Greenock, N.B.

" Sir John, Nash Mills, Hemel Hempstead, Herts.

Ewart, J. Cossar, The Bungalow, Penicuik, Midlothian. Christ's Collegc. 
Ewbank, L., Clare College.

Ewing, J. A., Langdale Louge, The Airenue.

Fagan, C. E., British Museum (Natural History), Cromwell Road, London, S.W. Trinity College.

Fatio, V., Valavran, près Genève.

Fauvel, Charles Albert (represents Société Entomologique de France), I6, Rue d'Auge, Caen. Bull Hotel.

Fauvel, Pierre L., I4, Rue Gutenberg, Angers. Trinity College. Fawcett, W. M. 3, Scroope Terrace.

Fayrer, Surgeon-Gen. Sir Joseph, Bart., I6, Devonshire Street, Portland Place, London, $\mathrm{W}$.

Feilden, Col. H. W., West House, Wells, Norfolk. Magdalene College.

Ferguson, Capt. A. F. H. (Delegate, New South Wales), Polebrooke Hall, Oundle.

Field, Herbert Haviland, Concilium Bibliographicum, ZürichOberstrass. Sidney Sussex College.

Mrs, Zürich-Oberstrass. Necunham College.

Figueira, Juan H., Museo Nacional, Montevideo.

Filhol, Henri (Delegate, France; represents Société Zoologique de France), 9, Rue Guénégaud, Paris.

Finch, Rev. G. B., I, St Peter's Terrace.

Finlayson, J. Harvey (Delegate, S. Australia), S. Australia.

Fletcher, IV. H. B., Fairlawn House, Worthing. St Fohn's College.

" IV. M., Trinity College.

Florentin, R., Université, Nancy. Trinity College.

Flower, Sir W. H., K.C.B., British Museum (Natural History), Cromwell Road, London, S.W.

$\left.\begin{array}{ll}\text { Forbes, Henry O. } \\ \text { * }, & \text { Mrs H. O. }\end{array}\right\}$ The Museums, Liverpool. 9, Peas Hill.

Forsyth-Major, C. I., British Museum (Natural History), Cromwell Road, London, S.W.

Fowler, Rev. Canon W. W., The School House, Lincoln.

Francis, T. Musgrave, I 7, Emmanuel Street.

* " W. H. Mrs W. H. $\} 4 a$, King's Parade.

Friend, Rev. Hilderic, Tipton, Staffordshire. The Leys School.

Fry, Sir Edward, Failand House, Failand, near Bristol.

Fulford, Rev. H. W., Clare College.

Fullarton, J. H., Scottish Liberal Club. Bull Hotcl.

Gadeau de Kerville, Henri, 7, Rue Dupont, Rouen. Red Lion Hotel.

Gadow, H. (Secretary to )

* " Mrs H.

Section B) Great Shelford, near Cambridge.

Galton, Francis, 42, Rutland Gate, London, S.IV. 
Galton, John C., New University Club, St James' St., London, S.W.

Gardiner, J. Stanley, Gonville and Cains College.

Miss S. A., 4, Bedford Place, Croydon. Newnham College.

Walter. Clare College.

Gaskell, W. H., The Uplands, Great Shelford, near Cambridge.

Gatty, Charles Henry, Felbridge Place, East Grinstead, Sussex. Gaudry, A., Muséum d'Histoire Naturelle, Paris.

Gemmill, James F., University, Glasgow. Jesus College.

Gerould, John H., Dartmouth College, Hanover, N.H., U.S.A. 2, Pembroke Sitrect.

Giles, H. A., West Rond.

Gilmour, Matthew A. B., Hamilton, N.B. Castlc Hotel.

Gilson, G. (Delegate, Belgium), Université, Louvain, Belgium. clo Rev. E. Nolan, St Edmund's House.

Ginn, S. R. (Mayor of Cambridge), Brookfield, Trumpington Road.

Girod, Paul (Delegate, France), Faculté des Sciences, ClermontFerrand.

Glasgow, Natural History Society of.

Godman, F. Du Cane, South Lodge, Horsham, Sussex.

Godwin-Austen, Lieut.-Col. H. H., Nore, Hascombe, Godalming, Surrey.

Goodrich, E. S., The Museum, Oxford. Sidncy Sussex College.

Gorham, Rev. H. S., The Chestnuts, Shirley Warren, Southampton. c/o G. H. Verrall, Esq., Sussex Lodge, Nezumarket.

Goss, H., The Avenue, Surbiton Hill, Kingston-on-Thames.

Graff, Ludivig v. (Vice-President; Delegate, Austria), Zoologischzootomisches Institut, Graz. c/o E. J. Bles, Esq., Nerunham Lea.

Gravier, Ch., 33, Rue Linné, Paris. Trinity Collegc.

Green, W. S., 5, Cowper Villas, Rathmines, Dublin.

Gregory, J. W. (British Museum (Natural History), Cromwell * Mrs J. W. Road, London, S.W. c/o A. C. Seward, Griffiths, J., 63, Trumpington Street.

Grose-Smith, H., 5, Bryanston Square, London, IV.

Gross, E. J., Gonwille Lodge, Parker's Piece.

Griinbaum, O. F. F., Trinity College.

Giinther, Albert, 2, Lichfield Road, Kew Gardens, London, S.IV. Guerne, Baron Jules G. de (Delegate, France), 6, Rue de Tournon, Paris. clo F. W. Clark, Esq., Scroopc House.

Guiart, J. (represents Société Zoologique de France), 19, Rue Gay Lussac, Paris. Emmanuel College.

Guillemard, F. H. H., Mill House, Trumpington.

Gurney, J. H., Keswick, Norwich.

Gwatkin, Rev. H. M., 8, Scrope Terrace. 
Haddon, A. C., Inisfail, Hills Road.

Hadfield, Charles F., Trinity College.

Haeckel, Ernst (Vice-President), Zoologisches Institut, Universität, Jena. clo Dr H. Gadow', Great Shelford, near Cambridge.

Haecker, V., Kaiserstrasse, 7, Freiburg i. B., Germany. St John's College.

Hampson, Sir G. F., Bart., British Museum (Natural History), Cromwell Road, London, S.W.

Harker, A., St John's College.

Harman, N. B., St John's College.

Harmer, F. W., Cringleford, near Norwich. King's College.

Harmer, S. F. (Secretary to the Reception Committee), King's College, Mrs S. F., 98, Huntingdon Road.

Harrison, Ross G., Johns Hopkins University, Baltimore, Md., U.S.A. St John's College.

Hartert, E., Zoological Museum, Tring. University Amns Hotel. Hartog, Marcus, Queen's College, Cork. Trinity College.

Harvie-Brown, John A., Dunipace House, Larbert, N.B.

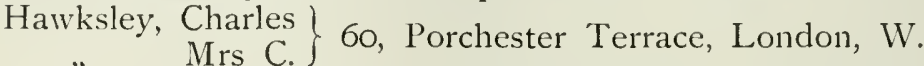

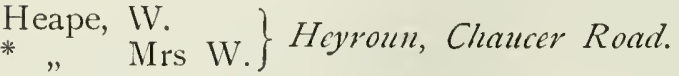

Heitland, W. E., St John's College.

Hennings, C. Frau C.\} 78, II., Rathenowerstrasse, Berlin. Bull Hotcl.

Herdman, W. A., University College, Liverpool.

Hertwig, R. (Vice-President;) Siegesstrasse, 30, München. c/o R. Delegate, Bavaria) Assheton, Esq., Birnam, Chancer Frau R.

* Heycock, C. T.

Heymans, J. F., Université, Gand. c/o the Vice-Chancellor, The Lodge, Downing College.

Heymons, Richard, Zoologisches Institut, Invalidenstrasse, 43, Berlin, N. c/o Dr Willey, Christ's College.

Hickson, S. J. (Treasurer) (Ellesmere House, Withington, * "Mrs S. J. $\{$ Lancs. c/o C. T. Hejcock, Esq., 24,

Higgins, H., 4, Trinity Strect.

Hill, Alex (Vice-Chancellor of the University) The Lodge, Downing College.

" M.D., Eton College, Windsor. King's College.

Hoek, P. P. C. (Secretary to Section A; Delegate, Netherlands), Zoologisch Station, Helder, Holland. Selwyn College.

Holdsworth, E. W. H., South Town, Dartmouth.

Horniman, F. J., Surrey House, Forest Hill, London, S.E.

Horst, R. 
Horváth, G., Muséum National Hongrois, Budapest. King's College.

Houssaye, P. E., 5, Rue Jomard, Paris.

Howvarth, E., Public Museum, Weston Park, Shefficld. I9 a, Market Hill.

Howes, G. B. (Delegate, Victoria), Royal College of Science, S. Kensington. Sidney Susscr College.

Hoyle, IV. E. (represents Manchester Museum), The Owens College, Manchester. King's College.

Hubrecht, A. A. IV.

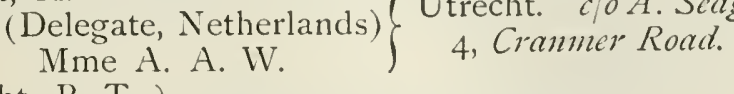

*Hubrecht, P. T. )

* J. B. Utrecht. Christ's College.

Huddleston, T. F. C. I4, Selayyn Gardens.

Hudleston, IV. H., S, Stanhope Gardens, S. Kensington, S.WV.

Hudson, James (Delegate, New Zealand), Nelson Philosophical Society, New Zealand. St John's College.

Hudson-Beare, T., University College, London, W.C. King's College.

Hughes, T. McKenny, 4, Cintra Terrace, Cambridge.

Humphry, A. P., Foxton Honse, Royston.

" Miss E. Groz'c Lodge.

" L. 2, Trinity Strcet.

" Stewart, Foxton House, Royston. c/o Lady Humphry, Grove Lodge.

Hunt, A. R., Southwood, Torquay.

Hutchinson, A., Pembroke College.

Jonathan, I 5, Cavendish Square, London, IV.

Hyslop, James (Delegate, Natal), Natal Society.

Irby, Lieut.-Col. L. H., I 4, Cornwall Terrace, Regent's Park, London, N.W.

Jameson, H. Lyster, I, Belvedere Terrace, Tunbridge Wells. Clare College.

Janet, Charles (Secretary to Section D; Delegate, France; represents Société Zoologique de France and Société Entomologique de France), 83 , Faubourg St Jacques, Beauvais (Oise). St John's College.

Jayakar, Surgeon Lieut.-Col. A. S. G., The Residency, Muskat, Arabia.

Jenkinson, F. J. H., Io, Brookside.

Jentink, F. A. (Vice-President; Delegate, Netherlands), Museum of Natural History, Leyden. c/o R. D. Roberts, Esq., 4, Regcnt Strect.

Johnston, Sir H. H., Tannheim, Wimborne Road, Bournemouth. Jones, E. Lloyd, Corpus Buildings.

Jordan, K., Zoological Muscum, Tring. University Arms Hotcl. 
Joubin, Ch. (Delegate, France; represents Société Zoologique de

France), Faculté des Sciences, Rennes. Emmanuel College.

Julin, Charles, I 5 I, Rue de Fragnée, Liége.

Kane, Judge R. R., 4, Fitzwilliam Place, Dublin. Emmanuel College. W. F. de V., Drumreaske House, Monaghan, Ireland. 27, Trinity Street.

Kanthack, A., 2, Huntingdon Road.

Keith, A., London Hospital, E.C. Fesus College.

Kemna, Ad., 6, Rue Montebello, Anvers. King's College.

Kempen, Ch. van, I2, Rue St Bertin, St Omer (Pas de Calais). Emmanuel College.

Kenny, C. S., Westbye House, West Road.

Kent, W. Saville (Delegate, Queensland) The Rowans, Walling* "Mrs W. S.

Kerr, J. Graham, Christ's College.

Keynes, J. N., 6, Harvey Road.

Kirby, IV. F., Hilden, Sutton Court Road, Chiswick, Iondon. Red Lion Hotel.

Kirk, Sir John, Wavertree, Sevenoaks.

Kirkaldy, Miss J. IV., I 2, Banbury Road, Oxford. I 4, Trinity Street. Kirkpatrick, Rev. A. F., The Lodge, Selwyn College.

". R.. British Museum (Natural History), Cromwell Road, London, S.IV.

Kishinouye, K., Imperial Fisheries Bureau, Tōkyō. Trinity Coliege. Klein, S. T., The Red House, Stanmore, Middlesex.

Knubley, Rev. E. P., Steeple Ashton Vicarage, Trowbridge. Magdalene College.

Kraepelin, K. (Delegate, Hamburg). Steinthorwall, Hamburg. Hoop Hotel.

Lambert, Prof. (Delegate, France) Faculté des Sciences, Nancy. Gonville and Cains College.

Lameere, Auguste (Delegate, Belgium), I ig, Chaussée de Charleroi, Bruxelles. Emmamuel College.

Lanchester, W. F., King's College, Cambridge. c/o G. Ainslic, Esq., Castle Knott, Lady Margaret Road.

Latham, Rev. H., Sonthacre, Trumpington Road.

Latter, Oswald H., Charterhouse, Godalming. Emmanuel College.

Laurie, Malcolm (represents Natural History Society of Glasgow), St Mungo's College, Glasgow. King's College.

Lebedinsky, J., Université, Odessa. Red Lion Hotel.

Leech, J. H., Iford, Lewes.

Leicester Literary and Philosophical Society.

Lemon, F. E., 3, Hanover Square, London, IW. c/o Dr E. Barclay Simith, 57, Batcman Street.

Lindsay, Miss Beatrice, The Cottage, Port St Mary, Isle of Man. Lister, The Lord, I2, Park Crescent, Portland Place, London, W. 
Lister, Arthur I Sycamore House, Leytonstone. clo IV. Heapc, Esq., * "Niss G.J Heyroun, Chancer Road.

". J. J., St Fohn's College.

Liveing, G. D., The Piglhtle, Newnham.

Llewelyn, Sir John, Bart., Penllergaer, Swansea.

Lloyd, R. Wylie, St Cuthberts, Thurleigh Road, Nightingale Lane, London, S.IV.

*Lock, R. H., Herschel House.

Lortet, L. (Delegate, France) I 5, Quai de l'Est, Lyon.

Lubbock, Rt. Hon. Sir John, Bart.) 2, St James' Square, London, (President of the Congress). S.IV. clo Vice-Chancellor, The * " Lady Lodge, Downing College.

Lydekker, R., The Lodge, Harpenden, Herts. c/o Dr Guillemard, Mill Honse, Trumpington.

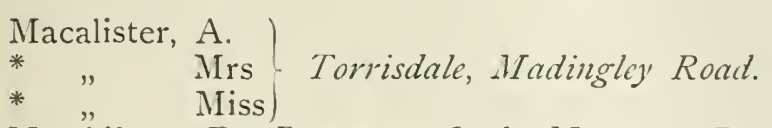

MacÄlister, D., Barmore, Lady Margaret Road.

MacBride, E. W., 72, MacGill College Avenue, Montreal. St Foln's College.

McIntosh, IV. C., 2, Abbotsford Crescent, St Andrews.

McLachlan, R., 23, Clarendon Road, Lewisham. Bull Hotel.

MacMunn, Charles i Oakleigh, Wolverhampton. Red Lion * " Mrs C. $\}$ Hotel. Macpherson, A. H., 5 I, Gloucester Terrace, Hyde Park, London, W. clo H. McL. Innes, Esq., Trinity College.

$" \quad$ Rev. H. A., Allonby Vicarage, Maryport, Cumberland. Bull Hotel.

Malard-Duméril, A. E., Laboratoire Maritime, Tatihou, par St Vaast-la-Hougue. Trinity College.

Manchester Literary and Philosophical Society. Microscopical Society.

Museum.

Marey, E. J., I I, Boulevard Delessert, Paris. Trinity College.

Mark, Prof. Edward L. (Delegate, U.S. America), I09, Irving Street,

Cambridge, Mass., U.S.A. St Fohn's College.

Marr, J. E.

Marsh, O. C. (Vice-President; Delegate, U.S. America), Yale University, New Haven, Conn. Bull Hotel.

Marshall, A., Balliol Croft, Madingley Road.

Masefield, John R. B. (represents N. Stafford- ) Rosehill, Cheadle, Mrs J. R. B.

Mason, P. B., Trent House, Burton-on-Trent. College.

Masterman, A. T., 3, Dempster Terrace, St Andrews. I7, Sussex Street. 
Maxivell, Rt. Hon. Sir Herbert, Bart. (represents Society for the Protection of Birds)

* Miss

49, Lennox Gardens, London, S.W. clo Professor G. H. Darwin, Neauham Grange.

Meldola, R., 6, Brunswick Square, London, W.C.

Melvill, J. Cosmo (represents Manchester Literary and Philosophical Society), Brook House, Prestwich, near Manchester. Trinity College.

Merrifield, F., 24, Vernon Terrace, Brighton. c/o Dr Verrall, 5, Selwyn Gardens.

Mesnil, F., Institut Pasteur, 25, Rue Dutot, Paris. King's Collegc.

Meyer, A. B., K. Zoologisches Museum, Dresden.

Meyrick, E., Elmwood, Marlborough. c/o F. F. H. Fcnkinson, Esq., Io, Brookside.

Michael, A. D., 9, Cadogan Mansions, Sloane Square, London, S.W.

Midgley, W. W. (represents Bolton Microscopical Society), The Museums, Bolton.

Millais, J. G., Melwood, Horsham, Sussex.

Millett, F. W., Marazion, Cornwall.

Milne Edwards, Alphonse (Vice-Presidcnt; Prcsident of the Permanent Committee. Delegate, France) Muséum d'Histoire Naturelle, Paris. c/o F. $\mathrm{W}$. Clark, Esq., Scroope House.

Minchin, E. A., Merton College, Oxford. Trinity College.

Mitsukuri, K. (Vice-President; Delegate, Japan), Imperial University, Tökyō, Japan. c/o W. Hcape, Esq., Heyronn, Chancer Road.

Möbius, K. (Delegate, Prussia), Invalidenstrasse 43, Berlin. Magdalene Collcge.

Mollison, W. L., 5, Crammer Road.

Morgan, C. Lloyd, University College, Bristol. Emmanuel College. " John, Coral Gallery, Hastings. Red Lion Hotel.

Murie, James, Canvey Cottage, Leigh, Essex.

Murray, Sir John, K.C.B., Challenger Lodge, WVardie, near Edinburgh.

Neil, R. A., Pembroke College.

Neumann, Oscar, Potsdamerstrasse, Io, Berlin, W. Unizersity' Arms Hotel.

Neville, F. H., Sidney Sussex College.

Nevinson, B. G., 3, Tedworth Square, Chelsea, London, S.W. St Fohn's College.

Newstead, Robert (represents Chester Society of Natural Science and Literature), Grosvenor Museum, Chester. Fesus College.

Newton, Alfred (Chairman of the Reception Committee), Magdalene College.

„ E. T., Geological Museum, Jermyn Street, London, S.W. " R. B., British Museum (Natural History) Cromwell "Road, London, S.IV. 
Nicholls, H. A. Alford, Roseau, Dominica, W. Indies.

Nicholson, H. Alleyne, The University, Aberdeen.

Nitsche, H., Forstakademie, Tharandt. King's College.

Nixon, J. E., King's College.

Nordgaard, O., Bergen, Norway: Oshorme Arms, Hills Road.

Norfolk and Norwich Naturalists' Society, Norwich.

Norman, Rev. Canon A. M., The Red House, Berkhamsted, Herts. Magdalene College.

Oates, E. WV., I, Carlton Gardens, Broadway, Ealing, London, IV. Ogilvie-Grant, IV. R., British Museum (Natural History), Cromwell Road, London, S.IV.

Oldham, H. Yule, King's College.

Olivier, Ernest, Io, Cours de la Préfecture, Moulins Allier, France. King's College.

Ommanney, Admiral Sir Erasmus, 29, Connaught Square, Hyde Park, London, WV.

Osborn, Henry F. I Columbia University, New York, I 5, King's * „Mrs H. F. ${ }^{\prime}$ Paradc.

Ovion, Mlle, Paris. I4, King's Parade.

Oye, Stéphane Van, 2, Rue de Coul, Lille, France. St Foln's College.

Parker, E. H., Thumeybrook, Herschel Road.

IV. N., University College, Cardiff.

Parkinson, John, 251, Camden Road, London, II. University Arms Hotcl.

Paterson, A. M., University College, Liverpool.

Patterson, R. Lloyd, Croft House, Holywood, Co. Down.

Peace, J. B., Emmanuel College.

Peal, C. N., Fernhurst, Mattocktam, Ealing, London, IV.

Pearson, Chas. E., Chilwell House, Notts. Emmanuel College.

" G., 3, Bolt Court, Fleet Street, London, E.C. IO, St Andrew's Hill.

Henry J., Bramcote, Notts. Emmanucl College.

Pechover, Alexander (Lord Lientenant of Cambridgeshire), Bank House, WVisbech.

Pelseneer, Paul, 53, Boulevard Léopold, Gand. Sidney' Sussex College.

Penrose, F. G., 84, IVimpole Street, London, II.

Perkins, R. C. L., I, Bateman Strect.

Perrier, Edmond (Delegate, France). Nuséum d'Histoire Naturelle, Paris.

Phear, Rev. S. G., 2, St Peter's Terrace.

Philipps, Miss E. G., Neanham College.

Phipson, H. M. (Delegate, India) $\int 6$, Apollo Street, Bombay: * ", Mrs Peche!" Road. 
Pickard-Cambridge, Rev. Octavius, Bloxworth Rectory, Wareham, Dorset. Magdalene College.

Piepers, M. C., Noordeinde IOa, 's Gravenhage. Fesns College. Pigott, T. Digby, H.M. Stationery Office, London, S.IV.

Plate, L. (Secretary to Section C), Zoologisches Institut, 43, Invalidenstrasse, Berlin. c/o Prof. Kanthack, 2, Huntingdon Road.

Poulton, E. B., Wykeham House, Banbury Road, Oxford.

Pousargues, E. de, 8, Rue Guy de la Brosse, Paris. Emmanuel College.

Powerscourt, Viscount, Powerscourt Castle, Enniskerry, Co. IVicklow.

Pratt, Miss Edith, Owens College, Manchester. Nezunham College.

Preston, Hugh B., The Manor House, Berrow, Burnham, Somerset. University Arms Hotel.

Proost, M. le Directeur-Général Alph. (Delegate, Belgium), Ministère de l'Agriculture, Bruxelles.

Protection of Birds, Society for the. London.

Pruvot, G., Université, Grenoble. Emmanuel College.

Pryor, M. R., IVeston, Stevenage.

Railliet, A. (representing Ministère de l'Agriculture de France), École Vétérinaire, Alfort, Paris. Clurist's College.

Raspail, Xavier, Goubieux (Oise).

Renshaw, G., Salebridge House, Sale, Cheshire. Bird Bolt Hotel. Reynolds, S. H., University College, Bristol.

Richardson, Nelson M.) Montevideo, near Weymouth. 59, Bridge Mrs N. M. S Street.

Riches, T. H., Kitwells, Shenley, Herts. Gonville and Caius College.

Ridewood, W. G., So, Oakley Street, London, W.C. Red Lion Hotel.

Robinson, Rev. J. A., Christ's College.

Rose, Rev., A., Emmanuel College.

Rothschild, Hon. N. Charles, Tring Park. University Arms Hotel. Hon. Walter, Tring Park. University Arms Hotel.

Rotrou, Alexandre, La Ferté-Bernard (Sarthe). Emmanuel College.

Roule, Louis (Delegate, France; represents Société Zoologique de France), I9, Rue d'Alsace-Lorraine, Toulcuse.

Rousselet, Ch. F., 27, Great Castle Street, Regent Street, London, IV. St Foln's College.

Rowley, F. R. (represents Leicester Literary and Philosophical Society), Corporation Museum, Leicester. King's College.

Royal Bounty Fund, London.

Royston, Horace, clo Oscar Brozuning, Esq., King's College.

Saint-Hilaire, Constantin, Frankfurterstrasse 25, Marburg a. d Lahn, Germany. University Arms Hotel. 
Salensky, W. (Vice-President; Delegate, Russia), Université, St Petersburg. King's College.

Salvin, O. (the late).

Samassa, Paul, Schackstrasse, 6, München. Clare College.

Sányal, R. B. (Delegate, Calcutta), I4, Doughty Street, London, IV.C. I 5, Earl Street.

Saunders, E., St Ann's, Mount Hermon, Woking, Surrey.

Howard, 7, Radnor Place, Hyde Park, London, IV. Emmanuel College.

Savage, IV. A., St Thomas Charterhouse, London. 44, Hills Road.

Sayle, C. E., 2, Hariey Road.

Scharff, R. F.

Science and Art Museum, Dublin.

* "Mrs R. F. clo T. Thorncly, Esq., Elterholm,

Scherren, Henry, 9, Cavendish Road, Harringay, London, N. Enmanuel College.

Schewiakoff, W. (Delegate, Russia) W Wassili Ostrow, 5, Linie 20, NIme W.

Schlumberger, C. (Delegate, France), I6, Rue Christophe Colomb, Paris, clo f. W. Clark, Esq., Scroope House.

Schnurmann, I. Nestor, Christ's College.

Schulze, F. E. (Delegate, Prussia), Zoologisches Institut, Invalidenstrasse 43, Berlin, N. Magdalene College.

Sclater, P. L. (Treasurer), Zoological Society, 3, Hanover Square, London, W. Christ's College.

Sedgwick, Adam (Secretary to the General)

*,$\quad$ Mrs A. Committee)

4, Cramer Road.

Seeley, H. G., King's College, London, W.C.'Sidney Sussex College.

Selous, F. C., Alpine Lodge, Worplesdon, Surrey.

Selys-Longchamps, Baron Edmond de, Liége.

* Sen, S., Peterhouse.

Seward, A. C., Westfield, Huntingdon Road.

Sharkey, J. A., Christ's College.

Sharp, David, Hawithorndene, Hills Road.

Sharpe, R. Bowdler, British Museum (Natural History). Cromwell Road, London, S.IV.

Shaw, IV. N., Emmanuel College.

Shelley, Capt. G. E., Tower House, Reigate. 37, Trinity Strect. Sherborn, C. Davies, 540, King's Road, Chelsea, London, S.IV.

Shipley, Arthur E. (Secretary to the Reception Committec), Clerist's College.

Simon, Eugène (represents Société)

Entomologique de France) I6, Villa Said, Paris. I4, Mme E.

Simpson, J. C. ${ }_{*}$ Mrs J. C. $\}$ Corpus Buildings.

Simroth, H., Universität, Leipzig. Sidney Sussex College. 
Skeat, Rev. W. W., 2, Salisbury Villas, Station Road.

Sladen, IV. Percy, I 3, Hyde Park Gate, London, S.W.

Slater, Rev. H. H., Thornhaugh Rectory, Wansford, Northants.

Smith, G. Elliot, St Fohn's College.

Sorby, H. C., Broomfield, Sheffield.

Souëf, IV. H. D. Le (Delegate, Victoria), Melbourne. Trinity College.

Southwell, Thomas, so, The Crescent, Norwich. Magdalene College. Spengel, J. W., Gartenstrasse, I7, Giessen. c/o E. J. Bles, Esq., Newnham Lca.

Staffordshire (North) Field Club.

Stead, F. B., King's Collcge.

Stearns, Arthur E., 99, Gloucester Terrace, London, W. I4, Trinity' Street.

Stebbing, Rev. T. R. R.) Ephraim Lodge, The Common, Tun* , Mrs T. R. R. $\int$ bridge Wells. 3, Bridge Strect.

Stejneger, L. ) U.S. National Museum, Washington, D.C. c/o " Mrs L.) A. H. Eians, Esq., 9, Harvey Road.

Stewart, Charles, Museum of the Royal College of Surgeons, Lincoln's Inn Fields, London, W.C.

Stiles, C. Wardell (Delegate U. S. America), United States Embassy, Berlin. Christ's College.

Stone, His Honour E. A. (Delegate, W. Australia), Acclimatisation Society, IV. Australia. 6, St Edward's Passage.

Struthers, Sir John, 24, Buckingham Terrace, Edinburgh.

Studer, Th., Hotelgasse, I4, Bern. Trinity College.

Swainson, Geo., 3, St George's Road, St Ann's on the Sea. Fesus College.

Sykes, E. R., 3, Gray's Inn Place, London, W.C.

" Mark L. (represents Manchester Microscopical Society), 19, Manor Street, Ardwick, Manchester. 27, Trinity Strect.

Taylor, Rev. Charles, The Lodge, St John's College.

" E. Cavendish, 74, Jermyn Street, London, S.IV.

" J. J.. Emmanuel College. 43, Hills Road.

Tegetmeier, W. B., I6, Alexandra Grove, N. Finchley, London, N.

Théel, Hj. (Delegate, Sweden), Kristineberg, Fiskebäckskil, Sweden. Bull Hotcl.

Theobald, F. V., Wye Court, near Ashford, Kent. I 2, Trumpington Street.

Thomas, Oldfield, British Museum (Natural History), Cromwell Road, London, S.W.

Thomasson, John F., Woodside, Bolton.

Thompson, D'Arcy W., University College, Dundee. Trinity College.

" I. C., 53, Croxteth Road, Liverpool.

Thomson, J. A., I I, Ramsay Gardens, Edinburgh.

Thornely, Miss Laura R., Baycliff, Woolton, nr. Liverpool. c/o T. Thorncly', Esq., Elterholm, Madingley Road. 
Thursby, Mrs Charles, Harleston, Northampton. c/o Dr Gadoa, Great Shelford.

Tims, H. W. Marett, 39, St George's Square, London, S.IV. * "Mrs H. W. Marett, University Arms Hotel.

Trapet, L. J., Châlons, Mourmelon-le-Grand (Marne).

Traquair, Ramsay H., Museum of Science and Art, Edinburgh. Trevor-Battye, Aubyn B. R., 2, Whitehall Gardens, Whitehall, London, S.W.

Trimen, Roland (Delegate, S. Africa) 34, Norham Road, Ox* „ Mrs R. J ford. Bull Hotel.

Tristram, Rev. Canon H. B., The College, Durham. Magdalene College.

*Tuck, Gnoh L., Emmanuel College.

Tuckett, I. L., Trinity College.

Turner, Sir William, 6, Eton Terrace, Edinburgh.

Vaillant, L. (Vice-President; De-) 36, Rue Geoffroy St Hilaire, Mlle. legate, France)

Paris. Unizersity Arms Hotel.

Vejdovský, F., Université, Prague, Bohemia. Bull Hotel.

Veley, V. H., 22, Norham Road, Oxford.

Verrall, Mrs A. W., 5, Selwyn Gardens.

G. H., Sussex Lodge, Nezumarket.

Vice, WV. A., 5, Belvoir Street, Leicester. King's Collcge.

Vipan, Capt. J. A. M., Stibbington Hall, Wansford, Northampton.

Vivian, H. W., Glenafon, Taibach, S. Wales.

Vosmaer, G. C. J., University, Utrecht. Christ's Collige.

Waldeyer, W., Lutherstrasse 35, Berlin, IV. clo Dr Gadow, Great Shelford, near Cambridge.

Walker, Alfred O. ) Nant y Glyn, Colwyn Bay, Denbighshire.

* , Mrs A. O. King's College.

" J. J., 23, Ranelagh Road, Sheerness. Clare College.

Wallace, R. Hedger (represents Natural History Society of Glasgow), 10, Caithness Road, W. Kensington, W. Trinity College.

Walsingham, The Lord (High Stcward of the University). Merton Hall, Thetford. c/o Professor Febb, Springfield, Newulham.

Warburton, C., Christ's College.

Ward, James ?

* , Mrs J.\} 6, Scluyn Gardcns.

" Rev. J. T., St Foln's College.

" H. Marshall, Cranmer Road.

Wardlaw-Ramsay, Lieut.-Col. R. G., Tillicoultry House, Tillicoultry, County Clackmannan. Clare College.

Watase, S., University of Chicago. Christ's Collegc.

Waterhouse, C. O., British Museum (Natural History), Cromwell Road, London, S.W.

Watson, A. T., Southwold, Sheffield. 4, Free Scliool Lanc. 
Watson, Rev. R. Boog (Switzerland), c/o Dr IV. H. Miller, 5 I, Northumberland Street, Edinburgh.

IVebster, Frank B., Hyde Park, Mass., U.S.A. Bird Bolt Hotel. IVeldon, W. F. R. 30a, Wimpole Street, London, W. c/o A. * " Mrs W. F. R.) Sedgwick, Esq., 4, Cranmer Road.

IVest, G. S. (represents Yorkshire Naturalists' Union). St Fohn's College.

Wherry, G. E., 56, Trumpington Street.

Whipple, R., Instrument Company.

Whitting, F., King's College.

* " Miss F. G., IO, Lexham Gardens, London, W. 5, St Edward's Passage.

Widdicombe, J. H., Downing College.

IViglesworth, L. IV., 42, Gloucester Place, Portman Square, London, IV. Mardalene College.

IVijhe, J. W. Van (Delegate, Netherlands), Groningen. Red Lion Hotel.

Willcox, Miss M. A., Wellesley College, Wellesley, Mass., U.S.A. Neronham College.

Willey, Arthur, I7, Maid's Causeway, Cambridge. Christ's College.

IVilson, Scott B., Heatherbank, Weybridge Heath. Castle Hotel.

IVindle, B. C. A., Mason University College, Birmingham. Fesus College.

Winton, W. E. de, 7, Southampton Row, London, W.C. Trinity College.

Witherby, Harry F., I, Elliot Place, Blackheath, Kent. Trinity College.

Woods, H., St Fohn's Collcge.

Woodward, A. Smith, 4, Scarsdale Villas, Kensington, W.

, B. B., British Museum (Natural History), Cromwell Road, London, S.W.

,

Henry (represents Malacological Society of London), British Museum (Natural History), Cromwell Road, London, S.W. King's College.

M. F., Royal College of Science, S. Kensington.

Wright, E. Perceval, Trinity College, Dublin.

R. Ramsay, University, Toronto. St Foln's College.

Wroughton, R. C. (Delegate, India), c/o Army and Navy Cooperative Society, I, Howick Place, London, S.W. c/o H. M. Plipson, Esq., Straithaird, Lady Margaret Road.

Yerbury, Lieut.-Col. J. W., Army and Navy Club, Pall Mall, London, S.IV.

Yorkshire Naturalists' Union. " Philosophical Society.

Zograff, N. de, Université Impériale, Moscow.

Zoological Society of London.

Zschokke, F. (Delegate, Switzerland), Universität, Basel. Christ's College. 


\title{
REGULATIONS.
}

\author{
I.
}

In accordance with the Resolution of the International Congress of Zoology held at Leyden in r 895 , a Fourth International Congress will assemble at Cambridge in I 898 .

The Congress will open on the morning of Tuesday, August $23 \mathrm{rd}$, and will continue for a week.

II.

The following are Members of the Congress :-

I. The Delegates of Foreign and Colonial Governments.

2. The Delegates of those Societies which organised the first three International Congresses of Zoology.

3. Persons who have paid a subscription of not less than $£ \mathrm{I}^{*}$ to the Treasurers of the Congress, either before or during the Session.

I II.

All persons who enter themselves on the List of Members are understood to agree to the following rules and arrangements.

$$
\text { IV. }
$$

The Congress will include General and Sectional Meetings. The Sections will be:-A. General Zoology. B. Vertebrata. C. Invertebrata (except the Arthropoda). D. Arthropoda.

$$
\text { V. }
$$

The subjects for discussion at the General and Sectional Meetings will be published in the Programme issued by the Executive Committee, which will also contain the titles of the Communications to be made to the several Sections. The titles of the Communications should be sent in good time to the Secretaries, in order that they may be arranged in the most convenient order. No Work or Paper which has been published previous to the meeting of the Congress will be admitted to the Programme; but the Executive Committee have the power to relax this rule in favour of such Papers as may be likely to give rise to important discussions.

\section{VI.}

The names of Officers of the several Sections will be proposed for election at the first General Meeting of the Congress.

* $£ \mathrm{I}=25$ francs $=20$ marks. 
VII.

A Report of the Congress, published under the Direction of the Secretaries of the Executive Committee and the Secretaries of the Sections, will appear each morning. Authors should send a brief summary of their Communications to the Secretaries of the Executive Committee not later than August Ist. In the absence of such summaries, the Secretaries cannot undertake to publish reports.

\section{VIII.}

No alterations in the Programme of the Meetings and Excursions will be admitted, except by the order of the Committee of the Congress.

\section{IX.}

A Report of the Session will be published under the superintendence of the Secretaries of the Executive Committee, and will be supplied, on application, to every Member of the Congress.

$\mathrm{X}$.

All communications during the Congress should be addressed thus :-

The Secretaries of the International Congress of ZOOLOGY,

RECEPTION ROOM,

CAMBRIDGE.

THE FOLLOWING WAS THE PROGRAMME.

The Reception Room (Masonic Hall, Corn Exchange Street), will be open from 9 a.m. to 7 p.m. on Monday, Ang. 22nd, and on the four following days; and from 9 a.m. to I p.m. on Saturday, Aug. $27 t h$.

\section{Monday, August 22nd.}

9 p.m. Reception at the GuILdHall by the Mayor of

11 p.m. Cambridge.

Members of the University and of the Town Council are requested to wear gowns; Doctors and Aldermen, scarlet. 


\section{Tuesday, August 23rd.}

10.30 a.m., at the Gurbdiall. Opening of the Congress by the President. Election of Officers. Receipt of Reports of Committees appointed by the Third Congress, and other business.

2 p.m. Meetings of the Sections.

5.50 p.m. Organ Recital in King's College Chapel.

9 p.m. L Reception by the Vice-Chancellor at Dowving 11 p.m. College.

\section{Wednesday, August 24th.}

10.30 a.m., at the Guildhall. General Meeting of the Congress to discuss the position of Sponges in the Animal Kingdom. The discussion will be opened by Professor Yves Delage, of Paris, and Mr Minchis, of Oxford.

Note. - There may also be Meetings of the Sections.

2 p.m. Neetings of the Sections.

9 p.m. Conversazione in the Fitziwlllial Museum in conjunction with the International Congress of Physiologists.

\section{Thursday, August 25th.}

10.30 a.m., at the Guildhall. General Meeting of the Congress to discuss the origin of Mammals. The discussion will be opened by Professor Seeler, of London, and Professor H. F. OsBokx, of New York.

Note. - There may also be Meetings of the Sections.

2.15 p.m., at the Senate House. The Conferring of Honorary Degrees.

4-6.30 p.m. Garden Party in the Botanic GARDEN of the University.

\section{Friday, August 26th.}

10.30 a.m., at the GUildhall. General Meeting of the Congress to hear an address by Professor HAECKEL, "on our present knowledge of the Descent of Man." The Rt. Hon. Sir Herbert Maxwell, Bart., M.P., will afterwards read a paper "on recent Legislation on the Protection of IVild Birds in Britain."

Nore.-There may also be Meetings of the Sections. 
2 p.m. Meetings of the Sections.

7.30 p.m. Dinner in the Hall of Trinity College. Tickets, price I $5 s$., must be applied for in the Reception Room not later than I p.m. on Wednesday, August 24th.

\section{Saturday, August 27th.}

9.30 a.m., at the GuIldHAll. General Meeting of the Congress to settle the time and place of the Fiftin International Congress.

\section{ARRANGEMENTS IN LONDON FOR THE CONGRESS.}

4 p.m. Reception by the President and Council of the

7 p.m. $\}$ GARDENS in the REgenT's PARK, London. Tea and light Refreshments will be served.

9-11.30 p.m. Reception by the Rt. Hon. Sir JOHN LubBock, President of the Congress, of the Members of the Congress, at the NaturaL History Museum, Cromwell Road.

\section{Sunday, August 28th.}

2.30 p.m. The Natural History Museum, Cromwell to Road, will be open. Tea and light Refresh-

7 p.m. ments will be served to Members of the Congress from 4 p.m. to 6 p.m.

9 p.m. The President and Committee of the Roral Societres' Club, St. James' Street, S.W., will hold a Reception in honour of the Congress (Gentlemen only).

\section{Monday, August 29th.}

Visit to TRING MUSEUM. Visitors will be received by the Hon. WALTER RotHSCHILD, who will entertain them at lunch.

Note, - Notice of intention to visit 'Tring must be given in writing to the Secretaries not later than noon on Wednesday, August 24th. 
Tuesday, August 30th.

His Grace the DUKE OF BEDFORD will be glad if such Zoologists as are interested in the study of the Cervidx will visit his Parks at WobURN on Tuesday, August 30 th. Mr R. LyDEKKER, F.R.S., has promised to conduct the party, which should not exceed in number sixty.

Further information may be obtained by applying to Mr Lydeliker, at the Lodge, Harpenden, Herts.

\section{Monday and Tuesday, August 29th and 30th.}

The Museum of the Royal College of Surgeons will be open to Members of the Congress on production of their tickets. An official of the Museum will be present to receive visitors.

\section{Tuesday, Wednesday \& Thursday, August 30th \& 37st, \&}

\section{September 7 st.}

A Dredging Expedition at Plymoutr with the Director of the Marine Biological Laboratory.

NoTE.-Visitors to the Dredging Expedition should give notice to the Secretaries in writing as early as possible.

The Gardens of the ZoOLOGical Society of London will be open to Members of the Congress on showing their tickets and writing their names in the book at the gates every day, including Sunday, from Thursday, August ISth, to Thursday, September Ist, inclusive.

The Committee of the Royal Societies' Club, St James' Street, S.W., will extend the privileges of Honorary Membership to Members of the Congress (not Ladies), on presentation of their cards of Congress membership, from August I $S$ th to September Ist, inclusive. Members of the Congress making use of the Club must enter their names in the Visitors' Book.

The President and Council of the Linnean Society, Burlington House, Piccadilly, will open their apartments to the Members of the Congress of Zoology from August 27th to September Ist, excepting Sunday, Aug. 28.

The Gardens of THE ROYal ZOological Society of IRELAND will be open to Members of the Congress who visit Dublin on presenting their cards of Membership at the Gate. 
The following Circular was issued at the commencement of the Mecting.

ARRANGEMENTS MADE BY THE RECEPTION COMMITTEE.

\section{Reception Room.}

The Reception Rcom (Masonic Hall, Corn Exchange Street) will be open on Monday, Aug. 22, and on the four following days from 9 A.M. to 7 P.M. On Saturday, Aug. 27, it will be open from 9 A.M. to I P.M.

The Reception Room is the Office at which the Member's or Associate's* ticket must be obtained, and where all enquiries should be made. It contains the Post Office of the Congress, a Writing Room, and an Office where type-writers and short-hand clerks will be in attendance. An Interpreter will be present at certain hours of the day.

The Daily Journal will be issued at the Reception Room each morning, and announcements may be made from time to time concerning matters affecting the arrangements of the Congress.

Members will be able to change Foreign money at the Reception Room on Monday between I I A.M. and 7 P.M. On other days, money may be changed at Messrs Barclay and Co.'s (Mortlock's) Bank, in Bene't Street, between 9 A.M. and 4 P.M. Foreign money will not be accepted in payments made at the Reception Room.

A Guide-book to Cambridge, by the Registrary of the University, with an account of the Museums and Laboratories specially prepared for the use of the Congress, may be obtained at the Reception Room, price one shilling.

\section{Meetings of the Congress.}

Admission to the General and Sectional meetings and to the Senate House on the occasion of the Conferring of Honorary Degrees will be by Members' or Associates' tickets.

The Meetings will be held in the following Rooms unless notice is given to the contrary in the Daily Journal or in some other way.

General Meetings of the Congress, Guildhall (entrance from the Market Place).

Section A. (General Zoology), Guildhall.

Section B. (Vertebrata), Lecture Room of the Physical Laboratory (No. 2 on the plan of the Museums on the Members' tickets).

* Ladies attending the Congress in the company of a Member may become Associates on the payment of ten shillings. This payment entitles them to attend all Meetings and Receptions held in Cambridge. 
Section C. (Invertebrata, excepting Arthropoda), Lecture Room of the Chemical Laboratory (No. 4 on the plan).

Section D. (Arthropoda), Lecture Room of Comparative Anatomy (No. 6 on the plan).

Demonstrations of specimens or apparatus will take place in the Zoological Laboratory or elsewhere, as announced from time to time.

The Museum of Zoology (including the Bird Room), the Museum of Geology (entrance opposite Clare College), the Museums of Human Anatomy, Botany and Mineralogy and the Zoological Laboratory will be open to Members and Associates of the Congress during each day.

\section{Meals.}

It is assumed that Members will breakfast at their lodgings. Luncheon and Dinner will be served at the Corn Exchange from Monday, Aug. 22, to Friday, Aug. 26, on the following terms :-

Luncheon, from I to 2 P.M., two shillings each.

Dinner, at 7 P.M., three shillings each.

The above charges will include beer and lemonade. Wine will be obtainable at prices stated on the wine-card.

\section{Refreshment Tent.}

The refreshment tent, in the grounds of the Museums, will be open for the sale of light refreshments, tea, coffee, beer, etc., from IO A.M. each day.

\section{Receptions, Garden-party, etc.}

Admission to the Mayor's Reception and to the Vice-Chancellor's Reception will be by Member's or Associate's ticket. Members wishing to introduce friends to either of these Receptions should apply for permission as early as possible in the Reception Room.

Admission to the Conversazione in the Fitzwilliam Museum and to the Garden-party in the Botanic Garden will be by Member's or Associate's ticket. A limited number of complimentary tickets, for the friends of Members, will be issued by the Reception Committee. For these, application must be made in writing to the Secretaries of the Reception Committee at the Reception Room. The envelopes containing the applications should be marked on the outside "Conversazione" or "Gardenparty" and must be sent in not later than 5 P.M. on Tuesday. They should be applied for, at the Post Office in the Reception Room, after 9 A.M. on Wednesday. 


\section{Dinner in the Hall of Trinity College on Friday, Aug. 26.}

A Dinner will be held on the last evening of the Meeting in Cambridge, but it will be necessary to restrict the number of tickets issued to 225 .

Application for tickets (gentlemen only) must be made by letter or in person at the Reception Room not later than Wednesday at I P.M., but no tickets will be issued before Tuesday, at 9 A.M. Letters should be addressed to the Secretaries of the Reception Committee, and marked on the outside "Dinner on Aug. 26." Each application must be accompanied by a payment of fifteen shillings, which will include the cost of wine and cigars.

The tickets of those who have applied by letter should be called for at the Post Office in the Reception Room after I P.M. on Thursday, Aug. 25.

\section{VARIOUS OBJECTS OF ZOOLOGICAL INTEREST} WERE PLACED ON VIEW IN THE ZOOLOGICAL LABORATORY.

Among them were-

\section{A. In Biology Class-room.}

I. Mr Assheton.

Specimens illustrating the segmentation of the Mammalian orum (Lepus, Sus, Ovis).

Specimens illustrating the mode of growth of the Vertebrate embryo.

Blastocyst of Onis with twin germinal areas (about 7 days).

2. DR GADOW.

Models illustrating the morphological constitution of the vertebrae in various groups of Vertebrata.

3. MR BUDGETT.

Specimens illustrating the life history of Phyllomedusa hypochondrialis (Cope).

4. Mr Warburton.

Specimens illustrating the means of identifying certain Coleopterous larvae. 
5. Mr BORRADAILE.

Remipes pacificus, Dana. Showing abnormal second antennae.

Pagurus deformis, H. Milne Edwards. A species in which a representative is present of the female genital opening.

Periclimanes parasiticus, 11. sp., parasitic on Linckia.

6. Mr BRINDLEY.

Specimens illustrating reproduction of lost parts in the legs of Blattidac.

7. Dr Sharp.

Specimens from the Haviland collection of Termites.

Various entomological specimens.

8. Mr Stanley Gardiner.

Collection illustrative of various points in the structure and biological relations of Coral Islands.

9. Mr J. J. Lister.

Specimens illustrating the life history of Foraminifera.

io. Prof. Hichson.

The medusae of Millepora.

II. DR HARIIER.

Specimens illustrating the structure of Cephalodiscus and the reproductive phenomena in Polyzoa.

I2. Mr Bateson.

Exhibits illustrating various points respecting Variation and Heredity.

I3. Prof, MacBride.

Preparations illustrating points in the development of Asterina gibbosa and of Amphioxus.

I4. MR SEDGivick.

Specimens illustrating the development of Peripatus capensis.

I 5. Prof. Hubrecht.

Preparations illustrating haematopoetic processes in the placenta of Mammals. 
I6. DR Willes.

Specimens illustrating:

The structure and development of Pcripatius novaebritanniac.

Asymmetron caudatum.

Ptychodera-two species, one of which is new.

Harpa, autotomy of the foot.

Eggs of Nautilus macromphalus.

Adult specimens of Nautilus, including a unique specimen of $N$. umbilicatus.

I7. Mr GRAHAM KerR.

Spermatophore in situ on a female Nautilus pompilius.

Eggs, embryos and adults of Lepidosiren.

i8. Prof. Apáthy.

Specimens illustrating the structure of the nervous system in general, including specimens figured in his recent paper.

19. Prof. Vejdovský.

Specimens illustrating fertilisation of the ovum in Rhynchclinis.

\section{B. In Upper Laboratory.}

20. Mr Rousselet.

Preparations of Rotatoria.

21. DR Heymons.

Specimens illustrating the primary segmentation of the Tracheate body.

22. Prof. Gilson.

New Nematodes from Fiji.

23. Cambridge Scientific Instrument Co.

Various forms of apparatus manufactured by them. 


\section{HONORARY DEGREES.}

The University conferred the Honorary Degree of Doctor of Science upon the following members of the Congress:-Professor A. Dohrn, Professor A. Milne Edwards, Professor E. Haeckel, and Professor A. A. W. Hubrecht.

The Speeches delivered by the Public Orator (Dr Sandys) on this occasion are subjoined.

(I) E Germanis quidam oriundus, patris iucundi filius, laudem ideo maximam est adeptus, quia, Italiae in litore hospitali, orbis terrarum in sinu amoenissimo, vivarium Oceani spoliis reservatum gentibus patefecit, quod quasi aquarum castellum appellaverim, unde doctrinae rivuli in omnes terras late diffluxerunt. Vivarii illius conditorem inter hospites nostros diu numeravimus; eidem alumnos nostros animo laeto commendarimus; ab eodem scientia varia instructos animo grato rursus accepimus. Ipse animalium in partu praesertim explorando laboris immensi prodigus, neque minorem quam in vivario illo condendo fortitudinem ostendit, neque fortunam minus prosperam expertus est. Per totam certe vitam feliciter confirmavit verba $a b$ ipso Plinio, historiae naturalis auctore locupletissimo, vitae suae in die novissimo prope Neapolim pronuntiata :- 'fortes fortuna iuvat.'

Duco ad vos Antoniun Dohrs.

(2) Gallorum e gente insigni, non vicinitatis tantum vinculis nobiscum coniuncta, ad litora nostra advectum salutamus, patris doctrina multiplici ornati filium, quem ipsum talium conventuum non modo praesidem primum sed etiam auctorem principem atque adeo patrem nominaverim. Avium in scientia diu versatus, etiam ex ipsis saxis avium formas latentes quam sollerter elicuit; rerum naturae museo maximo inter Parisienses praepositus, navium bene nominatarum auxilio, etiam Oceani ipsius e profundo rerum naturae veritatem quam feliciter extraxit. Quid non potuit rerum naturae,quid non potuit veritatis amor?

'Merses profundo, pulchrior evenit.'

Duco ad vos Alphonsum Milne Edwards.

(3) Germania ad nos misit non modo maris animalium minutorum investigatorem indefessum, sed etiam operis immensi conditorem audacem, in quo animalium omnium ortum ab origine ultima indagare est conatus. Ergo Caroli Darwinii, alumni nostri magni, praedicatorem inter Germanos magnum salutamus. Salutamus etiam virum, qui in ipsa rerum omnium origine recordatus omnia muta mansisse, 'donec verba, quibus voces sensusque notarent, 
nominaque invenere,' idem in ipsa animalium origine exploranda ob eam inter alias causam laudatur, quod, ingenio vivido praeditus, tot nomina nova invenerit,-quod totiens (ut Horati verbis denuo utar) 'sermonem patrium ditaverit et nova rerum nomina protulerit.'

Duco ad vos virum quem nominare satis est, ERNESTUM
HAECKEL.

(4) Vir Batavorum inter rura genio felicissimo natus, omnium corda ad sese allexit, Europae gentium prope omnium linguas sibi vindicavit, Oceani denique monstra (ut ita dicam) minutissima et tenuissima, quae Nemertea nominantur, accuratissime investiganda sibi sumpsit. Illa vero monstra, si poetis Graecis licet credere, satis antiqua et memoratu satis digna esse constat. Scilicet ipse

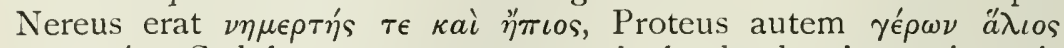
$\nu \eta \mu \epsilon \rho \tau$ '́. Sed haec utcumque sunt, in laudando viro, qui maris monstra illa forma multiplici praedita veracissime descripsit, nihil est facilius quam vera dicere, nihil iucundius quam (ut Homeri

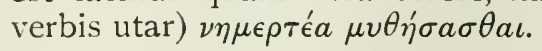

Duco ad ros Ambrosium Arnoldum Willelmum HuBRECHT. 
The Congress was welcomed to Cambridge by the MAYOR at a Reception which he gave in its honour at the Guildhall on Monday, August 22, from 9 to II p.m.

The Congress was opened formally by Sir John Lubbock at the First General Meeting on Tuesday, August 23. 



\section{FIRST GENERAL MEETING.}

TUESDAY, 23 AUGUST, AT THE GUILDHALL AT 10.30 A.Mr.

Chairman : Sik John Lubbock, Bart., M.P., LL.D., D.C.L., F.R.S.

The PREsident delivered the following Address:

My first duty to-day is to welcome our foreign friends who have done us the honor of attending the Congress. I may do so I know on behalf of all English Zoologists. They will I trust find much to reward them for their journey. It will have been to them, as it is to us, and to no one more than myself, a matter of profound regret that Sir IV. Flower, who had been nominated as our President, found himself unable to accept the post. Our regret is the keener on account of the cause, but I am sure we all hope that rest and change of air will secure him a renewal of health. Sir IV. Flower has sent me the following:

MY DEAR LUBBOCK,

$$
\begin{aligned}
& \text { IRELAND, } \\
& \text { August zoth, I8gs. }
\end{aligned}
$$

I shall be much obliged to you if you will take some suitable opportunity of telling the assembled Congress how deeply I regret that I am prevented by the state of my health from taking part in the meeting, and how cordially I wish that all those who attend from abroad may derive much pleasure and advantage from their visit to England, and that this meeting may be the means not only of promoting the advancement of zoological knowledge, but also of increasing the cordial cooperation and good fellowship already happily existing among zoologists of all nationalities.

Under your presidency, I feel sure that the meeting must be a success.

Believe me,

Yours very truly, IV. H. FlowER. 
The first Congress was held at Paris in I889, and was worthily presided over by Prof. Milne Edwards, whom we have the pleasure of seeing here to-day.

The second Congress was held at Moscow in 1892 under the presidency of Count Kapnist, and under the patronage of His Imperial Highness the Grand Duke Serge.

The third Congress was at Leyden in I 895 under the presidency of Dr Jentink, Director of the Royal Museum, and under the patronage of the Queen Regent.

Such meetings are of great importance in bringing together those interested in the same Science. It is a great pleasure, and a great advantage to us to meet our foreign Colleagues. Moreover it cannot be doubted that these meetings do much to promote the progress of Science.

What a blessing it would be for mankind if we could stop the enormous expenditure on engines for the destruction of life and property, and spend the tenth, the hundredth, even the thousandth part, on Scientific progress.

Few people seem to realise how much Science has done for Man; and still fewer how much more it would still do, if permitted.

From a practical point of view, especially as regards our food supplies and the prevention of disease, the future progress of Zoology will doubtless reward us with discoveries of great practical importance.

More students would probably devote themselves to Science, if it were not so systematically neglected in our Schools : if boys and girls were not given the impression that the field of discovery is well nigh exhausted.

We, gentlemen, know how far that is from being the case. Much of the land surface of the globe is still unexplored; the Ocean is almost unknown; our collections contain thousands of new species waiting to be described; the life-history of many of our commonest species remains to be investigated, or has only recently been discovered.

Take for instance the common Eel. Until quite recently its lifehistory was absolutely unknown. Aristotle pointed out that "Eels were neither male nor female and that their eggs were unknown." This remained true until a year or two ago. No one had ever seen the egg of an Eel, or a young Eel less than 5 centimetres ( $1 \frac{1}{4}$ inch) in length. We now know, thanks mainly to the researches of Grassi, that the parent Eels go down to the sea and breed in the depths of the ocean, in water not less than 3000 feet in depth. There they adopt a marriage dress of silver, and their eyes considerably enlarge, so as to make the most of the dim light in the ocean depths. Certain small fishes found in the same regions had been regarded as a special family, known as Leptocephali; these also were never known to breed. It now appears that they are the larvæ of Eels : that known as Leptocephalus brevirostris being the young 
of our common freshwater species. When they get to the length of about an inch, they change into the tiny eels known as 'elvers,' which swarm in thousands up our rivers. Thus the habits of the Eel reverse those of the Salmon.

I will only take one other case, the fly of the King Charles Oakapple so familiar to every school-boy. In this case the females were known; they are of course very common. But no one had ever seen a male. Hartig in 1843 knew 28 sp. of Cynips, and in 28 years' collecting had never seen a male of any of them. He and Frederick Smith between them examined over I 5000 specimens of Cynips disticha and C. Kollari, and every one was a female. Adler, however, made the remarkable discovery that the galls produced by these parthenogenetic females are quite unlike the galls from which they were themselves reared: that these galls produce flies which had been referred to a distinct genus, and of which both males and females were known. Thus the gall-fly from the King Charles Oak-apple, which are all females, creep down and produce a gall on the root of the Oak from which quite a dissimilar insect is produced, of which both sexes occur, and the fecmale of which again produces the King Charles Oak-apple. This is not the opportunity of course to go into details, and I merely mention these facts as another illustration of the surprises which await us even in the life-history of our commonest species.

Many writers have attributed to Animals a so-called "sense of direction." I have attempted to show elsewhere that some species of Ants and Bees certainly have none. Pigeons are often quoted, but the annals of Pigeon flying seem to prove the opposite; they are 'jumped' from one point to another.

We know little about our own senses-how we see or hear, taste or smell; and naturally even less about those of animals. Their senses are no doubt in some cases much acuter than ours, and have different limits. Animals certainly hear sounds which are beyond the range of our ears. I have shown that some of them at any rate perceive the ultra-violet rays, which are invisible to us. As white light consists of a combination of the three primary colors, this suggests interesting color problems. Many animals possess organs apparently of sense, and richly supplied with nerves, which yet appear to have no relation to any sense known to us.

Animals perceive sounds which are inaudible to us, they see sights which are not visible to us, they perhaps possess sensations of which we have no conception. The familiar world which surrounds us must be a totally different place to them. To them it may be full of music which we cannot hear, of color which we cannot see, of sensations which we cannot conceive.

There is still much difference of opinion as to the mental condition of animals, and some high authorities regard them as mere exquisite automata-a view to which I have never been able to reconcile myself. The relations of different classes to one 
another, the origin of the great groups, the past history of our own ancestors, and a hundred other problems, remain unsolved.

We are in fact only on the threshold of the Temple of Science.

Ours is therefore a delightful and inspiring Science.

We are fortunate in meeting in the ancient University of Cambridge, a visit to which is under any circumstances delightful in itself from its Historic Associations, the picturesque beauty of its buildings, and as the seat of a great Zoological School.

The University and the Corporation have given us a most hospitable reception for which we are very grateful.

This morning will be devoted to business, and the receipt of Reports. In the afternoon will be held the first meeting of sections, and to-night the Vice-Chancellor has been good enough to invite us to Downing College. To-morrow morning will be devoted to a discussion of the position of Sponges in the Animal Kingdom, and in the evening there will be a Conversazione in the Fitzwilliam Museum.

Thursday we are looking forward to a discussion on the Origin of Mammals.

Friday we shall have a very interesting programme beginning with a discussion On the Origin of Man.

Saturday morning we shall have to determine the time and place of the next meeting, and then we adjourn to London.

The President and Council of the Zoological Society have invited us to visit their gardens in the afternoon, and in the evening by the kind permission of the Trustees, I am permitted to invite your presence to a party at the Natural History Museum.

The Central Hall only will be open that evening, but on the following day you will have the opportunity of visiting the whole Museum.

In the evening the President and Committee of the Royal Societies' Club hope to have the pleasure of seeing you at their house in St James' Street.

On Monday the Museum of the College of Surgeons will be thrown open, and will be found well worth a visit. Mr Rothschild has also kindly invited us to see his rich Museum at Tring.

On Tuesday, the Duke of Bedford will permit us to visit his collection of Cervida at Woburn, and there will be dredging excursions under the auspices of the Director of the Marine Biological Laboratory at Plymouth, and of Prof. Herdman at Port Erin.

I trust therefore that you will have both a delightful and interesting week, and that our foreign colleagues will carry back with them pleasant recollections of their visit here which may induce them to return again in some future year. 
The PREsident read a letter as follows:

"The Lord Lieutenant of the County has written to Prof. Newton regretting that an accident prevents his attendance at the opening meeting."

And the following telegram was read:

"Mr Justice StoNe regrets inability to attend Congress owing to sudden indisposition. West Australian Society sends greeting. E. A. Stone, 2 Grand Parade, Hastings."

The Vice-Chancellor then welcomed the visitors to the Fourth International Congress of Zoology, saying that he and the Nembers of the University of Cambridge were deeply touched by the action of the International Congress in choosing Cambridge as their place of meeting on the first occasion on which they had met outside the Continent.

The Cambridge scientific school was especially delighted to welcome the distinguished foreign men of science who had come to attend the Congress, and to see the faces of those whose names had been household words to Cambridge students of science from their earliest days. He wished to give utterance to every expression of a hearty welcome on the part of the University.

Prof. A. Milne-Edwards of Paris then gave the following address :

C'est arec un bien grand plaisir que je viens remercier les savants de la Grande Bretagne de la gracieuse invitation qu'ils ont faite aux zoologistes de toutes les nations de se réunir en congrès à Cambridge.

Je serai le fidèle interprète des sentiments de tous mes compatriotes en exprimant à nos hôtes leur vive gratitude.

De France nous sommes venus nombreux; le gouvernement, les universités, les sociétés, les grands musées ont envoyé des délégués. C'est le meilleur témoignage du prix que nous attachons à ces relations cordiales qui fécondent le travail et lui donnent un attrait charmant.

Le congrès zoologique qui a eu lieu à Paris en I889, au moment de l'Exposition universelle, était un essai de nos forces; chaque session nouvelle a apporté une preure de la vitalité de la science que nous aimons. Ce congrès a formé le premier anneau d'une chaîne solide qui s'est continuée à Moscou et à Leyde pour arriver à Cambridge et qui ne se rompra pas.

Nous nous trouvons ici en pays ami et nous avons beaucoup à voir, beaucoup à apprendre. L'histoire naturelle est en honneur dans l'empire britannique. Les musées d'Angleterre sont d'une richesse qui exciterait l'envie, s'ils n'étaient pas ouverts à tous les savants avec une libéralité que nous savons apprécier et dont plusieurs de nous ont largement profité. 
Je n'oublierai jamais la complaisance inépuisable avec laquelle Richard Owen m'accueillait, il y a 40 ans, dans les collections dont il avait la direction. Sir IVilliam Flower et ses collaborateurs ont continué ces nobles traditions.

Dans chacune de vos grandes villes on trouve des musées qui méritent de longues visites et, pour sa part, Cambridge possède des pièces d'une extrême rareté, que l'on chercherait vainement ailleurs.

$\mathrm{Si}$ votre empire colonial est puissant, si vos possessions lointaines sont riches et prospères, c'est que vous avez su en étudier les ressources et que, tout d'abord, vous vous êtes préoccupés d'en bien connaître les productions naturelles. La zoologie a eu sa place marquée dans cette enquête préalable. Sur terre et sur mer, vous multipliez vos recherches et je citerai toujours comme un modèle l'admirable expédition du Challenger et la publication grandiose qui a fait connaître les résultats obtenus.

Nous vivons dans un siècle où l'activité est incessante et où les sciences marchent arec une telle rapidité que ceux qui s'arrêtent sont laissés bien loin en arrière. Elles se renouvellent si vite que les hommes dont les cheveux blanchissent ne reconnaissent plus les horizons où leurs yeux s'arrêtaient dans leur jeunesse. Le besoin des informations rapides se fait de plus en plus sentir. Dans ces congrès, les idées s'échangent, elles courent comme la flamme où chacun peut, sans en tarir la source, chercher la lumière et allumer de nouveaux foyers. Les peuples ferment parfois leurs frontières par d'impitoyables zones douanières, ils décrètent des lois protectrices pour le commerce ou l'industrie, mais les idées s'envolent par-dessus les barrières politiques et se répandent comme l'air que nous respirons. Ces congrès en sont la preuve et la conséquence. Nous rous remercions de nous avoir conviés à prendre part à celui de Cambridge.

Prof. F. E. Schulze then spoke on behalf of the German Delegates attending the Congress:

Im Auftrage der Deutschen Reichsregierung und im Namen der Deutschen Zoologischen Gesellschaft beehre ich mich diese hochansehnliche Versammlung bestens zu begrüssen.

Wie sich bei grossen internationalen wissenschaftlichen Congressen gegeniber den Vereinigungen nationaler Gesellschaften fiir jedes Mitglied die Aussicht auf vielseitige Anregung und Belehrung steigert, so diirfen wir hoffen, dass auch hier die wissenschaftlichen Verhandlungen in erliöltem Maase fruchtbringend sein werden, und zwar besonders da, wo es sich um eine Verständigung oder Einigung über wichtige allgemeine Bestimmungen formaler Art handelt.

In jedem Falle aber haben wir schon jetzt unsern liebenswürdigen Gastfreunden herzlich zu danken fïr die Umsicht und das freundliche Entgegenkommen, womit sie diesen Congress vorbereitet und organisiert haben. 
Professor HUBRECHT spoke as follows :

I have great pleasure in following the delegates from other countries whom we have just listened to, in order to express the gratification we experience at finding ourselves in Cambridge. How well I remember that last general meeting of the Leyden Congress, at which Sir William Flower, whom wc all regret not to see here on account of ill-health, and Prof. Sydney Hickson invited the Congress with kind insistance to come to England for its next meeting, and how this suggestion was accepted with alacrity by all members present.

Leyden and Cambridge have also in former centuries interchanged both men and ideas, and our celebrated countryman Erasmus undoubtedly had a delightful time of it when he was studying in Queens' College and enjoying the beauty and the stillness of this ancient seat of learning more than three hundred years ago. And in the eighteenth century you sent over to us a not less celebrated Englishman of the name of Oliver Goldsmith, who studied in Leyden for a while and thence commenced a tour through Europe, during which his flute stood him in good stead. I am afraid that in the present day Goldsmith's discreet and harmonious instrument has considerably gone out of fashion, and that we have become more accustomed to the sounds of the big trumpet.

True science, however, is most averse to the use of that instrument, and a Congress like this should frankly recognise that its general and sectional meetings do not pretend to do more than bring together, for a friendly intercourse of several consecutive days, fellow workers from the most different parts of the world, who will be all the better prepared for the scientific labour that awaits them at home, when they have here felt the bracing effects of international solidarity and of British hospitality.

\section{Prof. MARSH said :}

Mr President, I thank you sincerely for calling upon me to speak for the United States, and I am sure all of my associates appreciate very highly the privilege of being here, and the cordial welcome you have extended to the Delegates from other countries.

One of my colleagues at Yale University who knows England well has written a book about this country under the title "Our Old Home," and every American who comes here appreciates the sentiment, feels a natural pride in visiting the home of his ancestors, and claims a share in the history and literature of this country, as part of our common heritage.

When this Congress met three years ago at Leyden, my friend, Professor Hubrecht, who has just addressed you, showed me an old church in that city where the Pilgrim Fathers worshipped, and their leader, John Robinson, preached to them after they had left England, and before they emigrated to America. Then, I confess, 
I felt grateful to the Dutch who had received the exiles so kindly, and not quite so friendly to the English who had sent them away. These Pilgrim Fathers, narrow and bigoted as they were, had in them qualities that make successful colonists; and we are greatly indebted for what they dicl towards founding our nation.

But Science knows no nationality, and we now come back to our old home under the most pleasant auspices; and it is an especial pleasure to come to this hallowed shrine of science, Cambridge University, where Whewell, Sedgwick, Darwin, and last, but not least, Balfour, began their scientific work, and laid the foundation of their life-work.

I am sure all my associates who have come to this Congress will do what they can to make it a success, and at no distant day we hope to have the Congress meet in America.

Prof. SALENSKY then spoke on behalf of the Russian Zoologists in the following words:

Je suis très heureux de saluer le Congrès International de Cambridge au nom de l'Académie Impériale de Russie et de lui exprimer les plus cordiaux souhaits de succès.

Prof. MitsukURI spoke on behalf of the Zoologists of Japan :

I need not remind you, Sir, and this audience, of many peculiar phenomena in the distribution of animals and plants. We are told that animals or plants which can hardly be distinguished specifically are found in regions separated by half the circumference of the earth. At the present stage of the world's progress in science, there is a similar peculiarity in the distribution of scientific centres. By far the largest number is amassed on the two sides of the Atlantic, meaning by this, Europe and Eastern America. As we go eastward from Europe, we meet no indigenous growth of science, until we have left behind us the whole of the Asiatic continent. At the extreme eastern edge of that continent, viz. in Japan, there is a new growth, which, we sincerely hope, will become luxuriant in time. I come here as a delegate from that far-off centre. Although it is perhaps not familiar and known to you, the greetings which I have brought with me to this Congress are very hearty. We are taking a great interest in the International Zoological Congress, and are hoping that it will be one of the strongest forces for drawing nations together, and making a brotherhood of the whole world.

Prof. Newton replying as Chairman of the Reception Committee said :

My duty is to thank the previous speakers for the kind terms in which they have spoken of this place and of members of this University past and present; yet among the former there is one whom they have not mentioned, and I think it only befitting the 
present occasion that I should recall his name. At that period which is commonly designated the Revival of Learning there flourished, as all present know, a not inconsiderable number of writers on Zoological subjects. There were the ichthyologists Rondelet of Montpellier and Salviani of Rome, whose works appeared in I 554. There were Bélon of Le Mans and the great Conrad Gesner of Ziirich, whose works appeared the following year. A few years later came Aldrovandi of Bologna, who might indeed be called a compiler, but his was a wonderful compilation. But just ten years before the earliest publication of any of these men, namely in I 544 , there was printed at Cologne the little book I have in my hand, and this I believe to be the first work that appeared on Zoology conceived in anything like the spirit that moves modern naturalists. Its author was William Turner-we have one of that name now in Great Britain, and I wish he were present to hear my remarks on his homonym. Now this William Turner entered this University in I 529 or 30, graduating in 1533 and becoming a Fellow of Pembroke Hall. I am not going to trouble you with the events of his chequered life. It may interest you, Mr President, to know that he was also a botanist, and once sat in the House of Commons, while, having practised as a l'hysician, he died in 1568 a Dean, and is buried in St Olave's, Hart Street, London. Turner, as I said, brought out this little book in I 544 at Cologne, where he was living because (though it is dedicated to the then Prince of Wales, who afterwards became King Edward VI) it was pleasanter for him to be out of this country at the time. It is gratifying to me not only that he was a Cambridge man, but that he was also an Ornithologist, and it seems to me that he was a man of common sense, for he began his subject at the beginning, and wrote a brief and succinct history of the chief birds mentioned by Aristotle and Pliny, adding to it notes from his own experience which shew him to have been a good original observer, and by no means a mere repeater or compiler of other men's words. He travelled much and had a personal acquaintance with Gesner and Aldrovandi-each of whom acknowledges his indebtedness to Turner. I think I may claim him as the first to write and publish a zoological work since the Revival of Learning. I have no wish to dwell unduly on our

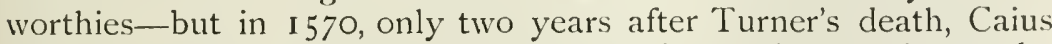
brought out in London and dedicated to Gesner his treatise on the History of the Rarer Animals. Now all this I mention not for the glory of Cambridge, but because it shews intercourse with other nations-we Britons were not so completely cut off from the rest of the civilised world as is often thought, and an International Congress of Zoologists would have been quite possible then.

On the motion of the Secretary, the following gentlemen were unanimously elected Vice-Presidents :

Prof. Milne-Edwards, Dr Jentink, Prof. R. Collett, Prof. Haeckel, 
Prof. von Graff, Prof. R. Hertwig, Prof. Marsh, Prof. Mitsukuri, Prof. Salensky, and Prof. Vaillant.

The following gentlemen were also unanimously elected Secretaries of the Sections :
A. Dr Hoek.
B. Dr Gadow.
C. Dr Plate.
D. M. Janet.

The Reports of the Committees were then taken.

I. RAPPORT SUR LES PRIX PAR LE PROF. R. BLANCHARD, SECRÉTAIRE GÉNÉRAL DU COMITÉ PERMANENT.

Messieurs,- Le Congrès de Moscou, en I 892, a prélevé sur les dons qui lui avaient été faits gracieusement par S. M. l'Empereur Alexandre III et par S. A. I. le Tsarévitch des sommes destinées à la fondation de deux prix triennaux. Il a été décidé que le capital resterait entre les mains du trésorier de la Société impériale des amis des sciences naturelles de Moscou et que cette Société décernerait aux lauréats soit une somme d'argent correspondante aux intérêts produits par ce capital, soit une médaille d'or de même valeur. Il a été décidé en outre que l'un des prix serait exclusivement attribué au Congrès international de zoologie, tandis que l'autre serait attribué alternativement à ce même Congrès et au Congrès international d'anthropologie préhistorique.

Conformément à ces résolutions, la Commission internationale des prix s'est constituće comme suit :

Président-M. le Prof. Milne-Edwards, membre de l'Institut, président du Comité permanent du Congrès.

Secrétaire-M. le Prof. R. Blanchard, secrétaire général du Comité permanent.

Membres-M. le Dr. Jentink, directeur du Musée royal d'histoire naturelle des Pays-Bas; Mr R. Bowdler Sharpe, du British Museum; M. le Prof. Studer, de l'Université de Berne; M. le Prof. Zograf, de l'Université de Moscou.

A cette liste, élue à la suite du Congrès de Moscou est venu s'ajouter ultérieurement le nom de Sir William Flower, directeur du British Museum.

Le Congrès de Leyde, en I 895 , a décerné pour la première fois le prix de S. A. I. le Tsarévitch, prix désigné désormais sous le nom de prix de S. M. l'Empereur Nicolas II. Le lauréat a été M. le 
Dr. Scharff, du Musée d'histoire naturelle de Dublin. Cette année, nous devons décerner tout à la fois le prix de S. M. l'Empereur Alexandre III et le prix de S. M. l'Empereur Nicolas II.

Peu de temps après le Congrès de Leyde, la Commission internationale des prix s'est mise d'accord pour arrêter le programme du prochain concours. Les questions choisies ont été les suivantes:

Pour le prix de S. M. l'Empereur Alexandre III : Étudc sur lcs Ruminants de l'Asie centralc;

Pour le prix de S. M. l'Empereur Nicolas II : Étude zoologique ct physiologique d'un groupe d'Invertébrés marins.

La plus large publicité a été donnée au programme du Concours: l'insertion en a été faite dans les publications de la Société zoologique de France, dans la Revue scientifique, dans la Revuc générale des sciences, dans la Nature, dans Nature, dans Natural science, dans le Zoologischer Anveiger, dans le Zoologisches Contralblatt, dans le Biologisches Centralblatt, dans le Monitore zoologico italiano, etc., en un mot, dans les périodiques qui se trouvent le plus communément entre les mains des zoologistes.

Néanmoins, le nombre des candidats est demeuré très restreint. La Commission n'a reçu qu'un seul mémoire pour chacun des deux prix. Elle exprime le regret qu'un plus grand nombre de candidats ne se soient pas présentés et souhaite qu'à l'avenir les prix décernés par le Congrès soient l'objet d'une compétition plus active.

En réponse à la question posée pour le prix de S. M. l'Empereur Alexandre III, la Commission a reçu un important mémoire manuscrit et anonyme, portant la devise Natura duce.

L'auteur a certainement vécu sinon dans l'Asie centrale, au milieu des nombreux troupeaux de Ruminants qui errent dans les steppes, tout au moins au milieu de collections zoologiques renfermant un grand nombre de ces animaux. Il connaît fort bien les espèces, les races, les variétés qui peuplent ces régions désolées et nous en donne une description zoologique fort intéressante; il discute les différentes espèces, démontre l'insuffisance des caractères invoqués par divers auteurs pour établir certaines coupes génériques ou spécifiques; il compare les spécimens du Muséum de Paris à ceux du British Museum ou du Musée zoologique de Saint-Pétersbourg. Par une critique serrée, il fixe la synonymie souvent fort embrouillée d'animaux dont peu d'exemplaires sont connus et dont les descriptions souvent insuffisantes ou contradictoires sont d'une interprétation difficile. L'auteur décrit ainsi 22 espèces de Ruminants. Son mémoire est accompagné de cartes indiquant d'une façon très précise la distribution géographique de ces différentes espèces.

Le mémoire en question élucide un grand nombre de points très controversés; il fait faire un progrès sérieux à la connaissance des Ruminants asiatiques et mérite d'être récompensé par le Congrès. Aussi la Commission internationale des prix a-t-elle 
l'honneur de vous proposer à l'unanimité de décerner à ce travail le prix de S. M. l'Empereur Alexandre III.

Le candidat qui s'est présenté pour le prix de S. M. l'Empereur Nicolas II est M. le Dr. Emile Hecht, préparateur de zoologie à l'Université de Nancy. Il nous a adressé un intéressant travail intitulé "Contribution à l'étude des Nudibranches." Ce travail, orné de 5 planches doubles, a été publié à la fin de l'année I 895 dans les Mémoires de la Société zoologique de France. L'auteur y expose d'une façon attachante toute une série de recherches et d'ingénieuses expériences qu'il a faites sur divers Nudibranches des côtes de France. Il s'est surtout appliqué à déterminer les conditions physiologiques et histologiques des changements de coloration dont ces animaux sont coutumiers, dans le but d'adapter leur couleur propre à celle du milieu ambiant. Chemin faisant, il décrit toute une série d'appareils histologiques qui concourent à ce but ou à d'autres fonctions encore peu connues.

Considérant que la partie zoologique, dans le sens descriptif du mot, n'occupe qu'une place restreinte dans le mémoire de M. le Dr. Hecht, l'un des membres de la Commission a pensé qu'il n'y avait pas lieu de décerner le prix, tout en reconnaissant d'ailleurs le mérite très réel du travail présenté. Tous les autres membres de la Commission sont d'accord pour reconnaître que la question était posée en de tels termes, que les candidats pouvaient à leur gré développer soit la partie zoologique soit la partie anatomique de leur travail. Dans ces conditions, la Commission à l'honneur, à l'unanimité moins une voix, de vous proposer de décerner à M. le Dr. Hecht le prix de S. M. l'Empereur Nicolas II.

Les conclusions du rapport de M. le Prof. R. Blanchard sont mises aux voix et adoptées à l'unanimité.

The President then opened a sealed envelope, and read a card bearing the name of $\mathrm{E}$. DE POUSARGUEs, Préparateur au Muséum d'Histoire Naturelle, who was declared to be the winner of the prize.

En conséquence, M. E. DE Pousargues est proclamé lauréat du prix de S. M. l'Empereur Alexandre III, et M. le Dr. E. HEcht lauréat du prix de S. M. l'Empereur Nicolas II.

II. Dr Stiles made a statement regarding the Proceedings of the Committee appointed to consider the Laws of Zoological Nomenclature and their Report, and it was then moved by $\mathrm{Mr}$ SCLATER and agreed,

"That the Report be referred for further consideration to the Committee, with power to add to its number."1

1 To this Committee the Executive Committee referred a report on the Nomenclature of Lepidoptera by Mr J. Hartley Durrant (see Appendix). 
Conformément à cette décision et en l'absence de M. le Prof. J. V. CARUs, retenu à Leipzig par une indisposition, les quatre autres membres de la Commission internationale de la nomenclature zoologique, MM. R. BLANCHARD, JENTINK, SCLATEK et IVARDELl STILES, se sont réunis hors séarce et ont choisi dix personnes pour faire partie avec eux de la susdite Commission. Celle-ci comprend donc désormais quinze membres, savoir :

R. Blanchard (Paris).

J. V. Carus (Leipzig).

R. Collett (Christiania).

R. Horst (Leyden).

F. A. Jentink (Leyden).

Von Merenthal (Berlin).

Howard Saunders (London).

F. E. Schulze (Berlin).

P. L. Sclater (London).

D. Sharp (Cambridge).

E. Simon (Paris).

L. Stejneger (Washington).

C. Wardell Stiles (Washington).

Th. Stüder (Berne).

R. Ramsay Wright (Toronto).

Cette Commission de quinze membres est chargée de centraliser, de discuter et d'élaborer toutes les questions relatives à la nomenclature zoologique. Elle se réunira en 1900 dans une ville de l'Europe continentale et présentera au Congrès de rgor un rapport définitif sur la question.

III. Dr P. P. C. HoEk then reported that the International Postal Commission had agreed to very favourable terms for the transmission of specimens of Natural History. 


\title{
SECOND GENERAL MEETING.
}

\author{
Wednesday, August 24th.
}

General Meeting of the Congress at ro.30 a.m., Professor NEWTON in the chair.

The Secretary read a letter from the German Ambassador in London announcing that the Imperial Government had appointed Privy Councillors of Government and Members of the Royal Academy of Sciences, Professor Dr Möbius, Director of the Zoological Collection in the Natural History Museum at Berlin, and Professor Dr Franz E. Schulze, Director of the Zoological Institute of the Berlin University and President of the German Zoological Society, to be Delegates of the Royal Prussian Department of Education at the fourth meeting of the International Congress of Zoology. Also Privy Aulic Councillor Professor Dr Wilhelm Blasius to be a Delegate of the Brunswick Government, and Professor Dr Kraepelin, Director of the Natural History Museum at Hamburg to be the Representative of the Senate of Hamburg at the Congress.

A congratulatory telegram was received on 23 August from the Vice-Rector of the University of Moscow.

Professor Dr Franz E. Schulze having taken the chair, Professor Yves DeLAGE opened a discussion on the position of Sponges in the Animal Kingdom with the following remarks:

Having been selected by the committee to open the discussion, it would perhaps have been my duty to give a general account of the question. But, the subject being very wide, I beg leave to limit my share in the discussion to one point, which, single as it is, seems to me to answer the question, and which my own researches have perhaps a little entitled me to treat. I am sure that the other points will be treated far better by others, and I hope that the so interesting historical part will be developed by Mr Minchin, who has published a very accurate paper on the subject.

If the question were only to assign the position of Sponges in the series of the animal forms, it would be very easy to answer it. 
Undoubtedly, their place is above the Protozoa, among the Metazoa, under the Coelenterata. The difficulty is to say if they are to be placed as a class at the foot of the phylum Coelenterata or are to be raised to the dignity of a phylum; and whether, from a phylogenetic point of view, they have taken their origin from the Coelenterate branch of the genealogical tree, or if they arose independently from its stem, forming, as well as the Colenterata, a main branch of it.

As we know nothing of this hypothetical tree, it is better to set it aside for the moment and to discuss only the taxonomic problem.

Here, the difficulty is that we want a criterion of the value of taxonomic characters. We lack means to establish a relation between the importance of the zoological characters and that of the taxonomic groups.

That is not a difficulty peculiar to the Spongida. It is the same throughout the animal kingdom. We are always at a loss to decide if a given character is fit to determine a phylum or a class, a class or an order, an order or a family, a family or a genus, to say nothing of the intermediate groups.

Were it a matter of fact, that more accurate observations would afford decisive arguments, we could hope to settle the difficulty. But, it is not so. We all agree as to what are the differences and the likenesses between the Spongida and the Coelenterata. But, to decide if these differences oblige us to separate them in different phylums, or if these likenesses permit us to put them together in the same phylum is a matter of taste. For instance, the Spongida have pores, have a true mesoderm, but want tentacles and nematoblasts; the Colenterata have no pores, nor true mesoderm, but possess tentacles and nematoblasts. All agree to recognise those characters. But are they characters of classes or of phylums? Who can say? Where is the touch-stone? We could discuss the subject during all the week without coming to a conclusion. The cause is that taxonomy is a subjective matter; and it is as easy to settle a subjective problem by means of objective arguments as to open a hole in water by throwing stones in it.

Moreover, practically, there may be means to solve the difficulty.

If the adequate value of the differences fit to characterize the various taxonomical groups is impossible to fix with precision, yet, all zoologists agree to admit that there is an average value of the importance of characters, required to determine a given group ; and when this importance is evidently far beyond what is necessary, there is no doubt that it is sufficient. For instance, nobody could think of putting in the same phylum two groups whose important organs as the nervous system or the excretory apparatus are built on quite different patterns.

So the problem may be reduced to this:

Are there to be found between the Spongida and the Colenterata 
such differences that-though we remain nuable to point out the precise value of the charactcristics of phylums-ive conld nevertheless be sure that these differences are more important than are required to characterize different phylums?

I think we may answer Yes! Such differences are to be found in the development.

If you examine the common larval form of a calcareous Sponge, the one known by the name Ampliblastula, you will find nothing puzzling in it. There is an upper part composed of cells long, slender, compressed, bearing each of them a long flagellum, and containing a pale cytoplasm devoid of food granulations. The under part, on the contrary, is formed of cells big, roundish, devoid of flagellum and abundantly furnished with granular food particles which make their cytoplasm dark. When you follow this larva in its development from the egg, you see that this egg, after having been segmented in two meridional planes into four equal blastomeres, is, at the third stage, divided in a transverse plane into two sets of cells, one upper of four small protoplasmic cells and one inferior of four large cells, rich in food yolk. The former set gives rise, by an active process of division, to the flagellated part of the larva, while the cells of the inferior group divide more sluggishly to give the granulated part of the larva.

This being so, I suppose that you are (what is really the case) very learned zoologists, perfectly acquainted with the general subject in embryology, but (what is not the case) knowing nothing of the development of Sponges, and I say: "Please, tell me where is the ectoderm, where is the endoderm, and try to foresee what part of this blastula will be invaginated to form the digestive epithelium, what part will remain outwards to form the skin?" Surely your answer will be: "The flagellated layer is the ectoderm, the large, granulated cells are the endoderm and will invaginate themselves in the former."

And yet it is just the contrary!

Were it the larva of any other animal, you were right; it being the larva of a Sponge, you are wrong. The flagellated cells get inside to form the digestive epithelium, and the granulated cells remain outwards to form the epidermis.

In the Coelenterata, the invagination takes place in the same normal way as in the other Metazoa. In the Spongida, the invagination is reversed.

Is it not that such a difference as this is more important than that required to characterize a phylum?

It seems that there could be no discrepancy of opinion in such a case as that.

However it is not so. Zoologists, generally, do not admit this inversion of the normal invagination which seems so evident. They prefer to take another course and to admit that the invagination takes place in the normal way, giving the name of endoderm to 
the invayinated layer, and laying no stress on the fact that the invaginated layer shows the characters of an ectoderm and vice versa.

There was indeed a strong reason to do so. This reason was that in the siliceous Sponges, which are far more numerous than the calcareous, the flagellated layer was believed to form the epidermis of the grown-up animal, and the granulated cells its digestive epithelium; and that it seemed impossible to assume that a difference could exist between such kindred animals as calcareous and siliceous Sponges in so important a feature as the relation between the organs of the adult and the layers of the embryo.

Yet, doing so was by no means to get rid of the difficulties. There still remained that the layer named ectoderm in the calcareous Sponges had the histological characters of the one named endoderm in the siliceous, and vice versa, a difference which remained unexplained.

Your celebrated embryologist, Francis Balfour, had a prophetic view of the matter when he wrote: "Considering the difficulties of observation, it appears better to assume..... that some observations are in error, rather than that there is a fundamental want of uniformity in development amongst the Spongida."

I have been so fortunate as to show the truth of the idea and to demonstrate that the course of the development is fundamentally the same in the siliceous as in the calcareous Sponges. In the former as well as in the latter, the flagellated cells get inside to become the choanocytes and the granulated cells pass outside to form the epidermis, a discovery which has been verified many times since by other zoologists, WELTNER, NÖLDEKE, and above all by O. MAAS, whose extensive and accurate researches have very much extended and improved our knowledge on the subject. Recently Mr Minchin in Leucosolenià and O. MAAS in Oscarella have succeeded in finding that these Sponges, which remained yet as exceptions to the general rule, in reality develop according to the same law as the rest of the Spongida.

Now the matter is settled in such a way that the following conclusion cannot be gainsaid: the layer which in lavial Sponges has the histological characters of an ectoderm has the evolution of an endoderm by becoming invaginated and forming the digestive epithelium; and the layer which has the histological characters of an cudnderm evolves as an ectoderm by remaining or passing ontside and forming the epidermis of the adult.

I lay stress on this that, expressed in those words, the fact is above all discussion. And I say again: is not such a difference important enough to check all attempt to place the Spongida in the same phylum as any other Metazoa, and especially as the Colenterata?

So, we could stop here.

But, there remains a last question. We have just seen that 
the layer showing the characters of an endoderm evolves as an ectoderm and vice versa. 'Thence, two hypotheses are possible: either the invagination has been reversed, each layer keeping its normal histological characters, or the invagination takes place in the normal way, the layers having interchanged their histological characters. Let us examine which of these is the best.

The last one is supported by nothing. Neither in my mind nor in the literature can I find the least reason to admit such a disguise of the layers.

However, Professor PERRIER from Paris-without indeed even attempting to give an explanation of the disguise of the layershas raised against my theory an objection which, were it of value, would come in support of this hypothesis. According to Professor Perrier, the principle of connexions of Is. GEOFFror SaINT HILAIRE obliges us to consider as endoderm the inner layer and as ectoderm the outer one throughout the animal kingdom, be the other characters as they will. But, we have seen that in the siliceous Sponges, the layer which is inside in the adult is outside in the larva, and that which is inside in the larva is outside in the adult. Therefore the principle is necessarily wrong in one of the cases, either in the larva, or in the adult. Hence it has no decisive value and gives no support to the theory ${ }^{1}$.

The principle of connexions is indeed a very valuable one, but it has been misunderstood by Professor Perrier. The real connexion of the layers depends not upon their situation inside or outside of the gastrula but upon their continuity at the equator of the blastula or at the blastopore of the gastrula. Invagination is a secondary process which depends on physiological causes and has nothing to do with the primitive connexion of continuity.

On the contrary, it is easy to understand that the invagination could have been inverted by various causes, perhaps not very significant in themselves, such as an increase or decrease of the rigidity, of the pressure, of the rate of growing, in one or in another part of the blastula. Some well-known experiments of HERBST, DRIESCH, GURWITSCH have demonstrated that a few thousandths of a salt of lithium mixed to the water where Pluteus-embryos of Sea-urchins are nursed, or even a temperature some degree higher, is enough to cause the invagination to lack or even to reverse itself outwards when already produced in the normal way.

Another fact comes in support of my idea. One can often observe the blastula of some calcareous Sponges invaginating itself, now in one way then in the reverse way, as if trying different

1 I beg leave to reply in advance to an objection which is likely to be raised by my honourable opponent. It is of no use to say that the larve of the siliceous Sponges have been modified by Canogenesis or such other factor of evolution. If the principle of connexions, such as it is understood by Professor Perrier, has been once defective, it can be so twice; if it has been mastered by Crenogenesis, it can have been checked by the unknown cause of the inversion of the invagination in the Spongida. 
directions before selecting one; which indicates that some trifling (although constant) cause can decide it to choose the way which it finally does adopt.

In Sycandra, one of the calcareous Sponges, before the larva is hatched, it is known that it is invaginated in the normal way; during a transitory stage named psendogastrula. In the common theory, this stage is rather puzzling and no satisfactory explanation has been given of it. In my theory, it is quite clear, being only an atavistic reproduction of the normal invagination.

So, we may characterize the Spongida in the following manner: what in the larva of the Spongida has the histological characters of an ectoderm, viz. the flagcllated cells, is really the cctoderm; what has the characters of an endoderm, viz. the gramulated cells, is rally the cndodem; but, the invagination is rcversed, the cctoderm being invaginatcd into the endoderm to form the chuanocytes, i.e. the digestive epithclium, while the endoderm remains (Calcarca) or passes (Silicca) outside to form the skin. And I say for the last time: is not that a character more important than is strictly necessary to mark off the Spongida as a distinct phylum among the Metazoa, sharply distinguished not only from that of the Coelenterata, but also from any other in the animal kingdom?

Now if, trying to advance more deeply into the subject, we turn to the phylogenetic point of view, we must put the question: When have the Spongida parted from the Metazoa?

I am of the opinion that we have no means to solve such questions with certainty, and that imagination plays by far too large a part in our attempts to establish the genealogical tree. But if we refer to the only test of the matter we can have, that is, to the embryological data, we have some right to suppose that the Spongida did keep up with the other Metazoa only during the few stages corresponding to the ontogenetic evolution from the egg to the blastula and have parted free before the gastrula stage.

The Spongida are a main, although small, branch arising directly from the stem of the genealogical tree, independently of the branches of the Colenterata and of the other Metazoa.

The discussion was continued by Mr E. A. MINCHIN, who laid on the table some letters of Dr Dobie, substantiating his claim to share with Dujardin the honour of having first recognized the animal nature of Sponges; the following is an abstract of $\mathrm{Mr}$ Minchin's remarks.

I. Historical. There is no group of organisms whose sy'stematic position is so much disputed, at all periods as well as at the present day.

Plants or Animals? Up to the end of the first half of the Igth century, it was still a matter of dispute whether sponges 
were plants or animals; this controversy was laid to rest by the discovery of cilia by Dujardin (I84I) and Dobie (I850), as well as by subsequent researches of Lieberkiihn and Carter. The animal nature of sponges was thus established, but their position was still uncertain.

(a) They were regarded by earlier writers as Protozoa, especially after the discovery by James Clark of the collar cells and their great resemblance to Choanoflagellata.

The Protozoan theory was soon, however, given up, since it is irreconcileable with any rational definition of Protozoa; Sponges are composed of tissues, which are made up of differentiated cells.

(b) They were compared by Leuckart (i 854) to polyps without tentacles, and hence regarded as true coelenterates; the same idea was expressed by Miklucho-Maclay and strongly advocated by Haeckel, who extended the comparison not only to the adult organisms but also to the larvæ. In both groups, it was supposed, there is a two layered larva, composed of "exoderm" and "entoderm," from which two layers arose, the dermal and gastral layers, respectively, of the adult.

The Cœlenterate theory became dominant, with the modification of Schulze, who distinguished between the epithelial and the skeletogenous portions of the dermal layer and hence made out three layers in the body wall, ectoderm, mesoderm and endoderm. This theory, however, found dissentients; two other views were advocated.

(c) That Sponges were Metazoa but not Colenterates; opinions differed as to the question of the homology of the germ layers. Balfour, Götte, Vosmaer, Maas.

(d) That Sponges were not even Metazoa, but an independent phylum descended separately from Protozoa; Bütschli, Sollas, Delage.

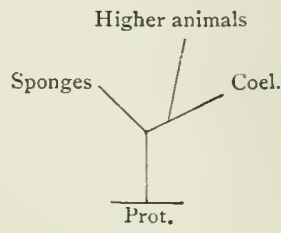

(c)

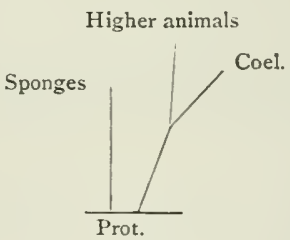

(d)

II. Present Position of Question lies between b, $c$ and $d$.

Are Sponges Cœlenterates? If not, what are they? There are two methods of attacking the question.

Ist. The Comparative Anatomy of the Adult forms.

2nd. The Embryology and especially the all important question of the germ layers and the share taken by them in building up adult. 
As a simple type may be taken the development of Clathrina blanca (= Guancha blanca Miklucho-Maclay, Ascetta blanca Haeckel).

The Segmentation is total and regular (Metschnikoff). The Blastula becomes oval, and the blastomeres are transformed into columnar flagellated cells all round, except at one pole (posterior), where there are two large granular cells, which are simply undifferentiated blastomeres.

The Larva is set free and swims for 24 hours; meanwhile an inner mass arises by modification of some of the cells of the outer layer. Here and there a flagellated cell retracts its flagellum, becomes amœboid, and passes into the interior. By the end of the larval period the cavity becomes filled up, and the larva in consequence shrinks in size.

The Larva fixes by its anterior end; the inner mass bursts out, and forms an epithelium which surrounds the flagellated cells; only a few cells of inner mass remain in the interior, to become the first porocytes. The posterior granular cells break up into a great number of minute cells (Ist day).

Next the porocytes come together in the centre and a cavity appears between them, the gastral cavity, from which the flagellated cells are at first excluded. At the same time cells of the dermal epithelium immigrate to form the skeletogenous layer (2nd day).

The gastral cavity enlarges, so that the porocytes become separated one from another, and the cavity becomes bordered by the former ciliated cells, which now acquire collars and flagella. The porocytes migrate outwards, and form the pores. The osculum is formed by a breaking through of the body wall (3rd-5th day). The minute cells which arose from the breaking up of the posterior granular cells of the larva become the wandering cells, amœbocytes.

Note in the above development,

(I) The first differentiation is into ciliated cells and amcbocytes.

(2) The second differentiation is brought about by a modification of some of the ciliated cells to form an inner mass, the future dermal layer ; the unmodified ciliated cells give rise to the gastral layer.

(3) In the Metamorphosis, the reversal of position of the larval layers.

(4) The gastral cavity is at first surrounded by the porocytes, just as in the adult when a completely contracted sponge is becoming expanded.

(5) There is no true mesoderm, but only a functional differentiation of the Dermal Layer into an epithelial (contractile) layer and a skeletogenous parenchyma.

(6) The origin of the amœbocytes, and hence of the sexual cells from the posterior granular cells, in other words, from simple blastomeres. 


\section{Conclusions.}

The larval development shows that Sponges cannot be considered Colenterates. Such a comparison must start either from the larva or the adults.

If it be based on the larvæ, then neither the architecture nor the composition of the adults is in any way comparable.

If it be based on the adult structure, then the larval development of Sponges is altogether anomalous and not similar to any other known development, since the ectoderm is internal, surrounded completely by the endoderm.

There are two possible views:

(I) That the sponge larva is comparable to a Coelenterate planula, after which point the groups must be supposed to have diverged; then sponges would be Metazoa, but an independent phylum.

(2) That no comparison is possible between either the larvæ or the adults, but sponges are to be regarded as independently developed from Choanoflagellata.

The latter view is most probable. In favour of it :

(a) In the adult, the remarkable collar cells, not known elsewhere except in Choanoflagellata. When those cells are not functional their collars are retracted.

(b) In the larva, a blastula stage at first directly comparable to a Choanoflagellate colony composed of $(\alpha)$ collar cells in which the nutrition is in abeyance, and consequently the collars are withdrawn, $(\beta)$ reproductive cells.

All the tissues of the sponge arise, by a series of modifications from $(\alpha)$, those which are least modified becoming the collar cells of the adult.

The discussion was continued by Professor Dr ERNST HAECkEL, who was followed by Dr VOSMAER, who said:-

Mr President, Ladies and Gentlemen,-Some time ago I was requested by the Subjects Sub-committee to take part in the discussion about the question of the position of Sponges in the Animal Kingdom. It was my firm intention to decline this request for reasons which will soon be obvious to you. If I, nevertheless, claim your attention, it is only because some of my friends insisted that I should give my opinion in the matter.

The chief reason that I first declined, is simply this, that I am thoroughly convinced that it is not possible to say more than-ice do not know.

I am afraid it is not very pleasant for those who are not especially interested in Sponges to hear a man, who is more or less a specialist, proclaim his ignorance; but I beg you to believe that it is still less pleasant for himself.

I think we may safely say that Sponges do NOT belong to the 
Protozoa. This does not involve, however, that Sponges are Metazoa, in the ordinary sense. Biitschli, Sollas and lately Delage are of opinion, on different grounds, that Sponges belong to a separate phylum. My opinion is, that if we HAvE to classify, we must either bring them to a separate group of the same value as the Metazoa, or consider them as Metazoa, but forming a separate Class, like Colenterates, Echinoderms, etc.

I have just published, in collaboration with my friend Pckelharing, a paper in which we draw attention to the fact, which may be of value for classification, that in Sponges the cells seem not connected in a way so as to enable them to conduct stimuli from one cell to another, in other terms that they are destitute of the principle, the significance of which culminates in nervous tissue. But this is a mere suggestion, and I repeat once more, that $I$ believe we cannot yet answer the question about the position of Sponges.

\section{Dr Vosmaer was followed by Mr SAville KENT, who said :-}

It being desirable, I presume, that this sponge question should be examined and discussed from every available standpoint, I would crave leave to advocate a re-opening and fuller investigation of the problem in association with its formerly-propounded, but for a long time practically-abandoned, Protozoic interpretation.

It is now some 16 or more years since, when rnaking a particular study of the Infusoria, that I devoted a little attention to sponge organisation. It was about this time that the late Prof. H. James Clark, of Boston, U.S.A., made known his discovery of a hitherto undescribed modification of the Flagellate order of the Protozoa, whose most important distinction consisted of the possession by its nembers of a remarkable hyaline funnel-shaped extension of the sarcode substance which encircled the base of the flagellum. This structure he appropriately named the collar, and gave to the Flagellate Protozoa that possessed it the title of collared monads. Concurrently with the description of this species, Prof. Clark announced that he had found that the flagelliferous cells that line the interstitial cavities of the various sponges he examined were similarly constituted, and on these grounds he maintained that sponges must be regarded as aggregated colony-stocks of collared monads. The observations recorded by Prof. Clark were to a large extent confirmed in this country by $\mathrm{Mr}$ Carter. A similar confirmation attended my own investigations in the same direction, and I was also fortunate in adding very considerably to the number of four species only that were originally recorded by $\mathrm{Mr}$ Clark. The late Prof. Stein almost concurrently published a monograph of the flagellate Infusoria, which also included several newlydiscovered collared types.

It fell to my lot to have the privilege of first interpreting the true nature and function of the hyaline collar-like structure that is 
common alike to the independent collared monads and the essential flagelliferous sponge elements: how that this structure is an exquisite funnel-like trap for the arrest of food particles, and how within its substance a continuous outward and inward flow of its constituent sarcode is maintained, as obtains in the attenuate pseudopodium of Gromia and other typical Rhizopods. In addition to this, each of these collared elements, whether belonging to the independent monads or to the sponge aggregations, were found to possess posteriorly two or more very distinctly-defined contractile vesicles, which dilate and collapse with rhythmical regularity, after the manner of the corresponding vesicles or rudimentary excretory organs that are characteristic of all of the ordinary flagelliferous and other Infusoria.

Now, however much the sponge body may be complicated by the development of intricate canal systems or by spicular or other skeletal elements, which are actually non-essential, the very fact of the possession in common by the sponges and by the flagelliferous Protozoa of these very peculiarly modified cell elements, which are found nowhere else throughout the animal kingdom, must, I think, carry with it the assumption that a very close phylogenetic relationship subsists at all events between these two groups.

The tendency of late years has been to correlate sponge structures with Colenterata, and unfortunately none of the many eminent authorities who have decided in favour of this interpretation have given any special attention to the life-history and organisation of that peculiar group of the Collared Flagellata to which the sponges are apparently related. Since, in fact, the regretted deaths of Stein, Carter, and H. James Clark, the field of investigation opened up by their labours has been practically abandoned, and, so far as I have been able to ascertain, there is but a single authority who has made a critical examination and fully verified the facts recorded by myself eighteen years ago concerning the precise function and significance of that exquisitely translucent collar-like structure that is shared by both the collared monads or choano-flagellate, and the essential sponge elements. That authority is an American, $\mathrm{Mr}$ S. Foulke Andrews, and the confirmation referred to is contained in a very elaborate and painstaking essay entitled "The Living Substance," published at Boston so recently as the year I $\$ 97$.

What I would urge as most reasonable is, that this vexed problem of sponge affinities should be fairly approached and examined from a protozoic as well as from a colenterate basis, and that those undertaking the task should familiarise themselves with both the collar-bearing flagellata and the corresponding sponge elements in their living state.

So far, all of the many elaborate and exquisitely-rendered representations and descriptions of sponge tissues have been derived from preserved specimens in which the very characteristic life aspects and contours of the essential collar-bearing elements are 
altogether eliminated or distorted. What I would urge is the abandonment of the pickle bottle and the recourse to a thorough and painstaking investigation of the living aspects and phenomenon of the structures that have now for so long and yet so vainly sought for a resting-place at the hands of biologists in the zoological system.

I am sanguine enough to anticipate that the results of such a thoroughgoing investigation will proceed a long way towards releasing the sponges from that ill-deserved position of doubtful parentage and relationship which it is scarcely to the credit of biologists they are permitted to occupy in this penultimate year of the nineteenth century.

Prof. F. E. Schulze bezweifelt, ob sich nach den jetzt vorliegenden Resultaten der Embryologie die systematische Stellung der Spongien sicher bestimmen lässt und ist der Ansicht, dass man einstwveilen die Spongien als radiaere Coelenteria neben die Cnidaria zu stellen hat. 


\section{THIRD GENERAL MEETING.}

Thursday, August 25th.

A General Meeting of the Congress was held at 10.30 a.m. to discuss the Origin of Mammals.

The President having taken the Chair, introduced Prof. Hubrecht, who had been appointed Chairman for this discussion. Prof. Hubrecht having sketched briefly the lines which the discussion should follow, called on Prof. SEeLEy, of whose remarks the following is an abstract.

When certain fossil reptiles proved to have some bones of the skeleton almost identical with those of birds, reptiles and birds were united in a division of Vertebrates named Sauropsida. Similarly when other extinct reptiles showed forms of bones and teeth which were almost indistinguishable from those of mammals, the lower mammalia and Anomodontia were thrown together into a group named Theropsida. The Iguanodont reptiles have been regarded as ancestors of birds, and Theriodont reptiles have been regarded as ancestors of mammals.

The imperfection of the evidence has favoured differences of interpretation.

When Theriodesmus was described, the mammalian resemblances of the bones appeared to prove it a mammal; but after Pareiasaurus was found, there was proof that Theriodesmus approached still closer to that genus in its limbs; and therefore was no mammal but a reptile. In the same way when the imperfect skull of Tritylodon was described, its molar teeth were so similar to those of mammals and so unlike any known reptiles that the animal was accepted as a mammal. Subsequently the group of Gomphodont reptiles, represented by several genera, was found with teeth as complicated as those of Tritylodon, and skull structures which are regarded as reptilian. So that Tritylodon also is now classed among reptiles.

Few skeletons of these extinct reptiles are known. Pareiasaurus is nearly complete. Dicynodonts are fairly complete. Cynognathus wants nearly the whole of the limbs. These and other skeletons show different affinities in different parts of the skeleton; and from the skull of Pareiasaurus and Dicynodon no indication could be inferred of mammalian resemblances seen in other parts of their skeletons. This difference between skull and skeleton in affinity is in harmony with other fossil reptiles, since no one could have inferred from the skull of Iguanodon the bird-like characters of its pelvis and hind limb. 
Another chief difficulty in interpreting these extinct animals arises first, from the diversity of the organic types included in the Anomodontia, and secondly from the difficulty of defining the terms mammal and reptile. The Anomodontia appear to show affinities with the lower limit of the reptiles as well as with more than one type of mammal; besides indicating some affinity with the extinct reptilia.

The form of the brain if it were available would be evidence of affinity of some value. The lateral expansion of the cerebral hemispheres and their extension backward over other parts of the brain are mammalian features; but they are not found in Anomodonts. The brain cavity is imperfectly known, and there is no evidence that the brain filled it. Its hinder part is deeper than wide at the base, its sides are flat, and its superior border is a sharp ridge, in some Dicynodonts. In form it is more like the mould of the brain cavity in some Dinosaurs than the corresponding region in any living reptile or mammal. One American ally of the African Theriodonts has been shown to have the mould of the brain cavity compressed from side to side, and like that of Belodon and some Dinosaurs. Anomodonts are therefore not intermediate between reptiles and mammals in form of the brain-cavity, any more than Dinosaurs in this character are intermediate between reptiles and birds.

The Monotreme mammals in being oviparous give a lower limit for the inammalia, which invites comparison with Anomodonts, but no Anomodont has shown pre-pubic bones or even such structures as are found in marsupials and Ornithosaurs. On the other hand the back of the skull shows a foramen above the articulation for the lower jaw in Ornithorhynchus, which is situate in the same position as the foramen which cuts into the quadrate bone in Dicynodonts, in Hatteria, and other animals. Thus the articulation with the lower jaw is made in the same way in both, and presumably by the quadrate bone. Owen did not recognise the quadrate bone in Ornithorhynchus only because he believed that bone to be the tympanic. He figured a skull which shows many distinct sutures, some of which are reptilian divisions of the skull. One skull in the Royal College of Surgeons' Museum shows pre-frontal and postfrontal bones, and indication of separation of the bone, in the place of the supra-temporal, which is external to the quadrate bone. These bones, hitherto characteristic of reptiles, are thus common to Monotremes and Anomodonts, and comparable.

The Theriodont division of the Anomodonts with teeth of mammalian type, want the foramen above the condyle for the lower jaw; the quadrate bone is very small, and the articular region for the lower jaw is like that in higher mammals. It is a distinct type from the Dicynodont group. Thus the Anomodonts have affinities with at least two chief divisions of the mammalia.

The Theriodonts also have affinities with the Labyrinthodont reptiles, in the presence of intercentra in the vertebre, and bones in 
the skull like the supra-temporal which are not known in the higher reptilia.

Some Dinosaurs like Belodon are near to Anomodonts.

The animal types which are included in this extinct group comprise the heavy Pareiasauria, the Dicynodontia, the more slender Theriodontia, the Mesosauria and others represented by Endothiodon and Procolophon. In common with their North American allies these Permian reptiles agree in having the head of the rib articulated between the bodies of two vertebræ in a manner which is typically mammalian. The nearest approach to this condition among reptiles is seen among Chelonians.

The shoulder girdle in Pareiasaurus and Dicynodon may be closely compared with the same bones in Monotreme mammals, although they are blended together in most of the specimens by sutures. The clavicular arch in Pareiasaurus and Kisticephalus appears to include a pair of epiclavicular bones which are only found in Labyrinthodont reptiles. These epiclavicles are unknown in reptiles and mammals.

The pelvis is usually comparable to that of a mammal though no one Anomodont parallels all the conditions in any mammal. In the hind limb the femur in Procolophon is a type between Testudo and Ornithorhynchus; in Dicynodonts the bone is Edentate. In some Theriodonts the femur is not typically mammalian and is more like some Dinosaurs.

There is a similar diversity of character in the fore-limb. Theriodesmus shows a humerus more Marsupial, while Microgomphodon is more like a Monotreme.

The skull in many Theriodonts is typically mammalian in form, but the lower jaw is always formed of many bones; and the dentary bone never quite reaches the articulation for the lower jaw. This makes an interval of structure between Anomodonts and Mammals.

The teeth show some new types, such as Ptychocynodon, but the molars may mostly be compared with carnivora in Cynognathus, rodents, insectivora in Diademodon and Trirachodon, and there are other mammalian types. The mammalian characters of the teeth may be compared with the mammalian characters of the skeleton.

Anomodonts are not the parents of mammals, but a collateral and closely related group. The common parent of both may be sought in rocks older than Permian, perhaps in Silurian or Devonian strata. The remains thus far discovered in Permian rocks show so near an approach of the higher reptiles to the lower mammals, that it is reasonable to believe that the interval between them is now so small that it may be obliterated by future discoveries. There is however thus far no evidence that the manmalian type of brain had come into existence in these animals.

Professor OSBORN ${ }^{1}$, of New York, said that certain general 1 For a full report of Professor Osborn's remarks, see Appendix. 
principles were useful guides as to the probable nature of the ancestral mammal; in the present imperfect state of the palæontological record he preferred to commence by working backward from the well known comparatively recent forms. In the first place, mammals possess the power of rapid adaptation to their conditions of life. There have been four main centres of adaptative radiation, of which the best case is that of Australia, where the marsupials have acquired forms which among placental mammals are divided between different orders. The starting point of each adaptative radiation has been a small, unspecialized land mammal. Finally it is probable that the ancestral mammal was insectivorous or omnivorous. Remembering these principles we can trace the line of mammalian descent backward; it leads us to the Jurassic, when the mammals were all small and belonged to three groupsthe primitive insectivores, which have been regarded as marsupials, although there is no evidence to support that view; second, the Multituberculates, which are probably early Monotremes; third, the Marsupials. Reversing the order of enquiry, Professor Osborn then referred to the fact that in the Permian there are three groups of reptiles, one of which is surprisingly mammalian in some of its characters, and tempts us to connect the herbivorous section of anomodonts with the monotremes. He thought, however, that the many striking points of resemblance between these reptiles and mammals were due to parallelism, similar characters having been independently acquired. He agreed with Professor Seeley that the known anomodonts are not the direct ancestors of mammals, but are a collateral line. But he disagreed when Professor Seeley sought for a much earlier common ancestor of the mammals and the anomodonts, for he believes that an undiscovered and less specialized third sub-group of anomodonts will be found to be the true ancestor of the mammals. The chairman, however, has shown that the mammalian egg is amphibian rather than reptilian in character; and if much weight is to be laid on this point, then the mammals may have descended from some reptile which retained certain amphibian characters.

Professor MARSH said that the question under discussion is not new, but one of a series of similar nature and difficulty. The origin of Birds, of Reptiles, of Amphibians, and of Fishes really precede it, and offer less difficulties in solution. The answer to each, in my opinion, belongs to the future, and how far it may profitably be sought in the present limited state of our knowledge is a fair question in itself.

Too often in the past, a discussion on the origin of Mammals has seemed a little like the long philosophico-theological controversies in the middle ages about the exact position of the soul in the human body. No conclusion was reached, because, for one reason, there were no facts in the case that could settle the question, 
while the methods of investigation were not adapted to insure a satisfactory answer. The present discussion is on a much higher plane, and the previous speakers have made an admirable presentation of their side of the case. I cannot, however, quite agree with them as to the value of the facts and theories they have presented, and shall consider the question from another point of view.

The Mammals, as we know them to-day, are classed by themselves, yet contain such diverse groups that it may fairly be regarded an open question whether all have a common origin. The attempt to ascertain whence they came is likely to bring out indications that they may have had several sources of origin, and this, if so, may help to explain the great diversity among them.

It is of course evident that some of the most characteristic features of recent mammals, for example, the hairy covering, the circulatory system, and the milk glands, cannot be used in a comparison with fossil forms. The osseous structure only is now available in the early mammals and other vertebrates, and in this alone points of resemblance must be found if different groups are connected genetically.

In considering the relations of reptiles to mammals so far as the fossil forms are concerned, which seems to be the main question before us to-day, I have only time to speak of the skull, and shall refer to some of its salient features already mentioned in this discussion; namely, the teeth, the squamosal bone, the quadrate, the occipital condyles, and with them the lower jaw. These perhaps may serve as crucial points in distinguishing the skull of a reptile from that of a mammal, even if they fail to indicate a near affinity between them.

The different kinds of teeth seen in the reptiles regarded as mammalian in type, I consider of comparatively small importance, for the reason that the same general forms of teeth are to be found, not merely in the reptiles supposed to be nearest to mammals, but also in other groups widely different. In the Crocodiles, for example, the extinct genus Notosuchus, recently discovered in Patagonia, has all three kinds of teeth well distinguished. Again, some of the Dinosaurs, especially the genus Triceratops, have teeth with two roots, a supposed mammalian character. In some Fishes, also (Anarrhichas), three kinds of teeth may be seen. It is more than probable, therefore, that the peculiar resemblance between the teeth of mammals and those of the lower vertebrates is merely one of parallel development, the adaptation being along similar lines, and in no sense an indication of genetic affinity.

The great development of the squamosal bone in Theriodonts is not seen in them alone, for somewhat similar proportions are found in some other reptiles, for example, in the Plesiosaurs, where the squamosal is very large, and wrapped round the quadrate. In some of the Dinosaurs, also (Torosaums), the squamosal has an enormous development, while the quadrate remains of very moderate size. 
The quadrate bone, always present in Birds, Reptiles, and the other lower vertebrates, is well known as the suspensorium of the lower jaw, which meets it with a concave articular face. The quadrate, however, appears to be wanting in mammals, or at least has not yet been identified with ccrtainty.

What represents the quadrate bone in mammals is a vexed question in itself, and some of the best anatomists in the past, Cuvier, Owen, Peters, Huxley, and others, have endeavoured to solve the problem. The tympanic bone, the incus, and the malleus have each in turn been regarded as the remnant of the quadrate, but up to the present time the question has not been settled. It is not improbable that the quadrate may have coalesced with the squamosal.

The occipital condyles of mammals, as well known, are two in number, and separated from each other. This is not the case with any true reptile, although the contrary has been asserted. The nearest approach appears to be where there is a single bifid condyle, cordate in shape, with the two lobes meeting below, as in some reptiles and a few birds, but not separate as in mammals and amphibians.

Finally, in all known mammals, recent and extinct, the lower jaw is composed of a single piece, and has a convex condyle meeting the skull by a distinct articulation. All reptiles, even those supposed to be nearest the mammals, have the lower jaw composed of several pieces, and these show distinct sutures between them, a profound difference that must be explained away before an approach can be made between the two classes.

It may fairly be said that the separate elements of the lower jaw, if present, would naturally be looked for in the Mesozoic mammals, and this point I have long had in mind. I may safely say that I have seen nearly every species of Mesozoic mammals hitherto described, and have searched for evidence on this point without success. I have also sought for the separate elements in the young of recent forms, but without finding any indications of them.

Beside the crucial points I have mentioned in the skull, there are others of equal importance in the skeleton, which I must not take time to discuss, but will venture to allude to one of them in passing. I refer to the ankle joint, which, when present, is at the end of the tibia in mammals, but in reptiles between the first and second series of tarsals. When we really find an approach between these two classes, the ankle joint will probably show evidence of it.

Having thus shown, as I believe, that we cannot with our present knowledge expect to find the origin of mammals among the known cxtinct reptiles, and that in attempting this we are probably off the true line of descent, it remains to indicate another direction in which the quest seems more promising. 
Since 1876 , when Huxley visited me at New Haven, and we discussed the probable origin of both Birds and Mammals, I have been greatly impressed by his suggestion that the mammals were derived from ancestors with two occipital condyles, and these were doubtless primitive Amphibians. I have since sought diligently for the ancestors of birds among the early reptiles, with, I trust, some measure of success, but this is a simple problem compared with the origin of mammals which we have before us to-day.

In various interviews with Francis Balfour, in I88I, at the York Meeting of the British Association, we discussed the same questions, and agreed that the solution could best be reached by the aid of Embryology and Paleontology combined. He offered to take up the young stages of recent forms, and I agreed to study the fossils for other evidence. His untimely death, which occurred soon after, prevented this promised investigation, and natural science still suffers from his loss. Had Balfour lived, he might have given us to-day the solution of the great question before us, and the present discussion would have been unnecessary.

The Birds like the mammals have developed certain characters higher than those of reptiles, and thus the two classes seem to approach each other. I doubt, however, if they are connected genetically, unless in a very remote way.

Reptiles, although much lower in rank than birds, resemble mammals in various ways, but this may be only an adaptive likeness. Both of these classes may be made up of complex groups only distantly related. Having both developed along similar lines, they exhibit various points of resemblance that may easily be mistaken for indications of real affinity.

In the Amphibians, especially in the oldest forms, there are hints of a true relationship with both Reptiles and Mammals. It seems to me, therefore, that in some of the minute primitive forms, as old as the Devonian, if not still more ancient, we may yet find the key to the great mystery of the Origin of Mammals.

Professor HAECKEL said that he had discussed the problem with Huxley and Lyell 32 years before, and the former then strongly held the polyphyletic origin of the placental mammals, the carnivorous and herbivorous groups having descended respectively from carnivorous and herbivorous marsupials. This view was now untenable, and the speaker believed that the different series of placental mammals converge so nearly that they must have all been derived from one marsupial ancestor.

Mr SEDGwiCk called attention to the fact that embryology, which had been appealed to by previous speakers to assist in the solution of the problem, in reality gave very little, if any, light. With regard to organs, which on the ordinary view of evolution, must have been recently altered, such as the wings of birds, limbs 
of snakes, the feet of ungulates, and the absence of teeth in living birds, there was no sign of a more complete development in the embryonic state. As to the earliest stages of mammalian embryos, which differed considerably in the various orders, but little importance can be attached to them, when we remember the fact that within the limit of a single genus, viz. Pcripatus, a greater amount of variation is found in the earliest embryos than in the whole Mammalian class.

Finally on examining the relationship of living and extinct animals and endeavouring to classify them, and remembering that all the great classes of the animal lingdom which could be preserved as fossils had already made their appearance in the lowest Palæozoic rocks, one could not but be struck by the fact that there was much to be said for the view that the greater part of evolutionary change had already taken place in precambrian times before the fossiliferous period. If this view were correct,-and the possibility of it should be borne in mind, - the main part of the evolution of organisms must have taken place under totally different conditions to those now existing, and must remain for ever unknown to us. We should then have to look upon fossils in the main as being rather collaterally than ancestrally connected with living forms, and evolution during the fossiliferous period as having consisted mainly of a process of extinction of the less fit varieties than of the formation of important new types.

Professor HubRECHT, in closing the discussion, said, in reply to $\mathrm{Mr}$ Sedgwick, that the value of embryology was in many cases destructive, not constructive. Its evidence was of value as often prohibiting certain lines of speculation. He differed from his great teacher, Professor Haeckel's present views, which he thought untenable, since Hill has shown that in Perameles, a genus of Australian Marsupials, a distinct placenta is found, which is deciduous. What Caldwell and Semon have shown to exist in another Marsupial, Phascolarctos, seems rather to be a phase of retrogressive than of incipient placentation. He predicted that one great battlefield in the future of this controversy would be over the question whether mammals other than Monotremes had descended from oviparous ancestors.

Professor NEwTon proposed a vote of thanks to Professor Hubrecht for his conduct in the chair. 


\title{
FOURTH GENERAL MEETING.
}

\author{
Friday, August 26th, at I0.30 A.M.
}

\section{Chairman: The President.}

The Secretary read the following telegram from H.R.H. THE PRINCE OF IVALES, Patron of the Fourth Meeting of the Congress: "Delighted to hear from you that Zoological Congress is such a success. AlbERT EDWARD."

The Secretary further announced that, in consequence of the small number of applicants, the proposed dredging expedition to Port Erin was abandoned, but Prof. Herdman cordially invited visitors next Easter.

Prof. HAECKEL read a paper in English on "Our Present Knowledge of the Descent of Man," of which the following is an abstract :

Our present knowledge of the Descent of Man is immensely improved by the great progress in Palæontolozy, in Comparative Anatomy and Phylogeny during the last twenty years. The monophyletic origin of all Mammalia from the Monotremata upwards to Man is at present no more a vague hypothesis, but a positively established fact. All the living and extinct Mammalia, which we know, are descended from one single common ancestral form, which lived in the Triassic or Permian period, and this form must be derived from some Permian or perhaps Carboniferous Reptile (allied to Progonosauria and Theriodontia) as well as the latter from a Carboniferous Amplibian (Stegocephalia). These latter descend from Devonian fishes and these again from lower Vertebrates. Much more difficult is the question of the origin of the great Vertebrate-Stem, and its descent from Invertebrates. But these questions are not so important as the fixed fact that $M a n$ is a member of the PrimateOrder (Linné) and that all Primates (i.e. all Lemurs, all Monkeys, and all Man) descend from one common stem (Huxley). Zoology may be proud to have proved this fact, based on the theories of Lamarck (ISO9) and of Darwin (I 859). The immense progress of 
human science, effected by this knowledge, will be one of the greatest conquests of our igth century.

Dr GADOW, at Professor Haeckel's request, explained the meaning of a spectral diagram, designed by Prof. Haeckel, to illustrate the evolution of the animal kingdom.

The Rev. T. R. R. Stebbing followed Prof. Haeckel and called attention to Lord Kelvin's calculation of 25 millions of years as the age of the earth. He begged Prof. Haeckel to be satisfied with something less than a thousand million years.

Prof. Haeckel said he had taken the calculation of one of our Geologists, and for himself he had no intuition as to the matter.

Prof. MAREY then read his paper:- "Du concours nécessaire de la physiologie et de l'anatomie comparée pour la connaissance de la locomotion animale."

MI. Marey montre que, sur certains points, la physiologie et l'anatomie comparées doivent se combiner pour donner l'interprétation des phénomènes du transformisme. Il rappelle les expériences par lesquelles il a démontré que le muscle, dont l'action mécanique modifie le squelette, se modifie lui-même et s'adapte par sa forme à la nature du travail qu'il doit effectuer. Il montre que, sur les espèces animales dont les allures habituelles sont connues, on peut facilement saisir cette harmonie entre le caractère de la fonction et la forme de l'organe.

Pour généraliser cette étude, il faudra connaitre à la fois les caractères de la fonction locomotrice et l'anatomie de l'appareil locomoteur. La partie physiologique laisse déjà peu à désirer car la chronophotographie permet de tout connaitre relativement aux mourements d'un animal. La méthode de M. Marey consiste à faire d'après les images photographiques les décalques successifs des diverses parties d'un animal en mouvement et à en former une véritable épure qui renferme non seulement les contours extérieurs des membres, mais encore la position des différentes pièces du squelette et les changements de longueur qu'éprouvent les différents muscles à chaque instant de l'allure considérée.

La partie anatomique ne serait pas moins avancée si l'on pouvait rassembler les documents épars que l'on possède sur l'appareil locomoteur. En effet, certaines collections possèdent des squelettes sur lesquels se trouvent, bien déterminées, les insertions des principaux muscles. D'autre part, certains anatomistes possèdent les moulages des muscles de plusieurs espèces de vertébrés; mais ces pièces, disséminées dans des établissements divers, sont, par conséquent, inutilisables pour la myologie comparée. M. Marey fait donc une proposition, que plusieurs anatomistes ont déjà favorablement accueillie. C'est que ceux qui possèdent quel- 
ques-uns de ces moulages de myologie les fassent reproduire à plusieurs exemplaires de façon que chacun d'eux puisse se procurer, par voie d'échange, une collection aussi complète que possible des principaux types de musculature chez les Vertébrés.

The Section then adjourned to the Cavendish Laboratory to hear the remaining papers.

Mr DuckworTH read his "Notes on Anthropoid Apes," illustrated by Lantern Slides. The following is an abstract:

(i) General considerations.

The general study of the higher members of the Order Primates.

Special notice of Gorilla savagei (Geoffr.).

Principal Contributors to our knowledge of Gorilla, in America, England, France and Germany.

The material at their disposal at Le Havre, Liverpool, Paris, London, Berlin.

Character of the earlier studies on Gorilla, e.g. those of Wyman, Owen, Duvernoy.

Character of later studies on this animal, e.g. those of Deniker, Waldeyer.

(ii) An account of specimens at Cambridge, with a description of the author's dissection of an anthropoid ape, which appears to be a variety intermediate between Gorilla and Chimpanzee. The cutaneous nerve supply to the lower extremity of this specimen (as well as of examples of Orang-utan and of Chimpanzee) has been dissected out so that comparisons can be instituted.

In conclusion some of the most recent additions to the Cambridge Collection were described.

Canon TRISTRAM then took the chair and Mons. E. Dubois read his paper on "Pithecanthropus erectus."

\section{REMARKS UPON THE BRAIN-CAST OF PITHECANTHROPUS ERECTus. By Dr Eug. Dubois.}

At one of the meetings of the Third International Congress of Zoology, held at Leiden in I895, I had the honour to show to those who attended that meeting the remains of Pitlucanthropus erectus, brought by me from Java only six weeks previously.

On that occasion I preferred to speak of the questions which are raised by these interesting but, at the same time, somewhat paradoxical fossil specimens, only in a very cursory way.

During the three years that have elapsed since then, much additional study has been devoted by me to them, and I consider it to be my duty now to bring some of these questions before 
this distinguished ordeal of the Fourth International Congress of Zoology.

I am very happy indeed that it is at Cambridge, whose University has inscribed in its roll, amongst so many other distinguished names, such a glorious one as that of Darwin. No one, I am certain, if he were now amongst us, would have taken a keener interest in the evidences, which it has been my good fortune to produce in the favour of the application of the doctrine of evolution to man. For Darwin as well as for Huxley " the ascertainment of Man's place in nature, was the question of questions for mankind-the problem which underlies all others and is more deeply interesting than any other."

Three years ago I had already pointed out, that I consider Pithecanthropus erectus as contributing in a large degree towards that ascertainment. Consequent study fully bore out the views then advocated by me.

The details of the questions concerning the remains of that species have grown very numerous, and it would be impossible for me to point out, even in a cursory way, the conclusions to which a closer study of them necessarily leads. I am now preparing a larger treatise, containing a full description of all the remains, and which will still, I hope, in this year be issued. To it I may refer for a fuller treatment of the questions which I now only can shortly point out.

This is the reason why I propose to say but little about the skull-cap and to cast only some indirect glances at the femur and the teeth.

Of the femur I want first to make this preliminary remark, that, having now examined more than a thousand human thigh-bones from different races and from many sources, and having made further studies on the peculiarities of the Trinil femur, I am quite certain that by some of its features this bone distinctly deviates from any human femur. Moreover it appears to me beyond doubt, that these anatomical features can be interpreted by a partial difference in the physiological function of the bone from that in man. Though unquestionably Pithecanthropus erectus had assumed a very perfect erect attitude and his mode of progression, when walking on the ground, was completely bipedal, still his lower limbs were adapted at the same time to a tree-climbing locomotion. The arms and the hands, not being entirely liberated from locomotor functions, could not possess that perfection as organs of prehension and of touch which they have attained in man, and by which they "minister to the purposes of man's higher intelligence" (Turner). A posteriori it appears quite impossible to me, and contrary to the laws of correlation and harmony prevailing in the organic world, that such an inferior brain as that of Pithecanthropus erectus should have been accompanied by legs and feet, arms and hands of an equally high differentiation as that of the two pairs of limbs in man. 
These features perhaps may contribute to convince those who still may doubt of the appertaining to the same individual of the skull-cap and the femur. Further evidence, pointing to the same conclusion, was afforded last year by the discovery of a new tooth.

The Dutch-Indian Government, whose benevolent support has enabled me to find and bring home a large collection of specimens, mostly belonging to new species of fossil vertebrata, have still further increased the debt which science owes to them on that account. They ordered that the digging of a large irrigation canal, cutting the ossiferous strata, should be surveyed by one of my late assistants under my directions, and that at the same time the excavations at Trinil should be continued during the dry season.

Under the auspices of Mr Pierson, chief Civil Engineer and director of those canal works, a valuable supplementary collection has been made and was sent to me after my leaving Java. Thus last year the above-mentioned tooth, which can only be attributed to Pithecanthropus erectus, was found whilst removing a new part of the ossiferous rock, lying close to the place where the skull-cap and the two molars had been found, and exactly at the same level of the strata. This tooth is one from the lower jaw. It is the second left premolar and bears in a more marked degree than the other teeth an intermediate character. My well-founded hope, that in the current year the inferior maxillary bone itself might be brought to light, seems to have been sadly frustrated by certain unfavourable circumstances.

Before speaking now of the conclusions to which I arrived regarding the brain of Pithecanthropus crectus, as founded upon study of the cast of the interior of the skull-cap, I want to say a few words about that skull-cap itself.

The importance of this part of the skull is owing chiefly to its having contained the most highly developed parts of the brain, the cerebral hemispheres. Anatomists and anthropologists are accustomed to draw some inferences as to the relative development of these hemispheres of different races of men and also in comparing man with the lower mammalia from the form of the skull-cap.

have followed that practice during a certain time, but at last I found that where we have to compare small species with large ones, or such as occupy a very different degree in the scale of cerebral development, we are liable to fall into grave errors. Indeed, the cranium of a small animal possessing a quantity of brain relatively very large, cannot directly be compared with that of a bulkier species, the brain of which is relatively smaller. Therefore, for instance, the greater relative height of the vault of the cranium in the smaller species of Hylobates, when compared with the corresponding dimension in Hylobates syndactylus, appears to be a simple result of the relatively larger maxillæ of the latter.

On the other hand, if an equally bulky species has an absolutely much smaller brain, other organs (such as the eyes or the teeth), 
influencing the development of other parts of the skull, being of an equal or a relatively larger size, the proportions and the form of the cranium must be modified in a large degree. It appears to me that some of the chief "pithecoid" features of the cranium of the ape really are only the expression of the relative smallness of the brain in comparison to the eyes and the maxilla. So for instance the obliquity of the orbital surface of the frontal lobe going so far as to form a real "rostrum," a foetal and a simian and also a microcephalic character, is simply the result of a different proportion between the size of the brain and that of the eye.

There are further differences in the form of the cranium, which must be taken as peculiarities of the species, as for instance the characteristic height and narrowness of the cranium of the Orangutan.

If we compare the cranial arcs of man and apes and of Pithecanthropus as based on the line from the glabella to the inion, we certainly can only arrive at very rough estimations of cerebral development, the inion being a point determined by muscular action, and the place of it pretty well independent of the size and the formation of the brain.

We obtain a better comparison of cranial arcs by taking as base the line from the glabella to the upper border of the sulcus transversus, because it more nearly represents the degree of development of the cerebral hemispheres.

However, we find that the arcs, thus obtained, by no means represent the real development of the brain or of the cerebrum. For even when such arcs are represented in accurate projection and drawn to the same scale we do not obtain natural relations.

After removal of the stony matter, which almost entirely filled the calvaria, when I showed it at the Third International Congress of Zoology at Leiden, I was able to measure exactly the capacity, and to make a cast of the interior of it representing a large part of the brain. This brain-cast, which I would consider as the most important evidence indirectly bequeathed to us by our ancestor, is now lying here before you.

If viewed from above, in the "norma-verticalis," the most peculiar feature of the brain-cast is the narrowness of the frontal part of the cerebrum, whereby it differs as well from every normal human brain as from all ape-brains. This narrowness of the frontal lobes and the very marked convolutions are undoubtedly due to the very pronounced scaphocephaly of the frontal region (trigonocephaly), a peculiarity well known in man as a result from the premature obliteration of the medial frontal or metopic suture (the reverse of metopism, which from the researches of Anutchin and of Papillault seems to be more common in the higher than in the lower human races). Thereby the growth of the frontal part of the cranium having been much checked in a lateral direction and a certain extent of frontal cerebral cortex being necessary, the frontal 
convolutions of the brain must have developed considerably and made strong impressions on the inner surface of the frontal bones. Without doubt the frontal scaphocephaly was not peculiar to the species, but only an individual variety, as otherwise the frontal lobes would have had sufficient space for their development, and would not have made such strong impressions on the inner surface of the bony wall containing them.

Another important feature of the cerebrum to be remarked when viewed from above, and which is certainly more than an individual one and is independent of the described narrowing of the frontal lobes, is given by the shape of the posterior part of the cerebrum. The largest diameter is at the temporal lobes just before the fossa petrosa. About three-fifths of the length falls before the largest transverse diameter, two-fifths behind that line. In all the apes, with the exception however of some small New-world genera (Chrysothrix, Midas), the largest diameter at the temporo-occipital lobes, observed in casts of the cranial cavity, is situated much more behind, and the anterior part of the length is about double of the posterior part, but in man the same proportion prevails as that observed in Pithecanthropus. In every case the greatest width of the cranial cavity corresponds to the anterior part of the linea semicircularis, and the processus mastoideus, and evidently thus depends upon the point of the greatest muscle-traction by the sternocleidomastoideus muscles, for those muscles want the broadest place of the calvaria for their insertions. These are situated in the apes, except in Chrysothrix and Midas, behind those in man, by reason of the occipital condyli being situated much more behind in apes than in man. The agreement in this respect, of the brain of Pithecanthropus with that of man, can in my opinion only be accounted for by similar insertions of the named muscles and an erect attitude. For in accordance with the other very human features of the brain-case, it is highly improbable that we should have to account for this feature in a way similar to that of accounting for the forward shifting of the occipital condyli in the small New-world monkeys.

In the frontal region of the hemispheres the convolutions are most perfectly distinct. Those on the left side are a little different from those on the right side; the latter are, further, best preserved. For first orientation the central and precentral fissures are easily identified. The intraparietal sulcus is only very partially distinct, but seeming to point to a relatively large occipital lobe, an apelike condition, undoubtedly consequent on a relatively larger development of the sensory centres of the cortex in contrast with smaller areas of association. In the neighbourhood of the medial part of this sulcus the brain is very flat.

The most conspicuous feature is the second frontal fissure, as clearly developed as in any human hemisphere, originating in the common $\mathrm{T}$-shaped form from a clearly distinct inferior precentral 
sulcus and having the shape of a reversed $\therefore$. The two segments of this figure encircle the two limbs of perfectly definite $Y$-shaped anterior branches of the fissura Sylvii, the stem of which is about I $\mathrm{cm}$. long.

The second frontal sulcus is only very partially preserved on the left side.

On both sides a medial frontal fissure is very marked.

The first frontal fissure is interrupted in different pieces, a condition common in the apes as well as in man.

The important inferior frontal convolution has attained a fair development. I found the area of its exposed superficies equal to half the average area in twelve European hemispheres, but at least double that in the brain of a large chimpanzee or an orang-utan. This seems to indicate that our fossil being possessed already a certain amount of power of speech. The pars triangularis is present in this convolution, as results from the presence of two anterior branches of the Sylvian fissure. But the pars opercularis has only a very rudimental development. This part in man Broca regarded as the motor centre of speech, but later researches, especially by Beevor and Horsley on apes, and pathological observations have shown that the region in the cerebral cortex which presides the movements of the phonation-muscles is somewhat more extensive. By some pathologists even the whole inferior frontal convolution is brought in connection with phonation. Moreover in the brain of men who were not dumb at all the pars opercularis very commonly is found but poorly developed.

In the opinion of Cunningham and Marchand the sulcus rectus of the apes is the homologue of the sulcus frontalis inferior of man, from which it would follow that the inferior frontal convolution in the apes should be relatively of much larger extent than that of man, certainly a very improbable assumption. Hervé, Eberstaller, Waldeyer and others however regard the sulcus rectus of the apes as homologous with the sulcus frontalis medius of Eberstaller in man, and as the real homologue of the inferior frontal fissure (including the annexed sulcus fronto-marginalis) of man they regard the sulcus fronto-orbitalis of the apes.

The opinion of the latter anatomists is fully dealt with by the much regretted Italian anatomist Giacomini. Having examined a larger number and a more complete series of microcephalic brains than any other observer he could clearly follow the gradual transition from the most ape-like fronto-orbital sulcus to the perfectly human inferior frontal sulcus and did not hesitate in adopting similar views.

I can the easier abstain from a longer trespass on the controversial ground of the homologies of the frontal sulci and convolutions since we have here in the person of Professor Waldeyer one who is fully entitled to give his opinion in the matter. Only I wish to draw your attention to the fact that however in this fossil 
brain a human condition of the inferior frontal convolution occurs, it nevertheless is in such a simple condition, that it is not difficult to trace its development back from such conditions as are obtaining in the anthropoid apes.

Moreover I wish to point out one circumstance which in my opinion decides the question. According to Cunningham the anterior part of the second frontal sulcus should point to the frontal pole, that is to say much higher than it does in man, where actually its anterior part bends down to the orbital surface. Now if we compare man with the anthropoid ape of equal bulk and having eyes of equal dimensions, the impression from the upper roof of the orbita on the absolutely much smaller frontal lobe of the ape is proportionately much greater than it is in the cerebral hemisphere of man, and thus the anterior end of the second frontal convolution ought to be pressed backwards in the ape.

The suggestion may be put forward that the brain represented by this cast was that of a microcephalic individual. This I would meet by firstly referring to the overwhelming improbability of the discovery of just such a pliocene idiot. Secondly I would direct the attention to the calvaria which contained the brain. In the region of the temporal fossæ one notices a considerable lack of symmetry between the two sides, the left one being much damaged, and consequently the channelling seems to assume a more anterior position than on the right side. The latter side should be regarded as affording a true indication of the original conformation of this region, a conformation closely resembling that obtaining in the ape. The distance between the deepest part of the temporal fossa and the upper orbital margin depends upon the relative length of the maxillæ, and consequently it is much greater in the ape than in man. In this respect the men from Neanderthal and Spy as well as the microcephalics differ entirely from the ape-type, are entirely human. In Pithecanthropus a condition obtains quite similar to that in the ape, indicating a degree of development of the jaw certainly not much inore human-like than in the anthropoid apes.

Viewing the predominant importance of the brain in the animal kingdom and the large extent to which cerebral development enables us to place vertebrates and mammals in ascending order, it must be considered a prime necessity to have a reliable method of estimating brain development.

Evidently the most direct way is that of taking the volume or the weight of the brain as the basis of that estimation. To a certain degree this method can be applied for an estimation of the development of the brain of Pithecanthropus crectus, of which I was able to measure exactly the capacity of the calvaria having contained the chief part of the cerebrum. Duly varnished and thinly rubbed with a mixture of vaseline and paraffin, the skull-cap was laid on the balance, and having been equipoised, it was filled with water just to a transverse plane between the frontal pole of the cerebrum and 
the upper border of the sulcus transversus. This plane appeared to cut the impression of the inferior frontal convolution at the limit of its upper two-thirds and the lower one-third. The weight of this water was 565 grammes. A small quantity of stony matter, which could not be taken out of the skull-cap, because this is somewhat thin and weak at this place, could easily be measured on a cast to have a volume of 5 c. c. Thus then the capacity of the described cerebral part of the cranium was 570 c. c.

The same cerebral part of the cranial cavity measured with water in three European (Dutch) skulls, made impermeable by impregnation with molten paraffin and by filling up the holes with wax, was 884,1000 and IO40 c. c., and that in one Javanese skull II 50 c. c. The whole capacity in these four skulls was on the average equal to I'4 (I'35 to I*45) times that of the cerebral part. For the same calvarian cerebral capacity in the Neanderthal-skull, measured with rape-seed, I found 920 c.c. and about the same figure in the smaller cranium of Spy, in the larger one at least 1050. Thus it appears that these fossil crania are not smaller than other human crania.

In one cranium of a female Chimpanzee, a female Orangutan, and a female Hylobates agilis, all full-grown, in which the impression of the inferior frontal convolution was very clearly developed, I found an average proportion between the indicated volumes of 1.53 ( 1.43 to 1.58 ). In the cranium of a large male Gorilla with a total capacity of 540 c. c., the calvarian cerebral part measured at the utmost 280 c. c.; in the female Chimpanzee, with 366 total capacity, I found a calvarian capacity of 246 c. c.; in the female Orang-utan with 346 c. c. capacity of 2 I 2 c. c.

Considering the proportions quoted above, of which I am sorry that they are so few, and taking into account the shape of the crania, we may assume as a fair approximation to truth 1.5 for that proportion in the fossil Javanese cranium; we find then for the entire cranium a capacity of 855 c. c. With the aid of a method of deduction given by Welcker, we may calculate the corresponding brain-weight at 750 grammes.

The average capacity in the full-grown male European may be taken at about I $500 \mathrm{c}$. c. and the average brain-weight at about $1400 \mathrm{gr}$. A cranial capacity of 855 c. c. would certainly be very low for a normal human being. Still there have been measured normal human skulls which very nearly approach to that figure. Sir IVilliam Flower found the average capacity of I 3 male Andamanese crania $\mathrm{I} 2 \mathrm{~S}_{\mathrm{i}}$ c. c., with a minimum of I I $20 \mathrm{c}$. c., and of I 3 females I 48 c.c. with a minimum of IO40 c.c. Sir William Turner found the mean capacity in 39 Australian men I 280 c. c., the minimum was 1044. In 24 women the mean capacity was I I 6 c.c. and four crania were between 900 and I000 c. c., the lowest 930 c.c. The Drs Sarasin found for 22 male Weddas a mean capacity of $1277 \mathrm{c}$. c., the lowest was IOI2. In the opinion 
of Broca, normal male European crania might measure as little as 1050 c. c., i.e. 980 c. c. real volume, and normal female crania about 910 or 830 c. c. real volume. Other anthropologists have admitted about the same inferior limit of normal cranial capacity in Europeans.

It is well known that fossil human skulls do not fall below those of recent human races in their capacity. This we saw to be the case even for such a low fossil race as that of Neanderthal and Spy, as may be inferred from the measured calvaria.

Of the anthropoid apes the largest cranial capacity on record, 62 I c. c., is that of a male gorilla in the Laboratoire d'Anthropologie at Paris, recorded by Topinard; according to the reduction tables of $\mathrm{E}$. Schmidt (which ought to be lengthened for this purpose) 62 I c. c. as measured by the method of Broca would indicate a real volume of 574 c. c. Sir William Turner obtained by another method for five adult male gorillas a mean capacity of the cranium of 494 c. c., the maximum being 590 c.c., and the minimum 410 c.c.

The greatest cranial capacity in five adult male gorillas measured by A. B. Meyer was 560 c. c., the smallest 425 , the mean capacity being 497 c. c. The largest cranium of a male gorilla in the Leiden Museum measured by myself attained a real volume of 540 c. c. The weight of the brain in a full-grown male gorilla observed by Owen was 15 oz. av. or 425 grammes, which corresponds to nearly 510 c. c. capacity. Topinard gives 53 I c. c. (Broca) for the mean capacity of gorilla, which reduced to real volume indicates about 490 c.c. It appears from these and a few other data that, assuming for the adult male gorilla a mean capacity of 500 c. c., we more probably make too high than too low an estimate.

Topinard's measurements of the crania of 7 male chimpanzees afforded a mean capacity of 42 I c. c. Broca (corresponding to about 400 c.c. real volume). The capacity of the cranium in four adult male chimpanzees, observed by A. B. Meyer, ranged from 370 to 485 c. c., the mean being 415 . According to measurements of Bischoff the cranial capacity in two male chimpanzees was 410460 c. c. Three male chimpanzees measured by Turner gave a mean cranial capacity of 383 c. c. $(350-440)$. According to these observations we may estimate the mean cranial capacity in the male chimpanzee at about $400 \mathrm{c}$. c.

For the capacity of the cranium in eight male Orang-utans, Vogt found an average of 448 c. c., Topinard for thrce males of 439 c. c., Delisles in six males of 427 c. c., A. B. Meyer in six males 406 c. c. ( 360 to 500$)$, Prof. Selenka, from a personal communication kindly made to me, in about 60 males a mean of 460 c. c. and a maximum of 534. From these observations it results that we may consider the average cranial capacity of the adult male Orang-utan as to be nearer to 450 than to $400 \mathrm{c}$. c. The brain of a large male 
Orang-utan as observed by MM. Deniker and Boulart had a weight of 400 grammes.

From all these figures it is evident that even the largest cranial capacities in anthropoid apes remain very much behind that calculated for Pithecanthropus erectus. But on the other hand the latter apparently approaches very near to some low normal capacities in man.

However, our fossil cranium may, by individual variety, accidentally be a very large or a very small one of its kind.

Individual variation in the size of the brain is, as we know from observations on man, a very considerable factor. The individual weight of the brain is however (as can be shown from the tables of Boyd and from those of Bischoff, if compared with the variation of cranial capacity) very much dependent on the discase that was the cause of death. The cranial capacity is therefore a much better measure for judging of the individual variation in the size of the encephalon. Now, in about 2000 observations of the capacity of crania of all races and nations, taken from the records of many authors, the greatest differences were nearly 20 per cent. superior and 20 per cent. inferior to the average, and further it was apparent that the probability is as 50 to 100 against I that the difference of the capacity of a given human cranium, taken at random, is less than $\frac{1}{5}$ of the average capacity, further that we may bet $S$ to 16 against $i$ that the difference is less than $\frac{1}{8}-\frac{1}{7}$ from the average.

Assuming thus our fossil cranium to be an individually very large one, the average capacity in the species or the race might have been 7 I 2 c. c., assuming it to be a very small individual variety, the mean cranial capacity could have attained so much as IO7O c. c.

Thus then considering the mere capacity, without taking into account the size of the body, Pithecanthropus erectus certainly approaches more to man than to the anthropoid apes. But on the other hand the mere capacity is apparently not sufficient to separate the fossil form from either the Hominidæe or the Simiidae. The largest capacity actually measured under many thousands on a normal human skull, 2000 c.c. by the method of Broca, or I 890 c.c. real volume, was that of a giant, and it would appear that some equally high or even somewhat higher capacities or corresponding brain-weights were due to pathological processes, such as internal or external hydrocephalus. On the other hand, as far as could be ascertained by me, all the available very low cranial capacities, belonging to normal individuals, appear to have been accompanied by small bodies. Australian women are certainly very slender and light people, so are the Bushmen, the Weddas, the Andamanislanders and other negritos, which races afforded the lowest cranial capacities, small-sized people. From the observations of General Man the average height of the Andamanese men (48 individuals) is only $149 \mathrm{~cm}$. and the body-weight (40 individuals) 
$44.5 \mathrm{~kg}$. The Wedda-men (7 I individuals) as measured by the Drs Sarasin attain an average height of $157.5 \mathrm{~cm}$. The average height of the Bushmen, having a mean cranial capacity even lower than the Weddas, is also below that of these Ceylonese people.

As to the size of the body of the anthropoid apes the Gorilla considerably exceeds man in bulk. The body-weight of the adult male, of which Owen has observed the brain-weight, was estimated by him at 200 lbs., or about 90.7 kg. Ford observed a body-iveight without the intestines of $170 \mathrm{lbs}$. or $77 \mathrm{~kg}$. Adding for the intestines of the thorax and the abdomen and the blood lost I $3 \mathrm{~kg}$., we arrive at an estimation of $90 \mathrm{~kg}$. for this male Gorilla also. No observations of the body-weight of full-grown Chimpanzees have come to my knowledge. But of the Orang-utan the weight of one large adult male was observed by Fick to be $76.5 \mathrm{~kg}$., and of another by MM. Deniker and Boulart to $73.5 \mathrm{~kg}$. Thus these large man-like apes considerably exceed man by their bulk, the average weight of the London-man of the working classes being $6 \mathrm{I} \mathrm{kg}$. as deduced from a table by Beddoe, the mean of the full-grown Belgians observed by Quételet $63.7 \mathrm{~kg}$.

Now it is a well-known fact, that the size of the brain in animals as in man depends not only upon the degree of organic development of the brain, but to a large extent also upon the size of the body. It is perhaps less known that it is possible to estimate the extent of that dependency and to calculate the relative encephalisation. Allow me to bring before you the chief argumentation of two papers, published by me in the German Archiv fiir Anthropologie, - the one regarding mammalia, the other man.

While the relations of the animals to the external world become more manifold and intricate, the centres of the nervous system gain in complexity of structure and in volume, for here as in other cases function and organ are proportionate.

If we compare the Vertebrata from the lowest class, the fishes, to the highest, the Mammalia, we observe an ascending scale in accordance with an increase in the volume as well as in the concentration of the central nervous system in the skull. The nearer we approach to the mammalia and in this class to man, the larger the proportionate quantity and weight of the brain as compared to the spinal cord. Moreover it is the most differentiated part of the brain, the cerebral hemispheres, that makes the greatest advance.

All mammals of equal bulk with man have much smaller brains than he. Man has 4 times as large a brain as the most nearly allied man-like apes of an equal bulk of body, and Io times as large as those of dogs of the same weight. A horse, though having on the average a body-weight 6 times as large, possesses less than the half of the average brain-weight of man. Under the living mammalia only the elephant and the large species of whales surpass man by their absolute brain-weight. Comparing mammals of equal bulk but occupying a different degree in the scale of 
general organisation, the superior always has the larger brain. For example the Siamang (Hylobates syndactylus), an anthropoid ape, the Budeng (Semnopitliccus maurus), a lower ape, the Civet-cat (Viverra civetta), the Javanese Pangolin (Manis javanica), have about the same body-weight; however this is in the Siamang 73 times heavier than the brain, in the Budeng 126 times, in the Civet-cat 202 times, in the Pangolin 6I5 times. The Silky Marmoset (Midas rosalia) possesses one gramme of brain for every 26 grammes of body-weight; but the equally heavy common squirrel one gram of brain for 56 grammes of body-weight.

Comparing two mammals having an equally organised brain, but who are of very different bulk, the larger one has absolutely the heavier brain. The Lion has seven times as much brain as the Cat, the Brown Rat five times and a half as much as the Housemouse, the brain-weight of the Beisa, a species of Antelope equal in bulk to the Stag, is nearly seven times as large as that of the Pygmy-antelope, a species little bulkier than a Common Hare.

From these comparisons it is evident, that in every animal the size of the brain depends upon two factors, firstly upon the degree of organic development of the brain, i.e. of the cephalisation of the central nervous system, but secondly also upon the size of the body.

For the size of the body, however, it is not permissible simply to take the weight of the body. For comparing the body-weight of closely allied mammals, we do not find that the weight of the brain in every group is the same fraction of the weight of the body. Universally we observe that the smaller animals possess higher "relative brain-weights." In the Cat it was observed to be $\frac{1}{106}$ and in a full-grown Lion $\frac{1}{546}$, in the House-mouse $\frac{1}{49}$ and in the Brown Rat $\frac{1}{190}$, in the Pygmy-antelope $\frac{1}{88}$ and in the Beisa $\frac{1}{382}$. The relative brain-weight of man $\left(\frac{1}{46}\right.$ to $\left.\frac{1}{45}\right)$ is only exceeded by that of some very small animals, such as the Lesser Shrew (Sorcx pygmaens) with $\frac{1}{23}$ brain-weight, the Silky Marmoset with $\frac{1}{26}$, the Javanese Tupaya with $\frac{1}{41}$, the Whiskered Bat (Vespertilio mystacimus) with $\frac{1}{45}$.

Though the influence of body size upon the weight of the brain may thus be a very apparent fact, nevertheless seldom and with little results has an attempt been made to inquire into the nature and extent of that influence. Undoubtedly, this was principally due to the circumstance, that in all the older and in many new observations of brain-weight and of body-weight the fact was not sufficiently taken into account, that brain-weight increases very much less with age than body-weight. In man the brain attains about the 9 th year nearly the same weight as it has in the full-grown state, while on the contrary the weight of the youth at nine years is only less than the half of that of the full-grown man. The same holds good, as shown by Weber, for all mammals, the brain always reaches the end of its growth much earlier than the other parts of the body. Therefore only full-grown animals are to be compared. 
Further the animals to be compared should as much as possible be fair averages as regards size and state of nutrition of their body. If possible we should always use averages of a number of individual weights, but comparing with one another animals of very different size and choosing fair samples of their species, the individual weights may yield reliable results. In man also a mean ratio is to be arrived at by the exclusion of extreme cases and the selection of subjects of medium stoutness.

It is the great merit of Prof. Max Weber of Amsterdam to have given a list of observations of body-weight and brain-weight in a large number of mammals of different species, accompanied with data, from which in almost every case we are able to draw an inference as to the full-grown or younger state of the animal.

Putting to the test of our actual knowledge of the general structure of the central nervous system some data furnished by Weber, it is possible to determine with approximate accuracy the factor of the influence of the size of the body.

From the point of view of our present knowledge of the central nervous system the brain must be considered as entirely consisting of connecting pieces between sensory and motor nerves, bringing about-in a more or less complicated manner, according to the higher or lower organisation of the animal,-the encephalic communication between the organs of receptivity and activity of the body. In nearly allied animals of every natural group, occupying very much the same degree in the scale of organisation, it would appear that the number of these encephalic connecting pieces is proportionate to the number of the sensory and motor nerve-fibres, and (as the size of the nerve-cells changes but little with the bulk of the animal) also approximately their total weight. The different factors influencing the increase of the size of the brain may be taken together. For the moment neglecting the somewhat varying size and the differences in the number of the branches of the nervecells, we may arrive at an estimation of the influence of the size of the body upon that of the brain by the following method, first suggested by Dr Snell. Calling $e$ the weight of the encephalon, $s$ the weight of the body of the small animal, and $E$ the weight of the encephalon, and $S$ the weight of the body of a nearly allied but very much larger animal, $r$ an exponent, which we want to know, we have

$$
\begin{gathered}
S^{r}: s^{r}=E: e, \\
\left(\frac{S}{s}\right)^{r}=\frac{E}{e}, \\
r(\log S-\log s)=\log E-\log e, \\
r=\frac{\log E-\log e}{\log S-\log s} .
\end{gathered}
$$

By the application of this formula to 7 pairs of mammals of very 
different bulk (from $\frac{1}{3 \cdot 7}$ to $\frac{1}{36}$ ) and belonging to 4 orders, viz. the Primates, Ungulata, Carnivora, Rodentia, I found that in nearly allied and equally cephalisated mammals the weight of the encephalon is on the average proportionate to the 0.56 power of the weight of the body, and that in the compared animals the calculated exponent of relation only varied from about 0.54 to 0.58 .

Comparing animals of different relative cephalisation we want to know the quantity of the brain independently of the size of the body, i.e. the index of cephalisation, $c$, which can be determined now from the formula

$$
e=c s^{r} \text { or } c=\frac{e}{s^{r}} \text {. }
$$

In this manner I arrived at the result that Man has about four times as much brain as any anthropoïd ape of the same bodyweight. Chysothrix is the only ape of another family which comes alike to the man-like apes, but Midas rosalia equals the lower Old World apes. The latter do not distinctly exceed in this respect the Ungulata and the Carnivora. In the Lemuridae, Nycticebus and Tarsius occupy the same degree on the scale of brain development as measured by its quantity, about equal to that expressed by the lower indices in the Ungulata and the Carnivora. A very low degree is taken by some Rodentia, by Manis, by the Insectivora, by the Microchiroptera or insectivorous Bats and the Marsupialia, but the Cetacea are ranged amongst the Ungulata. Thus we obtain a very natural scale.

Now it appears to me of great importance to arrive at an estimation of the manner in which the weight of the brain in Man depends on the size of his body. Certainly it must be far more difficult to obtain here reliable results, because the differences of the brain-weights and the body-weights are relatively very much smaller. The Brown Rat is $2 \mathrm{I}$ times as heavy as the HouseMouse, and its brain $5 \frac{1}{2}$ times as heavy as that of the latter animal; the weight of the body of the Lion is 36 times, and its brain 7 times, as much as those of the Cat. But in full-grown men of the same nation differences from $I \frac{1}{2}$ to $I$ in the average body-weight and of $I \frac{1}{12}$ to $I$ in the brain-weight are already considerable. But in comparing men, it is true, we have the advantage, having at command real averages from larger numbers of individuals. However, the material at our disposal as fit for comparison is scanty. From data provided to me with very great kindness by Herr Otto Ammon and from others, found in a paper of John Marshall, "On the relation between the weight of the brain and the stature and mass of the body in man," I was able to estimate the power of relation, to which we have to raise the body-weight, in order to make it proportional to the brain-weight, at about 0.25 ,

$$
E: e=S^{0.25}: s^{0.25} \text { or } \sqrt[4]{S}: \sqrt[4]{s} \text {. }
$$


This is a result very different indeed from that obtained if we compare other mammals with one another. I cannot account for that difference, except by postulating a much more considerable increase of the folding of the cerebral cortex (and probably also of that of the cerebellum) simultaneously with the increase of the size of the body in Man than in the other mammals. Indeed, it is wellknown that the fissures on the surface of the cerebral hemispheres in Man become more complicated, as the hemispheres are of larger size. I was able to ascertain that this process really can account for that considerable difference in the increase of the size of the brain with the increasing bulk of the body, which we find to exist between Man and the other mammals, but have now to refer to my paper quoted as to the method applied.

I only wish to point out that the claim made upon the size of the cranium by the maxillary bones and the teeth as parts of the masticatory apparatus seems to me to be the reason why in the other mammals, contrary to Man, the adaptation of the brain to a larger body is attained less by folding of the cerebral cortex than by a real increase of the volume. It would be of no profit to Man that the size of the skull should be enlarged in such a high degree by the increasing brain. Man's already very much reduced maxillar bone easily finds space necessary for its fixing on the cranium even in the bulkiest individuals. A large cranium as such however is certainly not profitable. Therefore the folding process of the cerebral cortex progresses much faster with the increasing size of the brain in Man than in the other mammals, and our exponent of relation $(r)$ ought to be a much smaller number.

Though certainly the individual weight of the body in Man is a very variable factor, modified not only by the changing contents of the intestinal tractus, but also by the varying percentage of fat and water of the body, if managed with care and taken as the average from a certain number of individuals, as already has been pointed out, it may still yield fair results. As would appear from some comparisons it is a much more reliable basis of calculation than, for instance, the height of the body or that of the trunk in Man. Moreover, in Man only the fourth root of the body-weight ought to be applied in the calculation, the influence of a deviation of the body-weight on the result of the calculation being thus much lessened.

According to Dr Boyd's observations the average brain-weight of 306 men aged from 20 to 50 years belonging to the working classes in London was I 359 grammes, and the average body-weight of 3 I 8 living Londoners aged from 23 to 50 years belonging to the same classes, according to Dr Beddoe's tables, already quoted, was 6I kilogrammes. From these figures we now easily can calculate an index of cephalisation. Doing the same from the brain-weight of 364 South-German men as observed by Bischoff and from the body-weight of 32 men belonging to the same nations I found quite 
the same index of cephalisation, the difference being indeed less than I/I000. It thus appears that English and German men of the classes in question occupy an equal degree of cephalisation. But comparing the average weight of body of 40 Andamanese men observed by General Man with the brain-weight as computed from the observed cranial capacity by Sir William Flower (I28 I c. c.) I found their cephalisation to be 9I to 93 per cent. of that of the two European nations. In the same manner the cephalisation of the negro (the average body-weight of a large number of this race being communicated by Gould) can be estimated from the observed mean cranial capacity and some observations of the weight of the brain at 91 to 96.5 per cent. of that of those Europeans. Also the cephalisation of the Maoris of New Zealand (the body-weight being taken from observations by Thomson) appears to attain only 93 per cent., and the North-American Indians (the average bodyweight being observed by Gould) 94 per cent. of that in the Europeans.

In the Andamanese women the average cephalisation appears to be about $6 \frac{1}{2}$ per cent. lower than that of the men, even when taking into account the larger percentage of fat in the female body. The average encephalisation in European women then remains $4 \frac{1}{2}$ per cent. behind that of the men. Generally the Australians are regarded as being the lowest of existing human races. From about I 50 observations of the cranial capacity in Australian men by Flower, Turner, Broca and others an average capacity certainly little below I 300 c. c. is to be calculated. This corresponds (reduced by the method of Welcker) to I I 90 grammes of brain-weight. If we now assume as the average body-weight of the Australian men (having an average stature of about $165 \mathrm{~cm}$., but being slender and less muscular than the European) 50 kilogrammes, we find their cephalisation on the average to be 92 per cent. of that in the European.

From all these figures it is apparent that in the existing races of men the average cephalisation does change but very little, and, as already pointed out, the same must hold good for fossil men.

Certainly the calculated relative quantity of the brain in comparison to a certain reduction of the weight of the body is only a very rough estimate of the real cephalisation of the central nervous system, the finer structure being thereby entirely neglected. On the other hand, as a first approximation towards a just comparison of brain to brain, the importance of an estimation of the degree of cephalisation from a calculation based on the weight or the volume of the brain should not be undervalued, as it is highly probable that in most cases the finer structure, or, as we may still call it at the present state of our knowledge, the quality of the brain, keeps pace with that calculated relative quantity. We must feel satisfied that this certainly is the most important measure of the degree of cephalisation, bearing in mind, however, that the 
calculated ratio ought to be increased by potentiation with a certain unknown exponent expressing the complication of the structure, which however appears to be dependent upon the relative quantity: Man has four times as much brain as an anthropoid ape of equal bulk. But Flechsig has shown that the centres in the cerebral cortex, to which certainly we have to ascribe the highest functions, the association centres, connecting together centres belonging to different senses, form in man the two-third part, in apes only the half of the whole superficies of the cerebral cortex. Still a very much more important difference is founded upon the fact that the pyramidal cells of the cortex in the brain of man have more branches than those in the brain of the ape. Thus the relative functional value of man's brain in comparison to that of the ape ought to be measured by a much higher number than four.

Still, though representing but partially the real degree of brain development, our relative cephalisation appears to be the most important measure of that development as shown, since that by reference to it the mammalia may be ranged in a natural scale.

Thus it becomes apparent that it should be of the highest importance to calculate the relative cephalisation of Pithecanthropus erectus.

I have already pointed out that on the mere evidence of his cranial capacity, without taking into account the size of the body, he may have belonged to the ape-tribe or to the human species. It can be easily calculated how much the weight of the body of Pithecanthropus erectus should have been, had he had a relative cephalisation equal to that prevailing in the Anthropoid apes. We find nearly 230 kilogrammes. With a relative cephalisation equal to that of Man on the other hand, given the cranial capacity, he should only have weighed about ig kilogrammes.

Now we have the good fortune to possess in the femur a means of estimating the body-weight with some approximation to accuracy.

It is a fact, proven beyond any doubt, that the bones are adapted to the forces acting upon them. The researches of $\mathrm{H}$. Meyer and others have shown indeed that even their inner structure is calculated to resist the forces trying to break them-to such an extent as it ought to be theoretically according to the rules of mechanical science. The solidity of any given bone depending, according to certain formulæ, upon its length and its thickness, and the forces to which it is accommodated in nearly allied animals of similar form but of very different size, being in some way proportionate to the weight of the body, it must be possible to find a relation existing between the length and the thickness of the homologous bones and the body-weight.

Now by comparing in the Leiden Museum skeletons of such animals, of which the body-weights were approximately known, as Lions with Cats, Beisa- with Pygmy-antelopes, I found in fact such a relation, and can express it in figures. As an a posteriori argument, 
I may say that the relation found empirically is in accordance with theory; however that theory only conducted me in a general way. It is not my intention to enlarge on the topic of this relation, interesting though it may be, I now only want it for the purpose of its application to the femur of Pithecanthropus erectus.

Comparing the femur of Pithecanthropus erectus with human thigh bones, of which the body-weight belonging to them was known, it was now also possible to calculate with some approximation to accuracy the body-weight of Pithecanthropus erectus. I found it to have been about 70 to 75 kilogrammes.

Taking 70 kilogrammes as the basis of calculation, and admitting the exponent $r$ to be 0.56 or $0.25,1$ found the cephalisation of Pithecanthropus erectus to be ncarly the half of that occurring in Man and nearly the donble of that occurring in the Anthropoid apes.

I have pointed out already how far individual variety of the size of the brain in man oscillates, not taking into account the size of the body. The variety of the size of the brain accompanying a given body-weight certainly remains very much below that absolute variety, so that, even as an individual limit, the cephalisation of Pithccanthropus erectus would be far below that of even the smallest-brained normal human being and far above the most cephalisated Anthropoid ape.

From all these considerations it follows that Pithecanthropus erectus undoubtedly is an intermediate form between Man and the Apes. If further there is truth in our present conceptions of the continuity reigning in the organic world, I cannot look upon Pithecanthropus but as upon a real member, the first known, in our genealogy. And even should we prefer not to regard him as a grandfather but as an uncle, still in every case he is a most venerable ape-man, representing a stage in our phylogeny.

Prof. MACALISTER spoke and strongly urged that researches in Trinil should be continued, and moved the following resolution, which was seconded by Prof. O. C. MARsh, and carried:

"That, in the opinion of this Meeting of the members of the Fourth International Congress of Zoology, the Dutch Indian Government, by ordering the exploration of Trinil, Java, leading to that most remarkable discovery of Pithecanthropus erectus, have laid the Zoological world under a most weighty obligation; and, that the aforesaid members of the Fourth International Congress of Zoology hereby desire to express the fervent hope that these investigations may be continued in the future with the same thoroughness as in the past." 


\title{
FIFTH GENERAL MEETING.
}

\author{
Saturday, August 27th, at 9.30 A.M.
}

\section{Chairman: THE PRESIDENT.}

Prof. MöBIUS, in the name of the German Zoological Society, invited the Congress to meet in Germany in I9OI.

Prof. BELL said he was instructed by the Executive Committee to propose that "the place of the next meeting of the Congress be determined by the German Zoological Society in consultation with the Permanent Committee in Paris." This was agreed to without discussion.

The PRESIDENT proposed a vote of thanks to the University and Colleges of Cambridge for the kind and hospitable reception given to the Congress. The proposition was seconded by CAV. CARruccio (Italy), supported by Dr ZsCHOKkE (Switzerland), who spoke as follows:

Am Schlusse der festlichen Tage von Cambridge möchte ich nicht verfehlen, im Namen aller Gäste den herzlichsten Dank auszusprechen für die liebenswürdige Aufnahme, die wir gefunden, für die warme Gastfreundschaft, der wir uns erfreuen durften und für die reichen und schönen Erinnerungen, die wir mit nach Hause tragen.

Es ist vielleicht nicht ganz zufällig, dass einem Schweizer der letzte Scheidegruss zukommt. Wir Zoologen aus der Schweiz, deren Vaterland fernab vom Meer, mitten im grossen Hochgebirge des Continents liegt, müssen von Zeit zu Zeit hinabpilgern an die Ufer des Oceans, zur Quelle und Wiege des Lebens und zum Schauplatz seiner reichsten Gestaltung und Entfaltung.

Und noch ein anderes Meer, eine andere verjüngende und erfrischende Welle und Fluth thut uns Noth, die verjüngende Welle gegenseitiger Anregung und wissenschaftlichen und geselligen Verkehrs.

Und wenn diese erfrischende Welle uns ganz besonders reichlich bespült hat, und uns zur Arbeit neue Kraft verlieh, wenn die letzten Tage zu einem einzigen, harmonischen Fest der Forschung und der Geselligkeit geworden sind, so danken wir das verschiedenen Umständen. Wir verdanken es unserem treffichen 
und hochverehrten Präsidenten Sir John Lubbock, wir verdanken es den Herren der Comités, dic ihre Arbeit und Zeit in den Dienst des Congresses gestellt haben. Vor allem aber danken wir es dem klassischen Boden auf dem wir stehen-auf dem Darwin und Balfour wandelten-, der Luft, die wir einathmen, dem Geist freier Forschung, der uns umweht - mit einem Wort, der altehrwuirdigen Universität Cambridge.

Sie öffnete uns weit und in warmer Gastfreundschaft die Thore ihrer Colleges; aus diesen Thoren ziehen wir heute nur ungern aus; ein Stuick unseres Herzens bleibt zurück.

Cambridges Universität möchte ich vergleichen mit jenem Maulbeerbaum Milton's, der im prächtigen Garten von Christ's College steht. Gepflanzt vor Jahrhunderten durch die Hand eines Dichters und Idealisten, die Rinde zerrissen, der Stamm kinorrig. doch jugendstark, - und jedes Frühjahr bringt neue Blätter und Bluithen, und jeder Herbst streut reichen Segen neuer Früchte aus.

Im Namen von ihnen allen rufe ich:

\section{Salve Universitas Cantabrigiensis!}

Prof. NEwTON said that it was his duty, in the absence of the Vice-Chancellor, to return thanks on behalf of the University for the very kind way in which it had been spoken of, not only by the President, but by others after him. He need not say that to speak in the name of the University was a very serious responsibility. In respect of Zoology it had very ancient associations, and had acquired a reputation to which it was very difficult to live up. Of old times besides William Turner whom he had mentioned on a former occasion, there were Ray and Willughby. As regarded the biological school it had been continued through a long line of men. In the early part of this century it had been conducted by men like the elder Sedgwick, Professor Henslow and the late Professor William Clark. Henslow's line was especially botany, and Sedgwick's emphatically geology, yet both of them had a very strong sympathy with everything that was Zoological. The Zoological school of Cambridge was founded by these men, and especially by William Clark. Then they had men like Leonard Jenyns and Vernon Wollaston who, each in his own way, had done excellent work, while two others bore the greatest names that could in the present century be associated with Zoological ScienceCharles Darwin and Francis Balfour. The school therefore had flourished, and moreover was still flourishing, notwithstanding, and perhaps in spite of, the healthy rivalry, which was at times intense, of the physiological school, recently founded alongside of it. In some respects the ways of physiologists were not as their ways, the thoughts of physiologists were not as their thoughts, and they had had in them friendly enemies to oppose. It was that healthy rivalry which he thought had added very much indeed to their 
utility, supposing there was anything useful in what they professed to teach and do. Now having done with that, he wished to express his gratification at the great success, as he thought one might say, of the present Congress, and he could hardly say to whom it was really due. He knew how indefatigably the secretaries and others had worked, and how admirably they had made their arrangements, but they would be the subject, he understood, of a subsequent resolution. He knew he could speak for the Vice-Chancellor, that he had taken from the first the greatest possible interest in the Congress, and had been most kind in making his arrangements fit in with theirs. (Applause.)

The PREsident proposed a vote of thanks to the Mayor and Corporation. Prof. MILNE-EDWARDS (France) seconded the proposition, which was supported by Prof. MöBIUs (Germany) and Prof. von GRAFF (Austria), and carried with acclamation.

The MAYOR in reply said the Corporation of Cambridge, through him, thanked them for the very kind expression which they had given voice to that morning. He had had the good fortune to attend some of their meetings, but he was sorry to say he had given more attention to the social gatherings which they had been enjoying than the deliberations which they had had in the hall. But those social gatherings he had extremely enjoyed. He heard frequent mention of the great men which Cambridge had produced, but it would not be fair if the proceedings were to pass unless he told them one other fact which he had not mentioned in their midst, and that was Cambridge had had the honour during last year of having at the head of the Corporation a son of him whom they all loved, viz. Charles Darwin. He wished it had fallen to Mr Darwin's lot to occupy this year the place which he had the honour to occupy and receive the Congress. Cambridge felt it an honour that it should have been chosen for a meeting of so many distinguished men from all parts of the world. It might be that he was engaged more in civil government than in the pursuits in which they were engaged, but he drew one very valuable lesson from the meeting which they had had in Cambridge, and that was in reference to the cordiality and the amiability which existed between all countries of the world. It was a very valuable lesson to this country that gentlemen from all parts of the world could meet on such friendly terms, and the repetition of such meetings, as the President had said, must conduce to the happiness and prosperity of all.

After passing a vote of thanks to the President, Secretaries and other officers on the motion of Prof. YvEs DELAGE (Paris), seconded by Prof. Plate (Berlin), 
Prof. BELL moved: "That there be appointed a Committee consisting of Prof. Schulze, Dr Pelseneer, Mr A. H. Evans and Prof. Mark-Prof. Mark to be Secretary-to consider and report upon the practicability of securing uniformity in the use of abbreviations and in other matters of terminology, the Committee to be known as the Committee of Terminology."

The motion was adopted without discussion.

Professor Hickson then presented the following statement, and moved that the report be received and the recommendation accepted.

In view of the impossibility of transmitting to the various members of the International Committee the detailed accounts of the Concilium Bibliographicum, it was decided that the necessary control over the financial operations of the institute required the nomination of a finance committee, so situated that the revision of the accounts of the Concilium could be satisfactorily carried out. This action was demanded by the Swiss authorities subsidizing the work. For this reason a Committee was formed comprising delegates from the Federal Council of Education, the Cantonal Parliament and the Town Council of Zuirich.

The Committee therefore request the authority of the Congress to transmit the duty of supervision of the financial affairs to the Swiss Committee.

The motion was adopted without discussion and the Meeting adjourned. 



\title{
SECTION A. GENERAL ZOOLOGY.
}

TuesDay, 23 August, at the Guildhall at 2.15 p.m.

\author{
Chairman, Prof. SPExGEL. \\ Secretary, Dr HoEk. \\ Assistant-Secretary, Mr GRAHAM KERR.
}

Prof. Mitsukuri of Tōkyō read the following paper:-

\section{ZOOlOGICAL MatTers IN JAPAN.}

I ought perhaps to begin my paper by asking your indulgence for calling your attention to matters which are not strictly scientific, and moreover for treating them in a somewhat desultory manner. But I hope you will agree with me in thinking that at a Congress like the present, where persons of all nationalities come together and where the forming and renewing of personal acquaintances is necessarily a large and important feature, papers on subjects other than strictly technical ones are not out of place. Especially for those from a country like Japan, which is comparatively little known to the outside world, it is entirely proper, I hope, to tell in what status their science really is. If any of you should chance to visit Japan, I think you would probably wish to visit our laboratories, our marine stations, to look over what collections there are, to glance into our publications, to become acquainted with zoologists, and so forth-in short to know what and how much is being done in zoological work in Japan. But as it is not probable that I shall have the pleasure of welcoming many of you in my country, I have thought I might interest some of you by telling you about these matters in the present Congress. Since Mahomet cannot go to the mountain, the mountain must come to Mahomet, and I only fear you will find only a small mouse coming out at the end of that mountain.

As I have only so recently treated of the history of our Science in Japan ${ }^{1}$, I shall not go into it again here in detail, but I might be

1 Annotationes Zoologicae Japonenses, Vol. I. Introductory. 
permitted to recall some main features for the sake of those who do not know niy paper.

It is often said that Japan has within recent years made a grcat progress in all social, political, military, and scientific matters. And we, as a nation, sincerely hope that this is true, and that our efforts to bring ourselves abreast of other nations have met with some degree of success. But to people of other lands this progress seems simply phenomenal and without a parallel. To many in the Occident it appears to be the transformation of a semi-barbarous country into a modern civilized nation in an exceedingly short space of time, and on that account there is a certain amount of misgiving in regard to the genuineness of this transformation. We occasionally hear people expressing tears about a possible relapse into barbarism. To us this appears a very unjust view to take of the recent changes in Japan. If you examine into our history it will be very easy to discover that our country attained a high degree of civilization at the time when a large part of Europe was still in a comparatively primitive condition. The period extending from the seventh to the tenth centuries of the Christian era is often looked on as the golden period of our land, and the masterpieces in literature and art which were then produced are at the present day pointed to as something inimitable. In regard to the more scientific aspect of the period, I may perhaps be allowed to quote a passage from my paper, to which I have referred:

"It is probably unknown to most persons in the West that early in the eighth century of the Christian era, there was already established in Japan an Imperial University with four departments -Ethics, History, Jurisprudence, and Mathematics - and with the prescribed number of four hundred students. There were also at the same time a bureau devoted to Astronomy, Astrology, Calendar-Compilation, and Meteorology, and a Medical College, with Professors of Medicine, Surgery, Acupuncture, Necromancy (the art of healing by charms), and Pharmacology. The last named branch of study included the collection, cultivation, and investigation of medicinal plants, and thus a considerable amount of botanical knowledge must already have been acquired by that time. Towards the end of the ninth century, when a catalogue of books existing in Japan was compiled by the order of the then reigning emperor, the Imperial library was found to contain 16,790 volumes divided into forty departments-and this in spite of a disastrous fire of some years previous. Among the medical works were some with very modern sounding titles, such as 'The Curing of Diseases of Women' and 'On the Methods of Healing Diseases of the Horse.' Japan in those early days derived its culture from India, China and Corea, but the details above enumerated clearly show that educated society must already have attained a high degree of civilization." 
Coming to more modern times, for two hundred and fifty years immediately preceding 1868 , the country was in such profound peace that learning, the arts, and all peaceful industries were developed with remarkable vigour, and social refinement attained a degree which, to say the least, we must pronounce remarkable. I have not time to explain the severe discipline gone through, and the high degree of scholarship attained by, our sacants in those days, but I may quote again from my paper in regard to the Natural History studies :- "Apart from that innate love of Nature and the natural which was ever showing itself in poetry and other arts, the study of natural products was always pursued, ostensibly with the purpose of collecting materia medica, or of discovering things that might be used as food in case of a famine, or of identifying objects mentioned in the Confucian classic, 'Shi-King.' But it is not difficult to perceive that naturalists looked in reality beyond these simple or utilitarian ends, and investigated animals and plants for their own sake, although the principal aim of their researches seems to have been the comparatively barren one of establishing a relationship between Japanese products and those described in various Chinese works on Natural History. Frequent were the excursions and expeditions undertaken with the view of collecting natural objects, among which plants were especial favourites, and all parts of the country seem to have been tolerably well explored in this way. Numerous were the treatises on Natural History, published or unpublished. Many of these were encyclopædic in their comprehensiveness and size, such as 'Shobutsu Ruisan,' by Inao Jakusui (IOoO parts, early in the eighteenth century), and 'Honzō Kōmoku Keimō' by Ono Razan (48 parts, I 803). The last-named naturalist was so famous for his extensive knowledge, that we are told his pupils were nearly one thousand in number. My colleague, Prof. Matsumura, in his book on the enumeration of Japanese plant-names, gives 306 titles of Japanese works on botany compiled previously to I 868. Many of the Natural History* volumes had beautiful, coloured illustrations, which serve their purpose even at the present day. Natural History displays were of common occurrence, when naturalists came together with their treasures, and showed them to one another and to the public. Of these the exhibitions given by Hiraga Gennai in the middle of the eighteenth century were perhaps the most celebrated. The present Botanic Garden of the Imperial University was established in I68I, and was long renowned as the "O Yaku En" (Garden of Medicinal Plants). The mastery of the Dutch language by a few earnest physicians in the middle of the eighteenth century has always seemed to me one of the greatest triumphs ever achieved by patient scholarship. Originally undertaken with the purpose of ascertaining something about Western medicine, their efforts soon exerted an influence on all branches of learning. The whole rich treasury of Western civilization became suddeniy accessible through the 
channel thus opened. It is not possible to overestimate the effect of the new acquisition on the progress of Japan. Suffice it here to say that the country would not be what it is to-day but for this leaven which had been working through and through the whole mass of society for over a hundred years before the Restoration of I 868 enabled it to bear its legitimate fruit. This innovation, together with the visits of Thunberg (I775) and Siebold (I \&2I), had due effect upon the Natural History studies also. The system of Linné, especially in regard to plants, seems to have been well grasped, with very little delay. The most famous productions of the new school on Natural History subjects are probably 'Shokugaku Keigen" (Elements of Botanical Science) by Udagawa Yoan, I835; and 'Sōmoku Zusetsu' (Icones Plantarum) by Iinuma Yokusai, I 832 ; - the latter being a standard work at the present day. It is perhaps a circumstance interesting enough to record, that a work on the use of the microscope was published in I80I."

I have gone somewhat more extensively than I intended into the past of the Natural History studies in Japan, because I wished to show in one concrete case that the soil on which the seeds of modern science were sown in Japan was by no means barren or unprepared. If you look into the matter slightly, I think you will find that the development of modern sciences in Japan is but natural, that there is nothing forced about it, and that it was bound to follow as the necessary consequences of the given antecedents. I hope therefore that you will not regard us as sudden upstarts, but rather as those who have for a long time developed independently along a different line, but have recently converged towards that followed by other civilized nations of the world.

Historically, the study of modern Zoology dates from the creation of the chair of zoology in the Tökyō University in 1877 and the appointment of Prof. Morse of America as the first occupant of that chair. Twenty years are not a very long time, but a generation of zoologists representing various branches of our science has since arisen, and I may perhaps be allowed to claim that at least a very fair start has been made.

If any of you should visit Japan at the present day, I think you will soon find that the Zoological Institute of the Science College in the Tōkyō University is the centre of zoological activity in Japan.-Although I mysclf am intimately connected with it, and my colleague Prof. Ijima and I have charge of the Institute, I think I can safely claim this distinction for it without appearing immodest,

1 This work treated of the morphology of plants from quite a modern point. It was customary in those days for a friend of the author of a work to write the preface. In this case it was my grandfather who stood thus as a sort of sponsor, and you will perhaps allow me a bit of family pride and let me say that he was very sound in his views. He contended that apart from what might be called the mere natural history studies, plants should be dissected and their structure studied, and that this should form the basis of the botanical science, just as the dissection of the human and animal bodies serves as the basis for the science of Anatomy. 
for not only have almost all who are known as zoologists in Japan come out of that Institute, but there are always a dozen or more advanced students there eagerly carrying on investigations. Great encouragement is given by the University to those who wish to continue their studies after obtaining their first degree, and the results have so far been very satisfactory.

In the museum belonging to the Institute something more than a mere collection for instruction has been attempted. It has been devoted to the fauna of Japan, and is especially rich in the marine invertebrates. All the forms recently obtained from the deeper parts of the Sagami seas are deposited there. Very striking is the collection of Hexactinellida, a monograph on which is now being prepared by Prof. Ijima. Other groups are also well represented, and important additions are constantly being made.

The Science College publishes a journal embodying the results of investigations carried on in its various departments by professors, graduates and students, or relating to Japan : the zoologists have availed themselves of the opportunities thus afforded, and in this journal more extended zoological contributions from Japan may be looked for.

The Tökyō Zoological Society, which unfortunately has as yet no quarters of its own, is temporarily domiciled in the Zoological Institute of the Science College. It publishes a journal in Japanese called the Zoological Magasine, which is in its tenth volume. The part in foreign languages, which was at one time published with this Zoological Magasine, has been detached as a separate publication, and is known as the Amnotationes Zoologicae Japonenses.

In connection with the Tökyō Imperial University there is a second Zoological Institute belonging to its Agricultural College. This lies outside the city boundary and is about four or five miles from the other departments of the University. Prof. Ishikawa and Prof. Sasaki are to be found in this Institute.

There is also a Zoological laboratory belonging to the Fisheries Bureau. Dr Kishinouye, who is present here, presides over it. Various fisheries problems, some of which are peculiar to the Far East, are being studied by the workers in this laboratory.

Besides these there are several other Zoological laboratories connected with various schools.

In Tōkyō there is also a unique institution, i.e. the turtle-farm. The snapping-turtle (Triony'x japonicus) occupies in Japanese gastronomics the high place accorded to the green turtle in the English, and to the terrapin in the American. Some thirty years ago a man in Tōkyō conceived the idea of cultivating these delicious reptiles in a farm, and began experimenting in various ways. Within the last fifteen years his son has carried the business to such a high pitch of perfection that it is now firmly established and proves very lucrative. About 35,000 embryos are now annually hatched 
and they become marketable in three or four years. From the embryological standpoint such an abundance of material was not to be lost sight of, and having also had a breeding place established for our ordinary tortoise (Clemmys japonica) in the same farm, I have seized the opportunity thus afforded of studying the embryology of Reptiles. I believe that science and practical farming have in this case mutually benefited each other. From my experiences, I am inclined to think that we have now arrived at the stage of embryological investigation in which an abundant supply of good material has become a greater desideratum than heretofore, and I believe that such a farm will become a necessary part of a zoological institution.

There is also an Imperial Museum and a small Zoological Garden in the Uyeno Park in Tōkyō.

When we pass out of Tökyō I must take you first of all to the Marine Biological Station in Misaki. This is an appendage of the Zoological Institute of the Science College. It is therefore primarily intended for the use of professors and students of the Imperial University, but it also gives facilities to other persons. The course in Biology in the Science College is perhaps peculiar in the fact that students are required to pass at least one season in the station, and indeed, those who take up Zoology as their speciality spend much more time than is required at the seashore, and become familiar with the marine life at first hand.

Misaki is at the point of the peninsula which divides the Bay of Sagami from the Bay of Tōkyō, and is reached from Tōkyō by steamer in about five hours. The station was until recently in the town of Misaki, but the accommodation not being equal to the demand, it has been removed within the last year to a locality about two miles away to the north. The situation is one of the most beautiful in Japan, commanding a matchless view of the sea and of the immortal Fujiyama. The station occupies a small peninsula dividing the Sagami sea from an inlet, the latter forming one of the safest anchorages possible. On the peninsula there is a low level ground between two hills, and on that low ground stand the laboratory buildings, while on one of the hills is built the dormitory. The new laboratory is able to accommodate about twenty workers.

The station commands a very rich fauna. Many inlets along the coast have all kinds of bottom, yielding a rich variety of animal forms. In the immediate vicinity of the station there are ledges of Ascidians, beds of Lingula and Gephyreans, and grottoes of Alcyonarians and Actinians; while Corals, calcareous and silicious Sponges, Hydroidea, Nemerteans, all the orders of Echinoderms, Annelids, Compound Ascidians, Nudibranchiata and other Molluscan orders are found in great abundance. In fact we are only beginning to know the richness of the fauna. For instance, last year, just about this time, we discovered a place where a species of 
Balanoglossus is found in abundance, and since I came away I am informed that two more species have been found near the locality: The plankton is also very rich-the warm current Kuroshiwo which passes by, not many miles out, bringing many forms of the warmer seas. Various forms of Siphonophora and Ctenophora (among the latter a Cestus), Charybdea (several species), Aurelia, Dactylometra, Pilema, Liriope, Limacina, Carinaria, Pterotrachea, Sagitta, Salpa, Doliolum, Appendicularia, Actinotrocha, Pilidium, Tornaria, various Echinoderm larve, Noctiluca, are the names that occur to me at random, and the list could easily be made much longer. But it is only when we look beyond the immediate shores that it becomes evident how we are favoured by nature. I need not remind this audience that the Pacific is extremely deep near Japan, and that comparatively great depths occur close to the shore. The operations which have the Misaki laboratory for their base are at present confined mostly to the Sagami sea. Within this area we may perhaps distinguish two sections, the parts shallower than IOO fathoms and those that are deeper. The bottom of the sea seems to grow deeper comparatively slowly, down to the soo-fathom line, although this line is nowhere very far from the shore, and in some places extremely close. At the Ioo-fathom line there is, generally speaking, a very sudden deepening. In many places there must be almost perpendicular cliffs, for two soundings, distant only by a stone's throw, often give one So-IOO fathoms, and the other over 200 fathoms. Towards the centre of the sea there are 500600 fathoms, and in one spot 970 fathoms. There is another peculiar place near the mouth of the river Banyū which gives 908 fathoms. A very important spot is a shoal known as Okinose, where the shallowest water is only 37 fathoms deep. The declivities of this submarine peak form one of the richest grounds. It is evident that rolcanic phenomena have had a great deal to do in the formation of the peculiarities of the bottom in the Sagami sea. IVe still see abundant evidences of volcanic activity in this region. Oshima, which marks the southern boundary of this sea, is an active volcano, and its smoke is one of the great meteorological signals useful to fishermen. Fujiyama and Hakme, extinct rolcanoes, lie not very far off, and the peninsula of Izu is full of hot mineral springs. Moreover the Bay of Tōkyō is the centre of numerous earthquakes.

Faunistically, we can distinguish the shallower areas above the Ioo-fathom line as the home of Metacrinus and of many forms of Pennatulids. The cliff, which goes down at that line into deeper parts, seems to be very rich in animals. It is below this cliff in deeper parts that we find Hyalonema, Euplectella, Rhabdocalyptus, and other silicious sponges. It is also the home of Chlamydoselachus, Pleurotomaria, and Macrocheirus. Of the extremely rich and varied forms of life found in these deeper parts I can speak only of their existence. The materials have yet to be studied. Of 
the deep-sea Holothurians in which I myself have recently been dabbling, I may say there are about nine species, some being new, others already reported by the Challenger either from these seas or from remote seas like the Antarctic.

We are as yet unprovided with a steamer, and how in its absence we carry on our operations in these seas you may be interested to hear. The fishermen of Misaki are famous for their boldness and skill, and we utilise these qualities to the full. In addition to the surface fishes they catch bottom fishes to the depth of $300-400$ fathoms. This they do by means of long lines. Those used in the shallower parts are very slender, but others used in deeper parts, mostly for the purpose of catching the fish Bathyrissa, are somewhat stouter. The latter are the more useful for our purpose, and as my colleague, Prof. Ijima', has already described in full this mode of fishing and its importance for the collector, I need not go into details. Suffice it to say that, like all long lines, it is a line having at certain intervals (in this case at every fathom) short branchlines (snoods) with hooks at their ends. This is let down with weights to the bottom. The lines are kept coiled in baskets, each holding ioo fathoms. These can be spliced together to any required length. When therefore we say we have let down fifteen baskets, it means that we have laid on the bottom of the sea a long line of I,500 fathoms, with 1,500 hooks. If this line is moved by any means, it means that I,500 hooks are dragging the bottom of the sea. As each hook is baited, it is eminently adapted for catching fish or any other animals which seek prey, and is also adapted for hooking organisms fixed to the bottom. Fish that are caught help us by their struggling, thereby entangling fixed forms. It is one of the most interesting and exciting sights to watch this line being hauled up, for in successful parts one can see fishes and other animals coming up to the boat in a vertical procession, each keeping a distance of one fathom from the one before and behind it.

The arrangements and instruments used by these fishermen are all of the simplest kind, but sometimes very ingenious. Here I have brought this apparatus for sounding. Though it looks rather rough and unpromising it is very ingenious, and the principle that underlies it is the same as that of the most modern and improved sounding machines. It is a small stone tied with four lines. When about to be used, large stones are piled on the small one between the four lines, and are barely kept in their place by the little ring of twine. The whole is let down as rapidly as possible by a fine but very strong line, specially made for the purpose. When the instrument strikes the bottom the large stones fall off. The bamboo stick on the top keeps the line from revolving and thus untwisting. Soundings to $300-400$ fathoms can be made quite accurately with this. Members of our Zoological Institute have recently had a

1 The Zoological Magazine. 
friendly competition in devising a small brass tube which will bring up samples of the bottom, when used in place of the small stone.

The method used by the Misaki fishermen for fixing a locality in these seas is somewhat interesting, and has been adopted by us for identifying the locality of a specimen. It is done by a method very similar to a system of longitudes and latitudes. What correspond to the longitudes are fixed by sighting a certain mountain peak which is plainly visible in every part of these seas. The lines are known by the names of the spots on shore over which the peak is sighted. The latitudes are determined by the extent to which the Cape of Sunosaki overlaps the mountains of Mera in Bōshyu. For instance, when the locality of a specimen is mentioncd as the line of Iwado with the three peaks of Mera visible, the spot is easily identified. This is so accurate that when their fishing-lines become entangled or are caught, fishermen often leave them with a small float on overnight, and are able to find the spot next day without much difficulty.

Nowadays it is very rare to read of the pleasures of a naturalist roaming through woods and fields in search of animals and plants. Zoology and botany have become too serious a business to leave much margin for pleasure. But I have known some of the greatest pleasures of my life, wandering about these seas in small boats not more than twenty-five or thirty feet long, with these fishermen, quick, alert and eager. It has made me know Nature in one of its most genuine aspects.

I have spent so much time in speaking about Misaki that I have only a little time left for other subjects. I shall point out to you on this map some of the facts which may be of zoological interest.

One of the best known animals from Japan is the giant Salamander. This is found in the cool mountain streams of Iga and other provinces of the middle Japan. Although not common, it is not very rare. My colleague, Professor Ishikawa, is trying to obtain materials for its embryological investigation.

The Japanese ptarmigan, whose existence has been under some doubt in Europe, lives on the Mitake, Norikura and other high mountains of central Japan.

The Inland Sea, famous for the beauty of its scenery, is zoologically an interesting body of water. Its shores have a very rich littoral fauna. It is also the home of Limulus longispinus. It is the breeding ground of many kinds of fishes $(c . g$. the species of Pagrus, which enter from the two channels and spawn in about the middle of the sea). The plankton of the Inland Sea is quantitatively the richest that I know, and the accurate determination of it by modern methods may bring out some interesting results. The region around Hiroshima on the Inland Sea is famous for a very perfect system of oyster-culture that has been carried on for at least I 80 years. In the Bay of Kojima, the cultivation of Arca granosa and Arca subcrenata has been very successfully inaugurated within 
recent years. This place, together with another up north in the Miyagi Prefecture, enjoys the unenviable reputation of having an abundant supply of Distomum endemicum or spathulatum, which infests the human liver and proves fatal in so many cases.

Amplioxus has been found in Japan in three places, all on the island of $\mathrm{K} y \bar{u}$ shü, viz.: (I) in the Inland Sea, off the province of Bungo, (2) near the island of Shikajima, in the province of Chikuzen, and (3) in Amakusa, in the province of Higo. The animal has not so far been found in any place further north, although a larva has once been found in the surface collection in the Inland Sea.

As we approach the southern extremity of Kyūshū, the fauna becomes subtropical, and this becomes more and more marked as we pass on to the Loo Choo Islands.

Coming back further north, the Pacific shores of the island of Shikoku and the peninsula of $\mathrm{Kii}$ are famous for their mild climate. The warm Black Current (Kuroshiwo) sweeps by, and at Shiwo-no-Misaki (lit. Cape of Current) comes very close to the shore, influencing the fauna to a marked degree. Here, as indeed all along the Pacific shores of Japan, the fishes like the bonito and the tunny, which come with the current, are caught in a large number.

The river Nagara, in the province of Mino, is famous for the fishing of Plecoglossis with the cormorant. The art-for it cannot be called anything else-is here carried to perfection. A skilful fisherman can hold a dozen or more birds by separate strings, and can manage to keep the lines all disentangled and clear in spite of the complex movements of the birds. The fishing is carried on in dark, moonless nights in the summer. A fleet of these cormorantfishers descending the river, with their torches burning, amid the peculiar cries of the men urging the birds to do their best, is one of the most interesting sights to be seen in Japan.

In the town of Gifu, the centre of this cormorant-fishing, lives also an enthusiastic entomologist, well known in Japan-Mr Nawa. He owns a very extensive collection of Japanese insects, and is making a very interesting study of insects injurious to agriculture in that country.

The Bay of Mikawa is famous for the good quality of the holothurian, Stichopus japonicus, which is eaten largely in Japan, and, as dried trepang, is exported to China. Certain experiments with a view to the cultivation of this holothurian, or at least to keeping its supply undiminished, are here going on.

In the Bay of Agu, in the province of Shima, there occurs an abundance of the pearl-oyster, Avicula Martensii, and there has lately been formed a large establishment for the cultivation of this, which promises to give very good results.

In the Bay of Suruga, the water is very deep close up to the shore, and here has been found a very remarkable oceanic plankton, including many Siphonophora, Heteropoda, Medusae, and Oceanic 
Cephalopoda. At one point, a small laboratory for the investigation of fisheries problems is established.

At Kawana, in the province of Izu, Dr Kishinouye is trying experiments on the cultivation of Haliotis.

Sardines are caught all over Japan, and form one of the most important fisheries products. But the coast of Kujūkuri, in the province of Shimosa, is specially famous for the immense quantity of the catch, as well as for the huge dimensions of the nets used.

The warm Black Current is removed further and further from the shore as we go northward, and between it and the coast there comes down a cold northern current, which reaches down, in the colder season at least, as far as Cape Inubōzaki. In the northern part of Japan, many northern fishes like the cod, salmon, herring, and others are thus found.

Two bays-one in the extreme south, the Bay of Kayoshima, and the other in the extreme north, the Bay of Awomori-are famous for their abundance of Pectens. The southern form is Pecten laqueatus, and the northern Pecten Yessocnsis-the latter attaining a very large size.

The Strait of Tsugaru forms one of the marked boundary-lines in the distribution of animals, the fauna of Yeso being allied in many respects to that of the continent and different from that of the islands south of it.

In Yeso or the Hokkaido, the salmon, the trout, the cod, and the herring are found in immense quantities, and are of the greatest economic importance. The Bay of Hokodate is also famous for its species of Brachiopoda. A small marine laboratory has recently been established by the Hokkaido Fisheries Bureau. on

Prof. W. SAlEnsky, of St Petersburg, read the following paper

\section{HETEROBLASTIE.}

Verschiedene Forscher auf dem Gebiete der Embryologie der Ascidien und der Wirbeltiere haben einen bedeutenden Unterschied in der Entstehungsweise des Herzens und des Pericardiums bei den beiden eben erwähnten, sonst nahe verwandten, Tiergruppen hervorgehoben. Aus den Untersuchungen von Secliger und von E. Van Beneden und Julin, welche von mir bestätigt wurden, geht namentlich hervor, dass das Pericardium und das Herz der Ascidien nicht aus dem Mesoderm, wie es bei Wirbeltieren der Fall ist, sondern aus dem Entoderm ihren Ursprung nehmen. Diese Eigentümlichkeit der Entstehung des Herzens hat einen um so grösseren Wert, als bei allen übrigen Tieren ohne Ausnahme diese Organe aus dem Mesoderm entstehen. Man könnte noch hoffen, dass die ungeheuere Kluft, welche zwischen den Wirbeltieren und den Tunicaten in dieser Beziehung zum Vorschein getreten ist, durch den Nachweis der entodermalen Entstehung bei 
ersteren wenigstens eines Teiles des Herzens, namentlich des Endocardiums überbrückt werden würde; in diesem letzteren Falle könnte die Homologie des Ascidienherzens in dem Endocardium der Wirbeltiere nachgewiesen werden; doch ist dies nicht der Fall. Meine eigenen Untersuchungen über die Entwicklung des Endocardiums bei den Amphibien und Vögeln, haben mich zur Überzeugung geführt, dass auch dieser Teil des Herzens aus dem Mesoderm und nicht aus dem Entoderm seinen Ursprung nimmt, wie dies von manchen Forschern angegeben wurde. Wir stehen also der ziemlich feststehenden Thatsache gegenüber, dass bei den Ascidien das Herz seinen Ursprung aus dem Entoderm, bei den Wirbelticren aus dem Mesoderm nimmt und unsere nächste Aufgabe soll in der Erklärung dieser Anomalie in der Entwicklung des Herzens der Ascidien bestehen. Wie überall, so ist auch in vorliegendem Falle, die Methode der Vergleichung diejenige, welche den besten Erfolg verspricht, und wendet man diese Methode in unserem Fall an, so trifft man sofort in der Entwicklungsgeschichte der Tiere eine Reihe analoger Phänomene, die zunächst darauf hinweisen, dass die von mir hervorgehobene Erscheinung nicht isolirt dasteht, sondern einen Ring in einer Kette von analoger scharf characterisirter Erscheinungen bildet.

Wenn wir uns die Frage aufstellen: WVorin besteht die Anomalie in der Entwicklung des Herzens bei den Ascidien? so können wir dieselbe ganz einfach beantworten: dieselbe besteht in der Ersetzung des Mesoderms durch das Entoderm bei der Bildung des Herzens, und wenn wir nach analogen Erscheinungen in der Embryogenese anderer Organe suchen, so werden wir ziemlich leicht ähnliche Fälle bei verschiedenen Organen und bei verschiedenen Tiertypen finden. Die einfachsten Fälle solcher Ersetzung eines Keimblattes durch ein Anderes bei der Bildung gewisser Organe, bietet uns die Bildung des Darmcanals. Es ist bekannt, dass bei der typischen Entwicklung des Darmcanals, der mittlere Teil dieses Organs, das Mesenteron, aus dem Entoderm entsteht, während der vordere und der hintere Abschnitt des Darmes, das Stomo- resp. Proctodäum, aus dem Ectoderm ihren Ursprung nehmen. Bei den Isopoden beteiligt sich das Entoderm nur in der Bildung eines sehr kleinen Teiles des Darmcanals und verwandelt sich hauptsächlich in der Leberschläuche. Fast der ganze Darmcanal stellt als ein Product des Ectoderms dar. Dasselbe erweist sich bei einigen Insecten, wo nach den Untersuchungen von Heymons der ganze Darmcanal ectodermalen Ursprungs ist.

In einer viel extensiveren Weise treten die Erscheinungen der Ersetzung der Keimblätter bei den Ascidien auf. In dem allgemeinen Teile meiner "Beiträge zur Entwicklung der Synasidien" habe ich solche Beispiele angeführt und dieselben zu erklären versucht. Sie beziehen sich auf die Entwicklung der Peribranchial- resp. Cloacalhöhlen und des Kiemenapparates. Es ist bekannt, dass die Peribranchialhöhlen der Ascidienknospen und der 
Ascidienembryonen auf zwveierlei Weise entstehen. Bei den Embryonen entstehen dieselben aus den paarigen ectodermalen Einstülpungen, die sich im Inneren des Körpers ausbreiten und mit ihren distalen Teilen in die Pharyngealhöhle durchbrechen, wodurch eine Reihe sog. Kiemenöffnungen resp. Stigmen sich herausbildet. Bei den Knospen bilden sich keine Einstülpungen des Ectoderms, und die Peribranchialhöhlen entstehen nicht aus dem Ectoderm, sondern bilden sich durch Ausstülpungen der entodermalen Pharyngealwand, die sich später distalwärts vercinigen und in die unpaare Cloacaleinstülpung ausmünden. Mit cinem Worte, es bilden sich die peribranchialen und die cloacalen Höhlen bei den Ascidienknospen aus dem Entoderm, während sie bei den Ascidienembryonen aus dem Ectoderm entstehen.

Diese Beispiele, wenn wir noch die Entwicklung des Herzens der Ascidien hinzufügen, können das Wesen der Ersetzung der Keimblätter bei der Entstehung der Organe, also das Thema über welches ich hier reden will, gut illustriren.

Unsere nächste Aufgabe ist nun die angeführten Thatsachen zu erklären.

Die Morphologie der Tiere hat in der letzten Zeit einen IVeg betreten, welcher für die Zukunft sehr schätzbare Früchte verspricht. Ich meine eben die physiologische Richtung in der Morphologie, welche auf experimentalem Grundlage die Bildung der lebenden Formen zu erklären versucht. Obwohl die hierbei erworbenen Thatsachen noch zu wenig zahlreich sind, um eine förmliche Disciplin zu bilden, kann man doch nicht leugnen, dass die Deductionen, die bis jetzt gemacht wurden, geeignet sind manches in dem IVesen der Biomorphologie in ein helleres Licht zu stellen. Einige von diesen Deductionen können schon jetzt zur Erklärung der embryologischen Thatsachen angewendet werden und ich will nunmehr versuchen die eben auseinandergesetzten anomalen Fälle aus der Embryologie der Tiere vom Standpuncte der physiologischen Morphologie zu erklären.

Am nächsten zu den uns angehenden Fällen stehen die als Heteromorphose und Regeneration bekannten Erscheinungen, obwohl die von mir angeführten anomalen Thatsachen weder zu der einen, noch zu der anderen von diesen beiden Erscheinungsgruppen vollkommen passen. Loeb, welcher den Begriff von der Heteromorphose in der Wissenschaft eingeführt hat, giebt folgende Definition derselben. Als Hcteromorphose bezeichnet er namentlich "den Ersatz eines verlorenen Organs durch ein anderes, vom verlorenen nach Form und Lebenserscheinungen verschiedenes "; unter Regeneration versteht er den Ersatz eines verlorenen durch ein ihm yleiches Organ. Die Definition erfordert jedoch eine weitere Begründung und namentlich tritt diese Bedürfniss bei der Anwendung der von Locb angestellten Begriffe bei den embryologischen Thatsachen hervor. Es ist namentlich, bei dem grossen Wert, welchen man auf die Keimblättertheorie legt, schr wichtig unsere Aufmerk- 
samkeit auf die organogenetische Verhältnisse in Bezug auf die Keimblätter des ursprünglichen und des ersetzten Organes zu lenken. Das neue Organ kann an derselben Stelle entstehen, wo das verlorenes sich befand, und doch von einem anderen Keimblatte abstammen. Schon R. S. Berg ("Über den Begriff der Heteromorphose," Z. Anz. I896) hat ganz richtig bemerkt, dass bei der Praecision der Begriffe von der Heteromorphose und der Regeneration nicht der Platz, an dem das Organ gebildet wird, sondern die Quelle aus der es entsteht eine principielle Bedeutung hat. Aus diesem Grund rechnet er zur Heteromorphose auch die Regeneration der Augenlinse des Wassersalamanders und die Regenerationsvorgänge bei der Bildung des Stomo- resp. Proctodäums verschiedener Würner. Der von R. S. Berg angeführte Fall von der vermeintlichen Regeneration der Linse bei dem Wassersalamander bezieht sich auf Entwicklungsvorgänge oder auf Regeneration von bereits vorhandenen Organen und lässt sehr deutlich die Einseitigkeit der Loeb'schen Definition der Heteromorphose und der Regeneration erkennen. Der Grund der Locb'schen Definition ist ein rein physiologischer. Es handelt sich dabei um die Gleichwertigkeit des verlorenen und des ersetzten Organes, nicht aber um die Quelle, von der beide entstehen und es ist ein grosser Verdienst von Berg, wenn er auf die morphologische Seite des Ersatzes, namentlich auf die Quelle, von der die Ersatzorgane entstehen, als das Principielle in der Erscheinung hinweist. Besonders wichtig ist es bei den embryonalen Processen, namentlich diejenigen, welchen ich oben hervorgehoben habe und deren Erklärung auf die von Loeb definirten Erscheinungen basirt werden kann. Die Organe, welche in allen hervorgehobenen Fällen entstehen, sind dieselben, welche auch bei den nächstverwandten Tieren an denselben Stellen entstehen, nur ist die Quelle aus der sie sich entwickeln eine verschiedene. Es handelt sich nicht nur um den Ersatz des verlorenen Organes, wie in den von Loeb als Heteromorphose und Regeneration definirten Fällen, sondern um den Ersatz ihrer Anlagen. Dies ist der Grund, welcher mir zur Aufstellung einer besonderen Categorie von Erscheinungen führt, die mit der Heteromorphose und der Regeneration in so fern verwandt sind als sie ebenfalls den Ersatz der Organen betreffen, aber nicht in ihrem definitiven Zustande sondern in ihrer primitiven Anlage. Indem ich die Loeb'sche Definition der beiden ron ihm aufgestellten Erscheinungen, wenigstens in physiologischer Beziehung für passend halte, will ich diejenigen Erscheinungen, bei welchen die gleichwertigen Organe bei den verwandten Tieren an denselben Stellen, aber von verschiedenen Quellon (im Sinne der Embryologie) entstchen, in cine besondere Categorie der physiologisch-morphologischen Erscheinungen abtrennen, dic ich mit dem Namen "Heteroblastie" zu belegen pflege.

Es tritt uns nun die Frage entgegen: wie kann man diese heteroblastischen Erscheinungen mit den normalen Entwicklungserscheinungen in Einklang bringen und sie im Lichte der 
physiologisch-morphologischen Lehre crklären? Wenn ich im Folsenden auf diese schwer zu entscheidende Frage einc Antwort zu geben versuche, so muss dieser Schritt nur als ein Versuch betrachtet werden, dessen Zweck allein darinbestcht die anomalen embryologischen Thatsachen zu gruppiren und physiologischen Grund für dieselben zu finden.

Betrachten wir die oben hervorgehobenen Fälle der Hetcroblastie näher, so können wir leicht bemerken, dass sie (I) sich ihrer Complication noch in eine Reihe anordnen lassen, welche von den einfachen Fällen angefangen, $z u$ den complicirtesten führt, und (2) dass bei den complicirten Fällen, wie sie uns z. B. in der Bildung des Ascidienherzens entgegentreten, ein völliger Ersatz des organbildenden Substrates resp. des Keimblattes von dem das Organ entsteht, stattn̄ndet, während bei den einfachen Fällen ein nur teilweiser Ersatz zum Vorschein tritt. Ich brauche kaum hervorzuheben, dass die einfachsten Fälle der normalen Entwicklung am nächsten stehen und sich deswegen viel leichter als die complicirten erklären lassen. Wir beginnen mit ersteren.

In allen von mir angeführten Fällen der Entwicklung des Darmkanals der Arthropoden und der peribranchialen Höhlen der Ascidien, besteht die Anlage des Organes aus zwei Keimblättern, dem Ectoderm und dem Entoderm. Das Verhalten beider Blätter zu einander ist in den normalen Fällen in so ferne streng bestimmt, als jeder Teil des sich bildenden Organes aus einem resp. aus dem anderen von diesen Keimblättern entstehen soll. Tritt nun die Entwicklung eines oder des anderen von diesen Keimblättern in den Vordergrund, so wird die Entwicklung des Organes von ihren normalen Verhältnissen abgelenkt. Eines der an seiner Bildung trilnehmenden Keimblätter wird von dem anderen ersetzt und bei dem höchsten Grade der Unterdrückung eines der Keimblätter durch das andere bekommen wir endlich die Fälle, wo das Organ, welches normal aus zwei Keimblättern entsteht, nunmehr nur aus einem von diesen seinen Ursprung nimmt.

Nehmen wir zuerst die Entwicklung des Darmkanals der Arthropoden in Betracht, so finden wir dass bei normalen Verhältnissen derselbe aus zwei Keimblättern entsteht (ich meine natürlich nur den epithelischen Teil dieses Organes) und zwar nimmt speciell der mittlere Teil des Darmes (das Mesodäum) scinen Ursprung aus dem Entoderm, während der vordere und der hintere Teil (das Stomo- und das Proctodäum) aus dem Ectoderm entstehen. Stellen wir uns nun vor, dass der ectodermale Teil der Anlage des Darmkanals sich ausserordentlich stark entwickelt und den entodermalen Teil unterdrückt, so kann der Anteil des Entoderms schliesslich so stark vcrringert werden, dass dasselbe entweder nur einen kleinen Teil der Ernährungsorgane z. B. nur die Leberröhren bildet (wic z. B. bei Onisciden), oder aber der ganze Darmcanal sich nur aus dem Ectoderm entwickelt. Das Entoderm wird in diesen Fällen durch das Ectoderm vollständig ersetzt; es 
tritt endlich eine Heteroblastie auf, welche mit der normalen Entwicklung durch eine Reihe allmähligen Übergangsformen verbunden ist.

Eine ähnliche allmählige Reihe von Übergangsformen, von der normalen Entwicklung bis zur heteroblastischen, treffen wir auch bei der Entwicklung der peribranchialen Höhlen der Ascidien. Als normaler Entwicklungsmodus muss derjenige erkannt werden, nach welchem die embryonale Entwicklung dieser Organe vor sich geht. Die peribranchialen Höhlen bilden sich bei den Larven aus zwei Anlagen: (I) aus den paarigen Ectodermeinstülpungen und (2) aus paarigen Entodermausstülpungen, die mit den ersteren zusammentreffen, sich mit ihnen verlöthen und in die Höhlen derselben ausbrechen. Bei der Entwicklung derselben Organe in den Ascidienknospen nimmt das Ectoderm keinen Anteil; die genannten Organe bilden sich ausschliesslich auf Kosten der paarigen Entodermausstülpungen, die aus der Wand der Schlundresp. Athemhöhle ihren Ursprung nehmen, auf der Rückenseite der Knospe sich vereinigen und durch eine Öffnung-die Cloacalöffnung-nach Aussen durchbrechen. Vergleicht man die beiden Entwicklungsarten der peribranchialen Höhlen mit einander und behält man dabei immer in Auge, dass die peribranchialen Höhlen der Larve aus zwei Anlagen, den ectodermalen und entodermalen, cntsteht, so lässt sich der Unterschied zwischen den beiden Entwicklungsmodi mehr aus der quantitativen Entwicklung beider Anlagen, als aus der qualitativen, erklären. Bei den Larven treten die ectodermalen Teile der Anlagen, bei den Knospen die entodcrmalen, in den Vordergrund. Dic abnorme Entwicklung der peribranchialen Röhren der Ascidienknospen lässt sich also von demselben Standpuncte erklären wie die abnorme Entwicklung des Vorderdarmes der Würmer und der Arthropoden. Nur tritt im ersten Falle das Ectoderm, im zweiten das Entoderm, auf den vorderen Plan. Die Ursache des Vorwaltens in einem Falle des ectodermalen, im anderen Falle des entodermalen, Teile der Anlage, muss natürlich in der Unthätigkeit im ersten Falle des Entoderms, im zweiten des Ectoderms, bestehen. Die beiden unthätigen Anlagen bieten den thätigen gegenüber keinen Widerstand und überlassen den thätigen Anlagen einen freien Boden zum Wachstum; darin besteht das Wesentliche in den beiden aufgefiihrten Beispielen der Heteroblastie.

Das dritte von uns angeführte Beispiel, nämlich die abnorme Entwicklung des Pericardiums und des Herzens der Ascidien unterscheidet sich ziemlich bedeutend ron den beiden eben besprochenen Fällen, indem das Yericardium weder aus zwei Anlagen noch aus zwei Keimblättern, sondern aus einem einzigen Keimblatte seinen Ursprung nimmt. Bei allen Tieren, den Ascidien und vielleicht anderen Tunicaten ausgenommen, ist es das Mesoderm, welches allein dem Pericardium-Herz den Ursprung giebt. Die abnorme Entwicklung dieses Organs bei den Tunicaten ist also 
eine vollständige Ersetzung des Mesoderms durch das Entoderm und kann nicht von dem Standpuncte erklärt werden, von welchem wir die beiden ersten Fälle zu erklären versucht haben. Wir müssen annehmen, dass bei den Ascidien das Mesoderm nicht bildungsthätig ist und in diesem Umstande müssen wir die Ursache von der eigenthümlichen Entwicklung des Herzens suchen. In der That geht die Entwicklung des Mesoderms bei den Ascidien, so wie bei den Tunicaten, überlaupt ganz anders vor sich, als es bei den IVirbeltieren und bei den übrigen Tiertypen der Fall ist. Erstens tritt bei den Tunicaten keine Spaltung des Mesoderms in ein somatisches und ein splanchnisches Blatt ein, in dem Masse wenigstens, wie es bei den IVirbeltieren und bei allen sog. Coelomaten geschieht. Die Leibeshöhle, wenn dieselbe zur Anlage kommt, worüber wir die Angaben von $\mathrm{E}$. Van Beneden und von mir besitzen, verschwindet sehr frühzcitig wieder und das ganze Mesoderm des Rumpfteiles zcrfällt in einzelne Zellen, von denen der grösste Teil sich durch amöboide Bewegung auszeichnet. Bei den Appendicularien enthält der Rumpfteil gar keine Mesodermzellen, weder amöboide, noch Muskelzellen. Bei ihnen kann natürlich das Herz nicht aus dem Mesoderm entstehen, da überhaupt leine Mesodermzellen an der Stelle des Herzens vorhanden sind. Bei den übrigen Ascidien aber, bei welchen im Rumpfteile eine ungeheuere Anzahl von freibeweglichen Mesodermzellen vorhanden ist, können die letzten kein Material zur Bildung des Pericardium-Herzens wenigstens in der Weise, wie dies bei den Wirbeltieren der Fall ist, darbieten. Indem die Leibeshöhle bei ihnen zur Zeit der Bildung des Pericardiums schon fehlt, kann von der Entwicklung des Pericardiums nach dem Typus der WVirbeltiere keine Rede sein: die freibeweglichen Zellen andererseits geben, wie es scheint, kein Material ab, um die Bildung des Herzens nach irgend einem anderen Typus zu ermöglichen. Hierin liegt meiner Meinung nach der Grund davon, dass das Pericardium und das Herz, welche bei allen Tieren aus dem Mesoderm entstehen, hier aus den benachbarten Körperteilen, und zwar aus einer ganz anderen Quelle, namentlich aus dem Entoderm, ihren Ursprung nehmen.

Die hier angeführten Fälle von abnormer Entwicklung der Organe können, wie ich hoffe, das Principielle derjenigen Erscheinungen erläutern, welche ich mit dem Namen der "Heteroblastic" $\mathrm{zu}$ bezeichnen pflege. Ich werde dann schon meinen Zweck für erreicht halten, wenn durch vorliegende Zusammenstellung der Thatsachen die Aufmerksamkeit der Embryologen auf diese interessanten coenogenetischen Erscheinungen hervorgerufen wird.

Schliesslich will ich noch besonders hervorheben, dass in jedem Falle der Heteroblastie,-möge dieselbe nur in der Überwältigung eines Teiles der Organenlage durch den anderen, oder in der Ersetzung eines Keimblattes durch ein anderes bei der Bildung der Organe bestehen,-die Organe immer an derselben Stclle, wie 
bei der normalen Entwicklung entstehen. Diese Beziehung der Organbildung zu dem Orte an welchem sic typisch normal entstehen, unabhängig von dem Material aus welchem die Organe gebildet werden, scheint mir für das Verständniss der Heteroblastie besonders wichtig. Die neuen Forschungen auf dem Gebiete der Embryologie haben den absoluten Wert der Keimblättertheorie in bedeutendem Masse herabgesetzt. Die heteroblastischen Erscheinungen beweisen es nochmals, dass die Keimblättertheorie nicht im Stande ist uns alle embryologischen und organogenetischen Fragen $\mathrm{zu}$ beantworten, und dass die Lagerung der Zellen resp. der Gewebe, ihre gegenseitige Beziehung im entwickelten, oder in der Entwicklung begriffenen Organismus einen grossen Wert hat. Mit anderen Worten zeigen sie die Richtigkeit des von Driesch zuerst hervorgehobenen und meiner Meinung vollkommen richtigen Satzes, dass die prospective Beziehung der Blastomeren die Function des Ortes ist. Ich möchte bemerken, dass wir noch weiter gehen und die Gedanke von Driesch nicht nur auf die ersten Entwicklungsstadien, sondern auch auf spätere ausdehnen können und sagen dürfen, dass die prospective Bezichung der embryonalen Zellen die Function des Ortes ist.

Dr Samassa, Munich, on the whole supported Prof. Salensky's views. Points of detail in which he differed would be found fully treated in the paper now in the press: "Bermerkungen über die Methode der vergleichenden Entwicklungsgeschichte," Biolog. Centralbl. Bd. I 8, No. I 7 u. I 8.

Prof. Marcus Hartog, Cork, adduced in support of Prof. Salensky some work by the late Prof. Milnes Marshall.

Mr Stanley GaRdiner of Caius College then read the following paper on

\section{The Building of Atolls (with Plate I).}

Since 1888 , when a discussion took place at the Bath meeting of the British Association on "The Theories of Coral Reefs and Atolls," several important papers have appeared on the question. A singular feature of these papers is the almost complete unanimity with which those authors, who have themselves practical experience of coral reefs, reject the subsidence theory as inadequate, or unnecessary.

A few papers are extremely suggestive, first among which may be mentioned Dr Guppy's description ${ }^{1}$ of the Cocos-Keeling Islands -Darwin's typical atoll-in which he came to the conclusion "that neither of upheaval nor of subsidence is there any evidence of an unequivocal character." The lagoon is stated to be very slowly filling up with sand and débris, while the islets are advancing seaward on the reef-flat by the formation of successive ridges of reef débris.

1 Scottish Geog. Mag., vol. v, pp. 28I, 457 and 569 (1889). 
The crescentic or ring shape of islets on the reef is explained by sand, carried into the lagoon by the currents, being deposited at their extremities.

A very suggestive paper by Mr J. J. Lister ${ }^{-1}$, in I89I, pointed out the occurrence of both high volcanic and limestone islands in the Tonga Group. The elevation is considered to have been "in progress for a long period," and to have been of a recurring nature with intervals of rest.

In I 894 appeared a long account by Professor Alexander Agassiz of the Bahamas and the elevated reefs of Cuba?. The paper concludes with a chapter on recent views of the formation of coral reefs in reference to the West Indies. Attention is especially drawn to the formation of marine limestones at great depths by accretion.

Prof. Sollas' "Report on the Coral Reef at Funafuti"," in which he comes to the conclusion that the facts collected by himself support the subsidence theory, was closely followed by a short paper from Admiral Wharton ${ }^{4}$ to impress more fully the importance of the cutting down action of the sea on volcanic islands and the formation of flat banks at depths, within which the reef-building organisms are known to live.

An important paper by Prof. Agassiz on "The Great Barrier Reef of Australia"," in which he points out the absolute impossibility of explaining its manifold conditions on the subsidence theory, suggested to me the propriety of re-examining my specimens and notes, collected during a six month' residence at Funafuti and Rotuma, and four months in Fiji, which I spent simply in travelling round the islands of that Group, on which also a short paper has since been published by Prof. Agassiz ${ }^{6}$.

In a previous paper ${ }^{7}$ I pointed out that a determinable amount of oxygen is given off by corals of the genera Pocillopora, Prionastraea, Madrepora, and Eupluyllia. Since then I have examined a large number of polyps from different specimens of these genera, and find that they are all crowded with zooxanthellae, either imbedded in the endoderm or free in the gastro-vascular cavity. In no case have I been able to find any organisms, which might be supposed to have served the polyps for food. It is noticeable too that Fowler ${ }^{8}$ and Bourne $^{8}$ in their accounts of the structure of different corals almost invariably mention the occurrence of these algae. Some specimens of the Pccillopora and Madrepora examined

1 "Notes on the Geology of the Tonga Islands," Quar. Four. Geo. Soc, vol. xlvir, p. $590(1891)$.

2 Bull. Mus. Comp. Zool., Harvard, vol. xxvi, No. I, p. I (1894).

3 Nature, vol. Lv, p. $373(1897)$.

\& Nature, vol. Lv, p. 390 (1897).

${ }^{5}$ Bull. Mius. Comp. Zool., Harvard, vol. xxvin, No. 4, p. 98 (1898).

- Ann. and Mag. Nat. Ilist., ser. 7, vol. 1, p. 231 (1898).

7 "The Coral Reefs of Funafuti, Roluma and Fiji, together with some Notes on the Structure and Formation of Coral Reefs in general," Proc. Camb. Phil. Soc., vol. Ix, p. $417(18 y 8)$.

${ }^{8} Q . \mathcal{F} \cdot M . S .$, vols. xxv--xxx $(1885-90)$. 
were obtained from depths exceeding 30 fathoms, and in these the abundance of zooxanthellae and the absence of foreign organisms, serving for food, were equally marked.

In Prionastraed, from which I obtained the greatest amount of oxygen, there is, so far as the preservation of the material will allow me to see, no gastro-vascular cavity between the mesenteries, and the stomodoeum is but small. The tentacles are not well marked, and the nutriment of the polyps appears to have been obtained entirely from the commensal algae.

If the zooxanthellae are the main source, as I contend, of food for the polyps of most species of Madreporaria, the vertical distribution then of these corals probably depends entirely on the depth to which light of sufficient intensity can penetrate sea water.

The chief organisms, so far as I have seen, engaged in building up coral reefs are massive and incrusting nullipores, and the depth at which such algae can grow depends likewise on the light.

In my paper, previously referred to, I pointed out that photographic plates are affected in fresh water, which is not nearly so translucent as sea water, at a depth of 120 fathoms, and that nullipores were dredged by the Penguin below 75 fathoms off Funafuti. The greater translucency the nearer the observer is to the equator is, I think, an obvious fact. The depth from which a reef could grow up to the surface would be at the latitude and longitude of Funafuti, I should suppose, about i 50 fathoms. Generally speaking, the lower the latitude the greater would be the depth, and the higher the less, but in the latter case another factor comes in-probably temperature-preventing the formation of reefs at higher latitudes than $30^{\circ}$. The rate of growth of reefs would depend, then, on the intensity of the light and the temperature, supposing other conditions equal.

If this view is a correct one ${ }^{1}$, the depth from which a reef could be directly built up to the surface by the reef organisms must be greatly increased, bringing necessarily a large number of submarine mountains and elevations into its limits.

With regard to the foundations of atolls, I have nothing new to add to what Murray, Wharton, Agassiz and other observers have pointed out. Mounds can be and are being, I believe, slowly built up on submarine mountains to the bathymetrical limits of the reef organisms. The numerous dredging expeditions show that animals naturally congregate on any elevations, and by the accretion of their remains and those of pelagic organisms, mounds would be built up much in the same way as the raised limestone of Viti Levu, Fiji, appears to have been formed. A few corals are found in this lime-

1 The marked decrease in the steepness of the slope at a depth of $120-150$ fathoms in sections off atolls in the Pacific Ocean gives a general support to this view, but it is not clear how far it may not rather be due to the talus spreading outwards on the mound on which the atoll is built. The sudden change however is equally well marked off the Tizard, Macclesfield and other banks, which have not yet reached the sea level and where the talus is not probably of much importance. 
stone, but generally it bears little or no resemblance to the limestone of a coral reef such as we know it at the present day. It consists, indeed, mainly of foraminifera, remains of sponges, echinoderms, molluses and other organisms, such as might be supposed now to be building up mounds on any elevations of the sca-floor.

One of the most characteristic points about the formation of this limestone is its alternation with layers of the so-called "soapstone," a deposit, according to Brady", such as might be expected to form "from 150 to 200 fathoms (rather more than less) in the neighbourhood of any of the volcanic islands of the Pacific." In my previous paper I feel that I did not lay sufficient stress on Brady's immense experience and unique knowledge of foraminifera. I would still, however, point out the general resemblances between this rock and the muddy sand inside the barrier reefs of Viti Levu and Vanua Levu. The greatest height, at which I found the limestone, I calculated at about 900 feet, and, if it has been formed in shallow water and Brady's view of the "soapstone" is correct, an almost incomprehensible series of elevations and subsidences, each of at least 900 feet, would be required.

Hence it seems probable that the limestone was built up at depths greater than I 50 fathoms and alternated with layers of soapstone, the whole being elevated by one continuous upheaval, a view which is supported by the absence of conspicuous terraces on its slopes.

On a plateau within the bathymetrical limit of the reef organisms an atoll could be directly formed by their growth, which would naturally be greater at its edges owing to the more frequent renewal of the sea water. Such banks as the Tizard, Macclesfield, Coombe, Waterwitch, Alexa, Great Chagos and others appear to be growing up in this way. The irregularity of their slopes is absolutely opposed to the view that they are being built up on the tops of drowned atolls, which themselves were formed in the first place by slow subsidences. Nearly all occur in areas of great volcanic activity, and it is more probable that their foundations have been formed as Wharton has suggested by the cutting down of volcanic islands. Each separate bank should, however, be considered in relation to the reefs and coral islands in its vicinity.

I am myself rather concerned to show that mounds, such as I have suggested above, may be the foundations of atolls. Such mounds would generally be dome-shaped, and on their summits I consider that limestone peaks can be built up by reef organisms from a depth of $100-200$ fathoms to the surface. Numerous peaks such as these are found on the charts of the Red Sea, Torres Straits, East Indies and other coral seas. By the breaking off of masses of corals and nullipores, and by the heaping up of the remains of various other organisms, such pinnacles then gradually approximate

\footnotetext{
1 "Note on the so-called "Soapstone of Fiji'," Quar. Four. Geo. Soc., vol. xLIV. p. 1 (1888).
} 
to the slope generally found, so far as is known, outside reefs, i.e. a gradual slope to 15 to 50 fathoms and then a steep at an angle of something over $45^{\circ}$. The sections run by the Penguin off Funafuti exhibit considerable variation in the depth at which the steep commences; and it seems to be probable that the different depths off different sides of the same, or off different reefs, may be explained by the depth of the ocean currents, local currents, etc. From the reef as observed at Rotuma there appeared to be a strong undercurrent seawards, both with the rising and falling tide. This sweeps out the sand and small masses of rock, forming the steep, which simply represents the angle of rest of such detritus under the water. In support of the latter I may notice that the muddy inner reefs of Viti Levu and Vanua Levu have a slope of $40^{\circ}$ to $60^{\circ}$ in many places, the slopes too off Falcon Island, Tongan Group, which is merely a heap of cinders and ash, appear from the soundings on the chart to be equally steep.

The next stage would be the gradual broadening of such a small reef by the fusion to it of buttresses and masses, formed outside, by the direct upward growth of nullipores and corals. The reef, as are all the living reefs which I have seen, would be of a more or less open structure underneath with a rather flat, solid crown. The corals and nullipores on the central part would be killed as the reef broadened by sand, thrown on them, and by exposure to the sun, being at some distance from the breaking edge, and the middle no longer being protected by the living organisms would be slightly hollowed out by solution as are the reef-flats of fringing, atoll and barrier reefs. On the solution continuing the pool might be comparable to the "barachois" of Diego Garcia, described by Bourne", and the so-called "mangrove swamp" and other pools in the islets of Funafuti atoll. Later by the further broadening and solution an atoll would be formed, the depth of which would be comparable to the number and particularly to the depth of the passages through the reef.

In support of my contention of such a considerable amount of solution taking place I would point to the Lau, or Eastern Group of the Fijian Islands. The limestone here is extremely hard, dense and crystalline, and its cliffs are always very extensively undermined at the base. In the Lau Group there are over 20 islands formed of this rock, the highest of which is 1030 feet. Among them may be found forms with no reef, a fringing reef, or a distant barrier reef, perlaps only surrounding one or two small rocks. Many of the larger seem to be raised atolls, having marked depressions in their centres. Fulanga, the two Ongea and Namuka appear as if the sea has broken through the rims of the former atolls into their lagoons. In Fulanga the solution has gone further, for the island merely consists of an incomplete ring of high land, surrounding a lagoon, 4- Io fathoms deep, studded with rocky islets up to roo feet

1 " The Atoll of Diego Garcia and the Coral Formations of the Indian Ucean," Proc. k. S., vol. XliII, p. $4+0$ (1888). 
in height. These islets are generally undermined for $10-20$ feet between tide levels, and have narrow reefs around them, which however extend only to the edges of the overhanging rocks, ending precipitously against the lagoon. These give direct evidence of solution, for of large masses, which can be seen to have split off and fallen into the lagoon only recently, little trace can be found and the reefs formerly under them are often completely gone. Finally Murray and Irvine ${ }^{1}$ have shown that globigerina ooze, coral sand and corals, indeed the ordinary constituents of a modern coral reef, are several times as soluble as such limestone in sea water.

In further support of Murray's solution theory I may draw attention to the great uniformity in breadth of the reefs of the Pacific, which I think may best be explained on some such hypothesis; and also the small cliff from the edge of the reef to the bottom of the lagoon, which, as far as I have seen, is of very general occurrence, and would not be found were the lagoons being gradually filled up by detritus as the subsidence theory requires.

The Lau Group suggests another method of the formation of atolls by the complete solution and erosion particularly of raised limestone islands. Although I am inclined to believe that most of the atoll-reefs of Fiji have been formed in this way, yet I do not consider that it is anywhere of more than local importance.

Lastly, as to the formation of islets on the reefs, I would draw attention to the opinions of Mr G. C. Bourne and Prof. Sollas as to the elevations of Diego Garcia and Funafuti atolls. With regard to the latter I entirely agree with Prof. Sollas, and further, from the information given me by Mr J. J. Lister as to the Phoenix Group and by numerous trading captains in Fiji as to the Ellice, Union, Gilbert, Marshall and Caroline Groups, I am inclined to believe that all the atolls of the Central Pacific have been so raised, or possibly that there has been some change of level in the sea. It must be noted, however, that Mr Hedley ${ }^{2}$ for Funafuti and Dr Guppy for the Cocos-Keeling Atoll consider that the islets have been rather formed by the heaping up of material from the reef in heavy storms and hurricanes. I would ask Mr Hedley to explain why, on Funafuti, corals are found so frequently in the position of growth on masses or "pinnacles" $4-5$ feet above the low-tide level. I have been informed too by Mr Bourne that he likewise found subfossal corals on Diego Garcia absolutely similarly situated.

Mr BOURNE accentuated the rarity of occurrence of Copepods, \&c., in the gastrovascular cavity of the coral anthozoa and the abundance of Zooxanthellae. Confirmed congregation of Zooxanthellae in outer layers of colony, i.e. next light. He recommended the study of the coral reefs of the Indian Ocean.

1 "On Coral Reefs and other Carbonate of Lime Formations in Modern Seas," Proc. K. Soc., Edin., vol. Xvil, p. 79 (1889).

2 "The Broadening of Atoll-Islets," Nat. Sci., vol. xir, p. I $7+(1898)$. 


\title{
SECTION A. GENERAL ZOOLOGY.
}

\author{
WEDNESDAY, 24 August, at the GuILDHALL at 2 P.M.
}

\section{Chairman, Prof. Milne-Edwards.}

Prof. HAECKEL developed the principles of modern phylogenetic classification which he had first enunciated in his "General Morphology" and most recently in his "Systematic Phylogeny" (I 896). He brought forward arguments in favour of the complementary value of the three great "Phyletic Archives," Palæontology, Comparative Anatomy and Ontogeny. He proceeded to explain the modern pedigree of the Animal Kingdom and the relations of the IO or I 2 phyla to the lower Cœlenteria, and the higher Cœlomaria as the two main groups of the Metazoa.

The following were recognised as true plyyla (i.e. monophyletic groups, each arising from a common stem); Vertebrates, Tunicates, Echinoderms, Molluscs (all derived from Vermalia which in turn were derived from Platodes), Cnidaria and Spongia, the two last named being below and independent of the others.

The unity of the Articulata (= Arthropoda and Annelida) was much debated. The group might be considered to comprise three sub-phyla, the Crustacea and Tracheata arising from two different groups of the Annelida. These again have originated from Vermalia, i.e. the so-called "Vermes" after removal of the Annelids and Platoda. Four groups of Vermalia were distinguished, Prosopygia, Frontonia and Strongylaria-all three developed from Rotatoria (Trochophora).

Prof. MARCUS HARToG (Cork) rejected the view that the Rotatoria are to be placed at the base of the Annelids-the view being founded mainly on the resemblance between the trochophore larva and the female of the pelagic Rotifer Trochosphaera, an extremely modified form.

Prof. L. V. GRAFF (Graz) explained his map showing the Geographical Distribution of the Land-planarians and exhibited the plates of his monograph of this group.

Mr G. C. BOURNE gave an account of the formation and structure of the calcareous skeleton in Anthozoa, showing that in the case of the spicules of Alcyonarians there is a matrix of organic threads upon which the calcareous structure is moulded, and that in the case of Heliopora and the Madreporaria the corallum is not 
formed by the calcification of ectoderm cclls in situ, but is a secretions-product, separated from the cells which gave origin to it by a distinct basement membrane. The structures which have been described by some authors as calicoblasts were shown to be special structures formed as metamorphosed cells, and to have no share in the formation of the corallum.

Owing to a misunderstanding, the paper of Prof. S. V. APÁtry, which is printed below, was not read. Prof. V. APÁTHY however gave several demonstrations of his preparations in the Zoological Laboratory.

\section{UEBER NEUROFIBRILLEN UND ÜBER IHRE NERVÖS LEITENDE NATUR.}

\section{Von Prof. Stephan v. Apáthy.}

Ich ergreife die Gelegenheit, um wieder über Neurofibrillen zu sprechen und besonders um einige Präparate Fachgenossen, die sich für die foinere Structur des Nervensystems interessiren, vorzuzeigen. Das meiste, was ich in dieser Hinsicht zu sagen hätte, befindet sich zwar bereits in meiner im Sommer des vorigen Jahres erschienenen Abhandlung "das leitende Element des Nervensystems und seine topographischen Beziehungen zu den Zellen "; aber diese Arbeit wurde von manchen in mehreren Punkten missverstanden, und die dort erbrachten morphologischen Beweise für die leitende Natur der Neurofibrillen wurden, wie ich glaube, nicht sehörig gewürdigt. Sogar Forscher, die die Existenz, den continuirlichen Verlauf und die Specificität der Neurofibrillen nun bereits anerkennen, geben die leitende Natur derselben nicht unbedingt zu. Allerdings habe ich den sogenannten höchsten Beweis, den experimentellen nicht erbracht, aber die schon vorhandenen morphologischen Beweise genügen, wie ich glaube, vollkommen, um jene nervös leitende Natur ausser allen Zweifel zu setzen.

Meine erwähnte ausführliche Arbeit ist auch nichts weiter, als die Schilderung sämmtlicher Eigenschaften der Neurofibrillen, die direct oder indirect durch das Mikroskop erkannt werden können, sowohl als auch eine lange Reihe von morphologischen Beweisen für die leitende Natur der Neurofibrillen. Alles übrige ist blos der Rahmen, welcher lediglich dazu dient, um die geschilderten Befunde übersichtlich zu gruppiren und sie, zunächst provisorisch, zu einem Ganzen zusammenzufügen. Sollte diese Construction keinen Anklang finden, so bestehen die entdeckten Thatsachen doch ebenso gut auch für sich, und es mag ein anderer, gliicklicherer, sie in einer IVeise zusammenfügen, welche der momentanen Geschmacksrichtung in der Neurologie besser entspricht. Nur soll man Thatsachen, die ich so zu sagen handgreiflich darthun kann,

1 In Mitth. Zool. Stat. Neapel, 12. Bd. 4. Heft (IS97), pp. 495-7+8, Taf. 23-32. 
nicht in Abrede stellen wollen, weil sie etwa unbequem sind. Sie lassen sich ja, mit einigem guten Willen, sogar mit der gegenwartig üblichen Auffassung des Nervensystems versöhnen, und sie streben keineswegs danach, die grossartigen neurologischen Errungenschaften, die in erster Linie an den Namen Golgi's geknüpft sind, irgendwie umzustürzen, sie wollen dieselben nur ergänzen, in gewisser Hinsicht vertiefen.

In friheren Perioden der Neurologie musste man sich damit begnügen, dass man die im Nervensystem sichtbaren Faserzüge bei schwachen Vergrösserungen verfolgte. Als man die Nervenfasern als anatomische Individuen erkannte, so musste das Hauptgewicht auf das Verfolgen von diesen und auf den Nachweis der Verbindungen von diesen mit den centralen und peripherischen, innervirten und innervirenden Zellen gelegt werden. Nun sind wir durch meine Arbeiten um einen Schritt weiter gekommen. Wir haben die Neurofibrillen als ebensolche und für das Nervensystem ebenso specifische histologische Individuen, wie die Nervenfasern anatomische Individuen sind, erkannt. Wir müssen uns also auf das Verfolgen von diesen in den Nervenfasern, in den innervirten und innervirenden Zellen und ausserhalb der Zellen im Organismus, und zwar sowohl in dem fertigen als auch im werdenden, verlegen.

Dabei hat es sich bereits gezeigt, dass die nur noch aus der isolirten Neurofibrille bestehende leitende Bahn weiter zu verfolgen ist, als wie weit die Nervenfaser mit ihren centralen und peripherischen Verzweigungen nach den bisherigen Methoden, nach der Vorvergoldung, nach der Golgi'schen Schwarzfärbung und nach Methylenblaufärbung, darzustellen war. Unsere Auffassung des Nervensystems muss also denıgemäss erweitert werden; die Thatsachen werden bestehen, von der Theorie muss man hier und da etwas opfern.

Doch will ich mich in keine Discussion über dieses Thema vertiefen; ich stelle einfach die wichtigsten Beweise für die leitende Natur der Neurofibrillen, welche ich demonstiren möchte, im Folgenden kurz zusammen.

Um uberhaupt entscheiden zu können, welcher histologische Bestandtheil des Nervensystems der eigentliche Leiter des nervösen Stromes ist, dazu ist natürlicher Weise die erste Bedingung, dass man im Stande sei, die Nervenbahn, und zwar besonders die Enden der Bahn, durch welche sie mit den innervirten und innervirenden Zellen in eine innigere Beziehung tritt, in weitere histologische Bestandtheile $\mathrm{zu}$ zerlegen. Ich glaube, letzteres ist mir zuerst, und zwar bereits vor etwa I2 Jahren gelungen. Max Schultze sah die Streifung, woraus er die fibrilläre Structur des Nerven und der Ganglienzellen erschlossen hat; viel später gelang es, wie bekannt, zuerst $K$ upffer, die Fibrillen in den peripherischen Nervenfasern färberisch zu differenziren, nicht aber sie in die peripherischen und centralen Verästelungen derselben hinein zu verfolgen, oder wenigstens auch in diesen darzustellen. Die feinste 
Nervenfaser oder den feinsten Ast einer Nervenfaser, welche er als anatomisches Individuum unterscheiden konnte, nannte $\operatorname{Max}$ Schultze die nervöse Primitivfibrille und er nahm an, dass eine jede solche einem Längsstreifen in der Nervenfaser, welche ein gestreiftes Aussehen besitzt, entspricht.

Nun kann ich zeigen, dass die isolirt verlaufende Primitivfibrille Schultze's mindestens aus zwei verschiedenen histologischen Bestandtheilen, nämlich aus der Neurofibrille und aus einer von ihr gänzlich verschiedenen Substanz, welche sie umhüllt, aus der Perifibrillärsubstanz besteht. Diese Neurofibrille kann ich nun direct in eine Nervenfaser, welche meist mehrere Neurofibrillen enthält, verfolgen, und ebenso auch den perifibrillären Mantel der Neurofibrille, welche in der mehrere Neurofibrillen enthaltenden Nervenfaser in die Interfibrillärsubstanz derselben übergeht. Die Nervenfaser besitzt in der Regel eine besondere, nicht bindegewebige Hülle: bei Wirbelthieren z. B. die Schwann'sche Scheide, bei Wirbellosen die aus besonderen Fibrillen zusammen gewobene Gliascheide. Diese Gliascheide folgt den feinsten Aesten der Nervenfaser weder im Centrum, noch auf der Peripherie; ebensowenig folgt ihnen der in der Nähe des Nervenkernes am meisten entwickelte, eigentlich protoplasmatische Theil der Faser. Es bleibt, wie gesagt, blos die Neurofibrille und die Inter-oder Perifibrillärsubstanz übrig, welche von dem Somatoplasma aller Zellarten, welche mit dem Nervensystem im Zusammenhange sind, gänzlich verschieden ist. Also kann nur entweder die Neurofibrille oder die Inter-, beziehungsweise, da jene peripherischen Enden in der Regel nur eine Neurofibrille enthalten, Perifibrillärsubstanz das Leitende sein.

Von beiden dringt in die innervirte Muskelzelle, in die Drüsenzelle, in die muskellose Gefässwand, in die Sinneszelle, ja sogar in die Ganglienzelle nur die Neurofibrille ein; der perifibrilläre Mantel verliert sich auf der Oberfläche oder bald unter der Oberfäche der Zelle, wogegen die Neurofibrille in der Zelle stets charakteristische weitere Verästelungen zeigt und in charakteristische topographische Beziehungen zu dem Zellkörper tritt. Dabei kommt es, wie ichglaube zeigen zu können, nirgends zu einer Endigung der Neurofibrillenäste im Zellkörper; die Neurofibrille oder ihre Aeste verlassen die Zelle wieder, um wahrscheinlich continuirlich, aber meist durch ein Elementargitter, in Neurofibrillenäste, welche aus anderen Zellen kommen, zu übergehen. Doch will ich dieses Thema der Geschlossenheit der Nervenbahnen hier blos einfach berührt haben.

Die verschiedenen Typen des Verhaltens der Neurofibrillen in den Zellen möchte ich ihnen heute besonders demonstriren. Sie werden dieselben Neurofibrillen in den Nerven, in den Ganglienzellen, in Sinneszellen, in Muskelzellen, in Drüsenzellen etc. zu Gesicht bekommen. Sie werden sich davon überzeugen, dass ein innigerer materieller Zusammenhang zwischen den einzelnen mit einander in der Beziehung der Innervation stehenden Elementen 
des Organismus durch Neurofibrillen und zwar nur durch die Neurofibrillen existirt. Und das ist, wie ich glaube, ein genügender Beweis für die leitende Natur derselben.

Also können die Beweise der leitenden Natur der N'eurofibrillen in der folgenden Weise gruppirt werden :

(I) Die Specificität der Neurofibrillen.

(2) Die Continuität der Neurofibrillen.

(3) Das Verhalten der Neurofibrillen in der Ganglienzelle.

(4) Das Eintreten und zwar ausschliessliche Eintreten der Neurofibrillen in die Sinneszellen und ihre specifischen toposraphischen Beziehungen in dem Körper der Sinneszelle.

(5) Ein Eindringen und zwar ebenso ausschliesslich der Neurofibrillen in die Tiefe der Muskelfasern und specifische topographische Beziehungen zu dem Sarcoplasma.

(6) Das Verhalten der Neurofibrillen in den Drüsenzellen,

(7) in den Zellen, welche die Wand von muskellosen Gefässen bilden.

(8) Die Beziehungen der Neurofibrillen zu verschiedenen anderen Epithelzellen.

(9) Die extracelluläre Fortsätzung der Neurofibrillen, die Verästelungen und gegenseitigen Beziehungen derselben im Centrum.

(IO) Dieselben auf der Peripherie.

(I I) Bestehen der Nervenbahn Stellenweise nur aus Neurofibrillen.

(I 2) Das innige Verhältniss zwischen der Länge des Weges, den eine Neurofibrille in einer gewissen specifischen Zellart zurücklegt, und dem Entwickelungsgrade des Organs, dessen Hauptbestand theile jene specifischen Zellen sind.

Nun möchte ich diese Beweise mit einigen Bemerkungen erläutern im Interesse der Verständlichkeit der zu demonstrirenden Verhältnisse, da ich nicht annehmen kann, dass alle Fachgenossen, die sich für dieselben interessiren dürften, meine ausführliche $\mathrm{Ab}$ handlung gelesen habe.

Der eigentliche Zweck jener Arbeit war die eingehende Schilderung der physikalischen, chemischen und besonders morphologischen und tinctoriellen Eigenschaften sowohl als auch der Vertheilung und Anordnung des specifischen histologischen Elementes im Organismus, welches das gesammte Nervensystem in erster Linie charakterisirt. Diese Elemente nannte ich mit einem allgemeinen Namen Neurofibrillen, und in Anbetracht ihrer mit grosser Sicherheit anzunehmenden leitenden Function leitende Primitiofibrillen", wenn sie als morphologische Individuen im Nervensystem auftreten, und leitende Elementarfibrillen als letzte, gelegentlich auch mikroskopisch nachweisbare Componenten jener Primitivfibrillen.

1 Die Max Schultze'sche Prinitivfibrille ist meine leitende Primitivńbrille+perifibrillärer Mantel. Um Missverständnissen vorzubeugen, will ich den Ausdruck leitende Primitivfibrille in Zukunft meiden und lieber den allgemeineren Namen Ncurofibrille gebrauchen. 
Die Neurofibrillen habe ich bei Wirbellosen schon i 885 thatsächlich nachgewiesen und scitdem in mehreren Aufsätzen beschrieben und zwar seit I 887 auf Grund von nach besonderen Methoden verfertigten Goldpräparaten und seit I89I auch von ebensolchen Methylenblaupräparaten. Namentlich in meinen Goldpräparaten sind die Neurofibrillen mit einer solchen Schärfe und so different von allen möglicher Weise mit ihnen $z u$ verwechselnden histologischen Elementen dargestellt, wie es bisher bei keinen Gewebselementen möglich gewesen ist. Abgesehen von dem zuerst durch Kupffer erbrachten Nachweis der Axencylinderfibrillen im Ischiadicus des Frosches, war vor mir eigentlich blos das durch die Neurofibrillen bedingte gestrcifte Aussehen der Nerven und der Ganglienzellen bekannt, allerdings auch dieses von vielen bestritten oder anders gedeutet. Die Neurofibrillen selbst sicher $z u$ differenziren und $z u$ isoliren ist überhaupt mir zum ersten Mal gelungen.

Die bereits erschienene erste Mittheilung meiner Untersuchungen beschäftigt sich zwar nur mit meinen bei Wirbellosen, besonders bei Hirudineen (Hirudo medicinalis, Aulastomum gulo, Nephelis octoculata, Clepsine sexoculata, Pontobdella muricata, Branchellion torpedinis, Pseudobranchellion margóï) und dem Genus Lumbricus gewonnenen Resultaten ganz eingehend, doch schildere ich schon hier zum Theil auch meine an Wirbelthieren gemachten Beobachtungen, welche im Wesentlichen gleiche verhältnisse der Neurofibrillen bei Wirbelthieren und Wirbellosen bekunden.

Ich wollte hier für einen speciellen Fall, für das Nervensystem, die bei meinen verschiedenen Untersuchungen gewonnene grundlegende Thatsache, den Grundstein der vergleichenden Histologie demonstriren, dass mit den specifischen Functionen der Zellen, nicht nur der Drüsenzellen, Fettzellen dergl., das Vorhandensein von specifischen Protoplasmaproducten verbunden ist, wie hier meine Neurofibrillen, welche in allen Zellen, denen eine nervös leitende Function zukommt oder welche mit dem Nervensystem irgend wie leitend verbunden sind, nachgewiesen werden können, da sie ganz charakteristische morphologische Eigenschaften, specifisches tinctorielles Verhalten und andere ihnen eigene Reactionen zeigen, einerlei ob die betreffende Zelle die in ihr nachzuweisenden Neurofibrillen selbst producirt hat oder ob die Neurofibrillen in sie, auf dem Wege von praeexistirenden protoplasmatischen, embryonalen Zellbrücken, nachträglich hineingewachsen sind. So glaube ich um einen Schritt näher zu dem Bewcise meiner Grundthese der vergleichenden Histologie gekommen zu sein. Diese Grundthese lautet nun folgendermassen: die histologische und die, in der Ontogenese wenigstens, erst aus dieser folgende sonstige, functionelle Differenzirung der Zellen geschieht nicht dadurch, dass sich das Protoplasma in verschiedene Protoplasmasorten (z. B. Nervenprotoplasma, Muskelprotoplasma, Drüsenprotoplasma etc.) 
verwandelt, sondern dadurch, dass sie sich überwiegend oder ausschlicsslich auf die Prodaction von specifischen, morphologisch, physikalisch und chemisch gekennzeichneten und mikroskopisch nachwcisbaren Substanzen (welche nicht mehr Protoplasma sind) verlegen, dadurch aber auch in der Regel die Fähigkeit, die sie ursprünglich alle besitzen, verlieren, Zellproducte anderer Art zu erzcugen. Was jedoch das Wichtigste fuir die vergleichende Histologie ist, so zeigen die betreffenden specifischen Zellproducte in allen Thierklassen, wo immer nur Zellen mit derselben physiologischen Bedeutung verkommen, die gleichen Eigenschaften, sie sind in morphologischer, physikalischer und chemischer Hinsicht in der gleichen Weise gekennzeichnet.

Das Protoplasma, richtiger Somatoplasma, selbst ist in allen Zellen eines Organismus gleich, zeigt uiberall im Wesentlichen gleiche morphologische und ganz gleiche physikalische und chemische Eigenschaften; nur hat es, auf einer gegebenen Entivickelungsstufe des Organismus, von seinen urspriinglichen Fähigkeitcn in der einen Zelle mehr, in der anderen weniger, hier diese, dort jene bewahrt. Also sind das sogenannte Nervenplasma und Muskelplasma im Wesentlichen ganz gleich, grundverschieden sind aber die Neurofibrillen, das specifische Zellproduct der Nervenzellen in meinem Sinnc, und die Myofibrillen, das specifische Zellproduct der Muskelzellen. Und wo leitende und contractile Zellen uiberhaupt vorkommen, werden in denselben wahrscheinlich auch Neurofibrillen, beziehungsweise Myofibrillen mit denselben Eigenschaften bei den verschiedenen Thierklassen nachweisbar sein.

Was die Neurofibrillen betrifft, so wird demnach die erste von vielen bestrittene These der Arbeit, welche ich endgültig bewiesen zu haben glaube, in der folgenden Weise formulirt: Der wesentlichste specifische Bestandtheil der Nerven und das Nervöse überhaupt sind die Neurofibrillen. Diese verlaufen als sowohl optisch, wie auch mechanisch isolirbare Einheiten in der betreffenden Nervenbahn überall ununterbrochen bis zum peripherischen Ende der Bahn, in so fern diese nicht auch peripherisch geschlossen ist. Im entwickelten Organismus ist nämlich im Centrum nirgends ein Anfang der Neurofibrillen zu constatiren. Sie gehen entweder unmittelbar, nachdem sie sich unter wiederholter Verzweigung in dünnste Fibrillen, meist wohl in ihre Elementarfibrillen, gespaltet haben, in das von mir so genannte Elemcntargitter über, oder sie passiren erst eine Ganglienzelle (gelegentlich mehrere); und die Maschen des Elementargitters werden nicht durch Kreuzung, sondern durch eine Verschmelzung an den Knotenpunkten, durch ein Übergehen der Fibrillen ineinander gebildet. In dieser Hinsicht ist das System der leitenden Bahnen mit dem Blutgefässsystem zu vergleichen. Ebenso wie die Arterien und Venen im entwickelten Organismus in der Regel nirgends endigen, sondern durch Vermittlung des Capillarnetzes in einander übergehen, gehen die in verschiedener Richtung leitenden Bahnen durch das Elementargitter 
ohne Unterbrechung in einander über, und zwar nicht nur im Centrum, sondern wahrscheinlich auch auf der Peripherie, da eine Endigung der Neurofibrillen auch in den innervirten Zellen (in Muskelzellen, Drüsenzellen, Sinneszellen etc.) nicht statt zu finden scheint.

So wie die specifische Muskelsubstanz in den Muskelfasern verschieden angeordnet, aber von dem Somatoplasma der Muskelzelle stets getrennt ist und ausser aus Myofibrillen aus einer Interfibrillärsubstanz besteht, ist in den Nervenfasern die Nervensubstanz, welche verschieden angeordnet sein kann, von dem Nervenprotoplasma stets räumlich getrennt und besteht ausser aus Neurofibrillen aus einer Inter- oder, bei isolirt verlaufenden Neurofibrillen, Perifibrillärsubstanz. Diese Interfibrillärsubstanz, ein mehr- oder weniger eingedickter, ölartig gewordener Zellsaft, ist in der Muskelund in der Nervensubstanz ziemlich gleich, aber in die Interfibrillärsubstanz des Nervensystems ist in verschiedener Vertheilung Myelin eingelagert und in den verschiedensten Thierklassen nachweisbar. In den mit Markscheide versehenen Nerven der Wirbelthiere ist die Nervensubstanz lediglich durch den Axencylinder repräsentirt, welcher also nicht etwa aus Nervenplasma von fibrillärer Structur, sondern aus einer Anzahl von gesondert und ununterbrochen verlaufenden Neurofibrillen besteht, welche in eine weiche Interfibrillärsubstanz eingebettet sind. Die Markscheide entsteht aber sowohl bei Wirbelthieren, als auch bei gewissen Wirbellosen dadurch, dass sich die Einlagerung des Myelins in die Nervensubstanz auf eine peripherische Zone beschränkt, hier aber in einer so grossen Menge erfolgt, dass die Neurofibrillen axialwärts verdrängt werden.

Je nachdem mehrere oder wenigere Elementarfibrillen in ihnen vereinigt sind, giebt es verschieden dicke Neurofibrillen. Bei den Wirbelthieren ist diese Verschiedenheit nicht sehr gross, da die dicksten Neurofibrillen bei Weitem nicht die bei Wirbellosen beobachtete Stärke erreichen. Bei den Hirndineen und bei Lumbricus sind die stärksten Primitivfibrillen $0.75 \mu$ (bei Pontobdella bis iiber I $\mu$ ) dick, die dünnsten nicht mehr als $0.05 \mu$, und doch sind auch solche deutlich als Individuen zu verfolgen. Sie sind immer sehr scharf gezeichnet, vollkommen glatt, ohne irgend welche Varicositäten. Sie verlaufen meist mehr oder weniger wellig, in dem zusammengezogenen Nerv stark gewunden, hingegen schnurgerade in den maximal gestreckten. In Betreff ihrer weiteren Eigenschaften muss auf meine ausfiihrliche Arbeit verwiesen werden.

Um jeden Verdacht einer Verwectselung mit anderen fibrillären Elementen des Organismus auszuschliessen, habe ich bei Hirudo auch die Stütz- und Hüllvorrichtungen des Nervensystems genau beschrieben. Es müssen hier 6 Arten von Fibrillen auseinandergehalten werden, welche alle eine besondere charakteristische Anordnung, besondere morphologische Eigenschaften und Re- 
actionen zeigen. Das sind in erster Linie die Neurofibrillen, die Myofibrillen der in die Neurilemmscheide der peripherischen Nerven und der Ganglien eingebetteten Nervenmuskeln, die Gliafibrillen, die collagenen Bindegewebsfibrillen der Neurilemmscheiden; zu diesen gesellen sich noch die Somatoplasmafibrillen (richtiger der optische Ausdruck der Wabenwände des Somatoplasmas der Ganglienzellen, der Nervenzellen und der Gliazellen) und durch die Fixirung entstandene Coagulumfibrillen der interstitiellen Grundgallerte, bezichungsweise eines interstitiellen Serums. Die centrale Fasermasse der Ganglien (die Leydig'sche Punktsubstanz) selbst ist aus folgenden Substanzen zusammengesetzt: aus Neurofibrillen, aus Peri- oder Interfibrillärsubstanz mit eingelagertem Myelin, aus Gliafibrillen, aus collagenen Bindegewebsfibrillen, welche als Fortsätze der Hiillen in das Ganglion eindringen, aus dem wabigen Somatoplasma der zwei "grossen medianen Sternzellen," aus einer spärlichen interstitiellen Grundgallerte und einem das Gewebe durchtränkenden Serum. In der ganzen centralen Fasermasse sind kleine lymphoide Zellen (Wanderzellen) zerstreut, auf welche man nur nach guten Kernfärbungen, durch ihre Kerne aufmerksam wird.

Die Anordnung der Glia, welche in den wesentlichsten Punkten eine grosse Ähnlichkeit mit der der Wirbelthiere zeigt, habe ich besonders eingehend geschildert; sie ist aber zu verwickelt, um kurz referirt werden $\mathrm{zu}$ können.

Auf Grund der Beschaffenheit ihrer Hüllvorrichtung, der Zahl, Stärke und Anordnung ihrer Neurofibrillen kann man bei Hirudo und Lumbricus (und auch bei anderen Wirbellosen) dreierlei Nervenfasern unterscheiden, die ich vorläufig als motorische Fasern, als sensorische Schläuche und sensorische Bündel bezeichnet habe, indem ihr Verhalten im Centrum und auf der Peripherie die erste Art als motorisch (oder wenigstens centrifugal leitend), die zwei letzteren als sensorisch (oder wenigstens centripetal leitend, receptorisch) zu betrachten gestattet. Dieses Verhalten wird ausführlich beschrieben. Wahrscheinliche Aequivalente der drei Sorten von Nervenfasern weise ich auch in den Wurzeln der Spinalnerven von Loplizus nach. Die motorischen Fasern enthalten meist nur je eine, höchstens wenige Neurofibrillen von der dicksten Sorte. Die starke Neurofibrille wird von einem dicken, homogenen, myelinarmen perifibrillären Mantel und ausserdem noch von einer besonderen Gliascheide umgeben.

Eine solche dicke Neurofibrille entspricht der Gesammtheit der dünnen Neurofibrillen, welche in dem Axencylinder einer motorischen Nervenfaser der Wirbelthiere enthalten ist. Gelegentlich sind aber auch die Neurofibrillen eines solchen motorischen Axencylinders so eng zusammengedrängt, dass sie als eine einheitliche, sehr starke Primitivfibrille erscheinen. Namentlich ist dies stets der Fall innerhalb des Centralnervensystems eine Strecke weit von der Ganglienzelle, deren Fortsatz (im anatomischen Sinne 
wenigstens) der motorische Axencylinder ist. Die in verschiedener Richtung aus dem Körper der Ganglienzelle, zum Theil direct aus einem Dendriten kommenden Neurofibrillen convergiren und gehen zunächst in den compacten Axon über, um jedoch bald wieder etwas auseinanderzuweichen, zwischen sich einer grösseren Menge von Interfibrillärsubstanz Raum $z u$ geben und in der die Axencylinder der peripherischen Nerven charakterisirenden losen Anordnung zu erscheinen. Dass andrerseits die dicke, isolirte Neurofibrille der motorischen Fasern der Hirudineen und von Lumbricus (und auch von anderen Wirbellosen) wirklich aus mehreren dünneren Neurofibrillen besteht, die nur sehr eng, mit ausserordentlich wenig Interfibrillärsubstanz, zusammengekittet sind, habe ich ebenfalls auf verschiedene Weise gezeigt.

Die sensorischen Schläuche, zu welchem Typus auch die sogenannten Neurochorde der Chaetopoden (Borstenwürmer) gehören, enthalten je eine grosse Anzahl meist sehr dïnner Neurofibrillen, welche genau so wie in den Axencylindern der peripherischen Wirbelthiernerven, in eine myelinlose Interfibrillärsubstanz eingebettet sind. Die Wand des Schlauches bildet eine dicke Gliascheide. Hart an dieser Wand befindet sich eine schmale (in den Neurochorden breitere) Zone von myelinhaltiger Interfibrillärsubstanz. Die sensorischen Schläuche sind den colossalen Nervenfasern der dorsalen Wurzeln von Lophius sehr ähnlich.

Die sensorischen Bündel bestehen aus einer kleineren oder grösseren Anzahl von weniger dicht als in den sensorischen Schläuchen gelagerten Neurofibrillen, welche, innerhalb einer gemeinsamen, dünnen Gliascheide, in eine sehr myelinreiche Interfibrillärsubstanz eingebettet sind. Die sensorischen Bündel vergleiche ich mit den Bündeln von sehr dünnen Nervenfasern, welche bei Lophius (und auch anderen Wirbelthieren) in den dorsalen Wurzeln zu sehen sind.

Von dem in meiner Arbeit eingehend geschilderten Verhalten der sensorischen Schläuche und der sensorischen Bündel in den Ganglien sei hier blos ihr Verhältniss zu dem Elementargitter der centralen Fasermasse (Leydig'sche Punktsubstanz) erwähnt. Die Neurofibrillen der sensorischen Schläuche gehen stets in demselben Ganglion, in welches sie eingetreten sind, die der sensorischen Bündel zum Theil in demselben, zum Theil in dem benachbarten oder in einem entfernteren Ganglion, das sie auf dem Wege der Längscommissuren (Connective) erreichen, in das Elementargitter über. Die sensorischen Schläuche verzweigen sich in der centralen Fasermasse hirschgeweihartig, und ihre Neurofibrillen treten zum Theil seitlich, zum Theil an den Astenden (den centralen Endkolben der Autoren) aus, um sich in das Elementargitter zu begeben, in welches sie nach wenigen dichotomischen Theilungen eingehen. In demselben Elementargitter lösen sich andrerseits auch Neurofibrillen auf, welche direct aus Ganglienzellen her zu verfolgen sind. Dieselben Neurofibrillen stammen aber aus dem intracellulären 
Neurofibrillengitter der Ganglienzelle, und das Neurofibrillengitter entstelit aus Theilungen und netzbildenden Verschmelzungen von Neurofibrillen, welche in die Ganglienzelle eingetreten sind und zum Theil direct aus peripherischen Nerven her zu verfolgen sind.

An dem Aufbau des fertigen Nervensystems der Hirudineen sind ausser den Ganglicnacllen noch zweierlei Zellen wesentlich betheiligt; die eine Art deute ich als Nervenzellen, d. h. als Bildner der Neurofibrillen, die andere als Gliasellen, d. h. als Bildner der Gliafibrillen. In gewissen frühen Stadien der Histogenese mögen dieselben Zellen Gliafibrillen und Neurofibrillen gebildet haben; später hat sich ein Theil von ihnen ausschliesslich auf die Herstellung von Gliafibrillen, ein anderer vorwiegend auf die von Neurofibrillen verlegt, doch auch die Fähigkeit behalten, nebenbei Gliafibrillen zu produciren. Bei Hirudineen deutet alles darauf hin, dass die Ganglienzellen selbst keine Neurofibrillen produciren, sondern erst secundär von solchen durchwachsen werden. Es muss also andere Zellen geben oder wenigstens bis zu einem gewissen Stadium der Histogenese gegeben haben, welche Neurofibrillen als specifisches Zellproduct herstellen. Diese Zellen glaube ich auch im entwickelten Organismus der Hirudineen (und auch von Lumbricus und mehreren anderen Wirbellosen) gefunden $\mathrm{zu}$ haben. Entwickelungsgeschichtlich habe ich bisher nur soviel ermitteln können, dass die späteren leitenden Bahnen ursprünglich protoplasmatische Zellbrücken sind. Zu Nerven werden diese erst dann, wenn in ihnen die Neurofibrillen erscheinen, ebenso wie ein protoplasmatischer Fortsatz einer Zelle erst dann zur Muskelfaser wird, wenn darin contractile Substanz in Form von Myofibrillen erschienen ist. Das grosse Problen der Histogenese des Nervensystems besteht mun darin, zu cntscheiden, welche Glieder der ab ovo protoplasmatisch verbundenen Zellcnkette die Neurofibrillen producircn. Die späteren Ganglienzellen scheinen es nicht zu sein, und auch zellenphysiologische Erwägungen schliessen es aus, dass sie es sind. Das Problem wird aber sofort gelöst sein, sobald es uns gelingt, die Neurofibrillen gleich bei ihrem ersten Auftritt so deutlich, wie in späteren Stadien und besonders im entwickelten Organismus zu differenziren. Es genügt noch nicht, nachzuweisen, dass z. B. eine embryonale Ganglienzelle einen Fortsatz in die Anlage einer ventralen Wurzel sendet. Es muss auch nachgerviesen werden, dass in diesem Fortsatz und in der Ganglienzelle Neurofibrillen entstanden sind, bevor diese letztere mit anderen Zellen in Verbindung getreten ist, oder, da ja solche Verbindungen meist ab ovo vorhanden sein werden, dass die Neurofibrillen zuerst in der Ganglienzelle aufgetreten und aus dieser weiter gewachsen sind.

Das charakteristische Zellproduct der Ganglienselle sind nicht die Neurofibrillcn, sondern eine gezvisse chromatische Substanz, welche in der Form von minimalen Körnchen auftritt und bei Wirbellosen im gansen Zellkörper oder in gewissen Zonen desselbon glcichmässig vertheilt ist, bei Wirbelthicren dagegen die bekannten Flemming- 
Nissl'schen Formationen bildet. Ein grosser histologischer Unterschied zwischen den Fortsätzen der pluripolaren Ganglienzellen besteht sowohl bei Wirbelthieren, als auch bei Wirbellosen darin, dass ein Fortsatz (seltener mehrere), der Axon der Wirbelthiere, der Stielfortsatz oder (im anatomischen Sinne) Hauptfortsatz bei den Wirbellosen, chromatische Körnchen stets entbehrt, weshalb er als achromatischer Fortsatz bezeichnet werden kann; dagegen enthalten die übrigen Fortsätze, die Dendriten der Wirbelthiere, die Nebenfortsätze der Wirbellosen, in verschiedener Vertheilung stets chromatische Körnchen, weshalb sie als chromatische Fortsätze bezeichnet werden dürften. Dic Dendriten sind in histologischer Hinsicht directe Fortsetzungen des Somatoplasmas der Ganglienzellen, während die Axone nicht aus Somatoplasma, sondern lediglich aus Neurofibrillen und Interfibrillärsubstanz, also nur aus Nervensubstanz bestehen, welche den ursprünglich vielleicht vorhandenen protoplasmatischen Fortsatz der Ganglienzelle ganz verdrängt hat. Volkommen gleich sind aber sämmtliche Fortsätac der Gangliensellen darin, dass sic cine leitende Function besitzen, indem sie alle Ncurofibrillen enthaltcn. Auch in den Dendriten hört das Somatoplasma bei ihren weiteren Verästelungen auf, und diese bestehen blos aus leitender Substanz und zwar schliesslich, ebenso wie die feineren Kollaterale, aus einer Primitivfibrille, welche von einer dünnen Hülle aus nicht protoplasmatischer Perifibrilläısubstanz umgeben ist. Von einer Contractilität der Dendritenoder Kollateralenden kann also keine Rede scin.

Die zweite Hauptthese meiner Arbeit betrifft die topographischen Beziehungen der Neurofibrillen zu den Ganglienzellen und sie lautet folgendermassen : Neurofibrillen dringen in das Somatoplasma der Ganglienzelle ein, und ebenso viele Elementarfibrillen, wie in den eintretenden Neurofibrillen enthalten sind, verlassen wieder, meist anders gruppirt, die Ganglienzelle in den Neurofibrillen, die aus ihr heraustreten, nachdem sie sich (bei den Wirbelthieren blos ein Theil von ihnen) im Zellkörper zu einem leitenden Geflechte oder Gitter ausgebreitet haben, in welchem ihre Umgruppirung erfolgt. Eine Endigung oder ein Anfang, etwa eine Auflösung der Neurofibrillen im Somatoplasma, findet in der Ganglienzelle nicht statt, irgend welche Verbindung der Neurofibrillen mit dem Zellkern ist auch nicht vorhanden. Diese bei vielen Formen von Ganglienzellen nachgewiesene Thatsache könnte man als allgemeines Gesetz auch so formuliren : der ununterbrochene Verlauf der zu mehr oder weniger starken Neurofibrillen vereinigten leitenden Elementarfibrillen geht in der Regel durch ein oder mehrere Ganglienzellen, in denen sie zeitweilig auseinander weichen und in deren Somatoplasma sie (bei den Wirbelthieren blos ein Theil von ihnen) ein leitendes Geflecht oder Gitter bilden.

Nun habe ich besonders bei Hirudineen und Lumbricus verschiedene Typen centraler und peripherischer Ganglienzellen sehr 
ausführlich beschrieben. Betont sei hier nur folgendes. Die centralen Ganglienzellen der Hirudineen sind zum grössten Theil unipolar, während die sympathischen Ganglienzellen der Darmwand typisch pluripolar sind. Der Fortsatz (Stielfortsatz) der ersteren vereinigt in sich den Axon und die Dendriten der Ganglienzellen der Wirbelthiere und der meisten von Lumbricus. Ich unterscheide zwei Hauptformen, den Typus G der grossen Ganglienzellen und den Typus $K$ der kleinen Ganglienzellen. Im Typus $K$ verläuft eine dem Axon entsprechende, meist sehr starke Primitivfibrille in der Axe des Fortsatzes. In den Zellkörper angelangt (oder kurz davor) verästelt er sich dichotomisch und bildet unter Verschmelzung, nicht blos Kreuzung der Drähte an den beinahe immer dreischenkeligen Knotenpunkten um den Kern herum das Innensitter (einen perinucleären Neurofibrillenkorb). Aus dem Innengitter gehen radiäre Neurofibrillen zur Peripherie der Zelle und bilden hier, aber noch innerhalb des Zellkörpers, das Aussengitter. Aus dem Aussengitter entspringen in der Nähe des Fortsatzpoles Neurofibrillen, die wieder in den Fortsatz austreten und hier peripherisch gelagert sind. In dem Typus $G$ besitzt der Fortsatz keine besondere, differenzirte Axenfibrille, sondern er enthält in seinem ganzen Durchschnitt ziemlich gleichmässig vertheilte, entweder lauter sehr dünne, oder dickere und dünnere Neurofibrillen. In den Zellkörper angelangt, verlaufen diese im Ganzen und Grossen meridional, theilen sich aber wiederholt, anastomosiren mit einander und bilden so ebenfalls ein Neurofibrillengitter, welches in der Regel auf eine bestimmte, mehr peripherische Zone des Zellkörpers beschränkt ist. Die in dem Fortsatz vereinigten Neurofibrillen beider Typen gehen meist erst in der centralen Fasermasse auseinander, doch giebt es in der Nähe der Seitennerven gelegene Ganglienzellen, bei welchen ein Theil der meist sehr starken Neurofibrillen des Fortsatzes direct in den Seitennerv einbiegt und nur der andere sich in die centrale Fasermasse begiebt. Sehr auffällige Homologa dieser Ganglienzellen habe ich auch bei Lumbricus beschrieben, wo sie indessen, wie überhaupt die grosse Mehrzahl der Ganglienzellen, pluripolar sind. Hier ist eine sehr dicke Neurofibrille unmittelbar vom Seitennerv her in die Ganglienzelle zu verfolgen; in der Ganglienzelle theilt sie sich sofort wiederholt und bildet ein dichtes, den ganzen Zellkörper durchwebendes Neurofibrillengitter ebenfalls mit deutlicher Verschmelzung der Balken an den Knotenpunkten. Die Drähte dieses Gitters sammeln sich, abgesehen von einigen sehr dünnen, die für sich aus der Zelle treten, zu einer, oder zwei-drei starken Primitivfibrillen, welche in verschiedener Richtung centralwärts die Zelle verlassen. Ausserdem werden auch bei Lumbricus verschiedene andere Formen von Ganglienzellen beschrieben. Bei den Wirbelthieren durchweben die Neurofibrillen, ebenso wie bei Lumbricus, den ganzen Zellkörper. Während aber bei Lumbricus in der Regel sämmtliche Neurofibrillen, die durch die Ganglienzelle ziehen, an der Bildung 
des Neurofibrillengitters theilnehmen, gehen bei den Wirbelthicren vicle Neurofibrillen, und zwar die stärksten, also auch auffälligsten, sogar zum Theil ohne Verästelung von einem Fortsatz in den anderen durch.

Ebenso gut, wie diese Verhältnisse, kann ich die verschiedenen Formen von Anastomosen, die bei Hirudineen vorkommen und besonders leicht in der Darmwand von Pontobdella zu constatiren sind, demonstriren. Ganglienzellen können mit einander in dieser oder jener Weise anatomisch verbunden sein, ohne dass eine nervöse, d. h. leitende Anastomose zwischen ihnen vorhanden sein müsste. Man kann nur dann sicher von einer solchen reden, wenn man den Übergang von Neurofibrillen aus einer Ganglienzelle in die andere constatiren konnte. Auf dieser Grundlage werden auf der Peripherie bei Hirudineen und Lumbricus zahlreiche leitende Anastomosen verschiedener Form nachgewiesen. Dagegen sind im Centrum Anastomosen, bei welchen der Zellkörper von zwei Ganglienzellen durch eine auffällige Zellbrücke leitend verbunden wäre, ziemlich selten. Die centralen leitenden Anastomosen werden meist nur durch die Neurofibrillen hergestellt, welche in die Bildung desselben Elementargitters eingehen. Dasselbe dürfte auch bei Wirbelthieren der Fall sein.

Weiter schilderte ich das Verhalten der Neurofibrillen in den epidermalen und subepidermalen Sinneszellen der Hirudineen. Zu den ersteren gehören die Sinneszellen der von mir so genannten Tastkegelchen (an den Lippen die becherförmigen Organe Leydig's), zu den letzteren die grossen hellen Zellen der Augen (Retinazellen). In beide Sorten von Sinneszellen tritt nur je eine Neurofibrille ein, welche sich von einem sensorischen Bündel abzweigt. Eine Endigung an der Sinneszelle, oder um die Sinneszelle herum findet nicht statt. In die Zelle tritt einzig und allein die Neurofibrille ein; der perifibrilläre Mantel, welcher sie bis an die Zelle begleitet hat, verliert sich auf der Oberfläche derselben. Die Perifibrillärsubstanz kann dort auch einen kleinen Hügel dergl. bilden. Frühere Autoren, welche die Neurofibrille nicht differenziren konnten, glaubten in solchen Fällen eine hügelförmige Nervenendigung (oder Endplatten etc.) gefunden zu haben. Die eingedrungene Neurofibrille verästelt sich in beiderlei Sinneszellen und bildet ein geschlossenes intracelluläres Neurofibrillengitter. Während aber in zwei Typen von subepidermalen Sinneszellen nämlich bei Hirudiniden und Pseudobranchellion das Gitter sich in der Nähe derOberfläche um die ganze Zelle ausbreitet und nicht besonders den Zellkern umschliesst, ist das Neurofibrillengitter in den epidermalen Sinneszellen ein rein perinucleäres, indem die gitterbildende Verästelung der Neurofibrille meist erst dicht vor dem Zellkern beginnt und das Gitter hinter dem Kern wieder in eine einheitliche Neurofibrille ausläuft, welche in der Zellenachse wciter zieht.

Einen Übergang dieser beiden Formen in einander stellt der dritte Typus der subepidermalen Sinneszellen bei Pontobdelli. und 
Branchellion dar, dessen Verhalten ich hier zum ersten Mal schildere und demonstrire.

Bei Pontobdella-bei Branchellion ist dieses Verhalten weniger typisch-dringt nämlich die Neurofibrille in die subepidermale Sinneszelle tiefer ein und gelangt eventuell, nach Abgabe von einigen gröberen Aesten, in die Nähe des Kernes; dort zerfällt sie in mehrere Aeste, und diese bilden dicht um den Kern eine ziemlich engmaschige Gitterkugel; aus dieser treten in verschiedenen Richtungen mehrere radiäre Aeste aus, welche sich gegen die Peripherie der Zelle wieder verästeln und dicht unter der Oberfläche der Zelle ein weitmaschiges, peripherisches Gitter bilden, welches, ebenso wie bei Hirudo, ganz geschlossen ist.

Die drei verschiedenen Typen des Verhaltens der Neurofibrillen in den subepidermalen Sinneszellen (Retinazellen) lassen sich einfach aus der relativen Grösse und den topographischen Verhältnissen einerseit jener für diese Zellen charakteristischen hellen Körper und andrerseits des Kernes erklären, da die Neurofibrillen weder die hellen Körper noch den Kern je durchsetzen, aber mit dem letzteren doch in eine engere topographische Beziehung treten. Bei Hirudo und Aulastoma ist der helle Körper sehr gross; das eigentliche Somatoplasma bildet, mit dem verhältnissmässig kleinen, bei Seite geschobenen Kern, eine schmale peripherische Zone, welche sich typisch blos an einer Stelle hügel- oder leistenförmig hervorwölbt und den hellen Körper entsprechend einbuchtet. Bei Pseudobranchellion ist der helle Körper kleiner, kugelförmig und der daneben liegende, nicht an die Wand gedrückte Kern sehr gross. Bei Pontobdella bildet die helle Substanz mehrere grosse kugelförmige Körper, und zwischen diesen liegt mehr in der Mitte der Zelle der Kern, welcher viel kleiner als bei Pseudobranchellion, aber grösser als bei den Hirudiniden ist.

Aus dem äusseren Gitterwerk dieser Zellen treten Neurofibrillenäste, welche, wie es an günstigen Zellen gut zu beobachten ist, die Zelle wieder verlassen, heraus. Solche austretende Aeste treten gelegentlich in benachbarte Zellen ein und stellen in dieser Weise leitende Anastomosen dar. Noch besser ist aber das Heraustreten von Neurofibrillenästen an den epithelialen Sinneszellen von Hirudo zu demonstriren.

Ich konnte nämlich sicher constativen, dass die hinter dem Kern axial weiter wichende, wieder vercinigte Neurofibrille der epidermalen Simneswelle wiedcrholt Scitenäste abgiebt, die aus der Zelle treten und sich ausscrhalb der Zelle, zwischen den benachbarten Epidermiszellen weiter verästeln, bis sie mit sehr dïnnon Acstchen in die Nähe der Cuticula angelangen, dort umbiegen und sich der weitercn Beobachtung moist entriehen, olne dass man sagen könnte, dass sie endigen. Sie scheinen vielmehr ein subcuticulares Elementargitter, das peripherische Gegenstück des centralen, zu bilden.

Eine ähnliche intraepitheliale, aber extracelluläre Verästelung erfahren auch andere, von kleinen subepidermalen Ganglienzellen 
herkommende Neurofibrillen ohne erst in irgend eine Sinneszelle einzutreten. Andrerseits passirt aber ein Theil der in die epidermalen Sinneszellen eintretenden Neurofibrillen erst cbenfalls solche subepidermale Ganglienzellen, in welchen sie auch ein perinucleäres Gitter bilden.

Wie gesagt, konnte ich auch die Verbindung der Ncurofibrillengitter benachbarter Retinazellen und epidermaler Sinneszellen untereinander durch übertretende Neurofibrillenäste nachweisen.

Von grosser Wichtigkeit ist num weitcr dic Thatsache, dass das Nenrofibrillengitter in den Retinazellen des weniger entzvickelten Auges von Aulastoma ans dickercn Balken besteht, zueniger zahlrciche, also grössere, unregelmässigere Maschen bildet, als in den Retinazellen des entrvickelteren Anges von Hinudo. (Auf diese und andere ähnliche Thatsachen bezieht der eingangs aufgezählte I2te Beweis der leitenden Natur der Neurofibrillen.)

Nicht weniger deutlich als in den Sinneszellen, kann ich das Verhalten der Neurofibrillen in den Muskelfasern zeigen. Dasselbe wird dadurch charakterisirt, dass sich die in die Zelle eingedrungene Neurofibrille meist T förmig oft wiederholt verästelt und dabei die ganze Dicke der Muskelfaser in ziemlich grosser Länge durchzieht, aber kein geschlossenes Gitter bildet und auch zu dem Kern in keine nähere topographische Beziehung tritt. Besonders interessant dürfte der Umstand sein, dass bei den Muskelfasern der Darmwand von Pontobdella die feinsten Neurofibrillenäste schliesslich an verschiedenen Punkten wieder aus der Faser treten und sich in der interstitiellen Grundsubstanz der Beobachtung entziehen, und zwar ebenfalls stets nur deshalb, weil sie unter für ihre weitere Verfolgung ungünstige Verhältnisse kommen, nicht als ob sie nachweisbar endigen würden. Oft sieht man scheinbare punktförmige Endigungen von Neurofibrillenästen hier wie in dem Epithel, welche sich bei näherer Prüfung als optische (in Schnittreihen gelegentlich wirkliche) Querschnitte der umgebogenen Fibrille erweisen. Bei den Hirudineen dringt auch in die Muskelfaser stets nur eine Primitivfibrille an einem Punkte ein; doch sind an den grossen Muskelfasern der Darmwand von Pontobdella in rerschiedener Höhe, ja gelegentlich in derselben Höhe mehrere solche Punkte vorhanden. Der perifibrilläre Mantel bildet an der Oberfläche der Faser einen nach innen vorspringenden Längswulst, begleitet aber die eingedrungene Neurofibrille nicht weiter. Ein und derselbe Nervenast innervirt durch successive abgegebene Seitenzweige Muskelfasern sowohl der beiden diagonalen, als auch der circulären Muskelschichte. Die parallel neben einander verlaufenden Muskelfasern sind nicht nur mit ihren unmittelbaren Nachbarn, sondern auch mit entfernteren durch mehr oder weniger feine Querbrücken verbunden, die im letzteren Fall von einer Muskelfaser bis zur anderen mehrere dazwischen liegende kreuzen, gelegentlich aber auch an diese feine Ästchen abgeben. In der Darmwand der Hirudineen sind auch Längsmuskelfasern mit Querfasern durch schräge 
Brücken verbunden. Ein Theil der dünnsten Brücken erweist sich als je eine mit dünnem perifibrillären Mantel umgebene Neurofibrille, welche also ihren Weg in eine Muskelfaser durch eine andere genommen hat. Solche, die Muskelfaser durchsetzende Neurofibrillen habe ich bei Ascaris schon vor längerer Zeit beschrieben. Sehr verjüngte Muskelendäste verschmelzen gewöhnlich auch mit dünnen Nervenästen, so dass es meist gar nicht möglich ist, anatomisch zu unterscheiden, wo der Muskel aufhört und der Nerv anfängt. Natürlich handelt es sich in der That blos um eine eigenthümliche Art von Innervirung, wo der Nervenzweig auf dem durch den Muskelast vorgezeichneten Wege in die Faser eindringt, wie man sich davon nach Differenzirung der betreffenden Neurofibrille im Nervenzweig überzeugen kann.

Eine gevisse principielle Übereinstimmung besteht in der Anordnung der Neurofibrillen im Somatoplasma zwischen Muskelzellen und Flimmerzellen, falls wir die Fibrillen, welche den von Ebner entdeckten intracellulären Fibrillenconus gewisser Flimmerzellen der Darmwand von Unio und Anodonta zusammensetzen, als Neurofibrillen deuten. Hierfür könnte ich nämlich zahlreiche, an nachvergoldeten Schnitten demonstrirte Gründe aufzählen. Leider konnte ich das Eindringen von extracellulär verfolgten, deutlich als solche erkennbaren Neurofibrillen in die Flimmerzellen nicht constatiren. Auf den Goldpräparaten kann ich mehrere neue oder strittige Einzelheiten des Baues der Flimmerzellen demonstriren, auf welche ich hier wohl nicht eingehen darf. Erwähnt sei nur, dass die Flimmerzellen im Darm der Muscheln eine deutliche, dicke, aber wenig dichte Cuticula besitzen, welche ausserhalb der Reihe der Basalkörperchen liegt und nicht durch diese vergetäuscht wird. Der einheitliche Faden, in welchen der Fibrillenconus übergeht, ist über den Kern weg bis zur Basis der Zelle sehr deutlich zu verfolgen, er besitzt ganz den Charakter einer dicken Neurofibrille.

Ein geschlossenes Neurofibrillengitter kann ich weiter in der Wand von kleinen subepidermalen Gefässen und in der Wand der Sammelblase der Nephridien demonstriren. In der letzteren hat das Neurofibrillengitter zum Theil eine subepitheliale, zum Theil intraepitheliale, intracelluläre Ausbreitung. Nervenendigungen giebt es auch hier nicht. Endlich sah ich gitterbildende Neurofibrillen auch in gewissen nicht specifisch sensorischen Epidermiszellen von Hirudo und in Darmepithelzellen sowohl als auch einzelligen Drüsen verschiedener Hirudineen.

In was für physiologische Beziehnngen auch Nenrofibrillon mit was fiir Zellen immer treten, so geschieht dies demnach bei Hirndineen und bei Lumbricus, und, so weit ich nach meinen bisherigen Erfahrungen urtheilen kann, wahrscheinlich bei allen Thieren in der Weise, dass die Neurofibrille erstens in die Zelle eindringt und aweitens sich dort verästelt. Die Fibrillenäste endigen aber nie in der Zelle, anch treten sie mit dem Kern in keinerlei unmittclbare 
Verbindung, wohl nungeben sie ihn jedoch in gezvissen Typen der Nenrofibrillcnanordnung mit eincm meler oder woniger engen Gitter. Extracellulär gchen die Nenrofibrillenäste schliesslich ebenfalls in cin Gitter, Elemcntargitter iiber, so dass auch extracellulär keine Nervenendignng nachweisbar ist. Die Nenrofibrillengitter sind bci Hirndineen nud Lmmbricus stcts Polygon-Gitter mit meist drcischcnkcligen Knotcnpunktcn und keine Geflächte mit sich blos krenzenden Fäden. So glaube ich in meincr Arbeit allerlei Berveise, die anf morploologischem Wege nur zu erbringen sind, fïr die leitende Natur meiner Nenrofibrillen erbracht su haben.

Allerdings könnte man gegen die Thatsache, dass nur die Neurofibrillen in die mit dem Nervensystem leitend verbundenen Zellen eindringen, noch einwenden, dass vielleicht das Somatoplasma selbst die eventuelle leitende Function der an der Oberfläche aufhörenden Perifibrillärsubstanz übernimmt. Wozu aber dann das verwickelte, charackteristische Verhalten der Neurofibrillen in den Zellen, woher die Abhängigkeit der Länge des von der Neurofibrille in der Zelle zurückgelegten Weges von dem Entwicklungsgrade des betreffenden Organs, wie ich es am Auge von Aulastoma und Hirudo am schönsten zeigen kann? Endlich hat ja die aus einer Zelle wieder herausgetretene Neurofibrille oft keinen perifibrillären Mantel mehr, so dass für die Leitung des nervösen Stromes nichts als die Neurofibrille übrig bleibt. 


\section{SECTION A. GENERAL ZOOLOGY.}

Friday, 26 August, at the GuIldhall, at 2 p.m.

Chairman, The President.

Prof. E. W. MACBRIDE read the following paper:

\section{ON THE ORIGIN OF ECHINODERMS.}

Although all the great divisions of the animal kingdom are isolated from each other, in the sense that no forms exhibiting intermediate types of structure are known, yet this is true in a very special sense of Echinoderms. In the case of the other phyla there is sufficient fundamental agreement in structure to enable us to at least picture to ourselves an evolutionary series by which they could have been derived from the same ancestors; but this, if we have regard only to the structure of the adult, is impossible in the case of Echinoderms.

These are radial in structure, yet the older attempts of Cuvier and the elder Agassiz to ally them with the Coelenterata fail on account of the omission to explain the important fact that the radial symmetry is broken by the asymmetry of the madreporite and the stone canal so intimately connected therewith. The attempt repeated in modern times to get suggestions as to the origin of the group by seizing on the indications of bilateral symmetry found in some modern Holothuridea and in some ancient forms such as the Cystidea, is equally unsatisfactory, since the bilateral symmetry of Holothurids has every mark of secondary origin : it is totally unconnected with the bilateral symmetry of Spatangids, as Cuénot has pointed out, and of the internal structure of Cystids we know next to nothing.

Since the examination of the adult structure yields so little result, there has been a general tendency to look for light on the question in the structure of the larva. Leaving the Crinoids apart for the moment, Joh. Müller has demonstrated the fundamental similarity in structure of the larvae of Ophiurids, Echinids, Asterids and Holothurids. In every case we have a strongly marked bilateral form, with a complete alimentary canal and a ventral ciliated band passing in front of the mouth and then on each side fringing a well-defined ventral skin area, behind which is found the anus. All the bizarre arms and processes which give these larvae such 
a curious aspect are with one or two exceptions mere wrinklings or folds of this ciliated band-the organ by which both locomotion and feeding are carried on. Between the gut and the body wall we have on either side a simple sac, part of the future body cavity of the adult; and one or both of these sacs communicate with the exterior by a pore.

The remarkable agreement in broad outline, combined with infinite diversity in detail, of these larvae strongly suggests that the characters of a bilateral ancestor of the Echinoderms have supplied the foundation of their structure. Such an ancestor must have been practically on a level with the Coelenterates so far as differentiation of the tissues was concerned, but it differed radically from Coelenterates in its mode of life and outer form related thereto. It must have been essentially a swimming animal with a definite head directed forwards. It seems to me to have been a fertile source of error in the earlier days of evolutionary zoology, that, when a living animal of simple structure was found with a condition of tissues corresponding to that found in the embryo of a higher form, it was assumed that the ancestor of the higher form resembled in all respects the lower. Thus, for example, because in the general condition of the nervous, muscular and alimentary systems an Actinia recalls conditions met with in the embryos of higher forms, it was supposed that all the higher animals were derived from an Actinia-like ancestor, a conclusion which seems to me to have been unjustifiable when applied to outer form.

The conclusion that Echinoderms were derived from a bilateral ancestor of very simple organisation is received with increasing favour, and a recapitulation of the grounds which support it would not justify a new paper. The main object of the present communication is to endeavour to throw some light on the manner in which this ancestor was converted into the radial prototype of Echinoderms.

All students of Echinoderm development are familiar with the fact that the first trace of the metamorphosis observable is the appearance of an inner asymmetry. From the body cavity of one side an anterior portion becomes divided off. This becomes developed into a rosette shaped structure, a hoop-like tube with 5 outgrowths - the rudiment of the circular canal and the five radial water-vascular canals of the adult. The circular canal is eventually completed by the bending round of the two ends of the hoop till they form a ring. This hoop shaped rudiment has received the convenient name of hydrocoele.

It seems to me that the key to the solution of the problem of the ancestry of the Echinoderms lies in the answer to the question "What is the origin and meaning of the hydrocoele?"

If a developing larva of Asterina gibbosa be carefully examined, it will be found that at one stage both the right and the left body cavity become divided into anterior and posterior parts, 
the anterior portions are fused to form one cavity. In some species of Asterias at any rate both the anterior portions open to the exterior by pores although the right pore subsequently becomes closed up.

The hydrocoele is budded off from the left anterior cavity, and at the same time a small closed sac appears in a similar position with regard to the right anterior cavity. This little sac is the rudiment of a right hydrocoele, the fellow of the left one. This is shown (I) by the fact that it is budded off from the right anterior cavity in a corresponding position to that in which the left hydrocoele originates from the left anterior cavity and (2) above all by the fact that it developes in some cases into a rosette shaped structure similar to the left one.

Bury has described the segmentation of the body-cavity vesicle into anterior and posterior parts in Ophiurids and Echinids. This I can confirm by sections through larvae of Echinus esculentus, as also the assertion that the pore communicates with the left anterior cavity, not into the hydrocoele directly. Strangly enough Bury denies the existence of a right hydrocoele, though this has been seen and figured in Ophiurid larvae by Johannes Müller and Metschnikoff. In a recent work on the development of Asterias pallida, Seitaro Goto ${ }^{1}$ denies my interpretation of the sac which I have above called the right hydrocoele. This work in my opinion calls for severe comment, for Mr Goto has neither seen nor figured the earlier stages of the organ in question.

We have nearly reached the limits of discovery possible under the old methods carried out with such splendid results by Johannes Müller, Alex. Agassiz and many other distinguished zoologists. If we are to penetrate any further into Echinoderm embryology, it can only be by the use of the most refined modern methods, and any attempt to jump to conclusions on the basis of insufficient and indifferently preserved material can only hinder our progress.

If the hydrocoele is really a paired structure, then the body cavity will have three divisions on either side, and a fundamental similarity to the Tornaria larva of Balanoglossus, as well as to Actinotrocha, would exist. We should thus be induced to think that three such widely divergent groups as the Enteropneusta (and through them the Vertebrata), the Echinodermata and the Phoronidea had remote pelagic ancestors of simple structure in common. In this connexion it is interesting to notice that in Cephalodiscus and in Actinotrocha the middle division of the body cavity grows out into long arms comparable to the radial canals of Echinoderms. Such a conclusion seems to me eminently reasonable. If the various phyla of the animal kingdom really belong to the same stock, it seems more probable that this stock was of a primitive undifferentiated character, rather than that nature having elaborated

1 "The Metamorphosis of Asterias pallida with special reference to the fate of the Body Cavities," by S. Goto. Journ. Coll. Sci. Imp. Univ. Tokyo, Vol. x. pt. iii. 
a well-marked type of structure like that of the Annelid converted it into such a totally different type as the Vertebrate.

The objection may be made that it follows from this hypothesis that the primitive stock was pelagic, whereas a large part of the modern pelagic fauna can be shown to have been derived from the shore.

I see no force at all in this objection. If from primitive times the fiercest struggle for existence has taken place in the open sea, it follows that evolution must have gone on with most rapidity there and that animals retaining archaic traits in their organisation could only survive in so far as they became adapted to more sheltered situations. The modern tyrants of the sea are the fish and there is no evidence whatever that their ancestors were ever other than free-swimming pelagic animals.

It may not be inopportune to remark that such statements as that Vertebrates are descended from Echinoderms, or that Phoronis is a Chordate, are gross caricatures of the view I have sketched above. I much prefer a name such as Protocoelomata for the common ancestors of the three groups mentioned above.

Having recognized that the hydrocoele is a paired structure, we can see that at any rate one important factor in the metamorphosis is the preponderant growth of the organs of the left side. This is rendered clear by the fact that the right hydrocoele does not disappear, but is found throughout life as a sac embedded in the body wall just under the madreporite. In Asterina gibbosa ${ }^{1}$ I have been able to trace every stage in the development of this structure from the first inception to its adult condition. Here again I must call attention to the carelessness of Seitaro Goto, who appears to have failed to recognize the same organ in different stages and who speaks of the adult right hydrocoele as a portion of the axial sinus from which it is quite distinct. The axial sinus, the space which in the adult accompanies the stone canal, is formed in Asterids from the union of the two anterior body cavities.

The fate of the body cavities has not been followed in either Ophiurids or Echinids, but the following facts indicate that when known it will be found to be in substantial agreement with that of Asterids. A sac corresponding to the axial sinus of Asterids, and like it communicating with the stone canal, is found in Ophiurids, where it is known as the Ampulla, and in Echinids, where it is called the cavity of the dorsal organ. A space in adult Ophiurids corresponding to the right hydrocoele, is as we have seen unmistakeably present in the larva, and was described by me under the designation of sinus $b^{2}$. In Echinids a similar space has been described by several authors, notably Leipoldt ${ }^{3}$. In Holothurids

1 "The development of Asterina gibbosa," by E. W. MacBride. Quart. Journ. Micr. Sc. 1896 .

2 "The development of the genital organs \&c. of Amphiura squamata," by E. W. MacPride. Quart. Journ. Micr. Sc. I $\$ 92$.

3 "Das angebliche Fxcretionsorgan der Seeigel." Zeit. fir wiss. Zool. I 89.3 . 
Bury ${ }^{1}$ has given reasons for supposing that the internal madreporite of the adult is the representative of the axial sinus, but neither in adult nor larva is there apparently any trace of a right hydrocoeleanother added to many reasons for believing Holothurids to be the most modified group of Echinoderms.

If the main factor in Echinoderm metamorphosis be the preponderant growth of one side, we have still to suggest how a free-swimming animal came to lose its symmetry.

Whilst discussing the fundamental agreement in type of the Echinoderm larvae, the Crinoids were left on one side. This was necessary, because the only Crinoid the development of which is known has a very modified life history. The free-swimming existence of the larva of Antedon is very short and its ciliated bands are not comparable to those of other Echinoderm larvae: these bands may however have been derived phylogenetically from the breaking up of a longitudinal ring, on similar lines to those on which the Holothurid pupa has developed transverse bands out of a longitudinal ring. In the Crinoid larva the alimentary canal is a blind sac, but a larval stomodaeum is present as a blind pouch by means of which we can determine the position of the mouth. This is found to be situated in a corresponding position to that of the Asterid larva; in both cases there is a long praeoral lobe, which contains a distinct anterior body cavity.

As is well known the Crinoid larva fixes itself by the anterior extremity of the praeoral lobe, this position of the body becoming converted into the stalk, whilst the stomodaeum is slowly displaced backwards until it reaches the posterior end of the larva, and a young stalked Crinoid is developed. In Asterina gibbosa I have shown that the larva also fixes itself by the apex of the praeoral lobe which is likewise converted into a stalk. A new mouth is formed to the left of the old one and, as metamorphosis proceeds, the remains of the stalk are found to be inserted close to the mouth within the hydrocoele ring, whereas in the Crinoid the stalk is inserted in the centre of the aboral pole. Sucl a fixed stage with a similar stalk probably occurs in the development of most Asterids: it has been recognised in a typical Bipinnaria by Bury and in every case where a shortened and modified development has brought the later stages under observation. I need only mention the Antarctic Asterias spirabilis described by Perrier, Henricia (Echinaster) sanguinolenta discovered by Sars and Müller, Asterias Mülleri and several others. Seitaro Goto it is true denies that Asterias pallida has a fixed stage, but as the larva possesses an apparatus similar to that used by other species in fixation it is possible that the conditions of artificial culture prevented fixation being accomplished. The general occurrence of a stalk in Asterids would explain the presence of an immense praeoral lobe in the

1 "The Metamorphosis of Echinoderms," by H. Bury. Quart. Journ. Micr. Sc. I895. 
larva by which it is easy to distinguish the Asterid larvae from those of Ophiurids, Echinids and Holothurids.

If we suppose a creeping and then a fixed condition to have intervened between the ancestral condition represented by the larva and the modern condition, we can find at least a suggestion as to the cause of the loss of bilateral symmetry. It is too often hastily assumed that bilateral symmetry is something fundamental in the organisation of animals; or again that it is one of two equally probable alternatives, viz. symmetry and asymmetry, whereas bilateral symmetry is really only one out of an innumerable number of possible alternatives. As Roux has justly pointed out the wonder is not that animals should be asymmetrical but that they should be symmetrical, and the persistent bilateral symmetry can be best explained by pointing to its functional importance for free-swimming animals which pursue a definite direction. It is significant that one of the first signs of the unhealthiness of an Echinoderm larva is the absorption of some of the arms of one side, thus producing marked asymmetry.

The moment that a fixed stage is acquired bilateral symmetry ceases to be of importance, whereas a radial arrangement of the external organs is of advantage. Any tendency to inequality in the hydrocoeles would be taken advantage of to produce this result, and the predominance of the left hydrocoele need no more surprise us than the existence of one genital duct in Cephalopods or of one ovary in the fowl.

To some one result of the above considerations will be unwelcome, namely that the Echinoderm stem is cloven into two at the very base, and that from the inception of the fixed stage on, the Crinoids have pursued a different path to that of other Echinoderms.

I can only say that the embryological evidence appears to me to be quite unequivocal on this point, and that the utter hopelessness of attempting (even from the stand-point of comparative anatomy) to homologize the aboral poles of Asterids and Crinoids has already impressed itself on competent palaeontologists such as F. Bather.

An explanation of this extraordinary difference may perhaps, like that of many other zoological divergences, be found in the fact that the Asterid and Crinoid stocks have adopted two different plans of meeting the same difficulty. The study of the development of sessile forms such as Cirripedes and Ascidians seems to show that one of the first problems which a newly fixed form had to contend with, was that of bringing the mouth into a favourable position for catching food. Like the Cirripede and Ascidian the Crinoid rotates the mouth backwards and upwards; the Asterid on the other hand rotates it on to the left side whilst a distinct ventral flexure of the disc on the stalk takes place. In all cases of development where the larval mouth is continuously transformed into the adult one a movement to the left takes place. 
The fact that a fixed stage occurs only in Asterids need excite no surprise. A review of any series of larvae will show that in the development of the more modified forms there is a constant tendency to shorten life history by dropping out intermediate stages. I need only mention as an instance the complete loss of the Mysis stage in the development of Crabs. In Ophiurids and Echinids the larval mode of life is kept until the last moment, and when the internal changes are complete it is suddenly given up and the adult mode of life assumed. A development like this, comparable only to the sudden breaking forth of the imago from the chrysalis, cannot be taken as a basis for phylogenetic reasoning; the slow continuous Asterid development not only serves to connect the adult and larval modes of life but shows the essential points of agreement and disagreement with the Crinoids.

Holothurid development has been regarded by some as primitive, but even putting aside the fact that in the Auricularia internal asymmetry is pushed back to a very early stage, the researches of Bury have shown that the mouth does not as was supposed retain its larval position, and that the metamorphosis is almost as sudden as in the case of Echinids and Ophiurids, so that here also we have every mark of a secondarily modified development.

Mr MASTERMAN pointed out that some pelagic larvae of the Echinodermata have a dorsal thickening of the pharyngeal wall agreeing both functionally and histologically with the notochord of the early Chordata, with which it is to be homologised.

Sir Herbert Maxwell, Bart., read the following paper on :

"Recent Legislation on the Protection of Wild Birds in Great Britain."

In offering some observations on recent legislation for the protection of desirable or rare species of wild birds in the United Kingdom, I feel that the only grounds on which this subject may be considered worthy of your attention are strictly either ornithological or economical. It must be the object of every ornithologist to prevent the native species of any country being rendered excessively rare, or brought within danger of extinction, and the whole community is interested in the preservation of those birds which act as the natural check on injurious insects or other animals; but beyond that I cannot go on this occasion, and I must leave altogether on one side those humanitarian and sentimental considerations, which have so powerfully assisted in promoting legislative action.

It is inevitable that wild creatures should suffer from the encroachment of a civilised and rapidly-increasing population upon their haunts, and the avifauna of the British Isles has already lost some interesting species for ever. The great auk, the black tern, 
the avocet, the black-tailed godwit, the bittern, the great bustard, and Savi's warbler must be reckoned extinct as breeding species; the first-named has ceased to cxist anywhere; the rest are known to us only as vagrant individuals, almost invariably shot as soon as their presence is detected, to be added to some private collection or local museum. Other species, once very plentiful, have been reduced to the verge of extermination, partly by the drainage of their native swamps, partly by that rigour of game preservation which has caused all birds of prey to be entered in the black list, and, lastly, in the case of the ruff and reeve, by the diligence with which they have been persecuted at all seasons because of their edible qualities. In only one instance has the attempt to reestablish a lost species been rewarded with success, that, namely, of the capercaillie in Scottish woods.

In one respect, Great Britain has shown itself more hospitable to its native birds than has almost any other European land. It has never become the fashion with us to shoot or capture many species of small birds which are eagerly sought for on the Continent for the table: and the destruction of birds of prey in this country in the process of game preservation has tended to maintain an abundant stock of song birds. So general has been the destruction of small birds in parts of Europe, notably in France, parts of Germany, and Italy, that agriculture and horticulture have suffered seriously owing to the consequent increase of injurious insects and land molluscs. In I 895 the French Government invited all European Governments to send delegates to an International Congress, to consider the question of concerted action for the purpose of protecting birds useful to agriculture. M. Méline, the late Prime Minister of France, acted as President of the Conference, at which every European State, except Turkey and some of the Danubian Principalities, was represented, Mr Howard Saunders, Mr F. D. Harford of the British Embassy in Paris, and mysclf having been appointed delegates by Her Majesty's Government. The proceedings were exceedingly earnest and harmonious, and resulted in a series of very strong recommendations. It was gratifying to the British delegates to know that the principles of these regulations (except as regards prohibition of the importation of birds killed in other countries) had already practically been carried into effect in this country by the Wild Birds Protection Act of ISSo, followed by the amending Acts of I 894 and I 896 .

I have said except as regards the prohibition of importation of birds killed in other countries during whatever close time may be provided in those countries. That was a point strongly pressed during the Conference by certain continental members thereof. It is little use, say the authorities in Holland, for us to prohibit the sale of such useful species as, say, the lapwing, if you in England allow lapwings shot in Holland during the close time to be exposed for sale in England. It is quite true that bird protection, owing to 
the migratory habits of nearly every species of bird, if it is to be effective, must be international. I have mentioned the lapwing as an example of a useful bird. It is indefatigable in devouring grubs, molluscs and insects which, if unmolested, would make very short work of our crops. We reward it by gathering every egg we can lay our fingers on, and, as if that were not enough, the practice of shooting and eating green plovers is increasing rapidly. It is the only wild bird of which we in Great Britain both kill the parents and take the eggs for food. Really, if lapwings were hurtful vermin, instead of a beautiful graceful bird and a valuable agricultural police, we could hardly have devised surer means for its extinction.

Now do not understand me to advocate prohibition of taking plovers' eggs. Far from it. They are a palatable and nutritious diet, and their collection creates quite a valuable little industry in rural districts. But I do say that if it is desirable (and every farmer knows that it is desirable) to keep a good stock of lapwings in our land, County Councils ought to put in effect the powers with which they have been invested, and absolutely prohibit the killing of these birds between Ist February and ist October.

In addition to this, I think measures should be taken to prohibit the importation of species protected in other countries during the months of close time in those countries-and this in our own interests. The lapwing is a good case in point, because it is fairly numerous at all seasons in most parts of these islands. Most people, those I mean who have made no particular study of birds and their ways, assume, because they see lapwings on our coast or in our fields at all seasons, that the lapwings they see there in December are the same that were bred there in May. I need not detain you by showing that such a belief is quite erroneous : you know it as well as I do; but I may borrow from Mr Abel Chapman an illustration to show how erroneous it is. Take the map of Europe: during spring and summer the lapwing population occupies a position somewhat approaching to this :-

As winter draws near the whole body of lapwings moves southward, and not a single pewit is to be found in these islands north of a line drawn across the county of Caithness. Hence, although there are lapwings all the year round in any given spot in the British Isles south of that line-say at Cambridge-the birds that feed there in winter were bred far away to the north, and those that were bred at Cambridge are away in the south of Europe. Hence it is clear that if lapwings are to be protected effectively it must be done by international concert. If we in Great Britain destroy all the eggs in spring, we are diminishing the winter stock to the south of our latitude: if we shoot and net indiscriminately during winter, we are diminishing the spring and summer stock to the north of our latitude. Lying as we do in the mean centre of the annual migration, we may perhaps be the last to suffer diminution our- 
selves, but we are acting injuriously to our neighbours, and, in time, cannot but come to suffer loss ourselves.

I have taken the lapwing as a typical example of a migratory, insectivorous bird, but the same considerations apply to the preservation of other species. I daresay you have seen complaints in the Times about the scarcity of swallows in some districts. I cannot say I have observed it myself, but it is said that very large numbers of these and other small birds are netted on alighting on the shores of the Mediterranean. Bird-catchers there have a peculiarly hateful way of attracting birds to their nets. They thrust red-hot needles into the eyes of living birds and then set them as lures to the passing flocks. Birds thus deprived of sight generally die, but those that survive acquire a peculiarly plaintive note, which seems irresistible to their kindred, and these, settling in large numbers round them, are taken in nets and sent to market. It is obvious that people on the Italian and French shores of the Mediterranean thus intercepting the spring flights of migrants are depriving more northern lands of their full supply of beneficiai visitors.

This shows how necessary is international action in any scheme for the preservation of desirable species of birds.

I shall now very briefly indicate how the British legislature has interfered to protect birds other than game.

\section{SUMMARY OF THE ACTS.}

Wild Birds Protection (Principal) Act, 1880 (43 \& 44 Vict. c. 35).

(1) Shooting or snaring all wild birds during a particular period (close time) is prohibited, and in the case of certain wild birds, named in the Schedule, special and fuller protection is granted.

(2) Offering for sale, after March $15^{\text {th }}$, any wild bird recently killed or taken is prohibited.

(3) Provision is made for the extension or variation of the close time.

Wild Birds Protection Act, I88I (4t \& 45 Vict. c. 51).

(I) Amends the law as to the offering for sale in respect of wild birds killed abroad.

(2) Adds the Lark to the Schedule.

Wild Birds Protection Act, I894 (57 \& 58 Vict. c. 24).

(I) Enables orders to be made, on the application of County Councils, to prohibit the taking or destroying of the eggs of certain wild birds, and of the eggs of any wild bird in particular breeding areas.

(2) Enables orders to be made to add further species of wild birds to the Schedule.

Wild Birds Protection Act, 1896 (59 \& 6o Vict. c. 56).

(1) Enables orders to be made to prohibit the taking or killing of any wild bird beyond the breeding period (or close time), and orders prohibiting the taking, \&c., of all wild birds, in particular places, during the period to which the Act of I 880 does not extend.

(2) Enables application to be made by the Council of a County Borough to prohibit the taking of eggs, and to add birds to the Schedule. 
(3) Gives power to forfeit traps, nets, snares, decoy birds, \&c., on conviction, in addition to any penalty, under any of these Acts.

These four Acts are to be read as one, and may be quoted as the Wild Birds Protection Acts, I880-1 896.

\section{PROTECTION OF WILD BIRDS.}

OfFENCES :-Any Wild Bird. During the close time:

(a) Any person (other than the owner or occupiers of any land or his authorized agent on such land) is guilty of an offence who shall knowingly and wilfully shoot, or attempt to shoot any wild bird;

(b) Or who shall use any boat for the purpose of shooting, or causing to be shot, any wild bird;

(c) Or who shall use any lime, trap, snare, net, or other instrument for the purpose of taking any wild bird ;

(d) Or who shall, after March 15 th, offer or expose for sale or have in his possession or control, any wild bird recently killed or taken.

OfFENCES:-Scheduled Wild Birds. During close time, or the further period which may be fixed under the Act of I896, it is an offence for any person, including the owner or occupier of land and his agent, to commit any of the acts enumerated in respect of "any wild bird."

The penalties are to be recovered under the Summary Jurisdiction Acts, and all informations must be laid within six months.

A special Act was passed in I 888 with reference to the Sandgrouse ( 51 \& 52 Vict. C. 55), under which any person who shall kill, wound or take or expose or offer for sale any Sandgrouse, killed or taken in the United Kingdom, shall be liable, on conviction, to a penalty of $\mathcal{E}_{\mathrm{I}}$ for every bird.

\section{III. "SCHEDULED BIRDS."}

The original list of about one hundred birds appears in the Schedule to the Act of 1880 , but power has been given under the Act of 1894 for orders to be made so that other birds may have the special protection "as if such species were included in the Schedule to the Act."

\section{CLOSE TIME.}

By the Act of I 880 the close time for scheduled birds was fixed as between Ist March and Ist August in each year. Power, however, was granted to vary the close time locally, and this varies in different districts between the maximum of February Ist to October ist, and the minimum (Essex) March I 5 th to August 1st.

Under the Act of 1896 the following further period has been granted for Middlesex, viz., October Ist to February ist, for forty-seven birds, many of whom are migrants. This in effect gives protection to these birds all the year round.

\section{PROTECTION OF EGGS.}

Applications may be made by County Councils to the Secretary of State for an order to prohibit

(I) The taking or destroying of wild birds' eggs in any specified place or places ;

(2) The taking or destroying the eggs of any specified kind of wild bird within a county, or county borough or any specified place.

It is incumbent on the Council applying to specify

(a) The limits of the place or places or otherwise ; 
(b) The particular species of wild birds to which the prohibit is to apply; and

(c) The reason on account of which the application is made.

\section{BREEDING AREAS.}

Orders may be issued by the Secretary of State on the application of a County Council, defining specified areas within which the taking or destroying the eggs of any wild bird is prohibited. Various areas have been thus protected, such as Holy Island in Northumberland, and part of the Island of Sheppey in Kent.

Any person may take up the duty of preventing disobedience to the Acts and Orders, and help in obtaining convictions for any offences.

There remains now to be considered what effect all this legislation has had upon the stock of British Wild Birds.

The Acts are left in large measure to the discretion of County Councils, and these have shown a satisfactory degree of activity in adopting the optional powers committed to them. No doubt the original Act of I880, which is universal and compulsory as regards scheduled species, has had a distinct effect. A notable local increase has taken place in some species, especially, I think, in gulls and shore birds, while the breeding range of others, such as pochards, tufted duck, turtle-doves, and great crested grebes, seems to be steadily increasing.

As to the more recent Acts, sufficient time has scarcely elapsed to allow of an estimate being formed of the extent of their effect. There has been some want of uniformity in their admimistration, which will probably be remedied by further experience.

I know that high authorities are divided in opinion as to the usefulness of prohibiting taking the eggs of certain species, owing to variability in the eggs of different individuals of the same species, and also of the close resemblance of the eggs of certain species to those of other species. But all agree, I think, that advantage is sure to follow the adoption of that power contained in the Act of I896-namely, the power to prohibit all egg-taking whatever within limited and strictly defined areas, frequented by birds which it is desirable to protect.

Any notice of what has been done to protect British wild birds would be incomplete without some reference to the work and objects of the Society for the Protection of Birds, under the Presidency of the Duchess of Portland. Although I have been appointed to represent that Society at this Conference, I can take very little credit for diligence in the actual work of the Society. I can therefore speak of the great discretion shown by the Society in avoiding ultra-humanitarianism, and its constant activity, under guidance of the indefatigable secretary, Mrs Lemon, in the diffusion of knowledge and the attraction of intelligent and discriminating sympathy by means of lectures, pamphlets, leaflets, etc. 
The fact is there is lots of sympathy, but a very limited stock of popular understanding on the subject. Everybody loves song-birds ; nightingales and thrushes have plenty of friends; but our ignorance of the true nature of a bird sometimes leads to its receiving a misleading and injurious name. Take the night-jar (Caprimulgus) as an example. Caprimulgus, the scientific (!) name of this bird, perpetuates a libel as old as classical times, that this bird sucked the milk of goats and cattle. That was scarcely likely to win it favour at the hands of dairymen-every cowherd and goatherd thought it to be his duty to destroy these beautiful birds by every means in his power. Well, that lie lived for thousands of years and died very hard, if indeed it is dead in all country districts. But its place has been taken by another. When we became too intelligent to call the Caprimulgzus "goat-sucker" in plain English, we took to calling it night-hawk, because its flight and figure bear some resemblance to a hawk, and fern-owl because it has soft noiseless feathers like an owl. Well, these names were in turn fatal to the poor night-jar, because when game-preserving grew into fashion, all hawks and owls alike were condemned to death by the gamekeeper. I need hardly say that all these bad names given to the night-jar with such fatal effect were utterly unjust, and applied in profound ignorance of the bird's real habits. The night-jar was called goatsucker, because of his habit of flying round cattle and goats, even under their bellies, in pursuit of flies: he was called fern-owl because he flies noiselessly by night: he was called night-hawk because he hawks diligently after insects, but it would have been as sensible to accuse him of house-breaking or high treason as to suspect him of any of the crimes of which he has been accused and for which he has been so cruelly punished. The fact is he is one of the best friends the farmer and gardener have, living chiefly on moths (the parents of caterpillars), on chafers (the parents of the destructive wire-worm), and on daddy-long-legs (the parent of the not less hurtful leather-grub, or pout as we call it in the north).

It is the object of the Society for the Protection of Birds to disseminate sound information on the habits and functions of useful birds, and I desire to commend that Society to your most favourable consideration.

After some remarks by Canon Tristram, Mr Howard SaUnders pointed out the futility of legislation against killing such species as the lapwing, ruff and reeve, so long as the birds were allowed to be sold in the open market under the pretext that they were imported from abroad.

He considered that woodcock and other Limicolæ should be protected from Ist February onward; and he testified to the great increase in the number of several species of ducks as breeders in this country, owing to recent legislation. 
The PREsident said they were much obliged to Sir Herbert Maxwell both for his paper and for what he had done in Parliament. The so-called egrets to which Canon Tristram had referred, were used not only by ladies but formed part of the head-dress of certain regiments. He was glad to say that the Government had promised to put an end to this and to employ some other decoration.

Mr J. A. Harvie-Brown made a communication on A Correct Colour Code, or Sortation Code in Colours, to serve for Mapping the Zoogeographical Regions and Snb-Regions of the IVorld, and also to be of use as an Eye-Index for Librarians.

After discussing the well-known divisions proposed or adopted by Sclater, Wallace, Heilprin, Allen and Beddard, he gives his reasons for accepting the following:-

\author{
I. Arctic Realm. \\ Palæarctic Region. \\ Nearctic Region. \\ Neotropical Region. \\ Ethiopian Region. \\ Oriental Region. \\ Australasian Region. \\ 2. Antarctic Realm.
}

The author then recommends the adoption of an International Colour-Code for Zoogeographical purposes (Maps \&c.), and especially as an Eye-Index for facilitating References to the shelves of a Library. He discusses Werner's 'Nomenclature of Colours,' Ridgway's work with a similar title, and Saccardo's 'Chromotaxia seu Nomenclator Colorum,' and practically he adopts and Anglicises the last, while further adopting the principal colours of Hay's 'Nomenclature.' In so doing, he does not ignore the contributions of Möbius, Camerano, Beddard and others.

The Primary Code-Colours stand as :

I. Arctic Realm

2. Antarctic Realm

3. Palæarctic Region

4. Nearctic Region

White $\begin{cases}\text { Sub-Region } & \text { Circumpolar. } \\ \text { Old World } & \text { Red label. } \\ \text { New World } & \text { Brown } "\end{cases}$

Grey Is. of S., except Falklands.

Red $\begin{cases}\text { European } & \text { White } \\ \text { Siberian } & \text { Grey }, \\ \text { Cisatlantean } & \text { Black ", } \\ \text { Manchurian } & \text { Yellow ", } \\ \text { Japanese } & \text { Green ", } \\ \text { Tartarian } & \text { Brown ", } \\ \text { Persian } & \text { Blue }\end{cases}$

Russet
Brown Canadian , Red 
SECTION A. GENERAL ZOOLOGY.
5. Neotropical Region

Blue $\left\{\begin{array}{l}\text { Antillean } \\ \text { Transpanamania } \\ \text { Andean } \\ \text { Amazonian } \\ \text { S. Brazil } \\ \text { Patagonian }\end{array}\right.$
Red label.
Brown "
White "
Orange "
Yellow ",

Patagonian Grey ,"

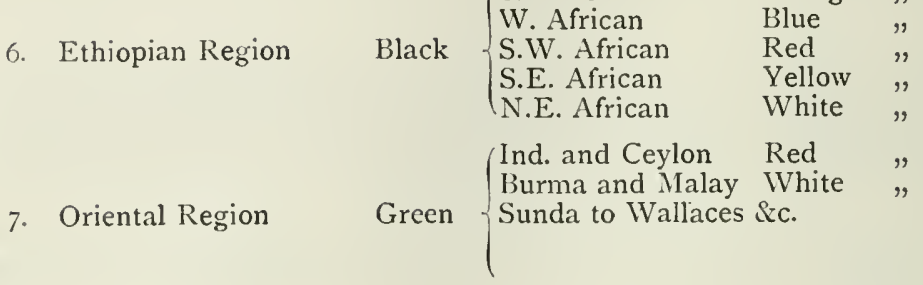
8. Australasian Region Yellow
$\begin{array}{l}\text { 9. Madagascarian or Mala- } \\ \text { gasy Sub-Region }\end{array}$ Purple $\}$ may be grafted on Ethiopian Black. The Author.

The author proceeds to describe the materials suitable for binding, and the colours (specimens exhibited); gives list of manufacturers and cartographers, who have supplied the materials in agreement with the code; and points out that the colour-code can be applied to the edges of book-shelves or on plates where it is not desirable to alter bindings. 


\title{
SECTION B. VERTEBRATA.
}

\author{
Tuesday, 23 August, at the Cavendish Laboratory, \\ at 2 p.m.
}

Chairman, DR JENTINK.

Secretary, DR Gadow; Assistant Secretary, E. J. BlES.

\section{SUR les Animaux Éteints de MAdagascak par M. A. MILNE-EDWARDS.}

M. le Professeur A. Milne-Edwards rend compte des découvertes faites récemment à Madagascar par M. Bastard et par M. Guillaume Grandidier. Le premier a trouvé à Antsirabé de nombreux ossements appartenants à des espèces disparues, parmi lesquels presque tout le squelette du grand palmipède décrit par M. Andrews sous le nom de Centromis Forsythi. L'étude de ces os montre que le Centrornis avait de grandes affinités avec un Anséride Australien: l'Anseranas melanoleuca. C'est donc un lien entre la faune de Madagascar et celle des terres australes.

M. Guillaume Grandidier a découvert dans la partie Sud-Ouest de l'île, près de Mouroundava, des gisements où abondent les grands Æpyornis ( $E$. ingens). Il a exhumé deux pattes entières pourvues de toutes leurs phalanges et indiquant l'absence complète du doigt postérieur. Le pied n'est pas approprié à la natation, comme on aurait pu le supposer en trouvant toujours les ossements de ces grands oiseaux mêlés à ceux des Hippopotames, des Tortues et des Crocodiles.

Prof. NewTON did not entirely agree with the conclusions arrived at by Prof. Milne-Edwards, especially concerning the supposed close relationship between the fauna of Madagascar with that of the Australian and New Zealand regions.

Mr IV. T. BLANFORD likewise insisted upon the isolated nature of the fauna of Madasascar. 
The Value of Type Specinens and Importance of their Preservation. By Professor O. C. Marsh.

In the present state of Natural Science, there are too many obstacles in the path of the original investigator. That this is the case in the study of Botany, we may well believe, as authorities of that Science have frequently placed the fact on record. It is certainly true that everyone who does original work in systematic Zoology, either among the living or extinct forms, meets many difficulties at the start in endeavouring to ascertain what others have done before him. The literature of the subject is often discouraging from its extent, and especially from its uncertainty. If the work in hand requires the comparison of type specimens, the difficulties greatly increase, and often prevent definite conclusions. The type will frequently be found the most important element in the problem, far more so than the literature, however extensive. This is more especially true among the extinct vertebrates, with which the present communication mainly deals.

\section{(1) The Value of Type Specimens.}

The value of a type depends first of all upon whether it is a characteristic specimen, worthy of being the representative of a new group of individuals. Without this distinctive quality, its importance is greatly diminished. If, for example, the specimen first described is immature, its essential features may thus be obscured, and its value as a type much diminished. On the other hand, a very old animal may be uncharacteristic. The teeth of a mammal, for instance, may be worn down or even lost, so as to make the normal dentition uncertain. This is true of recent forms, but is more important if the type belongs to an extinct fauna, as then the chance of duplicating it is much less.

The value of a type specimen again may depend largely upon its completeness. Among the invertebrates, especially those now living, types are usually complete enough to shew the more important features. This, however, is far from being the case among extinct forms, particularly from the older formations, and the records of Paleontology are burdened with the names of many fragmentary fossils, types of species practically unknown.

Among the vertebrates of the past, the case is much more serious, and here especially reform in methods is a pressing necessity. From the nature of the case, the older extinct forms are usually represented by fragmentary remains, the investigation of which is one of the most difficult problems offered to natural science. A single tooth or a vertebra may be the first specimen brought to light in a new region, and thus become the sole representative of a supposed new form. The next explorer may find more perfect fragments of the same or similar forms, and add new 
names to the category. A third investigator, with better opportunities and more knowledge, may perhaps secure entire skulls or even skeletons from the same horizon, and thus lay a sure foundation for a knowledge of the fauna.

As the number of described forms increases, the necessity of a direct comparison of types becomes imperative, and the comparative value of each type specimen is thus brought into notice. It will then frequently be found that not a few are uncharacteristic, while others are too incomplete to disclose their own essential features, and hence of little aid in indicating the affinities of forms found with them.

Type specimens that do not shew characteristic features are, of course, of little value to science, and many such prove a delusion and a snare to the investigator, however faithfully he may endeavour to study them. The imperfect types require still more labour to decipher them. Not a few specimens to-day are types, for the simple reason that they are imperfect. If they had been entire when described, their true nature would have been recognized, and much confusion in nomenclature have been avoided. The chance preservation of some marked features may, indeed, give a hint as to what the whole specimen once was, but too often a suggestion only is thus offered, while the real nature of such types must always remain in doubt.

A type in Paleontology should consist of the remains of a single individual, and this should stand as the original representative of the name given. A second specimen, or even more, may be used later to supplement the first, but not to supplant it. This substitution, however, has been made by some authors, with the natural result of causing endless confusion in the nomenclature.

\section{The Selection of Type Specimens.}

The descriptions in Paleontology are too often descriptive only, and not comparative. Such work, if well done, is preferable to academic discussions in regard to the affinities of a specimen of which the main characters are not known, or not placed on record. A vertebra of a reptile, or the tooth of a mammal, if perfect and characteristic, may form a type that will be distinctive enough for the present requirements of the investigator. What the future may demand, will depend upon the advance of knowledge in that branch of science.

In the choice of specimens worthy of being types, I can only suggest a course that seems to me the proper one. I believe experience has already shown that to make types of incomplete or uncharacteristic specimens is seldom of permanent advantage to an author, and almost always a lasting injury to the branch of science he represents. There are more good specimens waiting to be found than any naturalist can possibly describe, and one such specimen is worth many of inferior grade. 
I may perhaps be permitted to mention, in this connection, my own experience in the matter of type specimens. As a student in Germany, years ago, I had my attention called particularly to this subject, and was then strongly impressed with the importance of using only good specimens for first descriptions. This rule I have endeavoured to follow. My researches, especially in western North America, have resulted in the discovery of more than one thousand new species of extinct vertebrates, and of these I have described about five hundred. Had I been satisfied to use inferior specimens as types, I might have increased the number by one-half at least.

No small part of the present literature of the paleontology of vertebrates is based on names applied to fragments, and a long period of more accurate work will be required before these can be rejected or incorporated into the digested knowledge of the subject. I recall one collection of types of extinct vertebrates, described in a single volume, and nearly a hundred in number, the greater part of which are uncharacteristic fragments, well fitted to burden science for all time with a legacy of uncertainty and doubt. Such work is a positive discouragement to all future investigators in the same field, and its value to science may well be questioned.

The necessity of greater care in selecting type specimens, in Paleontology, at least, needs no argument to any student of the science who has done sufficient original work to appreciate the increasing difficulties of accurate investigation. To those who have had less experience, a word of warning, I trust, will not be in vain.

\section{(2) The Preservation of Type Specimens.}

The careful preservation of their own type specimens is a sacred duty on the part of all original investigators, and hardly less so of those who are the custodians of such invaluable evidence of the progress of natural science.

Local museums, as a rule, are less desirable repositories of type specimens than private collections, since the former usually can have little chance of permanent care, while the latter, if important, may, perhaps, by gift or purchase, become part of a large endowed museum, where those in control are more likely to appreciate the importance of types, and carefully preserve them.

For the preservation of type specimens, fire-proof buildings are indispensable. I recall no less than five Museums of Natural History, in America, that have either been destroyed, or their contents consumed, or seriously damaged by fire, since I became actively interested in natural science. Several others, in the meantime, have had narrow escapes from the same danger, so that I regard all type specimens as insecure that are not preserved in buildings practically safe from fire.

Another danger to which type specimens are subject, is loss or injury during transit, when loaned or otherwise sent away from their regular place of deposit. This evil has become so serious, 
that some museum authorities do not permit type specimens to leave the building. This I regard as a wise regulation, and it is now in force at New Haven, and various other scientific centres.

If a type specimen is important, the investigator will come to the type. I once made a long pilgrimage to a famous university town, mainly to see a single bone, the "tibia" of an extinct reptile, according to the description, and the type of a new genus. I found the bone in good custody, and well preserved. It was not a tibia, however, but a radius, and this fact changed the classification based upon it. Had that bone been lost or destroyed, a new animal of strange proportions might have existed on the records of Paleontology, if not in Nature. That bone fortunately is still preserved, a witness whose testimony is conclusive.

When fossil skeletons are discovered in position, the best methods of preservation, especially of types, require the retention as nearly as possible of the bones as found. One fore and one hind foot, at least, should always be kept in the rock, and all impressions in the matrix carefully preserved.

The importance of indelibly marking type specimens, and the separate parts of each, so that all may be studied essentially as found, is also evident. If a type is restored with plaster or other substance, the limits of each should not be so obscured that investigators cannot distinguish them. These are not imaginary precautions. Cases of the kind mentioned are not uncommon in vertebrate paleontology, as every worker knows. One well-known skull, with portions now preserved in two museums, is restored in one of them, as an original, and is thus misleading.

Type specimens preserved from other dangers may be injured unintentionally. Among the rare specimens damaged by zealous but unskilful hands in the house of their friends, three of the most important to Paleontology, a reptile, a bird, and a mammal, are well-known examples, and not a few others both in this country and America might be mentioned if it were proper to do so on this occasion. Such lack of intelligent custody of types will make the work of future investigators much more difficult.

An indirect way of preserving type specimens is by means of casts. These, if accurately made, may be of much service, and, in fact, an insurance on the original specimen. They may often save an investigator a long journey, and in case the type itself is lost or destroyed, the copy may prove of great value in indicating what the name was intended to cover.

Another indirect means of protecting type specimens would be to publish catalogues of them, giving the places where they are preserved. Such a list of a single group would be of great service to anyone investigating it, and could be renewed from time to time whenever necessary. It would be well if everyone who described a species also stated where the type was deposited. In time this would become the established usage, and thus greatly 
facilitate the preparation of catalogues of types and their places of preservation.

Paleontology has been called an exact science, but its records up to the present time do not bear out this statement. If, as I believe, it will yet be worthy of such a distinction, one means of its advancement will be for those who represent it to select better type specimens, and preserve them more carefully.

In all branches of Natural Science, type specimens are the lights that mark the present boundaries of knowledge. They should be, therefore, not will-o'-the-wvisps, leading unwary votaries of science astray, but fixed beacon lights to guide and encourage investigators in their search for new truth.

\section{A SHORT DEMONSTRATION ON THE "URODELEN DER Alten Welt."}

\section{By Dr Wolterstorff.}

An exhibition of a series of water-colour drawings of Urodeles iliustrative of a comprehensive work by Dr Wolterstorff, which will appear in the Bibliotheca Zoologica.

The author wished to enlist the sympathy of zoologists, he being especially desirous of living, or well preserved specimens of Urodeles from Southern Europe and Eastern Asia. No remarks.

\section{On Reptilian Affinities in the Temporal REGION OF THE MONOTREME-SKULL.}

\section{By Dr J. F. Van Bemmelen.}

When inspecting the skull of Monotremes, and comparing it to that of Reptiles, with a view to discover Sauropsidan affinities, my attention was immediately drawn by the fact that the temporal region, both in Ornithorhynchus and in Echidna, is pierced by a canal from before backwards, just over the glenoid cavity for the under-jaw. This canal reminded me vividly of the passage between quadrate and quadratojugal in Sphenodon, and still more of the perforation in (or rather covered by) the squamosum of the Anomodont Ptychognathus declivis (Zittel, Handb. der Palacont. p. 358). In vain I looked through the recent literature about Monotremes, I could not even trace a simple mentioning of the peculiar structure in question, much less any comparison of it to corresponding arrangements in Reptilian skulls. Quite the contrary : in Gegenbaur's recently-published Manual of the Comparative Anatomy of Vertebrates I met with the following passage:

"In its outer formation, the cartilaginous (Mammalian) skull possesses relations to that of Amphibia, and partly also to Reptiles (Tortoises) in so far as only one bony bar occurs: the infra-orbital. Though further differentiations are developed from this bar at the 
surface, these may be attributed to secondary processes, and no system of bars, like that of Rhynchocephalians and other Reptiles, is derived from them. The quadrate having changed its function" (having become, after Gegenbaur's opinion, the incus), "the zygomatic bar starts from the squamosum, and in this structure the last remnant of the lateral osseous belt of the head, that sprung up in fishes, makes its appearance."

It was only on the day before my departure for the congress at Cambridge that I became acquainted with a short note of Prof. Seeley, published two years ago in the Proceedings of the Royal Society for 1896 and reprinted in the Amuls and Magasine of Natural History, Ser. 6, Vol. xvii., No. 98, p. I 83 , and entitled: "On the complete skeleton of an Anomodont Reptile (Aristodesmus ritimeyeri, Wiedersheim) from the Bunter Sandstone of Reihen, near Basel, giving new evidence of the relation of the Anomodontia to the Monotremata." This note ends with the following conclusion :

"The author argues that the points of structure are so few in which Monotreme Mammals make a closer approximation to the higher Mammals than is seen in this fossil and other Anomodontia that the Monotreme resemblances to fossil Reptiles become increased in importance. He believes that a group Theropsida might be made to include Monotremata and Anomodontia, the principal differences (other than those of the skull) being that Monotremes preserve the marsupial bones, the atlas vertebra, and certain cranial sutures. Ornithorhynchus shows prefrontal and postfrontal bones, and has the molar arch formed as in Anomodonts."

As however till the present moment the publication of this note has not yet been followed by that of the paper in full, and therefore this important feature in the Monotreme skull has generally remained unnoticed in the scientific world, I deemed it very desirable to bring my observations before the audience of this congress. In doing so, I am happy to meet with Mr Seeley's kind approval, and of course fully acknowledge his priority as well in the observation of the fact as in the interpretation of its possible phylogenetic value.

In connection with this observation, three questions arise, pointing to three different lines of investigation, which must necessarily. be worked out, before coming to any final conclusion concerning the real importance of the perforation in the temporal region and its bearing on phylogenetic questions.

In the first place it is absolutely necessary to come to a clear and unequivocal understanding as to the exact homologies and the best nomenclature of the bones composing the temporal region and surrounding the canal in question.

Secondly, it is desirable to get a full knowledge of the soft parts that occupy this canal, and thirdly to search for similar passages in the temporal region of other animals, especially Mammals. 
I hope soon to be able to make a clear and satisfactory statement about these questions; for the present I would confine myself to pointing out the considerable difference of opinion as to the real names that must be applied to these bones, and especially about the true nature of the bone that forms the outer boundary of the temporal perforation. This bone is now generally taken to be the squamosum, a view which was already held by Owen and Köstlin, but which forcibly leads to the conclusion that a jugal (malar) bone is wholly absent, and furthermore involves the diffculty to find an explanation for the large squamous upward extension of the petrous bone, which occurs on the inner side of this so-called squamosum and excludes it from the walls of the braincavity. By Owen this upper prolongation of the petrous bone is called the mastoid; Köstlin takes it to be a posterior temporal ala of the sphenoid. Assuredly its position shows much resemblance to the mastoid of other Mammals, but also to the opisthoticum of Testudinata. This and other questions can only be satisfactorily settled by the investigation of young stages, showing all the sutures, and by careful comparison to other Mammals and to Reptiles.

Prof. SeELey concurred with Dr van Bemmelen's views, and referred to his forthcoming paper in the Phil. Trans.

5. Mr GRAHAM KERR made some remarks on

An Exhibition illustrating the Life-history of LEPIDOSIREN (with lantern slides).

The SECRETARY remarked that these numerous and important results have been laid before the Congress within ten months of Mr Kerr's return from his expedition. 


\section{SECTION B. VERTEBRATA.}

Wednesday, 24 August, 3 p.m.

Chairman, THE President, and for papers 2-4 the Rt. Hon. Sir Herbert Maxivell, Bart., M.P.

I. QUELQUes DONNÉES SUR LE SYSTEMAE NERVEUX

DE L'AMPHIOXUS.

By Profs. Heymans and Van der Stricht.

No remarks were made.

2. Demonstration ON "Hybrids" (Horse AND ZEBRA). (With Lantern Slides.)

\section{By Prof. J. C. Ewart, F.R.S.}

Prof. Ewart exhibited slides showing photographs of Hybrids between the Horse (female) and the Burchell Zebra (male).

Hon. W. Rothschild made some remarks on a few other hybrids of the Zebra and Horse and then dilated upon certain differences between the various species of Zebras.

Dr DIXEY said that he had had the advantage of seeing Professor Ewart's actual stud, and could affirm that the points to which Prof. Ewart had drawn attention were easily recognisable in the hybrids themselves. In one respect the photographs were necessarily inadequate,-they could not show the peculiarities of gait and action which formed interesting features in the comparison of the living specimens. He wished to point out that Prof. Ewart's interpretation of the markings of some of his hybrids as reversionary, should it turn out to be well grounded, would not stand alone; for it agreed with one result of Darwin's famous experiments in the crossing of pigeons, and also with a more recent series of elaborate researches conducted by Standfuss in Zürich. The latter investigator, working with insects, had repeatedly found that the hybrid progeny of his crossings "threw back" in a manner seemingly analogous to the behaviour of Prof. Ewart's hybrid colts. This was attributed by Standfuss himself to the "prepotency of the phylogenetically older" of the two parent species. But though Standfuss did not in these cases admit reversion in so many words, it was significant that in certain instances he affirmed the occurrence of characters in his hybrids which must have belonged to an 
ancestor of the older parent species, rather than to that parent itself. Dr Dixey hoped that in due time Prof. Eivart would communicate further results of his experiments, which raised questions of great interest; as for instance that of the fertility of hybrids, and that of the alleged phenomenon of telegony.

Mr P. L. SCLATER said that in his opinion by far the most important of Prof. Ewart's experiments were those which related to telegony, and wished to know whether they had thrown any light upon the question. He then described the differences of the various species of Zebras known to him, and pointed out that hybrids sometimes resembled one of their parents and sometimes the other.

Prof. EWART replying said that he had tried to find out by his experiments what the less remote ancestors of the Zebra and Horse were like, as in the detailed pattern of the striping the hybrids resembled neither the mother nor the father.

\section{TSETSE Disease in Mammals .}

\section{By Prof. Kanthack, $\mathrm{Mr}$ Blandford, and Mr Durham.}

This paper, of which the following is an abstract, was read by Mr Durham.

\section{Abstract.}

Tsetse disease or N'gana is one of the many scourges of South Africa. Bruce discovered that the cause of the disease is a parasite. It belongs to the flagellated protozoa and to the genus Trypanosoma. According to Bruce's observation the fly merely acts as a carrier; if it feeds on the blood of an infected animal, and again feeds within two or three days upon a healthy susceptible animal, it communicates the disease. A fact of importance in the dissemination of the disease is Bruce's discovery that the fly is viviparous; the mother flies have to feed frequently in order to nourish their young. Bruce has further shown that the blood of certain of the wild animals of the "Fly districts" may contain the parasite (e.g. the Koodoo).

At the instance of the Colonial Office and the Royal Society the living parasite was brought over to this country, where a large number of experiments have been made.

The inoculation with the parasite not only gives rise to a fatal issue in the horse, ass, ox, goat, dog, and such domesticated animals, but is also fatal to mice, rats, \&c., including the hedgehog. The guineapig is able to withstand the infection for several months in some cases.

The parasite may be present in enormous numbers in the blood of the infected animal, especially in the last few days of life; in

1 A more exhaustive report on the subject will be found in the "Proceedings of the Royal Society," Nov. I 898 , under title "On Nagana or Tsetse fly disease." 
some animals, such as the rabbit, the hamatozoa are as a general rule very scarce or absent during the greater part of the course of the disease. In most animals the parasites appear intermittently for one or more days, and then disappear for a time, again to reappear.

The distribution of the disease is rather widely spread; besides South and East Africa it occurs on the Congo; the fly itself is found up to the Niger on the IVest, and from the accounts received of the way transport animals died in Lugard's expedition, it is more than probable that the disease is prevalent there.

A French observer (Rouget) has described a parasite which seems to be the same in an animal (horse) at a remount depôt in Algeria; the source of infection in this case was not known. In India there is a disease affecting horses, \&c. known by the name of Surra. From the descriptions of the Surra parasite and its pathological effects, it appears to be identical in all respects with that of N'gana or Tsetse. Surra appears to be widely spread over India in localised areas. In former years and still in certain districts it is supposed to be connected with the bite of a blood-sucking fly ; but the matter is not yet worked out.

In England and Europe generally a somewhat similar parasite is found in the blood of wild rats. It differs slightly in its appearance under the microscope from that of N'gana. It does not affect the health of the rat to any appreciable extent; moreover the attempts to inoculate dogs, guineapigs, \&c. have all proved negative.

So far we have no means of curing the disease when it has once begun, nor have we any means of preventive inoculation or salting. Some drugs like arsenic help to prolong the life of the animals, but the end is always fatal. Prof. Cossar Ewart has with the true scientific spirit allowed certain of his valuable zebra hybrids to be inoculated with the tsetse disease in order to see whether they will shew a degree of refractoriness which the zebra must possess, in that it is capable of living in the fly infested districts. It is too early to make any statement with regard to these animals, since they have only been recently inoculated; they have all shown signs of illness and the parasite has been found in their blood; whether they recover eventually must be left to the future to decide'.

$\mathrm{Mr}$ Sclater asked whether the parasite itself was found in the blood of wild animals, and Mr Stiles asked whether the disease was carried by other biting flies; the latter also made some remarks concerning the Texas fever of cattle, which is communicated by. means of ticks. A further question was as to whether man was refractory.

In reply $\mathrm{Mr}$ Durham said that the experiments of Bruce had shown that certain of the wild animals in the fly districts harboured the parasite of tsetse disease. This had been shown by inoculation

1 These all succumbed to the disease about 8 weeks after inoculation. 
experiments, and might be considered a conclusive proof, for the apparent absence of the parasite on microscopical examination did not necessarily show the complete absence of the parasite. Bruce's experience at his experimental station was that although other biting flies were constantly biting the animals, no accidental contaminations occurred, and the reason why the tsetse and no other fly carried the disease was probably on account of the fact that it is viviparous. As the mother fly has to nourish the developing larvæ within it, it is necessary for it to feed frequently and often.

All the evidence that we have in regard to the susceptibility of man is entirely negative. Man is bitten by the fly, and accidental scratches and cuts have been incurred during experimental investigation which would have been sufficient to have communicated disease had man been susceptible.

\section{Bipedal Locomotion among existing Lizards.}

\section{(With Demonstration.)}

\section{By $\operatorname{Mr}$ W. Saville-Kent, F.L.S., F.Z.S.,}

Past President and Delegate to the Congress of the Royal Society of Queensland.

Abstract. A bipedal plan of locomotion among existing lizards was first demonstrated by the author in the case of the Queensland and North Australian Frilled lizard, Chlamydosaurus kingi, brought by him to England in the year I 895 .

A further investigation of the subject by the author has shown that a similar bipedal gait is adopted, under favourable conditions, byother Australian Agamidæ,including the large Queensland Waterlizard, Physignathus Leseuri, and the Queensland Tree-lizard, Amphibolurus muricatus. It has also been found by the author to obtain, though to a much less marked degree, in the African Agamoid, Agama stellio.

The facts recorded by the author concerning the bipedal locomotion of Chlamydosaurus has elicited interesting evidence as to the possession of similar bipedal proclivities by other lizard types. Mr Henry Prestoe, long resident in the West Indies, has attested to the author to having observed it in a large number of West Indian species, chiefly Iguanidæ, but most notably in the Diamondlizard of Trinidad, Ameiva surinamensis belonging to the Teiidx family. Mr W. F. H. Rosenberg has also testified to the author to having observed small slender-limbed members of the Iguanidæ, including the young of the Basilisk, Basiliscus Americanus, run erect on their hind legs only along the surface of the water of the rivers of Columbia and Ecuador. 
Following up the evidence adduced by $\mathrm{Mr}$ Prestoe concerning the bipedal habits of the Diamond-lizard, the author has by recent experiments with the large tropical American Teguexin, Tegucxin Americanus, demonstrated that that species is also very distinctly endowed with the faculty of bipedal locomotion.

The author suggests that the manifestation of bipedal tendencies by so numerous and diversely related representatives of the lizard tribe appears to justify the assumption that the attribute has been inherited with unbroken continuity from a Reptilian race wherein bipedal locomotion constituted a yet more general and distinctive method of progression. Such a Reptilian race, with apparently predominating bipedal habits, is presented by an important section of the extinct Dinosauria.

The author supplemented his paper with the exhibition of living specimens of the Australian Water-lizard, Physignathus, and the American Teguexin, whose bipedal proclivities were practically illustrated by turning them loose in an adjacent enclosure. 


\section{SECTION B. VERTEBRATA.}

Thursdai, 25 August, at I 2 noon.

Chairman, Mr Saville-Kent.

1. Tile Scientific Experiments to test the fFfects of TRAWLING IN THE WATERS OF SCOTLAND, I 886-97.

\section{By Prof. W. C. McIntosh, F.R.S.}

The paper, of which the following is an abstract, was taken as read.

These experiments were definitely arranged for by the Royal Commission on Trawling under Lord Dalhousie, and were carried out by the Fishery Board for Scotland-by aid of the small steamvessel "Garland." Certain lines within the territorial limit of three miles, and certain lines beyond, were selected by the Fishery Board and trawled over in St Andrews Bay and the Forth for ten years, and in the Moray Frith and the Clyde for a shorter period.

The results, which are combined with other observations, are handled in a different manner from that followed by the Fishery Board. They show no gradual accumulation of fishes due to the closure. The high and low numbers follow each other in such a way as can only be explained by the irregularities and uncertainties invariably attendant on fishing-operations. The idea thatbecause the first five years of the decade had a higher average than the second five years-diminution had ensued, is shown to rest on insecure data. The divergent number of hauls of the trawl respectively made during the six winter and during the six summer months in each half of the decade demonstrates the inequality of the circumstances. The results, further, show that the mere closure of the three-mile limit has little or no effect on the fishes, invertebrates and plants of the area. The distribution of life in the ocean is on too great a scale to be affected by a measure so minute.

In regard to the individual food-fishes, no proof of the serious diminution of any is made out in these experiments. Some, such as the plaice and the haddock, show considerable variations in the captures throughout the decade. Both follow the general law of having the highest numbers in the warmer months of the year, the maximum being in August. 
Dabs in the Forth had their highest average in September, though, in a total of 4678 , August was only 62 less. The longrough dab also has its maximum in September, but the curve is less pronounced than in the plaice and the dab.

The highest average for the whiting is in October, August and September following.

The complex circumstances surrounding the problem of the food-fishes is well illustrated in the cod, which (in the Forth) differs from the foregoing in having high figures in November, December and January.

No marine species shows more clearly than the gurnard the futility of attempting to increase the supply of fishes in the open sea and its neighbourhood by the closure of the inshore area. The numbers remained at the end very much as at the beginning. The highest averages were in May and June.

Considerable importance has been attached to the alleged diminution of the lemon-dab during the second quinquennial period, and it is found that, while the total of the averages of the first five exceeded those of the second five years by seven, the disproportion between the captures in the warmer and the colder months of the two periods was marked.

The alleged diminution of the size of the fishes captured in the second period of five years is found to a great extent to be due to the fact that in the first period only 46 small fishes per haul were obtained, whereas, in the more thoroughly worked second period, 74 were procured.

The time during which the experiments were carried on would appear to be sufficient, especially when supplemented by the work of the Trawling Commission in I884, and subsequent observations.

Though the Moray Frith has not been so continuously worked, yet the observations made in 1884 , when comparatively little progress had been made in trawling, those of the "Garland" in subsequent years, and the examination of the area beyond the enclosed limit in 1898 , enable satisfactory conclusions to be drawn. So far as facts go there is no evidence that the fishing operations in and near the Moray Frith have proved detrimental to the haddock, or that the maintenance of the closure can have the support of science.

In conclusion, it would appear from the investigations of i 884 , from a minute examination of the statistics made on board the "Garland" on the east coast since I886, and from other observations, that little is to be gained in the way of increasing the numbers and size of the food-fishes by closing the inshore areas. 


\section{SECTION B. VERTEBRATA.}

FRIDAY, 26 August, at 2 I'.M.

Chairman, Prof. Newton.

I. Hæmatopoietic Processes in the Placenta.

By Prof. A. A. W. Hubrecht.

Discussion by Messrs. Sedgwick, Gadow, Bles.

Reply by Prof. Hubrecht.

Professor Hubrecht's paper is printed in full in the Appendix under the title,--" Ueber die Entwickelung der Placenta von Tarsius und Tupaja nebst Bemerkungen über deren Bedeutung als haematopoietische Organe."

2. On Pliohyrax Kruppi Osborn, a fossil Hyracoid, from Samos, Lower Pliocene, in the Stuttgart ColLECTION. A NEW TYPE, AND THE FIRST KNOWN TERTIARY Hrracoid. (With Plate 2.)

By Prof. H. F. Osborn.

In the Museum of Stuttgart is a collection from the Lower Pliocene of Samos, presented in I 895 by Herr Krupp, the wellknown manufacturer. Its most unique feature is the facial portion of the skull of the first extinct member of the order Hyracoidea known to science. This type has been mentioned by Roger and Smith Woodward ${ }^{2}$ as Hyrax Kruppii, a name provisionally assigned by Professor Eberhard Fraas in honour of the donor. During my visit to Stuttgart in July, I 898, Professor Fraas with rare generosity placed the type in my hands for description, and we agreed that it was worthy of presentation before the Zoological Congress.

It proves to be not only a new species, but a new genus, which may be termed Pliohyrax, and possibly the representative of a new family, Pliohyracidae, of the Hyracoidea, an order which has been distinguished hitherto by our total ignorance of its ancestral forms.

The skull as here shown in life-size photographs kindly taken under the direction of Professor Fraas (see Plate 2 ) is more than twice the size of the largest living Hyrax. It is further distinguished by three very important characters :

I. The elevated union of the premaxillæ anteriorly, thus elevating the anterior nares. (Compare Figs. 2 and 4.)

2. The elevated position of the orbits.

1 Verzeichniss d. bisher bekannten fossilen Säugethiere. Augsburg, 1896.

2 Vertebrate Palæontology, 1898 , p. 292. 
3. The extreme backward extension of the posterior nares by the broad union of the palatines. (See Fig. 3.)

These structures indicate decided differences in habits from those of the modern Hyrax, and so far as they go, point to an aquatic or amphibious mode of life.

The relationship of Pliohyrax to Hyrax is, however, obvious in the enlarged pair of incisor teeth and in the lophoselenodont structure of the molar teeth, which characters respectively determine its subordinal and ordinal position.

New and most interesting differences of detail are observed in the dentition :

I. In Pliohyrax the enlarged median incisors are strongly invested with enamel upon the anterior face only. The second and third incisors are both functionally present, and they are separated from the first incisor by a wide diastema, whereas in Hyrax the third incisor has disappeared and the second is a restigial tooth, found in young specimens just behind the first incisor.

2. The canine is present as an entirely unique tooth, having two fangs and a complex premolariform crown.

3. The first, second and third premolars are submolariform, with a flattened outer wall (ectoloph) and more or less complete internal crests. The anterior premolars have therefore less completely transformed into the molar pattern than in Hyrax.

4. The fourth premolar, however, has a median buttress (mesostyle) upon the outer wall (ectoloph), and is thus completely molariform. The third and fourth premolars present an inward and backward cingular extension of the protoloph (see Fig. 3) which may be a specific character.

5. The molars increase in size posteriorly, and are extended well back behind the junction of the zygomatic arch with the face. (The molar pattern can only be made out in the first superior molar of the right and left sides, in which a prominent mesostyle is seen separating the external lobes, and these are of the lophoselenodont type of Palcotherium and Hyrax.)

Pliohyrax is thus a very unique animal, quite distinct from Hyrax. It affords us a suggestion of adaptive radiation among members of the order Hyracoidea, hitherto quite unsuspected. We also derive from it a number of clues which may enable us to connect this basal Pliocene representative of the order with still older European or American types.

\section{Explanation of Plate 2.}

Pliohyrax Kruppii Osborn: Type. After photographs under direction of Professor Eberhard Fraas.

Fig. I. Side view of type in Stuttgart Museum.

Fig. 2. Front view of type.

Fig. 3. Palatal view of type.

Fig. 4. Skull of Dendrohyrax arboreus, anterior view. All figures natural size. 
3. Restoration of Extinct Vertebrates, from the AMerican Museum of Natural Histori.

\section{By Prof. H. F. Osborn.}

Several very artistic water-colour drawings purporting to be life-representations of various extinct Reptiles and Mammals were exhibited on the front table.

These restorations constitute Nos. $20-24$ of a series of watercolours executed in the American Museum of Natural History by Charles Knight. The ultimate object is to present leading types of the extinct vertebrate succession, partly for purposes of popular scientific instruction, partly as serious hypotheses relating to the external form and colouring, pose and gait, feeding habits and sexual characters. Every available source of knowledge is drawn upon to render the restorations as scientifically accurate as possible. The artist has travelled purposely to study the landscape conditions of sub-tropical climates similar to that of the North American Mesozoic and Tertiary. Extensive studies are also being made by him in the Museums and Zoological Gardens of Europe, under the advice and direction of the writer, to secure collateral information. The criticism and advice of various specialists in Zoopalæontology are also sought. It is thus hoped to give this series of restorations a permanent value and interest in the eyes of palæontologists and zoologists. The pictures now exhibited at the Congress are as follows:-

Phenacodus primavus, executed from the remounted skeleton of the famous type described by Cope.

Coryphodon testis, a pair of Amblypods of the Wasatch or Suessonian period, male and female, showing the sexual characters.

Hoplophoneus primavus, the Oligocene ancestor of the great sabre-tooth cat, Machærodus.

Teleoceras fossiger, the short-legged type of Rhinoceros, from the Upper Miocene, characterized by the presence of a small horn upon the tips of the nasals.

Camarasaums supremus, a group of great herbivorous Dinosaurs, similar if not identical with the Brontosaumus of Marsh, represented in a habitat resembling that of the St John's River, Florida, as amphibious in habit.

4. DE LA STRUCTURE SPÉCIALE DES ÉPINES CHEZ LES Apogonini ET QUelques Autres poissons ACANTHOPtérlGIENS.

\section{Par MI. Léon Vaillant.}

La constitution singulière des épines chez les Apogon et les Ambassis, dont je désire m'occuper aujourd'hui, n'est pas sans aroir été signalée, au moins iconographiquement. Dans son grand Atlas d'Ichthyologie des Indes Néerlandaises, dans différentes publications 
où il a étudié plusieurs de ces Poissons, pour lesquels, assez mal à propos, il a repris le nom d'Amia, Bleeker a nettement indiqué en effet la disposition dont il va être question.

Chez ces animaux les épines qui constituent la première nageoire dorsale, celle qui commence la seconde, celles de l'anale, celles des pectorales, sont toutes construites sur un type uniforme. Elles sont généralement fortes, plus ou moins aplaties en lame de sabre (Ambassis Wolfii), et si l'on se contente d'un examen superficiel, paraissent, à première vue, peu différentes de celles qu'on rencontre chez la plupart des Acanthoptérygiens, elles sont d'ailleurs formées histologiquement de tissu scléro-dentineux, si non de véritable dentine, comme ce paraît être la règle chez ces derniers.

Toutefois au lieu d'être homogènes dans toute leur longueur, elles sont en quelque sorte décomposables en deux portions. On trouve en premier lieu deux lames latérales (Fig. I $a$ ) réunies et
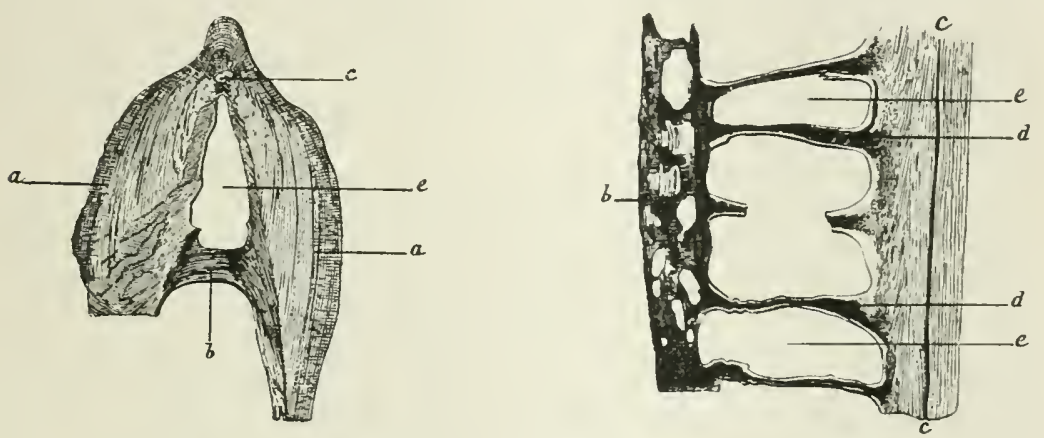

Ambassis Wolfir, Bleeker. Épine de la Nageoire dorsale.

Fig. 1. Coupe horizontale; Fig. 2. Coupe sagittale. (Gross. I+/1 environ).
a. Lames latérales.
d. Cloisons horizontales intervacuolaires.
b. Lamelles réclinées.
c. Vacuoles.

c. Canal nourricier.

continues en avant, légèrement écartées et libres sur une certaine partie de leur longueur en arrière. Sur une coupe transversale on reconnaît que ces lames résultent de la superposition d'une multitude de lamelles emboîtées; dans leur ensemble les lames donnent une figure anguleuse ayant la forme d'un $\mathrm{V}$ à ouverture postérieure. Un autre système de lamelles superposées, appuyé sur la face interne de l'une des branches du V se dirige en avant, puis se recourbe pour venir s'appliquer sur la face interne de l'autre branche (Fig. I b), formant ainsi une sorte de pont, qui limite une cavité antérieure. Cette cavité (Fig. I et $2 e$ ) pourrait au premier abord être prise comme analogue du canal nourricier connu par exemple dans l'épine de la Perche (Perca fluviatilis), mais ce canal trouve son analogue dans un petit tube (Fig. I et $2 \mathrm{c}$ ) situé au point d'union antérieur des branches du $\mathrm{V}$. 
Le grand tube limité par les lames du V et la lame en pont seraient donc en quelque sorte surajoutés à l'épine typique de la Perche. Mais ce qui est plus inattendu c'est qu'au lieu d'être continu ce tube se trouve, par des cloisons horizontales (Fig. $2 d$ ), disposées assez régulièrement, subdivisé en un grand nombre de loges superposées (Fig. $2 e$ ), lesquelles, lorsqu'on examine l'épine intacte au microscope par le côté, apparaissent en noir, étant remplies d'air ou d'un corps gazeux d'une réfringence analogue. Cette disposition, dans une comparaison grossière, rappelle assez bien la disposition connue pour la gousse cloisonnée de la Casse. C'est ce qu'on voit très fidèlement représenté dans les planches de Bleeker, auxquelles je faisais plus haut allusion.

Les cloisons sont-elles complètes ou permettent-elles une communication plus ou moins libre entre les loges successives? La seconde condition me parait la plus probable. Sur les coupes transversales de l'épine les cloisons sont anfractueuses, souvent perforées, seulement, sur les coupes longitudinales sagittales, je n'ai pu encore avec certitude constater si ces perforations intéressent directement toute l'épaisseur de la cloison. La question reste donc pour moi douteuse.

Ces épines cloisonnées ne sont pas exclusivement particulières aux Apogons et aux Ambasses; dans un Equula fasciata, Poisson du groupe des Scombéroïdes, j'ai pu reconnaitre une disposition analogue, la division de l'épine en une portion antérieure pleine et une postérieure à vacuoles horizontalement disposées les unes au-dessus des autres, paraît même encore plus nettement accusée. L'insuffisance des matériaux dont je pouvais disposer, n'a pas permis de pousser l'étude aussi loin qu'il eût été désirable. Il est possible que divers Acanthoptérygiens en fournissent d'autres exemples, l'attention une fois attirée sur cette particularité anatomique.

D'autre part, chez les Poissons fossiles du genre Smerdis d'Agassiz la structure des épines reproduit si exactement celle indiquée plus haut pour les Apogonini, que je ne vois pas comment on pourrait les en distinguer. Si on a égard à l'aspect général de ces animaux, à la disposition et à la composition de leurs nageoires, on devra regarder comme très probable qu'ils doivent prendre place dans cette tribu, il est même permis de se demander s'ils méritent d'être distingués à titre de coupe spéciale d'un des genres actuels de ce groupe. Le rapprochement a d'ailleurs déjà été indiqué par Bleeker ${ }^{1}$, qui avait saisi ces affinités morphologiques.

1 Bleeker, 1876 . Systema Percarum revisum. Arch. Néerl. Sc. exactes et naturelles, T. XI. (p. 14 du Tirage à part). 


\section{ZUR ENTWICKLUNGSGESCIICHTE DES ICHTHYOPTERYGIUMS.}

\section{Von Prof. W. Salensky.}

Die sehr wichtige Frage über die Phylogenese der paarigen Gliedmassen der Fische ist bekanntlich erst seit ungefähr dreissig Jahren zur Discussion eingetreten, und es gebührt dem Prof. Gegenbaur das Verdienst diese Frage hervorgehoben zu haben. Auf Grund der zahlreichen und ausführlichen Untersuchungen des Gliedmassensheletts hat Gegenbaur seine scharfsinnige Theorie von der Entstehung der Gliedmassen gebaut, die als "A rchipterygiumtheoric" allgemein bekannt ist. Nach dieser Theorie soll bekanntlich das Flossenskelett der Fische (sammt dem Gürtel der Gliedmassen) phylogenetisch aus dem Skelett des Kiemenbogens entstanden sein, wobei der Kiemenbogen selbst in den Schulter- resp. Beckengürtel, die Strahlen in die Radien sich verwandeln. Ursprünglich soll nach der Theorie von Gegenbaur einer von den Strahlen mehr auswachsen als die andern; er bildet die Axe, auf welcher alle ubrigen Strahlen in zweireihiger Anordnung articuliren. Dieses federförmige Skelett der Gliedmassen, welches unter den jetzt lebenden Tieren beim Ceratodus vergegenwärtigt ist, ist von Gegenbaur für die Urform des Flossenskeletts genommen und mit dem Namen "biseriales Archipterygium" bezeichnet.

Die Archipterygiumtheorie ist ausschliesslich auf allerdings sehr umfangreiche, anatomische Untersuchungen begründet. Das entscheidende Wort in solchen phylogenetischen Fragen gehört jedenfalls der Embryologie, und es ist deswegen begreiflich, dass die Gegenbaur'sche Theorie cine Reihe embryologischer Untersuchungen im Gebiete der Entwicklung der Fischflossen hervorgerufen hat. Dieselben haben keineswegs die Archipterygiumtheorie bestätigt. Balfour, der erste der an der Entwicklung der Selachierflossen ausführliche Untersuchungen unternahm, kam zu Schlüssen, die mit der Gegenbaur'schen Theorie nicht in Einklang gebracht werden könnten. Er hat namentlich gezeigt, dass die Entwicklung des Skeletts der paarigen Flossen mit der des Skeletts der unpaaren Flossen in einer Übereinstimmung steht. Ein bedeutender Schritt in der Lehre von der Phylogenese des Ichthyopterygiums wurde durch seine Entdeckung der Knospen von Myomeren gemacht, die in die Flossenanlage hineinwachsen und dort zu den . Iuskeln der Flosse sich entwickeln. Das Verdienst der weiteren Erforschung in diesem Gebicte gehört dem Prof. Dohrn, und seine an den Selachierembryonen ausgefuhrten Untersuchungen wurden später durch Rabl, Molizer, Corning, Boyer und Harrison nicht nur an den Selachiern, sondern an einer Reihe anderer Fischgruppen bestätigt. Es wurde dabei auch erwiesen dass (I) die Anlage der Flossenmusculatur viel früher, als die des Skeletts, zum Vorschein tritt und (2) dass die Zahl der Muskelknospen resp. 
der Myomeren mit der Zahl der knospeligen Flossenstrahlen in Zusammenhang steht. Es ergiebt sich jedenfalls aus den angeführten Untersuchungen, dass jedem von den primitiven Radien eine oder ein Paar Muskelknospen resp. Muskeln entspricht, oder umgekehrt; demzufolge soll jeder Teil des Ichthyopterygiumskelettes, welchem ein oder ein Paar Muskeln entspricht, als Radius anerkannt werden. Dieser letzte Punkt ist besonders für solche Fälle wichtig, bei denen, wie wir es in den Ceratodusflossen weiter sehen werden, nach dem definitiven Zustande nicht die wahre Natur der Skelettteile genau bestimmt werden kann.

Die Ceratodusflosse nimmt in der Archipterygiumtheorie eine sehr wichtige Stellung, indem dieselbe am nächsten $\mathrm{zu}$ der von Gegenbaur aufgestellten Urform der Flossen aller übrigen Fische steht. Die Entwicklung derselben ist beinahe vollständig unbekannt. Es existiren freilich die Angaben von Semon in seinem grossen Reisewerke, die beziehen sich aber hauptsächlich auf die Entwicklung der äusseren Form der Flosse; doch giebt schon Semon' ${ }^{\prime}$ an, dass in der Flosse des Ceratodus zunächst nur ein axialer Knospel entsteht, welcher von Gegenbaur als axialer resp. basaler Knospel betrachtet ist. Ich war sehr glücklich indem ich eine Reihe der kleinen Ceratodus bekommen hatte und dadurch im Stande gesetzt war die Entwicklung der Ceratodusflosse zu studiren. $\mathrm{Zu}$ gleicher Zeit habe ich durch die Güte von Prof. Ostroumoff in Kazan eine grosse Anzahl von jungen Sterleten bekommen. Dieses Material war für mich um so mehr wichtig, als die Flossen der Acipenseriden einen typischen Bau der Fischflossen besitzen, und ein gutes Vergleichungsmaterial darstellen.

Die Entwicklung der Flosse bei den Acipenseriden (Acipenser stutrio) wurde in der letzten Zeit durch Mollicr ausführlich untersucht. Seine Ergebnisse sind bis jetzt nur in Form von vorläufigen Mitteilungen publicirt ${ }^{2}$. Die Entwicklung der Flossen beim Sterlet weicht von der des Störs in mehreren wichtigen Punkten ab. Ob das von dem Speciesunterschied abhängt, soll man die Entscheidung den späteren Untersuchungen überlassen.

Die erste Anlage der Flosse tritt beim Sterlet schon zu der Zeit auf, wenn äusserlich noch kein Spur von der Flosse zu sehen ist. Ich meine eben die Muskelknospen, welche sich bedeutend viel früher herausbilden, als die bekannte wulstförmige Anlage der Flosse zum Vorschein tritt. Dieselbe können ganz gut bei den conservirten Embryonen resp. Larven beobachtet werden und erscheinen dann in Form von kleinen Fortsätzen der Myomeren, die etwas nach vorne und nach der Bauchseite des Fischchens wachsen und rund abgeschlossen sind. Die Zahl der in die Flosse hineingehenden

1 Fs ist während des Druckes dieser Bogen eine ausfuhrliche Arbeit von Semon (Zoologische Forschungsreisen in Australien itc. I.ief. I 4 ) ïber die Entwicklung der Ceratodusflosse erschienen, welche in meiner ausführlichen Arleit besprochen wird.

2 Mollier, "Die Entwicklung der paarigen Flossen des Sitörs" (Anutomischer Anziger; Bd. xır.). 
Knospen ist sechs, und darin liegt der erste Unterschied, welchen wir zıvischen der Entwicklung der Sterlet- und der Störflossen erkennen können. Diesc Zahl entspricht vollkommen derjenigen der später auftretenden Radien. Es sind namentlich die 5ten bis Ioten Myomeren, welche bei der Bildung der Flossenmusculatur teilnehmen und die Muskelknospen abgeben. Im Vergleich mit dem Stör es ist namentlich das Iote Myotom, welches beim Sterlet eine Muskelknospe bildet, während es beim Stör in dieser Bezichung unthätig bleibt. Ausserdem finde ich auf den nachhinten folgenden Segmenten ebenfalls die Bildung der Knospen, die von vorne nach hinten immer an Grösse abnehmen. Bei den Oberflächenansichten konnte ich 5 Paare solcher Knospen wahrnehmen (vom I Iten bis zum I 5 ten Myomer); in den Querschnitten ist aber jedes Myotom bis zu denjenigen welche später in der Bildung der Bauchflossen teilnehmen mit einer kleinen Knospe versehen. Es sind die abortive Knospen ; nach Mollier sollen sie beim Stör gar nicht erscheinen. Sie zeichnen sich nur durch ihre kleinere Grösse vor den wahren Knospen aus, sonst ihrem Bau nach sind sie den letzten vollkommen gleich.

Die ersten Spuren der Flosse treten erst bei der 2 Tage alten Sterletlarve auf. Sie erscheinen, wie bei den übrigen Fischen, in Form eines Längswulstes, der bauchwärts von der Kopfniere liegt und etwas schief gegen der Längsaxe verläuft. Das innere desselben besteht aus der verdickten Somatopleura, vom aussen ist derselbe durch das zweischichtige und etwas verdickte Ectoderm bedeckt, wobei diese Verdickung auf Kosten der inneren Schicht desselben beträgt.

Während der ersten fünf Tage nach dem Ausschlüpfen besteht die Entwicklung der Flosse nur in dem Wachstum der angelegten Teile: der Somatopleura und der Muskelknospen. Die letzten wachsen in senkrechter Richtung gegen die Längsaxe der Flosse, und verwandeln sich in Stränge; proximal sind sie erweitert und hohl, distalwärts schliessen sie sich in Form von kleinen abgerundeten, ebenfalls hohlen Spitzen ab.

Die nächsten wichtigen Erscheinungen in den Muskelknospen bestehen in der Bildung der Bauch-resp. Rückenportion derselben, welche die Anlagen der Bauch- resp. Rückenmusculatur der Flosse darstellen. Dies wird dadurch erreicht, dass von der Basis jeder Muskelknospe ein Vorsprung sich bildet, welcher in die Flosse hineinwächst und unter der Rückenfläche derselben zu liegen kommt. Die Muskelknospe bekommt dadurch die Form einer Gabel, deren ein Ast an der Basis der Flosse, der andere unter der Rückenfläche derselben liegt. Die letzte wird später zur Rückenmusculatur der Flosse, die erste wächst ebenfalls ins innere der Flosse hinein, bildet einen Fortsatz welcher unter der Bauchfläche der Flosse zu liegen kommt und sich später in dic Bauchmusculatur der Flosse verwandelt. $\mathrm{Zu}$ dieser Zeit wird die Verbindung der Muskelknospe mit dem entsprechenden Miotom aufgchoben. 
Jede gabelförmige. Muskelknospe umgreift den basalen Teil des Mesenchyms der Flosse, und dieser Teil des Mesenchyms stellt die Anlage des Flossenskeletts dar. Aus den Flächenschnitten ersieht man dass jede Muskelknospe an der Grenze zwischen den zwei Anlagen der Radien ihre Stelle nimmt. Die Anlagen der Radien erscheinen in Form von abgerundeten Platten, die proximalwärts allmählig in undifferenzirtes Mesenchymgewebe übergehen. Das letztere stellt nun die Anlage der Basale vor und ist im Vergleich mit den Radienanlagen ziemlich weit in seiner Entwicklung zurückgeblieben. Deswegen kann ich keineswegs die Meinung teilen, dass die Radien als Fortsätze der Basale zum Vurschein treten. Die Verknorpelung des Skeletts geht in den Radien und in den Basalen ziemlich gleichzeitig vor sich, aber die Vorbereitungsprocesse zu derselben treten in den Radien viel früher zum Vorschein.

Ich kann auch nicht die Ansicht teilen, dass der Schultergürtel als ein Fortsatz der Basale erscheint. Die Anlage des Schultergürtels tritt schon in den allerersten Stadien der Differenzirung des Skeletts ganz selbständig und zwar viel friher als die der Basale hervor, und erscheint in Form einer kurzen an der Basis der Flosse liegenden Platte, die von dem Mesenchym der Flosse durch einen scharfen Contour abgetrennt ist, und nach der Rückenseite der Larve allmählig in die Somatopleura übergeht. Der Schultergiirtel wird in zwei Stücken angelegt, die nicht gleichzeitig erscheinen. Aus der zunächst auftretenden Anlage entwickeit sich der Rücken- resp. Scapularteil, später und neben denselben erscheint eine neue Verdichtung der Somatopleura, aus welcher der ventrale resp. coracoidale Teil des Schultergürtels sich herausbildet. Die Vereinigung beider Teile tritt am 6ten Tage der postembryonalen Entwicklung zum Vorschein. An der Vereinigungstelle bildet sich der Gelenkfortsatz, auf welchem später die Gelenkverbindung mit der Basale erfolgt.

Die Entwicklung des Flossenskeletts ist im Vergleich mit dem des Schultergürtels etwas zuriickgehalten. Nachdem die Radien in der Mesenchymmasse in Form einer Gewebeverdichtung angedeutet sind, tritt auch solche im Bereiche der Basale auf. Die letzte erhält eine dreieckige Gestalt ; erst am gten Tage verknorpelt sie, wobei die Verknorpelung zunächst im proximalen Teile derselben zum Vorschein kommt. Es bildet sich daselbst eine abgerundete Gelenkfläche, welche noch lange Zeit ziemlich weit von der eben erwähnten Gelenkspange absteht. Zu gleicher Zeit, bei der Iotägigen Larve, verwandeln sich auch die Anlagen der Radien in ein knorpeliges Gewebe; gegen die Basale sind dieselben durch ein verdichtetes Gewebe abgegrenzt, welches die Gelenkflächen andeutet.

Die Entwicklung der Musculatur der Ganoidenflosse unterscheidet sich wohl von der der Selachier dadurch, dass von jedem Myomer nur je eine Muskelknospe nach rechts und nach links, während bei den Selachiern deren zwei sich abtrennen. Deswegen 
stimmt dic Zahl der Muskelknospen mit derjenigen der Radien vollständig überein. Im Laufe der Zeit und namentlich schon bei der 5tägigen Larve tritt auch beim Sterlet ein Vorgang auf, welcher der Verdoppelung der Selachierknospen als Analog betrachtet werden kann. Jede secundäre Muskelknospe, auf der Rücken- sowohl als auch auf der Bauchseitc der Flossc, spaltet sich der Länge nach in zwei Muskeln; es bilden sich in dieser Weise I 2 Muskeln auf der Rücken- und soviel auch auf der Bauchseite der Flosse, die sich durch ihre distalen Enden an der Grenze zwischen dem Skelettteil und dem Hautteil des letzten befestigen. $\mathrm{Zu}$ gleicher Zeit nehmen die Muskeln der Flosse eine schiefe Lage an, nähern sich mit ihren proximalen Enden an einander und haften dem Schultergürtel an. Es entsteht somit ein Muskel, welcher distalwärts sich fächerförmig ausbreitet.

Die Hauptergebnisse meiner Untersuchung in Bezug auf die Entwicklung der Sterletflosse können folgenclermassen recapitulirt werden :

(I) Bei der Entwicklung der Brustflossenmusculatur des Sterlets beteiligen sich 6 Myomeren ( 5 te bis Iote), die schon während der embryonalen Entwicklung die Muskelknospen (primären Muskelknospen) zu bilden pflegen.

(2) Die von dem Ioten Myomer caudalwärts folgenden Myomeren bilden auch Muskelknospen (abortive Muskelknospen).

(3) Der Schultergürtel entsteht unabhängig vom Flossenskelett in der Rumpfsomatopleura.

(4) Obwohl die Basale und die Radien in einem gemeinsamen Blastem (Mesenchym der Flosse) angelegt sind, stellen die Radien doch ontogenetisch keine Auswüchsc der Basale vor, so wenig wie dic Entstehung der letzten nicht als Resultat des Zusammenfliessens der ersteren erklärt werden kann.

(5) Die Sonderung der Bauch- resp. Rückenmusculatur geht nicht durch die Teilung der primären Muskelknospen, sondern durch Auswachsen derselben nach der Bauch- resp. Rückenseite der Flosse vor sich (secundäre Muskelknospen).

(6) Jede secundäre Muskelknospe spaltet sich der Länge nach in zwei Muskeln. In dieser Weise wird die Verdoppelung der Muskeln im Verhältniss zu den Radien erzielt.

Gehen wir nun zur Entwicklung der Brustflosse des CERATODUS über. Das Material, welches mir zur Disposition stand, war nicht so reich, wie dasjenige des Sterlets, deswegen konnte ich die Entwicklung der Ceratodusflosse nicht in einer so vollständigen Reihe der Stadien, wie diejenige des Sterlets, studiren.

Die äusseren Entwicklungsvorgänge der Ceratodusflosse wurden bereits von Semon ganz richtig beschrieben; er hat auch angegeben, dass das Flossenskelett zuerst in Form eines Knorpelstabes auftritt, welcher die Anlage des axialen Teiles resp. des Stammes darstellt. Über die Entwicklung des Muskelsystems der Flosse wissen wir 
doch so gut wie gar nichts. Die Verhältnisse der Flossenmuskeln zum Skelett sind doch für die Bestimmung der Homologien der Skelettteile sehr wichtig und zwar besonders für die Ceratodusflosse, welche jedenfalls ihrem Bau nach einige bedeutende Abweichungen vom Skelett anderer Fische darstellt. Die Lage der Skelettteile während ihrer Entwicklung, die Art der Entstehung derselben und ilne Beziehung zu den Muskeln, sind die wichtigsten Punkte, auf die man achten muss, um eine richtige Vorstellung von der Homologie des Skeletts zu construiren.

Die Entwicklung der Brustflossen des Ceratodus beginnt, wie diejenige der Sterlets- resp. anderer Fischflossen, mit der Bildung der Muskelknospen, die in Form von ziemlich grossen, hohlen Fortsätzen der Bauchmuskeln auftreten. Die Zahl dieser Muskelknospen ist fünf für jede Flosse; es sind namentlich die 6te-Iote Myomeren, welche sich bei der Bildung dieser Knospen beteiligen. Wie beim Sterlet, so bilden sich auch beim Ceratodus die Muskelknospen noch lange bevor die Brustflosse nach Aussen hervortritt.

Die erste Anlage der Bauchflosse erscheint in Form eines länglichen Wulstes, welcher ziemlich parallel der Längsaxe des Körpers, im Bereiche des 5-9 Myotoms verläuft. Erst später, in Folge des Wachstums, nimmt dieselbe eine verticale, von Semon bereits beschricbene, Lage an. Im weiteren Verlauf der Entwicklung wächst diese plattenförmige Anlage nach hinten fort und nimmt endlich die bekannte lanzettenförmige Gestalt an.

Die fünf Muskelknospen liegen schon bei den jungen Larven dicht einander an und spalten sich ziemlich frühzeitig in eine Rücken- resp. eine Bauchmuskelknospe, welche als secundäre Muskelknospen bezeichnet werden können. Während des weiteren Wachstums der Flosse, bei einem 4wöchentlichen Ceratodus, fliessen alle Muskelknospen zusammen und bilden in der Rückenso wie in der Bauchseite der Flosse je eine einzige Schicht longitudinaler Muskel aus.

Zwischen den beiden Muskelschichten tritt nun die Anlage des Skeletts auf. Sie erscheint bereits bei den 4wöchentlichen Fischen in Form eines aus Prochondrium bestehenden cylindrischen Stabes, welcher vom proximalen Teile der Flossenanlage beginnt und allmählig nach hinten, dem proximalen Rande der Flosse ziemlich parallel, wächst. Bei den 6wöchentlichen Fischen stellt das innere Skelett der Flosse bereits einen ungegliederten cylindrischen knorpeligen Stab dar. Diese erste Anlage des Skeletts ist die Anlage des Stammes, welcher zuerst ungegliedert crscheint und keine Radien trägt. Die Gliederung tritt erst bei dem IOwöchentlichen Fische hervor, wie es von Semon richtig angegeben wurde. Der Stamm besteht danı aus 6 ungleichmässig entwickelten Gliedern. Mit dem ersten von diesen letzteren ist schon der erste Radius verbunden. Die Radien bilden sich als Sprossen von dem knorpeligen Stamme, sind bei ihrem Erscheinen einfach, fangen sich aber schon ziemlich frühzeitig an zu gliedern. Bei 
dem Auftreten der Radien spaltet sich von den longitudinalen Muskeln eine Anzahl der Muskelzellen ab, die sich den Radien anschliessen und die radialen Muskeln darstellen.

Die ebengeschilderten Entwicklungsvorgänge derCeratodusflosse lassen schon jetzt einige Schlüsse über die Morphologie derselben und über ihre Stellung in der Reihe der Iclithyopterygiumformen ziehen. Die Hauptergebnisse meiner Untersuchungen sind folgende:

(I) Die Entwicklungsvorgänge der Ceratodusflosse sind denjenigen der Flosse anderer Fische vollkommen analog.

(2) Bei der Bildung der Flossenmusculatur beteiligen 5 Myomeren (vom 6ten-Ioten), welche eben so viele Muskelknospen zu jeder Flosse abgeben. Dieselben teilen sich später in die Bauchresp. Rückenknospen, die als secundäre Muskelknospen bezeichnet werden können. Alle Muskelknospen jeder Seite fliessen zusammen und bilden in der Bauch- resp. Rückenseite je eine Schicht longitudinaler Muskeln, die, beim Auftreten der Gliederung, in einzelne Portionen zerfallen und auch die Muskeln zu den entstehenden Radien abgeben.

(3) Das Flossenskelett tritt in Form eines einzigen Stabes auf, aus welchem sich später der Knorpelstamm herausbildet.

(4) Die Radien sind einfache Sprossen der Stammesglieder, die in Knorpelstadium die letzte sich herausbilden und in keiner Beziehung zu den Muskelknospen stehen.

Will man daraus Schlüsse über die Homologie einzelner Teile des Skelettes der Ceratodusflosse mit dem Skelett anderer Ichthyopterygiumformen ziehen, so sind wir, meiner Meinung nach, zu folgenden Sätzen berechtigt :

(a) Die Ceratodusflosse ist, wie diejenige anderer Fische, metamer und kann als pentamer bezeichnet werden.

(b) Der Stamm der Ceratodusflosse ist demjenigen der Flossen anderer Fische vollkommen homolog, indem er sowohl in seiner Bildungstelle, als auch in seinen Verhältnissen zu den Muskeln, der Basale anderer Fische gleichwertig ist.

(c) Die Radien des Ceratodus sind im Gegenteilden primitiven Radien gar nicht lomolog, indem sie erstens in keiner Beziehung zu den primitiven Muskelknospen stehen, und zweitens erst im Knorpelstadium von dem Basale abgetrennt sind. Man könnte sie am besten mit den secundären Radien der Flossen der Fischevergleichen.

Die Stellung der Ceratodusflosse in der Reihe der Ichthyopterygiumformen geht aus den eben angeführten Sätzen hervor. Das Skelett der Ceratodusflosse ist nur durch die Basale repräsentirt; die primitiven Radien sind in demselben gar nicht vorhanden. Da aber dic Muskeln der Flosse in derselben Weise wie bei den anderen Fischflossen entstehen, so ist man berechtigt die Abwesenheit der Radien als Verlust derselben während der phylogenetischen Entwicklung zu erklären, und, folglich, die Ceratodusflosse als eine stark reducirte Form in der Reihe anderer Ichthyopterygiumformen zu betrachten. 


\section{Présentation DẼ Planches COLORIÉES DU RHino-} PITHECUS BIETI DES DEUX SEXES ET À DIFFÉRENTS ÂGES.

\section{Par E. de Pousargues.}

Ces deux planches font partie d'un mémoire qui doit paraître prochainement dans les Nouvelles Archives du Muséum de Paris. Sur l'une de ces planches est figuré un mâle adulte, sur l'autre une femelle adulte, un jeune en pleine dentition de lait et un petit nouveau-né du nouveau Rhinopithèque découvert dans la vallée du haut Mékong, près de Tsékou, et décrit récemment par M. A. Milne-Edwards sous le nom de Rhinopithecus Bieti. M. de Pousargues expose d'abord les particularités de pelage les plus remarquables qui permettent de distinguer facilement ce nouveau Rhinopithèque de son congénère $R$. Roxellane de la principauté de Moupin, et il termine en insistant sur la valeur générique des caractères qui séparent et isolent ces deux espèces du reste des Semnopithèques.

\section{INDICATIONS PRINCIPALES SUR LES VERTÉBRÉS DE LA NOUVELLE COLLECTION RÉGIONALE ROMIAINE.}

\section{Par Prof. A. Carruccio.}

Prof. Carruccio de la R. Université de Rome fait quelques considérations sur l'importance de la taxonomie zoologique selon les progrès de nos jours, et en application des faunes locales : cellesci doivent être étudiées toujours avec un grand intérêt. Il fait après relever quelles étaient les conditions des études zoologiques en Rome il y a seulement quelques années, en exposant les grands progrès qu'on a fait dans les recherches faunistiques de toute sorte. C'est grâce à ces recherches qu'il a pu combler de très-nombreuses lacunes dans tous les ordres de vertébrés: ce qu'il démontre avec beaucoup d'exemples, en citant aussi de vraies rarités, surtout dans la classe des oiseaux.

Le Prof. Carruccio donne aussi un résumé des familles, des genres et des espèces pour toutes les autres classes de vertébrés; et il annonce qu'à présent le Musée zoologique de Rome est fourni d'une riche collection régionale des vertébrés, et aussi des invertébrés; collection tout récemment bien disposée et mise par son fondateur, Prof. Carruccio, à la disposition des visiteurs étrangers et italiens, et surtout de ceux qui désirent la connaissance scientifique des espèces d'animaux vivants dans leur propre pays. A ce propos il rappelle les services qu'a déjà rendus la Société romaine aux études zoologiques, et les publications qu'elle a fait regulièrement faire depuis l'année I 892.

No remarks were made.

1 Bullet. du Mus. d'hist. nat. Paris, No. 5, p. $156,1897$. 
8. ON The So-Called uterus masculinus of the Rabbit.

\section{By Prof. Ramsay Wright.}

The object of the present communication is to correct a current misapprehension of the morphology of the organ in question, which is frequently referred to in text-books and by teachers in illustration of the occasional abnormal development of the caudal ends of the Müllerian ducts in the male human subject. (Cf. e.g. Rolleston and Jackson, "Forms of Animal Life," p. 30 et seq.)

Sharing this misapprehension I was surprised to learn from a series through an embryo rabbit of $5 \mathrm{ctm}$. that the so-called uterus masculimus or vesicula prostatica is in reality an unpaired seminal vesicle developed from a fusion of the caudal ends of the Wolffian ducts. An examination of the literature showed that Kölliker (Entwickelungsgeschichte, p. 98 I) followed by Langenbacher (Arch. mik. Anat. XX, p. 92) had already made this statement. Krause, who quotes these authors in the second edition of his "Anatomie des Kaninchens," p. 234, still retains his former description of the "vesicula prostatica" (1st ed. p. 170), which is written on the assumption that the organ is the morphological equivalent of the vagina of the female, and of the utriculus masculinus of man.

A detailed description of the development of this region in the rabbit is reserved for another occasion.

9. Ueber die Hirschgeweihe mit Mehr als ZWEi Stangen, UND DIE HoERner WiederkaEuer iM ALLGemeinen.

\section{Von Prof. Dr H. Nitsche.}

Prof. Nitsche of the Forst-Akademie Tharandt, Saxony, gave the following short résuıné of his investigations about abnormal stags' antlers, their growth, and their difference from the horns of the Bovidae. A full account will be found in his forthcoming work entitled Studien iiber Hirsche.

Der Vortragende berichtet über die Ergebnisse einer Reihe von Untersuchungen, die unter dem Titel: Studicn ïber Hirsche, $4^{\circ}$, Heft I mit 12 Tafeln, unter der Presse sind und Anfang October bei Wilhelm Engelmann in Leipzig erscheinen werden.

Er erläutert, dass die überzähligen Stangen, die bei verschiedenen Hirscharten nicht gerade selten sind und stets dem Stirnbeine entspringen, zunächst auf 3 verschiedene Weisen entstehen können, entweder,

(1) von der Fläche des Stimbeines, oder

(2) aul einem Aste des sich am Ende theilenden, abnormen Rosenstockes, oder

(3) auf der Seitenfiäche eines normalen Rosenstockes. In 
allen diesen Fällen ist die Nebenstange der Hauptstange gleichwerthig. Es kann aber

(4) die Nebenstange nur einem Theil der Hauptstange entsprechen, indem die Nebenstange eine getrennte Augsprosse darstellt und erst zusammen mit der in diesem Falle der Augsprosse entbehrenden Hauptstange einer normalen Stange gleichwerthig ist.

Alle 4 Arten von Nebenstangen werden ursprünglich getrennt von der Hauptstange abgeworfen, können aber in späteren Jahrgängen mit der Hauptstange wieder verwachsen.

Der Vortragende erläutert ferner, wie seine Untersuchungen ihm gezeigt haben, dass die häufig angenommene Homologie aller Wiederkäuerhörner $z u$ verwerfen ist.

Das erste Geweih der Cerviden entsteht nämlich als Apophyse des Stimbeines und stellt nur den apicalen Theil des Rosenstockes dar. Sein Abwurf geschieht bekanntlich durch locale Necrose des nach Entfernung des Integumentes abgestorbenen Knochengewebes und das zweite und alle folgenden Geweihe entstehen nicht als gesonderte, dem Rosenstock später verwachsende Knochenkerne, sondern durch vom Periost ausgehende Regeneration, wie dies besonders Landois, Robin und Hermann gezeigt haben.

Dagegen entstehen nicht nur die Knochenzapfen des Giraffenhornes, sondern auch die des Bovidenhornes aus gesonderten Knochenkernen der Cutis, die erst nachträglich mit dem Stirnbein verwachsen, also Epiphysen darstellen. Diese neuerdings von Alexander Brandt an Hausthieren nachgewiesene Entstehungsart, fand der Vortragende auch bei der Gemse.

Wie der Knochenzapfen von Antilocapra americana entsteht, weiss man noch nicht, doch ist wahrscheinlich, dass auch er eine Epiphyse darstellt. Dagegen bildet die Hornscheide der Gabelantilope einen Übergang von dem behaarten Integument des Giraffenhornes zu der Hornscheide der eigentlichen Boviden. Die Substanz, welche wie längst bekannt die Haare des Knochenzapfenintegumentes von Antilocapra zu einer festen Scheide verbindet, besteht nämlich nicht einfach aus verhornten Epidermiszellen, ist vielmehr echte Hornsubstanz mit Hornröhrchen, wie sie die Hornscheide der übrigen Hohlhörner zeigt. Das Knochenzapfenintegument der Antilocapra erzeugt also Haare und intercrinale Hornsubstanz, das der Giraffe nur Haare, das der Boviden nur cchte Hornsubstanz. Die Epidermoidalbildungen des Giraffenhornes werden unregelmässig, die des Gabelantilopenhornes regelmässig, die des Bovidenhornes gamicht gewechselt.

Hieraus, sowie aus vielen anderen anatomischen Thatsachen folgt, dass die von Riitimeyer angenommene nähere Verwandtschaft der Giraffe mit den Hirschen nicht besteht. Seine besonders von den continentalen Palaeontologen gern angenommene Gruppe der Cervicornia (Hirsche + Giraffe) ist unnatürlich. Sehr natürlich ist dagegen die zuerst von Gray aufgestellte Eintheilung, bei 
welcher Giraffe und Gabelgemse je eine gesonderte klcine Familie darstellen welche die Cerviden und Boviden verbinden.

Immerhin ist die Giraffe den Boviden viel näher verwandt, als den Cerviden. Dies ergiebt sich auch aus den Verhältnissen des Gebisses. Denn wenngleich dic Form der Backzähne der Giraffe sehr der der Hirsche gleicht, so ist doch dic Reihenfolge des Wechsels der cinzelnen Zähne, die Art und Weise des Überganges des Milchgebisses in das Dauergebiss, bei ihr dieselbe, wie bei den Boviden. Das Tempo des Zahnwechsels bildet aber einen sehr scharfen Unterschied zwischen Boviden und Cerviden. Bei ersteren werden die einzelnen Paare der Milchschneidezähne einzeln, im langen, oft I 2 Monate dauernden Zivischenräumen gewechselt, die Backzähne dagegen in einer kurzen Periode, die hinter den Wechsel des 2ten Schneidezahnpaares fällt. Bei den Cerviden werden dagegen die Schneidezähne und die Backzähne in zwei kürzeren Perioden gewechselt, von denen die erste, die Periode des Schneidezahnwechsels, die mit der Bildung des Erstlingsgeweihes zusammenfällt, der Periode des Backzahnwechsels, welche mit der Bildung des zweiten Geweihes gleichzeitig ist, stets vorangeht. Der Zahnwechsel von Antilocapra entspricht, wie man ganz besonders schön an den beiden Exemplaren des zoologischen Museums zu Cambridge sehen kann, trotz der Rhytmik ihres Hornscheidenwechsels, dem Bovidentypus. 


\section{SECTION C. INVERTEBRATA.}

Tuesday, 23rd August, at the Chemical Laboratory, at 2 p.m.

Chairman, Dr BOAS.

Secretary, Prof. L. Plate.

Assistant Secretary, Mr E. S. GOODRICH.

The following papers were read:

\section{Beiträge zUr vergleichenden Anatomie der Chitonen.}

\section{Von Prof. L. Plate.}

Die folgenden Angaben haben den Charakter einer vorläufigen Mittheilung, in so fern sie möglichst kurz gehalten sind und sich nicht auf eine Besprechung der Litteratur einlassen. Sie werden in ausführlicher Form erscheinen in der zweiten Hälfte meiner Abhandlung: die Anatomie und Phylogenie der Chitonen, welche im nächsten Jahre in der Fauna chilensis (Suppl. der Zoolog. Fahrbiicher) veröffentlicht werden wird.

Die für die Systematik der Placophoren so wichtigen Hartgebilde des Mantels (Schuppen, Stacheln, Haare) sind zwar im einzelnen schon vielfach beschrieben worden, ohne dass jedoch der Versuch gemacht worden wäre, sie nach ihrer phylogenetischen Entstehungsweise von einander abzuleiten. Es ist klar, dass es hierbei sich nicht um die mannigfachen kleinen äussern Verschiedenheiten (z. B. ob schuppen- oder stachelförmig, mit oder ohne Rippen, pigmentirt oder durchsichtig) handeln kann, sondern nur um die durchgreifenden Merkmale der histologischen Zusammensetzung. Ich habe bis jetzt folgende Kategorien von Hartgebilden des Mantels gesehen.

(I) Einfache Kalkkörper, die an keiner Stelle von einer Chitinmembran bedeckt werden. Diese einfachste Form kenne ich nur von den grossen Kalkschuppen des Enoplochiton niger.

(2) Wie I, aber der ganze obere aus der Cuticula herausragende 
Theil wird von einer derben Chitinmembran überzogen (die grossen Stacheln von Acanthopleura cchinata).

(3) Wie I, aber der in der Cuticula steckende Theil (Ventralfläche) wird von einer Chitinmembran ïberzogen, die aber gleichmässig dünn bleibt (Callochiton laer'is).

(4) Wie 3 , jedoch verdickt sich diese Chitinmembran zu einem "Becher," welcher die Wurzel des Stachels oder der Schuppe umgreift. Die Bildungszelle (oder die Bildungszellen) kann beim Abrücken des Stachels strangförmig ausgezogen werden (Callochiton lacvis) oder nicht.

(5) Wie 4, aber der Becher trägt einen der Bildungszelle zugewandten "Zapfen." Diese Zelle wird meist ausgezogen, jedoch nicht bei Ischnochiton ruber.

(6) Wie 5, aber der Becher ist zu einem länglichen, stabförmigen "Becherschaft" ausgewachsen ungefähr von der Grösse des ihm aufsitzenden Stachels,

(7) Wie 6, aber der Becherschaft ist zu einer langen Borste ausgewachsen, welche an der Spitze einen winzigen rudimentären Stachel trägt (Tonicien, Chaetopleuren).

(8) Wie 6, jedoch besitzt der Becherschaft an seinem untern Ende einen kleinen Vorsprung, an den sich die Bildungszelle anheftet und so ausgezogen wird. Sie wird umgeben von isolirten Chitinstäbchen, die einen "Ring" bilden (Nuttalochiton hyadesi).

(9) Wie 8, aber der Becherschaft ist (wie bei 7) zu einer Borste ausgewachsen und der Ring ist durch Vereinigung und Längenwachstum der Stäbchen zu einer langen Röhre, dem "Ringschafte" geworden, dessen Lumen von der Bildungszelle eingenommen wird (Chaetopleura).

(IO) Wie 8, aber die Chitinstäbchen sind zu einem langen Ringschafte (wie bei 9) ausgewachsen, während der Becherschaft mit seinem Stachel zu einem ganz kleinen rudimentären Gebilde sich rückgebildet hat.

(1 I) Wie 3, aber die Chitinmembran bildet unter der Schuppe eine derbe Basalplatte und zur weiteren Befestigung der Schuppe hat sich eine umgebildete Partie der Cuticula ihrer mediaden Seite angelagert (Dorsalschuppen von Chiton olivaceus).

Das folgende Schema lässt mit einem Blick erkennen, wie die verschiedenen Hartgebilde in der eben geschilderten Weise von einander abgeleitet werden können : Eimer's Orthogenesis-Theorie, der zu Folge die Weiterentwicklung innerhalb jeder Gruppe von Organismen nur nach einigen wenigen Richtungen erfolgen soll, stimmt wenig überein mit diesem Schema; denn wenn schon die Untersuchung einer relativ geringen Anzahl von

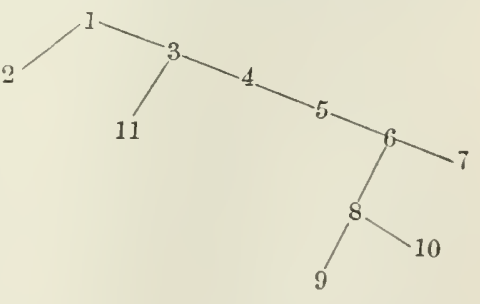
Arten lehrt, dass an mehreren Punkten $(3,6)$ die ursprüngliche 
Entwicklungsrichtung verlassen und eine neue Bahn eingeschlagen wurde, so ist anzunehmen, dass derartige Seitenäste in noch viel reicherem Masse vorhanden sind, und dass die Natur im Stande ist, an jedem Punkte den Typus nach neuen Variationsrichtungen abzuändern. Bei ganz jungen, eben aus dem Ei geschlüpften Individuen von Callistochiton viviparus n. sp. und Ischnochiton imitator sitzen die Stacheln und Schuppen nur auf der Ventralseite des Mantels und weichen erheblich von denen der Erwachsenen ab. Da die Schalen bis hart an den Seitenrand des Körpers hinanreichen, so ist die Rückenseite des Mantels anfangs noch nicht vorhanden. In demselben Masse, als sie sich anlegt, rücken die Hartgebilde auf sie hinüber, wobei sie-vermuthlich allmählichdurch solche ersetzt werden, welche die definitive Gestalt aufweisen.

Ich kenne keine Chitonenart, welche der Stacheln ganz ermangelte, und zwar kommen bei jeder Art mehrere Sorten (3-7) vor. Manche Charaktere derselben beruhen ohne Zweifel auf Anpassung, d. h. sie sind nützlich, so z. B. dass die Stacheln der Ventralseite ihre Spitze stets nach aussen kehren, um sie durch den Blutdruck in die Unebenheiten der Unterlage hineinpressen und auf diese Weise zur Befestigung dienen zu können, ferner dass die Kantenstacheln, welche besonders gefährdet sind, meist durch einen sehr stark entwickelten Becher ausgezeichnet sind und daher fester als die übrigen Hartgebilde in der Cuticula stecken, dass die haarförmigen Becherschäfte zum Tasten dienen, u. dgl. Aber trotzdem dürfte es ganz unmöglich sein, im Sinne von Wallace alle Structureigenthümlichkeiten durch Adaption und damit durch Selection zu erklären.

Hinsichtlich der Kiemen sei hier nur darauf hingewiesen, dass im allgemeinen der ursprüngliche merobranchiale Typus bei kleinen Arten, der hier von sich ableitende holobranche bei mittelgrossen und grossen Species beobachtet wird. Da bei zunehmender Grösse eines Körpers die Oberfläche in geringerem Grade wächst wie die Masse, so musste bei den Chitonen die Zahl der Kiemen zugleich mit dem Wachstum des Körpers zu nehmen. Die Kiemen sind als Neubildungen anzusehen, welche mit den Ctenidien der übrigen Gastropoden nichts zu thun haben. Da die Chitonen aber typische Osphradien zu beiden Seiten des Afters besitzen, so lässt sich mit einiger Wahrscheinlichkeit annehmen, dass sie ursprünglich auch zwei Ctenidien besassen. Diese gingen vermuthlich später verloren, weil erstens ihre Lage unmittelbar neben dem After für ein Respirationsorgan von ansehnlicher Grösse wegen der Gefahr der Verschmutzung wenig günstig war und zweitens in dem sauerstoffreichen Wasser der Gezeitenzone die ursprünglich weiche Körperoberfläche eine so intensive Hautathmung ermöglichte, dass diese allein genügte. Der Übergang aus dem Flachwasser in die Gezeitenzone war also zugleich mit den topographischen Verhältnissen die Ursache, dass die Ctenidien verloren gingen, ein Process, der sich in ähnlicher Weise bei den Patelliden zur Zeit noch abspielt. Die 
Voraussetzung einer ursprünglich weichen Körperoberfläche mache ich mit Rücksicht auf die wohl allgemein acceptirte Hypothese, dass die Gastropoden sich von turbellarienartigen Vorfahren ableiten. Auf einem späteren Stadium erwarben die Chitonen als Schutzmittel die acht Schalen und die derbe Cuticula des Mantels, und da hierdurch die Hautathmung natürlich herabgesetz.t wurde, entstanden die secundären Kiemen in der Mantelrinne und zwar, wie die vergleichende Anatomie lehrt, ungefähr in der Region des Intersegmentums VII, VIII, um sich von hier aus theils nach vorn, theils nach hinten auszubreiten.

Der Magcn lässt folgende Differencirungsstufen erkennen. Als Ausgangspunkt sehe ich einen einfach spindelförmigen Magen an, wie er bei Nuttalochiton hyadesi vorkommt. Hiervon leitet sich durch Rückbildung der bei Hauleya hauleyi gegebene Zustand ab, bei welcher Art eine eigentliche Magenerweiterung fehlt. Als Homologon derselben kann ein ganz kurzer gerader Schlauch gelten, der sich zwischen Schlund und Darm einschiebt und an seinem Hinterende die Leberdrüsen aufnimmt. Es liegt hier vermuthlich eine Folge der carnivoren Ernährungsweise vor, da diese Art, wie es scheint, vornehmlich oder ausschliesslich von Schwämmen lebt. In progressiver Richtung schliessen sich an Nuttalochiton die Lepidoplcuriden (Lep. cajetanus und asellus) an, bei denen am vordersten Theil des Magens die dorsale Fläche zu einer tiefen Rinne eingestülpt ist. Bei der Mehrzahl der Chitonen dehnt sich dann diese Rinne allmählich über die ganze Rückenseite des Magens aus, während gleichzeitig dessen linker Rand sich dorsalwärts emporwölbt.

Die beiden Leberdriisen sind bei eben ausgeschlüpften Exemplaren von Ischnochiton imitator vollständig symmetrisch entwickelt und münden durch zwei einander gegen überliegende Öffnungen von links und von rechts in den Darmkanal aus. Erst später differenciren sie sich in der Weise, dass die rechte Leber zur vordern und obern, die linke zur hintern und untern wird. Dabei vereinigen sich bei einigen Arten (Nuttalochiton liyadesi, Callochiton lacvis, Hanlcya hauleyi) beide Pori zu einem Ostium commune. Lepidopleurus cajetamus und asellus besitzen eine sehr auffallende Bildung in einem von der Cardia entspringenden langen Blindsack, dessen Epithel dem des Magens gleicht und der an seinem Hinterende beide Lebern aufnimmt. Es lässt sich ferner zeigen, dass auch die Lage der Leberöfnungen sich allmählich von rechts nach links verschoben hat. Bei dem primitiven Nuttalochiton hyadesi liegt die gemeinsame Mündung der beiden Drüsen am rechten Seitenrande des Pylorus. Bei einigen Arten (Lophyms albus, Callochiton laciris, Callistochiton rivipams, Ischnochiton imitator) findet die Einmündung ungefähr in der Mediane des Rückens statt und endlich bei der Mehrzahl ist sie bis zum linken Seitenrande des Magens gerückt, wobei beide Pori durch eine Rinne mit einander verbunden sind.

Die Geschlechtsorganc sind bei Nuttalochiton hyadesi paarig, 
sonst unpaar. Am Oviduct lassen sich stets zwei Regionen unterscheiden, eine innere nicht ausgesprochener Massen drüsige, mit starken Cilien besetzte und eine äussere, deren hohes drüsiges Epithel sich intensiv mit Haematoxylin färbt. In der Regel ist der innere Abschnitt sehr kurz, bei Lepidopleurus cajetanus und asellus hingegen nimmt er den ganzen in der Leibeshöhle liegenden Abschnitt ein und erweitert sich ausserdem bei der letzteren Art vor der Einmündung in das Ovar zu einem sackförmigen Vorraum. -Die Eihaut ist bei Isilnocliton imitator mit zahlreichen fadenförmigen Anhängen besetzt, die sich um einander herumwickeln und wohl dazu beitragen, die Eier in der Mantelrinne zu einer festen Masse zu vereinigen und so eine Brutpflege unter dem Mantel zu ermöglichen.

Gefässsystcm. Zu den schon früher erwähnten Arten mit nur einem Paar von Atrioventricular-Ostien kann ich hinzufügen Hanleya haulcyi, Ischnochiton ruber und imitator.-Bei Onithochiton undulatus liegt das hintere Ostienpaar ganz in der Nähe des hinteren blinden Endes der Kammer, ein Verhalten, das ich früher schon für Schizochiton incisus angegeben habe. Der Grund hierfür ist wohl in beiden Fällen in der Kleinheit der hintersten Schale zu sehen.--Ich ergreife diese Gelegenheit, um einen Irrthum zu berichtigen, der mir in der ersten Hälfte meiner "Anatomie und Phylogenie der Chitonen " untergelaufen ist. Ich habe dort (p. 108) angegeben, dass der Aussenrand der Vorkammern nur an bestimmten Stellen mit dem Herzbeutel verwächst, und dass au diesen Stellen zugleich das Blut aus dem Mantel in die Atrien übertritt. In Wirklichkeit stossen die dorsale und die ventrale Wand der Vorkammern am Aussenrande überhaupt nicht zusammen, sondern die Begrenzung des auf dem Querschnitte dreieckigen Lumens der Atrien wird am Aussenrande durch das Mantelgewebe vermittelt, welches mit Ausnahme der erwähnten Öffnungen von einem zarten Endothel überkleidet wird. Die Verhältnisse sind übrigens in meiner Figur 5 I (Taf. 7) ganz richtig gezeichnet worden.-Die Aorta fehlt bei Nuttalochiton hyadesi, wo der Spaltraum zwischen den beiden Genitalorganen das Blut nach vorn leitet. Eine Artcria visccralis fehlt bei einer ganzen Anzahl von Arten (Callistochiton viviparus, Nuttalochiton hyadesi, Callochiton lacvis, Ischnochiton ruber, Chiton olivacens); sie ist sehr kurz, d. h. ragt nur wenig über das Hinterende der Radulascheide hinaus bei Lepidopleurus cajetanns. Beiden merobranchen Arten ist die Vena branclizalis so lang wie die Kiemenreihe, während die Kiemenarterie sie bedeutend an Länge übertrifft.

Die Niercn stehen, wie ich dies schon früher betont habe, in engster Correlation mit den Kiemen, in so fern als ihr Vorderende in derselben oder nahezu in derselben Querebene liegt wie die vorderste Kieme. Weshalb beide Organe in ihrer Längenausdehnung von einander abhängen, ist mir freilich unverständlich, denn die Thatsache, dass jedes Respirationsorgan auch als Excretions- 
organ aufgefasst werden kann, erklärt jenen Zusammenhang nicht. An der Niere kann man stets den eigentlichen Hauptkanal mit dem Ureter und den Renopericardialkanal unterscheiden, dieser letztere zerfällt wieder in einen kurzen, mit starken Cilien ausgeriisteten und sich direct an den Herzbeutel anschliessenden Trichterabschnitt und einen längeren secretorischen Theil, dessen hintere Strecke in der Regel sehr dicht mit Concrementen gefüllt ist und sich daher durch besonders intensive Färbung auszeichnet. Auch der Ureter erhält in einigen Fällen (Lepidopl. cajetanus) ein secretorisches Epithel längs seiner innern, sich an den Hauptkanal anschliessenden Region, so dass dann der Ureter sensu strictiori, d.h. der nur zur Ausleitung dienende flimmernde Abschnitt, sich auf diejenige Partie beschränkt, welche nach aussen resp. ventral vom lateralen Markstrang liegt. Der secretorische Uretertheil ist zu einem grossen Sack umgebildet bei Nuttalochiton hyadesi, in geringerem Masse erweitert bei Callistochiton wiviparus. Am Renopericardialgang ist der Trichter immer gut entwickelt und zeigt keine besondern Modificationen, wo hingegen der secretorische Abschnitt sehr veränderlich ist. Abgesehen von seinem, schon früher erörterten, sehr variabelen Ursprunge am Hauptkanal zwischen dem III. und VI. Segment, möchte ich hier auf Folgendes aufmerksam machen. Bei Hauleya hauleyi trägt er kurz vor dem Übergang in den Trichter einen nach hinten gerichteten Blindsack. Bei Callistochiton viviparus und Lepidoplcumus cajetanus ist er ausserordentlich kurz und bei der letztern Art sacliartig erweitert. Für Nuttalochiton hyadesi muss ich meine in den S. B. Berliner Akademie, I898, p. 2 I 5 gegebene Darstellung dahin berichtigen, dass dieser Abschnitt des Renopericardialkanals überhaupt fehlt, indem der Trichter direct in den sehr weiten Hauptkanal der Niere einmündet.

Nervensystem. Variabel ist namentlich das Verhalten der Lateropedalconnective, die in grosser oder in geringer Zahl jederseits auftreten oder auch vollständig fehlen, und zwar finde ich, dass merkwürdiger WVeise nahverwandte Species in diesem Punkte von einander abweichen. So hat Lepidoplemms cajetamus zahlreiche, Lep. asellus nur wenige solche Verbindungstränge; bei Callochiton lacvis und Ischnochiton nuber vermag ich sie nicht zu finden, während sie bei Callochiton rubicundus (nach Thiele) und bei Ischnochiton imitator in grosser Zahl vorkommen, und derselbe Gegensatz besteht zwischen den Tonicien und Enoplochiton niger einerseits und Acanthopleura echinata andererseits.

Wie ich früher gezeigt habe, werden die Aestheten von Nerven der lateralen Markstränge versorgt, aber es blieb unerklärt, warum für die ungeheuere $Z$ ahl dieser Sinnesorgane nur verhältnissmässig so wenige Nerven vorhanden sind. Der Grund liegt darin, dass jeder dieser Nerven sich interepithelial zwischen den basalen Enden der Zellen ausbreitet und daher ein grosses Gebiet zu innerviren vermag. 
Bei Callochiton lacvis kommen Schalenaugen vor, die nach einem ganz anderen Typus gebaut sind als die Sehorgane der Tonicien und Liolophurinen. Das Auge liegt im Innern des Aesthetenkörpers und hängt mit dessen grosser Chitinkappe nicht zusammen. Es wird gebildet von einem Pigmentbecher, welcher eine kugelige Linse umfasst, an die sich eine einzige (vielleicht zuweilen auch zwei) Sinneszelle anschliesst.

Ein typisches Osphradium in Form eines neben dem After gelegenen Epithelhöckers von Sinneszellen kommt bei sehr vielen Chitonen vor, bald als länglicher Wulst, bald als kürzeres rundliches Gebilde. Es findet sich auch bei Arten, deren Kiemen bis unmittelbar an die Afterpapille hinan reichen (Enoplochiton niger). Ich kenne dieses Organ bis jetzt von I2 verschiedenen Arten, unter denen sich sowohl primitive (Nuttalochiton hyadesi) wie hochdifferencirte (Tonicia fastigiata) Formen finden. Es fehlt vollständig bei Callistochiton viriparus, Callochiton laevis, Hauleya hauleyi und den Lepidopleuriden. Bei den beiden letzten Gattungen wird es ersetzt durch ein hohes Sinnesepithel auf der Aussenkante der hinteren Kiemen, wobei es zunächst als unentschieden zu gelten hat, ob dieses Kiemenosphradium eine Neubildung darstellt oder durch Verlagerung aus dem typischen Geruchsorgan entstanden ist. In Zusammenhang mit dem Kiemenosphradium tritt bei Hauleya und Lepidopleurus je ein Ganglion in dem Nervus branchialis externus der betreffenden Kieme auf. Die Zahl derselben wie auch der zugehörigen Sinnesorgane ist nicht ganz constant, da sie etwas vom Alter abhängt.

Die von Thiele entdeckten Seitenorgane an der Aussenwand der Mantelrinne kommen ausser in der Gattung Lepidopleurus auch bei Hauleya hauleyi vor. Die Schleimkrausen der Mantelrinne können als pedale, neurale, palliale und branchiale unterschieden werden, je nachdem sie an der Seitenwand des Fusses, am Dache der Mantelrinne unterhalb des lateralen Markstranges, an der Unterseite des Mantels oder an der Innenkante der Kiemen auftreten. Die Kiemenkrausen kenne ich nur von den Gattungen Lepidopleurns und Hauleya. Die übrigen drei Sorten können in der verschiedenartigsten Combination auftreten und auch sehr verschieden lang sein. Bei Ischnochiton ruber sind sie alle drei zu den von Haddon beschriebenen "Fenestral glands" umgewandelt. Bei sehr vielen Chitonen, speciell bei den höheren Formen, fehlen die Schleimkrausen.

\section{Chitonicium SIMPLEx, EIN NEUER ZELlPARASIT.}

\section{Von Prof. L. Plate.}

In der Mantelhöhle des Ischnochiton imitator Smith (conservirtes Material aus der Bucht von Talcahuano, Chile) kommt in grossen Mengen ein neuer einzelliger Zellparasit vor, der mir wegen 
seiner einfachen Fortplanzungsweise von Interesse zu sein scheint. Er findet sich theils frei in der Mantelhöhle, theils in dem Epithel der Mantelrinne, der Kiemen und des Fusses, welches er auf grosse Strecken hin vollständig zu zerstören vermag. Sowohl im freien, wie im parasitischen Zustande tritt er in zwei verschiedenen Formen auf, die aber durch Übergänge mit einander verbunden sind, und als Rundstadium und Sichelstadium unterschieden werden mögen. Das erstere stellt eine kleine kugelrunde Zelle dar, die nach aussen von einer glatten Membran begrenzt wird und einen ungefähr $4 \mu$ grossen Kern umschliesst. Der Nucleus ist rund und erscheint intensiv und homogen tingirt oder er lässt einige Nucleolen erkennen. Der Zellleib ist bald im Vergleich mit dem in Grösse ziemlich constanten Kern sehr schmal, bald besitzt er den 2-3 fachen Durchmesser desselben, und zwar finde ich ersteres Verhalten hauptsächlich bei den intra-, letzteres bei den extracellulären Individuen. Befindet sich der Parasit im Innern einer Epithelzelle, so erscheint seine Membran in der Regel viel zarter als im freien Zustande. Nie habe ich irgend eine Andeutung von Pseudopodien oder erheblichen Formveränderungen gesehen, sodass ich dieses Rundstadium für unbeweglich halte. Der Parasit bewirkt den Tod der Epithelzellen, worauf deren Protoplasma zerfällt und sich auflöst, während ihre Kerne sich erheblich länger erhalten und als blass gefärbte Gebilde zwischen den Chitonicien beobachtet werden. Auch die Cuticula der zerstörten Epithelzellen behält stellenweise noch längere Zeit ihre ursprüngliche Lage bei und verhindert, dass die nach innen von ihr isolirt liegenden Zellschmarotzer in die Mantelrinne fallen, bis schliesslich auch sie abfällt. Dann sammeln sich die Parasiten zu Tausenden in der Mantelrinne, wo sie, wie es scheint, von dem Schleim der Schleimkrausen festgehalten werden.

Die Vermehrung des Rundstadiums erfolgt durch einfache amitotische Theilung und zwar sowohl intra- wie extracellulär, wobei in einzelnen Fällen die beiden Tochterkerne nicht genau gleich gross sind.

Das Sichelstadium findet sich hauptsächlich intracellulär, doch auch nicht selten frei in der Mantelhöhle. Es geht aus dem Rundstadium dadurch hervor, dass der Kern und der Zellleib sich in die Länge strecken und eine stab- oder spindelförmige Gestalt annehmen. Manchmal ist das eine Ende angeschwollen, wodurch das Thierchen keulenförmig wird. Sehr häufig krümmt es sich leicht zusammen und erscheint dann sichelförmig. Ich halte diese Formen für das Bewegungsstadium des Chitoniciums und zwar weil sie erstens zuweilen gleichzeitig in zwei Zellen liegen, zweitens mit dem einen Ende frei aus einer Zelle heraus ragen können und drittens die eine Körperhälfte manchmal etwas gegen die andere eingeknickt oder eingerollt wird. Auf diesem Stadium vermag also vermuthlich das Chitonicium simplex ruckweise beide Körperenden gegen einander $\mathrm{zu}$ schlagen und sich auf diese Weise nach 
Art der Sichelformen der Sporozoen zu bewegen. Auch auf dem Sichelstadium vermag der Parasit sich durch amitotische Theilung zu vermehren.

Obwohl ich mehrere stark inficirte Exemplare des Ischnochiton imitator auf Schnitten untersucht habe, ist mir nie irgend eine Andeutung von einer Cysten- oder Sporenbildung oder von einfacher Vieltheilung zu Gesicht gekommen, und da ich die Vermehrung durch directe Theilung sowohl im parasitischen wie im freien Zustande beobachtet habe, so ist es auch nicht wahrscheinlich, dass eine solche vorkommt. Da der Ischnochiton imitator seine Eier in der Mantelrinne aufspeichert und die jungen Thierchen sich hier unter dem Schutze der Mutter eine Zeit lang aufhalten, so kann eine Neuinfection derselben immer mit Leichtigkeit stattfinden, auch ohne wiederstandsfähige Cysten oder Sporen. Über die systematische Stellung des Chitonicium simplex will ich mich an dieser Stelle nicht ausführlich äussern, da ich den Schmarotzer später in der Fauna chilensis eingehend an der Hand von Abbildungen zu schildern gedenke. Die intracelluläre pathogene Lebensweise und das Sichelstadium weisen auf die Sporozoen hin, von denen sich unsere Form freilich auffallend durch den Mangel der Sporenbildung unterscheidet. Erzeugung zahlreicher Nachkommen durch Sporen stellt offenbar eine Anpassung an den Parasitismus dar, so scheint das Chitonicium simplex ein Protozoon zu sein, das zu der parasitären Lebensweise erst kürzlich übergegangen ist und daher diese Eigenschaft der Schmarotzer noch nicht erworben hat. Dieselbe oder eine sehr nahe stehende Form von Zellparasiten habe ich neuerdings im Mantelepithel von Chaetopleura peruviana Lam. gefunden.

\section{On a New TYPE OF NePhridium in THE Glycerid.E.}

\section{By $\operatorname{Mr}$ E. S. Goodrich.}

The nephridium of the Polychaete Glycera is of very interesting and peculiar structure. In this worm there is a well developed 'ciliated organ,' in connection with a 'nephridial sac' formed of cœlomic epithelium, over which spreads the true nephridium. The three closely connected organs may be called the "nephridial complex'; it is situated on either side in front of the septum in every segment excepting the first few. These organs have been described by Ehlers, but the structure and relations of the parts were not at all understood.

The nephridium has no internal opening. On reaching the nephridial sac its canal divides and branches, forming a network of secondary canals leading to chambers from the outer or cœlomic surface of which emerge 'tube-bearing cells' or solenocytes (somewhat similar to those of Nephthys). These solenocytes consist of a cell-body containing a nucleus, and a thin conical tube in which 
works a flagellum projecting into the underlying nephridial chamber. They are distributed in groups of from 2 to 5 over the surface of the nephridium.

In Glycera (unicornis, Sav., siphonostoma D. Ch.) the ciliated organ extends on the one hand to the body-wall, and on the other into the open mouth of the nephridial sac, reaching to the extremity of a blind outgrowth of this sac, which may be called its cæcum. Dead cells, solid excretory products, and waste débris of all kinds accumulate in the sac by the action of the ciliated organ. Here they appear to undergo dissolution, the soluble parts presumably pass through the thin wall into the nephridium. Direct observation and experiment seem to shew that the nephridium absorbs only the soluble waste products from the cœlomic fluid. The function of the solenocytes is perhaps the excretion of water.

\section{Note on Preserving Rotatoria.}

\section{By Mr Charles F. Rousselet.}

The object of this communication and demonstration, although of very secondary importance, may yet interest some members of this Congress, particularly those who take part in the biological study of fresh water lakes and their microscopic inhabitants, in which such great advances have been made of late years.

I find that Ehrenberg already tried to make preparations of Infusoria and Rotifera by allowing the animals to dry on a slip of glass and covering them with a piece of mica; in this way the flat outline of contracted Rotifers was obtained, but the real shape and internal organs of the animals were of course quite lost. Then a common mode of preservation has been to put gatherings of Rotifers in alcohol in which they contract to a shapeless mass and many serious errors have been made in attempting to describe new species from such material.

Many attempts have no doubt since been made at preserving Rotifera in a more natural condition with the result that up to quite recently all text-books have pronounced this group of animals to be unpreparable.

Having taken up the study of the Rotifera some years ago, I soon felt the want of type specimens which could be referred to for comparison and for the identification of species. After many experiments, extending over three years, I was successful in devising a method by which most Rotifers can be preserved and mounted as permanent objects in their natural form, fully extended, white and nearly as transparent as in life, with cilia, muscles, nerve threads and all tissues preserved in situ.

I will not trouble you with the details of the progressive steps by which this result was obtained, but will merely explain my method and afterwards show you the results. 
Rotifers cannot be killed off-hand by osmic acid or other agent, without complete contraction, and it is therefore necessary to use a narcotic, and the best for this purpose has been found to be a mixture of cocain and methylated spirit made as follows :

2 per cent. solution of hydrochlorate of cocain...3 parts

Methylated spirit ............................... ",

Water.........................................6 ",

The Rotifers must first of all be isolated, by picking them up one by one if necessary, in perfectly clean water in a watch-glass; one or two drops (not more) of the narcotizing solution is then added; after 5 to 10 minutes a few more drops are added, and so on until the animals move very slowly and, on trial, can be killed fully extended. The killing and fixing agent is very weak ( $\frac{1}{4}$ to $\frac{1}{8} \%$ ) osmic acid of which one drop only is added, and after one minute the animals are washed by transferring them by means of a very fine pipette into several changes of clean water, so as to remove all traces of the acid. Finally the Rotifers are transferred into $2.1 \%$ solution of formaldehyde (2 $\frac{1}{2}$ parts of the commercial $40 \%$ formalin and $37 \frac{1}{2}$ parts distilled water) in which fluid they are also mounted on micro slides with hollow ground cavities. The whole process is necessarily performed under a dissecting microscope.

For further particulars of details of manipulation and treatment of some difficult species, I will refer you to two papers I have published in the Fournal of the Quekett Microscopical Club of July I 893 and March I 895.

By this method I have so far made a collection of over 400 slides, containing about 260 different species of Rotifers, some samples of which are exhibited under is microscopes in the Zoological Laboratory, which will enable you to judge of their merit.

Since the publication of Hudson and Gosses' monograph in I 889 a large number of new species (355) of Rotifers has been described; many of these forms are merely synonyms and were previously known, but had not been figured and described with sufficient accuracy. It seems to me that collections of this kind afford the best means of identifying doubtful species and preventing the growing evil of giving new names to already known forms. I would suggest that mounted specimens of all Rotifers that are described as new should be deposited in some museum, say of Cambridge, where they would be accessible to examination. 


\title{
SECTION C. INVERTEBRATA.
}

\author{
WedNESDAY, 24 August, at 3 p.m.
}

Chairman, M. BLANC.

The following papers were read:

I. Sur L'Utilité DE L'Uniformitế D'ORIENTATION DES FIGURES ZOOLOGIQUES.

\section{Par Prof. Paul Pelseneer.}

Il arrive très souvent que des auteurs différents orientent différemment des figures correspondantes, relatives aux mêmes organismes.

Cette différence d'orientation rend très incommodes les comparaisons ultérieures et constitue ainsi un sérieux obstacle aux recherches.

Dans le but de faire établir une certaine discipline dans cette partie des travaux zoologiques, Prof. Pelseneer propose à la Section C d'émettre le vœu que cette question soit portée à l'ordre du jour du prochain Congrès. (Abstract.)

\section{Sur la CONDENSATION EMBRYOGÉNIQUe CHEZ UN NUDIBRANCHE.}

\section{Par Prof. Paul Pelseneer.}

Tous les Nudibranches quittent l'œuf sous forme de veliger libre, pourvu d'une coquille, d'un opercule et d'un grand velum bilobé.

Cenia Cocksi A. \& H. (forme voisine de Elysia et Limapontia) éclot au contraire avec la forme de l'adulte. Pendant la période de développement avant l'éclosion, il ne se forme ni invagination préconchylienne, ni coquille, ni opercule; cependant il existe, pendant quelques jours, un velum fort réduit et peu saillant, ce qui montre que le développement n'est pas direct et qu'il y a condensation embryogénique.

Cette condensation est en rapport avec les conditions d'existence presque supralittorale de l'adulte; elle a pour conséquence la grande réduction du nombre d'œufs contenus dans la ponte (4 à̀ 12). (Abstract.) 


\section{Fertilisation of the EgG of Rhynchelmis.}

\section{By Prof. F. Vejdovský.}

Prof. VEJDOVSKÝ of the University of Prague spoke on certain phenomena in the fertilisation of the egg of Rhynchelmis, the centrosome of which undergoes very complicated changes which were demonstrated by a series of beautiful microscopical preparations. He said :

In a preliminary note, which will be published in the "Sitzungsber. kön. böhm. Gesellsch. der Wissenschaften" for the year I 898, I have in collaboration with my assistant $A$. Mrázek announced the results of the new researches on the dynamic elements in celldivision, known as "centrosome" (Boveri), "corps central" (E. Van Beneden), and "periplast" (Vejdovský). The morphological significance of these bodies is up to the present time disputable, although it is certain that they originate from the spermacytoplasma.

In most, if not in all cases, the "centrosome" is surrounded with a hyaline sphere, the "sphère attractive" of E. Van Beneden. In my nomenclature the sphere is designated as "mother-periplast" and the "centrosome" of Boveri as "daughter-periplast." I have, that is to say, in opposition to Boveri and E. Van Beneden demonstrated that the dynamic body for the next cell-division-the daughter-periplast-originates in the centre of the sphere of the preceding division, or in the mother-periplast.

In our present researches on the fertilization and division of the ova of Rhynchelmis we are able to confirm my old interpretation, that the so-called "sphère attractive" is the increased daughterperiplast or the centrosome of Boveri. The ova of Rhynchelmis are the most favourable material to solve the question, the divisionbodies being of such a size, that it is possible to recognize them with the naked eye.

I shall now demonstrate a series of some successive stages of fertilization and division of these eggs, the results of which are as follows :

(I) The division-element in the egg of Rhynchelmis is a very small, punctiform corpuscle; it is not identical with the centrosome of Boveri, nor with the "corps central" of E. Van Beneden, corresponding only to the so-called "centriole." Notwithstanding this we designate it as centrosome. In the primitive state the corpuscle occupies the centre of a great sphere, the mother-periplast.

(2) In the period of fertilization, when the female pronucleus meets with the male one, our centrosome is surrounded by a small hyaline sphere, which I designated twelve years ago as daughterperiplast. It is probable that the sphere originates from the changed peripheral stratum of the centrosome, the last being smaller than in the preceding stage. 
(3) In the next following stage, when the pronuclei are still not fused together, the daughter-periplast begins to increase and the growth proceeds during the prophase in such a degree, that on the inside of the mother-periplast a great sphere appears, consisting of a fine reticulated protoplasma. In the centre of this daughterperiplast lies the indistinct centrosome.

(4) During the anaphase there is no primary mother-periplast, its place being now occupied by the daughter-periplast, which appears as a great reticulated sphere. The centrosome increases a little and is more distinct than in the preceding stage.

The protoplasmic radiation is in this stage double; the external one on the periphery of the sphere, and the interior, concentrated towards the centrosome. The inner radiation originates from the reticulum of the periplast, the radii thence are to be interpreted as a new formation (Neubildung). They afterwards lengthen from the centre to the periphery of the periplast and fuse with the external radii.

(5) During the stage of karyokinesis, when the new nuclei are reconstructed, the centrosome is again surrounded with a small hyaline sphere-the new daughter-periplast. The centrosome divides and in this way arises the "Centralspindel."

The nuclei move into the mother-periplast, the external radiation of which is resorbed in a granular protoplasma. Afterwards the nuclei reach into the "Centralspindel."

The centrosome with the periplast is therefore a whole, which can be designated as "centrosphere" (Strasburger).

Prof. R. HERTIVIG of Munich said:

Im Anschluss an den Vortrag des Herrn Vejdovský berichtete R. Hertwig (München) über ähnliche Umgestaltungen des Centrosoma, welche während der Encystirung von Actinosphacrium Eichhomi beobachtet werden. Die Encystirung dieses Rhizopoden ist mit Befruchtungsvorgängen combinirt und verläuft folgendermassen. Nachdem das Thier sich mit eines Gallertschicht umgeben hat und ein grosser Theil der Kerne aufgelöst worden ist, theilt es sich in eine grössere Zahl einkerniger Tochtercysten oder Primärcysten. Eine jede der letzteren liefert durch Theilung ein Paar Secundärcysten. Der Kern der Secundärcysten theilt sich karyokinetisch zweimal, wobei aber immer ein Theilproduct als Richtungskörper nach aussen entfernt wird. Die nach Bildung der Richtungskörper gereiften Secundärcysten verschmelzen paarweis unter einander zu den Keimkugeln, aus denen nach längerer Ruhe je ein kleines Actinosphaerium auskriecht.

Nur während der Richtungskaryokinesen beobachtet man Centrosomen, welche vom Kern aus neu gebildet worden, indem das Kernnetz in das umgebende Protoplasma hineinwuchert, indem ferner die hineingewucherte Partie sich abschnïrt und einen 
spongiösen Körper erzeugt. Letzterer, das Centrosoma, nimmt anfangs an Grösse zu, wird aber später aufgelöst mit Ausnahme von zwei kleinen Körperchen, welche sich als Verdichtungen im Centrosoma, Centriolen (Boveri), entwickelt haben. Die allein übrig bleibenden Centriolen werden die Centrosomen für die nun beginnende I. Richtungskaryokinese; sie nehmen an Grösse zu und bekommen wieder ein spongiöses Aussehen. Nachdem die Theilung beendet und ein Richtungskörper eliminirt worden ist, erfährt das Centrosom des übrigbleibenden Kerns abermals eine theilweise Resorption. Es erhält sich ein kleines Stäbchen, welches durch Theilung die Centrosomen für die zweite Richtungskaryokinese erzeugt. Während der anschliessenden Spindelbildung erfolgt abermals eine Vergrösserung der Centrosomen.

Es ist zweckmässig die vergrösserten und durch Flüssigkeitsaufnahme gelockerten Centrosomen Centrosphaeren zu nennen. Dann kann man die bei Actinosphaerium auftretende Metamorphose der Centrosomen in folgender Weise kurz beschreiben: Die Centrosomen schwellen zu Centrosphaeren an; in denselben entwickeln sich Centriolen. Nach Auflösung der Hauptmasse der Centrosphaeren bleiben die Centriolen allein übrig und werden zu Centrosomen, die nun von Neuem anwachsen. Der gesammte Vorgang wiederholt sich bei der nächsten Theilung. Wahrscheinlich sind derartige ähnliche Metamorphosen der Centrosomen bei den Metazoen weit verbreitet und liegen vielleicht auch in dem von Herrn Vejdovský beobachteten Falle vor.

\section{New Integumentary Sense Organs of Rhyncho-} BDELLIDE.

\section{By Prof. F. Vejdovský.}

Prof. VEjDovskÝ gave the results of the studies of Emil Bayer (University of Prague) on peculiar sense-organs in the skin of certain leeches consisting of a large projecting epithelial cell, the base of which is embraced by a cup-shaped muscle cell. The paper has just appeared in the Zeitschrift fïr wiss. Zoologie, I898.

5. Prof. S. J. HiCkson gave a Demonstration OF THE MEDUSÆ OF MilleporA. 


\section{SECTION C. INVERTEBRATA.}

FRIDAY, 26 August, at 2 p.m.

Chairman, Dr C. W. Stiles.

The following papers were read:

\section{ENTOZOEN DER APLACENTALEN SÄUgETIERE.}

Von Prof. Dr F. Zschokke.

Abgesehen von einigen von $G$. Krefft gesammelten, aber nur ungenügend beschriebenen Formen, sind aus Monotremen und Beuteltieren folgende Bandwürmer beliannt :

Taenia festiva Rud., aus Macropus giganteus;

T. eclidinae D'A. W. Thompson, aus Echidna hystrix;

T. obesa Zsch., aus Phascolarctus cinereus;

T. sarasinom Zsch., aus Phalanger ursinus;

$T$. edulis Zsch., aus Phalanger ursinus;

T. semoni Zsch., aus Perameles obesula.

Alle sechs Arten gehören der Unterfamilie der Anoplocephalinae an; sie wurden mit Ausnahme von $T$. festiva durch Redner genau untersucht.

Innerhalb der Gruppe der Anoplocephalinen verteilen sich die Cestoden der aplacentalen Säuger auf drei Gattungen. T. festiva zählt zu Moniezia, $T$. obesa, $T$. edulis und $T$. sarasinorum zum Genus Bertia; für $T$. echidnae und $T$. semoni endlich, muss eine neue Gattung unter dem Namen Linstowia geschaffen werden.

Die Gattung Bertia selbst zerfällt wieder in drei Unterabteilungen, deren Unterschiede sich im Bau und in der gegenseitigen Lage von Excretions-, Nerven- und Genitalsystem deutlich ausprägen. Gleichzeitig gehören die drei Gruppen verschiedenen Ordnungen von Wirthen-Nagetieren, Affen, Beuteltieren-an. Den Bertien aus Marsupialiern steht am nächsten $B$. plastica Sluiter, aus Galeopithecus volans. Die als B. studeri R. Bl., und $B$. satyri R. Bl., betitelten Cestoden anthropoider Affen können einstweilen nicht mit Sicherheit in das System eingereiht werden, da sie anatomisch ungenügend bekannt sind. Die Diagnose der Gattung Bertia hat sich auf die viel besser beschriebenen Formen von Cestoden aus Nagern, Beutlern und Affen zu gründen.

Linstowia n. g. schliesst sich eng an Bertia an; doch bleibt 
sie vollkommen selbständig in der starken Entwicklung der Rindenschicht, in der dorsalen Lage der Excretionsstämme und Längsnerven gegenüber den Genitalgängen, in der gewaltigen, walzenförmigen Streckung des Cirrusbeutels. Typisch jst auch die mediane Lage des Complex der weiblichen Drüsen und die Verteilung der Hoden. Dotterstock und Schalendriisen folgen sich in ventro-dorsaler Richtung; die Eier werden einzeln in Parenchymkapseln eingeschlossen: die engen, ursprünglich dorsalen Gefässstämme liegen lateral von den weiten, ventralen.

Aplacentale und placentale Säugetiere, die eine ähnliche Lebensweise fuihren, beherbergen anatomisch verwandte Cestoden. Moniczic ist characteristisch für die rein herbivoren Wiederkäuer und Känguruhs; eine gut umschriebene Untergruppe der Gattung Bertia bewohnt Phascolarctus und Phalanger, aber auch Galeopithecus, die sich alle von Blättern, Friichten und gelegentlich wol auch von Insekten ernähren.

In aplacentalen Insektenfressern endlich - Pcrameles und Echidna-schmarotzt die Gattung Linstowia, zu welcher eine Parallele aus placentalen Säugern einstweilen nicht bekannt ist.

\section{LES FORMES ÉPITOQUES DES ANNÉLIDES ET EN PARTICULIER DES CIRRATULIENS.}

\section{Par MM. Félix Mesnil et Maurice Caullery.}

Nous désirons, dans la présente communication, rendre compte d'observations qui nous ont révélé, chez des Polychètes Sédentaires, l'existence de particularités considérées jusqu'ici comme spéciales aux Errantes. Il s'agit du phénomène qu'EHLERS ${ }^{1}$ a appelé épitoquie, que CLAPARÈDE ${ }^{2}$ a désigné peu après sous le nom d'épigamie.

Rappelons d'abord la nature de ces phénomènes. Nous choisirons pour cela l'exemple étudié par EnLERs, les Néréidiens. Jusqu'en I 865 , on considérait, dans cette famille, comme des formes indépendantes les espèces des genres Nereis et Heteronereis. Les Heteronercis étaient caractérisées par une complication plus grande des parapodes, par la présence d'un faisceau puissant de grandes soies natatoires en palette et par le grand développement des yeux. MALMGREN ${ }^{3}$, le premier, eut l'idée que les Heteronereis n'étaient pas des formes autonomes, mais provenaient de la transformation des Nereis. D'une façon indépendante, EHLERs arrivait à la même conclusion, mais, par une étude minutieuse, il en établissait définitivement l'exactitude. Toute Heteronereis résulte de la métamorphose d'une Nereis correspondante. Cette métamorphose, qui

1 EhLers--Die Borstenwürmer, Leipzig, I 868.

2 Claparède-Supplément aux Annélides du golfe de Naples; Arch. Sc. Phy's. et Nat. Genive, xx, I870.

3 Malmgren-Nordiska Hafs Annulater, $K$. Vet. Acad. Förh., xxıI, I 865. 
survient au moment de la maturité sexuelle, a pour résultat d'accroître la mobilité de l'animal (les Heteronereis sont, en fait, des formes essentiellement nageuses, menant une vie presque pélagique), partant de favoriser la dissémination des produits génitaux et finalement de l'espèce. C'est une modification liée à la puberté, une parure de noces. L'Hcteronercis est la forme sous laquelle la Nereis est prête à la reproduction, d'où le nom de forme épitoque que lui donna EHLERS; par opposition la Nercis immature fut appelée forme atoque. CLAPAREDE préféra appeler phase épigame la période pendant laquelle se fait la transformation morphologique de la Nereis en Heteronercis.—L'existence de formes épitoques n'est pas limitée aux Néréidiens. Il suffit d'examiner ce qui se passe chez les Syllidiens pour reconnaître qu'à la maturité sexuelle, il y a aussi une transformation épitoque, mais que, le plus souvent, le phénomène est compliqué secondairement, par une scission du corps de l'animal en tronçons organisés pour une vie indépendante. Ainsi est mieux encore assurée la dissémination de l'espèce.

Ce sont là les deux exemples d'épitoquie ou d'épigamie qui sont classiques; il en est d'autres beaucoup moins connus et d'ailleurs moins frappants. Ils consistent en effet le plus souvent dans la simple adjonction de soies fines et longues (soies de puberté) aux soies ordinaires de l'espèce. On en a signalé chez un Hésionien (Kefersteinia cirrata Kef.), chez plusieurs Phyllodociens (Eulalia problema Malmgren, Mystides limbata de St Joseph etc.) et dans d'autres familles. Mais ce sont là des indications isolées, d'où on peut tout au moins tirer cette conclusion que les phénomènes d'épitoquie ont une assez grande généralité chez les Annélides Errantes ${ }^{1}$.

On ne connaissait aucune trace de ces phénomènes chez les Annélides Sédentaires. Or nous en avons trouvé, et des plus typiques, chez des Cirratuliens, notamment chez Dodecaceria conchamm CErst. et chez Heterocirmus wiridis Lghns. On est conduit, de plus, par l'étude bibliographique de la famille, à y soupçonner d'autres cas d'épitoquie, de sorte que celle-ci doit y être assez répandue. Limités par le temps, nous nous bornerons ici à l'examen rapide des faits que nous a révélés l'étude de Dodecacoria concharmm.

Dodecaceria conchamm est une Annélide décrite, il y a longtemps, par CERSTED ${ }^{2}$ et revue depuis par un grand nombre de zoologistes, sur les côtes océaniques et méditerranéennes de l'Europe, à Madère et sur les côtes d'Amérique. Son anatomie ne s'écarte pas sensiblement du type très homogène des Cirratuliens, mais néanmoins il occupe dans la famille une place spéciale et assez isolée. C'est un genre bien caractérisé par la limitation des appendices (I paire de palpes et $4^{-6}$ paires de

1 Nous nous bornons ici à cette indication. On trouvera le détail des divers cas publiés, dans un mémoire développé, en ce moment sous presse, dans les dunales de I Université de Lyon. Même remarque pour les autres points de cette communication.

2 CERsted-Annulatorum Danicorum conspectus, Copenhague, $1 s_{+3}$. 
branchies) sur les premiers anneaux métastomiaux et par la présence de soies tout à fait particulières. Il $\mathrm{y}$ a en effet: $\mathrm{I}^{\circ}$ des soies capillaires, $2^{\circ}$ des soies fortes, terminées par une excavation en forme de cuiller. Sans entrer dans le détail, disons que chaque rame comporte deux rangées de soies, l'une de capillaires, l'autre de soies en cuiller. Les 5-6 premiers anneaux n'ont que des capillaires. Ces dernières manquent à un certain nombre de rames vers le tiers antérieur du corps. Chaque rangée comprend typiquement de 2 à 6 soies. Les deux rames sont implantées directement dans la paroi; il n'y a pas à proprement parler de parapode. L'extrémité postérieure de l'animal est aussi très caractérisée par son aplatissement et sa forme légèrement en spatule.

Dodecaceria est une annélide littorale ou de faibles profondeurs et essentiellement calcicole. On la trouve, soit dans des roches calcaires, soit dans de vieilles coquilles de Mollusques, soit dans des algues calcaires. Sur la côte de la Hague, près de Cherbourg (Manche), où nous l'avons étudiée, nous l'obtenons en abondance (nous en avons examiné plusieurs milliers d'exemplaires), dans l'épaisseur du Lithothamnion polymorphum. Cette algue tapisse, de plaques formant un revêtement, qui atteint souvent $2 \mathrm{~cm}$. et même $3 \mathrm{~cm}$., les anfractuosités des rochers où la mer, en se retirant, laisse des mares toujours pleines d'eau. L'algue abonde surtout dans la zone qui découvre aux marées moyennes. Dans le Lithothamnion, Dodecaceria creuse et habite des galeries où il vit replié en $U$, la face dorsale étant à la concavité. A l'état d'extension, il laisse émerger, par l'orifice de la galerie, sa tête et son panache d'appendices. Jamais l'animal ne quitte son tube.

Toutes ces remarques mettent bien en évidence que Dodecaceria concharum est, au premier chef, une Annélide Sédentaire.

L'étude de cette Annélide nous a conduits à reconnaître deux catégories de faits très inattendus:

$\mathrm{I}^{\circ}$. l'existence de formes épitoques,

$2^{\circ}$. l'existence d'un polymorphisme.

Pour résumer les résultats nous dirons, dès maintenant, que nous avons trouvé trois formes:

l'une A qui mûrit sans subir de métamorphose,

l'autre B qui se métamorphose en une forme épitoque nageuse,

la troisième $\mathrm{C}$ qui, elle aussi, aboutit à une forme épitoque, mais d'un faciès moins errant que B. Etudions successivement l'histoire de ces trois formes.

FORME A.

C'est à elle que se rapportent presque toutes les descriptions des auteurs antérieurs. Les quelques traits cités plus haut pour décrire Dodecaceria en général s'appliquent plus particulièrement à elle.

A l'état adulte (fig. I), elle compte de 50 à 60 segments. Ce- 
pendant on trouve des exemplaires qui en ont 70 et même $80^{1}$. Elle mesure de $2 \mathrm{~cm}$. ̀̀ $3 \mathrm{~cm}$. 5 ; sa couleur est assez uniforme, d'un brun-verdâtre plus ou moins foncé, allant quelquefois presque jusqu'au noir chez les grands individus. Ces variations de teinte sont dues à l'accumulation progressive d'un pigment granuleux insoluble dans l'ectoderme. L'ectoderme présente en outre un lipochrôme jaunâtre analogue à celui de l'Árénicole.

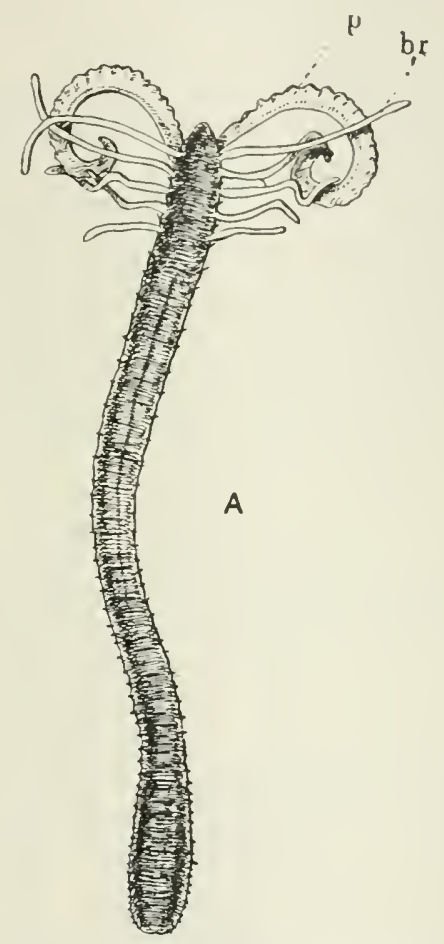

Fig. I. $p$, palpes; br, branchies.

Cette forme A est de beaucoup la plus commune, c'est la seule qui frappe au premier abord. Or, nous en avons vu plusieurs milliers, recueillies à toutes les époques de l'année, à la Hague, et une centaine recueillies en été à Guéthary (Basses Pyrénées); jamais nous avons trouvé un mâle, ni même un individu offrant trace de testicule ou de spermatogénèse. Nous nous croyons donc en droit de conclure qu'il n'existe que des femelles de la forme A.

Les ovules sont bien visibles en général, dès que l'individu atteint 35 sétigères; ils se détachent très tôt des glandes génitales

1 C'est le cas de ceux observés par DE Quatrefages (Hist. Nat. des Annelés, Paris 1865) et décrits par lui sous le nom de Fleterocirrus ater. 
qui tapissent la partie ventrale des dissépiments et ils tombent dans la cavité générale. Ils sont d'une couleur vert-bleuâtre et atteignent I 60 ou I $70 \mu$ environ, à l'état de maturité. C'est au printemps qu'ils sont à la fois les plus gros et les plus nombreux dans la plupart des individus: c'est donc vers le mois mai-juin que doit se placer, dans la Manche, la période la plus active de reproduction.

La cavité générale offre, outre les ovules, des cellules chargées de granulations de réserves éosinophiles sur lesquelles nous revenons un peu plus loin, à propos de la forme $B$, et qui, chez $A$, sont souvent groupées par quatre ou cinq.

$\mathrm{Au}$ moment de la maturité sexuelle, il ne se produit aucun changement extérieur, et, c'est là un des faits les plus curieux que nous ayons constatés, le développement des œufs se fait dans le corps maternel. La forme A est vivipare. Comme elle ne présente que des femelles, elle ne peut être fécondée que par une autre forme. Ce ne pourrait être que $B$, ainsi que nous le verrons. Mais, d'une part, on ne trouve jamais dans $\mathrm{A}$ aucun spermatozoïde et la copulation qui, seule, pourrait les introduire est bien invraisemblable chez les Cirratuliens; d'autre part, de nos observations semble résulter que le maximum de la reproduction de $\mathrm{A}$ a lieu en mai-juin, époque à laquelle $B$ n'est que très exceptionnellement mûr. Il est donc très-peu probable que $B$ féconde $A$ et nous arrivons à cette conclusion que $A$ est parthénogénétique.

Aư moment de la maturité, les ovules s'entourent d'une coque mince et transparente, puis émettent les globules polaires et subissent une segmentation totale. Nous n'avons pas étudié de près tous ces phénomènes qui ne nous intéressaient pas directement. Le développement se poursuit dans le cœlome maternel et on trouve des individus renfermant à leur intérieur des embryons au stade trochophore ou même ayant déjà l'ébauche de trois segments métastomiaux, d'ailleurs achètes. Le prostomium porte une paire d'yeux avec cristallin. Il existe une couronne de cils postérieure, de sorte que la larve est télotroque. Nous avons fait ces observations un grand nombre de fois.

Il est probable que ces embryons sont expulsés par les organes segmentaires. La forme A présente une grande paire de néphridies antérieures, dans les segments qui suivent immédiatement le prostomium; elles ont un rôle excréteur proprement dit. Ailleurs, il n'existe que des néphridies rudimentaires, consistant simplement en un contact des dissépiments avec une saillie de l'ectoderme, qui fait hernie à travers la couche musculaire. Il se perce sans doute à ce contact un pore, mais il ne se différencie pas de pavillon cilié interne et l'organe reste à l'état de rudiment. Il $y$ a là un point intéressant parceque nous trouverons tout autre chose chez $\mathrm{B}$ et $\mathrm{C}$.

Il est à remarquer qu'au moment où s'accomplit le développement des embryons, la cavité générale ne renferme plus de cellules à granulations de réserve. Celles-ci ont été employées pour achever l'édification des produits génitaux. 
Il faut observer d'autre part qu'à ce moment les glandes génitales n'ont pas disparu, mais qu'il se produit une nouvelle poussée d'ovules, de sorte que la forme A passe par plusieurs périodes de maturité successives.

Notons enfin que la viviparité présentéc par A est un phénomène tout à fait exceptionnel chez les Annélides. On ne peut en citer que les cas suivants: $\left(\mathrm{I}^{\circ}\right)$ chez des espèces que l'on a tout lieu de considérer comme unisexuées: Cirratulus chrysoderma? (CLAPAREDE et Metchnikoff, Zeits. fiir wiss. Zool., xix.), Syllis vivipara (KROHN, Arch. fiur Naturgesch., xxxv.), Syllis incisa (Levinsen, Vid. Meddel Nat. Förhandl., I 883); $\left(2^{\circ}\right)$ chez des espèces hermaphrodites: Nereis diversicolor (M. SCHULTzE, Abh. d. naturf. Gesells. Halle, III.), Nereis Dumerilii, forme hermaphrodite (Metchnikoff in Claparède, Arch. Soc. Plyys. Hist. Nat. Genève, xx.) et deux Serpuliens Salmacina dysteri, Ponatoceros triqueter (St Joseph, Ann. Sc. Nat., Se sér., Xvir.). Dans cette seconde série de cas, la viviparité paraît être occasionnelle plutôt que régulière; de plus, comme il y a hermaphrodisme, il y a peut-être autofécondation, tandis que la première série comporte probablement de la parthénogénèse et est par suite tout à fait analogue au cas de Dodecaceria.

\section{ForME B.}

Elle est relativement rare; nous en avons eu cependant, au cours de nos recherches, 2 à 300 exemplaires, aux divers stades.

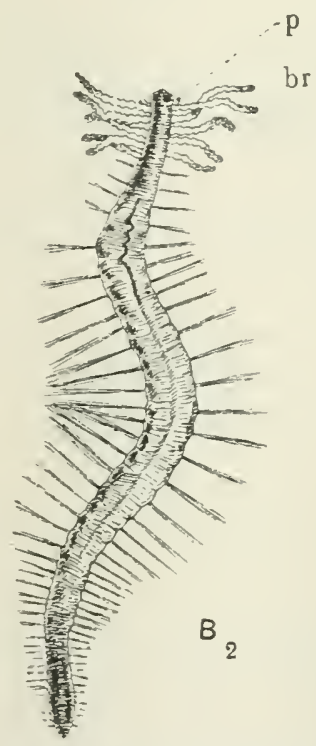

Fig. 2. $p$, palpes réduits à des moignons; $b r$, branchies. 
Cette forme B subit, lors de la maturité sexuelle, une métamorphose importante, de sorte qu'on peut la considérer à deux états :

$\left(\mathrm{I}^{\circ}\right)$ atoque, avant la métamorphose; nous l'appellerons alors $\mathrm{B}_{1}$.

$\left(2^{\circ}\right)$ épitoque, après la métamorphose, nous l'appellerons $\mathrm{B}_{2}$ (fig. 2 ).

$\left(\mathrm{I}^{\circ}\right)$ Etat atoque $B_{1}-\mathrm{A}$ cet état, la forme $\mathrm{B}$ offre avec $\mathrm{A}$ une ressemblance extrêmement étroite, et même, sur les jeunes stades, jusqu'à $20-25$ sétigères environ, il est très difficile de les distinguer. Elles ont même anatomie, même appareil sétigère. Cependant les soies en cuiller, particulièrement celles des dernières rames ventrales, offrent une différence très caractéristique. Chez $\mathrm{B}$, elles présentent, à la base de l'excavation terminale (fig. 3 B) une dent bien marquée. Si l'on fait l'étude minutieuse des soies, chez les très jeunes individus, on constate que cette dent correspond à une partie

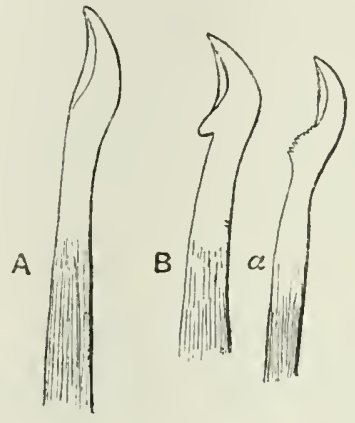

Fig. 3.

pectinée (fig. 3 a) occupant la même situation et qui, dans le cas des individus A, disparaît ensuite complètement (fig. $3 \mathrm{~A}$ ). Cette différence dans les soies ne se manifeste donc qu'à un stade relativement avancé.

En général, les individus $B_{1}$ se reconnaissent, surtout dès qu'ils ont 30-35 sétigères, à une coloration spéciale. La moitié antéri-

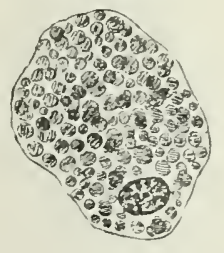

Fig. 4.

eure du corps est brune, la moitié postérieure est jaune assez vif, et la transition d'une région à l'autre est assez brusque, mais il y a à cet égard des variations. Enfin en examinant le contenu de la cavité générale, on constate chez les individus $B_{1}$ une accumulation de cellules à réserves beaucoup plus considérable que chez $\mathrm{A}$. Ce 
sont encore des cellules à granulations éosinophiles (fig. 4). Nous nous sommes assurés qu'elles présentent la plupart des réactions des granulations $a$, qu'EHRLICH a décrites chez les Vertébrés.

De plus, il y a dans la cavité générale, d'une façon qu'on peut dire absolument constante, une longue grégarine colomique du genre Gonospora (ainsi que le montrent les spores), que nous avons appelée $G$. longissima ${ }^{1}$ Cette grégarine est spéciale à la forme B. Il est intéressant de noter qu'il s'établit, entre elle et les amœbocytes de la cavité générale, une lutte très active. Les amœbocytes détruisent par phagocytose une partic des grégarines à l'état

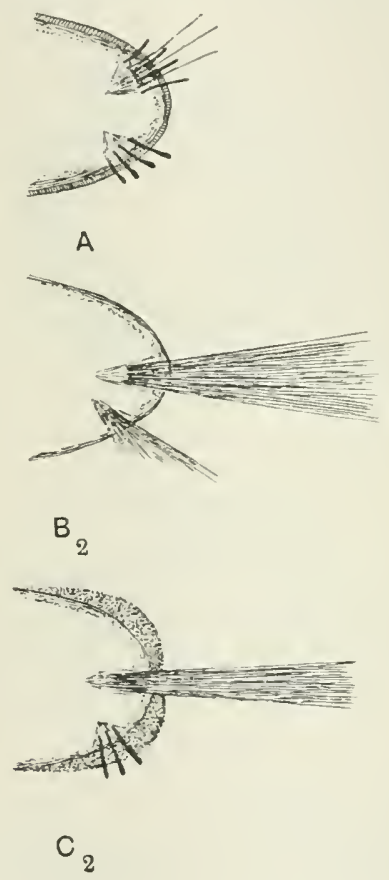

Fig. 5. Parapodes de la région moyenne du corps chez les formes $\mathrm{A}, \mathrm{B}_{2}, \mathrm{C}_{2}$.

végétatif. Ils englobent également par phagocytose un grand nombre de spores ${ }^{2}$.

Les individus $B_{1}$ atteignent en moyenne 50-55 sétigères, mais ils peuvent aller jusqu'à $65-70$; ils sont un peu plus petits que les individus A. Somme toute, ils n'offrent avec A que des différences

1 Caullery et Messil-Sur une Grégarine colomique présentant, dans son cycle évolutif, une phase de multiplication asporulée. (C. R. Ac. Sciences Paris, 17 Janv. 1898 .)

${ }_{2}$ La sporulation de la grégarine ne se fait jamais que quand l'annélicle est à l'état $\mathrm{B}_{2}$. La maturité de la grégarine coïncide ainsi avec celle de l'annélide, les spores sont évacuées avec les produits génitaux, et le parasite profite des moyens de dissémination de l'hôte.

$$
1+-2
$$


très minimes et ont essentiellement le faciès sédentaire d'un Dodecaceria.

Etat $B_{2}$-Quand le nombre définitif des segments est à peu près atteint et qu'arrive la maturation des produits génitaux, il se produit des transformations internes sur lesquelles nous revenons plus loin et une métamorphose extérieure dont voici les principaux traits.

Dans l'appareil sétigère, les soies en cuiller tombent successivement. Il n'en reste plus que dans les Io-i 2 derniers anneaux du corps, où les rames ne subissent aucun changement. Puis, entre le $7^{\mathrm{e}}$ anneau et les IO-I 2 derniers pousse à chaque rame dorsale un puissant faisceau de soies glabres fines et longues, atteignant en longueur 2 à 3 fois la largeur du corps, au nombre de 40 et davantage par rame vers le milieu de l'animal. Aux rames ventrales, les soies en cuiller disparaissent aussi et sont remplacées par des soies analogues à celles dont nous venons de parler, mais moins longues et moins nombreuses. Ces soies nouvelles, ou soies de puberté ou soies pélagiques, constituent un puissant appareil locomoteur qui va transformer le Dodecaceria, organisé jusque-là pour la vie complètement sédentaire, en une véritable forme nageuse.

Les palpes subissent à ce moment une atrophie assez inexplicable et il n'en subsiste que des moignons. Il se différencie sur le prostomium deux gros yeux, tandis que les formes $B_{1}$ et A adulte étaient aveugles.

Celles sont les modifications extérieures. Elles donnent à l'animal l'aspect d'une Annélide Errante. Ces changements sont absolument parallèles à ceux qui caractérisent les formes Hetcronereis par rapport aux Nereis, ou les formes mûres des Syllidiens par rapport aux individus immatures. $B_{2}$ est donc bien une forme épitoque, la phase de passage de $\mathrm{B}_{1}$ à $\mathrm{B}_{2}$, la phase épigame au sens de CLAPARÈDE.

Il se produit intérieurement des transformations non moins importantes. Quand la poussée des soies est terminée, la cavité générale est absolument bourrée de produits génitaux.

Par contre les réserves ont complètement disparu. Elles ont servi à l'édification des cellules sexuelles. Il y a ainsi, dans l'évolution de $\mathrm{B}$, deux phases très opposées au point de vue physiologique, l'une où l'animal croît et se constitue des réserves importantes, l'autre (phase épigame) où, ne croissant plus, il se métamorphose et consomme ses réserves pour produire ses ovules ou ses spermatozoïdes. Dès cette phase épigame, du reste, il survient comme un changement d'instinct de l'animal. Son tube digestif est vide et s'atrophie jusqu'à se réduire à un mince cordon (fig. 6), dont les cellules sont surchargées d'un pigment insoluble. L'atrophie de l'intestin s'effectue sans phagocytose de l'épithélium. Il y a comme une sorte d'autophagie. Les cellules cessant d'être nourries s'épuisent et sont éliminées, probablement par la lumière même de l'intestin. 
Une autre catégorie de modifications concerne les organes segmentaires. A l'état $B_{1}$, ils sont probablement représentés comme chez A par une ébauche, mais nous devons dire que nous ne les avons pas trouvés. Pendant la phase épigame, il sc développe, dans chaque segment, une paire de grands pavillons vibratiles, aux dépens des dissépiments. C'est par eux que les produits génitaux sont conduits à l'extérieur.

On voit donc l'étendue des transformations externes et internes par lesquelles la forme épitoque $B_{2}$ diffèrę de la forme atoque $B_{1}$.

Ajoutons que chez la forme $B$, on trouve nombres sensiblement égaux de mâles et de femelles et que les ovules sont cle couleur
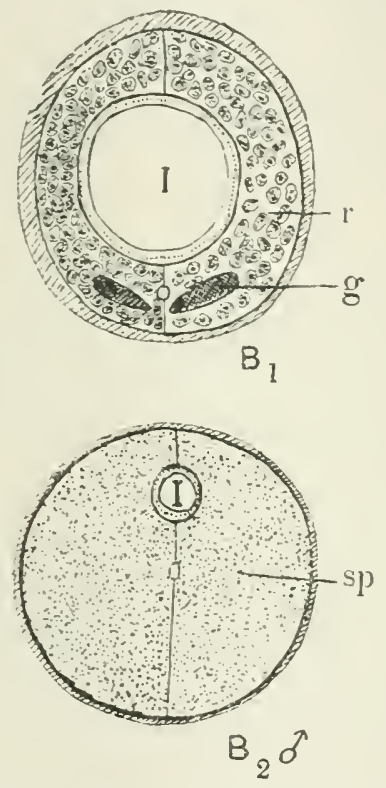

Fig. 6. Coupes transversales, par la partie moyenne du corps, dindividus B: $r$, cellules à réserves; $\varrho$, glandes génitales; $s p$, spermatozoïdes; $-I$, coupe de l'intestin dans la région glandulaire.

jannâtre, tandis que ceux de A étaient iert-bleuâtre. Ils peurent atteindre $200 \mu$.

Quand la forme $\mathrm{B}_{2}$ a atteint sa complète maturité, elle quitte le Lithothamnion et nage rapidement avec des mouvements sinusoïdaux analogues à ceux des Nephthys. Elle ne tarde pas à rejeter en abondance ses produits génitaux par les néphridies qui sont souvent extroversées dans cet acte. La fécondation de l'ovule a lieu dans la mer.

La forme $\mathrm{B}$ se vide ainsi complètement et ne tarde pas à tomber inerte, au fond. Sa mobilité ne dure donc que quelques heures au plus. Nous sommes très tentés de croire que le rôle de 
l'individu est terminé après cette ponte ; nous n'avons trouvé aucun fait qui conduise à supposer une survie.

Disons enfin que l'animal mûr' se rencontre dans la Manche, en été, de juillet à octobre. Au printemps, nous n'avons trouvé que l'état $B_{1}$.

Comme on le voit, l'histoire de la forme B differe beaucoup de celle de $\mathrm{A}$ au double point de vue morphologique et physiologique.

\section{FORME C.}

Elle est beaucoup plus rare que les précédentes et nous l'arons rencontrée pour la première fois au printemps de I898. Nous n'en avons eu qu'une trentaine d'exemplaires en tout. D'une façon générale, son histoire rappelle celle de la forme $B$, de sorte qu'il y a lieu ici aussi de considérer successivement un premier état que nous appellerons atoque $\mathrm{C}_{1}$ et un état épitoque $\mathrm{C}_{2}$, le passage de l'un à l'autre se faisant par une phase épigame. Presque tous les individus trouvés par nous étaient à l'état $C_{1}$ ou à la phase épigame.

Etat $C_{1}$ - A l'état $C_{1}, C$ est très difficile à distinguer de $A$. Tous les exemplaires que nous avons trouvés étaient de grande taille, $3^{\mathrm{cm}}$ au moins, et avaient une soixantaine de segments. L'appareil sétigère montre une identité parfaité avec celui de A; en particulier, les soies en cuiller sont, comme celles de $A$, dépourvues de dent sous l'excavation terminale.

Mais, ̀̀ la différence de $\mathrm{A}$ : $\left(\mathrm{I}^{\circ}\right)$ Les ovules sont de couleur jaunâtre, comme dans $\mathrm{B}$, tandis qu'ils étaient vert-bleucatre chez A. Ils sont toujours très abondants et tous à peu près de même taille. $\left(2^{\circ}\right)$ La paroi du corps est fort épaissie latéralement, dans toute la région moyenne (fig. 7). Il s'est différencié deux séries de bourrelets glandulaires, constitués par des cellules caliciformes à mucus, extrêmement hautes. Ces bourrelets sont interrompus au voisinage des rames sétigères; ils se développent énormément et la paroi atteint là trois ou quatre fois son épaisseur normale. Si on colore les tissus de C par l'hématéine, les glandes tégumentaires se colorent d'une façon intense et massive en violet.

Phase épigame-Telles sont les deux caractéristiques de la forme $C$. Peu à peu $C_{1}$ passe à $C_{2}$, les bourrelets glandulaires se développent; il se différencie sur les faces dorsale et ventrale des glandes à mucus isolées offrant les mêmes réactions que les glandes latérales.

1 Verril., Proc. of the U. S. Nation. Miss. t. II. I879, dans de vieilles coquilles d'huitres draguées, a recueilli, côte à côte, une forme qu'il appelle Dodecaceria concharum et une autre qu'il appelle Heterocirrus fimbriatus. De sa description de cette dernière résulte très probablement qu'il a eu sous les yeux notre forme $\mathrm{B}_{2}$. Quant à son Dode caceria, ce pouvait être, soit la forme $A$, soit la forme $B_{2}$. En tout cas, il n'a pas vu le lien reliant les deux animaux. Il semble résulter aussi des figures de quelques auteurs et notamment des figures qu'ils donnent des soies en cuiller, qu'ils ont eu entre les mains à la fois des individus $A$ et des individus $B_{1}$, mais ils ne les ont jamais distingués. 
Extérieurement, l'appareil sétigère subit des transformations importantes (fig. $5, \mathrm{C}_{2}$ ). Dans toute la région moyenne, les soies en cuiller de la rame dorsale tombent et il pousse, à chaque rame, un faisceau de très longues soies capillaires. Les rames ainsi trans-

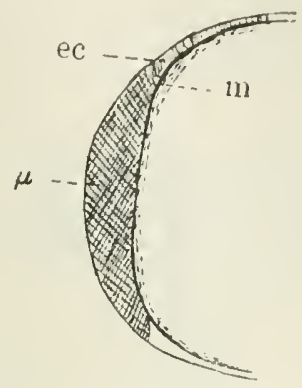

Fig. 7. Epaississement muqueux latéral d'une forme $\mathrm{C}: \iota c$, ectoderme normal; $\mu$, ectoderme muqueux; $m$, couche musculaire.

formées ressemblent à celles correspondantes de $B_{2}$, sauf que leurs soies sont moins nombreuses et un peu moins fines. Aux rames ventrales, le nombre des soies en cuiller diminue. Mais nous n'avons pas vu pousser de soies capillaires. Sur le prostomium apparaissent deux yeux rougeâtres, allongés, moins volumineux que ceux de $\mathrm{B}_{2}$.

En résumé, $C_{1}$ prend progressivement le faciès d'une forme épitoque.

Intérieurement, il se forme de grands pavillons vibratiles dans chaque segment comme dans $B_{2}$. Ils ont été précédés par une ébauche en tout semblable à celle que nous avons vue dans A. Au voisinage des pores segmentaires, l'épithélium des dissépiments devient cubique, de pavimenteux qu'il était et acquiert une ciliation serrée.

Enfin le tube digestif subit une atrophie parallèle à celle que nous avons vue dans $B$.

Etat $C_{2}-$ Nous sommes ainsi arrivés à l'état $C_{2}$ (fig. 8), dont nous n'avons malheureusement eu qu'un seul exemplaire entre les mains. Cet individu a été recueilli au printemps.

En juillet-août I $\$ 98$, malgré d'attentives recherches, nous n'avons trouvé que des $C_{1}$ assez peu évolués. Nous en concluons provisoirement (vu le nombre insuffisant d'observations) que la maturité sexuelle tombe au printemps.

Les ovules, atteignant $130 \mu$ de diamètre en moyenne, sont pondus par les organes segmentaires; l'animal secrétant du mucus en abondance, il est très probable qu'ils sont englobés par ce mucus et réunis en une ponte aggloméréc, à l'intérieur de laquelle ils se développent; mais, faute de matériaux et de temps, nous n'avons pu nous assurer de cette particularité. 
Les trente individus $\mathrm{C}$ que nous avons récoltés étaient tous des femelles; nous sommes par suite très portés à admettre que cette forme ne comporte pas de mâle. Il y a, à cette conclusion, moins de certitude que pour $A$, parce que les observations sont moins nombreuses, mais nous croyons pouvoir nous prononcer en vertu des considérations suivantes. Ce qui permet de reconnaître une forme C, c'est la présence des glandes à mucus et la couleur des

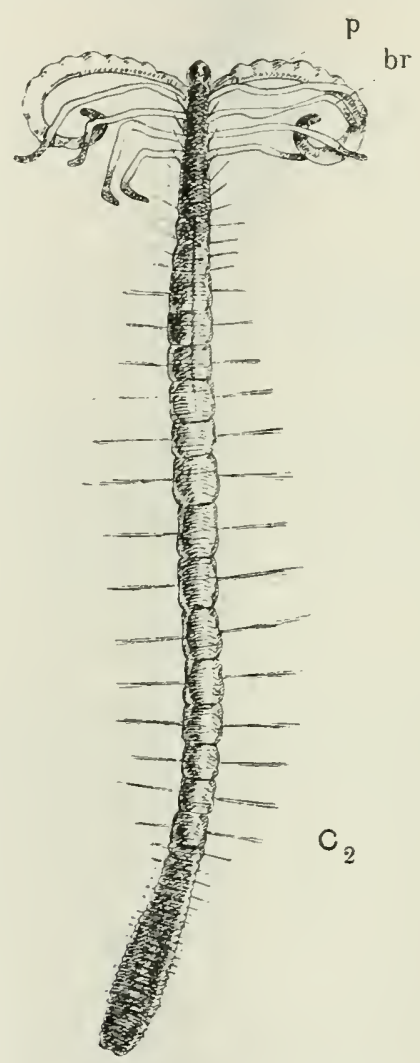

Fig. 8. p, palpes; br, branchies.

ovules. Que deviennent ces caractères chez un mâle? Le second n'est évidemment plus applicable. Il est probable qu'il en serait de même du premier. Car le développement des glandes à mucus, constaté chez $\mathrm{C}$, est une particularité très probablement corrélative de la ponte et qui par suite n'existerait pas chez le mâle. Dans ces conditions, aucun caractère ne permettrait de distinguer celui-ci d'un mâle de $\mathrm{A}$, à supposer que ce dernier existe, sauf que le mâle de $\mathrm{C}$ se métamorphoserait en une forme épitoque. Or nous répétons que parmi les milliers d'individus de faciès $A$ observés, 
nous n'en avons jamais trouvé un seul qui fût mâle ou annonçât une évolution vers le sexe mâle. Nous admettons donc que C n'a pas de mâle et se reproduit au printemps, très probablement par parthénogénèse.

$\mathrm{Au}$ point de vue des transformations que subit $\mathrm{C}$ à la phase épigame, nous avons constaté un parallélisme très grand avec $B$, tant morphologiquement que physiologiquement. Mais il faut remarquer que l'évolution génitale de $C$ est beaucoup plus graduelle. Il n'y a pas de période préalable pour l'accumulation de réserves comme cliez $B_{1}$, puis une période où les transformations se précipitent. Tout se fait peu à peu. Par l'abondance du mucus, par le moins grand développement des yeux et des soies pélagiques, la forme épitoque $C_{2}$ a un faciès moins errant que $B_{2}$. Et, de fait, nous n'avons jamais constaté chez elle la mobilité de $\mathrm{B}_{2}$. Mais nous n'avons pas vu suffisamment d'individus arrivés au terme de leur évolution pour préciser davantage.

Nous venons donc de constater l'existence de trois séries d'individus $\mathrm{A}, \mathrm{B}, \mathrm{C}$, dont l'évolution se fait vers des directions très différentes et aboutit à des états finaux bien distincts. Examinons maintenant les rapports de ces trois séries entre elles, en particulier au point de vue de la notion d'espèce.

On peut concevoir leurs rapports taxonomiques de trois façons différentes :

$\mathrm{I}^{\circ}$. A, B, C forment trois espèces distinctes dans le genre Dodecaceria.

$2^{\circ}$. A $+\mathrm{C}$ d'une part, $\mathrm{B}$ de l'autre forment deux espèces.

$3^{\circ}$. $\mathrm{A}+\mathrm{B}+\mathrm{C}$ est une seule espèce polymorphe.

Nous ferons remarquer d'abord, en ce qui concerne B, que rien n'empêcherait de la considérer comme une espèce autonome. Indépendamment des particularités spéciales à son évolution, elle possède des caractères morphologiques propres, tels que la dent que nous avons signalée aux soies en cuiller. Elle se suffit à ellemême pour se reproduire; les deux sexes sont représentés en nombres équivalents d'individus. Enfin elle a même un parasite spécial, Gonospora longissima, qu'on ne retrouve pas dans les deux autres formes. Si on adoptait cette opinion, il faudrait appeler B Dodecaceria fimbriata, afin de tenir compte de ce que VERRILL a vu cette forme $\mathrm{B}_{2}$, qu'il a rapportée faussement au genre Heterocirrics.

Mais, si l'on sépare $B$ de $A$ et $C$, que $A$ et $C$ forment à leur tour deux espèces distinctes (solution $\mathrm{I}^{\circ}$ ) ou que $A+C$ représente une espèce dimorphe (solution $2^{\circ}$ ), dans les deux cas, $\mathrm{A}$ et $\mathrm{C}$ ou $\mathrm{A}+\mathrm{C}$ constituent des espèces où il n'y a que des femelles et où la reproduction doit se faire indéfiniment par parthénogénèse: on peut nous répondre, qu'il reste à trouver le mâle; étant données la durée et l'étendue de nos recherches, nous croyons peu à son existence, sans affirmer naturellement qu'elle soit impossible. Or, 
dans le règne animal, il est au moins exceptionnel, chez des animaux élevés en organisation comme les Annélides que l'espèce se propage indéfiniment par parthénogénèse. En général ce phénomène est tempéré périodiquement par la fécondation.

Pour ces raisons nous conserverons $\mathrm{A}, \mathrm{B}$ et $\mathrm{C}$ dans une même espèce, Dodecaceria concharum, et nous admettrons, sans pouvoir le démontrer rigoureusement, que, dans des conditions d'ailleurs inconnues, il y a transformation de ces formes les unes dans les autres par génération. La démonstration comporterait des éducations successives en culture pure, que les difficultés matérielles nous interdisaient même de tenter. Nous devons dire toutefois que, suivant nous, $A$ produit normalement $A$, de même $B$ produit $B$, $\mathrm{C}$ donne aussi $\mathrm{C}$, mais il peut se faire qu'un certain pourcentage des oufs de l'une des formes évolue vers l'une des autres.

Envisageons maintenant plus spécialement les rapports de $\mathrm{A}$ et de C. A est, nous l'avons dit, susceptible de plusieurs poussées génitales, d'autre part les individus $C$ trouvés par nous étaient tous de grande taille. Il ne serait par suite pas impossible que la forme $C$ représentât seulement l'état terminal de $A$, qu'après s'être reproduits deux ou plusieurs fois à l'état $A$, ces individus $A$ prissent pour leur dernière période de reproduction la forme C. Dans cette hypothèse, ces individus se reproduiraient successivement à l'état $A$ puis à l'état $C$ en subissant dans l'intervalle une métamorphose. Ce serait un nouveau cas du phénomène que $\mathrm{CHUN}^{1}$ a découvert chez les Cténophores et qu'il a appelé la dissogonie. Rien n'indique d'ailleurs, d'une façon formelle, qu'il en soit ainsi et, en particulier, les individus $\mathrm{C}$ sont extrêmement rares par rapport aux individus $A$; ce qui semblerait indiquer, ou bien que $A$ n'aboutit pas à $C$, ou bien que quelques $\mathrm{A}$ seulement deviennent $\mathrm{C}$; de telle sorte que $\mathrm{C}$ formerait encore une série distincte de $\mathrm{A}$.

Quoiqu'il en soit, le polymorphisme que nous avons constaté, qu'il existe à l'intérieur d'une espèce unique, $D$. concharmm, ou entre espèces voisines du genre Dodecaceria, nous paraît dans les deux hypothèses un phénomène intéressant au point de vue général de la notion d'espèce. Car, avons nous dit, le genre Dodecaceria occupe une place isolée dans la famille des Cirratuliens. Donc, ou bien A, B, C constituent une espèce polymorphe, ou bien elles forment des espèces distinctes, voisines les unes des autres, et qui, étant donnée la place isolée du genre, proviennent récemment d'une espèce souche unique. Et dans cette dernière hypothèse il s'est effectué un polymorphisme évolutif à partir de cette forme souche. C'est-à-dire que ce polymorphisme s'est manifesté à l'origine dans l'espèce souche et que, peu à peu, les espèces se sont individualisées. Il y a donc eu autrefois, sinon aujourd'hui encore, polymorphisme évolutif dans une espèce unique. La seconde hypothèse revient donc à déplacer la question dans le temps.

${ }^{1}$ CHUN-Die Dissogonie, eine neue Form der geschlechtlichen Zeugung ; Festsch.f. Leuckart, Leipzig, I892. 
GIARD ${ }^{1}$ a désigné, sous le nom de pacilogonic, la propriété qu'a une espèce de présenter des modes de développement variés suivant les circonstances. Quelle que soit la solution adoptée pour les relations spécifiques de $A, B$ et $C$, la diversité des oufs, par conséquent des conditions initiales du développement chez elles, nous paraît légitimer de rapprocher le cas de Doulccaceria des faits de pœecilogonie déjà signalés.

Tels sont les faits que nous arons constatés chez Dodccaceria. Nous avons découvert aussi une épitoquie très nette chez Hetcrocirrus viridis Lghns., et peut-être $y$ a-t-il là aussi dimorphisme évolutif, mais nos données à cet égard sont trop incomplètes pour être exposées ici. Nous avons dit, au début de cette communication, que nous croyions pouvoir déduire de l'étude des travaux antérieurs, que l'épitoquie a une certaine généralité chez les Cirratuliens. C'est un fait assez inattendu de voir ces types sédentaires, presque tubicoles, comme Dodecaccria, prendre un faciès si net de formes errantes. Nous renvoyons à notre mémoire in extenso pour ces considérations.

Nous y faisons, de même, un parallélisme entre les divers cas d'épitoquie que présentent les Annélides. Autour de la métamorphose, plus ou moins accentuée d'ailleurs, se groupent toute une série de modifications corrélatives: atrophie du tube digestif, etc.

Nous nous bornerons ici à rappeler que le polymorphisme analysé précédemment chez Dodecaceria conchamm n'est pas absolument le premier que fournissent les Annélides. CLAPARÈDE 2 a relaté des faits analogues pour Ncreis Dumerilii. Il a décrit, pour cette espèce, plusieurs formes Hcteronercis et des formes Nereis qui, d'après lui, se reproduisaient sans subir la métamorphose épigame (l'une d'elles, découverte par Metchyikoff à San-Remo, et que nous avons retrouvée à la Hague, est hermaphrodite et occasionnellement vivipare).

WISTINGHAUSEN ${ }^{3}$, qui a étudié l'embryogénie de l'une d'elles, a, d’une manière générale, confirmé le polymorphisme signalé par CLAPARÈDE et, d'après lui, il y aurait à Naples trois séries d'individus de Nereis Dumerilii:

L'une $\alpha$, se reproduisant à l'état de Nereis.

L'autre $\beta$, donnant de petites Hetcroncreis que l'on recueille pélagiquement.

La troisième $\gamma$ donnant de grandes Heteronereis tubicoles sédentaires.

A ces trois séries s'ajouterait celle des individus hermaphrodites dont nous pourons certifier l'existence.

Une observation prolongée des individus, dans des aquariums

1 Giard-Comptes Rendus Acad. Sc. Paris, t. Cxvir. I89I.

2l. $c$.

3 Wistraciandex-Unters, ïb. die Entw. von Nercis Dumerilii-.With. a. d. zool. Stat. $z$ Neapel, x. I 89 I. 
bien installés, tels qu'en possèdent aujourd'hui les stations maritimes, permettrait peut-être de préciser beaucoup les rapports de toutes ces formes et de résoudre ainsi des problèmes très intéressants pour la conception générale de l'espèce.

Nous voudrions donc appeler dans cette direction l'attention des zoologistes, d'autant plus que, si l'étude systématique des Annélides est assez avancée quoiqu'encore imparfaite, la connaissance de leur évolution sexuelle et de toutes les questions qui s'y rattachent est encore à peine ébauchée. Il est à prévoir que les faits offerts par Nereis Dumerilii et par Dodccaceria sont loin d'être isolés.

Nous n'insisterons pas non plus longuement ici sur la signification générale des phénomènes d'épitoquie. Comme l'a très bien conçu EHLERS en $\mathbf{I} 868$, ce sont des transformations caractéristiques de la maturité sexuelle et dont beaucoup d'autres groupes offrent les analogues. Nous voudrions, pour notre part, indiquer un rapprochement, qui, à notre connaissance, n'a pas encore été fait. Il s'agit d'ailleurs d'un rapprochement plus physiologique que morphologique. Il nous semble que, dans l'économie générale de l'espèce, les transformations bien caractérisées, telles que l'épitoquie de Dodecaceria et des Néréidiens, jouent un rôle comparable à celui des métamorphoses complètes chez les Insectes qui les possèdent. Nous ferions volontiers un parallèle entre la forme épitoque et l'imago, qui, toutes deux, paraissent une phase surajoutée à l'évolution normale de l'être et semblent être surtout un appareil de perfectionnement pour la dissémination des produits génitaux et finalement de l'espèce. Dans l'un et l'autre cas, des transformations internes profondes accompagnent les changements extérieurs, surtout en ce qui concerne la nutrition, les réserves et l'élaboration des produits sexuels. Il n'est pas jusqu'à la condition éphémère de beaucoup de formes imaginales chez les Insectes que ne rappelle la brève période de mobilité et de vie chez la forme épitoque $B_{2}$ de Dodecaceria et qui ne nous semble donner à cette comparaison une part plus grande de légitimité.

\section{DÉmonstrations.}

\section{Par MM. Félix Mesnil et Maurice Caullery.}

I. Les auteurs montrent diverses préparations (état végétatif, kystes dans la Grégarine, kystes rendus libres) d'un parasite des Grégarines qu'ils ont décrit sous le nom de Metchnikovella spionis ${ }^{1}$. Ils ont indiqué dans cette publication les traits généraux de l'organisation de ces curieux êtres qui ne paraissent avoir d'affinités précises avec aucun groupe particulier, animal ou végétal. Ils signalent la présence d'un parasite du même genre $(M$. capitellidis

1 Caullery et Mesnil-Sur un type nouveau (Metchnikovella n.g.) d'organismes parasites des Grégarines (C.R. AC. Sciences Paris, séance du 15 novembre 1897 ). 
n. sp.) chez l'Anchorina de Capitellides Giardi Mesnil. Ce sont sans doute des kystes de Metchnikovella qui ont été déjà vus par Claparède ', chez la Grégarine d'une Phyllodoce, par Léger ${ }^{2}$, chez Sycia inopinata Léger du tube digestif d'Audoninia sp. (probablement Audouinia tentaculata Mont.) et chez une espèce du g. Platycystis Léger (Selenidium Giard) parasite de la même Audoninia; mais ces savants n'en ont pas reconnu la nature parasitaire.

En août dernier, les auteurs ont rencontré deux nouvelles espèces de Metchnikovclla: l'une parasite de la Grégarine en comète (voir Mesnil et Caullery, C. R. Soc. Biologic, séance du 20 novembre I 897) de la Capitella capitata de la Hague, l'autre parasite de la Grégarine intestinale de Pygospio seticomis (Spio seticomis (Erst, nec Fabr.). Mesnil et Caullery se proposent de faire connaître ultérieurement l'évolution de ces nouvelles espèces. Ils insistent sur la généralité de ces parasites chez les Grégarines intestinales des Annélides marines.

II. MM. Mesnil et Caullery montrent plusieurs préparations d'un Monstrillidac, copépode dont l'évolution se fait à l'intérieur du corps d'une annélide (Polydora Giardi Mesn.): les unes montrent le copépode à l'intérieur de l'annélide, dans un vaisseau sanguin; les autres, le parasite sorti artificiellement de la Polydore, mais encore enveloppé dans son sac ammiotique et muni de ses 2 suçoirs.

Le parasitisme interne de ce copépode, découvert par l'un des auteurs en I\$96, a été étudié et décrit par le professeur Giard (C. R. Ac. Scionces Paris, nov. I 896). Ultérieurement, Malaquin a reconnu le parasitisme de deux autres Monstrillides, l'un chez Salmacina Dysteri Huxley, l'autre chez Filigrana implexa Berk.; tous les deux évoluent dans le système sanguin de l'Annélide. En août dernier, les auteurs ont découvert le parasitisme d'une autre espèce chez un Syllidien : Syllis gracilis Gr.

Ces diverses observations montrent que l'évolution des copépodes de la famille des Monstrillidae se fait à l'intérieur du corps d'annélides polychètes. Il convient de remarquer que, des 4 espèces hôtes jusqu'ici connues, 3 ont normalement une multiplication scissipare; la $4^{\mathrm{e}}$ (Polydora Giardi) se présente fréquemment sous forme d'une extrémité postérieure de 20 à 30 sétigères ayant régénéré une extrémité antérieure (prostomium et $7-8$ sétigères).

\section{A New trpe of ACtinian.}

By Prof. E. L. Mark.

Prof. MARK, of Harvard University, gave an account of the external anatomy of a new and interesting deep-sea actinian, resembling Cerianthus, dredged by $\mathrm{Mr}$ Agassiz in the Gulf of

1 Claparède-Mém. Soc. Phys. et Hist. Nat., Genève, r86r, p. 159, pl. 1V. fig. 8-9. $13-16$. 
Panama, at the depth of nearly 300 fathoms. The most striking features of the animal are a strongly-expressed bilateral symmetry, and the possession of an incomplete circle of gill-like organs arising from the disk near the base of the oral tube. The disk is very oblique to the chief axis of the animal and its edges are apparently incurved in life so as to give the anterior end of the actinian a vaselike or scoop-shaped appearance. The circle of marginal tentacles suffers an interruption corresponding in position to that of the circle of gills. The smallest and youngest tentacles are nearest this hiatus. Radiating canals run across the disk from the base of the oral tube to the tentacles, with the cavities of which they communicate. The lower end of the swollen bulb-like column is provided with numerous small filamentous projections, and the case secreted by the basal end of the column also has long hollow filaments, which serve to anchor the small (three to four decimeters long) animal in the mud. Drawings illustrating these facts were shown. A more complete account will be found in Bull. Mus. Comp. Zoöl. at Harvard Univ., Vol. 32, No. S, entitled Preliminary Report on Branchiocerianthus urceolus.

\section{ON THE RANGE IN TIME AND SPACE OF Fusus (Neptunea) antiquns AND ITS ALLIES (with Plate 3).}

\section{By $\operatorname{Mr}$ F. W. Harmer.}

The question of the specific identity or otherwise of the different dextral and sinistral forms of mollusca, of which Fusus antiquns (now generally referred to the genus Neptunea) may be taken as the type, is one upon which considerable difference of opinion has existed. It is possible that the study of their geographical distribution, at the present day, and during the Pliocene epoch, may throw some light on the subject.

In the second edition of Lamarcli's Histoire Naturelle des Animanx sans Vertebres (Vol. IX. IS43), the names of five allied forms are given, which are there regarded as specifically distinct. Of these three are dextral, viz. :

$$
\begin{gathered}
\text { Fusus antiquns, Linn. } \\
" \quad \text { carinatus, Pennant. } \\
, \quad \text { despcctus, Linn. }
\end{gathered}
$$

and two sinistral, viz. :

$$
\begin{gathered}
\text { Fusus contrarius, Linn. } \\
\text { " sinistrorsus, Desh. }
\end{gathered}
$$

These two groups now occupy distinct areas, which do not, except perhaps with rare exceptions, overlap. Specimens of the latter have been recorded, although with some doubt, from the Mediterranean ${ }^{1}$, and they are found on the coast of Portugal, but I am not

\footnotetext{
1 Meli, Boll. della Soc. geol. ilal., vol. xi11. (189t), fasc. 2.
} 
aware that either of the sinistral forms mentioned has been dredged living north of Vigo Bay ${ }^{1}$. Neither Gwyn Jeffreys ${ }^{2}$, nor McAndrew ${ }^{3}$, whose investigations extended from the Canaries to the North Cape, and were carried on during many years, knew of any more northern locality for them. At Vigo, however, it is stated by the latter, specimens of Finsus contrarius are moderately abundant.

The dextral forms, on the contrary, are all northern. Neptunea antiqua is Scandinavian as well as British, but it does not range far to the south of our shores. Its carinated allies, $N$. carinata and $N$. despccta, are characteristically boreal, or even arctic, being common in the extreme north of Norway, Russia, and Greenland". McAndrew says that all the specimens of Fusus antiquus obtained by him in Norway were carinated ${ }^{5}$.

Referring to their former distribution, we find that none but sinistral species occur as fossils in the south of Europe, although during the later Tertiary period such forms extended further to the north than they do at present. They are found in later Pliocene beds on both sides of the North Sea basin, viz. in the East Anglian Crag and the Scaldisien deposits of Holland and Belgium in one direction, and in another at Wexford, on the Irish coast $^{6}$, and in Kintire in Scotland ${ }^{7}$.

On the other hand, the dextral species are unknown from any of the Pliocene strata of France, or of the Mediterranean, but they are common at all the later horizons of the English Crag beds.

Neptunea contraria is now a southern form, although it seems probable that it originated, as did its dextral congeners, in northern seas, at a time when the climate of northern Europe was warmer than it is at present, and that both groups invaded the AngloBelgian Pliocene basin from the north. No trace of the existence of representatives of either, dextral or sinistral, has been found in the earlier Pliocene deposits of Belgium, England or Normandy, nor is any species known from these or any older strata which can be regarded as an ancestral form ${ }^{8}$.

The arrival of Neptunca contraria in these latitudes preceded, however, that of its right-handed representatives. In the Scaldisien deposits of Belgium, and in the oldest part of the Red Crag of England, viz. that of IValton-on-Naze, contemporaneous with

I Reversed specimens of Neptunea antigua are very occasionally met with on the English coast, but except that they are left-handed, they cannot be distinguished from the right-handed shells among which they occur. The sinistral forms of Vigo Bay are, on the contrary, materially different from the dextral species of British or Arctic seas.

2 Brit. Conch. vol. Iv. p. 326.

3 Reports Brit. Assoc., i856, p. 131.

+ Sars, Edin. Neav Phil. Soc., July i 863 .

5 Loc. cil., p. 131.

6 Forbes, Ilem. Geol. Survey, rol. I. p. gr.

7 K'eports Brit. Assoc., I896, p. 390.

8 See also G. F. Dollfus, Soc. Kioy. Walac. de Belgique, t. Xrin. I8sz. 
them, sinistral specimens alone occur ${ }^{1}$, in both very abundantly. It is in Pliocene strata of later age, in East Anglia and on the continent, that dextral forms make their first appearance, including not only the typical species Neptunea antiqua, but the more northern $N$. carinate and $N$. despecta. At lower horizons of the Upper Crag (later than that of Walton), right-handed forms are very rare, but they are increasingly common in the higher zones, while pari passu, left-handed ones, which are abundant in the older, become more, and finally exceedingly scarce in the newer beds, until the relative proportion between them is reversed.

The facies of the molluscan fauna of the oldest of the Crag deposits is preponderatingly southern, resembling that of the Mediterranean, or even the Azores at the present day, but as the Glacial period approached, the climate of the Pliocene period gradually became colder, and the Crag basin was invaded from the north by boreal and arctic mollusca, at first in small, but afterwards in increasing numbers; at the same time the southern species became gradually less abundant, and finally died out altogether, so that eventually the molluscan fauna of the North Sea acquired a decidedly northern character. Now the dextral varieties of Neptumea antiqua, including its carinated allies, came into the Crag area with the northern shells, becoming abundant as they did, while, as the southern species became less so, and finally disappeared, Nepiunea contraria came to be correspondingly rare.

The fact that the latter appeared first in the Anglo-Belgian basin led Searles Wood to believe that the progenitor of these different shells may have been left-handed, and that the dextral rather than the sinistral forms should be regarded as varieties. Whether this be so or not, it seems that at the time of their first recorded appearance these mollusks had become separated into distinct groups, which migrated separately, and that the one penetrated during the Pliocene epoch, and still lives further to the south than the other.

Comparing these different mollusca, recent and fossil, we find there is a greater general resemblance between the varieties of each group than there is between any of the dextral and sinistral forms. The volutions of the left-handed are, as a rule, more obliquely spiral than those of the right-handed shells, the spire of the former being in consequence more produced, while in the latter the mouth is generally wider, and the canal shorter in proportion. The principal difference between the various forms of each division is in the sculpture. Fig. I is that of a specimen from the Pliocene beds of Sicily2 (type of Neptnnea sinistrorsa). The spiral markings by which it is ornamented are close together on the upper whorls, and on the body whorl are divided by a fine thread. Figs. 2 and 3

\footnotetext{
1 One right-handed specimen is said to have been found at Walton during the present century.

2 Fig. 1 is that of an immature specimen.
} 
are from the Scaldisien deposits of Belgium. In these the principal spiral ridges are more prominent, are further apart, and are separated by a number of finer ones of unequal size. The canal is longer than in the Sicilian fossil. Fig. 5 is from the Crag of Walton-on-Naze, contemporaneous with the Scaldisien. Its sculpture is similar to that of Nos. 2 and 3, but the striations are feeble, and the canal is much shorter. Fig. 4 represents a recent specimen from Vigo Bay, in the McAndrew collection in the Museum of Zoology at Cambridge. Its spiral markings are of a character intermediate between those of the Belgian and Sicilian forms ${ }^{1}$. All these sinistral shells have a strong family likeness.

The oldest beds of Pliocene age known to me in which dextral forms of Neptunea occur are at Little Oakley, between Harwich and Walton-on-Naze, in the county of Essex. They are, however, by no means abundant there, while specimens of $N$. contraria are exceedingly so. The Oakley deposits probably belong to the period when the right-handed species were making their first appearance in the Anglo-Belgian area. If the sinistral shells are to be regarded as varieties merely of the dextral form, these earliest recorded specimens of the latter group should show a greater approximation to the former than is the case with those now existing, or those that are obtained from later Pliocene deposits, but this is not so. More than half the dextral shells from the Oakley Crag are carinated (Fig. 6), but no carinated sinistral specimens are known to me from these or from any other strata of similar age, all the left-handed forms there occurring being smooth or indistinctly striated, and having the oblique volution, lengthened spire, and distinct suture of this group. In the typical dextral form of the Oakley Crag (Fig. 7) the suture is more nearly at right angles to the columella, and the whorls overlap, so that the spire is very short. In one specimen (Fig. 8), an extreme case, the mouth measures three-fourths, and the body whorl nine-tenths of the total length ${ }^{2}$.

I am inclined, therefore, to consider that Neptunea contraria may be regarded as a separate species, of which the Sicilian (var. sinistrorsa) and Anglo-Belgian fossil forms are geographical varieties, and that the Vigo Bay shell is a connecting link between them.

The carinated and non-carinated dextral shells of the Essex Crag on the one hand, and the existing $N$. antiqua and $N$. despecta on the other are more nearly related to each other than they are to the sinistral group. $N$. antiqua and $N$. despecta have at the present day, however, a very different range, and are rightly regarded as distinct.

1 Specimens may be obtained from the Crag and from the Scaldisien deposits which to some extent approach in their sculpture those found in Vigo Bay.

2 Examples of dextral and sinistral shells are met with in these beds which approach each other, but the typical form in each case is widely different; the sinistral specimens, moreover, attain a much larger size at Oakley than do the dextral. 


\section{SUR LES RELATIONS À ÉTABLIR ENTRE LES DIFFÉRENTS LABORATOIRES MARITIMES POUR L'ÉTUdE DE CERTAINES QUESTIONS DE BIOLOGIE GÉNÉRALE DES ÊTRES MARINS.}

\section{By Prof. E. Perrier and M. A. E. Malard.}

Il existe un certain nombre de Recherches relatives à la Biologie Générale des êtres marins qu'il est impossible à un Laboratoire Maritime isolé (si bien organisé qu'il soit) d'entreprendre. Ce sont les Recherches qui demandent comparaison.

Outre les changements périodiques annuels qui se produisent dans la Faune et la Flore Marine d'une localité : tous ceux qui ont eu l'occasion d'étudier pendant un certain nombre d'années un point de nos côtes, ont pu remarquer des changements: les uns plus ou moins brusques, les autres plus ou moins lents, qui modifient profondément le facies d'un rivage ou d'un fond donné. Telles espèces, comme l'Asterina Gibbosa, l'Antedon Rosacea disparaissent complètement d'une région où, quelques années auparavant, elles abondaient. D'autres espèces au contraire apparaissent soudainement en nombre presqu'innombrable.

Une observation suivie de la côte est du Département de la Manche pendant une douzaine d'années nous permet de croire que ces changements, non seulement ont leurs causes; mais que ces causes dans certains cas du moins peuvent être déterminées.

Il semble exister pour certaines Espèces Marines, tant Végétales qu'Animales, des points d'élection fixes, des Stations permanentes d'où la dissémination paraît irradier suivant des aires qui pourront être fixées par certaines conditions atmosphériques. (Salure et densité de la mer, température, intensité de la lumière, nature et intensité des courants marins, des vents, etc.)

Il importerait pour l'étude des relations qui peuvent exister entre les conditions physico-chimiques du milieu et ces migrations d'espèces, d'entreprendre des observations simultanées dans les diverses Stations Maritimes permanentes. Recherches conçues dans un même esprit, avec une même méthode et dont les résultats seraient par là même comparables.

Chaque laboratoire prendrait ou ne prendrait pas part à ces recherches; mais en tous cas l'ensemble des observations serait conçu d'après un plan unique. Il reste d'ailleurs bien entendu que le bénéfice de ces recherches serait le propre de chacun des Laboratoires qui les ferait publier annuellement ou périodiquement, où et comme il l'entendrait.

Pour préparer ce plan de recherches, nous pensons utile de demander à la Section C. du Congrès de vouloir bien nommer une Commission chargée d'élaborer un plan unique de recherches qui serait alors soumise à l'activité propre de chaque Laboratoire, à chaque Congrès International suivant les résultats obtenus, les 
moyens d'investigations acquis, le plan de recherches pourrait être modifié suivant les désidératas soumis à la Commission et introduits par elle dans le plan de recherches.

Il nous semble, au point de vue de la Biologie Marine, utile au plus haut point, de coordonner les observations de nos diverses Stations Maritimes et d'indiquer aux bonnes volontés latentes la voie qu'elles doivent suivre.

Tel serait le but de la Commission permanente des Laboratoires Maritimes et du Programme de Recherches qu'elle élaborerait.

La Section C. présidée par Mr C. W. Stiles adopte l'idée émise par MM. E. Perrier et Malard et charge Monsieur Malard de s'entendre avec ses collègues des différents laboratoircs maritimes pour fonder la commission et élaborer un programme.

\section{A NEW METHOD OF STAINING CILIA, FLAGELLA AND OTHEK LOCOMOTOR ORGANS OF PROTOZOA (with Demonstration).}

\section{By Prof. W. Schewiakoff.}

Prof. SCHEwIAKOFF announced a new method of staining the cilia, flagella and pseudopodia of Protozoa. The animals are first killed by letting a drop of osmic acid fall into the water drop containing the protozoa. They then remain in the moist chamber for two to eight hours after a cover-glass having been laid over them. Then a few drops of Delafield's Haematoxylin, which is diluted with water so much as to take a light claret colour, are added. In this they remain from 20 minutes to three hours, according to the different species, and are then brought into balsam in the ordinary way. The cilia are of dark greyish colour, and appear very distinct.

M. Certes (Délégué et ancien Président de la Soc. Zool. de France) demande la permission de rappeler que dès $1 \$ 79^{1}$ et alors que l'acide osmique n'était employé qu'en histologie proprement dite, il a appelé l'attention sur l'emploi de ce réactif et de ses vapeurs pour la fixation et l'étude des Protozoaires. Depuis lors M. Certes a multiplié ses recherches et ses communications sur les divers réactifs-serum iodé, liquide iodo-ioduré-chaleur à $70^{\circ}$; matières colorantes etc.-qui peuvent servir à la fixation et à l'étude des infusoires. M. Certes a même fait ressortir dès $1880^{2}$ la possibilité de se servir de ces divers réactifs pour l'analyse biologique des Eaux. Ses observations sur ce point ont été résumées, en I882,

1 Compt. rend. Acad. des Sc. de Paris, Séance du 3 mars 1879: "Sur une méthode de conservation des Infusoires." Note présentée par M. Pasteur, avec pl. et préparations à l'appui.

2 Compt. rend. Acad. des Sc. de Paris, Séance du $1+$ juin 1880 : "Sur l'analy'se micrographique des Eaux." Nole présentée par M. Pasteur.

$$
15-2
$$


devant l'association frarçaise pour l'arancement des Sciences et publiées avec planches à l'appui, dans le bulletin de l'Association '.

Avec un peu de pratique on arrive par ces divers procédés à faire d'excellentes préparations d'Infusoires, de Rhizopodes, de Microbes et autres micro-organismes. La principale difficulté réside dans l'extrême contractilité de beaucoup de ces organismes et nous venons de voir par la communication et les admirables préparations de M. Rousselet, comment cette difficulté pouvait être résolue pour les rotiferes.

M. Certes ne croit pas devoir insister sur ces détails qui exigeraient de longs développements; mais il ne lui parait pas hors de propos de rappeler brièvement les services que peut rendre l'emploi de certaines couleurs d'aniline pour l'étude du protoplasma et des tissus vivants ${ }^{2}$, soit au point de rue histologique soit au point de vue biologique ${ }^{3}$.

S'agit-il des cils, des cirrhes, des flagella et autres appendices locomoteurs qui font l'objet de la communication de M. Schewiakoff, on arrive à les voir tels qu'ils sont et d'autant plus facilement qu'ils continuent à se mouvoir dans un milieu coloré. S'agit-il des noyaux, des nucléoles, de la cuticule, des trichocystes, des diverses granulations du protoplasma, on constate qu'ils se colorent ou ne se colorent pas suivant les réactifs et quelquefois suivant les espèces. M. Certes a noté ce fait instructif, par exemple, qu'il n'existe aucun réactif, à sa connaissance, qui colore nettement, sur le vivant, la vacuole contractile. Au contraire les vacuoles alimentaires présentent toujours des phénomènes successifs de coloration et de décoloration qui nous renseignent sur l'acidité ou l'alcalinité des liquides digestifs, phénomènes variables selon les espèces et les réactifs.

Arec le bleu $\mathrm{C}_{2} \mathrm{~B}$ de Poirrier, M. Certes est arrivé à différencier, sur le vivant, les diverses parties du pédoncule contractile de certaines espèces de vorticelles. Lorsque cette expérience assez délicate est bien réussie, le liquide visqueux intersticiel du pédoncule est seul coloré, le filament central conserve sa contractilité et l'on reconnait que c'est le liquide bleu exsudé par l'extrémité du pédoncule qui fixe les vorticelles sur leur support. Enfin l'on peut avec certaines espèces d'infusoires plus robustes, réaliser de véritables expériences de pathologie expérimentale.

1 Congrès de La Rochelle, I 882: "Sur l'analyse micrographique des Eaux," avec pl.

2 Au sujet de la "Colorabilité du protoplasma vivant," cf. la note du Prof. Henneguy parue récemment (No. 9, 8 mars 1898), dans l'Intermédiaire des Biologistes. Paris, Reinwald.

${ }^{3}$ A. Certes, Compt. rend. Acad. des Sc. de Paris, Séance du 21 fevrier 188 1 : "Sur un procédé de coloration des Infusoires et des éléments anatomiques pendant la vie." Note présentée par M. Pasteur--Soc. Zool. de France. Notes des 21 janvier, 8 mars et 26 juillet 1881.-Zool. Anz. I $88_{1}$, No. 81, p. 208 and No. $8_{+}$, p. 28 $8_{7}$.-Société de Biologie. Séances des 12 mars 1885 et 5 avril 1886 . “De l'emploi des matières colorantes dans l'étude physiologique et histologique des infusoires vivants." Des préparations d'infusoires vivants ont toujours été placées sous les yeux des membres de la Société de Biologie et de la Śoc. Zool. de France à l'appui de ces diverses communications. 
Les avantages de ces méthodes pour l'étude des microbes ne sont pas moindres. Dans les eaux trìs pures, des colonies ou des voiles de bactéries très transparentes et qui auraient certainement échappé à un examen superficiel, se colorent par le violet Dahlia I70 et deviennent aussi nettes que s'il $y$ avait eu dessication préalable. Or il est incontestable que la plupart cles microbes sont plus ou moins déformés par la dessication. C'est avec le violet Dahlia I 70 que Laurent a pu étudier les microbes des nodosités des légumineuses et ce même réactif rend visible le filament de certains vibrions, sans qu'il $y$ ait besoin de recourir au procédé de Loeffler.

On pourrait multiplier ces exemples, mais M. Certes croit en avoir dit assez pour démontrer dans quelle large mesure les méthodes de coloration du protoplasma et des tissus rivants favorisent les progrès de la microbiologie?.

\section{SUR LES STADES POSTLARTAIRES DES ARÉNICOLES.}

\section{By M. Pierre Fauvel.}

M. P. Fauvel confirme la supposition de Cunningham et Ramage attribuant les pontes décrites par M. Schultze comme pontes d'Arenicola au Scoloplos amiger.

Il décrit une Annélide trouvée par lui à Cherbourg en Avril I 898 , annélide que ses caractères morphologiques et anatomiques permettent d'identifier avec le Brancliomaldane Vincenti LANG. d'une part, et avec l'A renicola Backii R. d'autre part.

Cette dernière espèce étant synonyme d'A. branchialis Aud. Edw. il en résulte que le $B$. Vincenti n'est qu'un stade jeune de cette espèce.

L'étude de l'anatomie interne et de la morphologie externe de cette forme lui a également permis de reconnaître qu'elle n'est ellemême qu'un stade un peu plus âgé de Clymonides incortus et Cly'. ccaudatus.

En rapprochant ces observations de celles des auteurs qui ont décrit et étudié Clymenides et les stades jeunes de l'Arenicola on arrive à cette conclusion que: Clymonides ecandatus, Cly. incertus et Branchiomaldane Vincenti sont des stades postlarvaires d'Arenicola

1 Je crois devoir rappeler que Brandt en $8_{79}$, puis en $188_{1}$ le Prof. Hemneguy et moimême avons démontré d'une façon simultanée et indépendante la possibilité de colorer le protoplasma vivant, par certaines couleurs d'aniline. C'est seulement en 1885 et i 886 que le Prof. Ehrlich a rendu compte de ses expériences avec le bleu de méthylène. Les expériences de Brandt étaient faites avec l'hématoxyline et le brun Bismarck, celles d'Henneguy avec le brun Bismarck, les miennes d'abord avec la cyanine, puis avec le Dahlia I jo, le vert acide et les bleus de Poirrier, le bleu de diphenylanine et plus récemment le rouge Congo, le neutral roth etc...Le Dr Henneguy, dans la note précitée, rappelle ces recherches et résume les travaux plus récents de Bolles Lee, de Douglas Campbell (1886-88), de Danilewski (1891), de Galeotti (1894), de Przesmycki (1897), de Trowasek (189j). 
branchialis comme Clymonides sulfureus est un stade jeune d'A. marina.

Ces genres Clymenides et Branchiomaldane doivent done disparaître ainsi que la famille des Clyménidiens créée pour eux.

9. Finally M. G. Pruvot read the following paper on LA Structure de la larve Actinotroque des Phoronidiens

\section{By Prof. Louis Roule.}

M. Masterman a récemment publié (Quart. Fourn. of Mic. Sc., I 897) un important mémoire sur l'organisation de l'Actinotroque. Il conclut, d'après ses recherches, à l'existence d'affinités étroites entre les Phoronidiens et les Bryozoaires Ptérobranches, qu'il rassemble dans un groupe commun des Diplocordés, puis entre ce dernier groupe et celui des Cordés. Je poursuis, depuis plusieurs années, l'étude du développement embryonnaire du Phoronis Sabatieri, commun dans l'étang de Thau, près de Cette. J'ai déjà fourni, sur ce sujet, plusieurs indications succinctes. Actuellement, mon travail est terminé; il paraîtra dans le courant de l'année prochaine. J'en détache pourtant quelques données, qui autorisent à n'accepter les conclusions de M. Masterman qu'avec une grande réserve.

$\mathrm{I}^{0}$ L'unique centre nerveux de l'Actinotroque du Phoronis Sabatieri est la plaque céphalique, située vers la zone centrale du lobe préoral. Aucun anneau nerveux, aucun neuropore, ne se présentent pendant l'évolution.

$2^{\circ}$ Cette larve ne possède point d'organe comparable à la glande subneurale décrite par M. Masterman. En revanche, elle a un diverticule digestif ventral, dont les cellules subissent une modification vacuolaire; mais cette expansion est simple, impaire, médiane, et ne se divise pas en deux pièces symétriques.

$3^{0}$ Le cœlome, formé selon le procédé schizocœlien, est loin d'avoir une grande complexité. Il se borne à une cavité spacieuse, circonscrite par une somatopleure et une splanchnopleure parfois discontinues; il est traversé par des brides mésentériques, dont le nombre, comme l'allure, varient souvent d'une larve à l'autre. Ces édifications mésodermiques de la larve n'ont aucune importance dans la morphogénèse, car elles sont appelées à se détruire par histolyse au moment de la transformation de l'Actinotroque en Phoronis. Pendant cette métamorphose, l'individu passe par un état de pupe, non signalé encore, où se manifestent d'intéressants phénomènes de destruction organique et de reconstitution.

J'ai suivi, en son entier, le développement embryonnaire de l'Actinotroque, depuis la segmentation ovulaire jusqu'à la métamorphose accomplie. Mon prochain travail, que j'annonce ici, 
renfermera les descriptions de toutes les phases successives. J'y joindrai des considérations sur les affinités zoologiques des Phoronidiens avec les autres groupes d'animaux. Je suis d'accord avec M. Masterman pour trouver dans l'Actinotroque un début de la conformation essentielle des Vertébrés, mais je m'écarte entièrement de lui sur la manière dont ces relations doivent être comprises. 


\title{
SECTION D. ARTHROPODA.
}

\author{
TuesDay, 23 August, in the Lecture Room of Comparative \\ Anatomy, at 2 p.m.
}

Chairman, Dr SHARP.

Secretary, M. CH. JANET.

Assistant Secretary, Mr CeCil Warburton.

The following papers were read :

\section{ON THE EVOLUtion OF COLOUR in LEPidoptera.}

\section{By Mr IM. C. Piepers.}

It is my wish to speak briefly about an important phenomenon that my studies in Lepidopterology have revealed. It is true the greater part of these investigations have already been published, but as this has been done in the German language, they are, I believe, little known in England; now it is precisely in that country that I should wish to draw attention to these investigations, for England and English-speaking America possess the greatest number of Lepidopterologists. Allow me then to ask the favour of your attention for a short time.

My studies on the caterpillars of the Sphingidae (the result of which was published in the Dutch periodical, Tijdschrift ioor Entomologie, Vol. XL., in an article entitled, Ueber die Farbe und den Polymorplismus der Sphingiden-Raupen) have convinced me that in the whole of this family the caterpillars are subject to a process of change of colour, which must already have begun in the primitive form before the division into the different genera and species. Hence at present the original whitish-yellow colour passes through green and brown of all shades into black; and there also exist intermediate colours such as red, loam-colour, etc. This change prevails in all species, but in nearly all follows a different course. The differences consist in the manner in which the colour changes or in the time at which such a change takes place, so that some species are already far advanced, while these changes have hardly begun in others, and the majority stand between the two extremes. This is evident on comparison of the colours of the adult caterpillars with those of their earlier stadia of growth; these presenting ontogenetically their former phylogenetical stadia; and still more so 
when we take into consideration the phenomenon of genepistasy, so called by the late German naturalist Prof. Dr Eimer, which causes the continuation of a certain colour in one of the stadia for an indefinite time.

If the fact is already long known that the caterpillars of the above-named family, belonging to the same species, appeared in different colours, and that in this respect the different ontogenetical stadia are at variance, no one, as far as I am aware, has stated the universality of this fact nor the constant succession of these colours in a certain order, so as to infer from this the general phenomenon of a regular succession of changes. On this account I think I may consider myself the discoverer of this phenomenon (which I also observed in caterpillars of other families) and give it a name. And the name I have selected is "evolution of colour." For though it consists in the revelation of a hitherto unobserved phenomenon as far as the colour of insects is concerned, it is indeed nothing else than the well-known fact called evolution, that all animal forms are constantly subject to organic changes in one direction or anotherthough they may now and then come to a temporary standstill. Thus the name of "crolution of colour" seems to me to be the proper term.

Before I had come to this conclusion I had perceived that the remarkable cases of polymorphism among the imagines of the Lepidoptera, of which I had been able to study at my leisure the most characteristic example, that of Papilio memnon, L., during my 30 years' stay in the Malayan archipelago, did not simply consist, as so many think, in the fact that by the side of the $\delta^{\lambda}$ several different forms of the $q$ exist, which forms also vary among themselves as well as from the $\sigma^{\gamma}$, but that all these varieties compared together manifest only the result of changing colours passing over from one to the other, making a series of which the $\delta$ forms one extreme and the female variety differing most from the $\delta$, Papilio achates Cram., the other. Indeed at the last International Congress of Zoology, which took place at Leyden, I stated this fact, as can be read in the reports of that Congress. But no sooner was the phenomenon of "evolution of colour" clear to me than I found in it the solution of this polymorphism.

In just the same manner as the shades of colour pass over one into the other in the above-mentioned caterpillars they also pass over one into the other in the different forms of imagines of Papilio momnon L., therefore it seemed clear to me that this polymorphism too could be nothing less than such an "evolution of colour," which, however, not only shows itself as a difference in colour between the species, but in these imagines also between the sexes of a same species. Now we are taught by investigations on the group of Papilionidae to which Papilio memnon L. belongs-in connection with other groups of the same family-and in particular by comparison of that butterfly with its next allied form found in the 
island of Celebes, Papilio ascalaphus Bsd., that when the case presents itself of an unequal advance in evolution between the sexes of the same species, only a certain number of times, as in the case of $P$. memnon L., some of the intermediate forms in which this is the clearest to be seen, have been preserved, most times, however, only the extreme forms. This explains the fact of there being sometimes a small, sometimes a great difference in colouroccasionally also in form-in the sexes of the same species of Lepidoptera, in consequence of the change of colour only having begun in one of the sexes, while the other was in a state of genepistasy and remained unaltered.

Such an evolution in the imagines of the Lepidoptera is certainly very common; most probably it is as general a rule as is the case with the caterpillars of the Sphingidae.

In order to obtain more certainty on this subject I have thoroughly investigated about a thousand species of the family of the Pieridae, particularly fit for this object by its peculiar colours, in an article entitled "Die Farbencvolution (Phylogenie) bei den Picriden," in the "Tijdschrift dor Nederlandsche dierkundige vereeniging," ser. 2, vol. 5. As the result my opinion has been completely confirmed. I found in truth that just as the caterpillars in the family of the Splinggidae, so all the imagines of the Pieridae were subject to an evolution of colour which must have begun in the original form, living in the tertiaries, and which, although constantly following the same direction, changes in a very unequal mannernot only with reference to the species but also to the sex; and besides that the region in which they live or the season in which they appear cause divergences; the evolution being moreover again and again retarded by genepistasy. According to my investigations the present colour of all the Pieridac must have proceeded from a general red colour, subsequently passing into white, be it directly through orange and yellow or green, or replaced by brown or black before or partly at the same time, which is, however, later on again driven away by white, and thus all become uniformly white; perhaps even the colour contained in the wing-scales will in time get quite exhausted and be lost. The difference in colour between the various species of this family is thus the result of the way in which this process makes its appearance on the different parts of the wings; all kinds of remnants of these different shades of colour are to be seen there, now in a greater, then in a lesser degree, now in one place, then in another, except in those species which are so far advanced in the evolution as to have become nearly completely white-the well-known "white ones."

But this investigation procured me still more results. It was made evident to me that this very phenomenon of "evolution of colour" must be in general the cause of the great difference in colour of the Lepidoptera, which characterises so highly this order of animals. But the succession of colours in this evolution seems 
not to be the same in all the families, and sometimes in the struggle for the upper hand between black and white for a certain time, now one, now the other is uppermost. As to the whole family of the Papilionidac, that of the Lycaenidae and the genus Vanessa of the Nymplialidae, I have no longer any doubt that there the "evolution of colour" is the same as that of the Picridac.

The recognition of this evolution has still a deeper significance. Through it a light is thrown on a number of phenomena hitherto insufficiently explained; such as on the melanism of the butterflies, and also to some extent on their albinism; on their polymorphism, be this permanent or presenting itself as season-dimorphism (it proves also the inaccuracy of the idea of it being caused by heterogeny); on the variation of their colour among the individuals or in the local races; on the nature of the change brought about by artificial temperature; on the origin of "eye-spots," and other phenomena. This gives a clue to much which is of importance respecting heredity under the working of newly-arising influences; the phenomenon of mimicry is thus also better understood. And lastly this knowledge throws a bright light on the fact that in this evolution going on from time immemorial and gradually changing a whole group of animals, natural selection (not even to speak of sexual selection) plays no part at all.

Truly, if I am not mistaken, and I do not think I am-but to err is human-I may speak of a new view on the phenomena of Lepidopterology and of a new field of investigation, which too is not without importance for other branches of zoology.

Now this new view it is my wish to introduce among the countrymen of Darwin; for though it appears to be in opposition to Darwinism in the latest and the narrowest sense, it is really a step forwards in the domain of that evolutionism with which Darwin's name and fame is incontestably associated.

2. EXPÉRIENCES SUR LA RELATION QUi EXISTE ENTRE LA COUleur du Milieu ET LA COUleur des ChrYsalides DE CERTAINS LÉPIDOPTĖRES.

\section{By IM. Edmond Bordage,}

Directeur du Muséum D'histoire Naturel,le de l'Ile de la Réunion (BOURBON).

Plusieurs observateurs ont signalé la relation que l'on peut constater entre la couleur des chrysalides de certains Lépidoptères et celle des surfaces sur lesquelles elles sont fixées. Les recherches les plus remarquables à ce sujet sont celles d'un éminent savant anglais, Mr Edward B. Poulton, de la Société Royale de Londres ${ }^{1}$.

1 E. B. Poulton, An Enquiry into the Cause and Extent of a special Colour-Relation between certain exposed Lepidopterous Pufe and the Surfaces which immedialdy surround them (Phil. Trans. Royal Society, 1887). Voir aussi: The Colours of Animals (r89o), du même auteur. 
Guidé par ses admirables travaux, j'ai entrepris une série d'expériences sur cinq Lépidoptères de l'Ile de la Réunion, avec l'intention de les étendre plus tard à d'autres espèces des Mascareignes.

Dans ces expériences, j'ai constamment tenu compte des indications de $\mathrm{Mr}$ Poulton, en isolant soigneusement les larves, et en enlevant les feuilles vertes destinées à leur nourriture, dès l'instant où l'immobilité de ces larves m'indiquait que le moment du changement en chrysalide était proche.

J'ai pu vérifier que, dans le cas où il y avait adaptabilité, l'influence de la coloration de la surface de fixation s'exerçait sur la chenille et non sur la chrysalide elle-même, et qu'elle se manifestait pendant les 20 dernières heures de la période durant laquelle la chenille, après avoir cessé de manger, reste immobile, puis se suspend la tête en bas.

Les cinq espèces sur lesquelles j'ai expérimenté sont: Atella phalanta, Euplaa gondotii, Danais chrysippus, Papilio demolens et P. disparilis ${ }^{1}$.

Voici quels sont les résultats auxquels je suis arrivé pour chacune de ces espèces.

$$
*^{*} *
$$

\section{Atella phalanta (Famille des Vanessida).}

La chenille de ce Lépidoptère-répandu dans différentes parties des Indes Orientales, ainsi qu'à Madagascar et aux Mascareignesvit, à la Réunion, sur les Pruniers malgaches (Flacourtia cataphracta et $F$. ramontchi, fam. des Bixacées).

Les chrysalides sont le plus souvent d'un joli vert, avec tubercules ou pointes à base argentée et à extrémité carminée du plus joli effet. Il en existe aussi chez lesquelles la teinte verte générale est remplacée par une sorte de glacis d'un blanc transparent et brillant à reflets argentés et légèrement irisés.

Si on considère ces chrysalides lorsqu'elles adhérent encore aux feuilles de l'arbre qui nourrit les chenilles, on peut remarquer qu'au milieu du feuillage, dans les parties les moins bien éclairées, se trouvent celles qui offrent la teinte verte, tandis que, sur les rameaux les plus extérieurs et les mieux éclairés, on constate quelquefois la présence de la forme à reflets argentés.

Cette observation m'engagea à entreprendre une série d'expériences dont voici les conclusions :

$\left(\mathrm{I}^{\circ}\right)$ Les surfaces à reflets métalliques (dorés et argentés) ne donnent que la forme brillante; le plus grand nombre des chrysalides présentant un éclat inusité qui les fait ressembler à de splendides bijoux ;

$\left(2^{\circ}\right)$ Les surfaces à coloration claire et surtout les surfaces blanches donnent déjà un assez grand nombre de chrysalides à reflets brillants;

1 Seule, la dernière de ces espèces est spéciale à l'Ile de la Réunion (Bourbon). 
$\left(3^{\circ}\right)$ Les surfaces à coloration foncíe-quelle que soit d'aillours leur couleur-ne donnent que des chrysalides vertes à tubercules et a pointes pen brillants;

$\left(4^{\circ}\right)$ Les surfaces noires très faiblenncnt iclairces ct surtout les tónèbres complètes, donnent des chry'salides presque entièrement noires, comme il nen existe pas dans les conditions normales. Sur ces chrysalides, les pointes ornementales ont presque complètement perdu leur éclat.

En résumé, ce qui influe sur la teinte des chrysalides, c'est l'intensité de la lumière; les surfaces colorées n'agissant qu'incidemment, pour ainsi dire, selon la quantité de lumière qui les traverse ou qu'elles renvoient par réflexion.

La forme verte, malgré ses ornements argentés et à extrémité rouge carmin, se confond encore assez bien avec la couleur du feuillage du Prunier malgache. Du reste, les ornements en question, de même que la coloration à reflets argentés et irisés de la forme brillante, doivent contribuer de leur côté à la protection des chrysalides-mais cela d'une façon tout opposée à celle de la couleur verte-en les rendant très visibles et par suite suspectes. Comme cela a lieu pour les insectes, les chrysalides qui offrent de brillantes couleurs, possèdent d'ordinaire une saveur désagréable, grâce à laquelle elles sont dédaignées par les animaux qui, autrement, pourraient être tentés de s'en nourrir.

J'ai présenté des chrysalides d'A. phalanta à différents animaux. Le Martin acridophage (Acridotheres tristis) et le Merle de Bourbon (Hypsipetes borbonica) les ont dédaignées. La Poule domestique, la Poule sultane (Porphyrio madagascariensis), et la Poule d'eau (Gallinula chloropus), après y avoir goûté une fois, ont manifesté ensuite une répugnance complète et n'y ont plus touché. Par contre, des singes de la ménagerie du Muséum de la Réunion (Cercopithecus monoides et C. pygerythrus), les ont mangées avec avidité, se les disputant même. Un saurien, le Galéote changeant (Calotes vicrsicolor), les a complètement dédaignées.

Je signalerai ici un fait intéressant que je n'ai jamais pu constater sur les quatre autres espèces qui seront étudiées dans cette communication. Les chenilles d'A. phalanta élevées dans les ténèbres, bien que la nourriture ne leur ait pas manqué, m'ont donné des chrysalides très petites et des papillons dont les dimensions atteignaient à peine le tier's de celles des spécimens ordinaires. J'ai encore pu obtenir ces formes naines en élerant en pleine lumière des larves auxquelles je donnais le moins de nourriture possible, à tel point que les deux tiers succombaient. Je dois ajouter que, dans les deux cas, les larves étaient enfermées dans des boîtes exigues et presque hermétiquement closes. J'ai donc ainsi obtenu, incidemment, un curieux exemple de transformisme expérimental. 


\section{Euplœa goudotii (Famille des Danaida).}

La chenille de ce Lépidoptère vit sur le Laurier-rose (Neriusn olecnder). Les chrysalides, réellement splendides, présentent, les unes, l'éclat de l'argent poli; les autres, des reflets dorés, légèrement verdâtres. On trouve les deux variétés en nombre à peu près égal.

La couleur de la surface de fixation n'a aucune influence sur la teinte de la chrysalide. Seuls, les milieux à reflets métalliques agissent: les reflets argentés donnan't un plus grand nombre de chrysalides à aspect doré.

En maintenant les chenilles dans les ténèbres complètes, j’ai obtenu une variété de chrysalide qu'on n'observe jamais dans la nature. Sur le fond habituel, d'aspect métallique, se développent des bandes et des taches symétriques, d'un brun-noirâtre, sur le corselet, sur l'abdomen, sur le milieu des ailes et tout le long de la saillie anguleuse de ces dernières ${ }^{1}$. Ce détail est d'autant plus remarquable que, jusqu'au moment même de l'éclosion, les autres chrysalides gardent presque complètement leur éclat métallique sans jamais acquérir de taches brunes aussi développées, lorsque ces dernières se présentent les 3 ou 4 derniers jours, ce qui est rare.

Les brillants reflets des chrysalides de l'E. goudotii doivent les protéger des attaques des animaux qui, sans cela, pourraient être tentés d'en faire leur proie. Prévenus par leurs couleurs si voyantes (waming colours), ces animaux ne se hasardent pas à y goûter. Tous ceux que j'ai cités à propos d'Atella phalanta, se sont comportés d'une façon absolument semblable à celle qui a été exposée plus haut, lorsque je leur ai présenté des chrysalides d'E. gondotii.

\section{Danais chrysippus (Famille des Danaida).}

La chenille de ce papillon si répandu vit, à la Réunion, sur une Aesclépiadée, le Gomphocarpus cornutus. Les chrysalides, du plus charmant effet, se présentent sous trois couleurs différentes : tantôt elles ont l'aspect de la cire rose pâle, tantôt elles sont d'un joli vert clair; plus rarement enfin, elles rappellent la cire blanche ou l'ivoire à peine jauni. Ces trois formes offrent, de part et d'autre de la ligne dorsale, des points dorés et, assez près de l'extrémité abdominale, une rangée de semblables points disposés en fer à cheval. Cette rangée de points brillants est soulignée d'un trait noir. Sur la forme verte, et plus rarement sur les autres formes, le trait noir est à peine estampé d'une légère teinte fondue d'un bleu très clair tirant sur le vert.

1 Pendant que je rédigeais cette communication, j'ai obtenu, dans les ténèbres complètes, 2 chrysalides d'E. goudotii dont la face ventrale avait l'éclat superbe de l'argent poli, mais dont la région dorsale était presque complètement noire. Une troisième chrysalide n'a pas noirci, mais elle n'a pas acquis de reflets métalliques, gardant simplement l'aspect de la corne transparente ou de l'écaille. Elle a malheureusement été écrasée accidentellement, de sorte qui je n'ai pas pu constater si elle était capable d'arriver à son éclosion. 
Si j'ai été le premier à étudier l'influence des lumières colorées sur les chrysalides d'Atella phalanta et d'Euplaa goudotii, il n'en est pas de même pour celles de $D$. chrysippus. En effet, des observations ont été faites sur cette espèce par M. R. Trimen, au Cap $^{1}$, et par M. Morris dans l'Inde anglaise ${ }^{2}$. Les conclusions de ces auteurs diffèrent complètement. Pour le premier, les différentes lumières colorées sont sans action sur les chrysalides; tandis que le second prétend au contraire que ces chrysalides jouissent d'une admirable sensibilité. J'ai alors pensé qu'il serait intéressant d'établir de quel côté était la vérité.

A près de très nombreuses expériences, j’ai été amené à constater que l'opinion de M. R. Trimen-à quelques petites restrictions près -était celle que l'on devait considérer comme exacte.

La coloration des surfaces de fixation n'a aucune influence sur les chrysalides de $D$. chrysippus. C'est tout au plus si j'ai pu constater que, pour les surfaces à reflets métalliques ou à coloration claire, le nombre des chrysalides vertes est un peu supérieur à celui des chrysalides rose pâle ou blanches, et que, réciproquement, les teintes foncées donnaient un nombre de chrysalides rose pâle ou blanches légèrement supéricur à celui des chrysalides vertes-l'éclat des points dorés restant sensiblement constant.

Je fus alors amené à rechercher quel serait l'effet produit par un fond noir et par les ténèbres complètes. Sur un fond noir peu éclairé, le nombre des chrysalides roses et des chrysalides blanches commença à l'emporter d'une façon sensible sur celui des chrysalides vertes. Dans les ténèbres complètes, la différence devint vraiment remarquable. Les chenilles sur lesquelles j'expérimentai eurent toujours en abondance air et nourriture. Quelquefois, toutes les chrysalides qui en résultèrent offrirent la coloration blanche ou rose pâle. Dans d'autres cas, il y eut aussi production de chrysalides vertes, mais le nombre des chrysalides blanches ou rose pâle ne fut jamais inférieur aux $\frac{3}{4} \mathrm{du}$ nombre total de chrysalides obtenues. L'éclat des points et du fer à cheval doré ne m'a pas paru sensiblement diminué chez les formes développées dans les ténèbres. La production des quelques chrysalides vertes est répartie sur toute la durée de chaque expérience, et il en apparaît aussi bien à la fin qu'au début.

Cela est d'autaut plus curieux que la forme blanche-assez rare dans la nature-et la forme rose pâle doivent être considérées comme étant plus claires que la forme verte qui, bien que légèrement colorée elle-même, représente cependant une forme relativement foncée ${ }^{3}$.

1 R. Trimen (cité par Mr E. Poulton, loc. cit.).

2 Morris, Fournal Bombay Nat. Hist. Soc., i S9o (cité par Mr F. E. Beddard dans son remarquable ouvrage intitulé Animal Coloration, 1895, p. 137).

${ }^{3}$ Il y a donc, en quelque sorte, antagonisme entre la teinte verte et les teintes rose pâle et blanc de cire, et c'est précisément pour cela qu'on ne voit jamais de chrysalides à la fois roses et vertes. Je me demande alors comment MI. Trimen a pu être anené à parler de chrysalides dont la teinte serait un mélange de rose et de vert. 
Les chrysalides rose pâle et blanches ne diffèrent nullement des vertes au point de vue de la grosseur, et les papillons qui en sortent sont absolument semblables au type ordinaire.

Sur les fonds colorés les plus divers, j’ai obtenu, assez rarement, des chrysalides rouges ou couleur saumon, de dimensions réduites. C'est là une forme anormale qui se produit lorsque la chenille est languissante et mal nourrie. Je n'ai pas encore pu m'assurer si des larves parasitées, mais ayant cependant encore la force d'opérer leur transformation, n'étaient pas surtout celles qui donnaient de pareilles chrysalides. A priori la chose me semble très probable. Elles ne m'ont jamais donné d'ailleurs que des papillons mal venus, à ailes plissées et chiffonnées, et qui n'ont pas vécu.

J'arrive maintenant aux expériences de M. Morris. Cet auteur rapporte qu'il a obtenu des chrysalides blanches, rouges ou couleur saumon; cela n'a rien d'extraordinaire, et j'ai dit en avoir également obtenu, et cependant, la couleur des surfaces de fixation n'avait pas l'influence que leur attribue M. Morris.

Mais, lorsque ce dernier déclare avoir recueilli des chrysalides bleues' et des chrysalides noires sur des surfaces présentant les colorations correspondantes, je déclare n'y plus rien comprendre; ces deux formes n'ayant jamais existé.

J'ai présenté aux différents animaux cités plus haut des chrysalides de $D$. chrysippus. Seuls, les singes ont paru s'en régaler. Ceux des oiseaux qui s'étaient hasardés à y goûter les ont rejetées ensuite avec les signes d'un réel dégoût. Le Galéote a agi de même. Les jolies couleurs de ces chrysalides semblent donc devoir les rendre suspectes (zuarning colours).

\section{Papilio demoleus (Famille des Papilionida).}

La chenille de ce papillon vit sur les Aurantiacées (Citronnier, Oranger et Orangine ou Triphasia trifoliata). Les chrysalides sont grises ou jaune verdâtre, ou bien encore elles présentent la teinte jaune verdâtre sur leur face inférieure et une teinte brun rougeâtre sur leur face supérieure?

Il m'est arrivé quelquefois d'obtenir des chrysalides grises accolées à l'écorce grise des rameaux, ou des chrysalides vertes fixées sur des feuilles ou des brindilles vertes; mais, la moitié du temps, les chrysalides du $P$. demolcus étaient grises sur fond vert et réciproquement. Enfin, dans certains cas, ayant placé des chenilles dans les petites boîtes dont les angles délimitaient des

' Sur les chrysalides non obtenues dans les ténèbres-quelle qu'en soit la couleur-il existe quelquefois, immédiatement au-dessus du trait noir en fer à cheval, sur toute Ia longueur de ce trait et sur une largeur d'un millimètre à peine, une teinte d'un bleu très pâle, passant insensiblement au vert sur les formes vertes; pâlissant puis s'éteignant dans la teinte générale, chez les formes blanches ou roses. Est-ce peut-être ces chrysalides que Mr Morris appelle bleues? Cela semble peu vraisembable. D'un autre côté, comme le trait bleu en question tire quelquefois sur un ton vert glauque, c'est peut-être ce qui a fait dire à M. Trimen que certaines chrysalides roses présentaient aussi la nuance verte.

2 Il existe toujours, d'ailleurs, pour les chrysalides des Papilionide surtout, des différences de coloration plus ou moins grandes entre la face dorsale et la face ventrale. 
parois de couleurs différentes, les unes jaunes et les autres brun rougeâtre, j'ai pu constater que, au nombre des chrysalides fixées précisément dans ces angles, il y en avait qui étaient complètement grises ou complètement jaune verdâtre. Enfin un certain nombre présentaient à la fois la teinte brun rougeâtre et la teinte jaune verdâtre; la première de ces teintes, comme je l'ai déjà dit, ornant toujours la face dorsale et la seconde la face abdominale. Or, une bonne partie de ces chrysalides tournaient leur face dorsale vers la paroi jaune et leur face ventrale vers la paroi brun rougeâtre. Il n'y a donc eu qu'une simple coincidence dans les cas où les couleurs des chrysalides semblaient correspondre à celles des parois.

Les chrysalides obtenues sur fond noir et dans les ténèbres complètes ne différaient en rien de celles recueillies en pleine lumière.

D'après des observations faites au Cap, et antérieures aux miennes, M. R. Trimen ${ }^{1}$ prétend que les chrysalides du $P$. demoleus prennent les couleurs des surfaces sur lesquelles elles sont fixées, à condition toutefois que ces couleurs correspondent aux variétés de coloration offertes par les chrysalides dans la nature.

Comment expliquer alors cette contradiction complète entre les conclusions de M. Trimen et les miennes? Cela est bien simple. Cet auteur dit en effet n'avoir fait qu'une seule expérience.

Or, de mon côté, quand je fis ma première expérience, je n'avais à ma disposition que 5 chenilles, dont 3 furent placées sur fond gris et 2 sur fond vert. Les chrysalides que j'obtins offraient parfaitement les colorations respectives des surfaces sur lesquelles elles étaient fixées. Si je m'en étais tenu à cette seule observation, j'aurais pu être également tenté de conclure au pouvoir d'accommodation des couleurs. Des expériences nombreuses me permirent ensuite de constater qu'il n'y avait eu là qu'une simple coincidence.

La nature semble se plaire à cacher ses mystères, à décevoir, à induire en erreur l'observateur qui, pour une cause quelconque, est amené à formuler des conclusions basées sur une seule expérience.

\section{Papilio disparilis (Famille des Papilionida).}

La chenille de ce magnifique Lépidoptère vit également sur les Aurantiacées citées plus haut. Les chrysalides offrent des couleurs absolument pareilles à celles du $P$. demoleus et ne m'ont pas donné de résultats plus intéressants.

Les observations faites par plusieurs auteurs sur le $P$. machaon et celles de Fritz Müller sur le $P$. poly'damus, espèce de l'Amérique tropicale, ont démontré que les chrysalides de ces deux espèces étaient également insensibles à l'action des différentes lumières colorées.

Jusqu'ici, il ne m'a pas été possible d'entreprendre pour le Papilio phorbanta, de l'île Maurice, et pour le $P$. epiphorbas, de

\footnotetext{
1 Poulton (loc, cit.).
} 
Madagascar, des expériences semblables à celles que j'ai faites sur le $P$. disparilis; mais, étant donnée la grande ressemblance de coloration des chrysalides et des Papillons (je laisse de côté le $P$. disparalis $q$ ), je suis porté à croire qu'ils doivent se comporter d'une façon identique.

Si, comme cela paraît probable, il a existé autrefois une adaptabilité générale pour les chrysalides des représentants du genre Papilio, cette faculté, pour des raisons qui nous échappent, semble avoir complètement disparu à l'époque actuelle; ou, si elle existe encore-soit dans toute son intégrité, soit déjà diminuée et en voie de disparition-ce n'est peut-être que chez quelques rares espèces sur lesquelles on n'a pas encore expérimenté.

Des observations sur le $P$. nirens, faites au Cap, par Mme. Barber-observations dont les résultats furent exposés, en I874, par Ch. Darwin, devant la Société entomologique de Londrestendraient cependant à établir que cette espèce africaine qui ressemble beaucoup au $P$. phorbanta, au $P$. epiphorbas, et au $P$. disparilis $\delta^{7}$, figure au nombre de celles qui auraient conservé une sensibilité spéciale, mais je crains que Mme. Barber n'ait fait qu'un nombre d'observations très limité et je crois qu'il serait nécessaire d'entreprendre de nouvelles expériences à ce sujet.

Ce qui me fait parler ainsi, c'est que Mme. Barber dit avoir obtenu une chrysalide dont le dos était brun rougeâtre et la face ventrale d'un jaune verdâtre, dans des conditions analogues à celles nù j'ai opéré moi-même pour $P$. demoleus. Elle conclut de là, que les chrysalides de $P$. nirens seraient tellement sensibles à l'action des lumières colorées, qu'elles pourraient prendre les couleurs de deux parois voisines en contact. Il est tout probable qu'il n'y a eu dans ce cas qu'une simple coincidence, semblable en tous points à celles que j'ai signalées à propos de $P$. demoleus; ce qu'un plus grand nombre d'expériences aurait presque sûrement démontré.

Tels sont les faits que je désirais exposer aujourd'hui. Je me propose de continuer sous peu ces recherches d'un intérêt si captivant, en prenant d'abord comme sujets d'étude le Salamis radama, introduit accidentellement de Madagascar à la Réunion, et la Vanessa hippomene, espèce spéciale à cette dernière île."

The following appendix to M. Bordage's paper was received by the Editor in November, I 898 :-

Euplœa goudotii Pendant l'impression de cette communication, j'ai pu faire une intéressante observation. J'ai trouvé quelques chrysalides d'E. goudotii au milieu du feuillage exceptionnellement touffu d'un laurier-rose qui, après avoir été récemment coupé au ras du sol, repoussait très vigoureusement et formait un véritable buisson dont le centre était assez sombre. 
Ce laurier-rose était recouvert lui-même par un massif de manguiers (Mangifera indica) au feuillage trìs dense. De cette façon, certaines des chrysalides, celles qui occupaient le centre du buisson, ćtaient plongées dans les demi-ténèbres. Détail remarquable: elles présentaient sur leur région dorsale une coloration brun-noirâtre très marquée, la région ventrale offrant une coloration argentée très brillante. Celles qui étaient fixées vers la périphérie du buisson ne présentaient pas cette coloration foncée et leur surface tout entic̀re était brillant et d'aspect métallique. En un mot, j'ai trouvé dans la nature, mais dans des conditions assez exceptionnelles, des chrysalides se rapprochant beaucoup de celles que j'avais précédemment obtenues expérimentalement dans les ténèbres complètes.

Les splendides reflets des chrysalides d'E. goudotii, rappelant ceux de l'or, de l'argent, et surtout ceux de la pyrite de cuivre et de la pyrite de fer, s'ils semblent actuellement avoir pour rôle d'annoncer une saveur répugnante, ont dû servir autrefois de protection homochromique. En un mot, le rôle de warning coloration ne serait venu qu'en second lieu et aurait été précédé par celui de protective coloration (homochromie). A ce sujet encore, je partage entièrement l'opinion de Mr Edward B. Poulton.

Danais chrysippus...................... Seules, les chrysalides vertes un peu foncées possèdent une teinte protectrice par homochromie avec le feuillage, en dépit des quelques ornements dorés, qui, d'ailleurs, ne sont pas plus apparents chez elles que chez les chrysalides de coloration claire. Elles jouissent même d'un double avantage: $\left(\mathrm{I}^{\circ}\right)$ leur coloration verte les protège en les rendant assez peu apparentes sur le feuillage ; $\left(2^{\circ}\right)$ lorsque, malgré leur coloration protectrice, elles ont été aperçues par quelque animal, leurs ornements dorés doivent les rendre suspectes et les faire dédaigner. Les autres chrysalides de $D$. chrysippus, qu'elles soient roses d'un blanc pur ou d'un blanc à peine teinté de jaune ou de vert, ne jouissent que du second des avantages précités. Elles sont très apparentes sur le feuillage vert et l'effet de leur teinte générale s'ajoute à celui de leurs ornements dorés pour les rendre suspectes à beaucoup d'animaux.

Malgré l'apparence tout d'abord paradoxale de l'action d'une plus ou moins grande quantité de lumière et des ténèbres complètes sur les chrysalides de l'espèce qui nous occupe, tout est cependant pour le mieux, en définitive. En effet, sur un buisson, sur une touffe de verdure, les chrysalides fixées vers le centre, dans la partie la plus sombre, seront surtout représentées par des formes à teintes claires qui seraient très visibles si elles étaient au contraire sur la bordure du buisson ou de la touffe. Quant aux chrysalides fixées vers la périphérie du buisson et occupant par suite la partie la plus éclairée, elles seront plus abondamment représentées par la forme verte et protégées par suite par homochromie.

Tout récemment, j'ai pu observer que, sur un fond à reflets dorés, éclairé jour et nuit, le nombre des chrysalides vertes obtenues 
était supérieur au double de celui des chrysalides roses ou blanches ${ }^{1}$. Cela prouve donc encore d'une façon plus évidente que, chez $D$. chroysippus, espèce offranı cependant une saveur désagréable, les chrysalides les plus claires, les plus voyantes, sont celles qui se forment sur les fonds les plus obscurs ; ce qui constitue une curieuse exception à ce que l'on observe d'ordinaire.

Les chrysalides roses et les chrysalides blanches de $D$. chrysippus ont-elles été autrefois protégées par homochromie? Répondre à cette question n'est pas chose facile. Dans tout cas, si la faculté homochromique s'est montrée, si une adaptabilité spéciale a existé autrefois, il faut chercher quels sont, dans la nature, les corps présentant les colorations correspondantes qui pouvaient servir à la fixation des chrysalides. Dans le règne végétal, je ne vois guère que les fleurs à périanthe rose ou blanc, soit isolées, soit groupées en inflorescences plus ou moins serrées. D'autre part, parmi les corps inorganiques, les beaux cristaux de feldspath qui existent dans certaines roches éruptives (granite, granulite, pegmatite, etc.), me semblent seuls capables de présenter avec une grande perfection et grâce à leur aspect nacré rose, blanc laiteux ou à peine teinté de jaune ou de vert, la coloration des chrysalides en question.

Je dois enfin ajouter que l'on peut obtenir, dans les ténèbres, des chrysalides d'une teinte verte aussi foncée que celle de certaines chrysalides formées sur un fond à reflets métalliques dorés. D'un autre côté, on peut obtenir des chrysalides à coloration également claire dans ces conditions absolument opposées (chrysalides roses et chrysalides blanches). En un mot, il n'y a pas ici, comme chez d'autres espèces, des teintes de chrysalides absolument spéciales, selon qu'elles ont été obtenues dans les ténèbres ou dans une lumière très vive.

Mr RoLANI TRIMEN said that M. Bordage's paper was of great interest. Of the five specimens three were of wide African distribution, and two of them, Danais chrysippus and Papilio, he had himself experimented on at the Cape, and found that while the Danais did not respond to artificially-prepared surroundings of different colours, the Papilio did respond to some extent, viz. when the colours (shades of green and brown) more or less corresponded with the surroundings found in the natural environment. He considered, however, that M. Bordage had perhaps too hastily concluded-from experiments with two species only-that the genus Papilio appeared to have lost any sensibility to colour which it may at one time have possessed; for $P$. Ly aus, a near relative of $P$. disparilis of Réunion, had been shown by Mrs Barber-who had bred a large number at Grahamstown-to be highly sensitive as a pupating larva, the pupa reproducing the green of leaves, the brown of bark, the yellow of planed deal, and

3 Cette observation a été faite pendant l'impression de cette communication. 
the red of brick. Mr Trimen expressed the opinion that far too few and too limited experiments had been made among the specics of such large genera as Papilio, to warrant our at present coming to any conclusion on the point in question.

$\mathrm{Mr}$ H. CARACCIOLO, who was present at the reading of the paper, but was obliged to be absent from part of the discussion, handed in the following remarks for publication.

The observations made by M. Bordage on $D$. clurysippus are certainly very interesting, though unfortunately he seems to have experimented on too few specimens to have arrived at his conclusions.

It happens to be one of our most common species of butterfly in Trinidad (West Indies), where I have had opportunities of observing the metamorphoses very closely.

Its food plant with us is the "Wild Ipecacuanha," a very common shrub, growing in every locality of the island, and I have collected hundreds of chrysalids, which were invariably of the green type.

I have likewise however bred them in confinement, and the results of my investigations force me to come to the conclusion that they do not respond to artificially prepared surroundings, for the following reasons:

(r) Every chrysalis found in its natural element has been invariably of the green type.

(2) In confinement I obtained specimens of a palish grey type, with others varying from that to a reddish tint.

(3) In the first case every specimen produced a perfect insect.

(4) In the second case the great majority never hatched, and those that did produced imperfect types.

I am therefore led to believe that these variations of colours are due to a diseased state of the insect consequent upon its confinement.

I may also add that this insect is a peculiarly favoured one, reproducing itself very rapidly owing to its being unpalatable and disagreeable to birds and other foraging creatures.

The caterpillar, though bright and showy and therefore very conspicuous, feeds independently on the shrub above mentioned and in localities environed by enemies, whilst the imago flies slowly and unconcernedly; this last form is likewise distasteful; so much so that it has given rise to one of the most prominent cases of protective mimicry in the case of the female of Hypolimmas misippus, which has succeeded in mimicking $D$. chrysippus to such a degree of perfection that an unexpericnced eye would scarcely distinguish the two species on the wing. 


\section{SOME POINTS IN THE ClASSIFICATION OF INSECTA HEXAPODA.}

\section{By Dr D. Sharp.}

Although there is a generally accepted opinion amongst zoologists to the effect that the branch of ontogeny called metamorphosis is of great importance in the study and classification of Insects, yet it is certain that the efforts that have been made to utilise the known facts are far from final. The terms Ametabola, Hemimetabola, etc. that have been used are not sufficiently definite for taxonomic purposes, or for a lucid consideration of the subject. One point of considerable importance has escaped attention, and this point I think will be found to furnish us with an additional, definite criterion as to the metamorphosis of insects. It is that in one set of cases the wings are developed outside the body, while in another set of cases they are developed inside the body and become suddenly external.

The number of insects that can be correctly said to be entirely destitute of the phenomena of metamorphosis is very small indeed. As all of us know they are called Ametabola. For those that exhibit the phenomenon of metamorphosis Packard has recently proposed to adopt four categories, viz. Manometabola, Heremetabola, Hemimetabola, Holometabola; these terms, in addition to that of Ametabola and to that of the condition of acquired ametabolism (indicated by Lang but apparently as yet without name), make no less than six categories of metamorphosis; and in addition to them we meet with other terms, such as Paurometabola.

These terms indicate the amount of metamorphosis. But they do so in only a very vague manner, and I think we shall gain by considering them as of subordinate importance to the nature of the wing development.

On the accompanying table the names of the great divisions of existing insects that have not been satisfactorily connected by morphological and ontogenetic study are placed in a consecutive arrangement, and are grouped in accordance with our present knowledge under four heads, Apterygota, Anapterygota, Exopterygota, Endopterygota: these four groups represent generalisations as regards the development of the wings.

The Apterygota include the two orders Thysanura and Collembola. These insects are quite wingless, and are usually considered to be the descendants of a stock never having possessed wings.

The Apterygota exhibit, so far as is known, but little or no metamorphosis during the postembryonic period.

The Anapterygota consist of wingless forms that are supposed to be descended from winged forms. They are all parasitic on vertebrates during the whole or part of their lives. The evidence 
as to their ancestors having formerly possessed wings is by no means satisfactory, and from a practical point of view there is a decided advantage in placing under a separate category the forms that are believed to exhibit either "acquired ametabolism," or acquired winglessness.

In the Anapterygota the tivo groups Mallophaga and Anoplura exhibit but little metamorphosis, while on the contrary the fleas have a very rapid development, accompanied by a metamorphosis complete except as to the appearance of wings ; as the young of the flea has no trace whatever of wings externally, and as it is possible that there is some slight trace of them in the subsequent instar, it is highly probable that a critical examination will shew that these insects should be treated as derived from the Endopterygota; in which case those who advocate the view of acquired ametabolism will be able, with considerable show of probability, to point to this group of insects as exhibiting an early stage of this process: the ametabolism being actually limited to the want of wings.

On the other hand it is nearly certain that if Mallophaga and Anoplura are really exponents of an acquired ametabolism, they will be found to be derived from exopterygotous insects.

The group Exopterygota consists of those insects that actually develop the wings outside the body, but it includes a few wingless insects that are undoubtedly closely allied to winged. A most interesting condition is found in the small division Embiida, where the females never have wings, while the males acquire them, though in other respects remaining almost in the condition of wingless insects. Although very little is known as to Embiidx, the notes as to its development, recently contributed by Mr IV. F. H. Blandford, shew that it is exopterygotous.

The Exopterygota exhibit most of the kinds and degrees of metamorphosis. WVe have already alluded to the fact that the female Embia is almost without metamorphosis, while the male acquires wings, but remains almost without some of the other features of metamorphosis. In the Hemiptera we find that these sexual differences as regards metamorphosis exist anongst Coccidre to a much greater degree, the female exhibiting but little metamorphosis, while the male passes through a complex metamorphosis.

The Endopterygota include an enormous majority of the existing forms of insects: if we estimate the number of known species of Hexapod insects at 250,000 , the number of Endopteryrgota is 90 per cent. or more, of this.

The Endopterygota are almost entirely holometabolous, the only exceptions being a certain number of species in which the female exhibits an arrest of development, departing very little from the condition of the larva; as an instance we may mention the females of certain Coleoptera of the family Malacodermidxe.

On the table there is also shown the elements of what is known 
as to the existence, in former geologic epochs, of forms that may have been ancestral to the existing divisions. It shews a preponderance of evidence that the exopterygotous condition was the primitive one in insects. The facts that the insects of the Palæozoic epoch appear to have been almost entirely exopterygotic, and that the great majority of existing insects are endopterygotic suggest the probability of the latter being descended from the former, but the origin of Endopterygota remains at present a mystery. It seems clear that Endopterygota could not possibly have been derived from Exopterygota except by intermediate states of Anapterygotism.

The only group of Endopterygota that we have any real reason for believing to have existed in the Palæozoic epoch is the Sialid division of Neuroptera planipennia, and the evidence is both scanty and uncertain: there is, too, no reason for supposing this group to have been actually ancestral to the great orders of Endopterygota, Coleoptera, etc.

In reference to these rtiological questions I may point out that the groups Apterygota and Anapterygota are each of them partly grounded on æetiological hypotheses.

Grassi was formerly of opinion that the wingless condition of the Apterygota is a truly primitive state; but he is now willing to admit that it may possibly be derived from a winged condition. Hence taking everything into consideration it seems far from impossible that all insects may have been derived from Exopterygotous forms, the Apterygota directly, the Endopterygota indirectly by means of Anapterygotous forms. But it appears more probable that Collembola - if not Thysanura-are truly apterygotous. 


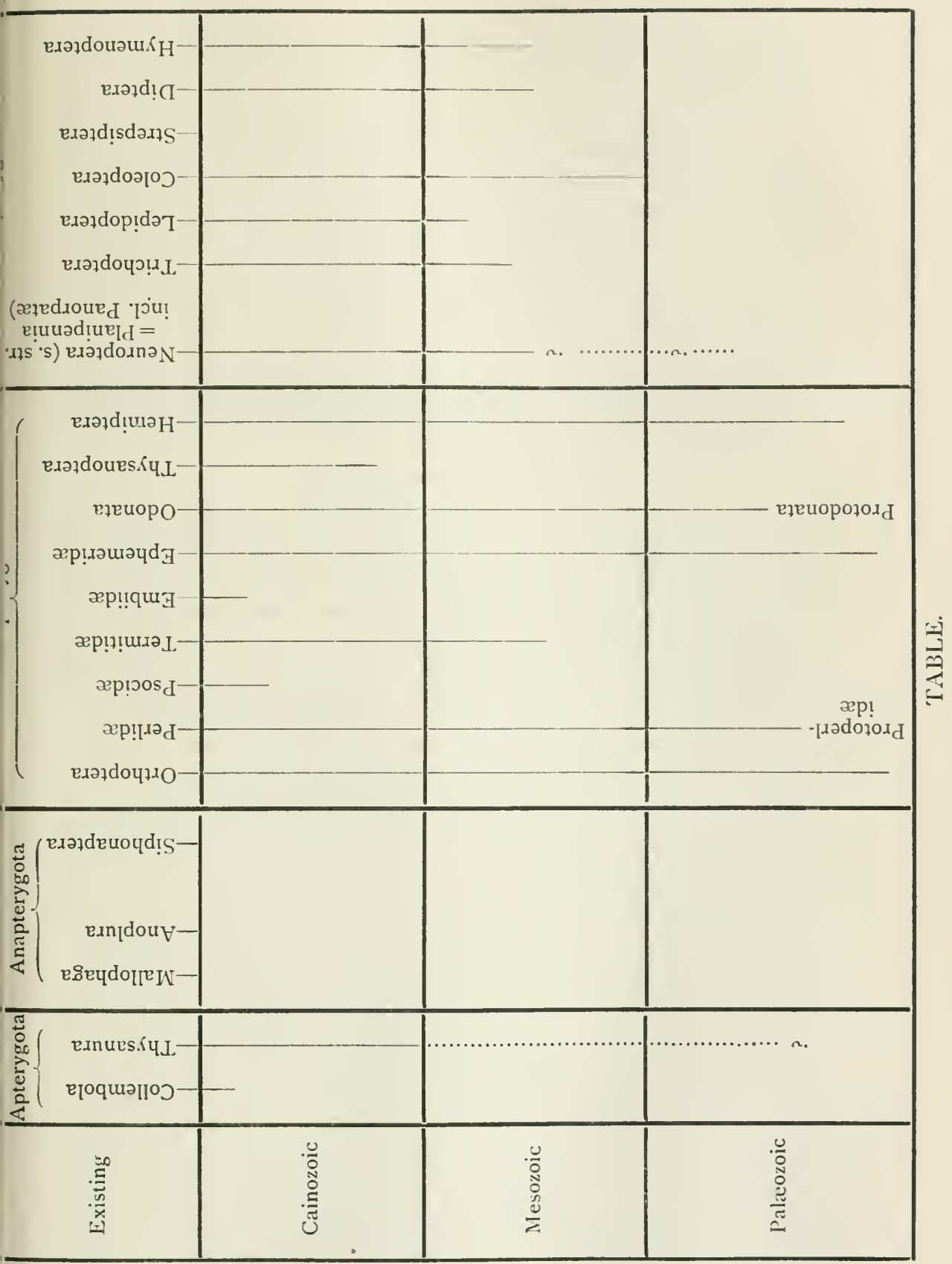




\title{
SECTION D. ARTHROPODA.
}

\author{
Wednesdar, August 24, at 3 p.m.
}

Chaiman, LORD WALSINGHAM.

The following papers were read:

I. SUR la distribution GÉOGRAPHIQUE DES IsOPODES TERrestres DAns l'Afrique Septentrionale, du SÉnégal А̀ OBOCK.

\section{By M. Adrien Dollfus.}

"Je compte exposer ici en quelques mots les caractères que présente la faune des Isopodes terrestres dans le Nord de l'Afrique, depuis le Sénégal et les îles du Cap Vert à l'Ouest jusqu'à Obock et Djibouti à l'Est. Tout d'abord, je tiens à faire remarquer qu'il ne s'agit que de régions peu éloignées de la mer, car nous n'avons encore presqu'aucun renseignement sur les Isopodes de l'intérieur. Au Sénégal, Podor est le point le plus éloigné de la côte d'où j’ai vu des échantillons; en Algérie, d'où les matériaux ont été envoyés en grand nombre, nous connaissons assez bien la faune désertique jusqu'à Ouargla et à Laghouat. Pour l'Égypte, nous avons des exemplaires provenant d'Assouan. Il serait bien intéressant que les explorateurs des contrées de l'intérieur ne négligeassent pas ces petits animaux qui, peu nombreux en espèces, ont souvent une dispersion très-étendue et importante par conséquent au point de vue de la géographie zoologique.

J'indiquerai ici successivement les principales espèces signalées dans les régions suivantes qui paraissent pouvoir constituer des groupes assez bien délimités: $\left(\mathbf{I}^{\circ}\right)$ Sénégal et îles du Cap Vert. - $\left(2^{\circ}\right)$ Iles Atlantiques-Canaries, Madère et Açores.- $\left(3^{\circ}\right)$ Maroc et Cap Blanc.- $\left(4^{\circ}\right)$ Algérie occidentale;-Algérie orientale et

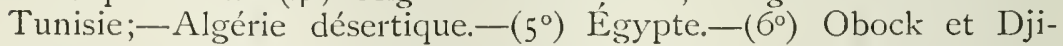
bouti.-Il est vrai que les affinités fauniques entre ces divers groupes sont souvent très-grandes. Ainsi, j'ai déjà eu l'occasion de faire ressortir l'étroite parenté de la faune Isopodique des Canaries, de Madère et des Açores avec celle du Maroc et même des contrées Méditerranéennes en général,-_et ces liens continus dont quelques uns vont presque d'une extrémité à l'autre de la vaste étendue de terres qui nous occupe, sont particulièrement intéressants à faire connaître. 
Je ne citerai que pour mémoire les deux espèces ubiquistes, Porcellio laevis et Metoponorthus prainosus qui paraissent se trouver dans les pays chauds et tempérés du monde entier; leur présence dans telle ou telle région n'a donc aucune importance à notre point de vue.

$\left(\mathrm{I}^{\circ}\right)$ Le Sénégal et les îles du Cap-Vert présentent un caractère mixte: on trouve au Sénégal le genre Mesamadillo qui devient prédominant dans l'Afrique tropicale. Nous y signalons une espèce de Porcellionien, Rhyscotns turgifrons, qui se retrouve bien plus au Sud le long du golfe de Guinée, ct qui a été décrite par Budde-Lund sur des exemplaires provenant des Antilles. Leptotrichus squamatus, du Sénégal, a été rencontré aussi à Landana. Par contre, Tylos Amadillo et Philoscia Couchi, trouvés en Sénégal et au Cap Vert, sont deux espèces très-communes dans la région Méditerranéenne et qui remontent même le long des côtes d'Europe jusqu'en Bretagne; Philoscia Conchi va jusqu'en Irlande et à l'embouchure de la Somme. Nous présenterons tout-à-l'heure quelques réflexions sur les Ligia en étendant ces observations à l'ensemble des côtes Africaines. Jusqu'à présent, nous n'arons à indiquer que deux espèces d'Isopodes terrestres spéciales au Sénégal: Mesarmadillo Senegalensis, élégant armadillien qui paraît trèsabondant, et Porcellio Nodieri, ainsi qu'une espèce du Cap Vert, Amadillo trifolium. Nous devons la connaissance, encore restreinte, que nous avons de cette faune, aux récoltes de MM. le Dr Nodier, le commandant Dorr, Chevreux, Thibeaudeau, Blondel, et Maindron.

$\left(2^{\circ}\right)$ Iles Atlantiques. Aux Canaries, où le Dr Koelbel n'arait signalé qu'un très-petit nombre d'espèces banales, nous avons affaire à une faune assez riche, bien comme depuis les recherches de M.M. Alluaud, Buchet, et Aussel.

Aux Açores, MM. Morelet et Droüet araient déjà, en IS60, indiqué quelques Isopodes. On doit aussi des renseignements à M. Arruda Furtado, mais l'exploration méthodique de ces îles a été faite par le prince de Monaco, et par MM. le baron de Guerne, Richard, Dr Barrois, et capitaine Chaves.

De Madère, quelques espèces sont indiquées dans l'utile ourrage général de M. Budde-Lund et proviennent surtout des récoltes de M. Sфrensen. M. A. Fauvel a fait au Muséum de Paris l'envoi des Isopodes qu'il a recueillis dans cette île.

Le caractère à la fois Atlantique et Méditerranćen de la faune Isopodique de ces îles ressort à première vue: Eluma purpurasccns, ce curieux Armadillien monocellé si commun dans les Archipels, va d'une part jusqu'en Andalousie et dans la province d'Oran, de l'autre se rencontre par-ci par-là dans le S.O. de l'Europe jusque dans les bassins de la Charente et de la Loire où il a été trouvé à Châteauroux, Armadillidium vulgare, plus abondant encore, Philoscia Couchi, Trichoniscus pusillus, appartiennent aussi aux deux faunes. Oniscus Asellus, des Açores, est surtout Atlantique, ainsi 
que Porcellio dilatatus, de Madère et des Açores, et $P$. scaber, des Açores et des Canaries.

Par contre, on peut citer comme plutôt Méditerranéennes, les espèces suivantes: A rmadillidium granulatum, A. sulcatum, Porcellio iariabilis, P. lamellatus, Metoponorthus sexfasciatus, Leptotrichus Panzeri, Platyarthms Schöbli. Toutes ces espèces sont particulièrement abondantes en Algérie.

Aux Canaries, citons Porcellio spinipes, espèce d'aspect désertique, des îles sablonneuses orientales, qui se retrouve au Sud du Maroc. On verra, dans la liste que nous donnons plus loin cinq espèces propres jusqu'à présent à l'Archipel; elles vivent plutôt dans la partie orientale, la plus originale au point de vue faunique, mais appartiennent toutes à des genres Européens: Armadillo (2), Porcellio (2), Metoponorthus (1). Il est vrai que le genre Armadillo, très peu nombreux en espèces dans le Sud de l'Europe et le Nord de l'Afrique, devient beaucoup plus variable et plus abondant sous les Tropiques; la présence de deux espèces aux Canaries accuse donc déjà le caractère méridional de la faune de ces îles.

Les Açores, moins riches que les Canaries, ne doivent leurs cinq espèces spéciales signalées ci-dessus, qu'aux recherches microfauniques des naturalistes que nous avons cités: les Trichoniscus, Chavesia, et A madilloniscus sont de très-petits Isopodes, généralement humicoles. À Madère on a signalé trois formes particulières.

$\left(3^{\circ}\right)$ Sur le Continent Marocain, la faune de la région côtière a une telle affinité avec celle des îles et surtout des Canaries qu'il est bien difficile de l'en séparer. Les chasses du Comte de Dalmas au Cap Blanc, et de M. Gaston Buchet aux environs de Mogador, bien que n'ayant donné qu'un très-petit nombre d'espèces, sont importantes pour la connaissance de ces parties peu explorées. Nous avons reçu aussi du commandant Schlumberger d'intéressants matériaux provenant de Rabat, de M. de Nerville, un petit envoi de Tetuan, et M. Budde-Lund signale quelques captures faites dans le Maroc septentrional jusqu'à Larache (El-Araish).

Du Cap Blanc, M. de Dalmas a rapporté le Porcellio spinipes, des Canaries, rencontré depuis près de Mogador par M. Buchet. Il nous en a rapporté aussi une espèce spéciale, mais appartenant à un genre européen, Armadillidium Chasalici.

Dans le Maroc méridional, le caractère canarien et mediterranéen s'accentue par l'abondance extraordinaire du Porcellio variabilis, espèce que nous avions décrite à tort, aux Canaries, sous le nom de $P$. Alluaudi, comme distincte de la forme si commune en Algérie. On y trouve aussi Armadillidium vulgare et Metoponorthus sexfasciatus qui deviennent très-communs à Rabat, et Porcellio Hoffmannseggi, espèce bien caractéristique de la région qui s'étend de Mogador aux limites de l'Algérie et à l'Andalousie. Porcellio echinatus, remarquable par son aspect spinescent, ne paraît pas aller aussi loin au Sud mais se retrouve dans la même zone IbéroMauritanienne. Sur I 8 espèces signalées jusqu'à présent au Maroc, 
IO ont été retrouvées dans les iles et 14 dans la région Méditerranćenne occidentale; une espèce de l'Europe Atlantique, Ligia occanica, non encore vue dans les îles non plus que sur les côtes de la Méditerranée, s'avance jusqu'à Tanger et à Rabat; nous y reviendrons plus loin. Enfin, les espèces autochthones paraissent presque nulles au Maroc proprement dit, où nous n'avons à signaler jusqu'à présent que Mrtoponorthus viresccns B.L., sur la valeur de laquelle nous émettons quelque doute.-La région Marocaine est une véritable zone intermédiaire entre les archipels atlantiques et l'Algérie occidentale.

(4º Algérie, Tunisie.-L'Algérie est probablement, arec l'Espagne du Sud et de l'Est, le point du globe où les Crustacés Isopodes terrestres acquièrent le plus grand développement: grandeur des formes, abondance des individus, nombre des espèces, tout contribue à rendre cette faune intéressante. Si nous n'y connaissons qu'une seule espèce appartenant au groupe des Porcellio géants, formes très-larges et très-plates, qui vivent en nombre sur les rochers ensoleillés de l'Espagne orientale, tous les voyageurs ont pu remarquer les bandes innombrables de Cloportes de grande taille, appartenant au groupe, assez riche en espèces, du Porccllio Wagneri qui sillonnent souvent les routes algériennes, surtout lorsque souffle le sirocco. Les espèces myrmécophiles et notamment les genres Lucasius et Platy'arthrus sont aussi fréquentes. Le genre Armadillidium est moins nombreux en formes que le genre Porcellio, bien qu'il y ait huit espèces signalées, mais les Onisciens, qui aiment l'humidité, sont très peu abondants à l'inverse des Isopodes trachéates.

Nous considérons, dans le pays qui nous occupe, trois régions distinctes que nous avons étudiées assez complètement dans une note sur les Isopodes d'Algérie parue il y a deux ans pour ne pas leur consacrer ici un examen détaillé. Ces trois régions sont: $\left(\mathrm{I}^{\circ}\right)$ l'Algérie occidentale ou plutôt le Tell Oranais qui a les plus grandes affinités avec le Maroc et l'Espagne méridionale ; $\left(2^{\circ}\right)$ l'Algérie occidentale et le Tell tunisien, à espèces plus nombreuses dont beaucoup se retrouvent en Sicile; $\left(3^{\circ}\right)$ la région désertique, très-intéressante à étudier, où les Isopodes ont souvent un aspect particulier et qui remonte jusque sur les Hauts-Plateaux. C'est là qu'on trouve ces singuliers Hcmilcpistus dont on voit plusieurs espèces jusque dans les déserts asiatiques. Ici, nous n'en avons qu'une, Hemilepistus Rcaumuri; il est rrai que sa dispersion est presqu'aussi grande que celle du genre tout entier; ce sont des Porcellioniens de grande taille, très-convexes, dont la partie antérieure du corps est couverte de fortes rugosités presque spinescentes qui sont utiles à l'animal pour se creuser des trous cylindriques où il s'abrite, un peu comme les larves des Cicindèles. Parmi les autres Isopodes désertiques, notons des Porcellio et des Mctoponorthuıs, presque tous de couleur blanchâtre et qui présentent parfois un grand développement des poils spinescents des pattes, tel est 
Porcellio albinus, analogue sous ce rapport au Porcellio spinipes des sables canariens et marocains.

Nous nous bornerons à indiquer ici, pour faire ressortir les affinités de cette faune avec celle des pays voisins, les chiffres suivants: sur un total de 29 espèces connues jusqu'à présent, l'Algérie occidentale en a 23 communes avec l'Espagne et Io communes avec la Sicile. Dans l'Algérie orientale (Alger, Constantine et Tunisie), sur 44 espèces on n'en retrouve plus que 20 en Espagne et par contre la part des espèces siciliennes monte à 19. Les espèces qui paraissent autochthones en Algérie, y compris celles de la régrion désertique, s'élèvent au chiffre de 23.

Les matériaux relatifs à la faune algérienne et tunisienne m'ont été envoyés par un grand nombre de correspondants dont j'ai donné les noms dans mon étude parue en I 896 . Je rappellerai ici que le premier travail d'ensemble sur cette faune est dû à Brandt, en IS4I, que Lucas a publié et figuré un certain nombre d'espèces dans l'Exploration scientifique de l'Algérie en I 849, que les belles récoltes de M. Eugène Simon, de M. Letourneux, etc. ont permis à M. Budde-Lund de créer un grand nombre d'espèces algériennes nouvelles; en me faisant don de sa collection, M. Simon m'a singulièrement facilité le travail que j'ai entrepris il y a quelques années et ces matériaux se sont beaucoup accrus par les envois si précieux de M. Ed. Chevreux et de quelques autres naturalistes.

Nous n'avons sur la faune des Isopodes de Tripoli qu'une note insignifiante de Rizzardi (in Contrib. alla fauna Tripolitana, Soc. Entom. Ital., I 896), mentionnant dans cette contrée, avec une erreur synonymique pour chacune d'elles, deux espèces: Porcellio lacvis Latr. et Hemilepistus Rcaumuri Aud. et Sav.

$\left(5^{\circ}\right)$ En Égypte, les Isopodes les plus répandus ont été figurés dès I 826 par Savigny, et sommairement décrits par Audouin l'année suivante. J. F. Brandt, dans son Conspcctus en I833, décrit Philoscia Ehrenbergi et Armadillidium decomum. Les collections des Musées de Saint-Pétersbourg, de Berlin et de Paris, ainsi que les envois de MM. Eug. Simon et IV. Innes, ont permis à M. BuddeLund et à moi d'augmenter quelque peu la liste des espèces signalées. Toutefois, cette faune est encore imparfaitement connue. Il serait surtout intéressant de noter d'une manière précise les localités, afin de déterminer l'influence des mers Rouge et Méditerranće sur la faune Isopodique égyptienne. La présence et l'abondance des Hemilcpistus et du Porccllio Olivicri rattachent la faune égyptienne à celle du Sahara algérien. La variété Swammerdami du Mctoponorthus pruinosus se retrouve en Syrie. Armadillo officinalis, Armadillidium frontirostre, granulatum, badium, Leptotrichus Panzeri, Philoscia Conchi, Tylos Armadillo, se voient dans d'autres pays méditerranéens. Les espèces spéciales aujourd'hui connues sont au nombre de 9, dont deux, appartenant aux genres Porcellio et Lcptotrichus qui m'ont été remis par M. Simon et ne sont pas encore décrits. Je signalerai le petit 
nombre relatif des Porcellio en Égypte, où les Armadillium paraissent l'emporter, contrairement à ce que nous avons vu en Algérie. A noter aussi la présence de deux espèces du Peryscjphis recueillis probablement (?) du côté de la mer Rouge et qui annoncerait déjà le voisinage de la faune tropicale de l'A frique orientale.

$\left(6^{\circ}\right)$ Cette faune est nettement caractérisée à Obock et à Djibouti d'où j'ai vu, dans les collections du Muséum de Paris, un petit nombre d'espèces rapportées par M. Maindron. Les genres tropicaux Peryscyphis et MIcsarmadillo y sont représentés chacun par une espèce.

J'aurais voulu étendre cet aperçu à l'Afrique méridionale, car les récoltes de M. Alluaud dans le golfe de Guinće, aux Séchelles et à Madagascar, celles de M. Eug. Simon au Cap, dans la république Orange et au Transvaal, du commandant Dorr à Madagascar, de Gerstaecker à Zanzibar et les riches collections du Muséum de Paris, m'auraient permis de donner dès à présent une idée de la faune de ces diverses régions, si des envois récents et non encore étudiés, notamment de MM. Alluaud, provenant de Madagascar et des Mascareignes, et du professeur Max Weber, du Cap à Lourenço-Marqués, ne m'avaient obligé à remettre à plus tard cette vue d'ensemble.

Je tiens cependant à préciser ici, autant que possible, les limites de dispersion des espèces peu nombreuses du genre Ligia dont la distribution très-étendue, avec peu de chevauchements, est d'autant plus importante à considérer: Nous avons vu que Ligia Occanica L., espèce des plages océaniques de l'Europe, fait une petite incursion en Afrique, dans l'angle S.W., entre Tanger et Rabat. Elle paraît avoir empiété sur le domaine propre de la Ligia italica Aud. et Sav., qui est non seulement la seule espèce méditerranéenne authentiquement connue, mais qui s'avance dans l'Atlantique jusque sur les plages des Açores, de Madère et des Canaries. Ligia gracilipes B.L. du Sénégal, des îles du Cap Vert et de la côte continentale jusqu'au Congo, ne me paraît être qu'une forme mineure de Ligia italica. Ligia exotica, l'espèce tropicale par excellence, qui se trouve dans les pays chauds du monde entier, où elle a été décrite sous des noms différents, a été signalée également au Sénégal. Sur les côtes orientales de l'Afrique, cette même espèce règne en maîtresse depuis Obock (il serait intéressant de savoir si elle ne remonterait pas jusqu'à Suez) jusqu'à LourençoMarqués où elle se trouve en concurrence, d'après le dernier envoi du prof. M. Weber, avec une espèce à dispersion beaucoup moins étendue, Ligia glabrata Brandt (=L. dilatata Brandt) qui est trèsabondante au Cap de Bonne-Espérance.

Je reviens, en terminant, sur ce que je disais au début: il serait très-désirable que les explorateurs qui visitent les régions de l’intérieur sur lesquelles nous n'avons encore aucun renseignement, voulussent bien ne pas négliger ces misérables Cloportes qui, sous les Tropiques, paraissent se faire encore plus modestes que partout 
ailleurs; les Armadilliens qui se roulent en boule, les Philoscia qui aiment les lieux humides, s'y trouvent cependant en assez grand nombre et on est parfois surpris de rencontrer des Isopodes dans des habitats bien imprévus, par exemple en battant les buissons et les arbustes; toutefois, c'est surtout dans les lieux riches en matières végétales décomposées, dans le bois pourri, etc., que l'on fera les meilleures chasses.

Je fais suivre ces observations de la liste des Isopodes recueillis jusqu'à présent dans les différentes régions indiquées ci-dessus :

\section{Sćnégal (S.) et Cap Vert.}

Mesamadillo (Eubelum, B.L. ?) Senegalensis, Dollfus-S.

Armadillidium trifolium, Dollfus-Cap Vert.

Porcellio Nodieri, Dollfus-S.

laevis, Latr.-S.

Metoponorthus pruinosus, Br.-S.-Cap Vert.

Leptotrichus squamatus, B.L.-S.

Rhyscotus turgifrons, B.L.-S.

? Philoscia Giernei, Dollfus - S.

Couchi, Kin.-S.

Ligia exotica, Roux-S.

- gracilipes, B.L. (=L. italica, Aud. et Sav. jeune?)-S.-Cap Vert.

Tylos armadillo, Latr.-S.-Cap Vert.

\section{Bibliographie spéciale.}

1S87. Dollfus $(A d$.).- Diagnoses d'espèces nouvelles de la tribu des Armadilliens-(Soc. Ét. Scient. Paris).

I89S. Dollfus $(A d$.).- Note sur les Isopodes terrestres du Sénégal (présentée à la Société Zoologique de France).

\section{Maroc et Cap Blanc.}

M.S. = Maroc septentrional (jusqu’à Rabat).

M.M.= Maroc méridional (Mogador, etc.).

Armadillo officinalis, Desm.-M.S.

? Eluma purpurascens, B.L.-M.S. ?

Amadillidium granulatum, Br.-M.S. vulgare, Latr.-M.S. et M.M.

Porcellio echinatus, Lucas.-M.S. Chizalici, Dollfus-Cap Blanc.

Hoffmanuseggi, Br.-M.M. et M.S.

flavocinctus, B.L.-M.S. variabilis, Lucas-M.M. (probablement aussi M.S.).

laevis, Latr.-M.M. (probablement aussi M.S.).

spinipes, Dollfus-M.M. et Cap Blanc.

Metoponorthus prinosus, Br.-(typique) M.M. (probablement aussi M.S.).

Br. var. tingitana $(=M$. tingitanus, B.L.)-M.S. (ne paraît être qu'une forme majeure de M. pruinosus). sixfasciatus, B.L.-M.M. et M.S.

? - fuscovariegatus, Luca

Leptotrichus Panzeri, Aud. et Sav.-M.S.

Philoscia Conchi, Kin.-MI.S.

Ligia Oceanica, Fabr.-M.S. (Rabat et Tanger). Il est probable que Ligia italica, qui est commune sur les bords de la Méditerranée et sur les plages des îles Atlantiques, se trouvera aussi sur les côtes du Maroc.

Bibliographie spéciale: voir ci-après (Iles Atlantiqués et Algérie). 


\section{Iles Atlantiques.}

Madère (M.)-Canaries (C.)-Açores (A.).

Armadillo canariensis, Dollfus-C.

A usseli, Dollfus-C.

Armadillidium tigris, B.L.-M.

$$
\begin{aligned}
& \text { gramulatum, Br.-M.-A.? } \\
& \text { vulgare, Latr.-M.-C.-A. } \\
& \text { sulcatum, Edw.-A.?? }
\end{aligned}
$$

Eluma purpurascens, B.L.-M.-C.-A.

Porcellio dilatatus, Br.-M.-A.

$$
\text { maculipes, B.L.-M. }
$$

ovalis, Dollfus-C.

canariensis, Dollfus-C.

scaber, Latr.-A.-C.

variabilis, Lucas-C.-A.? (=P. Alluaudi, Dollfus).

spinipes, Dollfus-C.

lacvis, Latr.-M.-C.-A.

laevissimus, Dollfus-C.

lamellatus, M.-C.-A.

Lucasius scitus, B. L.-M.

Metoponorthus sexfasciatus, Bl.-M.-C.-A.

$$
\begin{aligned}
& \text { pruinosus, Br.-C.-A. } \\
& \text { Barroisi, Dollfus-A. }
\end{aligned}
$$

stricticauda, Dollfus-C.

Leptotrichus Panzeri, Aud. et Sav.-C.

Platyarthrus Schöbli, B.L.-C.

Chavesia costulata, Dollfus-A.

Philoscia Guernei, Dollfus-A.

Couchi, Kin.-C.-A.

Oniscus Asellus, L.-A.

Armadilloniscus tuberculatus, Dollfus-A.

Trichoniscus pusillus, Br.-A.

- Chavesi, Dollfus-A.

insularis, Dollfus-A.

Ligia italica, Aud. et Sav.-M.-C.-A.

Tylos armadillo, Latr.-A.

\section{Bibliographice spéciale.}

I 860. Morelet. Note sur l'histoire naturelle des Açores, p. 97.

186I. Droüet. Eléments de la faune Açoréenne (Mém. Soc. Agr. Aube).

1885. Budde-Lund. Crustacea Isopoda terrestria.

1887. $J$. de Guerne. Sur la faune des îles de Fayal et de San Miguel (C. R. Acad., 24 Oct.).

1887. Note sur la faune des Açores (diagn. de Philoscia Guemei, par A. Dollfus) (Le Naturaliste, I Nov.).

I888. _- Excursions zoologiques dans les îles de Fayal et de San Miguel (Camp. Scient. de l'Hirondelle, pp. 44 et 70-7 I).

1888. Barrois (7.). Note préliminaire sur la faune carcinologique des Açores. I888. C Catalogue des Crustacés marins recueillis aux Açores en I 887 (Lille).

I889. Dollfus (A.). Isopodes terrestres recueillis aux Açores par MIM. le Dr Th. Barrois et le lieutenant Chaves (Rev. Biol. Nord, pp. 306-308) avec Liste supplémentaire (Ib.).

I 889.

Liste préliminaire des Isopodes extramarins recueillis aux Açores pendant les campagnes de l'Hirondelle, I $887-88$ (Bull. Soc. Zool., pp. 125-134). 
1892. Koclbel $(K$.$) . (Annalen K. K. Naturh. Hofmus. Wien, pp. 105-1I6).$

1893. Dollfus $(A$.$) . Voyage de M. Ch. Alluaud aux îles Canaries, Isopodes$ terrestres (Mém. Soc. Zool., pp. 45-57).

I898. Voyage de M. G. Buchet aux Canaries et dans le Maroc méridional, Isopodes terrestres (présenté à la Soc. Zool. France).

\section{Algérie et Tunisie.}

W.-Algérie Occidentale. E.-Algérie Orientale et Tunisie (Tell). D. - Région désertique.

Armadillo officinalis, Desm.-W.-E.-D.

Eluma purpuyeti, E. Sim.-D.

?. Armadillidium Pallasi, $\mathrm{Br}$ - $\mathrm{E}$.

$$
-\quad \begin{aligned}
& \text { granulatum, Br.-W. } \\
& \text { Zcnckeri, Br.-E. }
\end{aligned}
$$

- vulgare, Latr.-W.-E.

quinquepustulatum, B.L.-E. pilosellum, Dollf.-E.
sulcatum, M. Edw.-E

Porcellio platysona, Br.-W.-E.

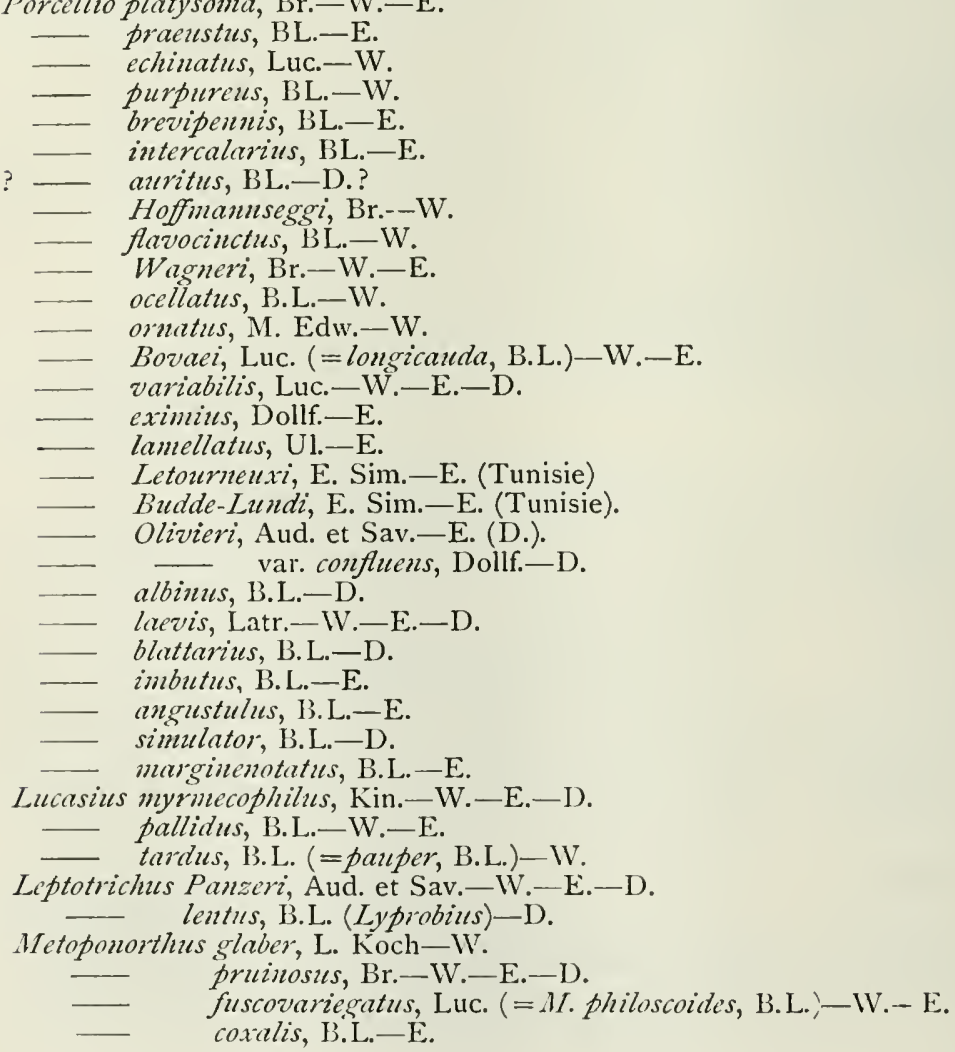


Metoponorthus viridis, B.I..-E.

melanumus, B.L.-E.

frontosus, B.L.-I).

lactcolus, B.L.-1).

sabuleti, B.L.-D.

fuscomarmoratus, B.L.-IV.

parcus, B.L.-E.

Hemilepistus Reaumuri, Aud. et Sav.-I).

Bathytropa Meinerti, B.L. $(=B$. costata, I3.L. $)-\mathrm{E}$.

Platyarthrus Schöbli, B.L.-E.

Philoscia muscorum, Scop. var. Algirica, Dollf.-E.

clongata, Dollf. (=pulchella, B. L.).-W.-E.

Couchi, Kin. (=longicornis, B.L.) - IV.-E.

Armadilloniscus candidus, B.L.- IV. l.ctourneuxi, E. Simon-E.

Trichoniscus roseus, Koch-W.-E. pusillus, $\mathrm{Br}$.- E.

Ligin italica, Aud. et Sav.-IV.-E.

Tylos Armadillo, Latr.-IV.-E.

bibliographie spéciale.

IS40. Milne-Edwards. Histoire naturelle des Crustacés, t. III.

I841. Brandt (F.F.). Ueber die asselartigen Thiere der Regentschaft Algier (Wagner's Reisen i. d. Regentsch. Algier).

1849. Lucas $(H$.$) . Exploration scientifique de l'Algérie: Hist. nat. des$ animaux articulés, partie I.

I8;8. Kinahau. Remarks on certain genera of terrestrial Isopoda (British Assoc. Adv. Science).

1885. Butde-Lund. Crustacea Isopoda terrestria.

I885. Simon (Eug.). Etude sur les Crustacés terrestres et fluviatiles recueillis en Tunisie (Explorat. Scient. de la Tunisie).

1896. Dollfus $(A d$.). Les Isopodes terrestres du Nord de l'Afrique du Cap Blanc à Tripoli (Mém. Soc. Zool. Fr., pp. 523-553).

\section{V. Égypte.}

Armadillo officinalis, Desm.

- soditis, B.L.

Peryscyphis albescens, B.L.

? convexus, B.L.

Armadillidium frontirostre, B.L

granulatum, Br.

fallax, Br.

mareoticum, B.L.

badium, B.L.

decorum, Br.

Porcellio lacvis, Latr.

Olivieri, Aud. et Sav.

n. sp. (voisin du P. angustulus, B.L., de l'Algérie du Sud); (coll.

Dollfus).

Hemilepistus Reaumuri, Aud. et Sav.

brevicaudatus, $\mathrm{Br}$.

Metoponorthus pruinosus, Br. (typique).

var. Szuammertami (=Porcellio Swammerdami Aud. et Sav.).

? Clairvillei, Aud. et Sav. 
Leptotrichus Panzeri, Aud. et Sav.

? n. sp. (coll. Dollfus).

Philoscia Ehrenbergi, Br.

- Couchi, Kin.

Ligia Italica, Fabr. (bords de la Méditerranée).

Tylos Armadillo, Latr.

\section{Bibliographie spéciale.}

1826-27. Savigny. Description de l'Égypte, t. XII. Crustacés, pls. 1-I3. Explication sommaire des planches par Audouin et Savigny.

1833. Brandt $(\mathcal{F} . F$.$) . Conspectus monographiae Crustaceorum Oniscodorum$ Latreillii (Bull. Soc. Imp. Nat. Moscou, p. I7 I).

1885. Budde-Lund. Crustacea Isopoda terrestria.

1892. Dollfus $(A$.$) . Note sur les Isopodes terrestres et fluviatiles de Syrie$ (par comparaison de faunes).

\section{Obock et Djibouti.}

Mesarmadillo (=Eubelum, B.L.?), n. sp. (coll. Mus. Paris).

Peryscyphis, n. sp. (coll. Mus. Paris).

Metoponorthus pruinosus, Br. (coll. Dollfus).

Ligia exotica, Roux (Mus. Paris et coll. Dollfus).

The Chairman, in thanking M. Dollfus for his interesting communication, remarked that it was interesting to find that in this, as in other zoological groups, the fauna of $\mathrm{N}$. Africa bore a greater resemblance to that of $\mathrm{S}$. Europe than to that of the more southern portions of the African continent.

\section{Constitution morphologique de la Tête DE L'INSECTE.}

\section{By IM. Ch, Janet.}

Les études embryogéniques ont montré que la tête de l'Insecte est formée par l'accroissement et la transformation profonde des six segments antérieurs de l'embryon.

On a cherché, depuis longtemps, à déterminer avec précision auquel de ces segments embryonnaires devait être attribuée chacune des parties que l'on peut distinguer sur la tête de l'Insecte arrivé à un stade avancé ou au terme de son développement. Le problème que l'on s'est ainsi posé est un problème bien déterminé, car même les parties qui semblent n'apparaître que très tardivement, au point qu'on les a considérées comme étant de nouvelle formation, dérivent cependant de cellules qui, si l'on remonte de proche en proche jusqu'à leur origine, finissent par dériver d'un segment embryonnaire bien défini.

C'est évidemment l'étude ontogénique qui doit être le point de départ des recherches sur la constitution morphologique de la tête. 
C'est ce qui a été fait par Heymons ${ }^{1}$ dans son intéressant travail sur la segmentation du corps de l'Insecte.

Si l'on aborde directement le problème pour l'Insecte arrivé à un stade avancé de son développement, le premier moyen qui se présente à l'esprit, pour déterminer les limites séparatives des différents segments, est l'étude des lignes visibles à l'extérieur du tégument. Malheureusement, cela ne peut conduire qu'à des résultats approximatifs et incomplets parce que des lignes très nettes existent dans l'intérieur de la surface d'un segment, tandis qu'elles font, souvent, absolument défaut à la limite même du segment. En somme, cette étude ne peut servir qu'à compléter ou à corroborer les données fournies par d'autres méthodes.

Le système nerveux fournit un criterium excellent. Viallanes", dans ses beaux travaux sur les centres nerveux des Arthropodes, nous a fait connaitre avec une grande précision la constitution de l'encéphale de l'Insecte. Les parties du tégument auxquelles aboutissent les nerfs d'un segment déterminé appartiennent certainement à ce segment. Mais, en réalité, l'examen des gros nerfs ne permet de résoudre le problème que pour un certain nombre de surfaces restreintes, et pour connaître, par cette méthode, toute la surface qui doit être attribuée morphologiquement à un segment, il serait nécessaire, et, sans doute, suffisant, de déterminer toute la surface innervée par les dernières ramifications des nerfs du segment.

Un quatrième criterium peut être fourni par l'étude de la musculature. Il y a, dans chaque segment embryonnaire, une masse mésodermique bien individualisée et bien séparée des masses mésodermiques des segments voisins. Chacune de ces masses donne un feuillet somatique qui formera la musculature du segment et, malgré les transformations plus ou moins compliquées que la musculature peut subir au cours de la nymphose, la musculature d'un segment de l'imago dérive du mésoderme du même segment de l'embryon.

Les aires d'insertion des muscles d'un segment peuvent bien arriver tout à fait au contact de la limite du segment, mais même aux stades les plus avancés du développement, ces aires d'insertion continuent à être situées, morphologiquement, sur le segment auquel elles appartiennent. Il suffit donc de savoir à quel segment appartient un muscle pour savoir à quel segment appartiennent morphologiquement les surfaces sur lesquelles il s'insère.

J'ai examiné, à ce point de vue, la tête des Hyménoptères arrivés à l'état d'imago et je vais vous exposer les résultats auxquels je suis arrivé.

Mais, auparavant, je dois, en m'aidant d'un schéma bien

1 Heymons, Richard. Die Segmentirung des Insectenkörpers, Berlin, 1895.

2 Viallanes, H. Etudes histologiques et organologiques sur les Cintres nirreux et les Organes des sens des animaux articulés. Ann. Sc. Nat. S. 7, T. ${ }_{1+}$, p. +05, Paris, i 893. 
simplifié, appeler votre attention sur la déformation extrêmement compliquée que peut subir la surface d'un segment en passant de l'état d'embryon à l'état d'imago.

Sur la figure qui représente schématiquement un segment vu sur l'embryon coupé transversalement on peut, au point de vue de la musculature de l'appendice futur, distinguer trois régions. La première fournira l'ensemble des muscles moteurs externes; la seconde, l'ensemble des muscles moteurs des articles de l'appendice; la troisième, l'ensemble des muscles moteurs internes.

Laissons de côté le rudiment mésodermique des muscles qui seront logés dans l'intérieur de l'appendice et représentons seulement sur le schéma du segment embryonnaire vu par sa face interne les rudiments des muscles situés en dehors et en dedans de l'orifice d'évagination de l'appendice.

Les appendices (antennes, mandibules, maxilles et pièces labiales) étant situés très bas chez l'embryon ont à remonter audessus ou sur les côtés ou, tout au moins, au voisinage de la bouche. Pendant ce déplacement de l'appendice les aires d'insertion des muscles moteurs de l'appendice doivent prendre, chacune, une grandeur et une situation en rapport avec l'importance et le mode d'action du muscle considéré. Non seulement chaque segment doit se déformer pour répondre à ces conditions, mais il doit encore se prêter à la déformation que pour les mêmes raisons que le segment précédent le segment suivant peut avoir à subir.

S'il n'y avait que ces déformations en surface, on aurait, malgré les nombreuses sinuosités des contours du segment, une disposition, somme toute, assez simple; mais deux nouvelles déformations viennent compliquer considérablement les choses.

C'est d'abord un plissement sagittal qui fait disparaître de la surface et amène à l'intérieur de la tête les muscles internes (abducteurs) des mandibules et des maxilles.

Ce sont ensuite des invaginations qui, situées sur les premiers segments fusionnent pour former cet endosquelette céphalique que l'on désigne souvent sous le nom de tentorium, et ce tentorium entraîne, lui aussi, dans l'intérieur de la tête, un bon nombre de surfaces d'insertions musculaires et occasionne une nouvelle et très considérable déformation des surfaces appartenant à chaque segment.

Examinons maintenant d'une façon moins schématique comment les choses se passent chez un Insecte supérieur et voyons à quelles conclusions ce criterium des insertions musculaires nous conduit pour la constitution de la tête. Prenons, comme exemple, la Fourmi.

Les figures que vous avez sous les yeux nous permettront d'examiner rapidement la musculature et les principaux organes de la tête.

La première figure représente une coupe de la tête faite par le plan sagittal, la seconde est une coupe transversale à peu près 
perpendiculaire à la direction de la partie du tube digestif qui est logée dans le trou œsophagien, la troisième une coupe passant par le tentorium.

On voit que ce tentorium est formé de deux tubes antéropostérieurs reliés, vers l'arrière, par une barre transversale. Ces tubes sont creux d'un bout à l'autre, en sorte qu'un fil suffisamment fin et rigide pourrait traverser, de part en part, la tête de la Fourmi.

Pour rendre ces coupes plus instructives j'y ai ramené les principaux des organes situés à leur voisinage immédiat.

Nous reporterons, sur une figure spéciale, les résultats auxquels nous aurons été conduits, au point de vue de l'attribution des surfaces tégumentaires aux segments auxquels ils appartiennent. Cette figure devra être disposée de manière à pouvoir être comparée, aussi facilement que possible, à la figure qui représente la répartition des segments céphaliques sur l'embryon. Cette dernière figure représente la surface de l'embryon coupé suivant sa ligne sagittale dorsale étalé sur un plan et vu par sa face interne. Opérons de même pour la tête de l'Insecte. Pour cela nous supposerons que la tête a été coupée suivant le plan sagittal, que ses deux moitiés ont été rabattues latéralement et, qu'après l'avoir débarrassée de tous les organes qu'elle renfermait, nous la regardons par sa face interne. Nous retrouvons, comme points de repère, le labre, l'orifice buccal et les orifices d'évagination des antennes, des mandibules, des maxilles et du labium. Sur cette figure, il a été impossible de représenter le tentorium, mais la lame sagittale ventrale, qu'il a fallu rabattre pour montrer sa face interne, est bien mise en évidence.

Une couleur, différente pour chacun des six segments constitutifs de la tête, indique, d'une façon bien visible, ce qui doit être attribué à chacun d'eux.

L'encéphale est teinté de manière à indiquer sa composition telle qu'elle résulte des travaux de Viallanes. Le tentorium porte également les couleurs des segments qui prennent part à sa constitution.

Au premier segment, auquel appartiennent les yeux, les ocelles et la bouche, appartiennent également: le pharynx, les glandes postpharyngiennes et tout ce que l'on appelle l'intestin antérieur.

Les insertions musculaires appartenant à ce premier segment sont les insertions:

$\left(1^{\circ}\right)$ des muscles adducteurs du labre, muscles qui se fixent sur les côtés de la partie antérieure du front,

$\left(2^{\circ}\right)$ des muscles moteurs du pharynx qui vont s'insérer sur le clypeus, et sur le front,

$\left(3^{\circ}\right)$ des muscles qui vont s'insérer sur la barre transversale du tentorium. Ces derniers sont: le grand dilatateur inférieur et les deux rétracteurs latéraux du pharynx.

Le premier segment, ou segment oral, comprend donc, la 
bordure de l'orifice buccal et toute la partie supérieure et postérieure de la tête jusqu'à l'orifice du tentorium. Cette surfacc est étranglée au droit des antennes. Elle s'élargit considérablement pour former les yeux et se rétrécit à nouveau pour laisser prendre aux surfaces d'insertion de l'adducteur mandibulaire l'énorme développement dont il a besoin. Entre ces insertions, et jusqu'aux deux orifices postérieurs du tentorium, le premier segment est réduit à une étroite bande affectant la forme d'un $\boldsymbol{T}$ renversé.

Le deuxième segment ou segment antennaire est, de tous, celui qui est le plus intéressé par l'invagination tentoriale. Ses deux aires d'insertions musculaires disparaissent dans cette invagination et nous les retrouvons sur le tentorium dont chaque branche porte les quatre muscles moteurs du scape correspondant. Au delà de l'invagination du tentorium le segment s'élargit notablement, refoule et étrangle le premier segment pour arriver à fournir non seulement le cadre articulaire de l'antenne, mais des surfaces qui reçoivent ses organes chordotonaux de l'antenne et le sac peut-être contractile qui envoie le sang dans son intérieur. Il est probable que le sinus si remarquable des yeux des Guêpes est une expansion du segment antennaire.

Le fait que le segment prend part à l'invagination tentoriale postérieure nous amène à le prolonger en passant par cette invagination, mais comme il n'a plus ici aucune raison pour être large, je le figure réduit à une bande extrêmement étroite. Il est même bien possible que, sur une certaine longueur de son trajet, cette bande presque négligeable disparaisse de la surface externe du tégument en s'enfonçant dans la bordure interne qui encadre l'œil.

Le $3^{\text {e }}$ segment qui correspond à celui de la $2^{\text {e }}$ antenne des Crustacés, antenne qui n'existe pas chez l'Insecte, semble n'avoir persisté chez l'embryon que pour pouvoir fournir la $3^{\mathrm{e}}$ portion du cerveau que Viallanes désigne sous le nom de tritocérébron. Quant à sa portion tégumentaire, non seulement elle ne présente au cours du développement postembryonnaire aucun appendice, mais de plus, comme elle ne prend aucun accroissement, elle devient relativement si petite et elle reste si intimement unie aux parties voisines qu'il est bientôt impossible de la distinguer, et si la petite portion d'ectoderme qui le représente pendant le développement embryonnaire ne se détruit pas, le segment ne reste, en tous cas, représenté que par une bande transversale si étroite qu'on peut la considérer comme ne prenant absolument aucune part à la formation du tégument céphalique.

A l'inverse du précédent, qui est devenu nul, le $4^{\mathrm{e}}$ segment est celui qui prend le développement maximum. Cela est dû au volume énorme des adducteurs maxillaires. Leur surface d'insertion vient, en arrière des yeux, refouler le $I^{\text {er }}$ segment et elle s'étend sur la majeure partie de la gula. L'abducteur maxillaire, beaucoup moins volumineux que l'adducteur, a son insertion refoulée sur le repli sagittal interne. 
Cet énorme développement du segment mandibulaire est cause que le $5^{\text {e }}$ segment ou segment maxillaire ne prend qu'une part très réduite à la formation de la capsule céphalique externe sur laquelle il n'a aucune insertion musculaire. Les insertions des adducteurs se sont, en effet, enfoncées dans le tentorium, tandis que les insertions des abducteurs se trouvent sur l'apodème sagittal, en arrière des insertions mandibulaires correspondantes. Puisque cet anneau est le dernier qui prend part à la formation du tentorium, la bande étroite qui le représente doit, pour aller se fermer en arrière, passer au niveau du dessous de l'invagination tentoriale.

Le $\sigma^{e}$ segment ou segment labial comprend: l'orifice de la glande labiale, la râpe qui termine le labium, le mentum et le submentum qui en sont des parties intégrantes et, enfin, la surface de cette cavité dans laquelle se loge le submentum. Arrivé à la gula, le segment disparaît de la surface qui est envahie par le segment mandibulaire. C'est seulement en arrière qu'il reparaît à la surface pour fournir les insertions des adducteurs et des abducteurs qui, dans ce segment, sont accolés l'un à l'autre. Quant au col qui termine la tête, il porte les deux minuscules traverses qui ne se sont pas fusionnées au tentorium comme cela a eu lieu pour les segments précédents. Ce col, tout entier, appartient à l'anneau labial. La membrane articulaire qui lui fait suite appartient, tout entière, au $7^{\mathrm{e}}$ segment ou prothorax.

Les figures qui montrent, étalées et projetées sur un plan, l'ensemble des 6 segments céphaliques nous donnent, ainsi, une idée des déformations que les contours des six segments subissent en passant de l'état embryonnaire à l'état d'imago. Mais, malgré ces déformations tégumentaires, les organes restent groupés dans la tête d'une façon qui est, somme toute, assez simple. La coupe transversale de la tête nous montre, en effet, que sous le groupe volumineux des organes du segment I, et séparé de lui par l'ensemble relativement réduit des organes qui appartiennent aux segments 2 et 3 , le segment 4 a pris un développement énorme et s'est replié sur lui-même en formant une sorte de gouttière au fond de laquelle se trouve refoulé l'ensemble de ce qui appartient au segment 5, ensemble qui, à son tour, enveloppe un faisceau d'organes appartenant tous au segment 6 .

Le nerf récurrent doit être considéré comme appartenant au premier segment. Cela semble en désaccord avec les descriptions de Viallanes qui n'attribue pas à ce nerf des racines protocérébrales, mais seulement des racines deuto et tritocérébrales. Cela n'a rien de choquant dans le travail de Viallanes qui attribue au $3^{\mathrm{e}}$ segment céphalique, avec le tritocérébron, le labre et la partie initiale du tube digestif; mais si l'on admet que le stomodaeum appartient au I $^{\text {er }}$ segment (acron) on est amené à se demander si de nouvelles recherches sur ce sujet difficile n'amèneraient pas à montrer que le nerf récurrent possède des racines protocérébrales. De même on peut se demander si l'innervation de l'intestin postérieur n'est 
pas sous la dépendance dée la masse nerveuse terminale qui appartient au dernier segment (telson) qui est le générateur de toute cette partie de l'intestin.

L'antenne de l'Insecte, celle de l'Hyménoptère en particulier, reçoit en réalité non pas un mais deux nerfs sensitifs antennaires ${ }^{1}$. Viallanes a montré que ces deux nerfs ont des racines bien distinctes.

D'après la description de Viallanes (pl. I2, fig. 2I), on voit que chez le Crustacé, le tritocérébron se décompose en deux parties successives nettement séparées qui forment:

$\left(\mathrm{I}^{\circ}\right)$ Un tritocérébron antérieur d'où partent le nerf tégumentaire tritocérébral et le nerf de la denxième antenne.

$\left(2^{\circ}\right)$ Un tritocérébron postérientr qui est en rapport avec le nerf stomatogastrique.

Viallanes admet que le tritocérébron antérieur manque chez l'Insecte et le Myriapode, formes qui n'ont pas de deuxième antenne et il admet que le tritocérébron postérieur est homologue de toute la partie nerveuse tritocérébrale de l'Insecte.

Il y aurait peut-être lieu d'examiner si le tritocérébron antérieur a vraiment absolument disparu chez l'Insecte ou si, au contraire, il n'aurait pas fusionné d'une façon précoce avec le deutocérébron, en lui apportant deux nerfs. Dans ce cas l'antenne résulterait de la fusion des deux antennes du Crustacé, le nerf antennaire olfactif de l'Insecte serait l'homologue du nerf de la première antenne du Crustacé, tandis que le $2^{\text {e }}$ nerf sensitif de l'antenne de l'Insecte et le nerf tégumentaire correspondant seraient les homologues du nerf de la deuxième antenne et du nerf tégumentaire tritocérébral du Crustacé.

Sir JонN LUBвоCK said that the difficulty and complexity of the subject made it impossible to pronounce, without further consideration, any opinion on the deductions so ably presented by M. Janet. He could, however, testify to the accuracy of the facts upon which M. Janet based his conclusions, and he was fully able to appreciate the difficulty of the problem so brilliantly attacked in the paper which had just been read, and which deserved, and would doubtless receive, the most careful consideration.

Dr HEMons said that M. Janet's conclusion, based principally upon a very careful study of the muscular system of the imago, that the insect head is derived from six segments, one pre-oral, five postoral, is quite in accord with the results obtained by those who have studied the embryology and the segmentation of the nervous system in Insecta. Compared with this main point, the differences in matters of detail which are necessarily the result of approaching

1 JAXEt, Charles. Sur les nerfs de l'antemue et les organes chordotonaux chez les Fourmis. Comptes rendus hebd. des séances de l'Ac. d. Sc. T. ir 8, p. 8It (séance du 9 avril $\left.\mathrm{I}_{9+4}\right)$, Paris. 
the problem by different methods, are quite unimportant. It should be remembered that, even in the embryo, the boundaries of the mesoderm somites do not preciscly agree with those of the ectoderm segments to which they belong, the somites always encroaching, to some extent, on the following segments.

As the muscular system arises from the mesoderm somites, it is easy to understand that the insertions of the muscles in the imago cannot always quite agree with the boundaries of the segmental plates of the skeleton originating in the ectoderm. A thorough comprehension of the structure of the insect head must be attained by a careful comparison of all the facts given by embryological and morphological study, and it is not safe to carry too far the deductions to which one particular series of facts would seem to point.

Dr SHARP said that, in his opinion, M. Janet had advanced a most able and brilliant hypothesis as to the relations of the complex structures of the imago to the simple structures of the embryo, but it would remain for the study of metamorphosis to corroborate or to contradict the details of the supposed homologies.

\section{Les LaMpyrides des ANTIlles.}

\section{By M. Ernest Olivier.}

Les Coléoptères de la famille des Lampyrides, connus jusqu'à présent comme habitant les nombreuses îles du grand archipel des Antilles, sont seulement au nombre de 33 espèces réparties en 6 genres.

Aucune de ces espèces ne se retrouve dans les régions voisines du continent américain et elles offrent un ensemble tout spécial qui donne à cette partie de la faune insulaire un faciès caractéristique.

Cependant si on étudie les espèces en particulier, on leur trouvera, sauf dans deux cas, des affinités plus marquées avec celles des États-Unis qu'avec celles de l'Amérique du Sud.

Le genre Alecton de Castelnau est identique à celui que Leconte a établi bien postérieurement sous le nom de Pleotomus pour une espèce du Texas et la dénomination de l'entomologiste américain doit venir en synonymie. Ce genre Alecton (= Pleotomus) est donc composé de trois espèces, discoïdalis Cast., de Cuba, pallens Lec., du Texas et Davisii Lec., du Kentucky.

Si on examine les Lucidota de ces îles qui rentrent toutes dans la section Lychmuris, on verra que leur petite taille, leurs antennes relativement grêles, à articles du sommet les plus élargis, les rapprochent davantage des Lucidota atra et californica des ÉtatsUnis et du Mexique que des grandes espèces de l'Amérique méridionale à articles antennaires démesurément appendiculés. 
Le genre Pyractomena qui compte 3 espèces, réparties à Cuba, à Porto-Rico, à Saint-Domingue en renferme une dizaine d'autres, toutes des États-Unis.

Le genre Photimus est de tous le mieux représenté et compte 19 espèces d'un aspect parfaitement homogène. Ordinairement brillamment colorées de flave, varié de taches ou de bandes noires, elles sont de taille petite ou médiocre; le corps est plutôt aplati; le prothorax est bien développé, arrondi, plat, débordant de beaucoup la tête et aussi large que les élytres : ce dernier caractère les différencie des autres petites espèces des États-Unis, mais elles s'éloignent bien davantage de celles de l'Amérique du Sud dont le corps est convexe, allongé et le disque du prothorax toujours plus ou moins fortement saillant.

Le genre Heterophotinus, dans lequel les femelles sont aptères et que j'ai créé pour une espèce du Paraguay, compte un représentant à Cuba, le limbipennis J. Duv. (sub nom. Photinus).

Le Photuris brmmipennis J. Duv., de Cuba, par sa petite taille et sa forme générale étroite, se rapproche plutôt du $P /$. fuluipes Blanch. du Brésil que des grandes et larges espèces des États-Unis et du Mexique.

Cette petite famille d'insectes intéressants impose donc à la faune des Antilles un cachet particulier; mais, si, en ce qui les concerne, on veut chercher des affinités à cette faune, c'est avec celle des États-Unis que l'on trouvera le plus d'analogie, car les deux dernières espèces seules rappellent leurs congenères de l'Amérique du Sud.

Maintenant, il est probable qu'il existe dans les collections des espèces inédites que je n'ai pas vues, de même qu'il est possible que des explorations méthodiques amèneront quelques nouvelles découvertes.

Je ne pense pas cependant qu'il en résulte des modifications importantes et que la conclusion que je viens d'émettre puisse être sensiblement modifiée. Car si les Lampyrides pullulent parfois comme individus, ils sont toujours restreints comme espèces: j'ai pu en examiner une quantité relativement importante et je crois que les captures futures devront être peu nombreuses.

De ce qu'aucun de ces insectes ne se retrouve sur le continent américain, faut-il en déduire que ces îles qui forment les Grandes et les Petites Antilles ont toujours été séparées et qu'elles n'ont jamais fermé le golfe du Mexique en rattachant la Floride au Venezuela? Il ne m'appartient pas de résoudre cette question, qu'une étude approfondie de la Faune générale pourrait seule élucider ${ }^{1}$.

1 J'ai reçu tout dernièrement de M. Sonthonnax, de Lyon plusieurs exemplaires d'Aspidosoma iguitum L. que cet entomologiste a trouvé communément à la Martinique au cours d'un voyage qu'il vient d'y faire. Il y a donc lieu d'augmenter d'un genre et d'une espèce le contingent de la Faune des Antilles. (Note ajoutée pendant Timpression. E. O.) 


\section{Sur les Caractères externes des Péripates.}

\section{By M. E.-L. Bouvier.}

Tous les zoologistes qui se sont occupés des Péripates, surtout des Péripates américains, ont reconnu les difficultés extrêmes qu'on éprouve quand il s'agit de déterminer avec précision les espèces de ce curicux genre. Ces difficultés ont leur source, d'une part dans le petit nombre de caractères externes que présentent les Péripates, dans la ténuité de ces caractères dont l'observation est parfois fort difficile, enfin et surtout, peut-être, dans la faible quantité d'espèces indiscutables qu'on en connaît jusqu'ici. Ayant eu l'occasion d'étudier, au Muséum d'histoire naturelle de Paris, quelques-unes de ces dernières, je crois être utile aux zoologistes en mettant en relief les caractères que cette observation m'a permis de constater.

Les plus importants sont rclatifs à la position de l'orifice sexucl, mais on les connaît depuis longtemps et il n'y a pas lieu d'insister. Les autres ont trait aux mandibules, aux soles en arceaux des appendices locomoteurs, au nombre de ces appendices, aux papilles primaires que porte leur partie pédieuse, enfin aux ornements en saillie qui sont à la surface de la peau.

Les dents des mandibules sont en nombre variable suivant les espèces. Outre la griffe terminale elles comprennent une ou plusieurs dents accessoires, sans compter la rangée de denticules de la mandibule externe. Dans les espèces américaines il n'y a généralement qu'une dent accessoire, pourtant $M$. Camerano en signale 2 dans le $P$. Corradi Cam., 2 ou 3 dans le $P$. quitensis Schm. et j'en ai compté jusqu'à 3 sur l'une et l'autre mandibules dans le $P$. tuberculatus Bouv. Ce caractère, toutefois, n'a pas la valeur absolue qu'on serait tenté de lui attribuer: dans des $P$. Edwardsii Blanch., recueillis par M. Geay au Vénézuela, tantôt on observe 2 dents accessoires, tantôt une seule, et, dans certains exemplaires, 2 d'un côté et une de l'autre.

Le nombre des soles pédieuses est considéré comme étant de 4 dans les espèces américaines, de 3 dans les espèces australo-africaines. Mais, ici encore, on peut relever des variations importantes. Si le $P$. Tholloni, Bouv., espèce congolaise qui ressemble à tant d'égards aux formes américaines, n'a déjà plus que 3 soles, le $P$. tuberculatus, par contre, en présente 5 auxquelles s'ajoutent souvent les ébauches d'une sixième. Quel que soit d'ailleurs le nombre des soles, l'orifice néphridien des pattes 4 et 5 se trouve toujours au-dessous de la troisième, dans laquelle il pénètre plus ou moins. Les variations que présentent ces orifices dans leur position, quoique très lćgères, mont paru constantes, faciles à observer et propres à élucider la nature spécifique des Péripates.

On sait que le nombre des appendices locomotcurs varie beaucoup chez les espèces américaines, beaucoup moins chez les espèces de 
l'Afrique australe, moins enzore chez celles de la région australienne; on sait en outre que ce nombre se réduit à mesure qu'il tend à se fixer. A l'heure actuelle, on connaît à peu près tous les passages entre les espèces qui ont plus de 40 paires de pattes ( $P$. torquatus Kennel) et celles qui n'en ont que I4 ( $P$. novae-zealandiae Hutton). Le $P$. Tholloni du Gabon en a presque autant $(23-26)$ que le $P$. Edwardsii, et le $P$. novae-Britamiae, que $\mathrm{M}$. Willey a récemment fait connaître, se place, à ce point de vue, entre l'espèce du Gabon, et les espèces du Cap, dont M. Purcell vient de signaler certains traits essentiels. Par leur grande dimension et le nombre considérable de leurs pattes, le $P$. tubcrculatus et une espèce de la Trinidad que m'a obligeamment communiquée M. Sedgwick ${ }^{1}$, se rangent entre le $P$. Edwoardsii et le $P$. torquatus.

Il y aura lieu, à mon avis, d'étudier avec le plus grand soin les papilles primaires qui ornent la partie pédieuse des appendices locomoteurs. Dans les espèces qu'il a observées, M. Sedgwick a trouvé 2 de ces papilles en avant et une en arrière, mais l'étude d'autres Péripates m'a montré qu'il n'en est pas toujours ainsi. J'ai déjà fait remarquer qu'il y en $\mathrm{a} 2$ en avant et 2 en arrière dans le $P$. tuberculatus, mais cette espèce n'est pas la seule où l'on observe un pareil caractère: dans un exemplaire de $P$. Corradi que M. Camerano a offert au Muséum de Paris, on trouve également deux groupes de 2 papilles et peut-être en est-il de même dans le type du P. Baliani Cam., que M. Camerano a bien voulu me laisser étudier. Au reste la position de ces papilles est loin d'être toujours la même: la papille proximale de la paire antérieure devient ventrale dans le $P$. novae-Britanniae, et s'avance plus ou moins dans cette direction chez beaucoup d'autres espèces.

Un autre caractère me paraît avoir une grande importance, c'est la grandeur relative et l'arrangement des papilles primaires des téguments. L'espèce la plus remarquable à ce point de vue est, à coup sûr, le $P$. tuberculatus où les plis annulaires de la peau présentent un certain nombre de papilles énormes, semblables à des verrues, entre lesquelles se trouvent de nombreuses petites papilles coniques, transversalement allongées à leur base. Dans cette espèce, les papilles de petite taille forment toujours plusieurs séries irrégulières à la surface de chaque pli. Dans le $P$. Tholloni, les papilles sont très grosses, en général unisériées, mais pourtant 2 ou 3 petites s'intercalent souvent, dans chaque pli, entre les grosses papilles. Dans le P. Balzani, toutes les papilles sont unisériées, mais entre deux grosses viennent s'intercaler plusieurs petites; enfin dans le $P$.quitensis, dont M. Camerano m'a communiqué un exemplaire, les papilles sont unisériées et subégales. A ce propos, je crois devoir signaler ici une espèce que mon excellent confrère, M. E. Simon, a recueillie au Vénézuela; elle présente par intervalles, dans chaque pli, des papilles coniques de faible taille entre lesquelles on

\footnotetext{
${ }^{1}$ Cette espèce est le $P$. torquatus comme j'ai pu m'en assurer depuis, en la comparant avec le type de M. Kennel.
} 
voit plusieurs séries longitudinales de 2 ou 3 papilles beaucoup plus petites. Cette espèce, sur laquelle je reviendrai plus tard, se fait en outre remarquer par la présence de 2 dents accessoires, dont l'une rudimentaire, par la gracilité et l'allongement de son corps, de même que par l'écartement exagéré de ses pattes. Par tous ces caractères, elle s'éloigne franchement du $P$. demeraramus Sedg., espèce qui s'en rapproche le plus, et dont j'ai vu les types dans la collection de M. Sedgivick. Je propose pour ce nouveau type le nom de $P$. Simoni.

Pour terminer je crois nécessaire de dire quelques mots sur les fossettes à téguments minces qu'on observe du côté interne des pattes, entre l'orifice néphridien et la sole pédieuse proximale. Ces fossettes et les bourrelets qui les entourent sont très développés dans toutes les espèces américaines, mais varient de dimension d'une patte à l'autre dans des proportions remarquables. Cela tient à ce fait qu'elles sont évaginables et que leur état d'évagination peut varier dans des limites fort étendues: elles étaient parfois énormes et formaient alors des vésicules très saillantes dans l'exemplaire de $P$. quitensis que j'ai étudié. Si l'on observe que ces fentes évaginables ont des parois fort minces, qu'elles doivent s'évaginer sous la poussée du sang, et que les Péripates sont des Trachéates primitifs où l'appareil trachéen vient à peine de se différencier, il y a lieu, à mon avis, de les tenir pour des organes respiratoires homologues des vésicules évaginables qu'on observe à la même place chez tous les Trachéates primitifs (Thysanoures, Pauropodes, Symphyles, etc.). Que l'on considère ou non ces vésicules comme étant d'origine branchiale, il n'en est pas moins vrai qu'elles sont un vestige de la respiration aquatique et ainsi se trouve justifiée, une fois de plus, l'hypothèse d'après laquelle on considère les Péripates comme étant sortis du sein des eaux. 



\section{APPENDIX A.}

\section{NOMENCLATURE OF LEPIDOPTERA:}

\section{CORRESPONDENCE}

RELATING TO QUESTIONS CIRCULATED BY

SIR GEORGE F. HAMPSON, BART. 



\section{PREFACE.}

When Sir George Hampson first consulted Lord Walsingham upon a scheme for exchanging ideas with some leading Lepidopterists in regard to questions of nomenclature with a view to secure as much uniformity as possible, it was scarcely contemplated that this correspondence would attain to the proportions it has now reached, but the importance of the views expressed and of the reasons given in support of them, together with some information hitherto unpublished, is thought to justify the proposal to print these papers in preparation for the meeting of the Zoological Congress at Cambridge.

After the papers had circulated for the first time, at Lord Walsingham's request I made a careful analysis of the replies given -this accompanied his Lordship's second reply. My analysis seems generally to have been accepted as an impartial one, and Sir George Hampson requested me to incorporate in it the second series of replies and edit the whole for publication.

This I have endeavoured to do in a spirit of absolute impartiality, only adding notes where it has seemed absolutely necessary to do so; the replies have been arranged in chronological order under the questions to which they are answers.

In conclusion, I should remark that intimately connected with this correspondence are two papers published under the joint authorship of Lord Walsingham and myself.

I. Rules for regulating nomenclature with a view to secure a strict application of the Law of Priority in Entomological work. London (Longmans), 2 Nov., I 896.

2. An attempt to elucidate and to fix the types of Tortrix, Tinca and Alucita, three of the Linnaean subdivisions of Phalaena, L. Entomologists' Monthly Magazine, xxxili. 37-42. London, I Feb., I $\$ 97$.

JNO. HARTLEY DURRANT.

Merton Hall, ThetFord.

I fuly, I 898 . 
"British Museum (Natural History), Sept. I 2 th, I 896.

\section{DEAR SIRS,}

As there is a probability of a new British Museum descriptive Catalogue of all the described species of Heterocera being shortly commenced, it is thought advisable to consult a certain number of the best known authors on the Lepidoptera as to the system of nomenclature which is to be adopted. With this object in view, the enclosed list of questions is sent to you, and if you will be good enough to express your views on the subject they will be of great assistance in forming the scheme of the work, and perhaps contribute to attaining a more uniform system of nomenclature in the Lepidoptera.

The names selected for consultation are:-Prof. Scudder, Prof. Fernald, Prof. J. B. Smith, Dr Staudinger, Herr P. C. T. Snellen, Prof. Aurivillius, Prof. A. R. Grote, Lord Walsingham, E. Meyrick, Esq., W. F. Kirby, Esq., and Sir G. F. Hampson.

Other names might easily have been added to this list, but it was thought that eleven would constitute a more manageable committee than a larger number would, and that those selected sufficiently represented the various opinions on the subject and the countries most interested in the Lepidoptera.

It is proposed to circulate the papers once for you to give your opinions and then again for you to see the answers given and make any additional remarks that strike you.

$$
\begin{aligned}
& \text { I am, dear Sirs, } \\
& \text { Yours faithfully, }
\end{aligned}
$$

\section{G. F. HAMPSON."}

\section{QUESTIONS ON WHICH OPINIONS ARE REQUESTED.}

1. Whether the Ioth or I 2 th edition of Linnaeus shall be taken as the basis of Zoological nomenclature?

[vide p. 279]

2. Is it necessary to add any other Pre-Linnaean author's names to the list of those whose works were accepted by the Committee of the British Association?

[vide p. 283]

3. Are the genera of Huibner's Tentamen to be accepted or not? If accepted, what date is to be assigned to them? [vide p. 285]

4. Are the genera of Hübner's Zuträge to be accepted or not?

5. Are the genera of Hubner's Verseichniss to be accepted or not? If accepted, what date is to be assigned to them?

[vide p. 298] 
6. Whether the terminations iidae, iinac, or iadac, ianae are to be employed?

[vide p. 303]

7. By what process is the type of a heterotypical genus to be ascertained?

a. What is the type of Phalacna, L.?

[vide p. 306]

[vide p. 319]

b. What is the type of Tortrix, L.?

[vide p. 323]

c. What is the type of Tinea, L. ?

[vide p. 326]

d. What is the type of Alucita, L. ?

[vide p. 328]

Show how the result is arrived at in each instance and discuss the value of the names Phalaena, L. and Tortrix, L., giving the reasons for your conclusions and stating on what published or unpublished rules you rely.

8. In the year 1850 , Jones proposed a heterotypical genus (say) Tortrix for two species (say) viridana and atrana.

In I855, Smith (without reference to Jones) proposed two monotypical genera (say) Hcterognomon type viridana (p. I), and Pandemis type atrana (p. 2).

In $\mathbf{1} 860$, Brown cited viridana as the type of Tortrix, Jones.

Give the synonymy of these genera, with their types, stating which names should be retained and the rules governing your decision.

[vide p. 33I]

9. In the event of there being any clear consensus of opinion on the above subjects by a majority of those to whom they are to be submitted, would you be willing to adopt their decision and abicle by it ?

[vide p. 337]

10. Can any useful object be served by the publication of the opinions elicited, and will you each consent to the publication of what you have written?"

[vide p. 34I]

"CAMBRIDGE,

Nov. 26th, 1896.

Present circumstances preventing my giving to the questions the special answers desired without unduly delaying the accompanying documents, I can only say that I agree in general with the views expressed by Lord Walsingham, except as they are opposed to the code of rules formulated by the American Ornithologists' Union, to which as a via media I have already given my adhesion. The latter circumstance prevents my further indefinite pledge, but I can hardly doubt that I shall be able to agree with the general consensus when I know what it is.

SAM. H. SCUDDER." 
"May 27th, 1897.

Let me in the first place express my sincere thanks to the gentlemen who have taken so much trouble in answering my questions and giving me their advice on the very difficult subject of nomenclature.

I circulate the papers a second time in order that they may see the opinions of all who were consulted and add any additional points that occur to them, and I would ask them to say whether they think any useful purpose would be served by the publication of the papers and will consent to the publication of what they have written.

I have very carefully considered the answers given, and, although they are extremely conflicting, I think that by their help, and after having talked over the subject with well-known workers in other branches of Zoology, I can arrive at a reasonable method of procedure which shall be in accordance with the modern methods adopted in the other branches and yet avoid unsafe ground and new departures.

\section{G. F. HAMPSON."}

[Additional notes included herewith have been referred to the Questions to which they relate. Durrant.]

WALSINGHAM (Lord).

Io Fune, I 897 .

"The following Analysis (by Mr J. Hartley Durrant) of the replies received to the questions circulated by Sir George Hampson, accompanied by comments and criticisms upon some of the points dealt with may be not uninteresting to those who have responded to his invitation to discuss them. More uniformity of opinion is shewn than I for one had ventured to anticipate, and some additional light has been thrown upon debated questions of publication. That any absolute uniformity will be reached by this or any other method of exchanging views appears to be still doubtful, although perhaps scarcely hopeless." 


\section{QUESTION I.}

"Whether the Ioth or I 2 th edition of Linnaeus shall be taken as the basis of Zoological nomenclature."

Analysis of Replies.

In favour of the roth edn. (1758).

I Hampson, 2 Walsingham, 3 Meyrick, 4 Kirby, 5 Fernald, (6 Scudder), 7 Smith, 8 Snellen, 9 Aurivillius, Io Staudinger, I I Grote. Scudder assents to Walsingham's replies so long as they are in accord with the A. O. U. Code-this code and his own published work justify me in including his name among those in favour of the roth edn. Result $\frac{\mathrm{II}}{\mathrm{II}}$; adopted by all.

[Snellen (vide Reply 13 ) notes that the binomial nomenclature originated in $175 \mathrm{I}$, this point would not appear to affect lepidopterists.]

Durrant.

\section{REPLIES.}

1. Hampson (Sir G. F.).

I 2 Sept. I 896.

"That the I2th edition of Linnaeus be taken as the basis of nomenclature in accordance with the decision of the Committee of the British Association based on Linnaeus' own expressed preference for that edition as representing the amended form of his system : also because the 12 th edition is generally accepted as the basis in the branches of Zoology other than Entomology, and it would be a mistake for authors on one Zoological order to set aside the decision of the ablest body of men which has ever considered the subject without a general agreement of Zoologists on the subject." Durrant.

2. Walsingham (Lord).

"The Ioth edition, 1758 , should be adopted. The British Association Committee in $\$ 1$ established the Law of Priority and in $\S 2$ they wrote :-

'The binomial nomenclature having originated with Linnaeus, the law of priority in respect of that nomenclature, is not to extend to the writings of antecedent authors.'

Strickland's rules were drawn up in I 842 and adopted by the British Association at Birmingham, I 865 (vide Sclater, pp. iii and 
23). In the original drafi no edition of Linnaeus was selected (Strickland having left a blank space for the insertion of the edition to be adopted), the I 2 th edition was inserted by the Manchester Committee in $\mathbf{I} 842$ (vide Sclater, p. 24). 'This was done not as being the first in which the binomial nomenclature had been used as it commenced with the Ioth, but as being the last and most complete of Linnaeus's works and containing many species the Ioth did not.'

The committee having admitted that the binomial nomenclature originated with Linnaeus in the Ioth edition 1758 , and having laid down the principle of priority from the inception of the binomial nomenclature, illogically stultify $\S \mathrm{I}$ and $\S 2$ by adopting the I 2 th edition $1766-8$. In this they can not be followed, their action was inconsistent with the principles they advocated."

\section{KIRBY (W. F.).}

"I hold that the roth edition of Linnaeus should be accepted, for the following reasons :

(a) The binomial nomenclature was fully established in it.

(b) The binomial nomenclature was accepted and employed by many eminent writers between 1758 and 1767 .

(c) The i2th edition was not a new work, and made no new departure. It is only a revised and enlarged edition of the roth.

(d) Linnaeus' own species, described in the I2th edition, cannot be properly elucidated without reference to works of his own, and of other writers, published between I758 and 1767. [The date of the 2 nd part of Vol. I. of the I 2 th edition, which contains the Insects, is 1767 ; 1766 is the date of the Ist part containing Vertebrates.]

(e) The number of alterations in nomenclature necessitated by going back to 1758 will not be so great as to produce serious inconvenience."

\section{Meyrick (E.).}

"Doubtless the Ioth edition has the best logical claims, for the reasons stated by $\mathrm{Mr}$ Kirby*. But as the I 2 th is, both in form and fact, adopted by other Zoologists, I should object to Lepidopterists upsetting a long-established practice without a general consensus of other naturalists. The adoption of the I2th was a convention; but the adoption of the Ioth would also be a convention only; the law of priority is likewise merely a convention. When conventions of such wide effect have been long and generally accepted, I hold that it would be pedantic and unpractical to upset them on abstract grounds."

[*Reply 3. Meyrick, I 8 July 1897 , agrees to the adoption of the Ioth edition, vide Reply I2. Durrant.] 


\section{FERNALD (C. H.).}

"I am positively in favor of regarding the roth edition of Linnaeus as the basis of Zoological nomenclature for the reason that in this edition of the Systema Naturac the author has not only given us a distinct idea of the binomial system of nomenclature but has also consistently used it, so that if the later editions of his work had never appeared there is no question in my mind but that the system would have been adopted by later writers, just as was done by Scopoli and Artedi. All agree that Linnaeus conceived this binomial idea, and that later writers perceiving its decided advantages adopted it. If it is claimed that it was not presented clearly enough in the Ioth edition, and for this reason the $\mathrm{I} 2$ th edition should be taken as the starting point, but that the works of Scopoli and Artedi using this system clearly should be recognized, why then do not those who argue in favor of the I 2 th edition propose to have it start from I 763 , the date of Scopoli's Entomologia Carniolica?"

\section{Smith (J. B.).}

"Logically the roth edition of the Systcme Naturae should be taken as the starting-point. In this work the binomial system is consistently applied to all classes of organisms, and may be said to have its real beginning.

The question is not a new one in the United States, and the almost universal tendency is to make the Ioth edition the startingpoint. Canon XIII. of the 'Code of Nomenclature' of the American Ornithologists' Union covers this point, and there the reasons for its adoption are given at length. They seem convincing to me, and this code is generally adopted by our Entomologists. I have adhered to this in my catalogue of the Noctuidae of Temperate North America, and in all my monographic papers."

\section{SNellen (P. C. T.).}

I 5 Jan. 1897.

"Certainement l'édition Io ( 758 ) du Systema Naturac doit être prise pour base et point de départ de notre nomenclature zoologique. C'est dans cet ouvrage qu'elle a été introduite pour la première fois. En reculant cette date jusqu'à celle de l'édition $12^{\mathrm{e}}$ (1766-8), on passe plusieurs ouvrages dans lesquels elle a été appliquée à l'exemple du Syst. Nat. éd. x. Non-seulement ceux de Clerck, Icones (I759-64) et de Scopoli, Entom. Carniolica ( I 763), mais aussi des ouvrages de Linné lui-même, Fanna Snecica, éd 2 ( 76 I), id., Mus. Lnd. Ulr. (1764), de Poda von Neuhaus, Insecta Musei Gracenssis ( $176 \mathrm{I}$ ) et de Müller, Fanna Fridichsdalina ( I 764). Il n'est que juste de tenir compte de ces ouvrages. La préférence de Linné lui-même pour sa $12^{\mathrm{e}}$ édition du $S$. $N$. ne doit pas nous 
influencer. J'adhère en outre complètement aux excellentes raisons données par Mr. le Prof. Fernald* et Mr. Kirby*** dans leurs réponses."

[*Reply 5. ***Reply 3. Durrant.]

\section{Aurivillius (C.).}

"Everyone who approves of the law of priority must, I think, also take as a starting-point the oldest work in which the binomial system is applied to the organisms with which he is occupied. As to the insects this work is, as far as I know, the Ioth edition of Systema Naturae, but, as Prof. Thorell long ago has pointed out, for the Aranea it is CLERCK'S Araneae Suecicae (I757), and for the plants Linnés Spccies Plantarum (I753). To reject the Ioth edition of Systema Naturace, Clerck's Iconcs, Linné's Fauna Suecica, and Museum Ludovicae Ulricae and other works published before the I 2 th edition, is therefore inconsistent with the law of priority."

\section{Staudinger (O.).}

5 March I 897.

"Eine für die zoologische Wissenschaft durchaus nothwendige, einheitliche, feststehende Nomenclatur ist ohne Beobachtung des strengsten Prioritätsprincips unmöglich. Deshalb muss zweifellos Linné's Editio X. reformata seines Systema Naturae (1758) als Ausgangspunkt der heute guiltigen Linnéschen Binomenclatur genommen werden. Wer die Editio xII. (I766-i768) als Ausgangspunkt nimmt, verletzt sofort das Prioritätsgesetz ohne welches eine feststehende zoologische Nomenclatur niemals zu Stande kommen kann."

10. Grote (A. R.).

25 May 1897.

"I am in favour of adopting the Ioth edition of the Syst. Nat. I 758 , and for the reasons given by Lord Walsingham* (also by Dr Staudinger)***."

[*Reply 2. *** Reply 9. Durrant.]

11. HaMpson (Sir G. F.).

[Vide Hampson I. Durrant.]

27 May 1897.

"I find I must alter my opinion and adopt the Ioth edition of Linnaeus as the basis of nomenclature, as authors in the other branches of Zoology seem all to be adopting it, and consider that its adoption gives, on the whole, the best results; the Arachnologists indeed are going back one year further to Clerck's Araneae, I757."

12. MEYRICK (E.). I 8 Fuly I 897 .

[Vide Meyrick 4. Durrant.]

"Finding that the tendency to adopt the Ioth edition is so strong, I am now prepared to agree with the majority on this point, and will adopt it also ; we are therefore all agreed on this." 
13. Snellen (P. C. T.).

8 Noi'. I897.

"DEAR Sir,

I received in good order the papers concerning the priorityquestion, and after lecture duly forwarded them to Dr Staudinger. After their expedition, however, still reflecting upon the subject, I perceived that I had overlooked a statement concerning it and enounced in a discussion on the same question. It may be found in the Tydschrift voor Entomologie, vol. 32, proceedings (Verslag) p. CIII and mentions that the real starting-point of the binomial nomenclature is in the Philosophica Botanica of Linnaeus, published in the year I75I and that Clerck, in his Araneae Suecicae, applied it as early as 1757 , thus one year before the publication of the Ioth edition of the Systcma Naturae.

I do not recollect that any of the gentlemen consulted on the question has alluded to the said Philosophia Botanica and thus thought it not improper to mention it to you.

I remain, Dear Sir, truly yours,

To Sir G. F. Hampson.

\section{P. C. T. SNellen."}

\section{QUESTION II.}

"Is it necessary to add any other Pre-Linnaean authors' names to the list of those whose works were accepted by the Committee of the British Association?"

\section{Analysis of Replies.}

The adoption of the rothedn. renders any addition unnecessary.

I Hampson, 2 Walsingham, 3 Kirby, 4 Fernald, 5 Smith, 6 Snellen, 7 Aurivillius, 8 Staudinger, 9 Grote $\left(=\frac{9}{\mathrm{I}}\right)$, in which opinion it may be assumed that Scudder concurs $\left(=\frac{\mathrm{IO}}{\mathrm{II}}\right)$ and Meyrick knows none $\left(=\frac{\mathrm{II}}{\mathrm{II}}\right)$. Result $\frac{\text { II }}{\text { II }}$ adopted by all.

[Snellen might perhaps now limit his opinion to the Lepidoptera (vide Reply I3).] Durrant. 


\section{REPLIES.}

14. Hampson (Sir G. F.).

I 2 Sept. I 896.

"The only Pre-Linnaean author on Entomology whose works were accepted in the revised Stricklandian Code was Scopoli and I am of opinion that there are no others who used anything approaching the binomial system of nomenclature of sufficient importance to be added to the list."

[Vide Hampson 24. Durrant.].

\section{WALSINGHAM (Lord).}

"The adoption of Linnaeus' Ioth edition makes it unnecessary to add any Pre-Linnaean (to the I2th edition) names; Scopoli, Clerck, \&c. are subsequent to 1758 and are included by the selection of the Ioth edition as a starting-point, thus we avoid the necessity of establishing a law with saving clauses."

\section{MEYRICK (E.).}

"Not that I know of."

17. Kirby (W. F.).

"I do not think it necessary to enlarge the list of so-called 'preLinnean authors' accepted, if we take the date of 1758 . One reason for going back to this date is on account of the inconvenience and inconsistency of admitting certain exceptions. If we make the date 1758 this is obviated."

\section{FERNALD (C. H.).}

"If the Ioth edition of the Systema Naturae be adopted I know of no writer of earlier date who should be considered."

19. Smith (J. B.).

"If the roth edition be accepted as the starting-point no exceptions need be made and no authors antedating 1758 need be considered."

20. SNellen (P. C. T.).

I 5 Fan. I 897 .

"Non; comme c'est Linné qui est l'inventeur du Système binominal et que c'est lui qui l'a appliqué le premier dans sa Io $^{\mathrm{e}}$ éd. du $S$. Nat., il ne peut pas être question d'ouvrages antérieurs."

21. Aurivillius (C.).

"Vide No. r." [=Aurivillius 8-adoption of edn. ro renders unnecessary. Durrant.] 
22. Staudinger (O.).

5 March I 897.

"Wird durch Annahme der Editio x als Ausgangspunkt erledigt."

23. Grote (A. R.).

25 May I897.

"The adoption of the Ioth edition makes it unnecessary to add any Pre-Linnaean names."

24. HAMPSON (Sir G. F.).

[Vide Hampson I4. Durrant.]

27 May I 897.

"The adoption of the roth edition will avoid the use of any pre-Linnaean names in the Lepidoptera."

\section{QUESTION III.}

"Are the genera of Hübner's Tentamen to be accepted or not? If accepted, what date is to be assigned to them?"

\section{Analysis of Replies.}

To be accepted.

I. As to Validity.

I Walsingham, 2 Kirby, 3 Fernald, 4 Grote $\left(=\frac{4}{\text { II }}\right)$. It may be assumed from his writings and note that Scudder concurs $\left(=\frac{5}{\mathrm{II}}\right)$.

To be rejected.

I Hampson, 2 Meyrick, 3 Smith, 4 Snellen, 5 Aurivillius, 6 Staudinger $\left(=\frac{6}{I I}\right)$.

Result $\frac{5-6}{\text { II }}$; majority against accepting these genera.

2. As to Date.

(No replies received from I Hampson, 2 Meyrick, 3 Snellen, 4 Aurivillius I I $-4=7$ ).

Published in $\mathrm{I} 806$.

I Walsingham, 2 Fernald, 3 Staudinger, 4 Grote, 5 Smith $\left(=\frac{5}{7}\right)$, it may be assumed that Scudder concurs as he has adopted this date $\left(=\frac{6}{7}\right)$. 
Published between I 807 and I8I6.

I Kirby $\left(=\frac{I}{7}\right)$.

Result $\frac{6-\mathrm{I}}{7}$; majority in favour of 1806 . Durrant.

\section{REPLIES.}

25. HAMPSON (Sir G. F.).

I 2 Sept. 1896.

"That the genera of Hibner's Tentamen be excluded for the following reasons :

That it has no possible claims to be considered a scientific work or more than a tentative list of names.

That its genera are entirely undefined and therefore excluded by the British Association rules.

That there is no evidence it has ever been published and that if published no even approximate date can be assigned to it. The first mention of the Tentamen known to me is by Ochsenheimer in the preface to his volume IV. (writing in I8I6). He gives its full title and says that it was distributed by Hibner and that he received it long after the publication of his $3 \mathrm{rd}$ vol. in $\mathrm{I} 8 \mathrm{IO}$.

We know from Geyer's account of Hiibner in Thon's Entom. Archiv, I. 2 p. 28,1827 , that Hubner's method was to print off a few sheets of his various works and send them off to his correspondents whenever it suited him and that his works were never regularly published till Geyer issued them after Hübner's death, so that this statement accords with what we know from other sources and the passage was thus interpreted by Hagen who assigns to the Tentamen the date 'before 1816 , possibly before 1810 ' quoting the passage in Ochsenheimer.

In the preface to the Verzeichniss dated I 816 Hübner says that he attempted a system of classification ten years before and immediately made it known. This may refer to the Tentamen but cannot be clearly shown to do so and in opposition to the theory that the Tentamen was distributed in I806 we have the fact that it includes the Fabrician genus Glaucopis published in I $807 . "$

[Vide Hampson 37. Durrant.]

26. WALSINGHAM (Lord).

"The genera of Hübner's Tentamen are all recognisable as the type is cited in each instance-they are more satisfactory than any genera in the Lepidoptcra which had preceded them. They were adopted by Ochsenheimer in I 816 (vide Schm. Eur. IV. p. viii), who regretted that he had not been able to employ any of the Tentamen names in his 3 rd vol. ( 18 IO), as at that time he had not seen a copy. Ochsenheimer moreover writes 'Herr Huibner hat unter dem Titel Tentamen...den Entwurf eines Systems der Schmetterlinge auf 
einem Quartblatte abgedruckt herausgegeben,' \&c. This can only mean that the Tentamen was PUBLISHED on a quarto sheet of paper by Huibner.

Now as to date-Sir G. Hampson in his opinion, No. 3," [= Reply 25] "seems to doubt that Hiibner refers to the Tentamen in the preface to the Vorzeichniss. Let Huibner speak for himself:-WVerz. bek. Schm. 3 (I8I6) 'Die Grundlage dieses Entwurfes habe ich sogleich, unter dem Titel: Tentamen determinationis, digestionis atque denominationis singularium stirpinm Lepidopterorum bekannt gemacht, damit sie von Verstandigen, bevor ich sie annahme, gepriift und beurtheilt werden mochte.' Compare the words italicised with the title of the Tentamen: 'Tentamen determinationis digestionis atque denominationis singularium stirpium Lepidopterorum, peritis ad inspiciendum et dijudicandum communicatum, a Jacobo Huibner.'

The words in italics are absolutely the same as those quoted in the preface to the Veracichniss, and it is impossible to imagine that they were used in reference to any other work than the Tentamen. This being accepted as a fact it is not difficult to arrive at the date of publication of the Tentamen. In the preface to the Verzeichniss (p. 3), it is expressly stated that Huibner drew up the Tentamen 'vor zehn Jahren' for his own purposes and immediately made it known. This preface was written in September I 8 I6, therefore I $816-10=1806$ (the approximate date of the Tentamen).

Zeller writing to W. H. Edwards, 23 June 1876, said: "The Tentamen was printed not in I806, but in 1805 ' [vide Can. Ent. VIII. I60 (1876)], but no reasons were given for this emphatic assertion.

To recapitulate, Ochsenheimer informs us that the Tentamen was published before 1810 , Huibner indicates the date of publication as I 806, while Zeller says that it was printed in 1805 .

The fact that Glaucopis for phegea is common to the Tentamen and to Fabricius, 1808 , proves nothing. Fabricius and Huibner corresponded and either author may have used the name in MIS. before the publication of either work.

So far I have only dealt with the question of publication and the acceptance of the Tentamen by Ochsenheimer, there now remains the question whether the Tentamen genera can be accepted as valid from the standpoint of a modern zoologist.

The British Association Committee laid down two essential points as necessary before any zoological term could acquire the right to recognition in the following words (Pp. IO-I I):

"Two things are necessary before a zoological term can acquire any authority, viz.: definition and publication.'

It has I think been proved that the essentials of publication were complied with, for Sir George Hampson's contention that Hübner's works were issued at irregular intervals and were not published until they were published by Geyer cannot be taken seriously. All works issued to subscribers have after a time a 
tendency to appear at irregular intervals. I suppose it will not be doubted that Herrich-Schäffer's work was properly published, but this appeared at all sorts of dates (vide HS. CB. Regensburg I 869), and the same remark equally applies to the Biologia CentraliAmericana and all such works'. The authors of the British Association code laid down the following rule :-

' I2. A name which has never been clearly defined in some published work should be changed for the earliest name by which the object shall have been so defined,' and they previously remark,

'Definition properly implies a distinct exposition of essential characters; and in all cases we conceive this to be indispensable, although some authors maintain that a mere enumeration of the component species, or even of a single type, is sufficient to authenticate a genus.'

No one will be disposed to doubt the necessity for full definition of all genera published after the acceptance of the British Association Rules, but it was impossible for authors who lived and died before these rules were made known to act up to them. All previous work must be tested by the meaning of the word 'definition.' Definition does not consist of a generic term accompanied by a greater or less number of mere words which are not diagnostic (e.g. the majority of Walker's genera in the British Museum Catalogues), but 'definition' means that the genus proposed shall be capable of comprehension. Hübner's works exemplify the two types of genera. In the Tentamen we have genera which are readily understood, for the type is always cited: we turn to Hibner's figure and can ascertain what species was intended, and for ourselves test whether the genus be valid or not; on the other hand, in the Verzeichniss the generic name is accompanied by what out of courtesy is called a diagnosis: these genera are for the most part composed of incongruous material and it is impossible to ascertain what was the original type of the genus, but they are accompanied by some 'verbiage,' and if we follow the British Association ruling they must be accepted, whereas from a scientific point of view the Tentamen genera, being monotypical and capable of absolute identification, are much more worthy of recognition.

Citation of type is practically equivalent to definition, for anyone can understand what was intended by an author like Hübner, who figured all the species with which he was acquainted. I am therefore disposed to think that Hubner's Tentamen genera comply with the requirements of 'definition,' and as they were 'published' we are bound to accept them.

The requirements of $\S 2$ of the German Zoological Society, 'Als wissenschaftlicher Name ist nur derjenige zulässig, welcher in Begleitung einer in Worten oder Abbildungen bestehend und nicht

\footnotetext{
1 In these works each part was published at a definite date, but Hibner, by Geyer's account, kept his type set up and printed off and issued a few copies whenever there was a demand for them. G. F. Hampson. March 1899 .
} 
misszudeutenden Kennzeichnung durch den Druck, veröffentlich würde,' are complied with, for all Hiibner's species were figured.

If the citation of a type subsequently iclentified with certainty either from specimens or from a recognisable figure is not to secure the acceptance of a genus, the types of many of Felder and Rogenhofer's genera (and equally species) are rendered useless and take no precedence. The citation of types with generic definition is the exact equivalent of figuring a species and not describing it, and in the latter case this is accepted as 'defining' it."

[Vide Walsingham 38 . Durrant.]

27. MEYRICK (E.).

"No; I reject them. The rule that generic names must be accompanied by some sort of definition other than the indication of a type is one of the few that have met with general acceptance by zoologists; there would be absolutely no justification for disregarding it in Hiibner's case and enforcing it with other authors; and if it were set aside, we should soon be flooded with new genera. There is no pretence of definition about these; I hold therefore that their claim fails absolutely on that ground. In this case there are also the additional reasons furnished by the doubt as to publication, and the undoubted fact that Hibner himself rejected them all as generic names in the Verzeichniss."

28. $\operatorname{KiRBY}$ (W. F.).

"If it is necessary for a genus to be characterised, the Tentamen must be rejected; if the assignation of a type is sufficient, it must be accepted. Although no genus ought to be proposed without characters, I hold that the least inconvenience would be produced by the latter course. Although Glaucopis of Hiibner is not co-typical with Glaucopis, Fabricius (published in Illiger's Magasine in I 807 ), yet they are so nearly identical that one was almost certainly copied from the other. Therefore $I$ think it likely that the Tentamen was not published before I807; for it is more probable that Hiibner should have quoted a published name from Fabricius, than that Fabricius should have adopted a single name, and one only, from private IIS. information from Hiibner. The date therefore may lie between I 807 and i $\$ 16$, when Ochsenheimer mentions the Tentamen; but possibly information may be available in Germany by which we can fix the date more exactly."

\section{FERNALD (C. H.).}

"I was opposed to the adoption of the Tentamen names years ago, but I now see that so many difficulties would arise if it should be ruled out that I am in favor of adopting it. If the genera of the Tentamen are rejected, I see no reason why those of Guenée's Index Methodicus should not also be rejected, and perhaps many other such lists in other departments of zoology; which have been adopted and are now in general use. I do not need to repeat the 
very cogent reasons given by Lord Walsingham* for adopting the 7intamen, but merely state that I heartily agree with them. I should certainly adopt the date 1806, from the showing of $\mathrm{Mr}$ Scudder in his Historical Sketcle of the Generic Names Proposed for Butterflies, p. 98, and from that of Lord Walsingham in his accompanying paper."

[* Vide Reply 26. Durrant.]

\section{Silth (J. B.).}

"No, the genera of Hübner's Tentamen should not be accepted. The evidence in Hibner's published works seems to indicate that this sheet was prepared somewhere about I806, and was primarily a scheme for his own guidance-a tentative classification, such as almost every student has at times made in the groups which he was studying. Hibner printed his scheme, and, apparently, sent out a few copies to correspondents to obtain suggestions or criticisms or for their information-much as if I should by means of a hektograph or other mechanical device multiply some scheme of my own and should send it about as a suggestion. It might induce some co-worker who found the scheme feasible, to adopt parts of it, just as Ochsenheimer did. It is in this light that I think that author's sentence 'daher konnte ich friiher nichts davon aufnehmen' should be construed. There is no sufficient proof of 'publication.'

Canon XXIV. of the A. O. U. Code, above referred to, reads :'A nomen mdum is to be rejected as having no status in nomenclature.' It is remarked in comment or explanation, that 'A name, generic or specific, which has been published without an accompanying diagnosis, or reference to an identifiable published figure or plate, or, in case of a generic name, to a recognizably described species, is not entitled to recognition, being merely a name, and therefore having no status in nomenclature.'

Under a very liberal interpretation of this, and assuming that the Tentamen was really published, the names might stand, because the generic terms are associated with those of known species. But except to one familiar with the associated species no information is conveyed, since no author is cited for the specific name, and no reference is made to any publication where any species is recognizably described. As a whole, it is a bare outline of a scheme of classification and nothing more; with not a clue to the characters upon which it was based, and not a syllable that would enable a student in Africa, not thoroughly familiar with the European fauna, to place a solitary specimen. It seems to me hardly possible to recognize Tentamen names."

31. Snellen (P. C. T.).

"Certainement pas. Cet écrit insignifiant est sans valeur, ne porte pas de date et rien n'indique qu'il soit véritablement publié. 
Il est vrai qu'il mentionne quelques noms génériques, mais sans aucune description et les noms spécifiques qui les accompagnent sont sans auteur. Il est important de ne pas perdre de vue que, si l'on découvre des espèces, on fait des genres. Quant à ceux-ci, je suis entièrement de l'avis de Mr le Prof. J. B. Smith (Revision of the Species of the genus Agrotis, p. 6), qui dit, 'that genera, as such, are mere artificial divisions of convenience, useful for the purpose of identification and for the expression of relationship, and that they were useful for that purpose just in proportion as they expressed clear and definite associations of characters.' Même quand il s'agit de genres qui sont publiés avec une énumeration de leurs caractères, nul ne peut être astreint à les accepter, s'ils ne lui conviennent pas; on est tout-à-fait libre de les remanier et même de les rejeter quand on établirait une autre base de classification."

\section{Aurivillius (C.).}

"The names of stirpes in Hubner's Tentamen are, as also all other generic names which are not accompanicd by a generic description, to be regarded as not published ('nomina nuda'), and must altogether be rejected. [All the stirpes of the Tentamen are also to be found in the Vcracichniss, and it seems to me very improbable that Hiibner ever had the intention to name our genera stirpes. If his coitus correspond with our genera, his stirpes are to be regarded as families or superfamilies.] I can by no means agree with those authors who regard a genus as established merely by naming a type. A genus is a systematical idea, and can therefore only be established by a description or by figures of the generic characters. If a genus could be established only by naming a typespecies, no one would be able to form an idea of the genus without possessing that species. It is easy to understand how disadvantageous this should be for the systematists. Everyone has therefore a right to demand that an established genus shall be accompanied by a description by which he can form an idea of what the author intended with his genus. I am unable to see how a genus can be said to be 'defined' by a type. For instance, Papilio type machaon means only a genus, which contains the species machaon, but leaves quite undecided whether such a genus comprises all organisms, all animals, all insects, all lepidoptera, all butterflies, all hexapodous butterflies, all Equitcs or only some greater or smaller part of the Equites, and is therefore not at all defuncd and certainly much less defined than Linné's genus Papilio.

In conclusion I beg to ask the defenders of Hibner's Tentamen, which is the type of the 'stirps' Oreas? Is it Papilio proserpina, Cyr., proserpina, IV. V., proserpina, Cramer, or proserpina, Fabr.?” 
[33. WALSINGHAM (Lord). IO Fune, 1897 .

"Professor Aurivillius asks which is the type of Oreas, $\mathrm{Hb}$. Tent. 'Is it Papilio proserpina, Cyr., proserpina, W. V., proserpina, Cramer, or proserpina, Fabr.?'

Vide Hb. Verz. bek. Schm.

P. 52. Stirps IX. Oreades.

P. 57. Familia D. Nubilae. Coitus 2 Minoes.

No '549. M. proserpina Schiff., Vers. Pap. F. 23. Circe Fabr. Syst. 226.'

Vide Hb. Syst., Alph. Verz., p. 8.

'Proscrpina, S. I I9, I2 I, Oreas mubila.'

What species was really his type will be determined by the identification of proserpina, Hb. Eur. Schm. I., P1. 26, figs. I I9-2I, text p. ?I.

Staudinger (Cat. 340) agrees with Huibner that proserpina Schiff. Hb. = circe F. If they are correct the type of Oreas is circe F. (=proserpina, Hb.), following Staudinger in giving precedence to circe. I observe that Scudder cites circe as the type."

34. Kirby (W. F.). $20 \mathcal{F}_{1 u l y}, \mathrm{I} 897$.

"Oreas really dates from Oreodes, Borkhausen (1788), in which section the two first species are hermione and proserpina (=circe), consequently the latter is a perfectly admissible type."]

\section{Staudinger (O.).}

5 March I 897.

"Huibner's Tentamen ist im I Bande meines Exemplars von Hübner's Sammlung europäischer Schmetterlinge (eines sicheren, alten Originalexemplars) gleich hinterdem mit I 805 datirtem Titelblatt eingebunden. Dahinter folgt ein Blatt über 'die um Augsburg wohnenden Testaceen' datirt I. Novemb. ISIO, dann folgen 2 Blätter Vorrede, datirt 'am 2I. Wintermonatstage I 805 ' darauf folgen 2 Blätter mit der Ueberschrift 'Zur Errichtung der Sammlung europäischer Schmetterlinge contribuirten': (es folgen die Namen von 46 Herren, die auf 75 Exemplare dieses Werks abonnirten), dann kommt der Text zu den Tagfaltern, S. I-74, ohne Datum. Hieraus schliesse ich, dass das Tentamen wirklich herausgegeben, und zwar mit einer Lieferung des I Bandes von Hübner's Sammlung europäischer Schmettcrlingo versandt wurde (an seine Abonnenten). Nach Huibner's eigenen IVorten, auf der ersten Seite des Vorworts zu seinem Verzeichniss bekannter Schmetterlinge, muss dies Tentamen I 806 von ihm herausgegeben sein. Es kann dies nicht schon 1805 der Fall gewesen sein, sonst hätte Hïbner dies sehr wahrscheinlich in seiner ziemlich umständlich geschriebenen Vorrede zum I Bande seiner Sammlung curop. Schm. erwähnt, die 'am 2I. Wintermonatstage i $\mathrm{SO}_{5}$ ' datirt ist. 
Indem ich auf das iiber die nächste Frage (4)* von mir Gesagte verweise, bin ich der Ansicht, dass dic im Tentamen gegebenen Gattungsnamen keinen Anspruch auf Gültigkeit erheben können, da die Artnamen, durch die sie begründet werden könnten, weder durch Autornamen, noch durch citirte Abbildungen sicher festgestellt sind, wie dies in den beiden folgenden IVerken Hübner's der Fall ist."

[* Vide Staudinger 49. Durrant.]

36. GROTE (A. R.).

25 May' IS97.

"The genera of Hiibner's Tentamen are unquestionably valid and the reasons given by Lord Walsingham* are the echo of my own. There can be no reasonable doubt that the date is 1 So6. I have long ago in print called attention to the fact that Ochscnhcimer's genera are also without diagnoses. Nomina muda of genera are not, or should not be held to be, names given to include already described species, thus (as I have stated in print) of published and known facts; they are names given without description or the inclusion of any named species, or for named species in uss., the descriptions of which had not appeared and where no possibility is offered for finding out what the author intended by them. Catalogue names proposed in substitution, or proposed as new names covering described species (with or without the original author's name), are to be held as valid. The test is a purely literary one and the question to be answered is: Are the published data sufficient to determine what the author meant? In every case the names of the Tcntamen can be identified through Hubner's own illustration of the species and the Tentamen is made by Hubner the basis of his arrangement of the Veraeichniss. The scientific value of the Tentamen must be measured by the literature of the period, upon which it was a great advance. Even to-day Hübner is quite modern in his ideas. There exists absolutely no criterion by which we can say what constitutes and what does not constitute a sufficient description except that it answers the purpose of identification. If we reject the Tontamen, we must logically reject the Zutrage and Vcraeichniss also, for genera, as well as Ochsenheimer and others for genera. We adopt authors' names for species for the one single reason that we can find out from the published data the species intended. Are there to be different rules for generic names? From the use of names in the Tentamen we can find out to a dead certainty every time what Hibner meant. Its rejection is an arbitrary action, one not in reason to be defended. The one weak point about the Tentamen is the absence of a date. Upon this point Mr Scudder's arguments and those adduced in the opinion of Lord Walsingham* are unanswerable. Practically the

[* Vide Reply 26. Durrant.] 
question affects mainly Ochsenheimer's work and this in but few cases. Ochsenheimer in I $8 \mathbf{I} 6$ adopts certain of Hübner's names out of the Tentamen, citing it and its author, and says that he only received it after his own volume in 1810 appeared and therefore (daher) he could not have used it earlier. This is decisive that Ochsenheimer regarded the Tentanen as of authority and as published. To sum up: the Tentamen can only be rejected upon the ground that the genera are without description although we perfectly well know what Hubner meant and can positively identify the type of each generic title. But if we do this we must reject also Ochsenheimer's generic names, also Schranck's and the confusion would be terrible. But I believe the rejection of the Tentamen to be virtually an impossibility. Alone through the use in the Tentamen can we settle the types of many genera, such as Agrotis; Plusia, etc. The Tentamen is a great help and convenience to the nomenclator. For my argument against Hagen and Edwards and for the Tentamen consult Check List, Part 2, pp. 3 I et seq. Buffalo i $876 . "$

"Roemer Museum, Hiluesheim, 25 May I 897.

DEAR SIR GEORGE,

I return with thanks for your kindness in consulting me my opinion on the various questions, the most important of which to Lepidopterists is the recognition of the Tentamen. The tendency in America is to adopt this publication for very many reasons. I may refer you to a recent paper by Dr Harrison G. Dyar, Proc. Am. Ent. Soc. xxiv. p. 6, Jan. I897*. From my correspondence with my friend Dr Dyar, I believe that in most, if not all (certainly in the important ones), he would agree with Lord Walsingham, Prof. Fernald, and myself. I shall be glad if my answers are sufficiently directly expressed to be of use.

Yours faithfully,

A. RADCIIFFE GROTE."

[* Vide Durrant 40. Durrant.]

37. HAMPSON (Sir G. F.).

27 May i $\$ 97$.

[Vide Hampson 25. Durrant.]

"I am very decidedly of opinion that all 'Nomina nuda' should be excluded as they are in all other orders of Insects and branches of Zoology; this will of course exclude the Tentamen, of the publication of which also there is no proof, the Zuträge and many other undefined genera." 
38. Walsingham (Lord).

10 Fune 1897 .

[Vide Walsingham 26. Durrant.]

"Dr Staudinger's information that in his copy of Hübner's Sammlung eur. Schm. (an old original copy) the Tentamen is bound up in vol. I. is most interesting and tends to confirm the opinion I expressed in Reply 4" (=26. Durrant).

\section{AURivillius (C.).}

"If we accept the 'nomina nuda' we shall also be compelled to take all the consequences for the future. For instance, if anyone, not knowing a word about systematic entomology, published a list of known lepidoptera and added a generic name to erery species, we should be obliged to acknowledge these names as entitled to priority."

\section{0. [Durrant (F. H.).}

I Fuly I 898 .

Lord Walsingham (Reply 26) wrote: "No one will be disposed to doubt the necessity for full definition of all genera published after the acceptance of the British Association Rules, but it was impossible for authors who lived and died before these rules were made known to act up to them. All previous work must be tested by the meaning of the word 'definition'.'

Those who agree with Lord Walsingham would consider that the publication of the British Association Rules (1842) marked an epoch in nomenclature and that 'nomina nuda' published before 1842 stood upon an entirely different footing to those published after that date. In the case cited by Dr Aurivillius it might be argued that the author of the supposed genera not having complied with a rule which has found general acceptance in other codes the names should be declared invalid. The expression 'nomina nuda' has been frequently used in these replies but it has not been agreed what constitutes a 'nomen nudum.' It may be well to introduce a note by Dr Dyar to which reference has been made by Professor Grote in Reply 36.

'Those who refuse to recognize the Tentamen names base their objection to them on the ground that the names are unaccompanied by description. Now while the abstract proposition that a generic or family name should be accompanied by a description to receive recognition would seem to command assent, yet the difference between an undescribed genus and one insufficiently described is so slight that I see no advantage in drawing a line between them. In the Lepidoptera, especially in the 'Bombyces,' the majority of genera are so described as to be of no use to the monographer, and it becomes a question of examining the type of each. Under these conditions Hübner's Tentamen genera and the families founded on them, though not described, have a better standing than many modern genera, for they contain but a single species, usually a well known and easily obtainable one and the type is never in doubt. 
Those who reject Hübner, and especially those who, like Mr Hampson, reject Verzeichniss names, which are really accompanied by description, should also reject all of Walker's names and many of those of several other authors, and this has never been seriously proposed.' H. G. Dyar, Transactions of the American Entomological Society xxiv. 6 (1897).

Having defined the term 'nomen nudum' it will then be necessary to determine whether the British Association Rule $\S$ I 2 can be held to apply to genera published before 1842 and if not at what date it became incumbent upon authors to obey this rule (? I 865) ; e.g. are the genera in Guenée's Index Methodicus (I 845) valid? They have been generally adopted but have no more claim to recognition than have Hübner's.]

\section{QUESTION IV.}

"Are the genera of Hübner's Zuträge to be accepted or not?"

Analysis of Replies.

To be accepted.

I Walsingham, 2 Kirby, 3 Fernald, 4 Smith, 5 Staudinger, 6 Grote $\left(=\frac{6}{\mathrm{II}}\right)$; it may be assumed from his writings and note that Scudder concurs $\left(=\frac{7}{\mathrm{I} I}\right)$.

To be rejected.

I Hampson, 2 Meyrick, 3 Snellen, 4 Aurivillius $\left(=\frac{4}{\text { I I }}\right)$.

Result $\frac{7-4}{\text { II }}$; majority in favour of accepting these genera. Durrant.

\section{REPLIES.}

41. Hampson (Sir G. F.).

I 2 September I 896.

"That the genera of Hibner's Zuträge be excluded as being 'nomina nuda' and entirely undefined."

[Vide Hampson 51. Durrant.] 


\section{WaLsinghaM (Lord).}

"There can be no doubt about the publication of the Zuträge and as to definition the arguments advanced in dealing with the Tentamen are held to apply with even greater force in the case of the Zuträge for the figures were issued with the text; at the same time I am strongly of opinion that the quarto sheet known as the Tentamen was issued with one of Huibner's quarto iconographic works."

[Vide Staudinger 35, Walsingham 38. Durrant.]

43. MEYRICK (E.).

"No; I reject these also as being without definition."

44. KIRBY (W. F.).

"The genera of Hübner's Zuträge will stand or fall on the principles discussed in the first part of my reply to (3) " [ = Kirby 2S. Durrant.]

45. FERNALD (C. H.).

"I am certainly in favour of accepting the genera of Hübner's Zuträge."

\section{6. $\operatorname{Smith~(J.~B.).~}$}

"Yes: I accept the genera of the Zutracge. In this work there is at least a chance to make an identification. The species referred to are figured, and as a rule well represented: hence external form and habitus at least are described, and quite frequently characteristic bits of information are given in the side view. This work, to my mind, stands on an entirely different plane as compared with the Tentamen, and comes within the requirements of the Code of the Am. Ornith. Union."

47. SNellen (P. C. T.).

I 5 Jamuary I $\$ 97$.

"Comme ces noms génériques ne sont non plus accompagnés de descriptions, on ne peut jamais décider autrement qu'arbitrairement dans quels cas ils devraient être appliqués pour d'autres espèces. Ils ne sont donc pas valables."

48. Aurivillius (C.).

"As 'nomina nuda' to be rejected. Vide No. 3 " [= Aurivillius 39. Durrant].

49. Staudinger (O.).

5 March I $\$ 97$.

"Sollten alle die Gattungsnamen unguiltig sein, welche nicht streng wissenschaftlich begriindet sind, so müssten sehr viele dieser 
bisher fast ïberall gebrauchten Namen verworfen werden. Vor allem wäre es sehr schwer (unmöglich), eine Grenze für die geniigend wissenschaftliche Begriindung der Gattungsnamen zu ziehen. Ich halte es daher, aus rein praktischen Gründen, für besser, die Gattungsnamen in Hübner's Zuträgen zu acceptiren, da sie durch eine kenntlich abgebildete Art sicher illustrirt werden; oft sicherer als dies bei so manchen oberflächlichen Beschreibungen von (ganz unwesentlichen, vagen) Gattungscharacteren der Fall ist."

50. GROTE (A. R.).

25 May 1897.

"The genera in the Zutrage are virtually without what is called a generic description, but in every case we can find out what the author meant to cover by them and they should therefore be adopted."

51. Hampson (Sir G. F.). 27 May 1897.

[Vide Hampson 4ז. Durrant.]

"I am very decidedly of opinion that all 'nomina nuda' should be excluded as they are in all other orders of Insects and branches of Zoology; this will of course exclude the Tentamen, of the publication of which also there is no proof, the Zuträge and many other undefined genera."

\section{QUESTION V.}

"Are the genera of Hubner's Verzeichniss to be accepted or not? If accepted, what date is to be assigned to them ?"

Analysis of Replics.

I. As to Validity.

Snellen is apparently opposed to their acceptance $\left(=\frac{\mathrm{I}}{\mathrm{II}}\right)$.

The remainder of the Committee are all in favour of their adoption $\left(=\frac{10}{\mathrm{II}}\right)$.

Result $\frac{\text { IO }-I}{\text { I I }}$; majority in favour of their acceptance. 


$$
\text { 2. IS TO DATE. }
$$

a. Commenced in $\mathrm{x} 8 \mathrm{I} 6$.

I Walsingham, 2 Kirby, 3 Scudder, 4 Grote.

B. Sig. $5(p .80)$, printed by the end of 18 1 8 .

I Scudder, 2 Kirby.

$\gamma$. Noctuilae not ante is23.

I Smith.

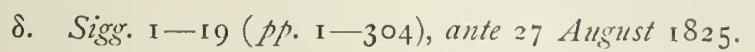

I Fernald.

є. Sig. $20(p .320)$, printed by end of I 822 ; or more probably sig. i 8 (p. 288 ) before autumn of $\mathrm{I} 825$.

I Scudder, 2 Kirby.

ל. Completed I 826 (? I 825 ).

I Walsingham.

$\eta$. Sigg. $20-27$ (p. 305 to end) between 27 August $\mathrm{I}_{25}$ and $\mathrm{I}_{3}$ September 1826 .

I Fernald.

\section{O. Completed i 826 .}

I Meyrick, 2 Smith, 3 Aurivillius, 4 Grote.

ı. Whole published by i 827 .

I Hampson, 2 Scudder, 3 Kirby.

к. Should like $\mathrm{I} 8 \mathrm{I} 8$ adopted for the whole work but the real dates are I 8 I $6-26$.

I Grote.

ג. Would be politic to accept i 826 as date of zuhole work.

I Meyrick, 2 Aurivillius.

$\mu$. Date of whole work end of $\mathrm{I} 826$ or beginning of $\mathrm{1} 827$; can find no proof of any portion being published before that.

I Hampson.

[The dates attributed to Scudder are taken from his published works; Kirby is assumed to accept these, for he writes "those assigned by Scudder are apparently fairly correct." Staudinger and Snellen make no replies: of the 9 members who gave their opinions as to the date of the Verzeichniss 7 are agreed that it was published in parts and Meyrick does not appear to disagree; on the other hand Hampson stands alone in considering the whole work to have been published in book form in [ $826-7$.

Result $\frac{7 \pm I-I}{9}$; majority in favour of considering the Verzeichniss a work issued in parts. Durrant. 


\section{REPLIES.}

52. HAMPSON (Sir G. F.).

12 September I 896.

"That the genera of Hiibner's Verzeichniss be accepted as they are to a certain extent defined and therefore not 'nomina nuda': I am of opinion that the date assigned to the Verzeichniss genera should be I 827 when Geyer published the collected work which Hübner had in part or perhaps wholly distributed in sheets at uncertain intervals during his life-time, but never definitely published.

If this date (1827) be assigned to it the nomenclature based on it would have some possibility of permanence."

[Vide Hampson 62. Durrant.]

53. WALSINGHAN (Lord).

"The Veraeichniss was undoubtedly published and the genera are accompanied by definitions. This work complies with all the requirements of the various codes and must be accepted. As to date-it was published in parts from i 8 I 6 to i 825 or 6 . The last page was published before January I827, for the whole work is reviewed in detail in the $I$ sis, vol. Xx. pp. I03-4 (January I827). Hubner died I 3 th September I 826, and as there is no evidence whatever that any part of the Veraeichniss was published posthumously we can say with certainty that the last page was published by I 826 and almost certainly that it was published before I 3 th September I 826. Page 312 was published after 27 th August I 825 , as noted by Scudder, and it is probable that the last page (p. 431) was published in the same year or early in 1826 .

The dates given by Scudder seem to be approximately correct and are in the main confirmed by results obtained by myself independently. (Vide Wlsm. Pr. Ent. Soc. Lond. I 895, p. xxxvi.)"

54. Meyrick (E.).

"These must be accepted; many have in fact been long in use. Their definitions, though largely based on colour, are honest attempts at diagnoses, and quite as scientific as most other work of that date; more scientific indeed than some later work, such as Walker's. With regard to the date, considering the uncertain mode of their publication, and the very slight available evidence, I think it would be politic to accept I 826 as the date of the whole work."

55. KIRBY (W. F.).

"The genera of the Verseichniss have a better claim to stand than those of the Zuträge or Tentamen, and have been recognised by so many authors that much inconvenience would result by 
rejecting them. The dates must be fixed by what evidence is available, and those assigned by Scudder are apparently fairly correct. The question is, however, of secondary importance; for the number of new genera published between ISO7 and ISI6 or between I 816 and I 827 is very small."

\section{FERNALD (C. H.).}

"I have never doubted the propriety of using the genera of Huibner's Versciclmiss. The title page is dated I816, but there is internal evidence sufficient to prove that it was not all published at that time. I have thus far only concerned myself with the date of publication of the part pertaining to the micros. There is a reference on page 3 I 2 to the 3 rd Century of the Zuträge, which was published Aug. 27, I 825 , but this page is in a signature which begins on page 305. The 3 rd Century of the Zuträge, p. 34, refers to page 294 of the Voraeichniss, but this page is in a signature which ends with page 304. I therefore conclude that the first 304 pages were published before Aug. 27, I 825, and the following pages between Aug. 27, I $\$ 25$, and the time of Hiibner's death, which occurred Sept. I 3, I $\$ 26 . "$

\section{Silth (J. B.).}

"Yes:-I can see no reason for rejecting the Verzeichniss genera. They are at least as well based as those of other writers of the same date, and the descriptions compare not unfavourably with some 'diagnoses' of a more recent period. No date earlier than I 823 can be accepted for the Noctuid portion of the Verzeichniss from my own researches, while Mr Scudder shows that I 826 for the completed work is probably correct."

58. SNELLEN (P. C. T.).

I 5 Jan. I $\$ 97$.

"D'abord ce Catalogue porte une date de publication qui est fausse, et pour lui en assigner une qui serait approximativement juste il faudrait toujours user de l'arbitraire. Puis, ce que Hübner donne comme description, est sans valeur. II est vrai que les genres de Schrank, d'Ochsenheimer, de Treitschke et en général de la majorité des auteurs qui ont écrit sur les Lépidoptères dans le premier tiers du siècle présent, ne valent guère mieux; on l'éprouve quand on tache de classer quelque espèce nouvelle dans ces genres."

\section{Aurivillius (C.).}

"The genera ('coitus') of Hiibner's Veracicluniss are accompanied by descriptions, and must be accepted.

They are often rejected as insufficiently or wrongly determined, but if we reject Huibner's genera we must certainly also reject all the old genera before the days of Herrich-Schaeffer, Doubleday 
and Westwood. It is a curious fact that some authors often accept the badly or not at all characterized genera of Boisduval, but reject the genera of Hiibner. The characters of a genus must of course always be estimated from the points of view taken at the time in which the author lived, and not from our own. By estimating the descriptions of Hübner's 'coitus' one must also take into consideration the descriptions of all the higher groups in which the 'coitus' are included.

With regard to the date, I agree with $\mathrm{Mr}$ Meyrick* and $\mathrm{Mr}$ Hampson**, and think it best to take the year I 826 for the whole work."

[* Reply 54. ** Reply 52. Durrant.]

60. Staudinger (O.).

5 March I 897.

"Aus den eben angegebenen Gruinden ist es auch rathsam die Gattungsnamen von Hibner's Verseichniss anzunehmen, um so mehr als hier noch Angaben (wenn auch meist recht ungenïgende) von Gattungscharacteren gemacht werden. Da Hübner hier in eine Gattung (Verein, Coitus) oft ganz verschiedene Arten setzt, so muss in solchen Fällen die zuerst von ihm aufgeführte Art als 'type' dieser Gattung gelten."

61. Grote (A. R.).

"The same is true" [that the genera are virtually uncharacterised, vide Grote 50] "of the Veraeiclnniss. The date of the whole of the latter is unsettled, on account of the coincidence of names, i.e. Acronicta, etc., and the truth seems to be that it was not all issued at one time. The first signatures were published evidently in I 816 , and there is no reason to dispute this date on the title page. The proof on the title page is positive that the first sheets were printed in 1816 . Also this date may be inferred from the Preface. It may be dated I 8 I6-I 826 , by which time the last signatures had certainly appeared (see the arguments of Scudder, Historical Sketch, and Fernald). I agree with Lord Walsingham* on this point. Possibly the approximate dates can be worked out. Practically the question has little interest. If we give Ochsenheimer's volume of I 16 the priority, which we must, the ten years from 1816 to 1826 cover a barren period as to generic titles. The principal author to be considered is Stephens, over whom Huibner has undoubted priority. In special cases the workers in different groups will have to decide when other authors' generic titles interfere with those in the Verzeichniss. In my special work the question has not arisen. I should be glad to have one date adopted for the whole Verzcichniss, and have proposed I8I8, but this date would only show that Ochsenheimer's volume of 1816 has priority, and does not settle the actual date of the supposed separate issues or pretend to do so. This bibliographical subject must await its monographer. In the mean-

\section{[* Reply 53. Durrant.]}


time we may date the Verreichniss $1816-1826$, in compliance with what now scems to be the truth of the matter. It appears not to be actually proven that the Verzeichniss appeared in 'parts,' but rather in 'signatures' (Scudder, Historical Sketch, p. 97). The generic names in the Verzeichniss are unquestionably valid, although their definition is virtually wanting, and for the reason that the intention of the author is everywhere clear where he cites described or figured species."

62. Hanpson (Sir G. F.).

[Vide Hampson 52. Durrant.]

27 May I 897.

"The genera of the Veracichniss should be accepted for the reasons given above, and the date assigned to it be the end of I 826 or beginning of $\mathrm{I} 827$, as I can find no proof of any portion of it being published before that."

\section{QUESTION VI.}

"Whether the terminations iidae, iinae, or iadae, ianae are to be employed?"

\section{Analysis of Replies.}

[Snellen declares himself incompetent to decide and we are not in possession of Scudder's views ; I I $-2=9$.]

a. In fazour of iadae, ianae.

I Hampson, 2 Walsingham, 3 Meyrick, 4 Grote $\left(=\frac{4}{9}\right)$.

Against iadae, ianae.

I Kirby, 2 Fernald, 3 Smith, 4 Aurivillius, 5 Staudinger $\left(=\frac{5}{9}\right)$.

[Kirby says that the question is a philological one, and Staudinger seems to admit that iadae is orthographically correct.]

Result $\frac{4-5}{9}$; majority against the use of iadae, ianae.

B. In favour of iidae, iinae.

I Fernald, 2 Smith $\left(=\frac{2}{9}\right)$.

Against iidae, inae.

I Hampson, 2 Walsingham, 3 Meyrick, 4 Kirby, 5 Staudinger, 6 Aurivillius, 7 Grote $\left(=\frac{7}{9}\right)$.

Result $\left(\frac{2-7}{9}\right)$; majority against the use of iidae, iinae. 
$\gamma$. In favour of idae, inae.

I Kirby, 2 Staudinger, 3 Aurivillius $\left(=\frac{3}{9}\right)$.

Against idae, inae.

I Hampson, 2 Walsingham, 3 Meyrick, 4 Fernald, 5 Smith, 6 Grote.

Result $\frac{3-6}{9}$; majority against the use of idae, inae.

[All are in favour of the terminations dae, nae. Those who favour iadae, ianae are in a minority as are also those who prefer iidae, iinae or idae, inae!

The meeting of the International Congress of Zoology at Cambridge is most opportune under these circumstances, and it is to be hoped that eminent classical scholars may be induced to attend and pronounce with authority a conclusive decision on this subject.]

Durrant.

\section{REPLIES.}

63. Hampson (Sir G. F.).

I2 Sept. 1896.

"That the terminations iadae, iance be accepted as more classically correct, for though the British Association rules say that the terminations shall be idae and ince this was meant to apply to the form of the patronymic and not to the use of the double ' $i$ ' and that using iadae, iance will be taking the rule in its spirit not in its letter."

[Vide Hampson 73. Durrant.]

\section{WALSINGHAM (Lord).}

"iidae and iinae are incorrect and iance and iadae should be used.

The Committee of the British Association had no power to promulgate the employment of terms not orthographically written and there is no evidence that they had such intentions. Whether they had or had not matters little, the question is orthographical not zoological and must be determined by laws of grammatical usage. The terminations dae and nae must be accepted but the preceding coincidence of vowels is merely circumstantial and must be dealt with accordingly."

\section{MEYRICK (E.).}

"The correctness of -iadae, -ianae, in place of -iidae, -iinae, has never been impugned by any competent orthographical authority, and is undoubted. The Committee's promulgation of -idae, -inae as invariable is doubtless a mere lapsus; they should have written -dae, -nae, but overlooked at the moment the existence of the two forms. I adopt the correct orthography." 
66. KIRLY (W. F.).

"I prefer-idae, -inae to-iadae,-ianae; but this is a question for philologists rather than for entomologists."

67. FERNALD (C. H.).

"I have long been accustomed to use the family termination idae, and the sub-family termination ince even if preceded by $i$, and see no good and sufficient reason for changing to iadac and ianac in such cases."

\section{Siltin (J. B.).}

"Under the Code of the American Ornithologists' Union, Canon Ir., the termination must be uniformly idae and ince. This necessarily excludes iadae and ianae. As a matter of fact, American (U.S.) Entomologists quite uniformly use the idae and inac terminations:- - see Henshaw's List of Colcoptera; Uhler's List of Hemiptera; Cresson's List of Hymenoptera; Williston's Mannal of Diptera, and Smith's List of Lepicloptera.

The view generally taken, and in which I concur, is expressed in the 'Remark' under Canon VI. of the A.O.U. Code:-'All that relates to the grammatical or philological proprieties, to elegance, euphony, appropriateness or the reverse, is not necessarily pertinent to zoölogical nomenclature."

69. SNellen (P. C. T.).

I 5 Fanuary I 897.

"Quant à cette question, je prends la liberté de me déclarer incompétent."

70. Aurivillius (C.).

"I prefer-idae and -inae as more frequently used."

71. Staudinger (O.).

5 March i $\$ 97$.

"Zoologen sind (meist) keine Philologen; auch sind sich die (besten) Philologen nicht immer über die richtige (klassische) Bildung mancher (in neuerer Zeit entstandenen) Worte einig. Sollten die zoologischen Namen (der Ordnungen, Familien, Gattungen und gar der Arten wie dies von manchen verlangt wird) aus philologischen oder anderen (Vernunfts-)Grinden geändert werden dürfen, so ist (nach meiner unmassgeblichen Ansicht) eine wirkliche Stabilität der Nomenclatur niemals zu erreichen. Bei den Benennungen der Ordnungen, Familien und selbst der Gattungen ist eine stricte Beobachtung der Priorität zwar nicht so wichtig (weil die Ansichten ïber diese sich ändern), während sie bei den Artnamen durchaus nothwendig ist. Ich halte es jedenfalls fur besser, die Endungen zu lassen, wie sie bisher fast stets gebraucht wurden, also idtae, inae (iidae, ïnae), statt sie der Philologie zu Liebe in iadae, ianae umzuändern. 
Kurz bemerke ich hier, dass ich, im Interesse einer völlig stabilen Nomenclatur, gegen jede Umänderung der Artnamen, aus welchem Grunde es immer sein möge, bin. Selbst die Aenderung der Endungen wegen des (zuweilen recht fraglichen) Geschlechts der Gattungsnamen halte ich für umgebracht, ganz abgesehen davon, dass viele Arten häufig die Gattungen wechseln. Ich halte es für richtiger, Artnamen niemals als Adjectiva, auch wenn sie solchen entnommen sind, sondern für zu Substantiven gewordene Nomina propria (Beinamen, Vornamen) anzusehen, weshalb ich bedaure, dass dieselben jetzt fast iberall mit kleinem Anfangsbuchstaben geschrieben werden."

72. GROTE (A. R.).

25 May I 897.

"As to this point I would be willing to follow custom, which we have been following in using iidae and innce. If now it is proposed to write iadae and ianae I should not object. But entomological latinity is open to general suspicion, and perhaps this question is not vital for the moment. Since the question is raised, I would agree with Lord Walsingham* that it would be better that iadac and ianae were used."

[* Reply 64. Durrant.]

73. HaMjeson (Sir G. F.).

27 May 1897.

[Vide Hampson 63. Durrant.]

"iadire, ianac to be adopted."

\section{QUESTION VII.}

"By what process is the type of a heterotypical genus to be ascertained?

a. What is the type of Phalaena, L.?

b. What is the type of Tortrix, L.?

c. What is the type of Tinea, L.?

d. What is the type of Alucita, L.?

Show how the result is arrived at in each instance, and discuss the value of the names Phalaena, L. and Tortrix, L., giving the reasons for your conclusions, and stating on what published or unpublished rules you rely?" 
Analysis of Replies.

[Heer Snellen stands quite alone in totally rejecting "]e système des types génériques." He does not admit that one species of a genus can be more typical than another, and says that "un genre doit être basé sur une description suffisante." In the following attempt to analyse and tabulate the replies to Question VII. Heer Snellen is considered to have retired from the discussion and the Committee to consist of ro.]

I. The type of a genus must be a species originally included in it by its founder.

I Hampson, 2 Walsingham, 3 Meyrick, 4 Kirby, 5 Fernald, 6 Smith, (7 Scudder), 8 Aurivillius, (9 Staudinger), Io Grote.

Result $\frac{10}{10}$; adopted by all.

2. The type must conform to the original description of the genus (a species excluded by the description cannot be the type).

I Hampson, 2 Walsingham, 3 Meyrick, + Kirby, 5 Fernald, 6 Smith, (7 Scudder), 8 Aurivillius, (9 Staudinger, by inference), Io Grote.

Result $\frac{10}{10}$; adopted by all.

2. A. Unless direct error of observation can be inferred.

I Meyrick, 2 Kirby.

Result $\frac{2 \pm 8}{10}$; probably all would agree.

2. B. And to the meaning (if any) of the generic name.

I Meyrick, 2 Kirby, 3 Hampson, 4 Walsingham.

Result $\frac{4 \pm 6}{10}$.

3. That a species included with doubt cannot be the type.

I Walsingham, 2 Grote, 3 Kirby.

Result $\frac{3 \pm 7}{\text { IO }}$; probably all would agree.

4. That a NAME included (without the species being known to the founder) cannot establish any claim to the recognition of the SPECIES as a possible type.

I Hampson, 2 Walsingham, 3 Smith.

Kirby is apparently opposed.

Result $\frac{3-\mathrm{I} \pm 6}{\mathrm{IO}}$.

[Some of the members have not expressed their opinions on each of the above propositions, but there appears to be no difference of opinion and probably all will accept these four rules.] 
5. The first species, or the first species agreeing with the description to be considered the type.

[It is to be assumed that specification (or actual indication of the type) by the founder when describing the genus would be accepted by Hampson, but that restriction or citation by subsequent writers would be ignored in favour of the first species that conformed.]

Hampson I. [2 Staudinger (Reply 60)].

Result $\frac{2-9}{10}$; majority against.

[Hampson must now be considered to have retired from the discussion and the Committee to consist of 9.$]$

6. Subsequent citation or restrictions must be accepted in chronological sequence:

6. A. If they are not at variance with the original intention of the author.

I Walsingham, 2 Meyrick, 3 Kirby, 4 Fernald, 5 Smith, (6 Scudder), 7 Grote. Staudinger apparently would not dissent.

Result $\frac{7 \pm I-I}{9}$.

6. B. Disregarding the supposed intentions of the author but not any clear or evident intention.

I Grote.

Result $\frac{\mathrm{I} \pm 8}{9}$.

6. C. Proziding that the subsequent author expressly fixed the type or intentionally divided the genus and that he retained the old name for one part; the effect of omission of species from merely faunistic works to be ignored.

I Aurivillius.

Result $\frac{\mathrm{I} \pm S}{\mathrm{~g}}$.

6. D. A species subsequently removed by the founder to another genus ceases to be a type of the original genus.

I Walsingham.

Result $\mathbf{I} \pm 8$

7. When the historical method has been exhausted the species (or group of species) which agries best with the description should be regarded as typical.

I Walsingham, (2 Meyrick), 3 Fernald, 4 Smith, 5 Aurivillius.

Result $\frac{5 \pm 4}{9}$; probably all would agree to this. 
7. A. But if all cqually agree the type may be fuxed at discretion.

I Meyrick, 2 Walsingham, 3 Smith.

Result $\frac{3 \pm 6}{9}$.

7. A. a. But would assume the type to be a species from the author's oun country, the one with which he seems to be most familiar, and if the preparatory stages are mentioned should assume the commonest species (as the one with which he r'as likely to have the greatest acquaintance) to be the type.

I Smith.

Result $\frac{\mathrm{I} \pm 8}{9}$.

7. B. If all agree equally woll the first species is the type.

I Fernald, 2 Kirby.

Result $\frac{2-3 \pm 4}{9}$.

7. C. If two or nore agree better than the remainder the first of those that do agrce is the type.

I Fernald, (2 Kirby).

Result $\frac{2-3 \pm 4}{9}$.

7. D. If one species is more fully described than the others, or if it is figured, it should be regarded as the type.

I Kirby.

Result $\frac{\mathrm{I}-3 \pm 5}{9}$.

7. E. The majority of homogeneous species should be taken as representing a restricted genus.

I Kirby.

Result $\frac{\mathbf{I} \pm 8}{9}$.

8. If the generic characters are better developed in one species (or group of species) this species (or group) must be held typical.

[Apparently ignoring previous action.]

I Aurivillius.

Result $\frac{\mathbf{I} \pm 8}{9}$; if previous action were respected Aurivillius would probably obtain a majority, but if ignored would be in a minority.

9. If the description and included species proze that two or more genera were intended to include the same animals they must be regarded as synonyms.

[This is British Association Rule $\$ 6$.

I Aurivillius.

Result $\frac{\mathrm{I} \pm 8}{9}$. 
[9. A. If however the original types of these genera were heterotypical each of the genera is walid for its oum type.

Durrant $=$ Br. Assn. Rule $\$ 7$.

9. B. If types heterotypical in structure have been assigned to each genus (there being no evidence to disprove the possibility of their having been the original types) the genera should be accepted in their restricted sense.

\section{Durrant.}

I have ventured to add these two paragraphs in the hope that paragraph 9 may be more fully discussed.] Durrant.

\section{REPLIES.}

74. HAMPSON (Sir G. F.).

I 2 Sept. I 896.

"Theoretically the type of a genus is the species from which the author originally described the genus; it therefore follows that no restrictions of the author subsequent to the creation of the genus, much less of any subsequent author, can in any way affect the type of the genus, and the modern system of taking out from the genus all the species for which other genera have been created by subsequent authors, till in many cases a species is left as the type, which came near the end of the original list of species and had often never been seen by the author, but had been included from the superficial resemblance of some figure of Cramer's, etc., is a reductio ad absurdum. In cases where no type is indicated, the species which heads the list is to be taken as the type if its characters agree with those given for the genus, and it is a well-known species such as the author is likely to have described the genus from. Guenée, for instance, often says that certain species which come at the head of his list do not quite agree with the body of his genus, and this would be sufficient reason for rejecting them as the type."

[Vide Hampson 84. Durrant.]

75. WALSINGHAM (Lord).

"In arriving at the conclusions given below under separate headings, I rely solely upon the absolute application of the Law of Priority, which is of equal importance in governing the fixation of types by elimination, by restriction, or by citation, as well as in relation to original nomenclature."

[Vide Walsingham 85, 88. Durrant.]

76. MEIRICK (E.).

"To fix the type of a genus I use the following rules:

(a) The type must be one of the species originally included under the genus. 
(b) It must conform to the characters originally assigned (including the meaning of the name), unless clirect error of observation can be inferred.

(c) Subsequent restrictions of the genus, which conform to these rules, must be adopted in their historical order.

(d) If, after this is done, the type may still be one of several species, it may be fixed at discretion.

The process of fixing a type by these rules is admittedly sometimes tedious and complicated, but it is logical. The selection of the first species in the list of those originally included has no justification whatever; we might as well choose the last, and better the middle one. The species placed first is usually not the most typical but the most exceptional."

77. KiRBY (W. F.).

"Heterotypical genera.

I. No species can be accepted as the type which

(a) was not included in it by the author of the genus, when he proposed the name,

(b) nor any which does not correspond to the characters, or to the meaning of the generic name, if any. For example, I hold that bocticus is not an admissible type for Polyommatus, Latreille, as against Corydon, and other spotted species; nor Polytes of Laertiades, Huibner, as against Uly'sses."

[Vide Kirby 87, 89, 91. Durrant.]

\section{FERNALD (C. H.).}

"I should select as the type of a heterotypical genus that species which most nearly answers the characters given for the genus by the author who established it. In case they all agree with these characters equally well, I would take the first one as the type. In case two or more agree with these characters equally well and others are associated with them which do not, I would take the first in order of those which do agree with the characters. If, however, the author specified the type I would adopt it unless there was a glaring error in the case. I should adopt the same course when the type is specified by a later author, but should adopt that specified by the earliest author."

79. Silti (J. B.).

"Assuming a very comprehensive description of a genus, sufficient to include a considerable variety of forms from which it becomes necessary to select a type, I would be guided by the following considerations :-

First: No species not considered by the author of the genus when he first proposed it can be considered its type. 
Second: No species not actually known to him or known only from a figure or description can be held as a type.

Third: No species in any way contradicting any part of the description can be so used.

Fonrth: The assumption should be that the author is most familiar with the species of his own country, has the best supply of material of the most common species, and is most familiar with the early stages, if referred to, of such as are most abundant near his home. Hence foreign species should be primarily excluded and the type sought in that species agreeing with the author's description, of which the author has most to say and with which he shows the greatest familiarity. Nevertheless, subject to the first, second and third considerations, subsequent authors may change or restrict as it suits them, and limitations must be accepted in the order in which they are made. The law of priority should be rigorously applied save that no meaning contrary in any way to that attached by the original author can be attached to any generic name."

80. Snellen (P. C. T.). I 5 Jan. I 897 .

"Je rejette totalement le système des types génériques. Un genre doit être basé sur une description suffisante; je ne reconnais pas de types et je ne vois que des espèces possédant plus ou moins les caractères requis."

[Vide Walsingham 86. Durrant.]

\section{Aurivillius (C.).}

"This is the most difficult of all nomenclatorial questions. I will first put down the following principles:-

a. Every generic name must be fixed to a species, the nomenclatorial type of the genus.

I agree with Mr Snellen, that a genus as a systematic idea has no type, but is only determined by the description, which must equally well be applicable to all the species of the genus, and only include characters common to all the species. A genus with many species can therefore never be said to be founded on one of these species only [Cf. Verba Linnaei: 'Genus dabit characterem, non character genus.'] From a practical and nomenclatorial point of view, however, the name must always be connected with a certain species. If we do not accept this, we must give up every hope for unity in generic nomenclature.

$b$. The type of a genus must be one of the species referred to it at its foundation.

$c$. The description of a genus must in every point fit the species which is to be elected the type, and no one has the right to fix as the type a species which does not fully agree with the original description of the genus. 
Pentila was described (1852) by Westwood with the species mudularis, abraxas, aenaea and ?evander. Abrexas is the only species which corresponds with the description, and must therefore be taken as type.

d. If the characters of a genus are better or in a higher degree developed in one species, or in one group of species, than in others, I think that species or that group must be held as typical.

Linné gives (Syst. Nat. X., p. 496) as characters of Alncita, 'alis digitalis, fissis ad basin.' The first species, monodactyla, cannot be taken as type, as not wholly agreeing with the description, but in the last species, hexadactyla, the characters given by Linné are best developed, and I therefore agree with Zeller, Herrich-Schaeffer, Wallengren and others in taking that species as the type of Alacita, L.

$e$. If the description fits all the enumerated species equally well and the author has not designated any type of his genus, I will follow the author, who first expressly fixed a type for the old genus or intentionally divided the old genus in two or more genera, provided that he has retained the old name for one of the new genera.

It follows that nobody, who had not the intention to divide a genus or to fix a type can be said to have done such a thing only by enumerating certain species of a genus and omitting others, as often is the case in faunistic works (e.g. in Poda).

$f$. If the description and the enumerated species clearly prove that two or more genera originally were intended to include the same animals, they must be regarded as synonyms and have the same type-species according to the sentence: 'once a synonym, ever a synony'n." [Vide Aurivillius 93. Durrant.]

"Cupido, Schranck ( I SO I), Polyommatus, Latr. (1 805) and Lyccena, Fabr. (ISO7) were all intended to embrace quite the same species. and therefore it seems to me quite erroneous to fix different types to these genera and use them in a different sense." [Vide Kirby 92. Durrant.]

"Even if one approves and applies these principles, it will often be very difficult to fix the types of some of the older genera. I would therefore propose that some distinguished lepidopterists (for instance in London) would undertake the trouble to fix the types, in such genera where the types could not be fixed only with the assistance of the above principles, and thereafter submit the result to the public. Such a procedure, by which common sense and common use could be in some way regarded, would, I am sure, give a much better result than the application of any new and arbitrary principles.

As such an arbitrary and ill-advised principle I regard the rulc to take the first species as the type. A consistent application of such a principle would be very unhappy, and make, for instance, 
priamus the type of Papilio, occllata the type of Sphinx, atlas the type of Phalaena, prasinana the type of Tortrix, sociclla a Pyralide the type of Tinea, etc.

It would be well here to remember Linné's own words in his Philosoplica botanica (p. I97): "Si genus receptum, secundum jus naturae et artis, in plura dirimi debet, tum nomen antea commune manebit vulgatissimae et officinali plantae.'

As to the special questions, I give here in short my views in accordance with the principles mentioned above :-" [Referred to the Questions to which they relate, vide Aurivillius IO2, I I3, I23, 135. Durrant.]

82. Staudinger (O.).

5 March I 897 .

"Da der Begriff einer Gattung (genus) selbst, nach den individuellen Ansichten der Systematiker, ein wechselnder war, ist und bleiben wird, so halte ich die manchen Zoologen so überaus wichtige 'Type-Frage' für recht unwichtig. Wenn eine Gattung nach einer Art aufgestellt wird, so ist diese zweifellos der Type dieser Gattung. Setzt aber ein Systematiker in eine Gattung mehrere (viele) Arten, die später theilweise in andere Gattungen gestellt oder nach denen neue Gattungen gebildet werden, so scheint mir die Feststellung eines Type's sehr schwierig, falls man in solchen Fällen nicht die zuerst aufgefuihrte Art als Type ein fuir alle Mal annehmen will."

83. Grote (A. R.).

25 May I 897.

"By the process of exhaustion, where the type is not indicated by name. In this process it is not necessary to have regard to the supposed intentions of the author further than to avoid taking as typical any species about the location of which under the title the author expresses himself as doubtful, by using an interrogation mark or otherwise. The first species cited has, from this circumstance alone, no claim to be considered the type. All the other species cited can become types under subsequent restrictions.

Where a diagnosis of the genus is given which by its terms excludes virtually one of the species cited, it would seem to be sensible to exclude that species as a possible type. I am of opinion that Linné did not understand by a genus what we mean to-day, but that his terms Papilio and Sphinx at least have come gradually to have our modern generic sense attached to them through their use in literature. I do not think we can deprive them of it at this date and that it would be the lesser evil to use them in a modern sense in connection with their specific types as now assumed: i.e. of 'Papilio,' machaon, of 'Sphinx,' ligustri. All names used in a plural form: 'Equites,' 'Plebeii,' etc. should be rejected, since generic titles should be in the singular number. 
These were indisputably intended by Linné as names of groups, not as the names for 'genera.' But there were no generic titles at the time out of which they could be formed, and they must fall away. The idea of associating a particular species as 'type' of a genus is comparatively modern, arising out of necessity."

\section{[Vide Grote 95. Durrant.]}

84. HAMPSON (Sir G. F.), (2).

27 May' I 897.

[Vide Hampson 74. Durrant.]

"I most strongly adhere to my opinions on the subject of the types of genera given above; i.e. that the first species in the list that thoroughly answers the generic description shall be considered the type, except that I accept Mr Meyrick's restriction* that the meaning of the generic name should be taken into consideration as helping one to arrive at the meaning of the original author, thus: no species could be the type of Tortrix that had not the appropriate larval habits, or of Xanthia that was not yellowish in colour, etc."

\section{[* Reply 766. Durrant. $]$}

85. WALSINGHAM (Lord).

Io Fune I 897 .

[Vide Walsingham 75. Durrant.]

"I accept Mr Meyrick's addition* that the type must conform to the meaning of the generic name (if any)."

\section{[* Reply 76 b. Durrant.]}

86. WALSINGHAM (Lord).

Io Fune I 897.

[Vide Snellen 8o. Durrant.]

"Heer Snellen stands quite alone in totally rejecting 'le système des types génériques.' He does not admit that one species of a genus can be more typical than another, and says that 'un genre doit être basé sur une description suffisante.' If zoologists were infallible everyone could accept the proposition, but in practice we find the reverse to be the case-the pure isotypical genus is the exception not the rule, and how is it possible to purify and establish a heterotypical genus without (consciously or unconsciously) typifying one section and weeding out the species differing in structure from what we assume from the description and other evidence (if any) to be the original conception before extraneous matter was added. This process has been in operation ever since the time of Linnaeus, and Heer Snellen has himself given his adhesion to the system by using in his Vlind. Ned. many genera as restricted by succeeding authors, e.g. 'Talaeporia Hübn., Zell.' 'Tinca, L.' as restricted by Zeller, \&c. \&c. It appears to me that Heer Snellen 
has not discriminated between the natural genus (i.e. the genus as evolved by the laws of Nature) and the human conception of a natural genus; the former of course has no type, but the latter is founded on one or more species, and these we call its types or exponents (not the exponents of the genus, but the exponents of the definition of the genus).

In ordinary life we talk of 'yards' or 'metres,' knowing well what we mean and what will be understood by these terms, and we buy and use representations of these measures, but even in such cases the 'type' is a necessity well understood by Governments who carefully preserve for reference the original standard or 'type" of each unit. In like manner zoologists recognise the necessity for having a standard of reference for each named conception, by which one person can carefully test and understand what another person means. Thus has arisen the system of types, without which all zoological work must be merely chaotic, for zoologists have not been infallible in the past, nor will they be in the future.

There is still another aspect to this question: we assume that we have established zoological conceptions which will endure, but a hundred years hence these conceptions may be proved to be utterly erroneous, and our isotypical genera may be found to be as heterotypical as we now deem those of Huibner's Verzeichniss to be. Then the only method by which the names of the present century will be capable of employment and of comprehension will be the adoption of our cited types carrying with them our generic names, to which may perhaps be applied definitions founded on characters of which at present we have no conception. When the time shall have arrived in which all genera shall have been rendered isotypical, and when no zoologist will be capable of committing the error of publishing a heterotypical genus, then and then only can we ignore "le système de types génériques,' but until that day shall dawn we must, as in the past, rely upon the type-system, in the principles of which practically all concur, difference of opinion being only noticed in matters of detail as to the method of fixing the type."

\section{KIRBY (W. F.).}

20 Fuly i $\$ 97$.

[Vide Kirby 77. Durrant.]

"VII. 2, $2 \mathrm{~A}$; VII. 3 ; VII. 6 A. I agree with these propositions."

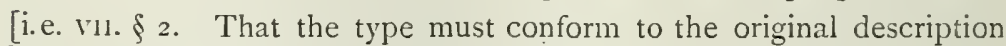
of the genus, \&c. 2 A. Unless direct error of observation can be inferred.

$\S 3$. That a species included with doubt cannot be the type.

$\$ 6$. Subsequent citation or restrictions must be accepted in chronological sequence:

6 A. If they are not at variance with the original intention of the author. Durrant.] 
"VII. 4." [i.e. That a name included (without the species being known to the founder) cannot establish any claim to the recognition of the species as a possible type. Durrant.]

"This proposition, if too literally interpreted, might exclude all genera founded on figures or descriptions of species otherwise unknown to the founder; but this is clearly not intended. §VII. 2, $2 \mathrm{~A}$, respecting possible error, must howerer be strictly applied in all such cases."

88. WALSINGHAM (Lord).

Io Fune I $\$ 97$.

[Vide Walsingham 75. Durrant.]

(VII. $\$ 6 \mathrm{D}$ ). "A species subsequently removed by the founder ceases to be a type of the original genus."

89. KIRBY (W. F.).

Io Fuly 1897.

[Vide Kirby 77. Durrant.]

"vII. $6 \mathrm{D}$. The founder of a genus would have no right to remove from it a species which he or some other writer had virtually" fixed as the type previous to such removal."

90. [Durrant (7. H.).

I Fuly is98.

Lord Walsingham's note 88 (=my VII. \$6D) had especial reference to the heterotypical genera of Hubner's Veracichniss; it was intended to apply to such cases as the following:

I. Hubner, Veri. 384-5, proposed Rhacodia for four species, the last being forskaleana, L. (Hb. fig. I 43).

2. Huibner, Verz. 39I-2, proposed Aleimma for four species, the last being forskalcana, L. (Hb. fig. I 43).

Lord IValsingham held that Huibner's subsequent action should be construed as restricting the genus Rhacodia to the first three species by the elimination of forskaleana, which species thus became a possible type for Aleimma, the argument being that Hibner knew which species he considered typical and that he removed what he thought heterotypical. If anyone had previously cited forskaleana as the type of Rhacodia, Hübner would have had no more right to limit the type to the other three species than any other author unless it could be proved that forskaleana did not agree with the original description.]

91. Kirby (IV. F.).

20 Fuly' I 897.

[Vide Kirby 77. Durrant.]

"vil. $\$ 7 \mathrm{~A}$. If one species is more fully described than others, or if it is figured, it should be regarded as the type of a genus; or I would take the majority of homogeneous species as representing a restricted genus. In a case of perfect indifference, I would take the first species as a readily applicable mechanical rule." 
92. KIRBY (W. F.).

"Dr Aurivillius* raises the question of the types of Cupido and Polyommatus. The type of Cupido I take to be C. Puer $\delta$ (the $q$ is another species), partly because of the name, and partly because it is described in much greater detail than any other species placed by Schrank under Cupido. I regard Corydon as the type of Polyommatus, because it is figured as an example of the section of the genus to which the name best applies."

[*Reply $8 \mathrm{r} f$. Durrant. $]$

\section{Aurivilius (C.).}

[Vide Aurivillius 8 I $f$. Durrant.]

" $\$ 7 \mathrm{f}$. Lord Walsingham says "this is opposed to $\S 7$ of the British Assoc. Rules.'

To me my proposition seems perfectly to agree with $\S 6$ of these same rules, which says: "When two anthors define and name the same gemus, both making it exactly of the same extent, the later name should be cancelled in toto and not retained in a modified sense.' Some of the most common and most deplorable differences of opinion between authors on lepidoptera are due to the disregard of this rule.

Everyone who knows the works of Linnaeus, Geoffroy and Fabricius must admit that the two later authors used the name Pterophorus in exactly the same sense as Alucita, L. It is also quite absurd to assert that Fabricius or Geoffroy 'selected their types from different sections of the genus' or that they had the intention to subdivide the genus Alucita, L. The fact is that they only (without reason) gave a new name to a systematic idea established by Linnaeus.

If we would assume that Fabricius and Geoffroy used Pterophorus in a sense differing from Alucita, L. we must also assume that the species included in Pterophoms by their action were removed from Alucita, the type of which accordingly must be the only remaining species tetradactyla, L. (!)."

\section{4. [Durrant (F. H.).}

I Fuly i 898 .

The note to which Dr Aurivillius takes exception was written by me when preparing the original analysis, not by Lord WValsingham.

Dr Aurivillius' $\$ 7$ f. (vide 8 I $f$.) was connected by him with his reply VII. $d$ (I 35$)$ and I treated them as inseparable, hence my note. Taking $\$ 7 \mathrm{f}$. as an independent note without reference to VII. $d$ (I 35) I should agree that the remark I made was erroneous and I have therefore cancelled it as it might prove misleading, but it would appear to be quite justified so far as Reply VII. $d$ (I 35 ) is concerned. I was of course dealing with Dr Aurivillius' argument that Linnaeus' 
type of Alucita, L. Was hexadactyla, L. Now if it can be proved that hexadactyla was indicated by Geoffroy himself as not being the type of Pterophoms, Geoffr. I was correct when stating that Dr Aurivillius' synonymy Alucita, L. = Ptcrophoms, Geoffr. was in opposition to $\$ 7$ of the British Association Rules. Geoffroy wrote of Pterophomis, pp. 24 and 90 'chrysalide nue et horizontale,' and again p. 90 'mais la chrysalide n'est point renfermée dans une coque.' Surely these words will prove that hexadactyla was not the type of the genus and that the type of Pteroplom was limited by Geoffroy to either pentadactyla, L. or monodactyla, L. (=*didactyla, Geoffr.)? Dr Aurivillius has since adopted pentadactyla as the type of Alucita, but this is not congeneric with monodactyla, which Wallengren in 1859 regarded as the type of Ptcrophorns, and he has been followed by most subsequent authors. I cannot see how this decision is to be upset and therefore consider Pterophonus and Alucita both valid names.]

95. GROTE (A. R.).

IO Noi'. 1897.

[Vide Grote 83 . Durrant.]

"Having looked over Lord Walsingham's* résumé of the opinions I do not find any objection occurring to me except that on p. $7 / 6$ under C" [= Analysis 6. c] "I am represented as disregarding the supposed intentions of the author. If these intentions are suppositions I would disregard them where the occasion demanded, i.e. I would support the rights of another name as against any supposed intention but not as against any clear or evident intention equivalent to a designation. It is a mere question of evidence. I would guard against a loose opinion as to what the author intended, or the use of possible and not probable opinions. I think it is a concession to the author in any case to find out his intention when he fails to select a type out of a number of species first included. I cannot attach much value to a generic diagnosis."

* "Mr J. Hartley Durrant's" vide Walsingham ante page 4. Durrant.

\section{QUESTION VII.a.}

"What is the type of Phalaena, L.?"

Analysis of Replies.

No type: not a genus (= super-family).

I Hampson, 2 Walsingham, 3 Meyrick, 4 Fernald, 5 Grote.

Result $\frac{5-3 \pm 2}{10}$. 
Had no type, but accept Lamarck's specification of SYR1NGAR1A.

I K.irby, 2 Smith (= super-family, but agrees with Kirby).

Result $\frac{2-5-\mathrm{I} \pm 2}{\mathrm{IO}}$.

Type sambucaria, papilionaria, grossulariata or syringaria: a valid genus = Geometra.

I Aurivillius.

Result $\frac{I-2-5 \pm 2}{\text { Io }}$.

No replies received from Scudder and Staudinger. Durrant.

\section{REPLIES.}

96. HAMPSON (Sir G. F.).

I 2 September I 896.

"There is no such genus as Phalaena, L., which is roughly the equivalent of Heterocer $a$ and includes the whole of them except the Sphingidae. It was never used, in the text, singly, but always in conjunction with other generic names Phalaena-Noctua, PhalacnaPyralis, etc."

\section{WALSINGHAM (Lord).}

"It is an indisputable fact that Papilio, Sphinx, and Phalacna are the assemblages of species to which Linnaeus applied the term 'genus,' but it is also equally true that the founder of zoological nomenclature recognised the necessity of splitting up these 'genera' into subdivisions which more nearly approximate to our modern 'genus.' Are we to quarrel about the meaning of the word 'genus,' or are we to endeavour to bring Linnaeus into line with modern thought? Surely the latter is the wiser plan, otherwise we shall merely waste our time in raising the value of the word 'genus' and sinking that of 'family.' As however the term 'genus' has by modern usage assumed a position inferior to that assigned to it by Linnaeus, it may well continue to exist in the grade which it has assumed, but it is obvious that the Linnaean 'genus' Papilio is the equivalent of the Rhopalocera, that the Linnaean 'genus' Sphinx is the equivalent of the Sphingina, and that the Linnaean 'genus' Phalaena is the equivalent of the remaining Hetcrocera, while the subdivisions of these Linnaean 'genera' more nearly approach the modern conception of a 'genus.' These Linnaean 'genera' should be altered in termination in accordance with modern usage, and while attributed to Linnaeus should be used in lieu of the more recent terms Rhopalocera and Heterocera, and the subdivisions of the Linnaean genera should be attributed to Linnaeus as 'genera' in the modern acceptance of the term. I. am therefore of opinion that Tortrix should be attributed to 
Linnaeus as a 'genus' although he did not designate this name by that term, and that Phalacna should be used instead of Heterocera.

There is no type of Phalaena, it is the equivalent of Heterocera minus the Splingina."

98. MEYRICK (E.).

"I agree with Lord Walsingham* that Phalaena, L. is not to be used as a generic name."

[* Reply 97. Durrant.]

99. KiriY (W. F.).

"I see no impediment to the use of Phalaena as a generic name although it had originally no type: it was used by Fabricius in 1775 to include Geometra and Pyralis of Linné combined, and was subsequently used by early French and English authors (Latreille, Lamarck, Cuvier, Leach, and Samouelle) in a more or less restricted sense to include part of Geometra, L. In fact Lamarck, Syst. Anim. sans Vertèbres, p. 286 (I 80 I), actually specifies syringaria as the type, to which there seems no valid objection, as it is a well-known species described in Linné's Ioth edition of the Systema."

100. FERNALD (C. H.).

"I do not regard Phalaena as a genus and therefore do not name a type. It should be regarded of super-family rank if used at all."

101. Smith (J. B.).

"Plualaena, Linn., as a genus has no type since it was never used alone in connection with any series of species. It is not quite the equivalent of Papilio, therefore, and should stand on a different footing. I am very strongly in favour of using the term in some way, however, if it be possible, and rather prefer to employ it for a super-family, to include all the macro-lepidoptera other than the Sphinges. Recent studies seem to indicate the existence of such a natural super-family, and it would seem to be a fitting use of the term. The fact that the name had no type originally will not prevent its use in a generic sense, if so employed by subsequent authors, and I agree with Mr Kirby* that in such case Syringaria should be considered the type. This would also leave the term free for use with a family and super-family ending."

\section{[* Reply 98. Durrant.]}

102. Aurivillius (C.).

[Vide Aurivillius 8I. Durrant.]

"Plalaena, L. seems to me as good a genus as Papilio and Sphinx. It was by Fabricius (1775) intentionally divided, and the name restricted to the Geometrae, and the Pyrales of Linné, in the Supplementum Entomol. Sy'st. (I798), Fabricius restricts still further 
to the Geometrae, and these are therefore the typical group of Phalaena, L., and the type must be selected among the species enumerated in Syst. Nat.x. Geometra must be rejected for Plaalaena. I am not able now to fix the type, but I suppose it will be sambucaria, papilionaria, grossulariata, or perhaps syringaria."

103. GROTE (A. R.).

25 May 1897.

"I do not know the type of Phalaena, L. and am under the impression that this name was not used binomially by Linné, in which I may be wrong. If I am right it has no standing."

104. Grote (A. R.). 30 May 1897.

"But the opinion of Latreille, Gen. Crust. Ins. 218, I So9, must effectually disprove the pretensions of Phalaena to be used as a genus in the modern sense. Latreille there says: Linnaeus genus plaalaena in septem sectiones distribuit: Attacus, Bombyx, Noctua, Geometra, Tortrix, Pyralis, Tinea, Alucita. These sections correspond to modern genera, and the true types of these are to be ascertained. The 'genus' phalaena is a 'family' in our sense and the word is not to be employed in a generic sense. This statement of Latreille's overrules the alleged action of Lamarck and disposes of the view that we are to search for the type of this supposed generic title. All the above sectional names must be credited to Linné as genera and their types sought for in the usual manner. It would be simply contradictory or illogical to take the terms 'Phalaena Geometra syringaria' and hold that both 'Phalacna' and 'Geometra' are genera and search for the type of both. The two terms are exclusive. Either Phalaena or Geometra is a 'genus' name, both cannot be. In accordance with Latreille's statement and following all modern usage we must seek for the type of Geometra and let Phalaena fall as a name used in a family sense without any corresponding genus of the name."

105. [Durrant (J. H.).

ro Fune 1897 .

"Professor Grote omits to note that Latreille, Gen. Crust. Ins. IV. 226 (I 809), wrote thus: "DCxvi. Genus Phalena, Phalène. Platana (Geometra), Limn.'" \&c.]

106. Grote (A. R.).

"The question of whether Latreille calls Phalaena a genus cannot affect the fact that it was not a genus in the modern sense as originally proposed. It has been wholly (except by a few early authors) neglected and should be dropped to avoid dispute.

Latreille's idea of a section accords with our modern idea of a genus, and the phrase above-quoted by me shows what Linnaean names can be taken over as generic and that Phalaena should be dropped. 
If the use of Phalaena for a genus in our sense was once improper it is always improper and cannot be altered by Latreille's or Lamarck's contrary action."

\section{QUESTION VII.b.}

"What is the type of Tortrix, L.?"

Analysis of Replies.

Viridana, L.

I Hampson, 2 Walsingham, 3 Meyrick, 4 Kirby, 5 Fernald, 6 Smith, 7 Aurivillius, 8 Grote $(9$ Scudder and 10 Staudinger may be assumed to concur).

Result $\frac{10}{10}$; all agree. Durrant.

\section{REPLIES.}

\section{Hampson (Sir G. F.).}

12 Sept. 1896.

"The type of Tortrix, L. is cereana, which heads the list in the I 2 th edition and agrees with the definition of the genus in the shape of the wings and their position in repose."

[Vide Durrant II5. Hampson ultimately agreed that viridana is the type; vide Hampson i 6. Durrant.]

\section{Walsingham (Lord).}

"The type of Tortrix, L. is viridana, $\mathrm{L}$.

The original definition of Tortrix, L. Syst. Nat. X. 496 (I758) is: 'Alis obtusissimis ut fere retusis, planiusculis,' to which on p. 530 the following restriction is added: 'Larvae contorquent \& filo connectunt folia, quae vorant \& intra quae se recipiunt." This prevents prasinana from being a possible type, for it does not conform to the subsequent limitation. Toerner, Diss. Acad. Upsal. III. 259 (I $80 \mathrm{O}$ ), recharacterised Tortrix as a 'genus' in the modern sense as independent from Phalacna, but as he mentions no species he cannot be considered to have affected the type provided that his diagnosis ('Antennae filiformes. Alae ampliatae, obtusae; margine exteriore curvo') does not rule out any of the original Linnaean 
types. [N.B.-It is stated that Thuinberg was really the author of these Disscrtationes.

Haworth, Prod.Lp.Br. I 5 ( I 802), places prasinana, L. (= fagana, Hw.) in 'Noctuae viridae,' a very proper correction of a Linnaean error. Unfortunately however Lp. Br. 2 (I803), 399 (I8I2), he replaces it in Tortrix, but his previous restriction which was justified must be held to exclude this species from being a possible type of the genus.

Leach, Edinb. Encycl. I 35 (I 8 I 5), quotes prasinana, L. (=fagana, Lch.) as the type of Tortrix, but this is held to be incorrect as the species does not conform to the larval definition.

Frölich, Enum. Tortr. Wiirt. 9-1 I (1828), and Treitschke, Schm. Eur. VII. 228-30 (I 829): VIII. 45 (1830), do not affect the type, but Stephens, Cat. Br. Ins. II. I68 (1 829), mentions only one of the species included in the genus by Linnaeus which fixes the type as viridana. L., and in Ill. Br. Ent. Haust. IV. 66, 68 (I834) Stephens gives reasons for considering this species the type. In this he has been followed by all subsequent authors (with the exception of Duponchel and Zetterstedt), and as it is an eminently typical species agreeing with the original and supplementary definitions of Linnaeus there is no reason to dispute this consensus of opinion. Therefore I regard viridana as the type, despite Sir George Hampson's citation of cereana, which was not an original type (being described subsequent to the Ioth edition) and which moreover does not conform to the diagnosis of the larval habits of the genus.

Fabricius in 1775 by an error of judgment transferred the Linnaean name Pyralis to the group which Linnaeus had designated Tortrix, raising it to generic rank and citing nearly all the species known to Linnaeus; his subsequent writings did not affect the type. Lamarck, Syst. An. sans Vert. 287 (I SOI) redescribed * Pyralis, F. (nec L.), and cited viridana, L. as the type; thus whether we study the genus under its Linnaean or Fabrician name the fact is equally brought home to us that the species considered typical by an overwhelming majority of authors is viridana, $\mathrm{L}$.

[Poda in I76I had enumerated two species as belonging to Tortrix; of these prasina, Poda (=bicolorana, Fuessl.), and the other avellana, Poda, is considered to rcpresent corylana, F., both non-Linnaean species, so the question of type was not affected.]"

\section{MEYRICK (E.).}

"I accept viridana, L. as the type of Tortrix, L., the reasons being sufficiently stated by Lord Walsingham**; but I may add that the meaning of the name Tortrix (obviously referring to the leaf-rolling habit of the larva) is sufficient in itself to disqualify prasinana, as well as cereana."

[** Reply io8. Dirrant.] 
110. KIRBY (IV. F.).

"I have not access to Poda; but I think Lord Walsingham's views * respecting the type of Tortrix are sound."

[* Reply i 8. Durrant.]

111. FERNALD (C. H.).

"I have long regarded viridana as the type of Tortrix for the reason that it is the first species under the genus in the loth edition that agrees with the characters so far as they are given."

112. SiITH (J. B.).

"I am quite agreed with Lord Walsingham on this point."

[i.e. type riridana L., vide Reply ı08. Durrant.]

113. Aurivillius (C.).

[Vide Aurivillius 81. Durrant.]

"Tortrix, L.-I hope the type by universal consent will be fixed as viridana."

114. Grote (A. R.).

25 May I 897.

"I agree with Lord Walsingham* that the type of Tortrix is viridana, which I doubtfully designated as the type in the Sy'stema Lep. Hildesiae I 895."

[*Reply ı08. Durrant.]

115. [Durrant (J. H.).

Fune I 897.

[Vide Hampson I07.]

"Hampson (Reply I I), accepting the Ioth edition, which did not contain cereana, and also accepting Meyrick's restriction (Reply 84) that the meaning of Tortrix must be respected, would now probably agree that viridana is the type, but he does not say so."]

\section{Hampson (Sir G. F.).}

9 Fune 1897.

[Vide Hampson го7. Durrant.]

"Tortrix: as the first species does not agree with the meaning of the generic name I should consider the second viridana as the type, as it seems to fulfil all requirements." 


\section{QUESTION VII.c.}

"What is the type of Tinea, L. ?"

\section{Analysis of Replies.}

Pellionella, I.

I Walsingham, 2 Meyrick, 3 Kirby, 4 Fernald, 5 Smith, 6 Aurivillius, 7 Grote (8 Scudder and 9 Staudinger may be assumed to concur).

Result $\frac{9 \pm \mathrm{I}}{\mathrm{IO}}$; Hampson is unable to determine, but it is to be hoped that he will accept the consensus of opinion on this point. Durrant.

\section{REPLIES.}

117. HaMPSON (Sir G. F.).

I 2 Sept. I 896.

"The type of Tinea, L. is gelatella, L. (congelatella, C1.) which heads the list in the I 2 th edition, assuming that it agrees with the definition of the genus, of which I am not sure."

[Vide Durrant 125. Vide Hampson I26. Durrant.]

118. WALSINGHAM (Lord).

"Poda, Ins. Mus. Graec. 94 (I76I), enumerated two only of the species placed in Tinea by Linnaeus-granella, L., and pellionella, L.and this restriction of the genus has been accepted by all subsequent authors. Both species were quoted by Geoffroy ( I 762 ), but Fabricius in I775, while retaining pellionella in Tinea, removed granella to his new genus, to which, by an error of judgment, he applied the Linnaean name Alucita; by this action pellionella was constituted the type of Tinea, and it was cited as such by Lamarck, Syst. An. sans Vert. 288 (I80I). Sir George Hampson considers gelatella, L., to be the type of Tinea, L., but this species was unknown to Linnaeus when originally describing the genus. It was first published by Clerck under the name congelatella, and was not included by Linnaeus until I $767 . "$

119. MEYRICK (E.).

"I accept pellionella, L., as the type of Tinea, L., in agreement with Lord Walsingham*; adding that, as the name Tinea signified in the common Latin acceptation a 'clothes-moth,' and was doubtless so understood by Linnaeus, it can only be applied to an insect with the larval habits of pellionella and its near allies, and gelatella, L. is therefore disqualified."

[* Reply i 18. Durrant.] 
120. KirbY (IV. F.).

"I have not access to Poda; but I think Lord Walsingham's views* respecting the type of Tinea are sound."

[* Reply I 18 . Durrant. $]$

121. FERNALD (C. H.).

"I agree with Lord Walsingham* that pellionclla should be regarded as the type of Tinca."

[* Reply i18. Durrant.

122. Silth (J. B.).

"I am quite agreed with Lord Walsingham on this point" [i.e. type pellionclla, L., vide Reply i I8. Durrant.]

123. Aurivillius (C.).

[Vide Aurivillius 8I. Durrant.]

"Tinea. As type I will gladly take pellionella."

124. GROTE (A. R.).

"I agree with Lord Walsingham* that the type of Tinea is pellionella, which I doubtfully designated as the type in the Systema Lep. Hildesiae, I S95."

[* Reply I 8 . Durrant.]

125. [Durrant (J.H.).

Fune i 897 .

[Vide Hampson I I 7.]

"Hampson (Reply I I) having accepted the Ioth edition, which did not contain gelatella, and also accepting Meyrick's restriction that the meaning of Tinea must be respected (Reply $8_{4}$ ), would now probably agree that pellionella is the type, but he does not say so. It should be noted that gelatella did not head the list of Tinea in the $\mathrm{r} 2$ th edition, but was the last species under Pyralis, being, however, cited thus: 'gelatella, 344. P. Tinea.'"

126. HAMPSON (Sir G. F.).

9 Fune i 897.

[Vide Hampson i 7 . Durrant.]

"Tinca: I must plead that my knowledge is quite insufficient to say which is the first species on the list fully agreeing with the description 'alis convolutis in fere cylindrum; fronte prominula.' It seems to me, however, that the meaning assigned by Mr Meyrick* to the word Tinea is somewhat straining it in order to give a convenient type."

[* Reply i i g. Durrant. $]$ 


\section{QUESTION VII. d.}

"What is the type of Alucita, L.?"

Analysis of Replies.

Pentadactyla, L.

I Hampson, 2 Walsingham, 3 Meyrick, 4 Kirby, 5 Fernald, 6 Smith, 7 Aurivillius, 8 Grote (9 Scudder and ro Staudinger may be assumed to concur).

Result $\frac{\text { IO }}{\text { IO }}$ all agree. Durrant.

\section{REPLIES.}

127. HaMpson (Sir G. F.). I 2 Sept. I 896.

"The type of Alucita, L. is monodactyla, which heads the list in the I 2 th edition and agrees with the characters given."

[Hampson subsequently accepted pentadactyla as the type; vide Hampson 137. Durrant.]

128. WALSINGHAM (Lord).

"Poda, Ins. Mus. Graec. 94, Pl. II. I4 (I76I), three years after the publication of Alucita, L., constituted pcntadactyla, L., the type of this genus."

[Vide Walsingham I 38. Durrant.]

129. MEYRICK (E.).

"As I reject Poda's restriction ( $176 \mathrm{I}$ ), and regard pentadactylus, L. as the type of Pterophorus, I hold that the type of Alucita, L. is monodactyla, L."

[Vide Walsingham I 38 -Meyrick ( 8 July, I897) agreed to accept pentadactyla as the type; vide Meyrick i 39 . Durrant.]

130. KirbY (W. F.).

"I have not access to Poda: but I think Lord Walsingham's views* respecting the type of Alucita are sound. Geoffroy's types of Pteropliomis were pentadactylus, didactylus and hexadactylus; and if the first is taken as the type of Alucita, Linn. and the last as that of Omeodes, Latr., didactylus will remain as the type of Pterophorus, as actually fixed by Latreille, Hist. Nat. III. p. 4I 8 (I SO2).

[* Reply i28. Durrant. $]$ 
131. [WALSINGHAM (Lord).

Io Fune I 897 .

"As an addition to Mr Kirby's note specifying didactylus as the type of Pterophorus, I would add-but as * didactylus, Geoffr. (nec L.) = monodactyla, L., the type of Ptcrophorus, Geoffr. is of course Alucita monodactyla, L. (= *didactylus, Geoffr.)."]

132. FERNALD (C. H.).

"I have heretofore regarded monodactyla as the type of Alucita, as it is the first species given under it by Linnaeus, but if Poda in his work, which I have never seen, constituted pentadactyla the type of Alucita, as stated by Lord Walsingham*, I see no reason for not adopting it, unless there be good reasons for rejecting Poda, as intimated by Mr Meyrick**. I wish Mr Meyrick had given his reasons."

[* Reply 1 28. ** Reply I 29. Durrant.

133. [Durrant (J. H.).

I Fuly i 898 .

Professor Fernald, in The Pterophoridae of North America (January 1898), has adopted pcntadactyla as the type.]

\section{Simth (J. B.).}

"I am quite agreed with Lord Walsingham on this point." [i.e. type pentadactyla, L. vide Reply i28. Durrant.]

135. Aurivillius (C.).

[Vide Aurivillius 8r. Durrant.]

"Alucita, L. type hexadactylus (vide above)" i.e.

[If the characters of a genus are better or in a higher degree developed in one species or in one group of species than in others, I think that species or that group must be held as typical. Linné gives Syst. Nat. X. p. 496 as characters of Alucita 'alis digitatis, fissis ad basin.' The first species monodactyla cannot be taken as type as not wholly agreeing with the description, but in the last species, hexadactyla, the characters given by Linné are best developed, and I therefore agree with Zeller, Herrich-Schaeffer, Wallengren and others in taking that species as the type of Alucita, L.' [Aurivillius $\delta_{1} \S d$.].

Pterophorus, which name was first introduced in the binomial nomenclature by Fabricius (1773), is nothing more than a synonym of Alucita, L. Geoffroy never used the binomial system before 1783 ."

[Aurivillius subsequently adopted pentadactyla as the type; vide Aurivillius I40. Durrant.]

136. Grote (A. R.).

25. Way' I 897 .

"I believe pentadactyla to be the type, as shown by Lord Walsingham*."

[* Reply 128. Durrant.] 
137. HAMPSON (Sir G. F.).

9 Junc 1897.

[Vide Hampson i 27. Durrant.]

"Alucita: the only species that seems to agree with the part of the description 'fissis ad basin' is pentadactyla."

138. WALSINGHAM (Lord).

[Vide Walsingham I 28. Durrant.]

Io Fune 1897 .

"The original definition of Alucita is: "AlucitaE. Alis digitatis fissis ad basin.'

Mr Meyrick* thinks that monodactyla best conforms to this description, but it seems impossible to admit that a species which Linnaeus describes thus: 'alis patentibus linearibus indivisis,' could have formed the type-conception of a generic description based on the division of the wings into lobes.

I have long been of opinion that the description was taken from Réaumur's figure which is cited-and the figure would well account for the name monodactyla.

Professor Aurivillius** writes that: 'if the characters are better or in a higher degree developed in one species or in a group of species than in others, I think that species or that group of species must be held as typical' (he would apparently add 'despite the action of subsequent writers'). For this reason he would reject monodactyla and pentadactyla and fix the type as hexadactyla, following Zeller, \&c. who did not adopt the first good work on this genus, viz. that of Latreille, who removed the most incongruous species, hexadactyla, constituting it the type of his genus Orneodes, and thus restricting the name Alucita to the five-lobed species. Linnaeus himself proves that 'fissis ad basin' was not intended to mean that the wings were cleft to the actual base of the wing, for in the description of didactyla he recognised the fact that both wings were clearly defined 'anticis bipartitis, posticis tripartitis,' and surely the use of 'digitatis' explains that the Linnaean meaning was really that the wings were cleft to a basal portion, and thus became digitate. Digitus (and its derivatives) implies a special reference to the human hand, and therefore the characters of the genus are better developed in the five-fingered species than in the abnormal 6+6-fingered species hcxadactyla. One species only was regarded as having five lobes on a common base, and this species, pentadactyla, agrees better with the description 'digitatis' than any other, and as all vary in the amount of basal area this species agrees as well with the definition 'fissis ad basin' as does any other. Linnaeus evidently overlooked the fact that both wings were developed in pentadactyla, for he described it thus: 'alis patentibus fissis quinque partitis niveis: digito quinto distincto.' The species that were described with greatest detail in Syst. Nat. x. were didactyla and pentadactyla.

[* Reply 1 29. ** Reply 88, i 35. Durrant.] 
It should be noted that the colour is omitted from only two of the descriptions, monodactyla and hexadactyla, and that Réaumur's figures are quoted for both species (? were both species described from Réaumur's figures). Only one species is recorded as from 'Svecia,' and it is therefore probable that this species was the original type of the conception of Alucita, L."

139. MeYrick (E.).

[Vide Meyrick I 29. Durrant.]

18 July I 897 .

"Arising from this" [i.e. Meyrick's adoption of the Ioth edn., vide Reply 1 2, Durrant] "I can now assent to pentadactyla as the type of Alucita; I think the point is not clearly established, but would nevertheless conform to the general opinion."

140. Aurivillius (C.).

[Vide Aurivillius I35. Durrant.]

"In this case I will yield to the majority for the reasons put forward by Lord Walsingham* and take pentadactyla as the type of Alucita, L., but I am quite unable to see how Ptcrophonus, Fabr. 1775 (Geoffr.), can be said to mean something else than Alucita or have another type (cf. $\S 7$ f.)."***

[* Reply r 38 . ** Vide Aurivillius 8 8 f., 93, Durrant 94. Durrant.]

\section{QUESTION VIII.}

"In the year i 850 Jones proposed a heterotypical genus (say) Tortrix for two species (say) viridana and atrana.

In 1855 Smith (without reference to Jones) proposed two monotypical genera (say) Heterognomon, type viridana (p. I), and Pandemis, type atrana (p. 2).

In I860 Brown cited viridana as the type of Tortrix; Jones.

Give the synonymy of these genera with their types, stating which names should be retained, and the rules governing your decision." 
Analysis of Replies.

I. Tortrix, Jones = PANDEmis, Smith.

Type atrana.

2. Heterognomon, Smith = Tortrix Jones $(\mathrm{p})=$. Tortrix, Brown. Type viridana.

I Walsingham, 2 Meyrick, 3 Fernald, 4 Smith, (5 Scudder would concur) 6 Aurivillius, 7 Grote.

Result $\frac{7 \pm \mathrm{I}-2}{\mathrm{IO}}$; majority in favour of this synonymy.

I. Tortrix, Jones $=$ Heterognomon, Smith.

Type viridana.

2. Pandemis, Smith.

Type atrana.

[Hampson selects the first species as the type, while Kirby obtains the same result by accepting Brown's citation.]

Result $\frac{2 \pm \mathrm{I}-7}{\mathrm{IO}} ;$ majority against this synonymy.

Staudinger makes no reply, and Snellen is considered to have retired from the discussion. Durrant.

\section{REPLIES.}

141. Hampson (Sir G. F.).

I 2 Scpt. I 896 .

"The type of Tortrix, Jones, is viriduna, being the first species placed under it: Heterognomon will be a synonym of Tortrix with the same type, whilst Pandemis will stand for atrana. Brown's citation of viridana does not affect the question in any way."

[Vide Hampson I52. Durrant.]

142. WALSINGHAM (Lord).

"In the year I855 Smith constituted viridana the type of Heterognomon and atrana the type of Pandemis, overlooking the fact that Jones, in 1850 , had established a heterotypical genus for the reception of the same two species.

It is obvious that one of Smith's genera must sink as a synonym of Tortrix, Jones; viridana was the first species which acquired an exclusive title to a generic name, and it was not open to a succeeding writer to restrict Jones' heterotypical genus Tortrix to the detriment of Smith's monotypical and natural genus Hcterognomon. Moreover when Smith constituted viridana the type of Heterognomon he left Tortrix absolutely monotypical, with atrana as its 
type, and consequently his genus Pandcmis was from its origin a synonym of Tortrix. The synonymy had thus become established, and it was not open to Brown to disturb it.

TORTRIX, Jones

Type T. atrana, Jones (Smith 1855)

TORTRIX, Jones (I850) partim

= PANDEMIS, Smith (I855), type atrana, Jones.

(2)

Heterogromion, Smith

Type T. viridana, Jones (Smith 1855)

= TORTRIX, Jones (I850) partim

Heterognomon, Smith (i855), type viridana, Jones =*TORTRIX, Brown (I 860), nec Jones + Smith.

The only rule governing this decision is the Law of Priority, of which the above is a crucial test. Such cases frequently occur and confusion must constantly arise tending to defer the attainment of desirable finality if this one great fundamental law is not applied with absolutely precise method."

[Vide Walsingham 151. Durrant.]

143. MEYRICK (E.).

"Applying the above rules" [vide Meyrick 76, Durrant] "to this special case, and assuming that the definitions of the imaginary genera, and the meaning of their names, offer no help in fixing the types (which would probably be seldom the case), then clearly. Smith's genus Heterognomon is good, and stands with viridana as its type; but in forming it he restricts Tortrix, Jones, to atrana only, which therefore becomes the type of Tortrix; hence his second genus Pandemis lapses as a mere synonym of Tortrix. Brown in I860 comes in altogether too late, and can effect nothing."

\section{KirbY (WV. F.).}

"In the case supposed if both species agreed equally well in all particulars with the characters and name of Tortrix, Jones, either would be an admissible type; but in such a case I think the first species should have a prior claim to be regarded as the type, and hence I think Brown's action was justified, as Smith's action really left the matter quite undecided. Hence the synonymy would stand thus :-

(I) TokTRIx, Jones; Brown (restr.). = Heterognomon, Smith.

(2) Pandenis, Smith. = Tortrix, p. Jones (nec Brown)." 
145. FERNAI,D (C. H.).

"If Smith established the genus Heterognomon with viridana as the type earlier in the year I855 than he did Pandemis, either in a different book or in a part of the same book, but published earlier, he thereby purified Tortrix by removing viridana. At this stage of the work we had two genera, each containing a single species which we must regard as the types (Tortrix atrana and Heterognomon viridana). If Smith in a later work, or in part of the same work published later, established the genus Pandemis with atrana as the type, we have as a result two genera with the same type, and hence the latest one published (Pandemis) is a synonym of the other (Tortrix). This is a simple application of the law of priority as it seems to me. If, however, Smith published his two genera in the same book and even on the same page, the one immediately following the other, I think we must then recognize priority of page and even of position on the same page. If we do this we shall obtain the result as before. It is presumable that an author prepares his manuscript in the order that it appears on the printed page, and therefore the earlier name on the page or in the same book should take precedence over a later one, if they prove to be synonymous. The matter was all settled before Brown came in so he could do nothing except to add to the synonymy. It then stood as follows:-

TORTRIX, Jones (Type atrana). $=$ Pandemis, Smith.

Heterognomon, Smith (Type viridana).

$=$ Tortrix, Jones (in part).

= Tortrix, Brown."

146. SмITH (J. B.).

"Taking the proposition in its simplest form the synonymy would stand:

Heterognomon, Smith. viridana, Jones $=$ Tortrix viridana, Jones.

TORTRIX, Jones.

atrana, Jones $=$ Pandemis atrana, Smith.

Or, in another way :

Heterognomon, Smith = Tortrix, Jones (part); Brown in error.

TORTRIx, Jones $=$ Pandemis, Smith.

This assumes that Jones's original description of Tortrix applied equally to both species, and pointed to neither viridana nor atrana. In a book containing descriptions of many genera and species, no one name can be properly said to have priority over another. All are published at the same time, and the name on page Ioo bears 
exactly the same date of publication as that on page I. In according to Heterognomon (p. I) preference over Pandemis (p. 2) an arbitrary rule is applied to secure uniformity. If Brown, in I860, points out any reason why atrana rather than viridana is typical of Tortrix he should be followed. If he makes a merely arbitrary selection of viridand he is too late and the rule must apply."

147. SNELlen (P. C. T.).

I 5 Fan. 1897.

"Je rejette totalement le système des types génériques. Un grenre doit être basé sur une description suffisante; je ne reconnais pas de types et je ne vois que des espèces possedant plus ou moins les caractères requis."

148. Aurivillius (C.).

"Supposed that the genera were described I agree with Mr Meyrick* respecting the synonyms in this imaginary (?) case. Besides Pandemis was preoccupied by Pandemis, Huibn."

\section{[* Reply i 43. Durrant.]}

149. [Durrant (J.H.).

Io Fune I 897 .

"The genera were assumed to be entirely imaginary and homonymy to be neglected.']

150. Grote (A. R.).

25 May I 897.

"The example cited makes it quite plain that Heterognomon was the first restriction of Tortrix (Jones) and that thenceforth the type of Tortrix became atrana, by exhaustion and after viridana was taken out as the type of Heterognomon. It matters not which species was cited first by Jones. What matters is: which species was first taken out by subsequent action; the residue falls to the original author. Pandemis is thus a synonym of Tortrix (Jones)."

151. WALSINGHAM (Lord).

Io Fune is97.

[Vide Wralsingham i42. Durrant.]

"I have asked the proposer of this conundrum to decide which solution of the problem is correct, and annex his reply.

'Those who specified atrana as the type of Tortrix, Jones, are right and those who cited viridana are wrong. I use the words right and wrong advisedly-not with reference to the methods by which the results were obtained, but with reference to the actual facts of the case. The replies only deal with the genus aftcr publication and do not pretend to decide which was the intentional type of Jones, being satisfied with a type obtained by historical or other methods. The assumption that the first species is the intentional type is certainly wrong in this instance, for the history of this genus was assumed to be as follows: in I 849 Jones described 
the genus Tortrix from the single species atrana, subsequently he received viridana and referred it to the genus Tortrix, thinking it congeneric with atrana. The genus was always monotypical so far as Jones was concerned, but he published it in a heterotypical form. Jones's reason for placing viridana first in the series was that he considered his new genus should be inserted between two known genera, the preceding one consisting of green species, while the following one contained black ones. This personal explanation (which in such cases is not usually forthcoming) tends to prove that there can be no real argument in favour of selecting the first species as the type, but as Jones did not himself state in print which was his type, subsequent authors were at liberty to fix the historical type, ignoring intentions which were not stated. In this instance the historical method has fixed as the type the species which was so regarded by "Jones " (alias John Hartley Durrant).'"

152. HaMPSON (Sir G. F.).

20 Fune r 897 .

[Vide Hampson I4I. Durrant.]

"It seems to me that the additional matter imported into the problem* as to the type of Tortrix and Pandemis has entirely altered the nature of the problem. I think we all took it to be a purely fictitious case as to which we had the whole of the available information given in the question. If there was any means of knowing that Jones described the genus Tortrix in 1849 from atrana and subsequently imported viridana into it, the former would of course be the type of the genus by my method of fixing it."

[* Vide Walsingham I5I. Durrant.]

153. [Durrant $(\mathcal{F} . H$.).

I Fuly i 898 .

The information given by 'Jones' (vide I5I) would not in the ordinary course of events be attainable. It was supplied too late to have any effect upon the action of his successors ; when he published his genus he had full opportunity for stating what was his type; this he neglected to do, and nomenclature could not be upset by his statement of the unpublished history of his genus; this assumed history was first made known when 'Jones' gave the information to Lord Walsingham (vide I $5 \mathrm{I}$ ).

The conundrum was drawn up for two reasons, first to ascertain how various entomologists would deal with a similar genus from Hübner's Verzcichniss; Jones, Smith and Robinson all represented Hubner (but of course the problem was simplified and slightly exaggerated), secondly it was given to demonstrate that the first species may sometimes be not the species from which the genus was described, and that therefore a hard and fast rule selecting the first species as the type rests on no sound basis. It may be the easiest way of choosing an exponent of the genus, but it can hardly be 
claimed that this process discovers the actual type from which the generic description was taken, and that the citation of another species by a subsequent author is to be considered erroneous and the first species substituted as the type. It should also be borne in mind that writers who were contemporaries of the original author, or who lived shortly after, are more likely to have known by actual information or by tradition what was the actual type-conception of a genus (or species) than are authors of a later date, and that therefore previous action should be accepted unless erroneous.]

\section{QUESTION IX.}

"In the event of there being any clear consensus of opinion on the above subjects by a majority of those to whom they are to be submitted, would you be willing to adopt their decision and abide by it?"

\section{Analysis of Replies.}

1. Hampson accepts consensus of opinion except that he will not give way upon the first species that agrees being considered the type.

2. Walsingtham accepts consensus so far as the decisions recognise the absolute and unalterable Law of Priority as governing ALL published work.

3. Meyrick accepts consensus in matters Lepidopterological if not conflicting with accepted principles-matters other than Lepidopterological must be settled by a general committee of Zoologists.

4. Kirby accepts consensus in official work.

5. Fernald would yield very much to obtain uniformity and fixity of nomenclature.

6. Smith accepts consensus on Lepidopterological questions (3, 4, 5, $7,8)$ : Nos. I, 2 and 6 miust be settled by usage of Zoologists.

7. Sculder makes no reply.

8. Snellen: publish the conclusions and leave the decision to other entomologists.

9. Staudinger says he has so short a time to live that whether or not he agrees with the majority seems to him as unimportant as ascertaining the type of a heterotypical genus.

10. Aurivillius accepts consensus, except that he will not give way on the adoption of the roth edition, and that a genus must be described. 
I1. Grote would not keep his own opinion a second longer than it satisfied him; no authority exists to bind present and future action; the rason of the matter will of itself be binding on all reasonably inclined.

I I have not yet quite recovered from the mental exhaustion consequent upon an attempt to ascertain the opinions on and to tabulate the replies to this question. I retain only one impression, each member is willing to accept the decision of the majority provided that he is in it. I must congratulate all the members of the Committee upon the very careful and guarded way in which they have answered this question.」 Durrant.

\section{REPLIES.}

154. HAMPSON (Sir G. F.).

I 2 Sept. I 896.

"I should be willing to accept and abide by any definite consensus of opinion on the above subjects of those to whom they are to be submitted, except in the matter of fixing types of genera, as I regard the fixity of the types of genera as an essential principle of Zoology."

[Vide Hampson i64. Durrant.]

155. WALSINGHAM (Lord).

"In the event of there being any clear consensus of opinion on the above subjects by a majority of those to whom they are to be submitted, I should be willing to adopt their decision so far as they recognise the absolute and unalterable Law of Priority as governing ALL published work."

\section{MEYRICK (E.).}

"I should be willing to adopt the decision of a majority of the Committee, whenever it did not conflict with principles adopted by the great majority of Zoologists. But there would be nothing gained by coming over to the opinion of a majority, if that majority of the Committee proved to be only an inconsiderable minority of the body of Zoologists. The convention known as the law of priority is presumably agreed to by us all. Three other conventions are here called in question, viz. ( $\mathrm{I})$ the date from which nomenclature is to begin, (2) the necessity of an attempt to define genera, and (3) the mode of arriving at generic types. If the consensus of the Committee is clear in desiring to modify any of these three conventions, I would agree to have the subject brought up again for discussion and settled by any authoritative general Committee of Zoologists, but I think it would serve no useful purpose to attempt such modification solely on our own account. In matters concerning Lepidopterists only, and wherever there is no obvious conflict of principle with the above conventions I should be ready to adopt the views of the majority." 
157. KIRBY (W. F.).

"In the case of a clear consensus of opinion, I should be willing to abide by it, at least in my official work, or in any work undertaken conjointly with others."

158. FerNald (C. H.).

"I very much desire uniformity and fixity in nomenclature, and would yield very much for the sake of securing this end."

159. Silth (J. B.).

"I would be willing, in the interests of a stable nomenclature, to agree to almost anything that secured general assent, provided, of course, it did not" [ $\mathrm{run}]$ "counter to the canons accepted by Zoologists in general. To be more specific, I am willing to abide by the decision of a majority on questions $3,4,5,7$ and 8 . No. 2 goes with No. I, which is settled in the United States in favor of the Ioth edition. No. 6 must also be settled by the usage of Zoologists."

160. SNellen (P. C. T.).

I 5 Fan. I 897 .

"Je crois qu'il serait bon de publier les points sur lesquels on serait parvenu à se mettre d'accord et de laisser la décision aux entomologistes."

161. Staudinger (O.).

5 March I 897.

"Ich bin ein alter Mann und habe, im besten Falle, nur noch kurze Zeit zu leben; ob ich daher einen Majoritätsbeschluss uiber die aufgestellten Fragen annehme oder nicht, scheint mir noch weit unwichtiger zu sein, als nach dem Type einer (heterotypical) Gattung zu forschen."

\section{Aurivillius (C.).}

"I think it impossible to reject the loth edition of Syst. Nat. or to accept generic names not accompanied by a description. Such names are, as far as I know, universally rejected in other classes of insects (e.g. Dejean's names of Coleoptera) and in other classes of animals. As to the other questions, I am willing to yield to the opinions of the majority of lepidopterists."

163. Grote (A. R.).

25 May I 897.

"Nomenclature is a matter of letters, and its value depends upon its identification with the object. As between conflicting names the Rule of Priority is the sole absolute guide. But as our conceptions of the object and its relations to other similar objects vary, these subjective opinions will prevent an absolute fixity in nomenclature. What seems possible of attainment, however, is the 
designation of the type-species (by following historical methods of research in literature) of every generic title. By using a generic title always in connection with the structural features of its typespecies, there is no doubt that a greater degree of accuracy will be attained. As the matter stands it is often impossible to follow statements in articles where generic names alone are used, for the reason that it is not apparent in what sense the titles are employed. The progress in lepidopterology may be roughly characterized as one in an increasing acquaintance with details. More than in any other department of entomology there was less attention paid to these in the Lepidoptera, to which many causes contributed, and the result has been that the generic nomenclature has been neglected. So far as my very modest powers are concerned, I would be glad to devote them in any way to assist the growth of a uniform system of nomenclature and to co-operate with any movement in that direction.

P.S. In the case of family or tribal names (names having a generic title as the unit), they are equally dependent upon the Rule of Priority, subject to the condition that they are derived from a living genus. It is not allowable, for instance, to have a Family Noctuidae without a living genus Noctua. If the genus Noctua disappears from any cause and its ascertained type receives a new or different generic title, that title inherits all the rights of the original and discarded Noctua, and among them the right to form all combinations for which Noctua was employed. The reason for this is, that all names must have an actual basis in a structure to which reference can be made, and that in practice the individual must exhibit all characters which are reflected in names."

[Vide Grote i 65. Durrant.]

164. HAMPSON (Sir G. F.).

[Vide Hampson 154. Durrant.]

27 May 1897.

"I am afraid it is clearly impossible for Lepidopterists to arrive at a consensus of opinion on nomenclature for the present, but there is little doubt that it will in time be arrived at, and the best way to help that is to keep to safe ground in the treatment of the subject."

165. Grote (A. R.).

Io Nov. I 897 .

[Vide Grote 163. Durrant.]

"Question 9 seems to me largely superfluous. What is aimed at is a consensus of opinion. No one is safe against a change of mind; I would not keep my own opinion a second longer than it satisfied me. I do not think any authority exists to bind present and future action, much as I should like a uniform nomenclature. But the discussion will bring out the reason of the matter and this we all want to get at as reasonable beings. This reason will appear 
gradually and will be of itself binding on all persons now and hereafter, who are reasonably inclined."

\section{QUESTION X.}

"Can any useful object be served by the publication of the opinions elicited, and will you each consent to the publication of what you have written?"

Analysis of Replies.

\section{Advocating publication.}

I Snellen, 2 Aurivillius, 3 Walsingham, 4 Kirby, 5 Fernald, 6 Smith.

7 Hampson, 8 Meyrick, (and 9 Grote do not object).

Staudinger and Scudder make no reply. Durrant.

\section{REPLIES.}

166. Siellen (P. C. T.).

I 5 Fan. I 897.

"Je crois qu'il serait bon de publier les points sur lesquels on serait parvenu à se mettre d'accord et de laisser la décision aux entomologistes."

[Vide Snellen 174. Durrant.]

167. Aurivillius (C.).

"I hope these answers may be in any way published and discussed by lepidopterists, or by the leading entomological societies."

168. HaMpson (Sir G. F.). 27 May I 897.

"I should wish entirely to be guided by the wishes of those who have so kindly given me their opinions, but personally think that the results arrived at are hardly definite enough to merit publication."

169. WaLsingham (Lord).

Io June I 897.

"Heer Snellen and Prof. Aurivillius had anticipated this new question by advocating the publication of the replies. I agree with them and am willing that my replies may be published." 
170. MEYRICK (E.).

18 July I 897.

"I have no objection to the publication of these answers; it could hardly serve much purpose, however, unless intended to give rise to a general discussion and pronouncement."

171. KIRBY (W, F.). 20 Fuly I 897.

"I have no objection to my replies being printed, and think that the publication of the whole series of answers would be useful and interesting. I have thought it better to abstain from making any alterations in my original replies, though certain points referred to have been cleared up by portions of the correspondence which I had not seen when writing."

172. Fernald (C. H.).

"I have nothing further to add, only that I think it would be well to publish the opinions of these gentlemen on the proposed questions."

\section{Sirtu (J. B.).}

"I think the replies should be published. I have nothing to add to what I have written, other than thanks for the careful analysis prepared by Lord Walsingham*, which shows that on most of the more important points there can be obtained practical agreement. I believe the publication would serve the useful purpose of bringing the evidence relied upon before the younger students."

174. SNellen (P. C. T.).

30 October 1897.

[Vide Snellen r66. Durrant.]

"Je regrette de ne pouvoir apporter des données nouvelles qui éclairciraient davantage les points en litige et je prends la liberté de maintenir mes opinions, énoncées plus haut. Néanmoins, je crois que la publication de toutes les réponses données, ainsi que du résumé que Lord Walsingham* a bien voulu faire, serait d'une grande utilité."

175. GROTE (A. R.). Io Nov. I 897 .

"As to the publication you" [i.e. Sir George Hampson-Durrant] "will be the best judge of whether it will serve your purposes, and I can only say you are very welcome to make any use of what I have written, from printer's copy to the waste-paper basket."

* “Mr J. Hartley Durrant” vide Walsingham, ante page 278 . Durrant. 


\section{APPENDIX B.}

UEBER DIE ENTWICKELUNG

\section{DER PLACENTA VON TARSIUS UND TUPAJA}

NEBST

BEMERKUNGEN UEBER DEREN BEDEUTUNG ALS HAEMATOPOIETISCHE ORGANE

VON

Prof. A. A. W. HUBRECHT. 

UEBER DIE ENTWICKELUNG DER PLACENTA VON TARSIUS UND TUPAJA, NEIBST BEMERKUNGEN UEBER DEREN BEDEUTUNG ALS HAEMATOPOIETISCHE ORGANE.

VON

\section{Prof. A. A. W. Hubrecht.}

Im Laufe einer mehrjährigen, bereits im Jahre I 885 angefangenen Untersuchung der frühesten Entwickelungsstadien verschiedener Säugethiergattungen, bin ich öfters durch meine Präparate auf die Frage gestossen: Findet Biutbildung in der Säugethierplacenta statt? Ich wusste, dass diese Frage bereits von mehreren Seiten bejaht worden war und dass I880 Masquelin und Swaen (80, p. 43) für das Kaninchen einen solchen Prozess behauptet haben, während in I 883 und I 888 Frommel $(88$, S. 21 ) das nämliche für die Maus und die Fledermaus festgestellt zu haben glaubte. Dennoch konnte ich mich durch die Beweisführung der erwähnten Autoren nicht für überzeugt halten: wo ich Gelegenheit hatte eigene Präparate zu vergleichen, kam ich zu entgegengesetzten Folgerungen und musste die gegebene Darstellung als eine falsche betrachten. So schloss ich mich denjenigell an, die, wie Duval (92, p. 400), Masius (89, p. I6), Nolf (96, p. 624), Maximow (97, p. 84), Blutbildung in der Placenta leugneten. Erinaceus, Sorex; Mus und Talpa, deren Placentation ich in Detail zu verfolgen Gelegenheit hatte, liessen wohl ab und zu die Frage wieder auftauchen, aber lieferten mir nie tadellose Bilder von unleugbarer Haematopoiese.

Die Sachlage änderte sich, als sich in den letzten fünf Jahren meine Sammlung von Durchschnitten junger Placenten von Tarsius spectrum und Tupaja javanica rasch vermehrte. Hier fanden sich Verhältnisse von ungleich grösserer Klarheit vor. Mütterliche und embryonale Elemente liessen ihre gegenseitige Betheiligung an der Placentabildung mit gewünschter Schärfe nachspüren und zu gleicher Zeit liess sich die Schlussfolgerung nicht von der Hand weisen, dass kernlose rothe Blutzellen in der Placenta in bestimmter Weise gebildet und dem mütterlichen Blutstrom, welcher auch in frühesten Stadien die Placentaranlage tränkt, einverleibt werden.

Diese Schlussfolgerung zu begründen, ehe ich sie der Oeffentlichheit zu übergeben wagte, bin ich sodann bestrebt gewesen. Dass 
dennoch mein Versuch, um in den folgenden Zeilen einen Beitrag zur Blutbildungsfrage bei den Säugethieren zu liefern, sich innerhalb verhältnissmässig enger Schranken bewegt, und dass ich nicht die gewaltige Literatur, welche über Blutbildung überhaupt vorliegt, in ihrer Vollständigkeit kritisch vergleichen und berücksichtigen wollte, möge seine Entschuldigung darin finden, dass die Blutbildungsfrage bei mir während des Durchsehens der eigenen Präparate incidentell auftauchte und dass ich meinen zu Anfang in anderer Richtung geplanten embryologischen Untersuchungen nicht länger Aufschub leisten möchte.

Die hämatopoietischen Prozesse in der Placenta sind nur dann $\mathrm{zu}$ verstehen und deren Beschreibung nur dann klar zu fassen, wenn über die Placentation selber genaue Daten vorliegen und eine zusammenhängende Reihe von Beobachtungen über die in rascher Veränderung auf einander folgenden Wachsthumsstadien der Placenta zur Verfügung steht. Solche besitzen wir vorläufig nur von Nagethieren und Raubthieren (Duval, Strahl, Masius, Sedgwick Minot, Fleischmann, Heinricius, Lüsebrink u. A.), von einigen Chiroptera (E. van Beneden, Nolf, Frommel) und von den drei Insectivorengattungen Talpa, Sorex und Erinaceus (Strahl, Vernhout, Hubrecht). Da bei allen diesen Säugethieren Blutbildung in der Placenta sich bis jetzt nicht mit genügender Sicherheit hat nachweisen lassen, so muss selbstverständlich eine ausführliche Schilderung der Placentation bei Tarsius, auf welche ich meine Schlussfolgerung basire, vorangehen. Ich werde nebenbei auch die Placentation bei Tupaja schildern, weil bei dieser Insectivorengattung ebenfalls Verhältnisse vorliegen, die auf eine im Wesentlichen ganz mit der von Tarsius vergleichbare Blutbildung in der Placenta schliessen lassen.

Die Arbeit zerfällt somit in die folgenden Abschnitten :

I. Die Bildung der Placenta bei Tarsins . . . . S. 347

II. Die Bildung der Placenta bei Tupaja. . . . . S. $35 j$

III. Die Entstehung a'on rothcn, kernlosen Blutkörperchen bei gewissen Säugethieren

\$. Die embryonalen Blutzellen der Sängethiere in ihrem Verhältniss zu den Blutkörperchen der Eracachsencn

$\$ 2 . \quad$ Blutbildung in der Placenta . . . . . S. 366

(a) bei Tarsius . . . . . . S. 368

(b) bei Tupaja . . . . . . . S. 372

IV. Vergleichung der bei Tarsius und Tupaja gewonnenen Resultate mit bei anderen Sängethieren bcobachteten Thatsachen

V. Vergleichung der erhaltenen Resultate mit dor Literatur iiber die Bildung von Blutkörperchen . . . . S. 382 


\section{Die Bildung der Placenta bei Tarsius.}

Die reife Placenta von Tarsius, welche von mir im $36 \mathrm{ldd}$. des Quartcrly Fourn. of Micr. Science beschrieben und abgebildet (Pl. Io, fig. I 8--2I) wurde, liegt immer gegen die mesometrale Mittellinie des trächtigen Uterushornes angeheftet und zwar dem Oviducte genähert, indem der Kopf des Foetus der Vagina zugewendet liegt. Sie ist mit einem in das Uteruslumen vorspringenden Knopf zu vergleichen, der vermittelst eines kurzen ungefähr ein Drittel des Placentardiameters messenden Stieles mit der Uteruswand verbunden ist (Taf. 4, Fig. 27).

In den allerfrühesten Entwickelungsstadien, wo die Keimblase noch in den Oviducten oder noch unverklebt in der Uterushöhle verweilt, finden in der Mucosa des Uterus bestimmte locale Veränderungen statt, welche diese Anheftung vorbereiten und welche wir mesometral-nie an der entgegengesetzten Seite-auftreten sehen. Diese Veränderungen sind locale Verdichtungen des subepithelialen, interglandulären Bindegewebes, und zwar in der Nähe der Oberfläche. Die Zellen stehen hier dichter zusammengedrängt, das ganze zeichnet sich nach der Tinction in toto als eine dunkler gefärbte Stelle (Taf. I2, Fig. 69). Es ist zu gleicher Zeit eine ausgiebigere Sprossung feiner Blutgefässe an diesen Stellen wahrnehmbar. Solche Stellen treffen wir mehrere in dem Uterushorn, wo sich die Keimblase festheften wird.

Es scheint grössentheils dem Zufall iiberlassen, an welchen von diesen zahlreichen, ad hoc vorbereiteten Stellen die Keimblase sich zunächst einnisten oder verkleben wird. Das geschieht jedoch immer nur an cinc zugleich, wie diese auch mit der Grösse der Keimblase gleichen Schritt hält. Nur wird, wie wir weiter sehen werden, nachher noch recht oft eine zweite und dritte von diesen vorbereiteten Stellen unter steigernden Proliferirungserscheinungen in der Placentation mit einbezogen (Taf. 7, Fig. 58, Taf. 9, Fig. 63), dann muss aber die Keimblase bereits in dem Maasse an Grösse zugenommen haben, dass die nächstfolgende mütterliche, durch diese Proliferation gekennzeichnete, potentielle Anheftungsstelle im Bereiche der dem Keimschild gegenüberliegende Wucherungsfläche der Keimblase geräth.

Vorläufig wenden wir uns zur Beobachtung desjenigen, was sich an dem ersterwählten Anheftungsfleck abspielt. Neben der ebenerwähnten Verdichtung des subepithelialen Bindegewebes, erkannten wir an dieser Stelle Neubildung feiner Capillargefässe in welchen sich auch rothe Blutzellen auffinden lassen, welche ron grösseren, zuführenden Gefässen dorthin geleitet werden. Die beschriebenen Veränderungen sind also dieselben, welche sich bei einer localen Congestion mit vasifactiven Wucherungserscheinungen vorthun.

$\mathrm{Zu}$ gleicher Zeit erleiden die benachbarten Drüsenparticn kennzeichnende Veränderungen. Die in der Nähe des uterinen 
Epithels gelagerten Drüsenhälse-nicht die tiefer gelegenen $\mathrm{Ab}-$ schnitte derselben Drüsen-erweitern sich (Taf. 7 , Fig. $55 \mathrm{D}^{1}$ und $D^{2}$ ); die Drüsenlumina haben auf Längs- und auf Querschnitten ein aufgeblähtes Ansehen. Anfänglich wird das Drüsenepithel dabei nicht verändert, aber bald sehen wir dieses Epithel recht characteristische Veränderungen erleiden. Die Kerne werden grösser und unregelmässig (Fig. $56 \mathrm{D}^{2}$ und $\mathrm{D}^{3}$, Fig. 69 und 70 ), die Zellsubstanz fliesst zusammen und verdichtet sich zu einer feinkörnigen Grundmasse, die schliesslich das ganze, bedeutend erweiterte Lumen der Drüse ausfüllt, und in welche Kernreste, die immer weniger deutlich werden, eingelagert erscheinen. Die respectiven Drüsengrenzen sind dann nur noch durch feine Bindegewebszüge erkennbar (Fig. 56). Zu und abführende Gefässe sowie Gefässwucherungen lassen sich in diesem die Drüsenresten trennenden Bindegewebe wahrnehmen.

Der eben beschriebene Prozess, der oberflächlich angefangen hat, setzt sich allmählich auch in die Tiefe fort. Während die oberflächlich gelegenen Drüsenpartien bereits in eine weit vorgeschrittene Degenerationsphase eingetreten sind, befinden sich die tieferen Abschnitte noch erst in dem aufgeblähten Zustande, und sind die allertiefsten blinden Drüsenenden noch nicht mitbetheiligt (Fig. 56). Schliesslich gehen aber auch diese in ähnlicher Weise zu Grunde (Fig. 59, 60, 62) und da bei der Vergrösserung der Placentarstrecke immer neue Drüsenbezirke mit einbezogen werden, die alle, sobald sie an der Reihe kommen, dieselben Umbildungsstadien durchmachen, so ist der geschilderte Prozess ein solcher, der für alle im späteren Placentarbezirk sich befindenden Drüsen seine Geltung hat. Es möge hier gleich die Hypothese von mir ausgesprochen werden, dass diese zahlreichen, unter so eigenthümlichen Erscheinungen zu Grunde gehenden Drüsen, die sich während der activen Placentationsprozesse so passiv verhalten, dennoch eine wichtige Rolle spielen. Und zwar diese, um dem in ihrer Mitte eingeschlossenen Bezirk, welcher die gleich näher zubeschriebenden, fast kugeligen Trophospongia darstellt, als schützende Hülle, oder, sit venia verbo, als eventuelle Blutextravasate stemmende Verbandmasse zu dienen. Die Congestion nach der Trophospongia, sowie nach der ihr aufliegenden embryonalen Trophoblastwucherung, ist nämlich auch in diesen recht frühen Stadien eine so bedeutende (vergl. Cap. III. 2, A), dass Blutextravasate nicht zu vermeiden sind. Allgemein finden wir nun rothe Blutkörperchen in verschiedenen Abschnitten der in oben beschriebener Weise veränderten Drüsen verirrt und aufgespeichert ${ }^{1}$ (Fig. 6 I, 63 und Fig. 70 links oben). Die zerflossenen Drüsen haben da keine weitere Rolle zu spielen; ebensowenig habe ich eine Andeutung finden können, dass die Driisenreste zu blutführenden

\footnotetext{
] Auch Masquelin und Swaen (80) beschreiben beim Kaninchen ähnliche mit Blutkörperchen gefuillte. Drüsenreste, die vielleicht in ähnlichem Lichte, wie wir es hier bei Tarsius gethan, betrachtet werden diirfen.
} 
Lacunen sich umbildeten. Ich nehme an, dass sie also als Tamponirungsmaterial die trophospongialen und trophoblastischen Wucherungen während ihrer friihen Bildungsstadien umhüllen, und damit dem so verwickelten Prozess der Ausbildung des specifischen Placentarkreislaufs einen ganz bedeutenden Vorschub leisten.

Ist einmal dieser Kreislauf zu Stande gekommen und handelt es sich in den späteren Stadien der Schwangerschaft nur noch um bedeutende Vergrösserung der Trophoblastwucherung, sowie der sich in ihr verzweigenden Mesodermzotten, so sind die Drüsentampons nicht weiter thätig, und finden wir von denselben an der Anheftungsstelle der reiferen Placenta nur kümmerliche Reste.

Wir haben somit mit den Drüsen abgethan, und wenden uns jetzt zu dem Uterinepithel an der Stelle, wo eben die Keimblase mit der mütterlichen Mucosa verklebt.

Wie bekannt, besteht in vielen Fällen (Kaninchen z. B.) noch ein lebhafter Streit über die Frage ob das Uterinepithel zu Grunde geht oder sich an der Placentation activ betheiligt. Voreilige Verallgemeinerungen haben die Meinungsverschiedenheit in vielen Fällen in Verwirrung und Missverständniss entarten lassen. Ich selbst habe beim Igel Epithelschwund, bei der Spitzmaus Epithelwucherung an der Placentationsfläche beschrieben $(89,94)$, aber auch im letzteren Falle die endgültige Vernichtung des Epithels, sobald das wucherende Trophoblastgewebe damit in Berührung kam, constatirt.

Bei Tarsius geht das Uterinepithel an der Anheftungsstelle der Keimblase gleich vom Anfang an zu Grunde und tritt die IVucherung der äusseren Trophoblastschicht der Keimblase, welche bald nachher mit der mütterlichen Trophospongia sich in engster Verbindung setzt, an der Stelle des dort zerstörten (anfänglich z. Th. aufgehobenen, weil von Trophoblastzellen untergrabenen) mütterlichen Uterinepithels. Auch in späteren Stadien lässt sich am Rande der Placenta die Grenzstrecke zwischen Uterinepithel und Trophoblastwucherung noch sehr oft deutlich nachweisen. In mehreren Fällen beobachtete ich, dass das Uterinepithel jenseits dieser Grenze (Fig. 56, 58, 63) seine normale Palisadenform behalten hatte - jedoch unter Degeneration der Kerne - in anderen hingegen, dass es bedeutend abgeplattet war (Fig. 6o). Hier müssen verschiedene Einflüsse im Spiele gewesen sein : Verallgemeinerung ist jedenfalls nicht erwünscht.

Wir kommen jetzt zur Beschreibung der weiteren Gewebsänderungen, welche die oben zu allererst angedeutete mütterliche Bindegewebs- und Blutgefässwucherung erleidet. Diese Gegend wird alsbald nach allen Seiten eingeschlossen und zwar nach oben von der festgehefteten Keimblase und der Trophoblastwucherung, nach unten und rings herum seitlich von den geschilderten, in Umwandlung begriffenen Uterindrüsen. Somit erhält dieser eigenthiimliche Proliferationsbezirk eine nahezu kugelige Gestalt: wenn man die Schnittserien durchnimmt, so zeigt sich dass ein oder 
mehrere mächtigere Gefässzüge, die ebenfalls durch Wucherung bedeutende Wandverdickung erlitten haben von der Muscularis zu der Kugel hinziehen: es sind dies die Hauptbahnen für die Blutzufuhr zu den Placentargeweben: sie treten an der der Keimblase gegenuberliegenden Seite mit der Trophospongia in Verbindung (Fig. I 5, 18, 2 I, 57, 59, 62). Den Namen Trophospongia werde ich weiterhin für diese specifische mütterliche Wucherung gebrauchen : es wurde der Name bereits I 888 von mir für den Igel vorgeschlagen $(88,89)$. Seitdem habe ich mich überzeugen können, dass er fuir placentale Säugethiere recht allgemein Anwendung finden kann, wenn auch die mit diesem Namen angedeutete mütterliche Gewebswucherung recht zahlreiche specifische Verschiedenheiten zeigt ${ }^{1}$.

Die Trophospongia hat in friihen Stadien ein ganz eigenthümliches Aussehen. Eine genaue Vergleichung der stärker vergrösserten Figuren 69 und 70 mit den schwächer vergrösserten Figuren 56 bis 63 soll uns in dieses sich histologisch so ganz eigenthümlich verhaltende Gewebe näher einführen. Anfänglich stehen deutliche und zahlreiche Kerne dichtgedrängt in einer körnigen, plasmareichen Grundmasse, in welcher Zellgrenzen nicht allerwege erhalten sind (Fig. 70). Ganz kennzeichnend für diese Region ist das Auftreten eines eigenthümlichen, adenoiden Gerüstwerkes, welches sich in dieser Grundmasse absetzt als Product des Zellplasmas und das verschiedene Kerngebiete wabenartig trennt. Es lässt sich mit einigen Tinctionsmitteln färben (Fig. I00, Pl. I5), bleibt aber den verschiedenen Carminfarben gegenüber blass oder schwach gelblich. In Fig. 57-59 und 62 ist es bei schwacher Vergrösserung sehr evident. In Fig. 62 und 6.3 (die zwei seitlichen accessorischen Trophospongialwucherungen $T a_{1}$ und $T a_{2}$ ) sieht man wie beim weiteren Wachsthum die Kerne verhältnissmässig weniger zahlreich werden: es verschwinden diese in einer Weise, die in Fig. 7 I näher ersichtlich ist und auf deren sonstiger Bedeutung in Cap. III. \$2 näher eingegangen werden wird. Bald darauf findet eine Invasion seitens der anfänglich der Trophospongia auflagernden Trophoblastzellen statt, wobei es aber zu gleicher Zeit nicht zu leugnen ist, dass Trophospongiazellen, die an Ort und

1 Es deckt sich der später von Nolf (95) für die Fledermäuse angewandte Name Paraplacenta fast ganz mit der älteren Bezeichnung Trophospongia, welche ich für den Igel vorschlug. Nur liesse sich Nolf's "couche épithéliale " ausserhalb der Paraplacenta auch noch wohl mit zur Trophospongia rechnen. Da, wie wir weiter unten sehen werden, auch bei Tupaja eine so eminent deutliche Trophospongia auftritt und da diese Bildung bei Igel, Tarsius, Tupaja und Vespertilio ibereinstimmend dadurch gekennzeichnet ist, dass sie das Product einer muitterlichen vasifactiven Proliferation ist, die die Zufuhr müitterlichen Blutes zur Placenta leitet und beherrscht, so muss Gewicht darauf gelegt werden schon jetzt diese Homologie anzuerkennen. In allen obenerwähnten Fällen bildet die Trophospongia, in der vor dem Partus stehenden Placenta, eine sehr unbedeutend gewordene und zerfetzte Deckplatte oder Stiel der fertigen Nachgeburt. Ich beharre nicht bei einem vor kurzem ausgesprochenen Vorhaben (98) um den Namen Paraplacenta und Ektoplacenta von Nolf und Duval zu adoptiren, weil diese Namen zu leicht Veranlassung geben können, um die falsche Vorstellungen einer Placenta foetalis und Placenta materna fortbestehen zu lassen. 
Stelle mehrkernig werden, den wuchernden Trophoblastzellen so sehr ähnlich sehen können, dass eine scharfe Unterscheidung der Gewebselemente nach ihrer Herkunft in dem Stadium der Fig. 63 oft sehr schwer ist. Embryonale und mütterliche Elemente vermischen sich hier zur Bildung eines mütterlichen blutführenden Lakunensystems und nehmen dabei einen so sehr übereinstimmenden histologischen Charakter an, dass die Frage, was als embryonaler, was als mütterlicher Bestandtheil aufgefasst werden muss, nur auf mehr indirectem Wege Beantwortung finden kann. Etwas erleichtert wird diese Frage, sobald der in Fig. 64 ersichtliche Fortschritt deutlich hervortritt, d. l. sobald die Trophoblastwucherung durch weiteres Dickenwachsthum sich über das Niveau der mütterlichen Mucosa zu erheben anfängt (vergl. Fig. 23 und Folge). Es ist von diesem Moment an nicht zweifelhaft, dass der Trophoblast kräftig weiterwächst, während die Trophospongia einer partiellen Rüickbildung und Aufösung anheimfällt. Diejenige Bezirke, welche noch unzweifelhaft der Trophospongia angehören und die sich um das grosse zuführende Blutgefäss (Taf. 4, Fig. I 5-27) herumgruppiren und als eine Kittsubstanz mütterliche Gefässe und trophoblastische Lakunen in Verbindung setzen, zeigen ein abweichendes (äusserst chromophiles) Verhältniss Tinctionsmitteln gegenüber, und werden in allen untersuchten Placenten an diesem Charakter, der auch in den Fig. 64, 66 6,67 angegeben ist, wiedererkannt. Dahingegen kommt der Trophoblast bedeutend ins Uebergewicht und eine Vergleichung der linken Placentarecke der Fig. 63,64 und 67 wird den Umfang und die Bedeutung des hier geschilderten Vorganges besser verständlich machen, als eine lange Beschreibung.

Ist also in späteren Placentationsstadien der Trophoblast leichter wieder zu erkennen, als in jenen Zwischenstadien, so gilt das nämliche für die Anfangsstadien.

Von den auf die obere convexe Fläche der Trophospongia lagernden, bedeutend massiveren, gross- und mehrkernigen Zellen der Trophoblastwucherung lässt sich die Herkunft aus embryonalen Gewebsschichten mit ebenso grosser Leichtigkeit feststellen, wie die Herkunft des trophospongialen Wabengewebes aus einer frühen mütterlichen Proliferation ausser Frage war. Die Unterscheidung beiderlei Elemente wird eben erst schwieriger, sobald wir den oben erwähnten Stadien der Fig. 62 und 63 genähert sind.

Verwechselung wird auch dadurch noch erleichtert, dass nicht, wie z. B. bei Tupaja, Vespertilio und anderen Monodelphia, in die Trophospongia von einem eigenen Endothel bekleidete Kapillargefässe verlaufen, sondern dass, wie wir das auch beim Igel finden, sowohl die Trophospongia als der Trophoblast bereits durch Lakunencirculation gekennzeichnet sind.

Die kugelige Form der Trophospongia (in Fig. I 5-2 I abgebildet) ändert sich somit allmählich. Sie wird mehr schüsselförmig und trägt die an Umfang zunehmende Trophoblastwucherung. 
Dabei treten ausserhalb der Trophospongia neue Umwandlungsprozesse in den Vordergrund, welche demselben Ziele: die Herstellung der günstigsten Blutzufuhrverhältnisse zur anwachsenden Placenta, nachstreben. Es hat sich nämlich von dem Stadium der Fig. 57 an eine neue Gewebswucherung eingeleitet, die in dem Stadium der Fig. 56 noch kaum angedeutet war und zwar in dem gefässführenden Bindegewebe zwischen den modificirten Drüsen, welches die Trophospongia allseitig umgiebt. Die Gefässıände in diesem Gebiete treten in lebhafteste Zellvermehrung, und bereits in Fig. 57 sehen wir wie zwischen den Drüsen, anstatt dünne Bindegewebszüge, massivere Gewebsstränge verlaufen, welche in den folgenden Stadien der Fig. 58-66 immer mächtiger werden und in dem Stadium der Fig. 64, so zu sagen, ein Gewebskissen bilden, auf welches jetzt sowohl Trophospongia, als Trophoblast ruhen, wie vorher (im Stad. der Fig. 56) die Trophoblastwucherung es auf die Trophospongia that. Das hier in starker Vermehrung getretene Gewebe der Gefässwände ist sowohl in seiner histologischen Bedeutung, als in dem Mutterboden, aus welchem es entspringt, mit der Trophospongia in eine Linie zu setzen. Alle diese Modificationen, welche diese ganze Region erleidet und welche sich in der Trophospongia und ihrer directen Umgebung abspielen, sind schliesslich darauf abgesehen, um die passende Blutzufuhr zu den Trophoblastlakunen zu besorgen. Bei der reifen Placenta finden wir diese Zufuhr in einige grosse Gefässlumina concentrirt (siehe Hubrecht, 94, 2, Taf. IO, Fig. I 8).

In den hier behandelten Stadien bis zu demjenigen von Fig. 64 ist ein Uebergang von mütterlichem Blut in die Placenta gewiss an zahlreichen Stellen der concaven Aussenfläche der Trophospongia möglich. Dennoch sind auch die späteren Hauptstämme bereits in den frühesten Anlagen deutlich erkennbar und z. B. in den Fig. 56-59, 62 und 68 unleugbar vorhanden. In allen diesen Figuren, am besten wohl in Fig. 62, bemerken wir wie das Gewebe dieses Hauptblutgefässes in nichts, als nur in seinem mächtigeren Umfang als Gewebsstrang, sich von den umliegenden wucherenden Gefässwänden unterscheidet.

Der hier in Umrissen skizzirte Vascularisationsprozess der frühesten Placentaranlage spielt sich $a b$ bevor noch von der Anwesenheit eines einzigen embryonalen Blutgefässes in der Placenta die Rede ist. Wir sehen aus der Fig. 64 wie die späteren Mesoblastzotten hier erst in ihrer allerersten Anlage als wellige Verdickungen der Mesoblastschicht, die sich über den Trophoblast ausbreitet und deren allmähliche Verdickung sich in den Fig. 67 und 68 leicht verfolgen lässt, erkennbar sind. Und ein Vergleich mit den Fig. 23-27 macht es deutlich-wie dies ebenfalls aus einer Reihe anderer Wahrnehmungen bei vielen anderen Säugethieren (Igel, Spitzmaus, Hubrecht 89 S. 306, 94, I, S. 5 I4) hervorgeht-dass die auf den eben beschriebenen Stadien folgende Bildung der wirksamen Placenta, in welche es zum Austausche 
zwischen mütterlichem und foetalem Blute kommen wird, nicht etwa beruht auf einem Durchdringen dieser Mesodermzotten in der Trophoblastwucherung, sondern auf einem centripetalen Ausspinnen, wobei die Zotten, sammt einer diese umhüllenden Trophoblastschicht mit reichem Lakunennetz, immer länger werden und das Dickenwachsthum der Placenta ganz auf ihre Rechnung nehmen.

Vordem wir aber diese Reifungserscheinungen der Placenta weiter betrachten, müssen wir den Antheil, welchen die Trophoblastwucherung an dem Zustandekommen der bereits geschilderten nimmt, noch genauer präcisiren. In dem Stadium der Fig. 56 besitzt die locale Wucherung des embryonalen Trophoblastes (welcher dem Keimschilde in diesem Stadium nicht diametral gegenüber, sondern dem Primitifstreifenende näher gelegen ist) den Charakter von etwas vergrösserten Zellen, welche denjenigen der Trophospongia sehr ähnlich sehen und, wie bereits oben betont, das mütterliche Epithelium an dieser Stelle verdrängen (vergl. Fig. 70). Recht bald nehmen die Zellen dieser Trophoblastwucherung sowie auch besonders ihre Kerne an Grösse bedeutend zu und es wird sodann der Unterschied zwischen Trophoblast- und Trophospongia-Gewebe zeitweilig recht deutlich (Fig. 57-6I). Die wucherenden. Trophoblastzellen verbreiten sich dabei nicht ausschliesslich auf die trophospongiale Wucherung, sondern greifen auch seitlich über diese hinweg, wobei entweder eine zweite (Fig. 58) oder sogar dritte (Fig. 63) als Trophospongia sich vorbereitende Stelle in Mitleidenschaft gezogen oder auch eine noch nicht zu Trophospongia ausgebildete Stelle der Mucosa mit überdeckt wird (Fig. 60 und 6I). Im letzteren Falle ist jedoch an der betreffenden Stelle die oben erwähnte Wucherung des gefässbildenden Bindegewebes, welches die dort degenerirenden Drüsen verdrängt, bereits weit vorgeschritten und bildet ebenso ein Anheftungspolster für die übergreifende und ihrerseits Blutlakunen zur Entwickelung bringende Trophoblastwucherung. Die Kerne der Trophoblastzellen verlieren dabei ihren einfachen Charakter, und während diejenige Kerne, welche dem Mesoblast der Keimblase (mes.) noch am nächsten liegen, den ursprünglichen Charakter einfach vergrösserter Kerne beibehalten, werden die gegen die Trophospongia vordringenden $z$. Th. bald $z u$ Riesenkernen, welche entweder gelappt aussehen oder thatsächlich proliferiren und in kleinere Kernabschnitte zerfallen. Daraus gehen sodann Megalokaryocyten hervor, welche ihrerseits während der Lakunenbildung in der Trophoblastwucherung sowohl destructiven, als constructiven Prozessen anheimfallen, die in Cap. III. $\$ 2$ näher geschildert werden sollen.

Aus den Fig. 62 und $\sigma_{3}$ geht mit grosser Deutlichkeit hervor, dass ähnliche Mlegalokaryocyten nicht nur im Gebiete des Trophoblastes, sondern auch in jenem der Trophospongia, auftreten, wenn das Wachsthum der Placenta fortschreitet. Es kann dabei gedacht werden an einem Vordringen trophoblastischer Riesenzellen 
innerhalb der sich lockernden Trophospongia, welche z. Th. den oben bereits beschiebenen adenoiden Charakter besitzt, aber auch an Entstehung neuer Megalokaryocyten innerhalb der letzteren gewucherten mütterlichen Elemente. Beides findet, soweit ich mich davon habe überzeugen können, statt.

In Fig. 62-64 sind also Megalokaryocyten embryonaler und mütterlicher Herkunft in unentwirrbarer Weise durcheinander gemischt. Es unterliegt wohl keinem Zweifel, dass dadurch die Herstellung einer innigen Verbindung der trophoblastischen und trophospongialen Lakunen bedeutend erleichtert wird. Ohne Widerspruch können wir jedoch behaupten, dass diejenige Megalokaryocyten, welche den embryonalen Mesoblast in allen diesen Figuren unmittelbar auflagern und sich in dessen Nähe befinden, ausschliesslich embryonaler (trophoblastischer) Herkunft sind.

Dieser letztere, ausschliesslich trophoblastische Abschnitt, der in Rede stehenden Gewebmaasse, findet weiterhin eine hochwichtige Verwendung und zwar in der schichtenweise Umkleidung des sich verdickenden und hier allmählich zottenbildenden und gefässführenden embryonalen Mesoblastes.

Die Figuren 64,67 und 68 zeigen zur Genüge, wie bei der weiteren Ausbildung der Mesoblastzotten diese einschichtige, deutliche Kerne führende Trophoblastumkleidung allen Verzweigungen, Auswüchsen und Theilungsproducten der Zotten folgt und sie umhüllt, kurz, wie von dem Moment an, wo der Trophoblast seine Anheftung an und Verklebung mit der Trophospongia zu Stande gebracht hat und seine Ausspinnung um die centripetal in die Länge wachsenden Zotten anfängt, die jetzt bedeutend an Dicke zunehmende Placenta ausschliesslich aus embryonalem Gewebe besteht, in dessen Lakunen mütterliches Blut circulirt. Ein kleiner Abschnitt der noch weiter reifenden, sowie der ganz reifen Placenta ist in Fig. 65 und 66 bei gleicher Vergrösserung gegeben: die Mesoblastzotten werden in Fig. 65 bie ihrem Längenwachsthum immer mehr auch in der Längsrichtung zerspalten (vergl, auch Fig. 25 und 26), in Fig. 66 sind sie lang und dünn, die Trophoblastbedeckung ist ebenfalls abgeflacht und eine entfernte Aehnlichkeit mit der menschlichen Placenta, wie sie Sedgwick Minot (94, S. 370) abbildet, ist nicht zu verkennen.

Wenn wir die hier in's Detail geschilderten Placentationsvorgänge bei Tarsius kurz zusammenfassen, so haben wir folgende Phasen hervorgehoben : $\left(\mathrm{I}^{\circ}\right)$ mütterliche, trophospongiale Vorbereitungen mit Drüsendegeneration und Wucherung des dazwischen liegenden gefässführenden Bindegewebes ausserhalb der Trophospongia; $\left(2^{\circ}\right)$ embryonale trophoblastische Wucherung und innige Verwachsung und Verlöthung von Trophoblast und Trophospongia unter bedeutender (circa 30-40facher) Volumenzunahme, wobei zunächst jegliche Betheiligung von Mesoblastzotten ausgeschlossen ist; $\left(3^{\circ}\right)$ Auswachsen der foetalen Mesoblastzotten in centripetaler Richtung, wobei eine embryonale Trophoblastschicht die Zotten 
von Anfang an vollends umkleidet, während die von dieser Schicht umfassten und allmählich durch Dehiscenz anderer Trophoblastpartien entstandenen Lakunen von mütterlichem Blute durchströmt werden; $\left(4^{\circ}\right)$ Reduction des Restes der Trophospongia zu einer dünnen peripheren Lage, welche die nur aus embryonalem Gewebe aufgebaute Placenta z. Th. gegen das mütterliche Gewebe abgrenzt.

Stellen wir nun einen Vergleich an zwischen dem was uns über die Tarsiusplacentation bekannt geworden ist und dem was wir von anderen im Detail untersuchten discoidalen Säugethicrplacenten (Kaninchen, Maus, Ratte, Meriones, Meerschweinchen, Maulwurf, Igel, Spitzmaus, Mensch) wissen, so überzeugen wir uns, dass recht grosse Differenzen zwischen allen diesen Gattungen bestehen. Ganz abweichend ist schon die Form der fertigen Placenta als dicke massive Gewebsknospe mit verhältnissmässig recht dünnem Stiel (Fig. 27). Wie das mütterliche Blut aus der Trophospongia in die embryonalen Trophoblastlakunen durchdringt, ist noch am ehesten vergleichbar mit dem, was wir beim Igel beobachten, obgleich eine Decidua reflexa und eine omphaloïde Placentation dem Tarsius ganz abgehen und somit die Verwachsung von Trophoblast und Trophospongia sich auf einem so viel kleineren Bezirke abspielt. Die ungemein viel grössere Aehnlichkeit, welche zwischen den Wachsthumsdetails der Tarsiuskeimblase mit denjenigen der menschlichen besteht (Hubrecht 96), als z. B. zwischen Affen- oder Menschen- und Igelkeimblase, darf uns jedoch nicht aus dem Auge verlieren lassen, dass die Placentarbildung bei Mensch und Igel wieder grössere Uebereinkunft besitzt, als jene von Mensch und Tarsius. In der menschilichen Phylogenese sind Stammformen zu erwarten, die zwischen diesem niedersten Primaten (Tarsius) und jenem Insektenfresser (Igel) ihre natürliche Stelle haben finden müssen, mit den aplacentalen und megallantoiden Lemures hingegen keine nähere Verwandschaft besessen haben.

\section{Die Bildung der Placenta bei Tupaja.}

Die Insectivorengattung Tupaja, ron welcher mir die Art Tupaja javanica als Untersuchungsobject gedient hat und über deren früheste Keimblasenbildung ich anderswo berichtet habe (95, S. I-I I), zeigt in ihren Placentationsverhältnissen einige sehr wichtige Abweichungen von anderen uns bchannten Insektenfressern. Er stimmt darin mit Erinaceus und Sorex, sowie auch mit Tarsius überein, dass mütterliche durch Gewebswucherung gekennzeichnete Anheftungsstellen in der mütterlichen Mucosa vorbereitet werden, ehe noch die anwachsende Keimblase mit irgend einem Theil ihrer äusseren Trophoblastschicht an dem mütterlichen Gewebe festklebt. Es sind somit diese Verklebungsstellen präexistirend: sie finden sich sowohl im linken, als im rechten Uterus-

$$
23-2
$$


horne. Normalerweise findet sich bei der Schwangerschaft immer je ein Foetus in je einem Uterushorne und da Tupaja durch das Vorhandensein einer Doppelplacenta, die links und rechts von der reifen Frucht gelegen sind, gekennzeichnet ist (Hubrecht 94, 2, Pl. II. Fig. 4I), so müssen wir normalerweise auch zwei vorbereitete Haftflecke im Uterus antreffen. Dem ist in der That so: die Stellen liegen einander diametral gegenüber, ungefähr halbwegs zwischen der mesometralen und antimesometralen Rinne im seitlich zusammengepressten Uteruslumen (Fig. I).

Es sind diese beiden Haftflecke dadurch gekennzeichnet, dass die Uterindrüsen hier in der Nähe der Oberfläche rückgebildet sind und nur in den tieferen Schichten der Mucosa fortbestehen. Während die Drüsen am Haftflecke bei Tarsius, Lepus und vielen anderen Gattungen unter Wucherung allmählich zu Grunde gehen, sind sie bei Tupaja in dieser Gegend unterdriickt und treffen wir hier hingegen eine Bindegewebs- und Blutgefässwucherung. Auch bei solchen Exemplaren, die vor kurzem geboren haben, und bei welchen Furchungsstadien in den Oviducten oder freie Keimblasen im Uteruslumen angetroffen werden, finden wir ähnliche Verhältnisse, nur dass sodann jene Stellen, deren eine in Fig. 28 stärker vergrössert wiedergegeben ist, anstatt einer compacten eine lockere Beschaffenheit besitzen und auch in den tieferen Schichten die stärkeren Gefässe der vorigen Schwangerschaft noch angetroffen werden. Die eben erneuerte Epithelschicht sieht in diesem Falle (sobald der Uterus sich wieder auszudehnen anfängt und die Keimblase fest haftet) recht flach (Fig. 35, 36), sonst mehrschichtig (Fig. 37, 42, 43) aus. Bei frühschwangeren Individuen, die nicht wie die ebenerwähnten zu gleicher Zeit puerperal sind, macht das compacte Gewebskissen der Fig. I einen anderen Eindruck als das eben beschriebene der Fig. 28: es handelt sich aber in beiden Fällen um genau denselben Vorgang.

Wenn die Keimblase sich festheftet (Fig. 2), befindet sie sich in dem Entwickelungsstadium bis zu welchem ich in meiner citirten Arbeit die Ontogenese verfolgt habe: es ist der epiblastische Embryonalknoten eben im Begriff die convexe Einbiegung (95 Fig. 65 und 66) zu verlieren und ein flaches Embryonalschild (95 Fig. 67-69) hervorgehen zu lassen. In Fig. 35 und 37 sehen wir die Anheftung angedeutet: der Trophoblast legt sich zunächst gegen das mütterliche Uterusepithel und fängt an dieses letztere an Ort und Stelle zum Verschwinden zu bringen. Die Trophoblastzellen nehmen dort, wo die Verklebung der beiden Epithelien zu Stande kommt, an Grösse zu, ihre Kerne werden ebenfalls grösser; hie und da drängen sich die Trophoblastzellen zwischen die mütterlichen Epithelzellen (Fig. 35, 36). Während letztere nicht an Zahl zunehmen, findet nun im Trophoblast an dieser Stelle ein sehr ergiebiges Wachsthum statt. Es wird der Trophoblast an der Anheftungsstelle mehrschichtig (Fig. 42, 43) und an einigen Stellen des verklebten Trophoblastes (Fig. 38-4I, 44) 
sieht man recht deutlich, wie die vergrösserten Kerne sich an Ort und Stelle amitotisch theilen, so dass hier megalokaryocytische Zellbezirke zu Stande kommen. Sobald dies der Fall ist, wird der Angriff gegen das mütterliche Epithel um so kräftiger: es werden zunächst die Zellgrenzen in letzterem undeutlich (Fig. 44, 45) und wir sehen nun kleinere mütterliche und grössere embryonale Kerne in einem gemeinschaftlichen Verschmelzungsplasmodium neben einander liegen (Fig. 45). Bald darauf sind die Reste der mütterlichen Kerne verschwunden und nun findet ein schnelles und mächtigeres Dickenwachsthum des Trophoblastes am Haftflecke statt, wodurch eine scharf umschriebene, mit grösster Deutlichkeit gegen das epithellose mütterliche Bindegewebe abgehobene, Trophoblastwucherung in die Erscheinung tritt. Sie ist in Fig. 4 und 5 bei schwacher Vergrösserung an beiden Seiten getroffen als erste Anlage der linken und rechten Placenta. Stärkere Vergrösserung (Fig. 46-50) zeigt uns, wie in diese Trophoblastwucherung neben kräftiger (amitotischer) Kermproliferirung eine Differenzirung auftritt zwischen den tieferen und den oberflächlicheren Schichten. Erstere, welche dem Centrum der Keimblase näher liegen, bilden sich zu einem Cytotrophoblast aus (cf. Vernhout, 94, S. I3), letztere verschmelzen zu einem syncytialen Plasmoditrophoblast.

Dennoch ist die Differenzirung dieser beiden Schichten, welche bereits im Stadium der Fig. 45 eingeleitet war, eine vorübergchende. In Fig. 5 I ist der Cytotrophoblast mächtiger geworden, hebt sich aber weniger scharf von dem Plasmoditrophoblast ab, in Fig. 5254 lässt sich eine Grenze kaum mehr unterscheiden.

$\mathrm{Zu}$ derselben Zeit ist die sehr scharfe Grenze, welche anfänglich (Fig. 46-50) zwischen dem Plasmoditrophoblast und dem darunter liegenden mütterlichen Gewebe der Trophospongia besteht, allmählich verloren gegangen, und wir treten in eine Periode, wo überhaupt die anfänglich so scharf gegeneinander zu unterscheidende Trophoblastwucherung und Trophospongia zu einem fast unentwirrbaren gemeinschaftlichen Complex verschmelzen, wie wir das an einem gewissen Moment auch bei Tarsius als eine vorübergehende Phase zu constatiren vermochten (Fig. 62, 63).

Um dieses gründlich $\mathrm{zu}$ verstehen, gehen wir an der Hand schwächer vergrösserter Präparate zunächst etwas näher auf die Vorgeschichte der Trophospongia ein. Es wird nämlich in der Gegend des mütterlichen Haftfleckes, den wir oben als eine prädisponirte, drüsenfrcie Stelle kennen lernten, eine starke Wucherung von feinen Capillargefässen constatirt. Die Drüsen, die seitlich vom Haftflecke liegen, werden in der Fig. 28 unverkennbar bei Seite gedrängt; bald nachher (Fig. 3O) ist dies in noch höherem Maasse der Fall. Beachtung verdient dabei, dass die blinden Enden der Drüsen, welche sich noch unter dem Haftflecke befinden während dieser Stadien (Fig. 2S-3I) und sogar bis zum Ende der Schwangerschaft (Fig. 33), ruhig, wenn auch sehr abgeflacht an Ort und Stelle verbleiben. 
Wie geht nun allmählich das gefässführende Bindegewebe des Haftfleckes in das compacte Trophospongiagewebe über?

Es findet hier ohne Zweifel in erster Linie eine starke Wucherung des intervasculären Bindegewebes statt, und zwar gleichzeitig mit der Capillargefässsprossung. $\mathrm{Zu}$ beachten ist dabei, dass bereits in dem Stadium der Fig. 29 diese Wucherung in dem dem Trophoblast näher gelegenen Bezirke intensiver ist, als in den tieferen Schichten. Eine Folge dieser Intensitätsdifferenz ist ein steigendes Hervortreten jenes oberen Bezirkes, welches uns bald (Fig. 30 und 3I) als eine immer schärfer umgrenzte Trophospongia entgegentritt. Die tiefere Schicht ändert allmählich ihren Charakter dahin, dass sie mehr fibrillär aussieht und nur noch eine Zeit lang gefässreich ist. Vom Stadium der Fig. 3 I an hat sie unverkennbar an Bedeutung abgenommen und wird auch in den späteren Schwangerschaftsstadien (Fig. 32, 33) bedeutend dünner, während hingegen die immer schärfer gegen sie abgesetzte Trophospongia in Wechselwirkung mit der embryonalen Trophoblastwucherung tritt. Die Trophospongia steht wohl in Fig. 3 I auf dem Höhepunkt ihrer Entwickelung: indem sie von nun an den Uebergang mütterlichen Blutes aus mütterlichen Capillaren in embryonale Trophoblastlakunen herzustellen hilft, tritt sie bald nachher dem kräftig weiter wucherenden Trophoblast gegeniber in den Hintergrund, ist in Fig. 32 bereits bedeutend von diesem verdrängt und in Fig. 33 (beim Ende der Schwangerschaft) bildet auch sie nur eine dünne äussere Schicht auf die mächtige, aus embryonalem Gewebe aufgebaute Placenta (vergl. Fig. 9-I 2).

Trophospongia und Trophoblast bilden in Fig. I I eine schüsselförmige Doppelvorrichtung (links und rechts vom Embryo), welche den Boden liefert, auf welchen sich jetzt jene definitive, zum kindlichen und mütterlichen Austausch dienende, Placenta aufbauen wird.

Vordem jedoch die mit Allantoisgefässen versehenen Placentarzotten sich an dem Aufbau dieser definitiven Placenta betheiligen werden, haben die erwähnten, aus embryonalem Trophoblast und mütterlicher Trophospongia bestehenden, Gewebskissen noch bedeutende innere Veränderungen zu erleiden, welche zunächst auf die Herstellung der complicirten Circulationsverhältnisse in diesen beiden Kissen gerichtet sind. Sie dienen in erster Linie während eines beschränkten Zeitraumes einer unleugbaren omphaloiden Placentation, die auch bei anderen Insektivoren, wie Erinaceus und Sorex, so deutlich ist und von mir anderweitig beschrieben wurde (89, Fig. 32-34, 43, 44, 94, I, Fig. 9- I I, 83). Eine bedeutende Differenz besteht darin, dass, während bei Erinaceus und Sorex die omphaloide Placentation die Keimblase ringförmig umgiebt und die allantoide Placentation sich später oberhalb des Rückens des Embryos einstellt und somit ganz verschiedene Bezirke dabei in Betracht kommen, bei Tupaja hingegen dieselbe Gewebskissen erst die Area vasculosa sich gegen sich ausbreiten sehen (Fig. 6- 
9), worauf nachher der Dottersack von diesen beiden Kissen wieder abgehoben wird und nun (Fig. 10-I2) die Allantois mit ihren Zotten sich an genau denselben Gewebskissen festheftet, sodass die allantoide Placentation die omphaloide nicht nur im physiologischen, sondern auch im topographischen Sinne verdrängt.

Es ist während jener Zeit, wo das Gefässnetz des Dottersackes sich gegen die convexe Oberfläche der Placentarkissen ausbreitet (Fig. 7-9, 3 I), dass die oben angedeuteten Veränderungen in den Gewebe der Kissen selbst stattfinden und wenn die Allantoiszotten sich gegen letztere anzuheften anfangen (Fig. IO, I I, 32), so haben Trophoblast und Trophospongia von Tupaja dieselben Phasen durchgemacht, welche wir vorher bei Tarsius beschrieben haben in den Stadien, welche dem der Figuren 23 und 64 vorangehen. Auch bei Tupaja besteht von dem Moment an das IVeiterwachstum der Placenta in einem centripetalen Ausziehen der Mesoblastzotten und der diese umgebenden trophoblastischen Aussenbekleidung, von welcher letztere Lakunen umschlossen werden, die das miitterliche Blut herbeiführen.

Die obenerwähnten Gewebsieränderungen sollen hier nun noch in aller Kürze recapitulirt werden. Ich gehe nicht näher auf das Detail ein, weil die Vergleichungspunkte, welche sich zwischen Tupaja, Sorex und Vespertilio darbieten, in mehrerer Hinsicht so auffallend sind, dass ich es mir lieber vorbehalte hierauf später in einer speciell darauf gerichteten Arbeit zurückzukommen. Die Veränderungen bestehen also darin, dass bei dem Vordringen der plasmoidalen Trophoblastwucherung die zahlreichen Capillarien der Trophospongia umsponnen werden und dass ihr Endothel nach einiger Zeit zu Grunde geht (Fig. 5 I, 52, 54) in derselben IVeise wie das Nolf (95) für Vespertilio beschrieben hat. So wird allmählich das Durchdringen mütterlichen Blutes in embryonalen Trophoblastlakunen eingeleitet. Bei dem nun folgenden Dickenwachsthum des letzteren, dessen Anfang in Fig. 32 ersichtlich ist, fällt das Hauptgewicht, wie ich es auch vorher für Sorex beschrieben habe (94 S. 52 I, Taf. 39, Fig. 89-94), auf die eher dem Cytotrophoblast zuzurechnenden tieferen Schichten. Horizontale Sprösslinge der sich verlängernden Allantoiszotten werden bei horizontaler Spaltung dieser wachsenden Trophoblastschichten immer wieder von diesen umhüllt: beim weiteren Breitenwachsthum ändert sich allmählich die horizontale Ausbreitung der Zotten in eine radiäre.

Dabei noch ist zu beachten, dass die Stelle, wo z. B. in Fig. 46 Uterinepithel, Trophoblastwucherung und Trophospongia zusammenstossen in den Stadien der Fig. 29 bis 32 recht gut wieder zu erkennen ist, und dass auch bei weiterem Dickenwachsthum der Placenta das Uterinepithel auf der Aussenfläche der Placenta verfolgt werden kann und sich dabei oft recht scharf von Trophospongia und Trophoblast abhebt (Fig. 34). 


\section{Die Entstehung von rothen, kernlosen Blutkörperchen bei gewissen Săugethieren.}

Bei der Beurtheilung der zahlreichen, abweichenden und sich widersprechenden Angaben über die Bildung rother Blutkörperchen bei den Säugethieren können wir der auftauchenden Vermuthung uns nicht enthalten, dass eine so grosse Meinungsdivergenz in der Auffassung des Baues und der Entstehung so einfacher Formelemente doch nur crklärbar werde, wenn man annimmt, dass ein Fehler in den Prämissen gemacht sein muss. Mir scheint es, dass dieser Fehler darin besteht, dass man den fundamentalen Unterschied, welcher zwischen den rothen Blutkörperchen der erwachsenen Säugethiere und denjenigen niederer Vertebratenklassen besteht, nicht genügend gewürdigt hat. Aus der Thatsache, dass die ersten Blutkörperchen, welche man bei den Embryonen der Säugethiere in ihrer Area vasculosa und anderweitig entstehen sieht, unverkennbare kernhaltige Zellen sind, ebensowie es bei den übrigen Vertebraten der Fall ist, wo ausserdem die Blutkörperchen der Erwachsenen sich als kernhaltige Zellen darstellen, schliesst man ganz allgemein, dass nun auch die Blutkörperchen der erwachsenen Säugethiere, die eben dadurch gekennzeichnet sind, dass sie einen Kern cntbchren und die viel kleiner sind, als die embryonalen derselben Species, dennoch als Zellen aufzufassen seien, woraus der Kern entweder ausgestossen (Bizzozero, Howell, Kostanecki, Rindfleisch, Saxer, van der Stricht) oder worin er durch Resorption unsichtbar geworden sein muss (Neumann, Kölliker, Sanfelice, Spuler, Löwit, Eliasberg, Freiberg, Grünberg, Israel, Pappenheim, u. A.).

Dieser Auffassung sind Schäfer und später besonders Minot scharf entgegengetreten, indem sie die Säugethierblutkörperchen nicht als Zellen, sondern als Zellproducte, welche in dem Zellplasma ihre Entstehung finden, kurz als Plastiden, auffassen. Minot hat dies in seiner menschlichen Anatomie ausführlich begriindet.

Damit ist jedenfalls ein Schritt in ganz anderer Richtung gethan ${ }^{2}$ und ist deutlich ausgesprochen worden, dass die Blutkörperchen der erwachsenen Säugethiere doch wohl etwas anderes seien, als jene der Sauropsiden und Ichthyopsiden. Dennoch scheint es mir, dass die Thatsachen uns noch einen Schritt weiter zu thun zwingen werden, und dass wir fortan das erwachsene Säugethierblutkörperchen nicht als eine Plastide im Minot'schen Sinne, sondern als ein Kernderivat von nucleolärer Beschaffenheit (im Gegensatz zur chromatischen Substanz des Kernspirems) werden betrachten müssen.

1 Die Ranvier'sche Beobachtung des Entstehens von Blutkörperchen innerhalb gewisser Zellen des Kaninchen-Epiploons ist durch die Vosmaer'sche Nachuntersuchungen (97) auf ihre wahren Verhältnisse zurückgebracht worden. 
Die hämatopoietischen Prozesse in der Placenta einiger Säugethiere werden uns die Begründung dieser Auffassung bcdeutend erleichtern : zunächst muss aber von uns geprüft werden, ob und in wie weit die Erscheinungen in der Area vasculosa, wo eben die allerfrüheste Säugethierblutbildung stattfindet, in demselben Sinne zu deuten sind. Kurz, es muss erstens festgestellt werden, wie die frühen, embryonalen Säugethierblutkörperchen, deren Zellennatur nicht geläugnet wird, allmählich in den definitiven Blutkörperchen des erwachsenen Säugethieres übergehen. Ist das definitive Blutkörperchen dem Zellenleibe des embryonalen Blutkörperchens, aus dem der Kern verschwunden oder ausgestossen ist, homolog? Oder ist es eine daraus hervorgegangene Plastide? Oder muss es als ein bestimmtes Derivat des Kernes (resp. als nucleoläre Substanz) aufgefasst werden?

Dabei ist im Auge zu behalten, dass die embryonalen, an Zellen gleichwertigen, Blutkörperchen nicht nothwendigerweise alle während ihrer individuellen Existenz die Entwickelungsphasen zu einem erwachsenen Blutkörperchen durchmachen: es ändert sich allmählich während der embryonalen Existenz der Blutkürperchentypus.

§ I. Die embryonalen Blutzellen der SäUgethiere in IHREM VERHÄLTNISS ZU DEN BLUTKÖRPERCIIEN DER ERWACHSENEN.

Die erste Blutbildung bei den Tarsiusembryonen (und wohl bei recht zahlreichen Säugethierarten) findet statt in der Nabelblasenwand, vordem noch das Gefässsystem sich innerhalb des Embryonalkörpers ausgebildet hat. Es thun sich da als allererste Blutanlage isolirte Zellen vor, welche zwischen Hypoblast und splanchnischem Mesoblast eingeschlossen sind und als Mutterzellen von Blutinseln zu betrachten sind. Saxer (96), in dessen Arbeit über Blutbildung auch von der Nabelblasenwand die Rede ist, betrachtet sie als "Wanderzellen" und äussert sich über ihre erste Herkunft nicht näher. Ich selbst fühle mich auch nicht berechtigt zu entscheiden, ob sie an Ort und Stelle entstehen oder ob sic von anderswo dorthin einwandern. Neben solchen, die einen einheitlichen Kern besitzen, finden sich andere, bei denen der Kern bedeutende Proliferation erleidet, und ich neige der Ansicht zu, dass diese Kernproliferation der allerersten Blutmutterzellen ein nothwendig zu durchlaufendes Zwischenstadium der embryonalen Säugethierblutbildung ist. Solche Zellen mit proliferirendem oder mit in mehrere Stücke getheiltem Kern finde ich bei Tarsius recht deutlich in vielen Präparaten, von denen eines in Fig. 76 abgebildet ist. Für die Sorexnabelblase habe ich ähnliche Stadien bereits früher abgebildet (94, Taf. 35, Fig. 58-62) ; bei der Katzennabelblase zeichnet sie Saxer (96) in seinen Fig. I2-I4, I8 und I9 A etc. auf Taf. XIX., XX.; beim Schwein derselbe auf Taf. XXI., XXII. Fig. 2 I, 22 etc. 
Weitere Entwickelungsstadien einer Blutinsel auf der Nabelblase von Tarsius bieten die Fig. 77-80. Hieraus ersehen wir, wie sich die Theilstücke des fragmentirten Kernes des vorigen Stadiums von einem separaten Protoplasmahof umgeben (Fig. 78) und wie sodann bei Wegfall der primitiven äussern Zellgrenze eine Anzahl Blutzellen aus der ursprünglichen, durch ihre Kernwucherung scharf charakterisirten, Blutmutterzelle sich entwickelt haben (Fig. 79, 80). Aehnliche in diesem Entwickelungsstadium sich befindende Blutmutterzellen hat auch wohl von Spee beim menschlichen Embryo beobachtet und beschrieben (96, S. 78). Die eben erwähnten Blutzellen sind bei Tarsius von sehr markirt verschiedenem Charakter und cirkuliren bald sowohl auf der Nabelblase, als in den Gefässen innerhalb des anwachsenden Embryonalkörpers. Fig. 8 I giebt von der Verschiedenheit dieser Zellen innerhalb eines grösseren Nabelblasengefässes eine Vorstellung: wir finden hier sogar noch Blutmutterzellen mit proliferirendem Grosskern beigemischt, neben solchen, die einen grossen Kern mit Nucleolen und Kernwand besitzen, und solchen, welche die eigenthümlichen Veränderungen erlitten haben, durch welche aus den primitiven embryonalen Blutzellen jene hervorgehen, welche während einer längeren embryonalen Periode als die typischen embryonalen Blutzellen bekannt sind. Letztere sind für Tarsius auch noch auf der farbigen Tafel 14 in Fig. 96 und 97 abgebildet: sie sehen vollständig jenen von Tupaja (Fig. 87 D-F), Sorex (Fig. 86 A), Sus, Ovis, Vespertilio, Talpa, Erinaceus, Perameles (Fig. 88 b) und anderen Säugethieren ähnlich, die wir in zahlreichen Specialarbeiten beschrieben und abgebildet finden.

Es sind nun auf der Taf. I3 dieser Abhandlung für drei Säugethierarten die Vorstufen der charakteristischen embryonalen Blutkörperchen abgebildet : für Tarsius bei dem obenbeschriebenen Stadium mit Kernwucherung anfangend (Fig. 76) und durch die erwähnten Z wischenstadien (Fig. 77-80) zu dem Stadium der Fig. SI führend; für Tupaja ausgehend von der grosskernigen Form des jüngsten Embryonalstadiums der Fig. $87 \mathrm{~A}$, durch die Figuren $87 \mathrm{~B}-\mathrm{D}$, bis zu jenem der Fig. $87 \mathrm{E}$, wo die typischen embryonalen Blutkörperchen auf ihrem Höhepunkt stehen; für Sorex in den Fig. 82 bis 86.

Wollen wir andeuten, welche Aenderungen die embryonale Blutzelle durchmacht, um von ihrem frühesten Anfangsstadium ihre typische Entwickelung zu erreichen, so liefern uns die erwähnten Abbildungen dafür Anhaltspunkte für alle drei der genannten Gattungen. Sowohl Kern, als Cytoplasma sind bei diesen Aenderungen betheiligt. Ersterer verliert seine scharfe Kernmembran und der Unterschied zwischen chromatischen und nucleolären Einschlüssen, welche sich anfangs innerhalb der Kernmembran ziemlich deutlich hervorhebt, hat jetzt aufgehört; es befindet sich ein mehr homogener Tropfen an der Stelle des vorher normalen Kernes, indem zu gleicher Zeit das Verhalten dieses Tropfens 
gegen die verschiedenartigsten Tinctionsmittel immer wieder darauf hinweist, dass bei dieser Kerncontraction es wohl nucleoläre Substanz im Ueberschuss ist, welche der sogenannte "Kern" des reifen und typischen embryonalen Blutkörperchens zusammensetzt.

Die Minderwerthigkeit an chromatischer Kernsubstanz der reifen embryonalen Blutzellen mag auch noch hieraus gefolgert werden, dass, während die jüngeren Stadien noch wohl mitotisch sich theilen (Fig. $\$_{3}$ B), bei weiter vorschreitender Entwickelung das Vermogen einer mitotischen Theilbarkeit abnimmt und zwar so, dass mitunter unvollkommene mitotische Theilung (wie sie auch Saxer auf S. $4 S_{5}$ seiner grossen Arbeit beschreibt) wahrgenommen wurde (Fig. 82); hingegen, in dem fertigen Stadium der typischen embryonalen Blutkörperchen, nur noch amitotische Zwei- (Fig. 83 A, 87 E) oder sogar Dreitheilung des kernähnlichen Einschlusses.

Absichtlich lege ich Gewicht darauf den Einschluss der fertigen embryonalen Blutzelle nicht kurzweg, wie jene der frühen Vorstufen "Kcrn" zu nennen, weil eben diese wichtige Veränderung, deren allgemeinere Bedeutung weiter unten noch näher gewürdigt werden wird, stattgefunden hat.

Was die Aenderung im Zellkörper der frühen embryonalen Blutzellen betrifft, so nimmt dieser nach dem Schwinden der Kernmembran (Fig. 79) den glashellen Charakter an, der anfänglich innerhalb der Kernmembran bemerkbar war und, da zu gleicher Zeit die anfangs nicht immer sphärische oder ellipsoidische Zelloberfläche jetzt eine prall gefüllte Gestalt zeigt, sieht eben die Zelle in ihrer neuen definitiven Gestalt viel eher einem Kern + Nucleolus der vorangegangenen Vorstufe ähnlich. An diesem täuschenden Umstand mag es wohl zugeschrieben werden, dass Foster und Balfour in der ersten Auflage ihrer Elements of Embryology (IS74) von den embryonalen Blutkörperchen behaupten (S. 69, Fig. I9 b,c), es seien Kerne, keine Zellen. In der zweiten Auflage finden wir diesen Ausspruch zurückgenommen. Ich musste dieses Ausspruchs an dieser Stelle Erwähnung thun, weil in der That die Figur 85 von Sorex und Fig. 8 I von Tarsius uns leicht zu einer ähnlichen Schlussfolgerung führen könnte, wären nicht eben genügende Zwischenstadien vorhanden, um uns viel eher von der Richtigkeit der oben vertheidigten Ansicht zu überzeugen. $\mathrm{Zu}$ gleicher Zeit ist hiermit der Unterschied gekennzeichnet zwischen jenem Balfour'schen Standpunkte und der meinigen weiter unten zu begründenden Anschauung, dass die kernlosen Säugethierblutkörperchen allerdings nicht Kerne sondern Kernderivate sind.

Diese Anschauung werden wir zunächst sich bei uns aufdringen sehen, wenn wir genau nachzuforschen suchen, in welcher Weise nun aus unseren typischen embryonalen Blutkörperchen diejenigen des späteren Embryonallebens und des erwachsenen Thieres hervorgehen. Es findet sich diese Frage, soviel ich weiss, in der Literatur nicht eingehend geprüft : es wird allgemein angenommen, 
dass aus den embryonalen Blutkörperchen durch Kernverlust jene des erwachsenen Thieres hervorgehen, wobei dann von vielen auf Analogie mit späteren hämatopoietischen Prozessen hingewiesen wird, wo ebenfalls durch Kernverlust Erythroblasten in kernlosen Blutzellen übergehen sollen (van der Stricht, Löwit, Howell, Bizzozero, Saxer, Kostanecki u. A.). Als ich sowohl bei Tupaja als bei Sorex dieser Frage näher trat, musste ich zu der Schlussfolgerung gelangen, dass es sich mit dem Uebergange der embryonalen in die definitiven Blutkörperchen anders verhält. Die Resultate, zu denen ich gekommen bin, kamn ich eben nicht besser vorführen, als an der Hand von Abbildungen von embryonalen Tupaja-blutkörperchen, wie wir sie in den embryonalen Gefässen antreffen in einer Reihe von Stadien, welche folgen auf den in Fig. 87 E abgebildeten Höhepunkt. Es lässt sich in dieser Präparatenreihe constatiren, dass die Grösse der typischen "kern"führenden embryonalen Blutkörperchen in weiteren Stadien der Schwangerschaft, welche auf jenem der Fig. $87 \mathrm{E}$ folgen, allmählich abnimmt. Und dass am Ende der Schwangerschaft keine "kern"führenden Elemente mehr in dem embryonalen Blute angetroffen werden, sondern kernlose Blutkörperchen, welche noch von verschiedener Grösse sind und von welchen die kleinsten den mütterlichen Blutkörperchen an Grösse und Tinctionsfähigkeit ähnlich sind. Ausserdem sei hervorgehoben, dass die Grösse dieser spätesten Embryonalstadien, sowie auch der mütterlichen Blutkörperchen, jener der "Kerne" der typischen Blutkörperchen der Fig. 87 E ungefähr gleich kommt.

Indem es also feststeht, dass Grössenabnahme stattfindet und dass vor dem Ende des intrauterinen Lebens alle die embryonalen Blutkörperchen Form und Grösse der mütterlichen besitzen und ebenso wie diese eines Kernes entbehren, haben wir uns zunächst klar zu legen, dass es sich hier um Prozesse handelt, die sich nicht an einem und demselben Vorrath Blutkörperchen abspielen. Kurz, es ist anzunehmen, dass auch während des embryonalen Lebens Blutkörperchen absterben, zu Grunde gehen und durch neue ersetzt werden und dass also die späteren Nachschübe allmählich ihren Charakter dahin verändern, dass sie gleich von Anfang an den mütterlichen mehr ähnlich sehen. So finden wir dann auch, dass die relative Zahl der kernhaltigen, grösseren Blutkörperchen, welche in dem Stadium Fig. $87 \mathrm{E}$ noch die einzig anwesenden sind, rasch abnimmt im Vergleich zu den kernlosen. Und da wir nun auf das Stadium der Fig. 87 E und folgg. das körperliche Austreten des Kernes mit der grössten Leichtigkeit und Häufigkeit wahrnehmen kömnen', so läge die Schlussfolgerung scheinbar vor der Hand, dass

1 Israel und Pappenhein (96), welche diese Erscheinung auch allgemein auftreten sahen im embryonalen Blute, glauben es hier mit einem degenerativen Prozesse zu thun zu haben, wobei junge rothe Blutzellen zu Grunde gehen, bevor sie reif sind. Dennoch geben sie zu, dass bei diesem Vorgang der Kern sich haltbarer erweist, als das Zellprotoplasma. Disse (96 S. 54) bemerkt dazu mit vollem Rechte, dass dieser Deutung die grosse 
diese ausgetretenen Kerne zu Grunde gehen und dass damit die Umwandlung von kernhaltigen in kernlose Blutzellen vollzogen sei. Allein es wäre damit nicht die bedeutende Grössendifferenz erklärt, sowic auch nicht die Thatsache, dass, wenn wir in unseren Placenta-durchschnitten die embryonalen kernhaltigen und die mütterlichen Blutkörperchen in der unmittelbaren Nähe von einander beobachten können, fast ausnahmlos die letzteren an Grösse und Färbbarkeit nicht dem Zellleibe der embryonalen Blutzellen, sondern deren sogenanntem "Kern" ähnlich sind. Verfolgen wir in den embryonalen Gefässen das Schicksal der ausgetretenen Kerne der Fig. 87 D und E näher, so sehen wir, dass die Kerne nicht wie es van der Stricht u. A. beschrieben haben, im strömenden Blute zu Grunde gehen, sondern dass diese Kerne durch zahlreiche Zwischenstufen hindurch (Fig. $87 \mathrm{~F}-\mathrm{K}$ ) dahin verfolgt werden können, dass ihre Tingirbarkeit mit den gerade angewandten Tinctionsmitteln abnimmt und dass sie dadurch schliesslich hell und ungefärbt aussehen können, ebenso wie wir es vorher von den Mutterzellen verzeichneten, denen sie entschlüpft sind. Ihre Dimensionen sind dann auffallend geringer, kurz wir finden alsdann neben einander im embryonalen Blute: $(a)$ normale typische "kern "haltige Blutzellen mit tingirbarem Kern; $(b)$ ausgetretene freie gefärbte Kerne; $(c)$ ebensolche aber ungefärbt, wiclche dadurch kleincre kernlose Zcllleiber vortäuschen; (d) geschrumpfte und zusammengefallene grössere Hüllen, die wohl der älteren Generation angehören und aus welchen eben die Kerne entschlüpft sind.

Die Blutzellen gehen also, nach dem Verlust ihres "Kernes," zu Grunde: die kleiner dimensionirten treten mehr in den Vordergrund.

Viel Gewicht lege ich noch auf die Beobachtung, welche in den Fig. $87 \mathrm{E}-\mathrm{K}$ näher documentirt ist, dass in den späteren Schwangerschaftstadien, wo die relative Zahl der "kern"haltigen Blutzellen abnimmt, letstere so wie so an Grösse abnehmen, dass also spätere Generationen "kern"haltiger Blutzellen, sie mögen dann auf der Nabelblasenwand, in der Leber des Embryos oder an anderen hämatopoietischen Heerden aus wahren Blutmutterzellen entstanden sein, immer kleiner werden. Auch der in diesen kleineren Blutzellen enthaltene "Kern" ist in dem selben Maassstabe verkleinert und nähert sich schliesslich völlig der Grösse der mütterlichen Blutkörperchen. Indem nun auch in diesen Stadien das Austreten des Kernes in einer bestimmten Prozentzahl der Blutzellen immer wahrnehmbar bleibt, so erklärt sich mit einem Schlage, wie wir in dem in Fig. 87 I, $\mathrm{K}$ abgebildeten Schwangerschaftstadium in

Zahl der freien Kerne im embryonalen Blute und in den blutbildenden Organen entgegen steht. Wenn er weiter hinzufiigt, dass eine sichere Entscheidung unmöglich erscheint, da die direkte Beobachtung des Vorganges im strömenden Blut unthunlich ist, so möchte ich dem gegeniiberstellen, dass die in Fig. $87 \mathrm{~A}-\mathrm{K}$ abgebildeten Stadien sich zu jenem Vorgange verhalten, wie die Einzelphotographien des Kinematographen zur Wirklichkeit: wir sollen uns eben unserer Vorstellungskraft bedienen, um sie zu beleben und den Vorgang zu ertappen. 
den embryonalen Gefässen kernlose Blutkörperchen verschiedener Grösse neben einander antreffen: es sind dies eben die frei gewordenen Kerne verschiedener vorangegangener Blutzellengenerationen: die grösseren entstammen den älteren, die kleinen den jüngeren Stadien. Schliesslich, wenn sich die Dauerzustände der Blutbildung eingesetzt haben, sind die embryonalen Blutkörperchen unter einander, sowie jenen der Mutter gleich gross.

Es sind dann aber diese Blutkörperchen nicht als Zellen zu betrachten, auch nicht als Zellen die ihren Kem entweder durch Ausstossung oder durch Resorption verloren haben, sondern die Blutkörperchen entstammen dem ursprünglichen Kerne einer Blutmutterzelle, an welche sich gewisse hier nicht in Detail beschriebene Veränderungen abgespielt haben, die, kurzgefasst, dahin definirt werden können, dass ihr Gehalt an Chromatine sehr in den Hintergrund getreten, wenn nicht ganz geschwunden ist, und dass hingegen ein Kernproduct, als welches doch eben die nicht karyosomatische, sondern plasmasomatische nucleoläre Substanzen aufgefasst werden müssen, bedeutend im Uebergewicht gerathen ist. Die Entstehungsweise der kernlosen Blutkörperchen, der von mir untersuchten Säugethiergattungen berechtigt mich also diese kernlosen Blutkörperchen als Kernderivate zu bezeichnen.

Huxley schrieb bereits vor 33 Jahren in der ersten Auflage seiner Lessons in Elementary Physiology (S. 63): "There is very great reason for believing that the red corpuscle is simply the nucleus of the colourless corpuscle somewhat enlarged, flattened from side to side; changed, by development in its interior of a red colouring matter; and set free by the bursting of the sac or wall of the colourless corpuscle. In other words the red corpuscle is a free nucleus." Der Unterschied zwischen diesem Ausspruch des grossen englischen Forschers und meiner oben entwickelten Auffassung liegt eben nur darin, dass ich der bedeutenden Aenderung, welche vorher in den Kern auftritt, völlig Rechnung tragen möchte und deshalb das kernlose Säugethierblutkörperchen nicht als "freien Kern," sondern als Kernderivat betrachte.

\section{$\S$ 2. Blutbildung in Der Placenta.}

Das im vorigen Abschnitt erreichte Resultat, welches zu gewinnen in der Reihenfolge der Zeit nicht vor, sondern nach meinen Untersuchungen über fragliche hämatopoietische Prozesse in der Placenta stattfand, war mir eben dadurch werthvoll, weil es mir erlaubte, die von mir in der Placenta beobachteten Thatsachen besser zu würdigen. Diese Thatsachen, die gleich näher beschrieben werden sollen, sind einerseits nicht im Einklang mit der in den Handbüchern gehuldigten Vorstellung über die morphologische Bedeutung der kernlosen Säugethierblutkörperchen und über deren Entstehung. Anderseits schienen sie mir doch darauf hinzuweisen, dass es vielleicht nicht schwer fallen würde, möglicherweise sogar in 
einer nahen Zukunft, die sich so schroff gegenüberstehenden Ansichten über die Rolle der Riesenzellen (Mega- oder Megalokaryocyten, Gigantocyten) bei der Blutbildung der Säugethiere, theilweise miteinander zu versöhnen, theilweise zu crweitern und schärfer zu definiren. Indem doch ein Theil der Forscher wie Sanfelice (90), van der Stricht $(\mathbf{9 1}, 92)$, Rindfleisch $(80)$, diesen Zellen alle direkte Betheiligung an der Blutbildung abspricht, sehen andere, wie Neumann (74), Foa $(82,91)$, Kuborn (90) u. A. in diesen Zellen sogar Blutmutterzellen, allerdings in dem Sinne, dass sie nach bedeutender Kernproliferation und Kernzerstückelung in kleineren Zellgebieten aufgelöst werden, die jedes für sich als eine kernhaltige Blutzelle (Erythroblast) aufzufassen wäre. Vorsichtiger äussert sich Saxer, der mit Bezug auf diese Riesenzellen schreibt (96, S. 487): "Der Ansicht Flemmings, dass es sich um funktionslose Lymphoidzellen, um eine "abgeartete und ausgeartete" Zellenform handelt [kann unmöglich] beigestimmt werden. Dagegen spricht die enorme Verbreitung im embryonalen Organismus...... ferner die konstante Anwesenheit an allen Stellen, wo Blutzellen und namentlich wo rothe Blutkörperchen produziert werden, wobei besonders zu betonen ist dass sie primär an den Blutbildungsstellen auftreten und die Produktion von Blutzellen dort erst nach ihrem Erscheinen einsetzt; dagegen spricht schliesslich, dass ihr einziger regelmässiger Fundort im postembryonalen Organismus zugleich das einzige sicher bekannte Organ ist, welches rothe Blutkörperchen liefert. Ich glaube daher, dass ihnen eine regelmässige Funktionwelche muss allerdings noch unentschieden bleiben-gar nicht abgesprochen werden kann."

Wir werden sehen, dass die Blutbildung in der Placenta von Tarsius eben die Funktion der Riesenzellen in ein helles Licht zu setzen im Stande ist. Und dass die aus diesen Riesenzellen entstammenden kernlosen Säugethierblutkörperchen grundverschieden sind von den kernhaltigen Blutkörperchen der embryonalen Säugethiere, haben wir oben bereits dargelegt; dass sie auch grundverschieden sind von den kernhaltigen Blutkörperchen der niederen Wirbelthiere, ist nicht wohl anders zu erwarten und wird, wo wir uns eben anschicken, um die aktive Rolle, welche dabei Riesenzellen spielen, näher zu begründen, in suggestiver WVeise uns noch näher auf Herz gebunden, wenn wir bei einem Leugner ihrer aktiven Betheiligung an der Blutbildung, wie van der Stricht, lesen (91, p. 88): "Bizzozero a constaté dans une série de travaux l'absence de cellules géantes dans les organes haematopœtiques de tous les vertébrés où les globules rouges possèdent un noyau. L'apparition de cellules géantes chez les embryons des mammifères correspond à celle dans le sang des globules rouges parfaits, sans noyau."

Die gleich näher zu entwickelnde Auffassung, welche dic beobachteten Thatsachen aus der Placentarentwickelung von Tarsius und Tupaja uns aufzwingen, steht nun darin mit den vorhin be- 
schriebenen Beobachtungen über die Umwandlungsstadien der embryonalen Blutkörperchen im schönsten Einklang, dass auch die Riesenzellen, in soweit sie als Bildner von kernlosen Blutkörperchen auftreten, diese nicht als Zellen, sondern wiederum als Kernderivate aus sich entstehen lassen. Dies näher zu begründen soll in den folgenden Zeilen versucht werden.

\section{(a) Blutbildung in der Placenta von Tarsius.}

Derjenige Abschnitt des Trophoblastes, welcher sich unter Proliferirungserscheinungen gegen die mütterliche Mucosa anliegt, bildet, wie wir das bereits oben (S. 35 I) beschrieben haben, ein eigenes Zellenpolster, das die Trophospongia überkleidet. Aus diesem Zellenpolster wird, unter unaufhörlicher Vermehrung und theilweise darauf folgender lokaler Auflösung des ihn zusammensetzenden Zellen- und Kernmateriales, zunächst das ganze Lakunensystem, welches in der fertigen Placenta die mesoblastischen Zotten umgiebt. Die äussere pseudo-epitheliale Bekleidung der Zotten, wie sie in den Fig. $67,68,65$ und 96 so deutlich ersichtlich ist, haben wir als eine rein trophoblastische kennen gelernt. Während der Ausbildung dieses Lakunensystems sind eine Anzahl Trophoblastzellen nach vorangegangener Kernwucherung zu Grunde gegangen : es sind eben diese, welche als Blutbildner in der Placenta grosse Bedeutung besitzen.

Ehe ich auf das Detail dieser Blutbildungserscheinungen eingehe, will ich in zwei Worten auf die vom allgemeinen Gesichtspunkt aus wichtigen Thatsachen die Aufmerksamkeit lenken, dass wir hier $\left(I^{\circ}\right)$ das embryonale Gewebe Elemente liefern sehen, welche in den mütterlichen Blutstrom aufgenommen werden, $\left(2^{\circ}\right)$ diese Elemente vollkommen mit den miitterlichen Blutkörperchen übereinstimmen sehen, $\left(3^{\circ}\right)$ die Schicht, aus welcher diese Blutkörperchen entstammen, als einen Trophoblast-d. h. als ein zunächst epiblastisches Zellenlager-betrachten müssen.

Die Lehre von der Specificität der Keimblätter, die bereits von anderer Seite gewisse Einschränkungen erlitten hat, ist somit in diesem Falle auf den Trophoblast sicher nicht anwendbar. Wir sehen uns genöthigt anzunehmen, da wir den Trophoblast und die den Embryo selbst herausbildenden Zellmasse schon recht früh von einander bleibend getrennt antreffen, dass bereits in sehr frühen Blastulastadien ein Theil des Erblichkeitsplasmas, welches sich sonst erst im Mesoderm zu Blutzellen zu entwickeln gewohnt ist, gewissen Trophoblastzellen mit beigegeben wird. Es ist dies nicht das einzige Beispiel im Thier- und Pflanzenreich einer so äusserst frühen Sonderung sonst erst später abgetrennt werdender Erblichkeitstendenzen. Ich erinnere nur an die Geschlechtszellen einiger Diptera u. s. w.

Kehren wir nun zu unseren grossen Trophoblastzellen zurück, so finden wir von diesen auf den Tafeln I4 und I 5 mehrere 
Beispiele. In Fig. 96 und 97 auf Taf. I4 sowie in Fig. I04, Taf. I 5 sehen wir Trophoblastzellen als direkte Bekleidung der Mesoblastzotten des Chorions auftreten: in Fig. 91-94 und 99IO3 solche, welche tiefer in der Placenta situirt sind. Sie sind hier alle bei derselben Vergrösserung gezeichnet, wodurch sich zu gleicher Zeit herausstellt, dass ihre Grösse innerhalb verhältnissmässig weite Abstände schwankt. Mit zu den grössten gehören die zwei in Fig. 99 abgebildeten. Der Kern des linken befindet sich in unverkennbarer atypischer Mitose: es ist die chromatische Substanz zu verflochtenen Faden ausgezogen, welche cinen bedeutend geringeren Platz innerhalb des Zellkörpers einnehmen, als es der rechtsgelegene Zellkern thut. In letzterem erblicken wir nebenbei eine bedeutende Menge innerhalb der Kernmembran vorkommende nucleolärer Substanz. Der Kern liegt hier in einem nicht geschlossenen Ringe zusammengebogen, an welchem keine oberfächliche Knospung bemerkbar ist. Solche finden wir hingegen in den Figuren 92 und 93 recht deutlich. Ganz glatte, äusserst feingekörnte Kerne sind in $\mathrm{IO}_{2}$ und $\mathrm{IO}_{4}$; solche wo atypische Mitose sich vorbereitet in IOI abgebildet. Die in Fig. 93 äusserlich sichtbare, in anderen Fällen mehr auf das Innere des Kernes sich beschränkende, Knospung führt schliesslich zur Auflösung des Kernes in kleine, aber gleichgrosse Stücke, wie das in den Fig. 9I-94, I00, I02, I04, I07, I09 und auf der Taf. I2, Fig. 72 mit mehr oder weniger Schärfe zu verfolgen ist. Die hier beschriebene Auflösung des Kernes kann rasch, sie kann aber auch langsam von statten gehen. Mehrmals beobachtete ich, dass, wenn der ganze Grosskern sich gleichzeitig zerstückelte, das Zellplasma zur selben Zeit im Zerfliessen begriffen schien, so dass an dieser Stelle eben eine Lakune entstand. Etwas Derartiges sehen wir z. B. in Taf. I 5 , Fig. IOO, IO2 und IO4, während hingegen ein langsamer Prozess, bei welchem nur ein Theil des Kcrnes sich in diese Theilstücke auföst, indem der andere Theil noch in dem alten Zustand beharrt, von den Figuren 9I-94 der Taf. I4 bekundet wird. Das letztere Bild ist selbstverständlich in soweit instructiver, als es den Umwandlungsprozess des Kernes eben zu ertappen Gelegenheit bietet und zu gleicher Zeit darthut (siehe besonders die Figuren 9 I und 94), dass die freiwerdenden Knospen reine Kernderivate sind und dem Zellplasma keine Spur einer Hülle entlehnen. Die freiwerdenden Kernderivate, für welche ich den Namen "Hämatogonien" vorschlage, sind somit Differenzimungsprodukte des Kerninhaltes. Ich kann eine grosse Reihe von Beobachtungen, bei welchen ich mit den verschiedensten Tinctionsmitteln immer wieder dasselbe zu Gesicht bekam, nicht anders deuten als dahin, dass diese "Hämatogonien" direkte Uebergangsstadien zu normalen Blutkörperchen bilden. Sie unterscheiden sich von letzteren durch eine kaum merkbare und nicht immer eintreffende Grössendifferenz (die Hämatogonien scheinen ab und zu ctwass grösser, als die Blutkörperchen, in weitaus den meisten Fällen sind sic aber gleich 
gross), dann auch durch einen selbstständig sich färbenden Einschluss von drei oder mehr kleinen Körnern, die in einigen Fällen mehr solid, in anderen--weit selteneren Fällen-wie kleine vacuolenartige Einschlüsse aussehen. Diese Einschlüsse verschwinden aber gradatim, zu gleicher Zeit wird die Grundfarbe, welche sodann das Körperchen mit dem angewandten Tinctionsmittel annimmt, gleichmässig vertheilt und nähert sich immer mehr zu dem Farbenton mit welchem das nämliche Tinctionsmittel die unzweifelbaren, in benachbarten Lakunen cirkulirenden, Blutkörperchen tingirt. Am schönsten sieht man dies in den drei Figuren 9I, 93 und 94 auf Taf. I 4, wo ich absichtlich drei mit verschiedenen Färbemitteln tingirte Schnitte ausgewählt habe und nun alle die Farbenabstufungen, deren ich soeben Erwähnung that, sichtbar sind. So ist in Fig. 9I der sich auflösende Kern dunkelroth, die Hämatogonien dunkelorange, die Uebergangsstufen zu Blutkörperchen hellorange, die Blutkörperchen selbst gelb. In Fig. 94 ist die Kernfarbe braunviolett, die Hämatogonien bräunlich, die Uebergangsstadien hellbraun und hellgrün, die Blutkörperchen (auch in der mütterlichen Muscularis) dunkelgrün. Endlich ist in Fig. 92 und 93 eine ähnliche Stufenleiter von braun und roth, zu dem hellgrau der Blutkörperchen, unverkennbar. Alle meine zahlreichen Präparate, von denen ich nur einen ganz kleinen Bruchtheil hier abbilde, zwingen zu der nämlichen Schlussfolgerung, dass nämlich bei der Lakunenbildung im Trophoblast (unter zu Grunde gehen des Zellplasmas, welches auseinanderfällt) gewisse Kerne sich in Hämatogonien auflösen, welche sich nach kurzer Frist in Blutkörperchen umwandeln? .

Der hier beschriebene Prozess der Kernverwandlung und dessen Uebergang in Blutkörperchen stimmt theoretisch in soweit überein mit dem, was wir bei der embryonalen Blutbildung von Tarsius constatirt haben, als auch hier eine Kernproliferation am Anfang und ein Blutkörperchen als Kernderivat am Ende steht. Das Stadium der freien Blutmutterzelle wird hier jedoch übergangen: die Hämatogonie repräsentirt eben keinen Zellkörper. Die sichtbaren Veränderungen, welche die Hämatogonien durchlaufen, ehe sie Blutkörperchen geworden sind, lassen sich in eine Linie stellen mit den oben beschriebenen Aenderungen, welche der Kerninhalt der embryonalen Blutmutterzelle zu durchlaufen hat, ehe sie die fertige Form des runden Tropfens, des "Kernes" der typischen

1 Es soll nicht unerwähnt bleiben, dass ich zu dieser Schlussfolgerung bereits gekornmen war als meine Präparatenserie nur noch mit Pikrocarminfärbung in toto behandelt worden war. Die zahlreichen Tinctionsversuche mit anderen Färbemitte!n, welche ich später anstellte, haben mir den Prozess viel deutlicher sichtbar gemacht, auf die Schlussfolgerung jedoch keinen Einfluss mehr ausüben können.

Eine Schwierigkeit bei der Beurtheilung der Hämatogonien ist diese, dass man sich so oft vor die Frage gestellt sieht, ob nicht eher die Einschlïsse jede für sich zu einem Blutkörperchen werden, wie es die geringe Grössendifferenz nicht unmöglich erscheinen liesse. Lange und sorgfältige Vergleichung lässt diesen Zweifel beseitigen. Wenn die Einschliusse (wohl letzte Chromatinreste?) verschwunden sind, ist auch Grössendifferenz nicht mehr wahrnehmbar. 
embryonalen Blutzelle angenommen hat, welch letzterer "Kern" ohne weiteres, wenn er frei wird, ein Blutkörperchen darstellt.

Die Hämatogonienbildung möchte ich betrachtet sehen als einen in zwei Stufen zerlegten Uebergang von dem Kerneinschlusse dieser trophoblastischen Blutmutterzellen zu kernlosen Tarsiusblutkörperchen.

Es verdient in hohem Maasse Beachtung, dass auch der kürzere Weg, wie wir ihn bei der Blutbildung in den embryonalen Gefässen beschrieben haben, in der Placentarwucherung und in den nämlichen, eben beschriebenen Trophoblastzellen unter gewissen Umständen eintritt. Es sind nämlich die Megalokaryocyten äusserst vielgestaltig und ihr Kern sogar proteisch. Anstatt der gleichmässigen Körnung der Fig. IO2 und 92 sind öfters weite Maschen innerhalb des Kernes wahrnehmbar und treffen wir in dem Riesenkern nucleoläre Einschlüsse, welche ganz bestimmt nicht karyosomatischer Natur sind (Fig. 7 I, 73, 91, 105). Diese nucleolenartigen Körper sind verschiedener Grösse: die grössten kommen den Dimensionen der Blutkörperchen gleich. Wenn der Grosskern knospenartig proliferirt, sehen wir, dass öfters jeder Knospe ein grösserer Nucleolus mitgegeben wird (Fig. IOO, IOI, IO3). Diese Knospen haben sodann eine gewisse Aehnlichkeit mit den typischen embryonalen "kern" haltigen Blutkörperchen. Wir haben es hier aber mit einer Kernmembran, nicht wie bei letzteren mit einer Zellwand zu thun.

Wie bei den erwähnten Blutkörperchen, sieht man aber auch hier den nucleolären Einschluss seine Hülle verlassen, und, freigeworden, in Farbe und Grösse so genau mit den circulirenden Blutkörperchen übereinstimmen, dass es keiner Frage unterliegt, ob wir es hier mit einem ähnlichen Blutbildungsvorgang zu thun haben. Den Moment des Freiwerdens habe ich offers beobachtet. Einmal schlüpft der "Kern" durch einen sich ausbuchtenden und öffnenden Fortsatz der Kernmembran nach aussen (Fig. Ioo bei*) oder die Kernmembran löst sich und verschwindet ( $7 \mathrm{I}, 1 \mathrm{k}, 103,105$ ). Durch direkten Uebergang von nucleolärer Substanz in Blutkörperchen wird also von den Megalokaryocyten eben so wohl an der Blutbildung beigesteuert als durch die Zwischenstufe der Hämatogonien. Den direkten Uebergang treffen wir in früheren Placentationsstadien in verhältnissmässig noch ergiebigerem Maasse an, indem sodann Zellenbezirke, die wir nicht als Megalokaryocyten auffassen können und die z. Th. zur mütterlichen Trophospongia gehören, den soeben beschriebenen Prozess regelmässig durchmachen. Es ist in den Placentationsstadien, welchen die Figuren 57-60 angehören, dass sich diese Erscheinung in der Trophospongia geltend macht. Aus dem adenoiden Netz fallen Zellen heraus, deren Protoplasma aufgeklärt wird, deren Kernwand verschwindet und deren nucleolärer Körper zu Blutkörperchen wird. Die sämmtlichen Details sind bei jenen dafür zu schwach vergrösserten Figuren nicht zu verfolgen; die Fig. 7 I zeigt uns 
jedoch den Vorgang bei starker Vergrösserung. An mehreren Stellen sieht man hier einen Nichtmegalokaryocyten sich an der Blutbildung in der eben angegebenen Weise betheiligen : auch die Fig. IOO, IOI, IO3 und I05 bieten dafür Belege.

Aber nicht nur in Trophoblast und Trophospongia findet Hämatopoiese statt, auch in den ausserhalb der Trophospongia sich zwischen den Drüsenresten ausbildenden Gefässbahnen werden gleichzeitig mit dem Zustandekommen des Gefässes Blutkörperchen frei. Und zwar in genau derselben Weise. Es tritt nämlich bei gewissen Zellbezirken der nucleoläre Kerninhalt den Chromatinfädchen gegenüber sehr bedeutend ins Uebergewicht: die betroffenen Kerne finden sich in nächster Nähe der sich hier eben ausbildenden Gefässbahn und, indem die Kernmembran sich auföst, wird der nucleoläre Körper frei (Fig. 75 und 95) und von dem vorbeiströmenden Blute, zusammen mit den in diesem bereits vorhandenen, und von jenen Nucleoli nicht unterscheidbaren, Blutkörperchen, weggeschwemmt. Auch diesen Vorgang habe ich an weit mehr Präparaten, als hier abgebildet sind, mehrfach beobachten können.

An welchem Momente die Hämatopoiese in der Placentargegend anfängt, ist nicht leicht zu bestimmen. Mir will es scheinen, als ob in einem so frühen Stadium, als das der Fig. 70, welches zwischen denjenigen der Fig. I4 und I 5 sich befindet, Blutbildung eben eingesetzt hat. Und es muss näheren Detailuntersuchungen vorbehalten bleiben fest zu stellen, ob gewisse, hier nicht näher zu präcisirende, Vorgänge in den Trophoblastzellen nicht auch schon hämatopoietischer Natur sind. Jedenfalls unterliegt kurz nachher die Betheiligung von Trophoblast und Trophospongia keinem Zweifel mehr. Seinen relativen Höhepunkt erreicht der Prozess in den zwischen den Fig. I 8-26 gelegenen Stadien. Ob er sich auch noch in der reifen Placenta forterhält, ist schwer zu sagen, aber weniger wahrscheinlich.

An Deutlichkeit lässt der Prozess in der Tarsiusplacenta nicht viel $\mathrm{zu}$ wünschen übrig: seine Bedeutung für die Oekonomie des Thieres ist auch nicht zu unterschätzen. Tarsius ist recht zart gebaut und die zahlreichen schwangeren Weibchen, welche gleich nach dem Partus auf's neue beschwangert werden, können eventuellen erschöpfenden Folgen dieser beiden Umstände nicht besser vorbeugen, als eben durch eine kräftige Hämatopoiese, für welche das Knochenmark vielleicht nicht ausreicht.

\section{(b) Blutbildung in der Placenta von Tupaja.}

Die Blutbildung in der Placenta von Tupaja findet unter anderen Verhältnissen statt, als diejenige, welche wir soeben für Tarsius beschrieben haben.

Es finden sich hier nicht die vielgestaltigen Megalokaryocyten, welche Hämatogonien hervorgehen lassen, noch treffen wir 
hier jene eine oder mehrere grosse Nucleolen enthaltenden Kerne an, welche nach dem Zerfall von Kern und Kernmembran als Blutkörperchen weiter leben. Aber dennoch ist es nicht fraglich, dass auch hier in der Placenta Blutkörperchen entstehen und in die Cirkulation aufgenommen werden, welche eben nur als Kernderiwate aufgefasst werden können.

Bei der Besprechung der Placentation von Tupaja auf S. 357 haben wir gesehen, wie der embryonale Trophoblast, und wahrscheinlich auch die mütterliche Trophospongia, eigenthümliche Gebilde hervorgehen lassen, welche am ehesten als Kernklumpen zu bezeichnen wären (Fig. 52, 53 und 54). Diese Kernklumpen müssen als Endstadien einer Kernknospung angesehen werden (cf. Fig. 45-50), welche jedoch nicht in der Weise verläuft, wic wir das bei Tarsius beschrieben haben. Es liegen hier die gleichgrossen Kerne oder Kerntheilstücke (Fig. I06-I09, Taf. I 5) dichtgedrängt beisammen in einer gemeinschaftlichen plasmatischen Matrix. Um dieselbe herum (Fig. I06, IOS) stellen sich öfters andere Kerne derart ein, dass man an die Bildung eines Gefässes oder einer Lakuna denken muss, wovon der sich fragmentirende Inhalt sich eben auf dem Wege befindet Blutkörperchen zu bilden, indem die IVand mit zum Lakunensystem gezogen werden wird. Ohne hier auf die Details der Herstellung der placentaren Cirkulation eingehen $\mathrm{zu}$ wollen, werden wir uns lediglich mit dem Schicksal der Kernklumpen befassen und finden dann, dass eine allmähliche Zunahme der nucleolären Substanz, der chromatischen gegenüber, eine recht charakteristische Erscheinung darstellt (Fig. IOg) und dass schliesslich jedes Kerntheilstück in einen rundlichen, frei werdenden Körper verwandelt, welcher in Grösse und Tingirbarkeit mit den mütterlichen Blutkörperchen genau übereinstimmt. Jener graduelle Uebergang ist besonders in Fig. IO7 ersichtlich und sogar die Farbennuancirung stimmt mit der vergleichbaren Erscheinung, wie wir sie für die auf Tarsius bezüglichen Figuren 9I, 93, 94 der Taf. I4 constatirt haben. Die rothe Kerntinction geht bei der bedeutenden Zunahme der nucleolären Bestandtheile in eine rothviolette über, diese führt durch blau zu grün, welch letzteres in diesem Präparat für die Blutkörperchen (auch jene der Muscularis) charakteristisch ist. Die Loslösung der in dieser Weise zu Blutkörperchen umgeänderten Kernderivaten ist in der Fig. IO7 ebenfalls demonstrirbar. Aehnliche, obgleich weniger complicirte Farbenübergänge zwischen dem Kerntheilstück und dem fertigen Blutkörperchen finden wir in den Figuren IoS und Iog. Nur muss bei dieser Besprechung der placentaren Hämatopoiese von Tupaja der Thatsache Erwähnung gethan werden (die allerdings auch bei Tarsius und Sorex bestätigt wurde), dass die freigewordenen Blutkörperchen einmal ihre markante Tinction beihalten, ein anderes $\mathrm{Mal}$ diese rasch $\mathrm{zu}$ verlieren scheinen und sich dann als gleichgrosse aber farblose Scheibchen vorthun. Dasselbe können wir für die bereits fertigen mütterlichen Blutkörperchen constatiren (vergl. 
Taf. 13, Fig. $87 \mathrm{D}^{\prime}-\mathrm{K}^{\prime}$, rechts). Auch diese zeigen sich, das eine Mal als in toto tief tingirte Körperchen, das andere Mal als schwächer gefärbt und öfters als farblose, nur durch ihren, sich als einen kleinen Kreis abzeichnenden, Aussenrand erkennbare Scheibchen. Dasselbe ist mit den Blutkörperchen innerhalb der embryonalen Cirkulation der Fall, wenn einmal die kernhaltigen nicht mehr angetroffen werden. Auch bei diesen finden sich tingirte und farblose neben einander, wie es die Fig. $87 \mathrm{D}$-K zeigt. Woran diese histochemischen Differenzen zugeschrieben werden müssen, wage ich vorläufig nicht zu entscheiden (vergl. S. 391). Jedenfalls muss auf dieses sonderbare Verhalten besonders Acht gegeben werden, will man sich nicht der Gefahr aussetzen die Erscheinungen der Hämatopoiese falsch zu beurtheilen.

Auch bei Tupaja ist während der Placentation eine Periode vorhanden, wo die Hämatopoiese am ergiebigsten ist, auch hier ist es schwierig diese genau abzugrenzen. In den späteren Schwangerschaftsperioden ist sie gewiss weniger energisch. Dieselbe Frage wie bei Tarsius, taucht auch bei Tupaja auf und wird später einer Specialuntersuchung unterworfen werden müssen: ob wir nämlich nicht bereits bei der ersten Anheftung der wuchernden Trophoblastzellen, gegen die ihres Epithels entblösst werdende Mucosa, Blutkörperchen aus diesen Trophoblastzellen als Kernderivate hervorgchen sehen (cf. Fig. 46-50). Vorläufig lässt sich eine so frïhe Hämatopoiese wohl vermuthen aber noch nicht zwingend beweisen. Wie der Trophoblast sich betheiligt an dem Zustandekommen der oben erwähnten und in ihrem Antheil an der Hämatopoiese gewürdigten Kernklumpen, konnte aus den Figuren 5254 abgelesen werden. Fragmentirung vom anfänglich grösseren Kerne, wenn auch auf andere Weise, als bei Tarsius, muss auch hier auf Grund dieser und anderer Präparate als Vorstufe der Blutbildung angenommen werden.

\section{Vergleichung der bei Tarsius und Tupaja gewon- nenen Resultate mit bei anderen Säugethieren beschriebenen Thatsachen.}

WVie oben (S. 345) bereits erwähnt wurde, haben meine eigene Untersuchungen der Placentation von Erinaceus, Sorex, Talpa, Mus und Lepus mir nicht erlaubt positives über Hämatopoiese in der Placenta dieser Säugethiere zu erschliessen. Ich werde auch jetzt die ron mir bei jenen Thieren beobachteten Thatsachen nicht einer kritischen Sichtung unterziehen. Wohl aber möchte ich hier in der Kürze Erwähnung thun von Arbeiten anderer Autoren, die sich auf die Placentation beziehen, und in welchen, auch wenn sie Hämatopoiese bestreiten, ich dennoch Abbildungen vorfinde, die eine besondere Besprechung verdienen oder welche, 
wenn sie Hämatopoiese befürworten mit den oben von mir beschriebenen Prozessen in Vergleich gebracht werden sollen. In erster Linie werde ich mich hier beziehen auf Arbeiten von Frommel und Nolf für Fledermäuse, von Maximow, Marchand, Masquelin und Swaen für Kaninchen, Duval für andere Nagethiere. Siegenbeek van Heukelom soll ebenfalls noch in der Kürze für ein frühes menschliches Stadium herangezogen werden.

Frommel hat in seiner ausführlichen Arbeit über die Placentarentwickelung von Myotus murinus (88 auf S. 2I) hämatopoietische Erscheinungen auf der Grenze der mütterlichen Trophospongia und des wuchernden Trophoblastes wahrgenommen. Ls ist die Rede von einem verdickten Epithellager, welches an jener Grenze mit wechselnden Erhebungen in eine blutführende Spaltlakuna hineinragt. Nun schreibt er: "Dieses Epithellager scheint eine besondere Bedeutung zu haben. An zahlreichen Stellen desselben sieht man Nester von besonderer Beschaffenheit, die sich als Blutbildungsheerde zu erkennen geben. Innerhalb dieser Heerde nämlich gehen die Epithelzellen als solche zu Grunde, auch ihre Kerne sieht man da, wo der Prozess weiter vorgeschritten ist, nicht mehr. Die Umwandlung der Elemente in Blut vollzieht sich, indem innerhalb des Zellkörpers kleine Kügelchen auftreten, die sowohl durch Boraxkarmin als Safranin dunkelroth gefärbt werden; dieselben vermehren sich, ob durch Theilung oder Neubildung mag dahingestellt bleiben. Im weiteren Verlaufe des Prozesses schwinden diese intensiv roth gefärbten Kügelchen und man gewahrt an ihrer Stelle grössere Kiigelchen, die jene Farbe nicht mehr zeigen und den Farbstoff gar nicht festhalten, sondern in der Blutfarbe erscheinen. In noch späteren Studien sind alle Zellgrenzen verschwunden, die Zellkerne nicht mehr zu sehen und die Masse der Nester besteht aus dicht zusammengelagerten, kernlosen Blutkörperchen normaler Grösse. Ich schildere hier den Vorgang, wie er sich an solch einem Neste in allen diesen rerschiedenen Umwandlungsstadien erkennen lässt, ohne mich im Speziellen auf eine Analyse des sehr complicirten Prozesses einlassen zu wollen, der ein spezielleres Studium erfordern wïrde. Ich konstatire aber die Thatsache der Blutbildung innerhalb dieses Epithellagers mit aller Entschiedenheit...... Nach innen entleert sich das in den Nestern gebildete Blut in die Spaltlakuna, nach aussen verbinden sich diese Heerde nach Vollendung des Prozesses mit den äusseren Uteringefässen."

In einem weiteren Abschnitt derselben Abhandlung kommt er noch einmal auf diese Blutbildung zuriick und schreibt: "Das Epithel dieser Gefässe [beginnt] in äusserst lebhafter WVeise unter Bildung zahlloser, mitotischer Figuren zu wuchern...... Im Innern dieser Zellen sieht man an zahlreichen Stellen merkwiurdige Veränderungen. Das Chromatin der Kerne scheint sich zu Klümpchen zusammenzuballen, die sich in zahlreichen Exemplaren intensiv gefärbt nebeneinander lagern. In anderen Zellen sieht 
man den Kern plattgedrückt an der Wand der Zelle liegen und im Protoplasma des Zellkörpers finden sich zahlreiche stark gefärbte Kügelchen, wie wir sie vorhin im Kerne sahen; wieder in anderen Zellen beobachtet man keinen Kern mehr, dagegen die ganze Zelle erfüllt mit jenen stark tingirten Klümpchen. Dazwischen sieht man in und neben diesen Zellen Körperchen von der Grösse dieser dunkel gefärbten Klümpchen, die sich in ihrer Färbbarkeit und Gestalt wie rothe Blutkörperchen ausnehmen."

Es ist aus den hier zitirten Beschreibungen deutlich, dass die placentare Blutbildung bei der Fledermaus sich eher mit jener bei Tarsius vergleichen lassen würde, welche ausserhalb von Trophoblast und Trophospongia in wuchernden Mucosagefässen stattfindet und welche in den Figuren 75 und 95 abgebildet ist. Eine Betheiligung von Trophoblastzellen an der Hämatopoiese wird von Frommel nicht angegeben. Die Abbildungen, welche er auf seiner Tafel $\mathrm{X}$. giebt, sind äusserst dürftig und ungenügend.

Das Detail der Frommel'schen Angaben weicht in verschiedenen Hinsichten von den meinigen ab, namentlich wo er die neuen Blutkörperchen innerhalb des Zellkörpers auftreten lässt und sie nicht als Kernderivate betrachtet. Dass dennoch die Möglichkeit nicht anzuschliessen ist, dass spätere Untersuchungen auch bei der Fledermaus den Kern und dessen nucleoläre Substanz als die wirklichen Blutbildner werden erkennen lassen, scheint mir aus dem zweiten Zitat hervorzugehen, wo auf das wichtige Zusammenballen einer stark färbbaren Materie innerhalb des Kernes hingewiesen wird (vergl. z. B. das oben für Tupaja beschriebene Verhalten). Diese Materie, welche Frommel Chromatin nennt, habe ich im Vorhergehenden nicht als solche betrachtet. Ob wir es bei Vespertilio mit einem mehr directen Uebergang nucleolärer Substanz in Blutkörperchen zu thun haben, oder ob Hämatogonien als Zwischenstadien auftreten, lässt sich aus Frommel's Beschreibung nicht sicher erschliessen.

Anders verhält es sich, wenn wir die Nolf'sche Schrift (96) über die Placentation der Fledermaus zur Hand nehmen. Er bestreitet die Frommel'sche Auffassung einer placentären Hämatopoiese ausdrücklich (96, p. 623 und 624). Wohl kennt er aus eigener Erfahrung die verdickten Stellen der Gefässwand, wo Frommel die Hämatopoiese hinverlegt, allein Nolf's Auffassung der an dieser Stelle sich abspielenden Prozesse ist eine ganz andere. Ich werde hier nicht in eine ausführliche Besprechung seiner Darstellung treten. Nur will ich bemerken, dass er zwei Gewebselemente beschreibt und abbildet (96, Taf. is und 19), welchen er den Namen "corpuscules de la première et corpuscules de la seconde espèce" verleiht. Von diesen identificirt er die ersteren mit den Leukocyten des mütterlichen Blutes, die letzteren werden dagegen als Abkömmlinge eines zu Grunde gehenden Endothels betrachtet. Mir will es scheinen, dass die Nolf'schen Abbildungen (besonders Fig. 3, Taf. 29) zusammen mit dem 
Frommel'schen Text eine starke Vermuthung erwecken, dass möglicherweise Blutbildung eben vermittelst "IHämatogonicn," sich dennoch bei erneuter Untersuchung in der Wand der trophospongialen Lakunen der Fledermaus wird nachwcisen lassen.

Auch für das Kaninchen, von welchem ich keine umfangreiche Sammlung eigener Präparate besitze, hege ich die Vermuthung, dass Hämatopoiese in der Placenta stattfindet und muss diese Vermuthung wiederum stützen auf Abbildungen und Figuren, welche uns von Maximow (98, p. 68), cin entschiedener Gegner jener Vermuthung, gegeben werden. Die früheren Angaben von Masquelin und Swaen haben weder ihn, noch mich überzcugt. Diese beiden Forscher geben eben keine Abbildungen des von ihnen beobachteten Prozesses, fassen aber ihre Resultate betreffs Blutbildung folgenderweise zusammen (80, p. 43):

"L'épithélium superficiel de la muqueuse utérine et l'épithélium de l'embouchure et du corps des glandes, après avoir subi différentes modifications, finit par se transformer en globules imprégnés d'hémoglobine et identiques aux corpuscles rouges du sang. Cet épithélium constitue aussi de petites cellules sphériques claires contenant un ou plusieurs noyaux, différentes des corpuscules blancs du sang, mais cependant mêlées aux corpuscules rouges...... Cette transformation de l'épithélium est certes un phénomène auquel on croira avec peine. Cependant il faut noter qu'à la périphérie du placenta des globules, des granulations imprégnécs d'hémoglobine se forment comme dans les cellules vasoformatives aux dépens du protoplasma des cellules épithéliales ciliées......Les cellules épithéliales sont fusionnées en une masse protoplasmique multinucléée; les modifications de ce protoplasme constituent à leur tour......les corpuscules imprégnés d'hémoglobine.

"Dans ces différents cas c'est le protoplasme des cellules épithéliales qui se charge d'hémoglobine et se transforme plus ou moins directement en corpuscules isolés identiques aux corpuscules rouges du sang."

Aus dieser Zusammenfassung, sowic auch aus dem ausführlichen Text, lässt sich also ableiten, dass die von Masquelin und Swaen beobachtete Blutbildung, von dem von mir beobachteten Prozesse in diesem Hauptpunkte abweicht, dass für sie die Blutkörperchen Gebilde des Protoplasmas und nicht wie für mich Kernderivate sind, während andererseits die erwähnte "transformation plus ou moins directe" eine entfernte Aehnlichkeit besitzen könnte mit dem für Tarsius beschriebenen doppelten Ursprung der Blutkörperchen, einerseits aus nucleolären Klümpchen, andererseits aus "Hämatogonien," die vielleicht den "petites cellules sphériques claires contenant un ou plusieurs noyaux" ähnlich wären (vergl. noch S. 37I).

Bei Marchand (98, Taf. VIII. Fig. 19) findc ich solche, den Tarsius-hämatogonien nicht unähnliche und Uebergänge zu Blutkörperchen darbietende, Gebilde dem Blute einer Placentar- 
lakuna beigemischt; auch seine Taf. VI. Fig. 7 und 9 wäre für eine ähnliche Auffassung verwendbar.

Auch bei Masius, welcher die Interpretation von Masquelin und Swaen bestreitet, finden wir (89, Pl. VI. Fig. 6-8 und Fig. I4) dennoch Abbildungen, welche für das Vorkommen von Hämatogonien in der Kaninchenplacenta $\mathrm{zu}$ sprechen scheinen. Ihre Fig. 7 macht sogar die Bedeutung dieser Hämatogonien als Kernderivate wahrscheinlich, während Masius im Text sagt (89, p. I 5): "Il est fort difficile de distinguer un corps protoplasmique autour de ces noyaux......La zone hyaline entourant le cordon chromatique de ces éléments répond-elle à la membrane nucléaire ou au corps protoplasmique des leucocytes? (p. I6)...... Pour résumer ce que nous savons sur ces éléments singuliers au stade que nous étudions, nous dirons qu'ils proviennent d'une transformation des leucocytes avec lesquels ils présentent beaucoup de stades de transition."

Es ist jedenfalls wohl kaum zu bezweifeln, dass das was Masius hier für das Kaninchen beschreibt, übereinstimmt mit den von Nolf (95) für die Fledermaus erwähnten und oben besprochenen "corpuscules de la première et de la seconde espèce." Nur soll noch darauf hingewiesen werden, dass, während Nolf diese Körperchen zum Theil als degenerirende Endothelzellen auffasst, Masius ausdrücklich sagt (89, p. I7): "Il est impossible de rattacher l'apparition de ces éléments à une dégénérescence de l'endothélium."

Weiterhin sieht Masius dieselben Körperchen später noch einmal, und dann in Gefässwandzellen mit Riesenkernen entstehen. Von letzteren sagt er $(89$, S. 30): "Les noyaux sont extrêmement grands......̀̀ côté de ces énormes noyaux, on en voit souvent de plus petits apposés immédiatement l'un contre l'autre; enfin toutes les formes de transition peuvent s'observer entre ces deux stades extrêmes: un très gros noyau et deux ou trois noyaux plus petits mutuellement accolés. La forme de ces noyaux est assez remarquable par son irrégularité provenant de bosselures à sa surface ${ }^{1 .}$

Hier nimmt auch Masius eine Umbildung dieser Kerne an und indem gewiss ein Theil des Prozesses degenerativer Art ist (wie wir das auch in der Tarsius-placenta beschrieben), sagt er dennoch folgendes $(89$, p. 3I) : "A ce stade......en succède un autre où ces formations chromatiques se répandent dans la cavité vasculaire par désagrégation du protoplasme endothélial ambiant." Er nimmt also auf Grund des von ihm Wahrgenommenen an, dass diese mit unseren Hämatogonien vergleichbaren Körperchen vom Gefässepithelium gebildet und in dem Gefässlumen frei werden. Er ist hierin anderer Meinung, als der jetzt von uns zu besprechende Autor A. Maximow (97).

1 Vergleiche z. B. Fig. 93, 100, 101. 
Letzterer hat mit ausgezeichnet conservirtem Material gearbcitet und giebt schöne farbige Abbildungen. Auf seine Tafel VI. Fig. 8 zeichnet er eine Stelle, die wohl mit der oben von Masius gemeinten übereinstimmt. "Hämatogonien" sind hier wieder deutlich wahrnehmbar, nach Maximow sind es aber Leucocyten und werdcn dieselben vom Gefässendothel (in dem wir fragmentirende Riesenkerne wahrnehmen) aufgenommen und resorbirt.

Aber auch die zweite, mehr directe Art des Entstehens von Blutkörperchen in der Placenta ist von Maximow wahrgenommen, obwohl er die Bilder (Fig. 2, IO Bk, I 5 c) anders interpretirt. Er schreibt: "Ausserdem befinden sich in diesen Zellen ${ }^{1}$......eine grosse Menge von Gebilden, von denen die grössten ihrer Form nach ausserordentlich den Erythrocyten des mütterlichen Blutes gleichen und durchaus dieselben Farbenreactionem aufweisen...... Auf welche Weise die Erythrocyten in den Leib der Glycogenzellen gelangen können, bleibt völlig unaufgeklärt, dass aber in den letzteren wirklich oft Erythrocyten vorgefunden werden, das ist bereits von einigen Autoren beschrieben worden, so z. B. von Masquelin und Swaen und Masius. Die ersteren haben diese Thatsache, ebensowie das häufige Auftreten von Blutkörperchen in den degenerirenden Uterinepithelmassen ${ }^{2}$ als den Ausdruck einer hämatoblastischen Function der Placenta aufgefasst. Man muss aber doch erwägen, dass die fraglichen, so sehr den Erythrocyten ähnlichen Gebilde möglicherweise ...... einfach ...... Tropfen von einer Substanz, welche in der Glycogenzelle selbst entstanden ist, sein können."

Es muss weiteren Untersuchungen vorbehalten bleiben, zu entscheiden, ob ich Recht hatte zu vermuthen, dass die oben citirten Figuren und Auseinandersetzungen das Vorkommen von Hämatopoiese in der Kaninchenplacenta mit zu bew'eisen helfen.

Es erübrigt zum Schluss noch des Ausspruches Duval's Erwähnung zu thun. Er bestreitet die Auffassung von Masquelin und Swaen über Blutbildung in der Kaninchenplacenta auf S. 39-45 seiner grossen Arbeit (92), und erinnert zu gleicher Zeit daran, dass auch Strahl (88, S. 54) diese Hämatopoiese nicht hat constatiren können. Aber auf S. 400, wo er eine Darstellung der Placentation von Meriones giebt, erwähnt er, wie in den Riesenzellen der Trophoblastwucherung, welche bei dieser Gattung ganz besonders gross werden (vergl. seine Fig. I 86 und I 87), ein Einschluss von Leukocyten immer zu constatiren ist. Diese Leukocyten sehen unseren "Hämatogonien," sowie den fraglichen "corpuscules" von Nolf, Masius und Maximow ganz täuschend ähnlich, werden aber von einigen der letzteren Autoren nicht mit derselben Sicherheit, wie es Duval thut, mit Leukocyten identificirt. Duval sagt (92, S. 400) "Évidemment personne ne songera à voir là des leucocytes qui

1 Es sind hier andere Zellen gemeint, als die eben erwähnten, Hämatogonien liefernden Endothelzellen.

2 Vergleiche oben S. $3+8$. 
auraient pris naissance dans les cellules géantes, mais bien des leucocytes qui ont pénétré, en vertu de leurs mouvements propres, dans. ces cellules." Es wird diese aprioristische Schlussfolgerung mit dem raschen Zerfall dieser Riesenzellen in Verbindung gebracht. Die Möglichkcit, dass beide Erscheinungen hämatopoietische Bedeutung haben können, obgleich von Duval verneint, darf eben nicht aus dem Auge gelassen werden. Eine Reihe von Präparaten von Meriones, welche Duval mir freundlichst zur Verfügung stellte, beweisen mir dass, falls eine placentale Hämatopoiese hier stattfindet, sie sicherlich weniger scharf $z u$ demonstriren ist, als bei Tarsius und Tupaja.

Was die Mäuseplacenta betrifft, so leugnet Duval (92, S. 435) ebenfalls das Vorkommen von Hämatopoiese, während Frommel in einer an seiner Fledermausentwickelung vorhergegangen Arbeit (83) diese eben bei Mäusen zu beweisen geglaubt hat. Die Behandlung der Schnitte mit Indigocarmin und Boraxcarmin und nachher mit Oxalsäure, hatte ihm dabei gute Dienste geleistet. Er hat aber die so in Riesenzellen entstandenen Blutkörperchen als Protoplasmagebilde, nicht als Kernderivate bezeichnet. Sie werden im Blute frei dadurch, dass die Wand der sie einschliessenden Zellen sich auflöst und stellen dann gleich kernlose Blutkörperchen dar. Frommel hat sich weiter zu dem Ausspruch verleiten lassen, dass auch kernhaltige embryonale Blutkörperchen in ähnlicher Weise in der Placenta entstehen sollen. Bemerkenswerth ist dabei, dass es ilın uiberrascht hat, dass die Tinctionsmittel dem "Kern" der embryonalen Blutkörperchen die Farbe verleihen der mütterlichen Blutkörperchen, während der Leib der ersteren ungefärbt bleibt (vergl. S. 365 und 392). Da die grüne Farbe, welche mit den von ihm gebrauchten obengenannten Reagentien erzielt wird, von Frommel dem Hämoglobin zugeschrieben wird, so schliesst er, dass letztere durch die Oxalsäure auf der Oberfäche des Kernes einen Niederschlag bildet und dadurch dessen Färbung hervorruft.

Zum Schluss muss hier erwähnt werden, dass auch in der frühen menschlichen Placenta Gebilde erwähnt werden, betreffs welcher es sich zweifellos lohnen würde einen engeren Vergleich mit den hier erwähnten, von verschiedenen Forschern beobachteten und dennoch fraglich gebliebenen und von mir bei Tarsius als Hämatogonien bezeichneten, Gebilden an zu stellen. Siegenbeek van Heukelom beschreibt $(98$, S. 23$)$ und bildet auch ab, bei der von ihm studirten und schön conservirten jungen menschlichen Keimblase, eigenthümliche Körperchen, welche in der Placenta dem Blute beigemischt sind. Er schreibt: "Die rothen Blutzellen verdienen kaum eine Erwähnung, sie sind normal, vom Formalin wunderschön fixirt. Die kernführenden Elemente aber sieht man in der Blutbahn in viel grösserer Zahl, als sonst. In den Ecken und Ausbuchtungen der vielgestalteten Blutbahn häufen sie sich an, wie auch normale Leukocyten sich gern bei schwacher Blutströmung dort aufzuhalten pflegen. 
Man vermisst sie aber nirgends und ihre Zahl ist überall grösser, als die normale. Die Kerne sind auch nicht alle so gestaltet, wie man sie bei polynucleären Leukocyten findet. Oft kommen vollständig abgeschnürte Viertheilungen, wie bei Tetrakokken vor, was jedenfalls an Leukocytenkerne nicht oft zu finden ist. Es kommen auch Kerne vor, die sich im Centrum nicht färben. Oft ist ein Protoplasmakörper nicht wahrnehmbar..... Für etwas Pathologisches kann ich sie nicht halten, und ich könnte die Möglichkeit aufstellen, dass hier ein Prozess sui generis vorläge."

Wichtig ist, dass van Heukelom einen direkten Vergleich mit Leukocyten für unzulässig hält. Seine Beschreibung passt genau fuir die oben beschriebenen Hämatogonien. Auch da finden wir, dass die farbigen Einschlüsse oft die eigenthümliche Viertheilung zeigen (Fig. 93, I00), während wieder andere van Heukelom'sche "Kerne, die sich im Centrum nicht färben" (Fig. 9I, $93 A$, 94 und IO2) enthalten.

Zum Schluss möchte ich noch hinweisen auf Taf. I3, Fig. 89, 90, wo ich die erwähnten Gebilde aus der Kaninchen- und aus der menschlichen Placenta bei derselben Vergrösserung, wie die daneben gezeichneten Tupajablutkörperchen abbilde, und zwar nach vorzüglich conservirten Präparaten, die ich Sedgwick Minot und van Heukelom verdanke. Das Kaninchenpräparat zeigt, dass die in Frage stehenden Körperchen Zellen mit fragmentirtem Kern ähnlich sind, Fig. $89 a$ ist als Ausgangsstadium zu betrachten, Fig. $89 b$ als Zwischenstadium, Fig. $89 c-f$ repräsentiren Endstadien, wie sie mit den Bildern von Masius und Maximow übereinstimmen. Von den Stadien $a$ und $b$ beobachtete ich recht zahlreiche Fälle, sodass ich nicht anstehe diese Entwickelungsreihe als richtig anzunehmen. Da nun bei dem Kaninchen auch öfters (Fig. S9 $g-i)$ Austreten der chromatophilen Inclosa wahrgenommen wurde und diese in Grösse mit den kleinsten Blutkörperchen ${ }^{1}$ übereinstimmen, die ihrerseits sehr oft den Farbstoff, jedoch in recht schwachem Maasse, aufgenommen haben, so würde, wenn sich den Uebergang dieser beiden in einander beweisen liesse, der Fall beim Kaninchen so liegen, dass auch wieder bei diesem Prozesse eventueller Blutbildung, das kernlose Blutkörperchen als Kernderivat $\mathrm{zu}$ betrachten ist. Somit wäre doch keine absolute Identität mit den Tarsius-Hämatogonien gegeben, welche eben in toto jede in ein Blutkörperchen umwandeln und nicht ihre farbige Inclosa ausstossen, sondern resorbiren. Hingegen könnte von diesen hingewiesen werden, dass sie eben nicht als modificirte Zellen, sondern direct als Kernderivate zu betrachten sind. Ausserdem sind die Tarsius-Hämatogonien merklich kleiner, als die den Blutkörperchen

1 Die recht beträchtliche Grössendifferenz, welche sich zwischen den vorlreflich conservirten rothen Blutkörperchen dieses selben Durchschnittes beobachten lässt und mit der Camera in Fig. 89 sorgfaltigst wiedergegeben wurde, verdient besondere Aufmerksamkeit. 
bedeutend an Grösse übertreffenden Gebilde des Kaninchenplacentarblutes. Andererseits ist zwischen dem fertigen kernlosen embryonalen Blutkörperchen und dessen allerfrühestem Ausgangsstadium (Taf. I3, Fig. I) ebenfalls Kernfragmentirung eingeschoben, welche da selbst jedoch noch gefolgt wird von einer zeitweiligen Selbstständigkeit als "kern"haltiges embryonales Blutkörperchen. Diese letzte Phase wäre bei der Blutbildung in der Kaninchenplacenta-falls sich die obige Darstellung als richtig erwieseübersprungen worden. Ein Vergleich der auf Taf. I 3 gegebenen Fig. $89 a-i$ vom Kaninchen und Fig. 87 A-I von Tupaja, wird den hier nur angedeuteten Gedankengang noch schärfer zu fassen helfen.

Beim menschlichen Präparate sah ich Vieles von dem, was sich beim Kaninchen wahrnehmen lässt, nicht. Es muss also dahin gestellt bleiben, ob hier die fraglichen Körper, auch wie es van Heukelom will, als Zellen aufzufassen sind oder ob diese einen engeren Vergleich mit den Tarsius-Hämatogonien zulassen. Die Frage ist gewiss eine complicirte; es will mir aber scheinen, dass eine erneute, speziell auf sie gerichtete Bearbeitung von Kaninchen, Fledermaus und Mensch, welche auf den Resultaten fussen würde, wie sie oben für die Nabelblase und für die Placenta von Tarsius und Tupaja gewonnenn sind, lohnend zu werden verspräche.

\section{Vergleichung der hier verzeichneten Resultate mit der Literatur über die Bildung von Blutkörperchen.}

Die in den vorhergegangenen Capiteln dieser Arbeit vorgebrachten neuen Thatsachen haben zu einigen theoretischen Folgerungen Veranlassung gegeben, welche vorläufig ziemlich isolirt darstehen und die ich eben deswegen in der Kürze mit gewissen Angaben anderer Autoren in Vergleich bringen möchte.

Kurz zusammengefasst sind die Thatsachen:

(a) Das Entstehen von Blutkörperchen, sowohl in dem trophospongialen, als in dem trophoblastischen Theil der Placenta von gewissen Säugethieren.

(b) Das Freiwerden in dem mütterlichen Blutstrom von in embryonalem Gewebe dieser Thiere gebildeten kernlosen Blutkörperchen.

(c) Die Identität dieser neuentstandenen Blutkörperchen mit einem Theil des Kerninhaltes gewisser Blutmutterzellen.

(d) Die allmähliche Umänderung der embryonalen kernhaltigen Blutkörperchen, welche in der Gefässbahn der erwähnten Säugethierembryonen circuliren, und zwar so, dass, wenn diese Umänderung ihren Abschluss gefunden hat, die kernlosen Blutkörperchen des reifen Fötus sich einerseits mit jenen der Mutter, 
andererseits wieder mit einem Theil des Kerninhaltes der früheren embryonalen Entwickelungsstadien identificiren lassen.

Für den sub $a$ erwähnten Prozess haben wir bereits in Cap. IV. den Vergleich mit den Resultaten früherer Autoren zu Stande gebracht.

Das sub $b$ erwahnte Factum ist durch die in Cap. I. dargestellte, detaillirte Entwickelungsgeschichte zweier Säugethierplacenten bewiesen worden. Es ist die Herkunft der Bluthörperchen aus embryonalem Trophoblastmaterial an der Hand der vorgefuilırten Präparate, welche in der Utrechter Sammlung zur beliebigen Controlle seitens anderer Forschern sorgfältig aufbewahrt werden, nicht wohl zu bezweifeln.

Es bestehen über ähnliche Fälle, wobei Formelemente des Embryos dem mütterlichen Blutstrom einverleibt werden, so viel ich weiss, keinerlei Angaben in der Literatur. Dennoch lässt sich die Entstehung dieses Prozesses mittels Selection nicht schwieriger begreifen, wie sonstige Anpassungen. In diesem Falle ist sogar der neue Vorgang, sowohl der Mutter, als dem Embryo vortheilhaft: erstere sieht die Zahl ihrer Blutkörperchen vermehrt auf Kosten des in ihr zeitweilig als Parasit hausenden Embryos, was auch ihrer eigenen Athmung und Stoffwechsel zu Gute kommen kann; letzterer bekommt, wenn die Zahl jener mikroskopischen Transportmittel zugenommen hat, selbstverständlich mehr Sauerstoff und kann besser ernährt werden.

Es liegt vor der Hand, dass dieses Uebertreten von Formelementen, die sich in letzter Instanz vom Furchungskern des kindlichen Organismus herleiten lassen, in das mütterliche Gefässsystem-und zwar in so bedeutender Anzahl-an die als Telegonie zusammengefassten Erscheinungen denken lässt. Ich muss hier die grösste Vorsicht anempfehlen?.

Hingegen scheint die kräftige Betheiligung des Trophoblastes an der Blut- und Lakunenbildung dazu bestimmt, um auf eine andere Reihe längst bekannter, aber noch heute zu lebhafter Controverse Veranlassung gebender Erscheinungen, ein helles Licht zu werfen. Ich meine die eventuelle Rolle von Riesenzellen bei der Blutbildung der Säugethiere.

Ausgezeichnete Histologen stehen in dieser Frage einander schroff gegenüber. IVir haben bereits oben (S. 367) gesehen wie diese Riesenzellen mit proliferirendem Kern, welche nur bei den kernlose Blutkörperchen besitzenden Säugethieren vorkommen, von Kölliker, Neumann, Foa, Kuborn u. A. als aktive Elemente bei der Blutbildung gedeutet werden, denen z. Th. die Rolle von

I Der bekannte, jedoch nicht ganz sicher gestellte und von Darwin vorgefühte Fall von Telegonie (die zebraisch gestreifte Stute Lord Norton's) betrifft eine Säugethierart bei welcher Blutbildung in der Placenta seitens der embryonalen Trophoblastzellen sicherlich nicht stattfindet. Bei der diffusen Placentation, wie sie z. B. das Pferd, das Schwein, Nycticebus und andere Lemures besitzen, ist also eventuelle Uebertragung von kindlichen Eigenschaften in den mütterlichen Organismus auf diesen IVege iöllig ausgeschlosscn. 
Blutmutterzellen zukommt. Von Löwit, van der Stricht, Kostanecki u. A. wird deren Betheiligung an der Blutbildung mit gleichem Nachdruck geleugnet. Es finden sich diese Formelemente in dem Knochenmark, der Milz, der Embryonalleber und der Decidua. Wie auf S. 367 erwähnt wurde, ist ein so vorzüglicher Cytologe, wie Flemming, ihrer Bedeutung bei der Blutbildung wohl am energischsten entgegengetreten. Er hat sie sogar bezeichnet als "abnorm ausgewachsene und functionslose Lymphoidzellen die ihre Entstehung nur den eigentümlichen Stoffwechselbedingungen in den wenigen Organen verdanken in denen sie vorkommen."

Es erscheint mir fraglich ob Flemming diesen Ausspruch auch aufrecht erhalten wïrde, für einen fast ausschliesslich aus Riesenzellen aufgebauten Gewebsbezirk, wie es die placentale Trophoblastwucherung von Tarsius ist.

Abnorm ausgewachsen sind die auf Taf. I4 und I 5 stärker vergrösserten, auf Taf. 7-I I noch leichter übersichtlichen Gebilde allerdings. Funktionslos können sie hier schon deswegen nicht sein, weil sie das Gewebskissen $\mathrm{zu}$ bilden angefangen haben, welches in Fig. 25-27 bei schwacher Vergrösserung, in Fig. 67 stärker vergrössert, über das Niveau der Uteruswand nach innen zu sich erhebt und bald als ein lakunenreiches, spongiöses Organ mütterliches Blut in nächster Nähe von embryonalen Nabelgefässverzweigungen bringen wird. Die Riesenzellen verdanken ihr Vorkommen an dieser Stelle nicht "nur eigentümlichen Stoffwechselbedingungen," sondern sie sind eben die geeignetesten Elemente für eine rasche Herstellung eines umfangreichen Blutlakunensystems.

Und wenn nun ausserdem die Präparate uns belehren, dass neben der zu dieser Lakunenbildung nöthigen Resorptionserscheinungen, Zelldurchlöcherungen, u. s. w., auch noch eine positive und unleugbare Blutbildung seitens dieser Riesenzellen zu Stande gebracht wird, so können wir uns des Gedankens nicht entwehren, dass vielleicht auch in andern Fällen der Flemmingsche Ausspruch den Riesenzellen nicht gerecht wird.

IVo ausserdem so viele Beobachter für ihre Betheiligung an der Blutbildung Belege und Abbildungen gebracht haben, die doch nicht ohne die zwingendsten Gründe alle als falsch und unrichtig bei Seite geschoben werden können, da wird es sich empfehlen in der Sache keinen definitiven Entschluss zu fassen ohne eine ins feinste Detail gehende Nachprüfung, welche zur selben Zeit die frühe Tarsiusplacenta, wo die Verhältnisse so ausserordentlich deutlich sind, zum Vergleich heranzieht.

Noch weniger kann auf die Riesenzellen von Tarsius die Hypothese van der Stricht's Anwendung finden, nach welcher diese Elemente die Rolle erfüllen ausgestossene Kerne, welche bei dem Uebergang der kernführenden Erythroblasten in kernlosen Erythrocyten frei werden, in sich auf zunehmen und zu verarbeiten. Eben deswegen schien es ihm erklärlich, dass sie nur zur Ent- 
wickelung kommen bei kernlose Blutkörperchen führenden Säugethieren, indem sie bei Sauropsiden fehlen.

$\mathrm{Da}$ in der Trophoblastwucherung von Tarsius keinerlei ihren Kern durch Ausstossung verlierende Erythroblasten gefunden werden, so ist diese Function bei jener Gattung ausgeschlossen und es bliebe nur noch die Möglichkeit zu diskutiren, ob eventuell mütterliche Blutkörperchen, wie sie da in den Trophoblastlakunen cirkuliren, von den Riesenzellen festgelegt und verdaut würden.

Es kommt mir vor, dass eine solche Aushilfshypothese nur dann diskutirbar wäre, wenn wir innerhalb der Riesenzellen öfters Blutkörperchen beobachteten. Dem ist aber nicht so. Und wir müssten ferner noch anerkennen, dass Blutkörperchen der Mutter (deren Entwickelung aus Hämatogonien auf S. 370 wahrscheinlich gemacht wurde) sich umgekehrt zunächst in den Lakunen in Hämatogonienartige Gebilde umwandelten, um sodann in eine Riesenzelle einzutreten und sich hier in den Kern anzusammeln.

Das gezwungene und unwahrscheinliche dieser Vorstellung ist einleuchtend, die Auffassung, wie sie oben gegeben wurde, scheint mir rationeller und richtiger. Besonders auch noch deswegen, weil es dann unerklärt bliebe warum solche zur Kernbildung zusammentretenden Hämatogonien nicht in einem umschriebenen Plasmabezirk gefunden werden, sondern gerade da, wo das umgebende Protoplasma immer die deutlichsten Zeichen der Dehiscenz trägt (Fig. 72, 74, 93, 94, 100, 102, 104).

Die von van der Stricht ausgesprochene Hypothese, dass die ausgestossenen Kerne der Erythroblasten ohne Weiteres zur Vergrösserung des Kerns der Leukocyten, resp. der Riesenzellen verwendet werden sollen (91, p. 99, fig. 49-5I), wird auch von Kostanecki zurückgewiesen (92, S. 3 I 8). Ich möchte daraus schliessen, dass die Beobachtungen von van der Stricht und von mir selbst sich gegenseitig zu stützen bestimmt sind, auch wenn unsere Interpretation momentan eine sehr abweichende ist. Eine eingehende Diskussion wäre hier jedoch voreilig, da seine eben erwähnten Abbildungen sich auf embryonale Kaninchenleber, die meinigen auf Tarsiusplacenta beziehen. Dennoch sind gerade die van der Stricht'schen sorgfältigen Zeichnungen für mich so wichtig, weil sie die unutnterbrochone Kette anerkennen und bildlich darstellen, welche zu finden ist zwischon don Kornmatorial einer Riesonzelle und den freien im Blut mitcirculirenden, von einer embryonalen Blutmutterzelle ausgestossenen Korn, welchor nach meinen Auseinandersetzungen auf S. 36I-66 und meiner Fig. $87 \mathrm{E}-\mathrm{K}$ eben nicht $\mathrm{zu}$ Grunde geht,' sondern ein wirkliches Bhttkörperchen darstellt. Wo ich oben den Uebergang der aus dem Kerne hervorgehenden Hämatagonien in Blutkörperchen hervorhob, habe ich ebenso die Nichtbetheiligung des Protoplasmas befürwortet und bewege mich in diesem Punkte auf paralleler Bahn mit den van der Stricht'schen Resultaten.

Ich möchte dies noch besonders hervorheben, weil die von 
mir angenommene Nichtbetheiligung des Protoplasmas in schroffer Gegensatz steht mit der Beschreibung und den Abbildungen welche Denys $(86$, Pl. I.) von einer endogenen Zellbildung in den Riesenzellen des Kaninchen-Knochenmarkes giebt. Dieser Gegensatz ist jedoch nur scheinbar. Ich kann nämlich aus seinen recht deutlichen und grossen Figuren nichts anderes herauslesen, als dass seine sogenannten "cellules-filles" eben reine Kernderivate sind, die mit meinen Hämatogonien in Allem übereinstimmen, während die sogenannte Umhüllung mit Protoplasma einfach die Wiederherstellung der vielleicht zeitweilig aufgehobenen Kernmembran bedeutet. Wird man doch auch nicht bei der Mitose sagen, dass die Chromosomen bei der Rückkehr zum Ruhestand sich von Protoplasma umgeben! Weiteres hierüber findet man in der Tabelle, S. 393. Die Denys'schen Abbildungen lassen mich eben nicht daran zweifeln, dass sich eine Verständigung anbahnen wird, wodurch die Blutbildung im Knochenmark und jene in der Placenta in demselben Lichte betrachtet werden können. Man hüte sich jedoch auch hier vor Verallgemeinerung. Wenn es sich vielleicht herausstellen wird, dass im Knochenmark erwachsener Säugethiere Hämatogonien, die bald darauf in kernlose Blutkörperchen übergehen, gebildet werden, so ist damit noch nicht gesagt, dass sich in der Leber und in anderen Geweben von Embryonen nicht auf andere Weise aus grossen Zellen mit fragmentirendem Kerne, kernhaltige Blutkörperchen herausbilden, die eben ein anderes Zwischenstadium zu den kernlosen darstellen, als es die Hämatogonien sind ${ }^{1}$. Eine solche Erscheinung in der Leber liesse sich direct vergleichen mit dem, was wir auf der Nabelblase beobachten und in Fig. 78-82 für Tarsius und Sorex bildlich dargestellt haben.

Es soll hier zum Schluss auch noch der Heidenhain'schen Betrachtungen über die Function der Riesenzellen $(\mathbf{9 4}, \mathrm{S}$. 6I3) Erwähnung gethan werden, da er wieder einer anderen Meinung ist, als van der Stricht. Dennoch möchte ich das von mir in der Tarsiusplacenta Vorgefundene auch mit den Resultaten Heidenhains in Vergleich bringen. Zunächst lesen wir bei ihm: "Aus dem Leibe der Riesenzellen werden ferner ganz gewiss niemals Leucocyten abgegliedert; die kleinen Kerntheilchen, welche sich ab und zu einmal von dem Hauptkern isoliren, haben niemals ein eigenes Mikrocentrum neben sich; ich wüsste also nicht wie da Lymphzellen entstehen sollten." Ich entnehme aus dem citirten, dass Heidenhain in der Interpretation der soeben erwähnten Denys'schen Figuren auf meiner Seite stehen wïrde: lege dabei viel Gewicht auf das hier von ihm anerkannte Vorkommen isolirter Kernderivate neben dem Hauptkern. Sind dies nicht wieder vielleicht unsere Hämatogonien? Heidenhain sagt ferner noch :

1 Könnte vielleicht die Reihe: Riesenzelle-Blutmutterzelle-kernloses Blutkörperchen einen in erster Linie embryonalen, die Reihe: Riesenzelle-Hämatogoniekernloses Blutkörperchen hingegen einen bei erwachsenen Säugethieren parallelen Prozess darstellen? 
"Die Aufnahme und Umarbeitung eiweissartiger Körper, welche aus dem Lymph- und Blutstrom entnommen werden und wieder dahin zurückkehren, ist die einzige Function der Megakaryocyten ...... IVir haben einen deutlichen Hinweis darauf, dass die Riesenzellen etwas mit der Blutbildung zu thun haben, und wie ich meine haben sie einen Einfluss anf die Zusammensetung des Blutplasmas ......es ist im übrigen Sache der Physiologen diese Angelegenheit weiterhin aufzuklären."

Sodann greift Heidenhain den Flemming'schen Ausspruch über die untergeordnete Bedeutung der Riesenzelle, gegen welchen auch ich oben (S. 384) Front gemacht habe, heftig an und schliesst folgendermasse: "Diese Zellen sind allerdings für unsern IVitz vor der Hand ziemlich unerreichbar, sic aber als unbequem einfach bei Seite zu schieben, das, meine ich, sei nicht statthaft. Nein, gerade wenn es gilt, allgemeine Anschauungen über den Bau der Zellen zu erwerben, müssen solche Fälle mit herangezogen werden, welche gegen unsere Neigung zu schematisirenden Auffassungen Zeugniss ablegen. Sollte wirklich die Natur so complicirte Gebilde ersinnen, wie es die Riesenzellen sind, nur um damit bedeutungslose Spiele zu treiben?"

Dieser inhaltsreiche Satz lässt mich hoffen, dass es den Histologen vielleicht gelingen wird (wo jetzt Blutbildung auf Kosten des polymorphen Kernes der Riesenzelle in der Tarsiusplacenta wohl nicht mehr zu leugnen ist) um auch die Riesenzellen des Knochenmarks definitiv als ähnliche hämatopoietische Herde anzuerkennen.

Die eben erwähnten Punkte haben uns hinüber geführt in das Grebiet der oben sub $c$ und $d$ zusammengefassten Erscheinungen, und wir haben gesehen wie das Mikroskop, sowohl van der Stricht als mir und auch noch wohl anderen Untersuchern Bilder gezeigt hat, welche eine Brücke schlagen zwischen Elementen, die wir frei im Blut antreffen einerseits und dem Inhalt gewisser, in vielgestaltiger Weise proliferirender, Zellkerne.

Es bedarf diese Erscheinung noch eine Besprechung von einem allgemeineren Gesichtspunkt aus.

Die gegenwärtige Lehre von Zelle und Kern, deren Ausbau wir neben recht zahlreichen Spezialarbeitern hauptsächlich van Beneden, Boveri, Flemming, Guignard, Henneguy, Hertwig, Strasburger, de Vries und IVilson verdanken und iiber deren IVechselverhältniss die wohlbekannten Weismann'schen Arbeiten so viele Frucht bringende Controversen angeregt haben, hat uns auf einen Punkt geführt, wo eben der Ausspruch: es seien die kernlose Säugethierbluthörperchen nicht als modificirte Zellen, sondern als Kernderivate aufzufassen, nicht mehr so heterodox, so unwahrscheinlich klingt, wie sie es vor vielleicht zehn Jahren gethan haben würde. Wohl ist die Bedeutung des Kernes und des in ihm enthaltenen Chromatins für die Erscheinungen der Erblichkeit in ein ganz neues Licht getreten und sehen wir in Folge dessen in dem Kern in erster Linie den Träger mehr oder weniger verwickelter Erblichkeitstendenzen, 
wohl scheint somit die Vorstellung, dass eben solche Erblichkeitssubstanz auf einmal zu einem kurzlebigen Blutkörperchen herabgesetzt werden konnte a priori verwerflich, aber daneben ist zu beachten, dass auch im Kern neben dem Chromatin noch anderes Material enthalten ist und dass neben die der Erblichkeit dienenden mitotischen Prozesse, noch andere Vorgänge sich innerhalb des Kernes abspielen. Eine dieser letzten ist u. A. die Bildung neben und unabhängig rom Chromatinnetz eines (plasmosomatischen!) Nucleolus oder mehrerer Nucleolen. Ich möchte hier ein kurzes Citat aus dem vortrefflichen Wilson'schen Handbuch einschalten. Er schreibt (96, p. 93)-allerdings mit Bezug auf der Eizelle-:

"The physiological meaning of the nucleoli is still involved in doubt. Many cases are, however, certainly known, in which the nucleolus plays no part in the later development of the nucleus, being cast out or degenerating in situ.... The evidence is very strong that the nucleoli do not contribute to the formation of the chromosomes, and that their substance represents passive material, which is of no direct further use.....We can hardly doubt....that the nucleoli... .are accumulations of by-products of the nuclear action derived from the chromatin either by direct transformation of its substance or as chemical cleavage products or secretions."

Bezüglich des Verhaltens der plasmosomatischen Nucleolen verschiedenen Tinctionsmitteln gegenüber äussert Wilson sich folgendermassen $(96$, p. 24$)$ :

"The true nucleoli or plasmosomes are of spherical form, and by treatment with differential stains such as haematoxylin and eosin are found to consist typically of a central mass staining like the cytoplasm surrounded by a shell, which stains like chromatin."

Ihre chemische Zusammensetzung lässt sie als Paranuclein (Pyrenin, Schwarz) erkennen, eine Verbindung oder Reihe von Verbindungen von Albumin und Paranucleinsäure, welche keine Xanthinkörper liefern. Wilson erinnert daran (96, S. 24I), dass Kossel zu der Schlussfolgerung gekommen ist, dass das, was wir als Chromatin bezeichnen, Verbindungen sind von Nucleinsäure mit mehr oder weniger Albumin, und dass sich eine chemische Reihe aufstellen lässt, welche anfängt beim Spermatozoenkern (wo kein Albumin und ein Maximum von Phosphor gefunden wird und wir es somit mit reiner Nucleinsäure zu thun haben), welche sodann das gewöhnliche Chromatin umfasst (in welchem Albumin vorgefunden wird), um in dritter Linie durch das Pyrenin der Nucleoli (nit einem grösseren Albumingehalt) zu jenen Nucleoalbuminen zu gerathen, welche wir auch in dem Cytoplasma antreffen (Vitellin, Caseinogin, etc.), und endlich zu schliessen mit den Globulinen und Albuminen, die für die Zellsubstanz charakteristisch sind und keine Nucleinsäure mehr führen.

Während des Lebens von Kern und Zelle finden sowohl constructive, als destructive Prozesse statt. Letztere müssten das Entstehen von nucleolärer Substanz auf Kosten des Chromatins 
begleiten und es wird sich die Kerntransformation, welche von allen Autoren bei dem Uebergang von embryonalen Blutmutterzellen in typische embryonale Blutzellen (mit deren eigenthümlichem "Kern") anerkannt wird, und welche in Fig. $87 \mathrm{~A}-\mathrm{E}$ : klar darliegt, wahrscheinlich unter diesem Schema einreihen lassen. Auch die Figuren IO7 und IOg zeigen unss wie bei dem dort stat1findenden Uebergang von Kernknospen in Blutkörperchen die nucleolären Einschlüsse sichtbar zunehmen, um schliesslich zu einem grossen Klumpen sich zusammenzuballen.

Bedenken wir nun, dass auch Wilson für die Wahrscheinlichkeit eintritt (96, S. 242), dass: "the chemical differences of chromatin and cytoplasm, striking and constant as they are, are differences of degree only," so werden wir das Auftreten von kernlosen Blutkörperchen als Kernderivate nicht mehr in dem Maasse unwahrscheinlich finden. Es ist nämlich unter Abnahme des Chromatingehalts der "Kern" eine Vorrathskammer anderer Substanzen geworden, einfacher in ihrer Zusammensetzung, aber eben in dieser modificirten Form dem Organismus nützlich als Vehikel des Hämoglobins (resp. Sauerstoffs), welches in früheren Embryonalstadien auch vom Cytoplasma herumgeführt wird. Ein Factor, welcher vielleicht mit im Spiel gewesen sein mag, wenn bei den Säugethieren die Rolle des Hämoglobintransports Kernderivaten zugetheilt würde, anstatt, wie bei den niederen Wirbelthieren Zellen, könnten wir vielleicht darin finden, dass die vergrösserte Gesammtoberfläche dieser eben kleineren Kernderivate eine hervorragende Leistung versprach.

Sehen wir uns nun einmal etwas näher darnach um, wie die anderen Autoren, die doch so auffallende Kernmetamorphose auffassen, die immer an der Bildung der kernlosen Blutkörperchen aus kernführenden Blutzellen vorangeht.

Israël und Pappenheim, welche Ausstossung des Kernes seitens der Blutmutterzellen nicht anzunehmen geneigt sind, sagen iiber die hier gemeinte Kernmetamorphose folgendes (96, S. 44I): "Die Degeneration des Kernes zu einem homogenen, strukturlosen, sich intensiv färbenden Nucleinklumpen, ist, für das Blut wenigstens an und für sich, noch nicht pathologisch, sondern eine blosse physiologische Alterserscheinung."

M. B. Schmidt fasst den Unterschied zwischen den reiferen und den früheren Stadien der kernführenden Blutmutterzellen in einer Weise auf, die keinen Zweifel darüber lässt, dass er diese Kernmodification zu gleicher Zeit in näheren Verband bringt mit dem Hämoglobingehalt der Zelle und zwar so, dass die "Kerne" der reifsten Stadien für die Hämoglobinproduction um so werthvoller geworden sein sollen (also eventuell nach ihrer Ausstossung begreiflicherweise selbst als Träger des Hämoglobins werden auftreten können). Wörtlich schreibt Schmidt (92, S. 205): "Die Substanz [der kleinen Kerne] erscheint hier dunkler und homogener, und nur wenige und undeutliche Körnchen und Fäden treten darin hervor, 
und bei der Behandlung mit Hämatoxylin kommt eine ziemlich gleichmässige, intensive Farbung ohne ausgesprochene Kernstructur zu Stande. Diese kleinen homogenen Kerne ${ }^{1}$ gehören den hämoglobinreichsten Zellen an, und bei der Betrachtung der Uebergangsformen zwischen ihnen und den grösseren ${ }^{2}$, lichteren und deutlich structurirten Kernen scheint eine gewisse Gesetzmässigkeit hervorzutreten derart, dass, je höher der Hämoglobingehalt einer Zelle, desto kleiner der Kern und desto enger und plumper sein Chromatingerüst ist. Nicht selten liegen in einem runden oder ovalen rothen Blutkörperchen zwei gleichgrosse getrennte Kerne ${ }^{3}$."

Kostanecki beschreibt (92, S. 3I4) den Uebergang der frühen embryonalen Blutzellen (Fig. $87 \mathrm{~A}$ und B) in die späteren (Fig. $87 \mathrm{E})$ folgendermassen :

"Die grossen runden Kerne mit ihrem schönen Chromatinnetz werden...auffallend kleiner, die Chromatinfäden viel dicker und dichter gedrängt, so dass der Kern ein beinahe homogenes Aussehen darbietet und schliesslich in der That nur einen sich in allen Kernfarbstoffen sehr intensiv färbenden Chromatinklumpen darzustellen scheint."

Den Beweis, dass wir es hier mit dem Chromatinnetz zu thun haben und dass es sich nicht etwa um Zunahme der doch ebenso stark tingirbaren nucleolären Einschlüsse handelt, bringt Kostanecki uns nicht. Ich muss gestehen, dass ich selbst bei jener Kerntransformation der embryonalen Blutkörperchen den Prozess viel schwerer zu enträthseln gefunden habe, als bei der Bildung von Blutkörperchen in der Tarsius- und Tupajaplacenta. Hingegen sehen wir sowohl bei Tarsius, als bei Sorex und Tupaja in den frühesten embryonalen Blutkörperchen oft einen so ungemein grossen und dem späteren modificirten "Kern" so ungemein ähnlichen Nucleolus, dass man oft geneigt ist-wie ich oben bereits hervorhob und wie es vielleicht auch Balfour (siehe S. 363) gethan hat-um die Zellgrenze für die frühere Kernmembran zu halten und den Kern für den früheren Nucleolus.

Haben wir Schmidt und Kostanecki citirt, um die eigenthümliche Kernmetamorphose von morphologischer Seite bestätigt zu finden, so geben uns Giglio Tos und Lavdowsky einige Daten, aus welchen wir ableiten, dass auch vom chemischen Gesichtspunkte aus Stoffe in dem fertigen Säugethierblutkörperchen vorhanden sind, welche als Umwandlungsproducten von Kernsubstanz aufgefasst werden müssen. Schreibt doch Giglio Tos (97, p. 94): "In tutti questi eritrociti esiste una sostanza speciale albuminoide derivata da metamorfosi paraiale o totale del nucleo; sostanza che io chiamo emoglobinogena e che serve, secondo me, alla formazione dell' emoglobina per trasformazione di una o piu sostanze preesistenti nel plasmo del sangue."

\footnotetext{
1 Vergleiche Fig. $87 \mathrm{E}$ und folgende.

2 Vergleiche Fig. $87 \mathrm{~A}$ und B.

3 Vergleiche Fig. 87 E.
} 
Während wir bei Lavdowsky (93, S. 7 und 8) lesen: "Im grössten Theile der rothen Blutkörperchen des Mcnschen und der Säugethiere sind in vollkommen reifem Zustande die Reste von Kernsubstanz enthalten, welche aber nur durch gewisse Reagentien hervorzurufen sind. Jene Substanz möchte ich zum Unterschiede von den wirklichen Kernen als "nucleoide Substanz" oder kurz. "Nucleor̈d" bezeichnen. Die letztere Substanz ist in Verbindung mit Hämoglobin diffus durch das ganze Blutkörperchen verbreitet"; und weiter noch: "Im Einklang mit dem Gesagten stellt sich heraus, dass die nucleoide Substanz viele physiologische Eigenschaften der eigentlichen Kerne entbehrt und somit von denselben unterschieden werden muss."

Allerdings fasst Lavdowsky das fertige Blutkörperchen nicht qua talis als Kernderivat auf und leitet sein "Nucleoid" aus dem verschwundenen Kern her.

Betreffs der verschiedenen Tingirbarkeit ron Chromatin, nucleoläre Substanz und Cytoplasma, finden wir noch bei Heidenhain die nachfolgenden sehr beachtenswerthen Bemerkungen (94, S. 548): "Die Affinitäten der chromatophilen Mikrosomen der Kerngerüste gegenüber den basischen und sauren Anilinfarbstoffen [reguliren] sich nach gewissen physiologischen Zuständen des Kerns oder der Zelle, in Betreff deren wir bisher eine genauere Einsicht noch nicht haben." Einige Zeilen früher heisst es: "Die Basi- und Oxychromatine sind durchaus nicht als für die Dauer unveränderliche Körper aufzufassen, sondern durch Aufnahme und Abgabe von Phosphor konnte eventuell auch die Färbbarkeit sich ändern."

In diesem Lichte sollen wir die auf Taf. I 3 Fig. 87 so scharf hervortretende Thatsache betrachten, dass nämlich sowohl mütterliche, als embryonale kernlose Blutkörperchen in einem und demselben Durchschnitt dunkel tingirt, blasser und sogar ganz farblos sich zeigen können (auch noch Fig. I09). Die physiologischchemischen Verhältnisse, welche dies bedingen, bedürfen noch der Erforschung.

So kann ich nicht mit genügendem Nachdruck betonen, dass wir Wilson's Ausspruch (96, p. 244) nicht aus dem Auge verlieren dürfen, wo er sagt: "The constancy and accuracy of these reactions await further test, and until this has been carried out we should be careful not to place too implicit a trust in the staining reactions as an indication of chemical nature, especially as they are known to be affected by the preceding mode of fixation."

Meine eigenen zahlreichen Versuche, um für die Blutbildung in der Tarsius- und Tupajaplacenta Belege zu erlangen, welche der respectiven Tingirbarkeit von Riesenzellkern, Hämatogonien und Blutkörperchen entlehnt waren, haben mich auf recht wechselnde Tinctionsmöglichkeiten aufmerksam gemacht, die ich mit dem erwähnten Heidenhain'schen Ausspruch in Verband bringe. Sie haben aber zu gleicher Zeit das für meine Beweisführung wichtige Factum an's Licht gebracht, dass die verschiedensten Färbemittel 
immer eine gleichmässige Uebergangsscala zur Darstellung brachten, durch welche die Farbe der mütterlichen Blutkörperchen, und diejenige eines Theiles des Inhaltes der Riesenzellenkerne sich verbunden zeigten, wie dies besonders aus den Figuren 9I und 94 hervorgeht.

Auch andere Forscher haben diese auffallenden Unterschiede in der Tingirbarkeit der nämlichen und neben einander vorhandenen Formelemente des Blutes bemerkt. So Israël und Pappenheim (96, S. 437): “[Es fanden sich] alle Uebergänge der Färbung vom zartesten Gelblichrosa bis zum dunkel gesättigten Ziegelroth und zwar......unabhängig von der Grösse der Zellen ......und auch unabhängig vom Alter des Kernes......Ebenso fanden sich kernlose Blutkörperchen jeglicher Grösse und Färbung.”

Es stösst also, im morphologischen, sowie im chemischen Gedankengange, die Anerkennung der kernlosen Säugethierblutkörperchen als Kernderivate, gegenüber den kernführenden Blut"Zellen" der frühen Embryonalstadien und der niederen Wirbelthiere' nicht auf so viele Schwierigkeiten, als man vielleicht auf den ersten Blick sich vorzustellen geneigt war.

I Nur bei den Amphibien sind neben kernfiihrenden auch kernlose Blutkörperchen heschrieben worden und zwar bei Salamandra (v. d. Stricht 92, Fig. 36) und bei Batrachoseps (Anat. Anzeiger i 899 , No. 16, Bd. xv.). Ehe wir daraus schliessen, dass anch in dieser Hinsicht die Säugethiere eher an Amphibien, als an Reptilien anknïpfen, wird diese Thatsache einer recht genauen Prüfung unterworfen und dabei festgestellt werden miissen, ob wir es bei jenen Amphibien mit kernlosen Zellfragmenten oder, wie bei den Säugethieren, mit Kernderivaten zu thun haben. 


\section{APPENDIX.}

Vergleichungs-Tabelle von Abbildungen und Figuren anderer Autoren mit einigen der hier gegebenen.

\begin{tabular}{|c|c|c|c|}
\hline Mit Figur: & Von : & $\begin{array}{c}\text { V'ergleiche } \\
\text { man meine } \\
\text { Fig.: }\end{array}$ & Und bemerke dabei: \\
\hline $\begin{array}{l}6 \text { und } 7 \\
\text { Taf. III. }\end{array}$ & 80 Rindfleisch & $87 \mathrm{E}-\mathrm{G}$ & $\begin{array}{l}\text { Ausstossung des "Kernes" aus } \\
\text { den embryonalen Blutkörperchen }\end{array}$ \\
\hline $\begin{array}{l}9,10, \\
\text { Taf. I. }\end{array}$ & 83 Arnold & 93,101 & Kernproliferation der Riesenzelle \\
\hline $\begin{array}{c}14,16-18, \\
\text { Taf. I. }\end{array}$ & $"$ & $93 \mathrm{~A}$ & Kernfragmente und Hämatogonien \\
\hline $\begin{array}{l}\text { 7, Pl. I. } \\
\text { I8, Pl. I. } \\
\text { 78, 86, 88, } \\
\text { Pl. II. }\end{array}$ & $\begin{array}{cc}86 & \text { Denys } \\
" & " \\
" & "\end{array}$ & $\begin{array}{c}\text { IOI, IO4 } \\
93,94 \\
99\end{array}$ & $\begin{array}{l}\text { Identität der von mir Hämatogo- } \\
\text { nien genannten Gebilde mit Denys } \\
\text { cellules-filles. Dass es sich in letz- } \\
\text { teren nicht um endogen enstandene } \\
\text { Tochterzellen handelt, sondern um } \\
\text { Kernderivate beweist ein Vergleich } \\
\text { von Denys' Fig. I1 b, cf, mit seiner } \\
\text { Fig. } 23 \mathrm{n} \text {. In letzterer Figur ist eine } \\
\text { Hämatogonie neben jungen Riesen- } \\
\text { zellen abgebildet; sie hat aber er- } \\
\text { sichtlicherweise nicht den Werth einer } \\
\text { Zelle, sonderneines metamorphosirten } \\
\text { Kernes. Für dieses ist ausser Fig. I I } \\
\text { auch noch Fig. I2 (links oben), sowie } \\
\text { Fig. } 24 \text { heranzuziehen }\end{array}$ \\
\hline 16, Pl. I. & $\begin{array}{l}91 \text { van der } \\
\text { Stricht }\end{array}$ & $87 \mathrm{~F}$ & $\begin{array}{l}\text { Der austretende Kern der Blut- } \\
\text { mutterzelle ist an Grösse dem kern- } \\
\text { losen Blutkörperchen gleich. Ver- } \\
\text { gleiche van der Stricht's Fig. I6, I6 } \\
\text { und I } 7 \text { mit seiner Fig. 3a (die gelben } \\
\text { Blutkörperchen) bei derselben Ver- } \\
\text { grösserung gezeichnet }\end{array}$ \\
\hline $\begin{array}{l}28,33 \\
\text { Pl. I. }\end{array}$ & 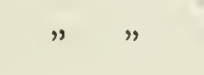 & 89 & $\begin{array}{l}\text { Vielleicht später zu einander in } \\
\text { Beziehung zu bringen }\end{array}$ \\
\hline
\end{tabular}


APPENDIX B. PROF. HUBRECHT.

\begin{tabular}{|c|c|c|c|}
\hline Mit Figur: & Von: & $\begin{array}{l}\text { Vergleiche } \\
\text { man meine } \\
\text { Fig.: }\end{array}$ & Und bemerke dabei : \\
\hline $\begin{array}{l}36-40 \\
\text { Pl. I. } \\
47-5 \text { I, } \\
59,60 \\
\text { Pl. II. }\end{array}$ & $\begin{array}{l}91 \text { van der } \\
\text { Stricht }\end{array}$ & $\begin{array}{l}9 \mathrm{I}-94 \\
\text { IOI, IO2, } \\
\text { IO4 }\end{array}$ & $\begin{array}{l}\text { Bildung von Hämatogonien aus } \\
\text { proliferirenden Riesenzellkernen }\end{array}$ \\
\hline $\begin{array}{l}87, \text { Pl. } \\
\text { II. }\end{array}$ & $" \quad "$ & 99 & $\begin{array}{l}\text { Pluripolare Mitose von Riesenzell- } \\
\text { kern }\end{array}$ \\
\hline $\begin{array}{l}\text { I8, Taf. } \\
\text { XXV. }\end{array}$ & $\begin{array}{l}92 \underset{2}{2} \\
\text { von Kostanecki }\end{array}$ & 99 & $\begin{array}{l}\text { Pluripolare Mitose von Riesen- } \\
\text { zellen }\end{array}$ \\
\hline $\begin{array}{l}\text { I6, Pl. } \\
\text { VIII. }\end{array}$ & $\begin{array}{l}92 \text { van der } \\
\text { Stricht }\end{array}$ & 82 & $\begin{array}{l}\text { Bildung von Blutmutterzellen in } \\
\text { der Leber vom Hasen und auf dem } \\
\text { Dottersack von Sorex }\end{array}$ \\
\hline $\begin{array}{l}3 \mathrm{I}, \mathrm{Pl} . \\
\text { VIII. }\end{array}$ & & 76 & $\begin{array}{l}\text { Früheste Entstehung von Blut- } \\
\text { mutterzellen in der Leber vom } \\
\text { Hasen und auf der Nabelblase von } \\
\text { Tarsius }\end{array}$ \\
\hline $\begin{array}{l}36, \text { Pl. } \\
\text { VIII. }\end{array}$ & $"$ & $8_{3} \mathrm{~B}$ & $\begin{array}{l}\text { Blutzellen von Salamander und } \\
\text { Sorex }\end{array}$ \\
\hline $\begin{array}{l}53, \text { Taf. } \\
27 \text { und } \\
72, \\
\text { Taf. } 29\end{array}$ & $\stackrel{94}{94}$ M. Heidenhain & $\begin{array}{l}99, \text { IOI } \\
93\end{array}$ & $\begin{array}{l}\text { Riesenzellen mit proliferirenden } \\
\text { Kernen }\end{array}$ \\
\hline $\begin{array}{l}58,61 \\
-63 \\
\text { Pl. } 35\end{array}$ & 94 I Hubrecht & $76-81$ & $\begin{array}{l}\text { Frühestes Auftreten von Blut- } \\
\text { mutterzellen mit proliferirendem } \\
\text { Kern auf der Nabelblase von Sorex } \\
\text { und Tarsius }\end{array}$ \\
\hline $\begin{array}{l}34,35 \\
55 \text { und } 60, \\
\text { Taf. } \\
\text { IX. }\end{array}$ & $\begin{array}{l}96 \text { Israel und } \\
\text { Pappenheim }\end{array}$ & $\begin{array}{l}87 \mathrm{E}-\mathrm{H} \\
\text { (Tupaja) }\end{array}$ & $\begin{array}{l}\text { Grössenübereinstimmung zwischen } \\
\text { mütterlichen Blutkörperchen und } \\
\text { "Kern" der embryonalen }\end{array}$ \\
\hline $\begin{array}{l}16 \text { und } \\
8, \text { Taf. } \\
\text { IX. }\end{array}$ & $"$ & $\begin{array}{l}87 \mathrm{D}-\mathrm{H} \\
96,97\end{array}$ & $"$ \\
\hline $\begin{array}{l}\mathrm{A} \text { b und } \mathrm{l} \\
\text { Taf. XI. }\end{array}$ & $"$ & $\begin{array}{l}87 \mathrm{E} \\
88 \mathrm{~b}, \mathrm{c}\end{array}$ & $"$ \\
\hline $\begin{array}{l}\text { A, kkl, } \\
\text { Taf. XI. }\end{array}$ & $"$ & $\stackrel{87}{I}$ und $\mathrm{G}$ & $\begin{array}{l}\text { Grössen-differenz zwischen fötalen } \\
\text { Blutkörperchen desselben Schnittes }\end{array}$ \\
\hline
\end{tabular}




\begin{tabular}{|c|c|c|c|}
\hline Mit Figur: & Von: & $\begin{array}{l}\text { Vergleiche } \\
\text { man meine } \\
\text { Fig.: }\end{array}$ & Und bemerke dabei: \\
\hline $\begin{array}{l}32 \text { und } 50 \\
\text { Taf. IX. }\end{array}$ & $\begin{array}{l}96 \text { Israel und } \\
\text { Pappenheim }\end{array}$ & $\begin{array}{l}87 \mathrm{C} \text { und } \mathrm{E} \\
\text { vier be- } \\
\text { stimmte } \\
\text { Zellen } \\
83 \mathrm{~A} \text { und } \\
8_{3} \mathrm{C}\end{array}$ & $\begin{array}{l}\text { Amitotische Kernvermehrung in } \\
\text { Blutmutterzellen }\end{array}$ \\
\hline $\begin{array}{l}38 \text { und } 47 \\
\text { Taf. IX. }\end{array}$ & $"$ & $83 \mathrm{~B}, 82$ & Mitotische Kernvermehrung \\
\hline $\begin{array}{l}\text { 7, Taf. } \\
\text { XV., XVI. }\end{array}$ & 96 Saxer & $78-82$ & $\begin{array}{l}\text { Entstehung von Blutmutterzellen in } \\
\text { der Herzwand vom Rind und auf der } \\
\text { Nabelblase von Tarsius und Sorex }\end{array}$ \\
\hline $\begin{array}{l}\text { I } 8, \text { i } 9, \\
\text { A und B, } \\
\text { Taf. XIX., } \\
\text { XX. }\end{array}$ & $", \quad$, & $81,82,84$ & Blutbildung auf der Nabelblase \\
\hline $\begin{array}{l}\text { Ig A, rz } \\
\text { Taf. XIX., } \\
\text { XX. }\end{array}$ & $"$ & 76 & $\begin{array}{l}\text { Frühestes Ausgangsstadium der } \\
\text { Blutbildung auf der Nabelblase von } \\
\text { Katze und Tarsius }\end{array}$ \\
\hline Tav. II. & 97 Giglio Tos & 85 & $\begin{array}{l}\text { Grosse Blutmutterzellen mit wand- } \\
\text { ständigem Kern }\end{array}$ \\
\hline Taf. VII. & 97 Maximow & 94 & Entstehung von Hämatogonien \\
\hline
\end{tabular}

\section{LITERATURVERZEICHNISS.}

J. Arnold. 83. Beobachtungen uiber Kerne und Kerntheilungen in den Zellen des Knochenmarkes.

Archiv f. pathol. Anatomic, Bd. 93, I883.

E. van Beneden. 88. De la formation et de la constitution du placenta chez le Murin (Vespertilio murinus).

Bull. de I'Académie royale de Belgique.

J. Denys. 86. La Cytodiérèse des cellules géantes.

La Cellule, vol. II.

J. Disse. 95. Wichtige neuere Arbeiten über die Bildung roter Blutzellen in der späteren Embryonalzeit und nach der Geburt.

Ergebnisse der Anatomie und Entwickelungsgeschichte, Bd. v.

M. Duval. 92. Le Placenta des Rongeurs (avec Io6 fig. dans le texte et un atlas de 22 planches).

Extrait du Foumal de l'Anatomie et de la Physiologie, I889-1892. 
Foà und Salvioli. 80. Sull' origine dei globuli rossi del sangue. Arch. per le Scienze mediche, IV. 1880.

P. Foà. 82. Sur l'origine des globules rouges du sang et sur la fonction hématopoétique de la rate. Arch. Ital. de Biologie, Bd. I. I882.

91. Neue Untersuchungen über die Bildung der körperlichen Elemente des Blutes. Internat. Beiträge zur wissensch. Medicin.

R. Frommel. 83. Zur Entwickelung der Decidua und Placenta bei Mäusen. Sitzungsber. der morph. physiol. Gesellschaft. Münchener medicinische Wochenschrift, 1883 , Bd. 30, S. 310.

88. Ueber die Entwickelung der Placenta von Myotus murinus. 4to, Wiesbaden, Bergmann.

M. Heidenhain. 92. Ueber Kern und Protoplasma. Festschrift fiur $A$. von Kölliker's 70 j. Doct. Fubm. Leipzig, 1892.

94. Neue Untersuchungen über die Centralkörper und ihre Beziehungen zum Kern und Zellenprotoplasma. Arch. f. mikr. Anat., Bd. 43.

D. Siegenbeek van Heukelom. 98. Ueber die menschliche Placentation. Archiz' fiir Anatomie und Physiologie (Anat. Abth.), I 898.

A. A. W. Hubrecht. 88. Keimblätterbildung und Placentation des Igels. Anatomischer Anzeiger, I11. No. 17 und 18.

89. The Placentation of Erinaceus europaeus with remarks on the phylogeny of the placenta. Quarterly Journal of Micr. Science, vol. 30.

94. I. The Placentation of the Shrew. Quarterly Fournal of Micr. Science, vol. 35.

94. 2. Spolia nemoris. Quarterly Foumal of Micr. Science, vol. 36 .

95. Die Phylogenese des Amnions und die Bedeutung des Trophoblastes. Verhand. kon. Akad. v. Wetenschappen te Ansterdam, Bd. IV. No. 5.

96. Die Keimblase von Tarsius ein Hülfsmittel zur schärferen Definition bestimmter Säugethierordnungen. Festschrift fiir Gegenbaur. Leipzig.

98. La formation de la decidua reflexa chez les genres Erinaceus et Gymnura. Annales du Jardin botanique de Buitenzorg, Supplément II.

O. Israel und A. Pappenheim. 96. Ueber die Entkernung des Säugethiererythroblastes.

Virchow's Archiv, Bd. 143.

K. v. Kostanecki. 92. I. Die embryonale Leber in ihrer Beziehung zur Blutbildung.

92. 2. Ueber Kerntheilung bei Riesenzellen nach Beobachtungen an der embryonalen Säugethierleber. Anatomische Hefte, Bd. I.

P. Kuborn. 90. Du développement des vaisseaux et du sang dans le foie de l'embryon.

Anat. Anzeiger, Bd. v. 1890 .

M. Lavdowsky. 93. Blut- und Jodsäure und der sogenannte Chemotropismus. Zeitschr. fiir wissensch. Mikroskopie, Bd. x. 1893. 
L. Malassez. 82. Sur l'origine et la formation des globules rouges dans la moëlle des os.

Archives de physiologie norm. et path. T. IX. I882.

F. Marchand. 98. Beiträge zur Kenntniss der Placentarbildung. Die Placenta des Kaninchens mit Bemerkungen über die Placenta der Katze.

Schriften der Gesellschaft zur Beförderung der gesammten Naturwissenschaften, Bd. I3, Dritte Abtheilung.

J. Masius. 89. De la genèse du Placenta chez le Lapin. Archizes de Biologie, vol. 9.

H. Masquelin et A. Swaen. 80. Premières phases du développement du placenta maternel chez le Lapin. Archizes de Biologie, vol. I. p. 25.

A. Maximow. 97. Zur Kenntniss des feineren Baues der Kaninchenplacenta. Archiv fïr mikrosk. Anatomie und Entwickelungsgeschichte, Bd. $5 \mathrm{I}$, p. 68.

E. Neumann. 69. Ueber die Bedeutung des Knochenmarks für die Blutbildung. Archiv f. physiologische Heilkunde, Bd. x. I869.

74. Neue Beiträge zur Kenntniss der Blutbildung. Archiz' fïr Heilkunde, $\mathrm{Bd}$. xv.

96. Haematologische Studien. Virchow's Archiv, Bd. 4I3.

P. Nolf. 95. Étude des modifications de la muqueuse utérine pendant la gestation chez le Murin (Vespertilio murinus). Archives de Biologie, vol. 14.

G. E. Rindfleisch. 80. Ueber Knochenmark und Blutbildung. Archiv f. mikr. Anatomie, Bd. 17, 1880.

F. Sanfelice. 90. La genèse des corpuscules rouges dans la moëlle des os des vertébrés. Arch. italiennes de Biologie, T. XuIr. 1890.

Fr. Saxer. 96. Ueber die Entwickelung und den Bau der normalen Lymphdrüsen und die Entstehung der rothen und weissen Blutkörperchen. Anatomische Hefte, Bd. VI. Heft 3, I 896.

M. B. Schmidt. 92. Ueber Blutzellenbildung in Leber und Milz, etc. Beiträge zur pathologischen Anatomie und allg. Pathologie, Bd. XI. I892.

Ch. Sedgwick Minot. 92. Human Embryology. New York.

F. Graf Spee. 96. Zur Demonstration über die Entwickelung der Drüsen des menschlichen Dottersacks. Anatomischer Anzeiger, Bd. XII. No. 3, 1896.

H. Strahl. 88. Beiträge zur Kenntniss der Entwickelung von Säugethierembryonen.

Sitzungsber. d. Gesellsch. zur Beföd. der gesammten Natumwissensch. zu Marburg.

O. van der Stricht. 91. Le développement du sang dans le foie embryonnaire. Archives de Biologie, T. XI. I89I.

92. Nouvelles recherches sur la genèse des globules rouges et des globules blancs du sang. Archives de Biologie, T. xil. I 892.

E. Giglio Tos. 97. La struttura e l' evoluzione dei corpuscoli rossi del sangue dei Vertebrati.

Mem. della reale Accad. delle Scienze di Torino, T. 47, I897.

J. H. Vernhout. 94. Ueber die Placenta des Maulwurfs. Anatomische Hefte, Bd. v. H. I. 
G. C. J. Vosmaer. 97. On the retrograde development of the blood-vessels in the omentum of the rabbit.

Verslag van de werg. d. koninkl. Akademie wan Wetenschappen te Amsterdam van October, 1897.

E. B. Wilson. 96. The Cell in development and inheritance.

New York. London.

\section{ERKLÄRUNG DER FIGUREN.}

Abkïrzungen.

all. Allantois

am. Amnion

ar. arterielle Gefässe der Muscularis

B. weitmaschiges, gefässf ührendes Bindegewebe der Mucosa

blg. capillare Blutgefässe mit Blutkörperchen

b. Blutkörperchen

chf. Chorionblutgefässe

D. Uterindrïsen im Ruhezustand

$D^{1}$. Utcrindrüsen, welche sich im Placentargebiet bedeutend erweitem

D². Uterindrüsen, deren Epithel nach der Erweiterung unter Vergrösserung der Kerne einer regressiven Metamorphose anheimfällt

$D^{3}$. Uterindrüsen, welche nach dieser Metamorphose mit einer körnigen Masse ausgefiillt sind, in welche die Kerne noch während einiger Zeit deutlich bleiben

D4. Uterindruisen in vollster Degeneration. Die körnige Füllmasse führt nur noch hie und da Kerntriimmer. Oft sind von Aussen her eingedrungene Blutkörperchen in der Füllmasse eingebettet

Dr. abgeflachte Drüsenreste

Ep. Epiblastschild der Keimblase

h. Hämatogonien

hy. Hypoblast

$\mathrm{k}, \mathrm{k}^{\prime}, \mathrm{K}$. Kerne und Kernfragmenten.

Kb. Keimblase

Kbw. Keimblasenwand

la. miitterliches Blut führende, von Trophoblastgewebe umhüllte, Lakunen

lk. in Auflösung begriffene Kernmembran

M. Muscularis des Uterus

mes. Mesoblast der Keimblase

Mk. Megalokaryocyten

mzo. Mesoblastzotten der Placenta

Na. Nabelblase

nbl. Gefässbahnen, welche als Wucherungen in dem interglandulären Bindegewebe sich neubilden und den Raum zwischen den degenerirten Drïsen ausfiullen

pam. Proamnion

Ta. Trophospongia

$\mathrm{Ta}^{\prime}, \mathrm{Ta}^{\prime \prime}$. accessorische Bildungsheerde trophospongialen Gewebes

Ta S. centraler, neugebildeter Gefässstiel der Trophospongia

Trw. gewuchertes Trophoblastgewebe

Ue. Uterusepithelium

wz. Gefässwandzellen 
TAFEL, 4.

Vergrösserung von allen Figuren $x_{1}^{0}$.

Die Entwickelungsstadien der Placenta von Tupaja und Tarsius mittelst der Camera in Umriss gezeichnet. Gewebsdifferenzen schematisirt, Muscularis schwarz, Mucosa hellgrau, der zur Trophospongia sich ausbildende Abschnitt der Mucosa dunkelgrau, die placentale Trophoblastwucherung schwarz punktirt.

Fig. I-12. Tupaja javanica.

Fig. 13-27. Tarsius spectrum.

Fig. I-3. Junge Stadien, mit noch nicht oder eben erst festgehefteter Keimblase. In Fig. I ist die Keimblase ganz klein und die Mucosa äusserst compact von jungfräulichem Charakter, in Fig. 3 hingegen deutlich puerperal. Die Trophospongia ist demzufolge in Fig. 2 und 3 etwas anders gestaltet als in Fig. I. Vergleiche bei stärkerer Vergrösserung Fig. 28.

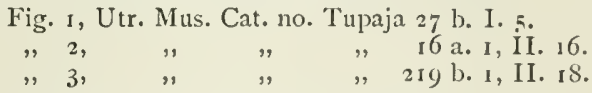

Fig. 4-9. Weitere Wachsthumsstadien bis zur vollendeten Amnionschliessung. Von Fig. 6 an wird der Hypoblast durch eine punktirte, der Mesoblast durch eine unterbrochene Linie angedeutet. Nach vollendeter Amnionschliessung und Ausbildung der Area vasculosa in Fig. 9 treten auch rapide Aenderungen in dem Verhältniss zwischen Trophospongia und wucherndem Trophoblastgewebe ein. Der Mesoblast ist in letztgenannter Figur nicht angedeutet.

Fig. 4, Utr. Mus. Cat. no. Tupaja I45 a. 2, I. I 8 (vergl. Fig. 29).

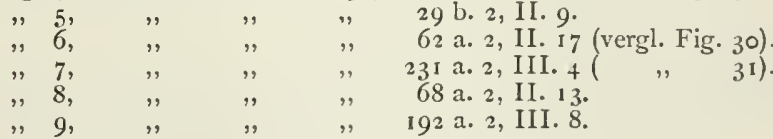

Fig. I0-12. Umänderung der anfänglich omphaloiden Placentation von

Tupaja in eine allantoide. In Fig. Io und I I erhebt sich der Allantois über den Rücken des Embryos und legt sich mittelst lateraler Zipfel in fortschreitendem Maasse und unter Ablösung des omphaloïden Placentarverbandes gegen die jetzt centripetal an Dicke zunehmende Trophoblastwucherung (vergleiche Fig. 32). Zotten entstehen auf der äusseren Allantoisoberfläche und verlängern sich ebenfalls centripetal. In Fig. I I ist der Kopf des Embryos in ein aus Epiblast und Hypoblast bestehendes Proamnion eingehiillt. Fig. 12 steht kurz vor dem Partus.

Fig. Io, Utr. Mus. Cat. no. Tupaja $27+$ a. XII. I. 1 (vergl. Fig. 32). "II, " ", , $\quad 39$ a. 5 , II. 3 .

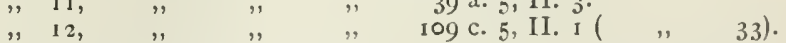

Fig. I3. Allererste Anheftung der Tarsiuskeimblase (vergleiche Fig. 55). Utr. Mus. Cat. no. Tarsius 1 Io b. II. g. 
Fig. 14-22. Weitere Entwickelungsstadien.

Fig. 14 , Utr. Mus. Cat. no. Tarsius 6i 7 a. 2, II. I8 (vergl. Fig. 56).

\begin{tabular}{|c|c|c|c|}
\hline ", & $15^{l}$. & " & ", \\
\hline , & 16 & , & ", \\
\hline ", & I 7, & ", & $"$, \\
\hline " & 18 & , & ", \\
\hline ", & 19, & , & ", \\
\hline ", & 20 & ", & $"$ \\
\hline , & $2 \mathrm{I}$, & , & , \\
\hline ", & 22, & , & , , \\
\hline
\end{tabular}

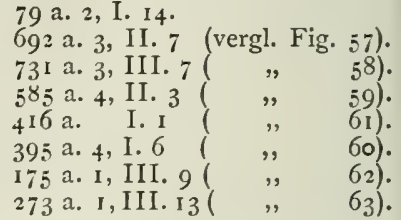

Fig. 23. Der dem Trophoblast anlagernde Mesoblast bekommt lokale Verdickungen als erste Andeutung von Zotten.

Utr. Mus. Cat. no. Tarsius 456 b. III. I3 (vergl. Fig. 64).

Fig. 24. Unter zunehmendem centripetalem Wachsthum des Trophoblastes sind auch die Mesoblastzotten vergrössert.

Utr. Mus. Cat. no. Tarsius 49 I a. 6, I. 2 (vergl. Fig. 67).

Fig. 25. Weiteres Stadium, in welchem die Zotten besonders an Mächtigkeit zugenommen haben. Die Zotten sind noch nicht gefässführend.

Utr. Mus. Cat. no. Tarsius I 88 b. II. I I (vergl. Fig. 68).

Fig. 26. Die Bildung der definitiven Placenta ist hier eingeleitet durch centripetale Verlängerung der von Trophoblastgewebe umkleideten Zotten, welche während ihrer Verlängerung auch in schmälere Abschnitte zerlegt werden.

Utr. Mus. Cat. no. Tarsius 595 a. IV. 7 (vergl. Fig. 65).

Fig. 27. Die Placenta kurz vor der Geburt: das im vorigen Stadium eingeleitete Verfahren ist immer weiter gegangen (vergl. Fig. 66). Die Placenta springt knopfförmig im Uteruslumen vor und ist nur vermittelst eines engen Gefässstieles mit der Muscularis verbunden.

Utr. Mus. Cat. no. Tarsius 15 a. 5 , I. I.

\section{TAFEL 5.}

Einige Hauptphasen in der Entwickelung der Tupajaplacenta.

Fig. 28-33. Vergrösserung: $\frac{80}{1}$.

Fig. 34 .

$$
\Longrightarrow \quad: \frac{160}{1} .
$$

Fig. 28.

Die linke Placentarstelle der Fig. 2, stärker vergrössert. Die vergrösserten Bluträume in der Muscularis, die verdickten Gefässreste in der Mucosa, sowie das Aussehen des regenerirten Bindegewebes an der Anheftungsstelle, deuten unverkennbar darauf hin, dass wir es hier mit einem puerperalen Stadium zu thun haben, in welchem eben eine neue Schwangerschaft eingeleitet ist. Die etwas zerrissene äussere Wand der Keimblase hat sich eben gegen das Uterusepithel angelegt.

Utr. Mus. Cat. no. Tupaja 219 b. I, II. I8.

Fig. 29. Die rechte Placenta der Fig. 4, stärker vergrössert. Die Trophospongia und das ihr von der Drüsenschicht trennende Bindegewebe tragen in dieser und der nächstfolgenden Figur einen eminent vasifactiven Charakter. Das Uterusepithel ist an der Placentarstelle vom Trophoblast verdrängt.

Utr. Mus. Cat. no. Tupaja I 45 a. 2, I. I8.

${ }^{1}$ Diese Figur entspricht der Textfig. c. meines Aufsatzes in der Gegenbaur'schen Festschrift. Leipzig, 1896. 
Fig. 30 und 3r. Zwei weitere Stadien (vergl. Fig. 6 und 7), wobei die plasmodiale Schicht des Trophoblastes mit der Trophospongia in engere Durchwachsungsverhältnisse tritt (cf. Taf. 6).

Fig. 30, Utr. Mus. Cat. no. Tupaja 62 a. 2, II. ${ }_{17}$.

$" 3 \mathrm{I}, \quad " \quad " \quad, \quad 23 \mathrm{I}$ a. 2, III. 4 .

Fig. 32. Die linke Placenta der Fig. Io, wo die Allantoiszotten in allererste Verwachsung treten mit der bercits tief in die Trophospongia eingedrungenen Trophoblastwucherung.

Utr. Mus. Cat. no. Tupaja $27+$ XII. I. I.

Fig. 33. Rechte Placenta eines Foetus kurz vor der Geburt von demselben Stadium der Fig. 12. Das in der vorigen Figur eingeleitete Verhalten hat zum bedeutenden centripetalen Wachsthum von Zotten und Trophoblast geführt, wobei die Trophospongia nur noch als dünne äussere Grenzplatte der Placenta bestehen bleibt. In dieser und der vorigen Figur hat die Bindegewebsschicht zwischen der Trophospongia und den Drüsen ein faseriges Aussehen erhalten.

Utr. Mus. Cat. no. Tupaja rog a. 9, III. I.

Fig. 34. Stück aus dem oberen Rande einer halbreifen Placenta, wo die Abgrenzung des Uterusepithels gegen den gewucherten Trophoblast (cf. Fig. 29-3I) sich noch deutlich erkennen lässt. Allantoiszotten und Trophoblastgewebe in enger Durchwachsung.

Utr. MIus. Cat. no. Tupaja 306 a. 2, V. 1.

TAFEL 6.

Entwickelungsstadien der Tupaja-placenta bei stärkerer V'ergrösserung von $2 \frac{40}{1}$.

Fig. 35. Erste Berührung der Keimblase mit dem einschichtigen Uterusepithel, gegen welches die Anheftung eben angefangen hat. Die Trophoblastzellen zeigen Wucherungs-, die Epithelzellen Degenerirungserscheinungen.

Utr. NIus. Cat. no. Tupaja i 6 b. 2, I. I3.

Fig. 36. Aehnliches Stadium, bei welchem an einer Stelle eine grosskernige Trophoblastzelle zwischen den Epithelzellen eindringt und sogar bis an das subepitheliale Bindegrewebe reicht.

Utr. Mus. Cat. no. Tupaja 2 I9 b. I, IV. Io.

Fig. 37. Noch früheres Stadium der allerersten Berührung. Wucherung des Trophoblastes durch Kernvergrösserung eingeleitet.

Utr. MIus. Cat. no. Tupaja 26 a. I, III. 16.

Fig. 38. Ein kleinerer Abschnitt der Berührungsfläche eines anderen Individuums, wobei ein grosskerniger Trophoblastkern sich in eigenthümlicher Knospung befindet.

Utr. Mus. Cat. no. Tupaja 3 I 2 a. I, III. I6.

Fig. 39 und 40. Zwei ähnliche Stellen.

Fig. 39, Utr. Mus. Cat. no. Tupaja ${ }_{2}+6$ a. I, IV. 16.

"40, " " " 246 a. 2, I. II.

Fig. 41. Die amitotische Vermehrung von Trophoblastkernen noch etwas weiter vorgeschritten als in Fig. 40.

Utr. Mus. Cat. no. Tupaja 219 a. 2, I. I. 
Fig. 42, 43 und 44. Drei Verklebungsstadien, wobei der Angriff des wucherenden Trophoblastes auf das bald zu Grunde gehende mütterliche Epithel deutlich hervortritt.

Fig. 42, Utr. Mus. Cat. no. Tupaja 29 a. 1, III. r8.

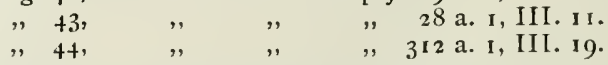

Fig. 45. Vom mütterlichen Epithelium sind in die Tiefe noch Kernspuren erhalten: der wuchernde Trophoblast wird auch diese bald zerstört haben. Ein Cyto- und ein Plasmoditrophoblast (van Beneden, Fledermaus, Kaninchen; Vernhout, Maulwurf) liess sich in dem Stadium der Fig. 45-5 I mehr weniger deutlich unterscheiden : später wird die Grenze, die nie eine ganz scharfe ist, noch weiter verwischt.

Utr. Mus. Cat. no. Tupaja 19 a. 2, I. 13.

Fig. 46-50. Fünf verschiedene Querschnitte durch die frïhe Placentaranlage differenter Exemplare, in welchen allen die verhältnissmässig scharfe Grenze zwischen mütterlichem Uterusepithel, gewuchertem embryonalem Trophoblastgewebe und gewucherter mütterlicher Trophospongia recht deutlich ist. Die fortgesetzte amitotische Theilung der Trophoblastkerne ist an verschiedenen Stellen evident. Zwischen Trophoblast und Trophospongia sind die letzten Reste des mütterlichen Epithels, die in Fig. 45 noch erhalten waren, verschwunden.

Fig. 46, Utr. Mus. Cat. no. Tupaja 19 a. I, V. 12.

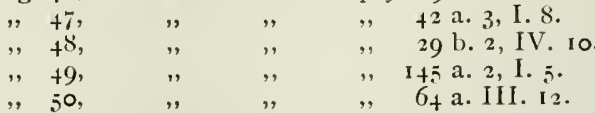

Fig. 51-54. Die scharfe Grenze zwischen embryonalem Trophoblast und mütterlicher Trophospongia ist verschwunden: Trophoblastderivate dringen deutlich in das Trophospongiagebiet ein und vermischen sich mit letzterem bis zur Unkenntlichkeit. Das Gebiet des früheren Cytotrophoblastes bereitet sich durch Ausbildung an der Oberfläche paralleler Gefässbahnen (vergleiche auch für Sorex Hubrecht 94, Pl. 37, Fig. 74, 75) auf die spätere Anlagerung der Allantoiszotten vor. In Figur 54 fangen die Gebiete mit Kernaglomeraten an sich zu zeigen, die auf Taf. I 5, Fig. 106-I09 in ihrer Beziehung zur Blutbildung abgebildet sind. Ebensowie bei Tarsius betheiligt sich sowohl Trophoblast, als Trophospongia an der Hämatopoiese.

Fig. 51, Utr. Mus. Cat. no. Tupaja 62, a. 2, IV. 10.

\begin{tabular}{|c|c|c|c|c|}
\hline & 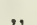 & & , & 62 , a. 2, III. \\
\hline 53 , & ", & $"$ & " & 231, a. 1, III. \\
\hline 54 & , & , & ", & 75 , a. I, IV. \\
\hline
\end{tabular}

TAFEI 7.

Frühe Stadien der Tarsius-placentation. Alle Figuren :

Vergrösserung : $\frac{80}{1}$.

Fig. 55. Allererste Anheftung der Keimblase gegen die mütterliche Mucosa. Das Uterusepithel ist nur an einer kleinen Stelle vom Trophoblastgewebe angefressen. Die Wucherung des interglandulären Trophospongiagewebes hat eben angefangen. Die tieferen Schichten des Drüsengewebes sind noch gar nicht 
in Mitleidenschaft gezogen. Das interglanduläre Bindegewebc persistirt ausserhalb der Trophospongia noch in seiner ursprünglichen Form.

Utr. Mus. Cat. no. Tarsius i Io b. IJ. 9.

Fig. 56. Weiter vorgeschrittenes Stadium. Der Trophoblast hat das Uterusepithel in grösserem Umfange verdrängt, die Drüsenwucherung ist weiter vorgeschritten, die Trophospongia bedeutend vergrössert, die Keimblase hat an Umfang zugenommen, die Nabelblasenanlage füllt die Keimblase nicht aus.

Utr. Mus. Cat. no. Tarsius 617 a. 2, II. I8.

Fig. 57. Weiteres Stadium. Die Trophoblastwucherung deckt die Trophospongia wie eine Kappe, es haben sich in beiden bereits Blutlakunen ent wickelt, obgleich jene der Trophoblastwucherung infolge der Conservation erweitert sind. Gefässwucherungen (nbl.) sind im interglandulären Bindegewebe aufgetreten, die bedeutendste ist wohl jene der das Blut zur Trophospongia führenden Hauptbahn (Tas).

Utr. Mus. Cat. no. Tarsins 692 a. 3 , II. 7 .

Fig. 58. Etwas weiteres Stadium, als das vorhergehende, wobei der Mesoblast nicht mehr als ganz diinne Membran, sondern als sich verdickende Schicht auf der Trophoblastwucherung liegt. Rechts eine accessorische trophospongiale 11 "ucherung nur eben von Trophoblastgewebe iiberdeckt, und von letzterem durch einen (künstlich erzeugten) Riss (welcher sich auch noch nach links und nach unten fortsetzt) getrennt.

Utr. Mus. Cat. no. Tarsius 731 a 3 , III. 7 .

TAFEL 8.

Bei allen Figuren ist die Vergrösserung : $\frac{x 0}{1}$.

Fig. 59. Weiteres Stadium bei welchem sich viel Blut zwischen Trophoblastwucherung und Trophospongia angesammelt hat. Der Trophospongiastiel ist fast bis in die Muscularis verfolgbar.

In der Trophospongia sind (sowie bereits in der vorigen Figur) Stellen bemerkbar, wo die Zellen vergrössert sind und Kernproliferation beobachtet wird.

Utr. Mus. Cat. no. Tarsius 585 a. 4 , II. 3 .

Fig. 60. Anderes Stadium mit etwas flacherer Trophospongia, welche deutliche Blutlakunen birgt. Die Trophoblastlakunen sind (wohl infolge Zerrung) etwas abnormal erweitert.

Utr. Mus. Cat. no. Tarsius 395 a. +. I. 6.

Fig. 6I. Schnitt durch eine Gegend, wo die Trophoblastwucherung direct dem entblössten Mucosagewebe aufliegt (vergleiche die vorige Figur links und rechts von der Trophospongia), während rechts eine Trophospongiawucherung durch den Schnitt eben gestreift wird. Die Trophoblastlakunen sind zahlreich und geräumig : von den peripheren Trophoblastzellen sind viele bedeutend vergrössert und zeigt der Kern eigenthümliche und sehr bedeutende Wucherungserscheinungen (vergl. Taf. I4 und 15). .

Utr. Mus. Cat. no. Tarsius $4 \mathbf{1} 6$ a. I. I. 
TAFEL 9.

Bei allen Figuren ist die Vergrösserung: $\frac{80}{1}$.

Fig. 62. In dem adenoiden Gewebe der Trophospongia wandern Trophoblastzellen ein, z. Th. entwickeln sich auch Trophospongiazellen zu Megalokaryocyten. Der Hauptstamm, welcher die Blutzufuhr zur Placenta besorgen wird, ist durch fortgesetzte Wucherung interglandulärer Gefässbahnen bedeutend verdickt und durchsetzt die der Degeneration anheimgefallene Drüsenschicht senkrecht.

Utr. Mus. Cat. no. Tarsius 175 a. I, III. 9.

Fig. 63. Der in Figur 62 angedeutete Prozess des Vordringens der Trophoblastwucherung hat hier noch weiter um sich gegriffen. Es sind drei scparate Trophospongiabezirke in die Placentarbildung mit einbezogen. Nur die mittlere ist bereits zu der Trophoblastwucherung in engere Beziehung getreten ${ }^{1}$; über die zwei seitlichen ist der Trophoblast eben erst im Begriff sich auszubreiten.

Utr. Mus. Cat. no. Tarsius 273 a. I, III. 13.

TAFEL 10.

Vergrösserung aller Figuren : $\frac{80}{1}$.

Fig. 64. Trophoblastwucherung und Trophospongia sind in zunehmendem Maasse zu einem neuen Ganzen verschmolzen und jetzt fängt die sich bisher parallel verdickende Mesoblastschicht der vorigen Figuren an, lokale, papillenartige Vorsprünge (m. zo) zu zeigen : die ersten Anlagen der Mesoblastzotten. Ein Vergleich der linken Ecke der Placentaranlage von Fig. 64 mit derselben Stelle in Fig. 60-63 macht es einleuchtend (auch wenn man die Grössenverhältnisse mit in Betracht zieht), dass die Trophoblastwucherung von jetzt an bei weitem im Uebergewicht kommt und dass die Trophospongia nur in der Basis der Placenta erhalten bleibt. Somit wird auch durch diese Zunahme der Trophoblastwucherung die innere Placentarfläche bereits in Fig. 64 über das Niveau der Uteruswand gehoben, was in Fig. 67 noch bedeutend schärfer markirt ist. Vergleiche besonders noch Fig. 23-27. Die beiden Riesenzellen in der Mitte dieser Figur, wovon der Kern des linken sich in atypische Mitose befindet, sind in Fig. 99 der Taf. I 5 bei stärkerer Vergrösserung abgebildet.

$$
\text { Utr. Mus. Cat. no. Tarsius } 456 \text { b. III. I } 3 \text {. }
$$

Fig. 65. Ein Stück aus einer grösseren, weiter vorgeschrittenen Placenta, wo die Mesoblastzotten sich centripetal verlängern und Trophoblastlakunen mit sich gezogen haben. Vergl. Fig. 26.

Utr, Mus. Cat. no. Tarsius 595 a. II. 6.

Fig. 66. Aehnliches Stück aus einer noch viel grösseren, reifen Placenta. Trophoblastgewebe umgiebt überall die jetzt sehr dicht verzweigten Zotten : mütterliches Blut zirkulirt in diesem spongiösen Netzwerk der Trophoblastlakunen. Vergleiche mit dieser Figur die Fig. 27.

Utr. Mus. Cat, no. Tarsius 15 a. 5, I. 2.

1 Eine etwas dunkler angegebene Zellreihe links unten im mittleren Abschnitt ist Folge einer geringen Falte im Originalpräparat. 


\section{TAFEL II.}

Vergrösserung beider Figuren : ${ }_{1}^{80}$.

Zwei Entwickelungsstadien der Placenta, welche zwischen den Stadien der Figuren 64 und 65 hinein gehören.

Fig. 67

Weiter vorgeschrittene Trophoblastwucherung. Knopfförmige Erhebung der Placenta über das Niveau der inneren Uterusoberfläche. Vergleiche Fig. 24. Die etwas weiter vorgeschrittenen Mesoblastzotten sind von einer epithelartigen Trophoblastschicht umkleidet.

Utr. Mus. Cat. no. Tarsius 49 I a. 6, I. 2.

Fig. 68. Stück einer noch weiter entwickelten Placenta, in welcher die Zotten die für ihre frühen Anfangsstadien charakteristische massive Entwickelung besitzen (vergl. Fig. 25). Die Trophoblastbekleidung der Zotten liegt, wohl infolge der Conservation, die Mesoblastzotten nicht überall eng an. In der Trophoblastlakunen und in dem zuführenden Hauptgefäss sind absichtlich keine Blutkörperchen mit eingezeichnet.

Utr. Mus. Cat. no. Tarsius I 88 b. II. I r.

TAFEL 12.

Fig. 69. Die frïhesten Vorbereitungen zur Bildung einer Trophospongia in der Tarsiusmucosa. Das Epithel ist noch ganz normal, die benachbarten Drüsenlumina fangen noch kaum an sich etwas zu erweitern. Das zarte interglanduläre Bindegewebe verdichtet sich, wobei Kernvermehrung und Gefässwandwucherung zu constatiren sind. Bei blg bildet ein Gefäss mit Wandverdickung die allererste Anlage des Trophospongiastieles der Fig. 57, 62, u. A. Das hier abgebildete Stadium ist noch jünger, als dasjenige der Fig. 55, es befindet sich die junge Keimblase bereits im Uteruslumen, sie ist aber noch nicht festgeheftet.

$$
\begin{aligned}
& \text { Vergrösserung : } \frac{240}{1} \text {. } \\
& \text { Utr. Mus. Cat. no. Tarsius } 8 \text { a. II. } 2 .
\end{aligned}
$$

Fig. 70. Eine junge Trophospongia kurz nach der Anheftung der Keimblase. Vergrösserung 240 . Die Trophoblastwucherung ist noch nicht durch Vergrösserung der Kerne unterscheidbar (vergl. Fig. 56, welche jedoch bereits ein etwas älteres Stadium repräsentirt). Blutkörperchen werden hie und da in den degenerirten Drüsen beisammengehalten. Ein in Mitose begriffene Trophospongiakern ist unten sichtbar.

$$
\text { Utr. Mus. Cat. no. Tarsius } 295 \text { a. II. ro. }
$$

Fig. 7 I-74. Vier verschiedene Stellen aus den V'erwachsungsgebiet von Trophoblastwucherung und Trophospongia, an welchen hämatopoietische Prozesse stattfinden. Vergrösserung: $\frac{609}{1}$.

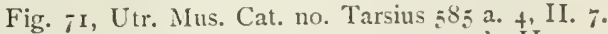

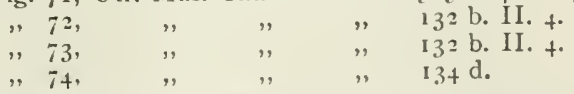

Fig. 75. Blutbildung in den sich neubildenden Gefässbahnen ausserhalb der Trophospongia, welche als vasculäre Wucherung zwischen den regressiv metamorphosirten Drüsen (rechts eine solche) auftreten (vergl. Fig. 57-63 nbl.). Vergrösserung: 300.

Utr. Mus. Cat. no. Tarsius 32 a. 3, II. 4 . 
TAFEL 13.

Die Blutbildung auf der Nabelblase und die allmähliche Umgestaltung der embryonalen kernhaltigen Blutkörperchen. Vergrösserung von Fig. 76-80, 82-86: 10.50.

Fig. 76. Frühestes Stadium der Blutbildung auf der Nabelblase von Tarsius. Zwei Wanderzellen mit proliferirendem Kern sind zwischen Hypoblast und splanchnischem Mesoblast eingeklemmt. Auclı die spätere Gefässwand ist bereits in der Anlage vorhanden.

Utr. Mus. Cat. no. Tarsius $45^{6}$ a. 1, II. 4 .

Fig. 77-79. Drei etwas weiter vorgeschrittene Stadien. In Fig. 77 und 78 ist der primitive Umriss der Blutmutterzelle noch erhalten, in Fig. 78 erhalten die eingeschlossenen Kernfragmente je einen eigenen Plasmahof, in Fig. 79 sind aus diesen Bildungen bereits embryonale Blutkörperchen hervorgegangen, die nicht mehr in einer gemeinsamen Hülle liegen.

Fig. 77 , Utr. Mus. Cat. no. Tarsius 273 a. 2, I. 7 .

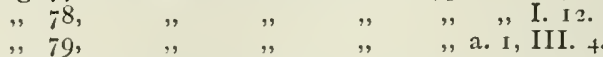

Fig. 8o. Etwas weiteres Stadium in welchem alle Derivate der primären Blutmutterzelle in embryonale Blutkörperchen umgewandelt sind, die aber in diesen Stadium noch wohl nicht zirkuliren.

Utr. Mus. Cat. no. Tarsius 4 I6 a. II. 24.

Fig. 81. Durchschnitt eines Nabelblasengefässes eines noch weiteren Entwickelungsstadiums. Es finden sich hier neben einander : (a) Blutmutterzellen, welche grösser sind und einen proliferirenden Kern besitzen ; (b) Derivate von diesen mit grossem Kern und dünnem Plasmamantel; $(c)$ in Uebergang befindliche Zellen, wo der Kern noch wenig verändert, das Plasma aber ganz durchsichtig hell geworden ist; $(d)$ typische embryonale Blutzellen verschiedener Grösse mit mehr tropfenförmigem Kern und sphärischer Zellwand.

Utr. Mus. Cat. no. Tarsius 491 a. 3, I. 8.

Fig. 82-86. Uebereinstimmende Phasen in der Entwickelung der embryonalen Blutkörperchen von Sorex.

Fig. 82. Eine mit der Fig. 78 und 79 vergleichbare Stelle. Einige von den Kerntheilstücken der Blutmutterzellen umgeben sich mit einem Plasmahof, andere sind bereits weiter auf dem Entwickelungswege zu typischen embryonalen Blutkörperchen vorgeschritten. Bei einem von diesen Mitose.

Utr. Mus. Cat. no. Sorex 61, b. I 7, II. 4 .

Fig. 83 A. $\quad 1 \mathrm{~m}$ Embryo cirkulirende Blutkörperchen, die sich noch in einem frühen Entwickelungsstadium befinden und die typische Form der Fig. 86 noch nicht angenommen haben. Rechts oben ein Kern in amitotischer Theilung. Sieben Kerne links und ein Kern rechts gehören zur Gefässwand.

Utr. Mus. Cat. no. Sorex 106 h. 2, II. 15.

Fig. 83 B. Einzelne Blutzellen eines ähnlichen Stadiums, eine davon in Mitose.

Utr. Mus. Cat. no. Sorex $8_{5}$ c. III. I I. 
Fig. $8_{3} \mathrm{C}$. Dasselbe einem anderen Präparate entlehnt, der Kern nach statt. gefundener 'Theilung.

Utr. Mlus. Cat. no. Sorex 125 b. Ill. 14.

Fig. 84. Ein Blutgefäss mit verschiedenen Uebergangsstadien zwischen den früheren IBlutkörperchen der vorigen Figur und den späteren, typischen der Fig. 86. Auflösung der Kernmembran, Durchsichtigwerden des Protoplasmas und Zusammenballıng der nucleolären Substanz sind dort wohl die charakteristischen Merkmale.

Utr. Mus. Cat. no. sorex 6r b. I7, II. I.

Fig. 85. Anderer Schnitt (durch dieselbe Nabelblase), aus welchem die Grossendifferenzen der embryonalen I3lutkörperchen hervorgehen.

Rechts oben ist ein "Kern" ausgretreten.

Utr. Mus. Cat. no. Sorex 61 b. 17.

Fig. 86 A. Typische embryonale Blutkörperchen von Sorex. Oben links ist ein "Kern" ausgetreten.

Utr. MIIs. Cat. no. Sorex 130 f. I. 11.

Fig. 86 B. Dieselben von einem anderen Exemplar. Links ist ein Kern eben im Austreten begriffen. Rechts drei embryonale Blutkörperchen ohne Kern, wie sie in grosser Anzahl den drei links abgebildeten beigemischt sind.

Utr. Mus. Cat. no. Sorex So c. 1, I. 2.

Fig. $87 \mathrm{~A}-\mathrm{K}$. Die successiven Entwickelungsstadien, welche die embryonalen Blutkörperchen von Tupaja während der verschiedenen Schwangerschaftsstadien durchlaufen. Von D an sind rechts neben den embryonalen Blutkörperchen auch der Muscularis oder sonstigen mïtterlichen Bluträumen entlehnten mütterlichen Blutkörperchen abgebildet $\left(D^{1}-K^{1}\right)$. Alles bei genau derselben Vergrösserung (Leitz Oelimmersion $\frac{x}{20}$ ) mit der Camera gezeichnet.

\begin{tabular}{|c|c|c|c|c|c|c|}
\hline $\begin{array}{l}\text { Fig. } \\
87\end{array}$ & & & & & & Utr. Mus. Cat. no. Tupaja \\
\hline A & Friihes & Stadium der & Fig. & & entsprechend. & I92 a. I, III. Io. \\
\hline B & Stadium & ungefähr &, & $9-10$ & , , , & 1,1 b. I, II. I1. \\
\hline $\mathrm{C}$ &,, & , & , & ," & , & $18+$ a. 2, IV. II. \\
\hline D &, &,, & , &, & , & I 85 a. 1, II. 14 \\
\hline $\mathrm{E}$ & , & & , & 10 & , & $27+$ a. 12, I. 8 und III. 6. \\
\hline $\mathrm{F}$ & , & ungefähr & , , & $11-12$ & , & 281 a. 7, III. + . \\
\hline G & , &, & , & , & , & $16_{5}$ a. I, IV. 2 und III. 2. \\
\hline $\mathrm{H}$ & , & , & , & , & , & I So c. I, III. 2. \\
\hline I & ", & , , & , , & ", & , & 306 a. $2, \mathrm{~V} . \mathrm{I}$. \\
\hline K & , , & & , & 12 & , & IOg c. 1, III. 2. \\
\hline
\end{tabular}

Fig. $88 a$ und $b$. Embryonale Blutkörperchen von Beutelthieren. ( $a$ ) Perameles nasuta, mit eben angefangener Placentarbildung. (b) Perameles obesula in einem weiter vorgeschrittenen Placentationsstadium.

Fig. $88 c$. Mütterliche Blutkörperchen von Perameles nasuta. Alle drei Figuren nach Präparaten von J. P. Hill.

Fig. 89. Aus dem mutterlichen Placentarblute eines Kaninchens. (a) Kernhaltige Blutzelle. (b) Der Kern schickt sich an zur Proliferation. $(c, d, e, f)$ Der Kern ist zerstückelt. ( $g$ und $h$ ) Die Kern. fragmente sind nicht mehr in einer Membran eingeschlos. sen sondern werden unter Schwund der letzteren eben dem 
Blute beigemischt. (i) Zwei Zellen mit fragmentirtem Kern; zwei ausgetretene Kernfragmente. Diesen, sowie den vorigen sind normale rothe Blutzellen verschiedener Grösse beigemischt. (k) Normale Blutzellen verschiedener Grösse. Alle diese sind einem Sedgwick Minot'schen Schnitt einer Kaninchenplacenta vom 9. Tage entnommen.

Fig. 90. (a) Blutzellen aus den placentaren Lakunen des Heukelom'schen (98) menschlichen Embryos. (b) Die diesen Blutzellen beigemischten fraglichen Elemente.

\section{TAFEL 14.}

Vergrösserung aller Figuren : ${ }^{520}$.

Fig. 91. Aus der wachsenden Placenta von Tarsius, vor der Anlage von Mesoblastzotten in derselben. Oben bei $k$ und $k^{1}$ zwei grosse gelappte Kerne, in welchen sich neben feinkörnigen, auch deutliche nucleoläre Massen befinden. In der unteren Hälfte Bildung von mütterliches Blut führenden Lakunen auf Kosten von Zellmaterial mit proliferirenden Kernen.

Fragmente des sich zerstiickelnden Kernes $\mathrm{K}$ bilden abgerundete "Hämatogonien" $(h)$, die in der Farbe eine Mittelstellung einnehmen zwischen den rothen Kernen und den hellgelben Blutkörperchen $b$. In mehreren Hämatogonien sind noch Einschlüsse sichtbar, in anderen sind sie verschwunden, letztere sehen in der Farbe den Blutkörperchen noch mehr ähnlich, und sind von damit übereinstimmender Grösse. Diese Farbe ist auch jene des obenerwähnten nucleolären Materials. Dieses Präparat wurde in toto tingirt mittelst Pikrocarmin'.

Utr. Mus. Cat. no. Tarsius 699 a. 6, II. 5.

Fig. 92. Anders gestaltete Megalokaryocyten während der Lakunenbildung in der Tarsiusplacenta. An wenigstens drei verschiedenen Stellen ist das Hervorsprossen von gleich grossen Hämatogonien direct aus dem Kernmaterial, ohne Betheiligung des Protoplasmas, deutlich wahrnehmbar. An anderen Stellen sieht man wie die Hämatogonien bald nicht mehr von den ihnen beigemischten Blutkörperchen zu unterscheiden sind, indem ihre Einschlüsse sich auflösen und ihre Farbe hernach mit jenen der Blutkörperchen genau übereinstimmt. Dieses Präparat wurde tingirt mittelst Pikrokarmin in toto, es wurden die Schnitte mit Hämalaun nachgefärbt.

Utr. Mus. Cat. no. Tarsius 125 a. I, IV. 5.

Fig. 93. Wieder andere Erscheinungen anderer proliferirender Riesenkerne in der Placenta während der Lakunenbildung. In der Mitte eine Lakuna, welche noch von Plasmafäden durchsetzt wird und nach links neun Blutkörperchen und zwei Hämatogonien enthalten; unten ein Kern K, der eben in Begriff ist sich in Hämatogonien aufzulësen. Zwischen diesen beiden ein

1 Es soll zu den Fig. 9r und 97 bemerkt werden, dass hier das Pikrocarmin eine sehr intensive Tinction der Blutkörperchen hervorgerufen hat, welche keineswegs bei allen jenen Placentadurchschnitten die in genau derselben IVeise behandelt wurden, erreicht wurde. Ein Fall wie dieser bleibt Ausnahme, wie es auch meine zahlreichen Erinaceus- und Sorex-Schnittserien beweisen. Weshalb gelegentlich die gelbe Farbe eine so starke Affinität für die Blutkörperchen besitzt, bleibt für mich fraglich : ich erinnere nur an den Ausspruch M. Heidenhain's (94 S. 548 ), welcher oben (S. 39I) citirt wurde. 
sich zur Hämatogonienbildung anschickender, aber dazu noch nicht ganz reifer Kern $\mathrm{K}^{1}$.

Färbung der Präparate mittelst Pikromagnesiacarmin (in toto 3 Tage). Nachfärbung der Schnitten mit Pikro-Indigocarmin.

Utr. Nus. Cat. no. Tarsius 49 I a. 6 , III. 6.

Fig. 93 A. Ein Kernfragment, fünf Hämatogonien und zwei Blutkörperchen an einer anderen Stelle des nämlichen Schnittes neben einander liegend.

Fig. 94. Lakunenbildung mit in deren Rand sich erhaltenden Kernen und mit Auflösung grosser Kerne in Hämatogonien, welche ihrerseits bald einem Blutkörperchen ähnlich sehen. Links unten ein solcher, sich aufösender Kern : die Hämatogonien vermischen sich centrifugal mit genuinen Blutkörperchen. In den linken oberen Lakunen sind die grünen Blutkörperchen im Uebergewicht, ihnen sind aber noch hellbraune Zwischenstadien beigemischt.

Färbung der Präparate mittelst Pikrocarmin in toto; Nachfärbung der Schnitte mit Pikroindigokarmin.

Utr. Mus. Cat. no. Tarsius 261 a. =, I. 2.

Fig. 95. Schnitt aus der unmittelbaren Umgebung der frühen Placenta, wo interglanduläres Gewebe Blutbahnen schafft. In der hier abgebildeten Gegend ist der Uebergang eines Theiles des Kernmaterials und zwar des nucleolären Einschlusses in Blutkörperchen, welche den sonstigen mütterlichen in Grösse und Farbe ganz ähnlich sehen, unverkennbar.

Färbung mittelst Pikrocarmin, in toto. Nachfärbung mit Indigocarmin.

Utr. Mus. Cat. no. Tarsius 22 a. 9, I. . .

Fig. 96. Der innere Placentarrand bei eben angefangener Bildung von Mesoblastzotten. In diesem, sowie in dem Chorionmesoblast finden sich bei chf. Gefässe mit embryonalen Blutkörperchen in den verschiedensten Reifestadien. Von den reifen kommt der "Kern" der Farbe und Grösse nach mit den mütterlichen Blutkörperchen b. überein. Bei h. eine Hämatogonie (sie liegt im Präparat weiter nach unten), Trw, Lakunenbekleidung aus Trophoblastzellgewebe hervorgegangen. Vergl. Fig. 67.

Färbung mittelst: Pikrocarmin (4 Stunden), nachher Indigocarmin ( 5 Minuten).

Utr. Mus. Cat. no. Tarsius $5 \neq 2$ a. 2 I, II. 8.

Fig. 97. Dasselbe an einer anderen Stelle eines anderen Präparates. Auch hier gilt das nämliche für das Verhälten embryonaler und mütterlicher Blutkörperchen. Buchstaben wie in Fig. 96. Färbung mittelst Pikrocarmin in toto (siehe Anmerkung $\mathrm{zu}$ Fig. 91).

Utr. Mus. Cat. no. Tarsius 595 a. II. 5 .

Fig. 98. Zahlreiche Variationen von Sorex-Blutkörperchen zu vergleichen mit den in Fig. 87 von Tupaja gegebenen: (a) aus einen grossen Gefäss der Allantois ; $(b)$ aus der embryonalen Aorta ; (c) aus einem embryonalen Gefäss in der Nasengegend ; $(d)$ aus den Nabelblasengefässen; $(e)$ aus embryonalen Blutbahnen innerhalb der Placenta; $(f)$ aus mütterlichen Blutbahnen innerhalb der Placenta; $(g)$ aus muitterlichen Bahnen ausserhalb der Placenta. Färbung mittelst Pikrocarmin. Schnitte nachgefärbt in einem Gemisch von Carmalaun, Indigocarmin, und Orange G. Ausgewaschen in gesättigter Pikrinsäure.

Utr. Mus. Cat. no. Sorex 61 b. 17 , I. r. 
TAFEL I 5 .

Alle Figuren bei einer Vergrösserung von 520 . Hämatopoiese in der Placenta von Tarsius und Tupaja.

Fig. 99. Zwei Megalokaryocyten aus dem Stadium der Fig. 23 und aus dem in Fig. 64 abgebildeten Schnitte.

Der Kern der rechten Zelle hat eine deutliche Kernmembran und zahlreiche plasmosomatische nucleoläre Einschliisse. Der Kern der linken Zelle befindet sich in dem Stadium einer atypischen Mitose ; die Kernmembran ist hier völlig verschwunden, das Chromatin sichtlich von viel geringerem Umfang, als die gefärbten Einschliisse des rechten Kernes. Färbung Pikrocarmin, in toto.

Utr. MIus. Cat. no. Tarsius +56 b. III. 13 .

Fig. 100. Ein Stück der placentaren Trophoblastwucherung aus dem Stadium der Fig. 67. Es finden sich Megalokaryocyten mit wurstförmig gebogenem und solche mit zerstückeltem Kerne. In der Mitte oben bilden Kernreste als Hämatogonien Uebergänge zu Blutkörperchen. In anderen Kernfragmenten hat sich nucleoläre Materie tropfenweise angesammelt und verlässt (links unten bei*) die Kernmembran um als selbständiges Blutkörperchen weiter zu existiren. Färbung des Präparates mittelst Pikromagnesiacarmin, in toto (3 Tage). Schnitte nachgefärbt mit Pikroindigocarmin.

$$
\text { Utr. Mus. Cat. no. Tarsius } 49 \text { I a. }-3 \text {, II. r. }
$$

Fig. 100--104. Vier Abschnitte der Trophoblastwucherung einer zwischen den Stadien der Fig. 22 und 23 befindlichen Placenta. Nachfärbung der Präparate mittelst Pikroinciigocarmin, angesäuert mit Salpetersäure, später Pikrinsäure.

$\mathrm{Zu}$ bemerken in diesen Schnitten: das feinkörnige und gelappte Aussehen vieler Riesenkerne. In Fig. IOI ist wieder eine atypische Mitose, jedoch in etwas anderer Form, als in Fig. 99 zu beobachten. In 102 und ${ }^{0} 04$ entstehen Blutkörperchen durch Vermittelung von Hämatogonien, welche ihrerseits durch Auflösung eines Riesenkernes zu Stande kommen. In Fig. IOI und IO3 auch durch unmittelbares Freiwerden eines nucleolären Einschlusses bestimmter Kernbezirke (lk).

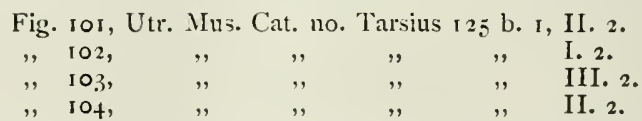

Fig. 105. Schnitt aus einer anderen, etwas jüngeren, grün tingirten Placenta. Nucleoläre Kerneinschlüsse werden direct als Blutkörperchen frei, nebenbei sind auch Hämatogonien wahrnehmbar.

Totale Färbung in Pikrocarmin. Nachfärbung der Schnitte mittelst Indigocarmin und eingetaucht in Pikrinsäure.

Utr. Mus. Cat. no. Tarsius 623 a. 6, II. 2.

Fig. 106-108. Drei Stellen aus verschiedenen tingirten Schnitten der reifenden Tupajaplacenta (vergleich Fig. Io und 32), in welche Kernfragmente unter Abnahme der chromatischen und unter Zunahme der nucleolären Bestandtheile direct in anders tingirten Blutkörperchen übergehen. Die allmählichen Uebergänge in der Tinction sind in allen drei Fällen (sowie auch in der nächsten Figur) unverkennbar. 
1)as Präparat der Fig. 106 wurde gefärbt mittelst Carmin, Carminsäure und Pikroindigocarmin ; dasjenige der Fig. 107 nur in Carmin und Pikroindigocarmin; das der Fig. 108 mit Carmalaun, Indigocarmin und Orange G., angesäuert mit Salpetersäure, nachher ausgewaschen in Wasser und in gesättigte Pikrinsäure eingetaucht.

Fig. 106, Utr. Mus. Cat. no. Tupaja 274, xvir. I. 1.

$$
\begin{aligned}
& \text { " } 107, \quad \text {, } \quad \text { " } \\
& \text { " ros, " , " } \quad 281 \text { a. +, II. } 3 \text {. }
\end{aligned}
$$

Fig. 109. Abschnitt einer Placenta, in welche neben den bereits in den drei vorigen Figuren abgebildeten Vorgängen 'Trophoblastlakunen mit mütterlichen Blutkörperchen und solche, worin Allantoiszotten (all.) eingeschlossen sind, zur Beobachtung kommen. Die Allantoiszotten erhalten embryonale Blutkörperchen, deren "Kerne" an Grösse und Tinctionsvermögen den mütterlichen Blutkörperchen gleich kommen. Die Farbe der letzteren variirt zwischen einem dunkleren und einem helleren gelb, auch kommen daneben solche vor, die ganz blass aussehen und nur durch ihren Rand hervortreten (rechts unten bei $b$ ). Färbung mittelst Carmin, Carminsäure und Pikroindigocarmin.

Utr. Mus. Cat. no. Tupaja $27+$ a. I r, III. I. 

413

\section{APPENDIX C.}

PROFESSOR OSBORN'S REMARKS AT THE DISCUSSION ON THE ORIGIN OF MAMMALS ON THURSDAY 25 AUGUST. (See p. 70.) 



\section{THE ORIGIN OF MAMMALS.}

Since the Source of the Mammalian phylum was later than that of the Reptilian phylum in the Permian and possibly Carboniferous, we are sure that it extended at least very far back into the Triassic, and the Triassic was apparently a time of great continental connections and of consequent wide geographical distribution even of land types. But in presenting a phylogenetic chart which traces the origin of Mammals to the Upper Permian, I am quite as conscious as the most conservative zoologist present that we are not on sure ground, that this is a castle of cards liable to fall at any moment. Yet such a chart, involving as it does numberless hypotheses, is necessary to set forth certain ideas.

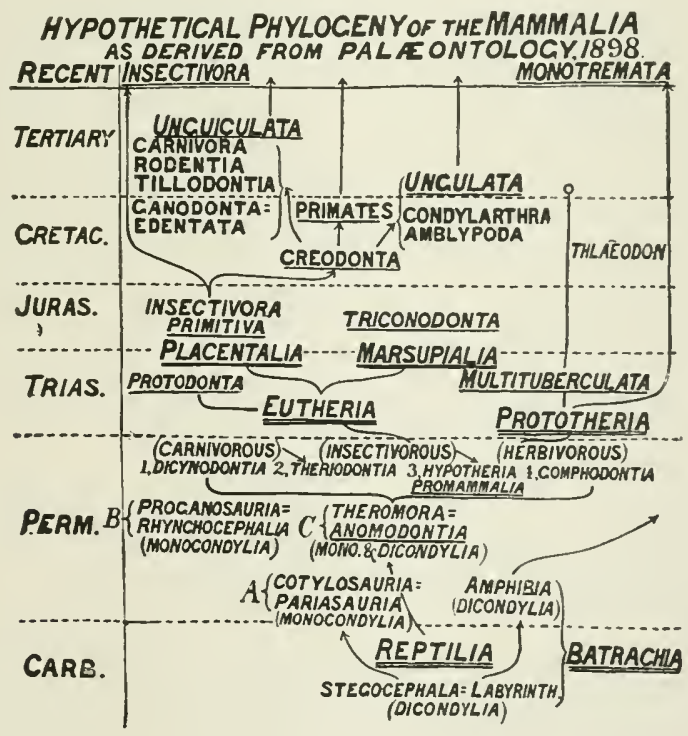

Clearing the way for this discussion, this chart first sets aside the general view defended by Huxley in I880, of a genetic succession between three sub-classes of mammals, which has become a matter of creed with many zoologists. In the last eighteen years not a scintilla of evidence has arisen to show that Placentals are descended from Marsupials, and of late, evidence has been coming in 
directly against this view. In fact zoo-palaeontology now indicates that Marsupials and Placentals are parallel phyla, arising from a common stock, while Monotremes are so different that they may even be considered diphyletic, or derived independently from the Reptilia, as maintained by Mivart among others, and latterly by Seeley.

So far as major classification is affected by this conception, it appears therefore that we must revert to Gill's divisions of I872, constituting only two sub-classes of Mammals, namely:
A. Eutheria
and
Marsupials,
B. Prototheria.
Monotremes.
Placentals.

Marsupials are less primitive than the placental Insectivores, and Marsupials and Placentals are certainly far nearer each other than either are to the Monotremes.

To guide our speculation in the unknown pre-Tertiary period, we may gather certain positive principles from the known evolution of the Tertiary mammalia. First, we know that adaptive radiation, characteristic of all vertebrates, and beautifully illustrated among Reptilia, is in a very high degree distinctive of Mammalia, because of their superior plasticity ${ }^{1}$. There is the (I) Marsupial radiation of Australia (Meteutheria ${ }^{2}$ )-now passing its prime, then the (II) Tertiary Placental radiation of the Northern Hemisphere (Ceneutheria), and another quite independent (III) Tertiary Placental radiation in South America (rendered less pure in course of the Tertiary period by migration from I and II). (IV) There is the entirely distinct and archaic Cretaccous Placental radiation of the Northern Hemisphere (Meseutheria), which extends into the Tertiary, and may have given origin to II and III, although as yet we have no direct proof of it.

We mark the fact that the above radiations are all of ordinal rank, for the Marsupial radii, although termed families, are adaptively equivalent to several Placental orders.

If we apply these same principles to the Jurassic, we apparently have evidence of a more fundamental, (V), Sub-class radiation of Placentals, Marsupials and probably Monotremes of world-wide distribution. (This involves a controverted question, to which I shall revert, for by some zoologists these animals of the Purbeck Clays, Como Beds, and Stonesfield Slates are considered exclusively Marsupials and Monotremes.) Finally far back in the Perm-Trias we certainly observe (VI), the Theromorph or Theriodont Reptilian radiation, spurs of which may have given rise to the Mammalia. The focal-types, or most primitive forms of the radiations, I-IV,

1 We know nothing of Africa, whether it enjoyed a radiation of its own or borrowed its fauna from other continents.

${ }^{2}$ The Eutheria may embrace the Meteutheria or Marsupials, the Meseutheria or primitive Mesozoic Placentals and Ceneutheria or Tertiary Placentals. 
were certainly small, terrestrial, clawed, insectivorous or omnivorous forms. It is noteworthy that in the evolution of each radiation, so far as we know at present, land types and organs are invariably primitive, and water types and organs are secondary, exactly as we find it among the Reptilia. In fact we have not found a single instance in which a mammal or reptile series is known to be transforming from a water into a land type, it is always the reverse. There is certainly no evidence for a cetoid (Albrecht) stem of the mammals. Again it is obvious that neither carnivorous nor herbivorous types with highly specialized or reduced teeth and feet can be so central as insectivorous and omnivorous types. In fact the Insectivores among Placentals, and Opossums among Marsupials, are the only animals which have preserved the dental prototype close to that of the Promammal.

The backward convergence of all Tertiary mammalia to a Creodont stem, as indicated in the chart, affords the clearest demonstration of the existence of an earlier insectivorous stem, and it not only accords with the above principles, but wc are thus carried a step further to realize that the Creodont ancestor must have been a generalized Insectivore.

To reconstruct the ancestral Eutherian skeleton, therefore, we should divest the Creodonta and Inscctivora, in their anatomy and development, of all their secondary specializations, and combine all their truly primitive characters. This ideal Eutherian is nearer the pro-Marsupial than we supposed, it has the following chief characters :- head large, body relatively small. Anterior nares terminal, face elongate. Insectivorous or omnivorous habit. Molar teeth pointed, tritubercular. Typical dental succession. Vertebrae with intercentra. Dorso-lumbars not exceeding 20. Back arched, tail long and powerful. Scapula and ilium narrow, acuminate. Humerus with powerful deltoid crest, condylar crests and entepicondylar foramen. Femur with three trochanters. Feet plantigrade. Centralia and tibiale. Fore-limb more or less prehensile, elbows everted.

Now the Creodonta are members of that Cretaceous radiation, IV, which we find in full bloom in the Basal Eocene, mingled with the dying group of Multituberculates, which belong to the Jurassic radiation, $\mathrm{V}$.

In the Mid- and Uppermost Jurassic (Stonesfield, Purbeck and Como Beds) however, occur all three types, which theoretically constitute radiation $\mathrm{V}$ : first, the Triconodonts primitively but typically Marsupial in structure ; second, the Insectivora primitiva, primitively Placental in type, insectivorous and without a single Marsupial character either in jaw or teeth; third, the Multituberculata, whose sub-class position is now assumed to be Monotreme.

Always keeping in mind that our direct evidence here is of the most limited character, since we have neither skulls nor skeletons, only teeth and jaws, we are tempted to hypothetically connect the 
Creodonta with the Insectivora Primitiva, and to assume that there existed, as above stated, a well advanced radiation (V) of the two sub-classes of EUTHERIA and PROTOTHERIA.

The problem of the Origin of the Mammals now resolves itself into the connections between these two sub-classes, either with the Reptilia or Amphibia, and we turn back to the three contemporary upper Permian reptile groups :

I. Pareiasauria or Cotylosauria, land animals with a solid skull and replete with Stegocephalian or Amphibian characters, certainly the most primitive reptiles.

2. Proterosauria or Proganosauria, with an open two-arched skull, specialized reptiles, which have apparent affinities with the Crocodilia, Dinosauria, Rhyncocephalia and Squamata (Dolichosauria, Mosasauria, Lacertilia and Ophidia).

3. Theriodontia or Theromora (Dicynodontia, Cynodontia and Gomphodontia), with an open single arched skull (as in the Chelonia, Plesiosauria and Ichthyosauria and Mammalia).

The Theriodontia as perceived by Owen in 1876 , and now fully confirmed by Seeley, are astoundingly mammalian in type. They are essentially quadrupedal, long-limbed, terrestrial reptiles, totally dissimilar from all other reptiles, and standing far away from them. They also present an advanced stage of functional radiation in tooth and skull structure in adaptation to carnivorous, omnivorous, and herbivorous habits, to which when known, their skeletons will probably be found to conform. The shoulder girdle is of Monotreme type, in other features of the skeleton they are strikingly like the ancestral Eutherian, described above. The skull may in fact be reduced to the Eutherian type by the coalescence of the prefrontals, postorbito-frontals, and quadrates with the adjacent elements, and by the loss of the ectopterygoids or transverse bones. The teeth are promammalian in formula, and pro-tritubercular or multitubercular in form. The skeleton so far as known is partly Eutherian, partly Monotreme or Prototherian.

Two questions at this point present themselves: first, Are the Monotremes directly derived from such a type as these Theriodonts, leaving an independent derivation for the Eutherian or Marsupioplacental stock, as has been suggested by Seeley? Second, Must we set aside the Theriodonts on account of the numerous Amphibian resemblances, which Hubrecht and others find in the development and anatomy of the lower Mammalia?

The first question is now unanswerable, although at present the evidence that the Mammalia are diphyletic is certainly considerable. Right here the investigation of the placental ovum rises to extreme importance, if the Eutherian ovum is of Amphibian type, the Mammalia are certainly diphyletic, for the Monotreme ovum is certainly 
of reptilian type. The second point may be met by supposing that at the time the Marsupio-placentals were given off, the Theriodontia conserved a number of Amphibian characters, which were at the time or subsequently lost.

The problem of most immediate concern, however, is whether the Theriodontia are actually the long sought Promammalia of Haeckel, Hypotheria of Huxley, or Sauromammalia of 13aur, or whether they present a fresh instance of extensive parallelism duc to the assumption of habits analogous to those of Mammalia. Professor Seeley has just presented the latter view ${ }^{1}$, and it is certainly true that none of the known Theriodonts fill the characters outlined above as those we must look for in the Promammal or Eutherian stem, for they are all too large and too specialized.

There are however grounds for the more sanguine former view, that the Theriodontia are the Hypotheria or Promammalia, because it appears that within the order may well have existed some small insectivorous types, far less specialized in tooth structure than either the carnivorous Cynodonts or herbivorous Gomphodonts, as one of those conservative spurs of adaptive radiation which form the focus of a new progressive type.

The problem will therefore be settled by additional discovery and knowledge of the skeletal structure of the diverse types which undoubtedly composed this remarkable group.

1 "Anomodonts are not the parents of Mammals, but a collateral and closely related sroup. The common parent of both may be sought in rocks older than Permian, perhaps in Silurian or Devonian strata." Abstract of Discussion, p. 70. 



\section{ALPHABETICAL LIST}

\section{OF AUTHORS AND SPEAKERS.}

\begin{tabular}{|c|c|}
\hline PAGE & PAGE \\
\hline Apáthy, S. v. & $\begin{array}{l}\text { Haeckel, E..........64, 74, 76, 77, } 124 \\
\text { Hampson, Sir G. F. ..............273 }\end{array}$ \\
\hline Bell, F. Jeffrey.................... 96,99 & Harmer, F. W. .....................222 \\
\hline Bemmelen, J. F. van ...............162 & Hartog, M. .................. 118, I 24 \\
\hline Blanchard, R. ......................5 & Harvie-Brown, J. A. .................155 \\
\hline Blandford, W. F. .................166 & Hertwig, R. ..........................20 I \\
\hline Blanford, W. T. ...................... 57 & Heymans, J. F. .....................165 \\
\hline Bles, E. J.......................... 72 & Heymons, R. .......................266 \\
\hline Bordage, E. .........................235 & Hickson, S. J. .................99, 202 \\
\hline Bourne, G. C. .................123, 124 & Hoek, P. P. C. ......................55 \\
\hline Bouvier, E.-L. ........................269 & Hubrecht, A. A. W...49, $68,75,172,343$ \\
\hline $\begin{array}{l}\text { Caracciolo, H.......................245 } \\
\text { Carruccio, Cav. A. ..............96, I } 84\end{array}$ & Janet, C. ... \\
\hline 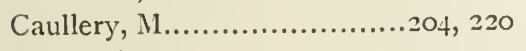 & Kanthack, A. A. .....................166 \\
\hline Certes, A. ..........................227 & Kent, W. Saville ...............65, I68 \\
\hline Delage, Y. .......................5 5,98 & Kerr, J. Graham .....................164 \\
\hline 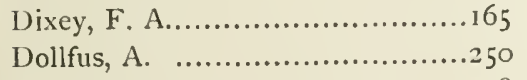 & Lubbock, Sir J......43, 96, 98, 155,266 \\
\hline Dubois, E. .............................78 & \\
\hline Duckworth, W. L. H. ...................78 & Macbride, E. W. .................. \\
\hline Durham, H. E. ...............166, 167 & 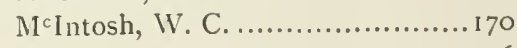 \\
\hline Durrant, J. H. .......................273 & Malard, A. E. .......................226 \\
\hline Ewart, J. C..................165, r66 & $\begin{array}{l}\text { Marey, E. J. .......................... } 77 \\
\text { Mark, E. L. ........................ I }\end{array}$ \\
\hline Fauvel, P..........................22y & $\begin{array}{l}\text { Marsh, O. C..............49, } 71,95,158 \\
\text { Masterman, A. T. .................. } 148\end{array}$ \\
\hline Gadow, H.................77, 164, 172 & Maxwell, Sir H. .................... I 48 \\
\hline ardiner, J. Stanley $\ldots . \ldots \ldots \ldots \ldots \ldots \ldots$ I 8 & Mayor of Cambridge, The $\ldots \ldots .4 \mathrm{I}, 98$ \\
\hline$\ldots \ldots \ldots \ldots 196$ & Mesnil, F.....................204, 220 \\
\hline Graff, L. von .....................98, I 24 & Milne-Edwards, A...........47, 98, 157 \\
\hline
\end{tabular}




\begin{tabular}{|c|c|}
\hline & \\
\hline Iinchin, E. A. ...................... & Saunders, H. ... \\
\hline itsukuri, $\mathrm{k} \ldots \ldots \ldots \ldots \ldots \ldots \ldots \ldots$, IOI & Schewiakoff, IV. ..... \\
\hline & $\begin{array}{l}\text { Schulze, F. E. ............... } \\
\text { Sclater, P. L. } \quad \ldots \ldots \ldots \ldots \ldots\end{array}$ \\
\hline ewton, A. $\ldots \ldots \ldots \ldots \ldots .50,75,97$, I 57 & gwick, A................. 74,172 \\
\hline linion $\mathrm{F}$ & 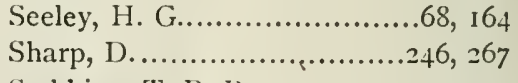 \\
\hline 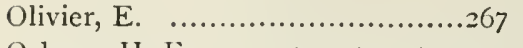 & ing, T. R. R. ..................77 \\
\hline 174,413 & O. Van der.................. 165 \\
\hline ............... Is & \\
\hline$\ldots \ldots \ldots \ldots \ldots \ldots \ldots \ldots \ldots \ldots \ldots \ldots \ldots \ldots+226$ & $\cdots .244$ \\
\hline C. & .......I 54 \\
\hline $\begin{array}{l}\ldots \ldots \ldots . . .68,188,194 \\
\ldots \ldots \ldots \ldots \ldots \ldots \ldots \text { 1 } 84\end{array}$ & ........174 \\
\hline ublic Orator, The $\ldots \ldots \ldots \ldots \ldots \ldots \ldots .39$ & he $\ldots \ldots \ldots \ldots \ldots \ldots \ldots+\ldots \ldots \ldots+200,202$ \\
\hline$\ldots \ldots 165$ & Vosmaer, G. C. J............ \\
\hline$\ldots .230$ & $\ldots 260$ \\
\hline F. .................... 197 & $\begin{array}{l}\text { Wolterstorff, W. } \\
\text { Wright, R. Ramsay } \ldots \ldots \ldots \ldots \ldots \ldots \ldots \ldots \ldots \ldots \ldots \ldots \ldots \ldots\end{array}$ \\
\hline & \\
\hline
\end{tabular}



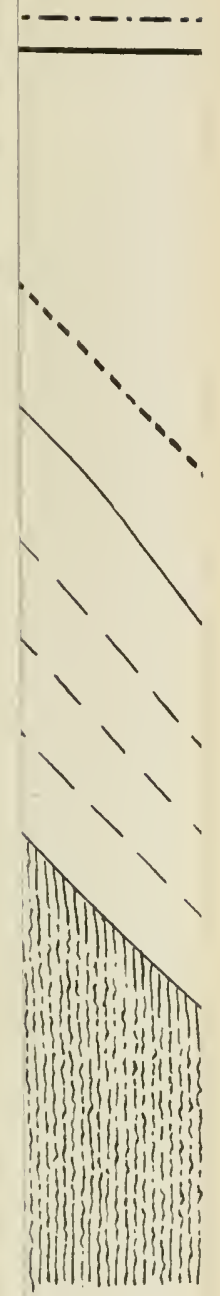

SUBMARINE

: same time th to form in th too fathoms a on Island, $\mathrm{Pr}$

- further broz central part ize and depth des by a low. rose run by $t$

B. Sections 


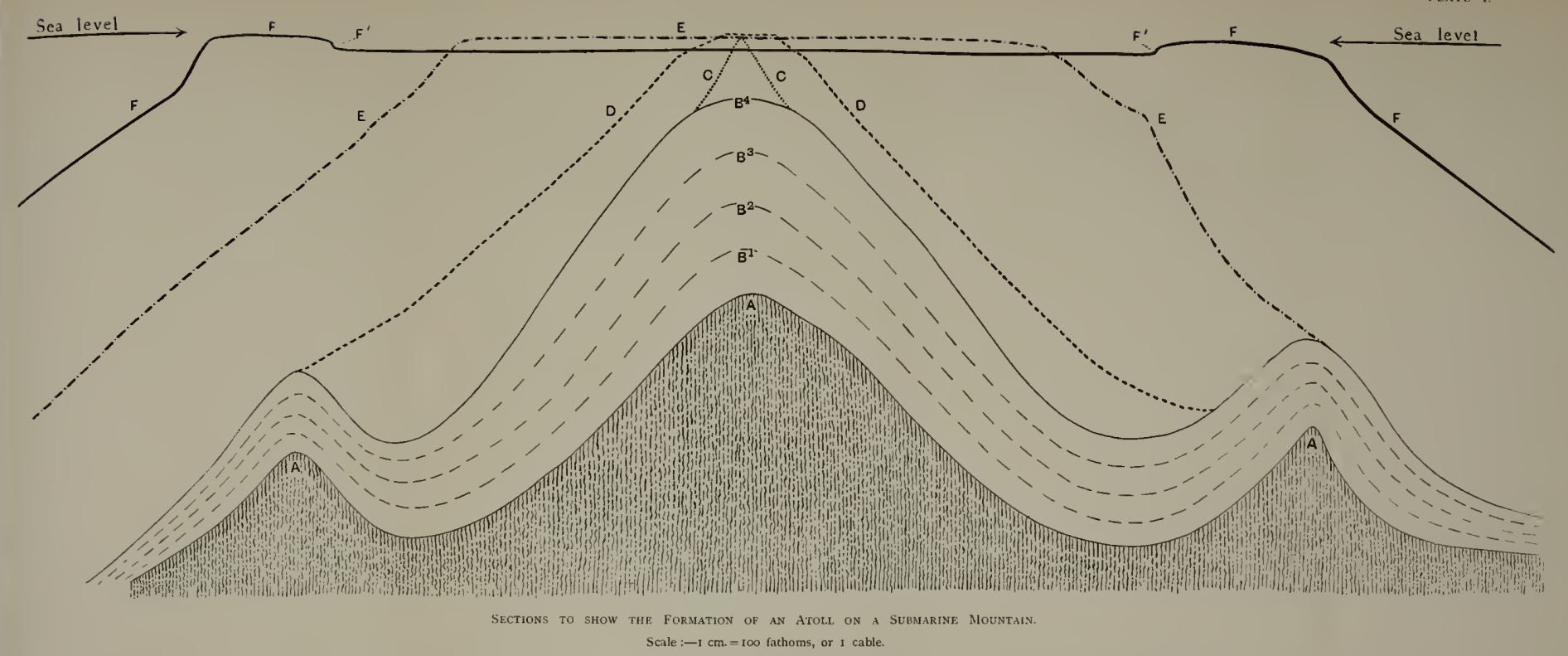

A. Contour of the sea floor, showing a submarithe
of 600 fations from the surface and two lower hills.

the mountain at a depth BH- Contour lines showing the building up of mo
by the accretion of the remains of various organisms. C. The highest mound has been built up to the bathymetrical limit of
the reef-building organisms, which at once raise a pinnacle on in to the the reef-building organisms, which at once raise a pinnacle on it to the
surface.

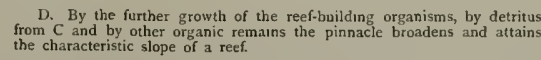
E. The surface of the reer broadens by the fusion to it of buttresses,
forned by the direct upward growth of the reef organisms on its shallow

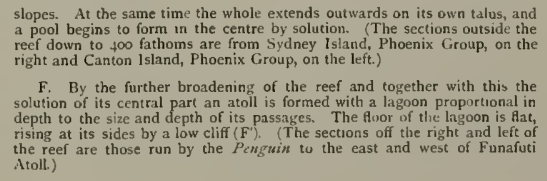

(N.B. Sections taken from the Admıralty Charts.) 


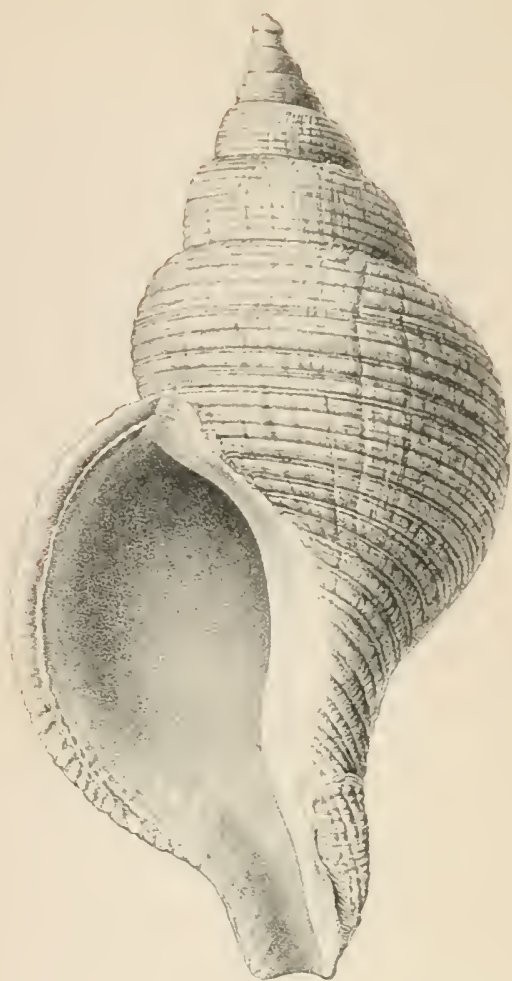

4

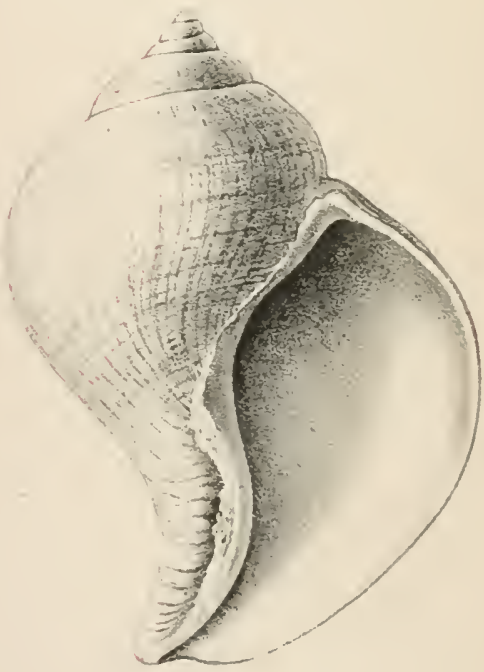

8

Limn., var. carinata. Fossil, Little Oakley.

Fig. the typical form at Oakley.

2 var. brevispira. 

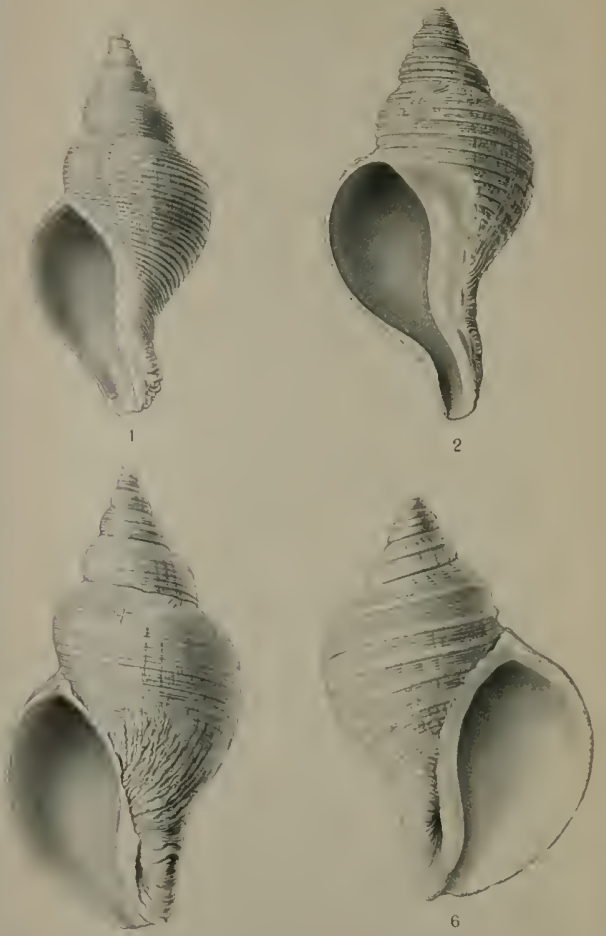

กg. 1 Nepluses coacrara, Limm, ver. alpistrores. Fossil, Plocene of Sicily. $2 * 3 . \quad . \quad$ Fossil, Benldasien of Belgura.

4 . ". Heceut. Vigu Bay

B. Fossal, trag thedn, Little Oakley, Essex
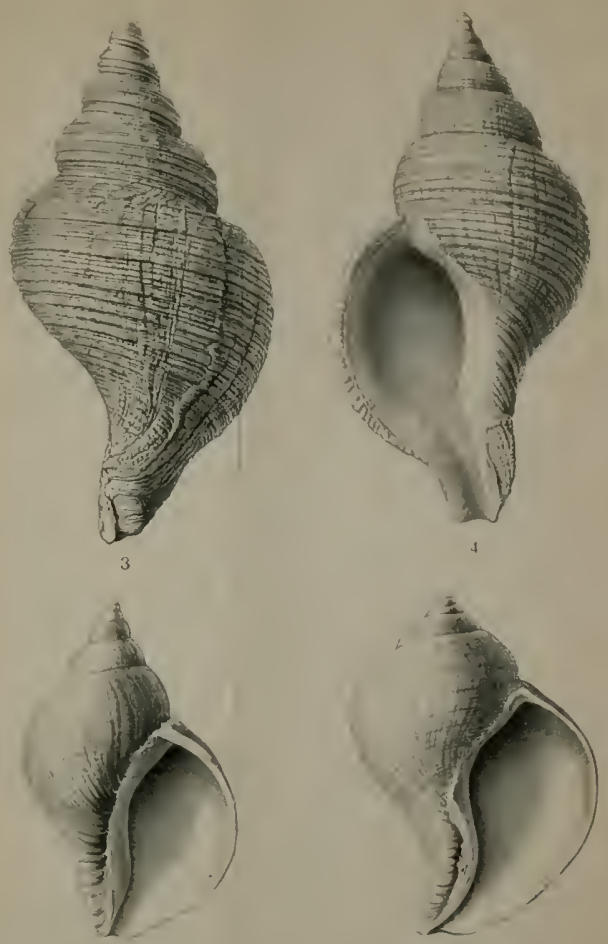

ng 6. Meptuasa ontqua. Limn, var. carianta Fimssi, Littie Oakley. the typieal furan at Oskley inr oreviopla 



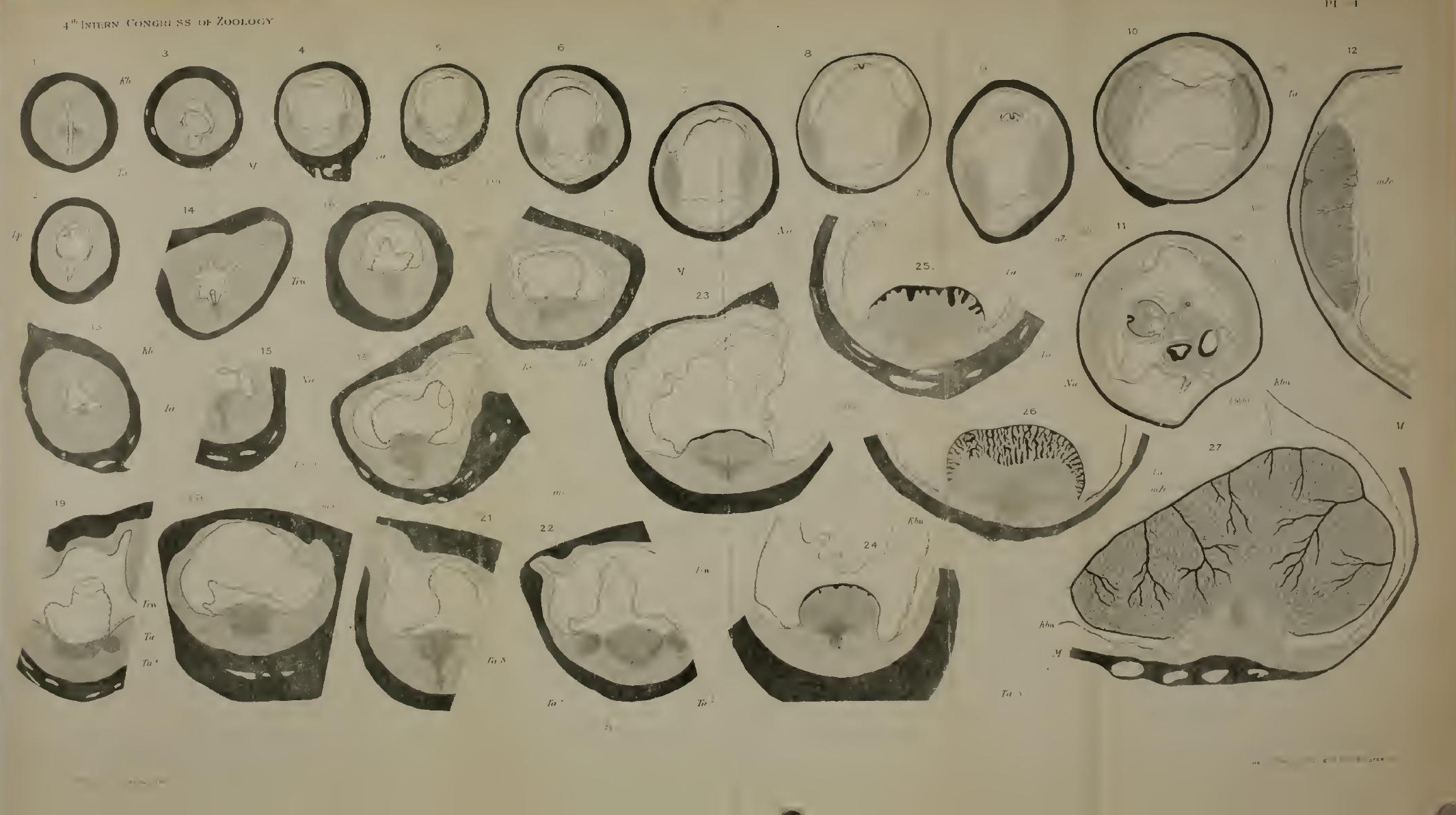





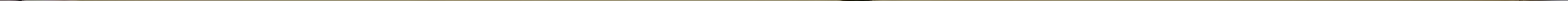




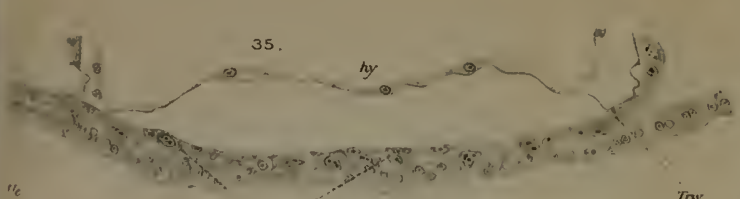

$y_{1}=$

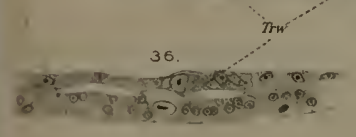

$\because 39 \quad \ldots$ Trw 40.

neverar

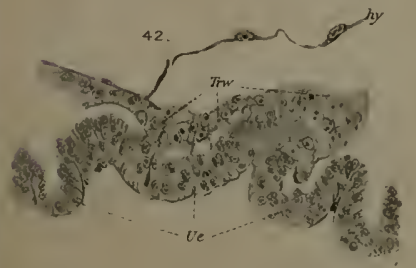

$\pi_{N w}$

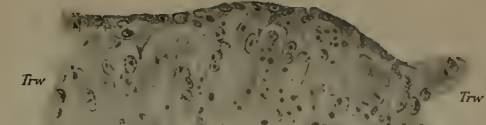
$\therefore \ldots$ ont
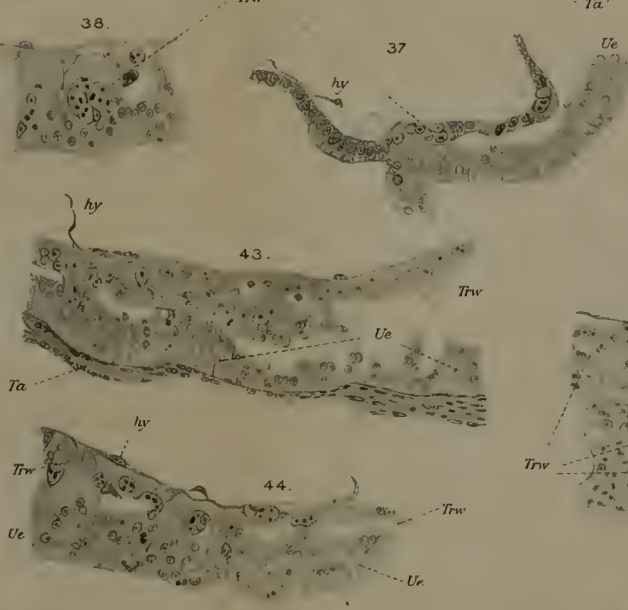

Trv
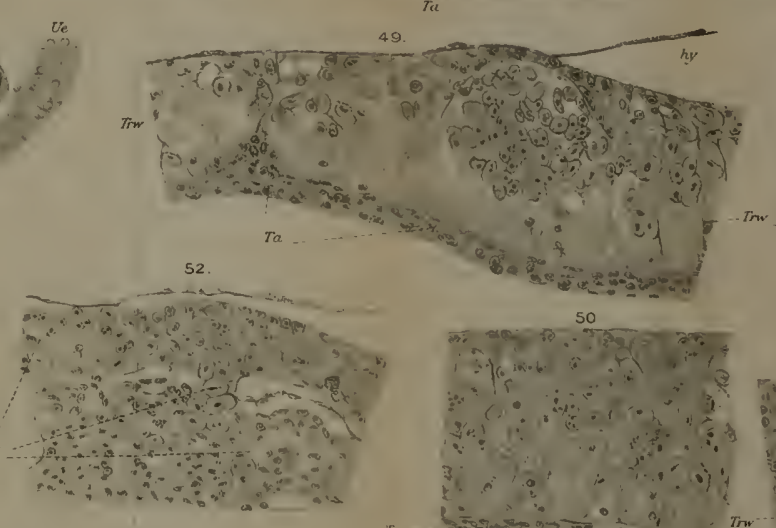

(qu) $y=$ (2) $\div=:$ की $\pi$
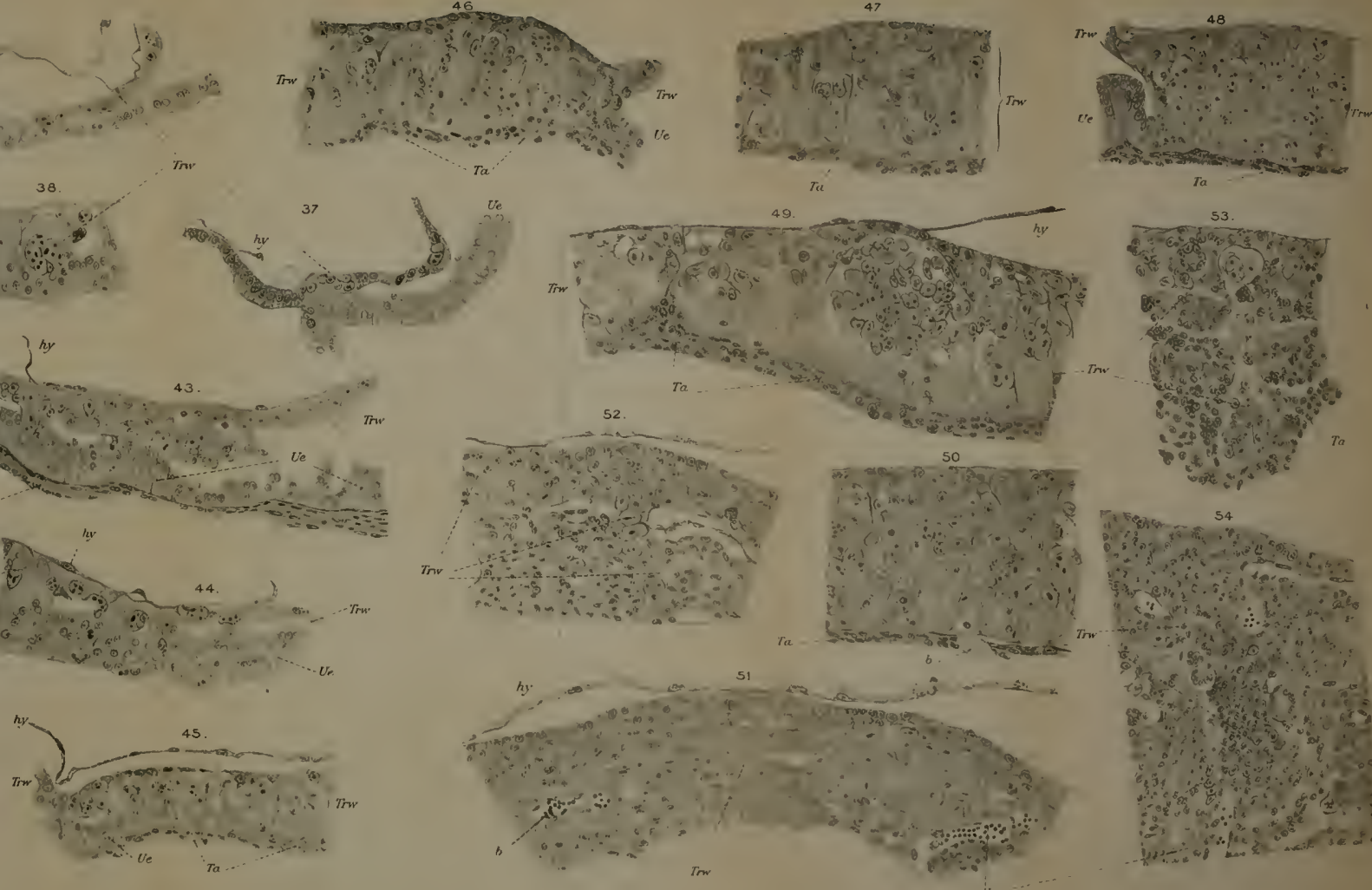

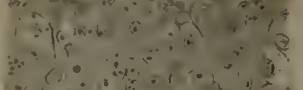

31000

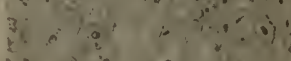

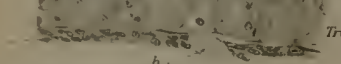

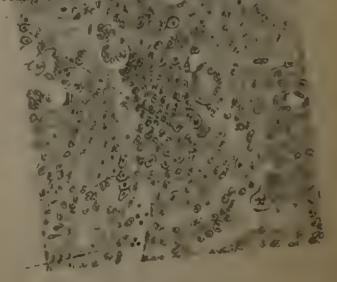


$\because$

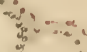

4 , e

xet (1) ? $\therefore \quad x-1$

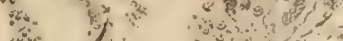
מ.

+ $14 \times$ to $\because 4$ (1) $\therefore \quad$ a 40 $\therefore$ os $\quad \because 40$ $\therefore$.

2 5 a and

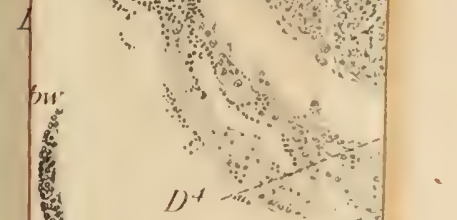

梠

.

(1)

Trw

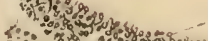

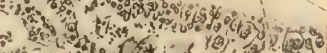

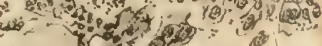

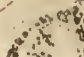

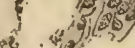
2.

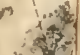

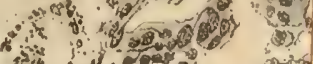
+4 fin

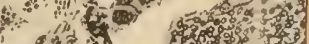
ct? $x$, $\therefore$ $3 x^{3}$ jugen sing

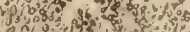

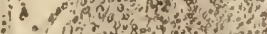
$\because$ i b

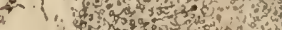
3.- Is. 3 s

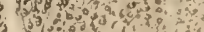

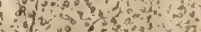

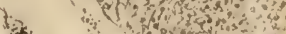
制 \&

(3) 3

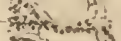

(1) an

$=0$ + int $\because$. 

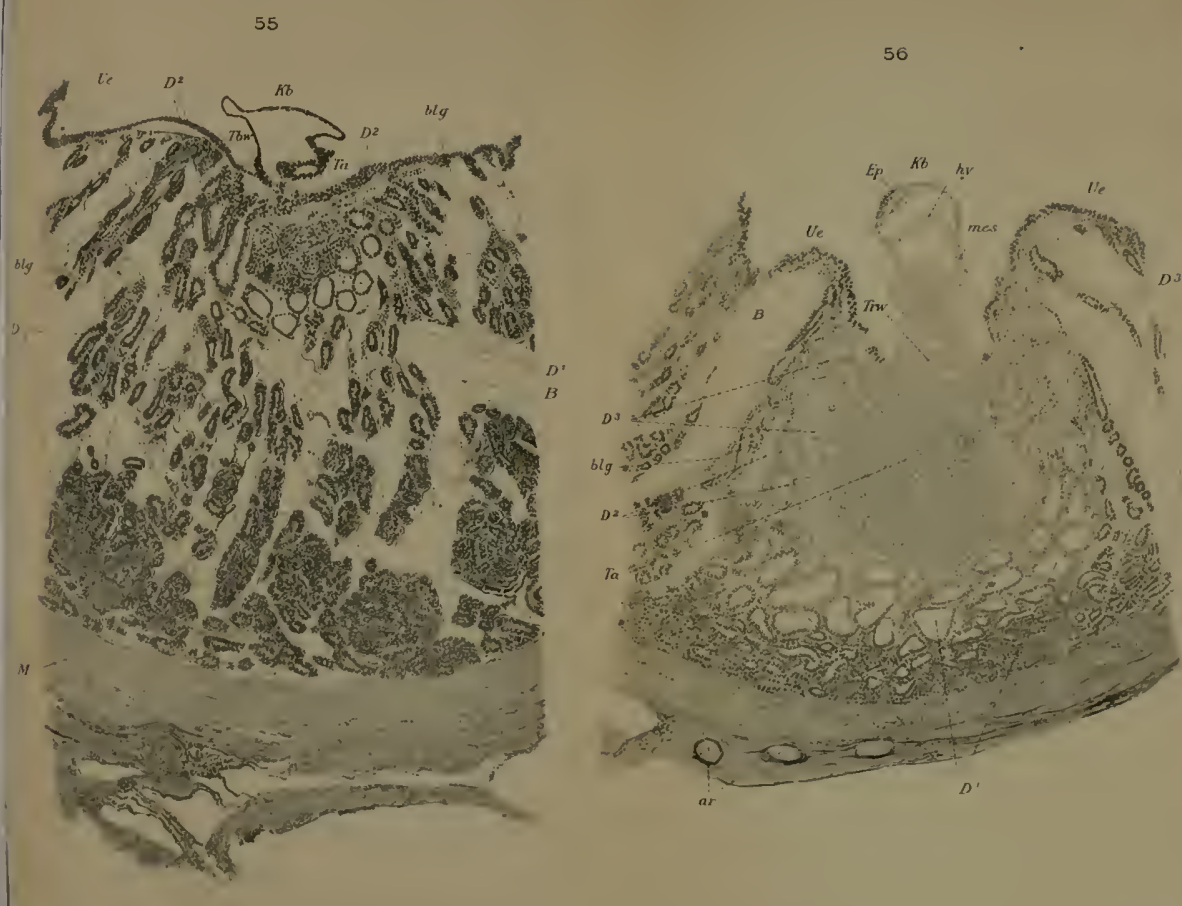

$\frac{1}{2}$

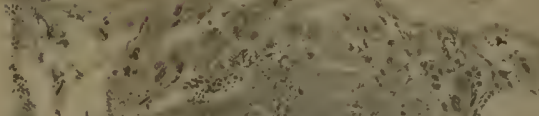

low

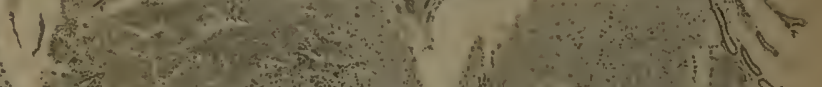

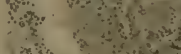
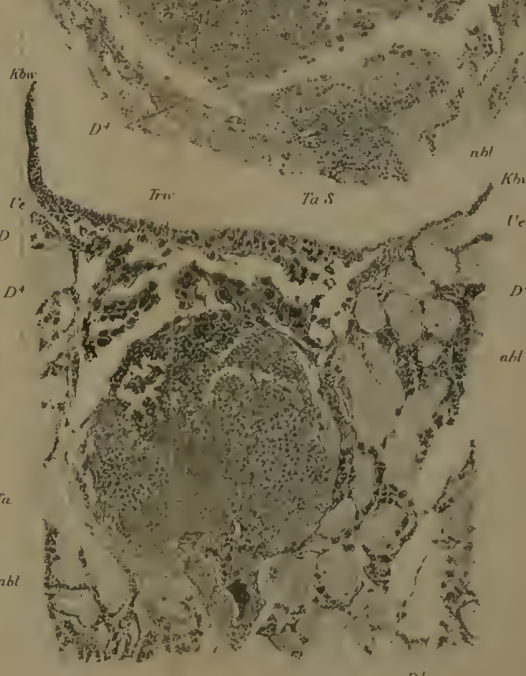

Tas

$$
\text { D.A D. D D }
$$




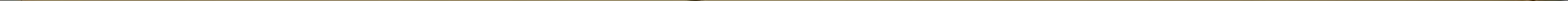





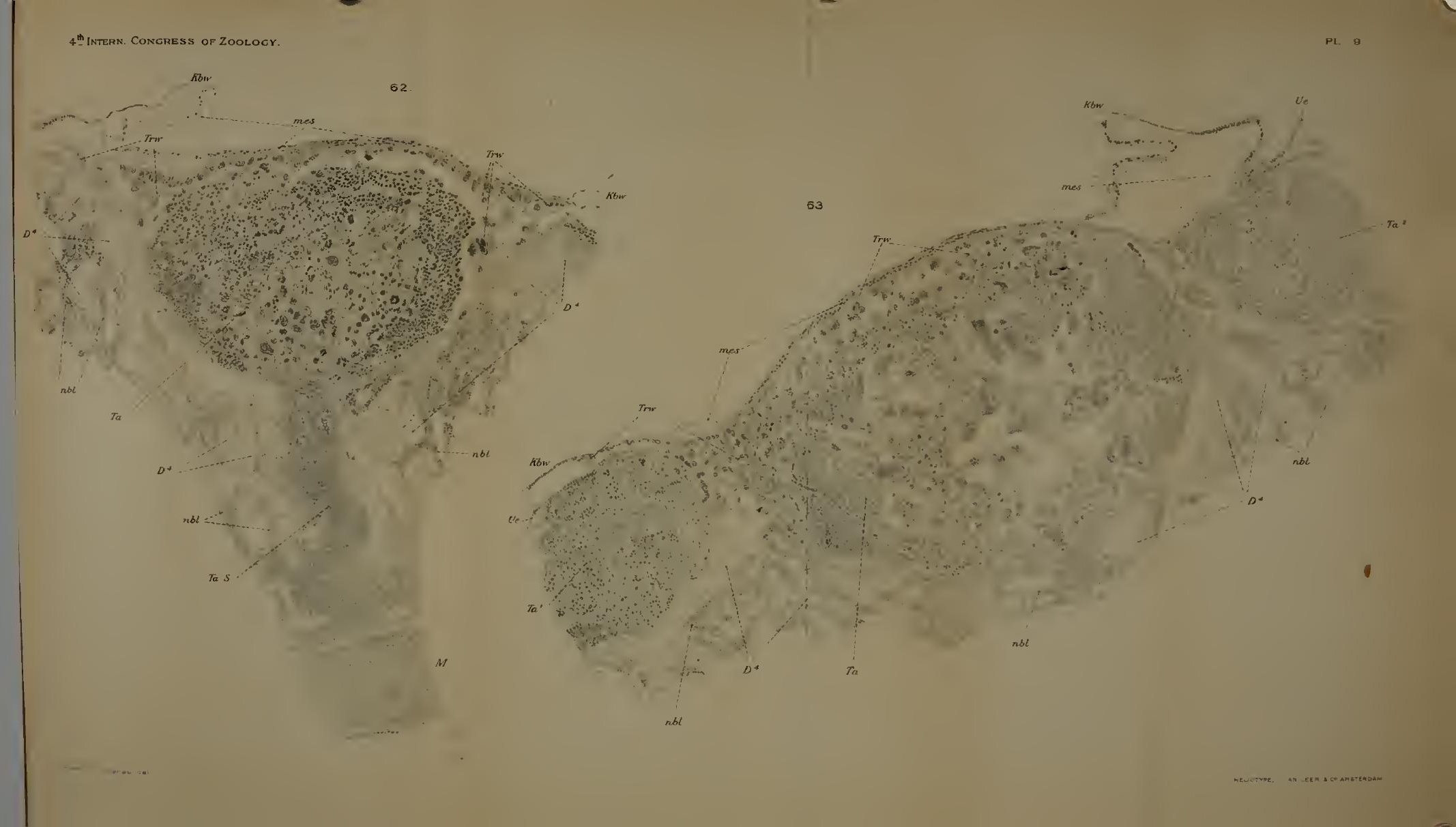




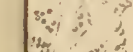

3.

$\because$

:

:

:

-

be

tros

50

3

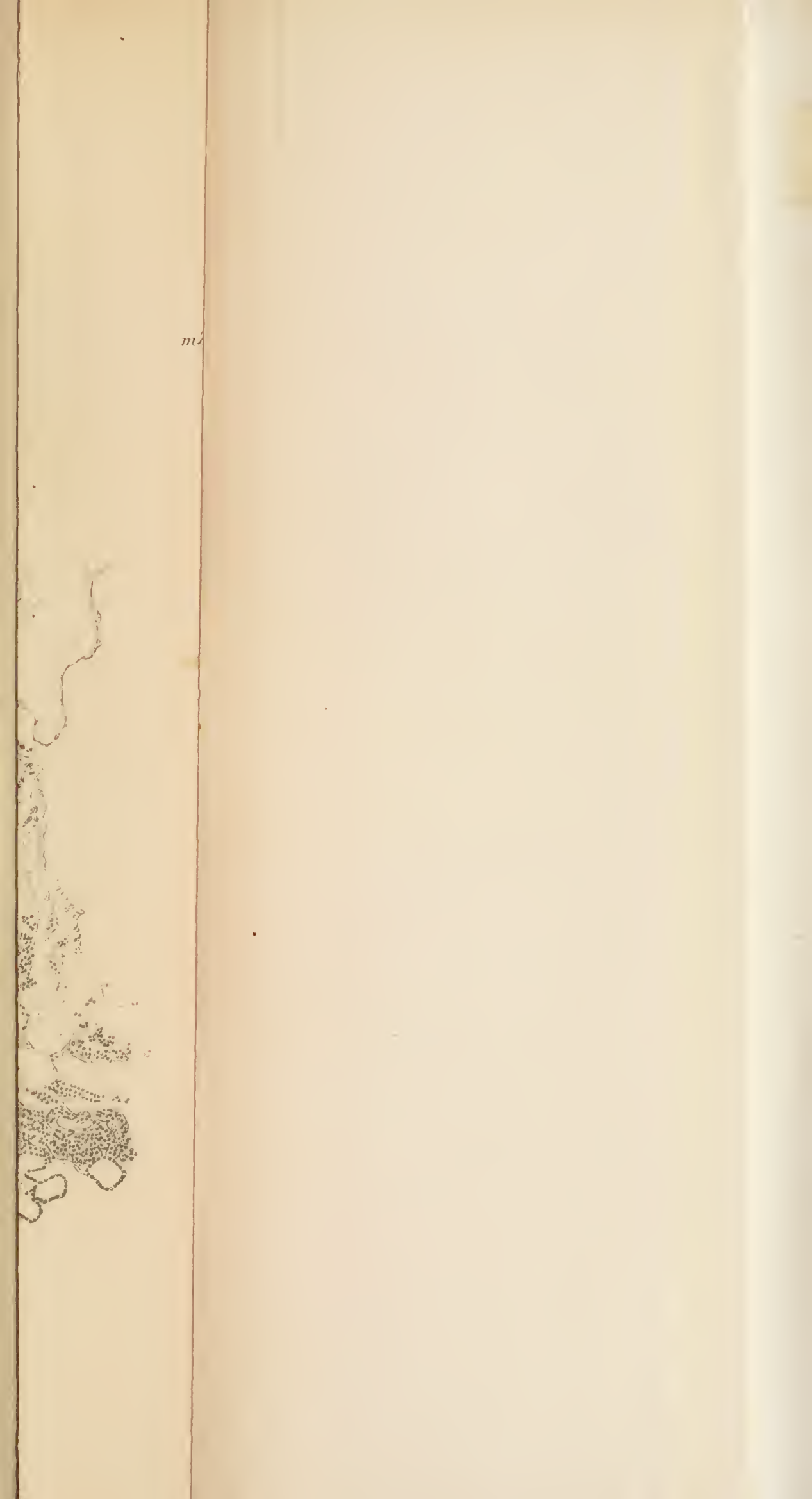



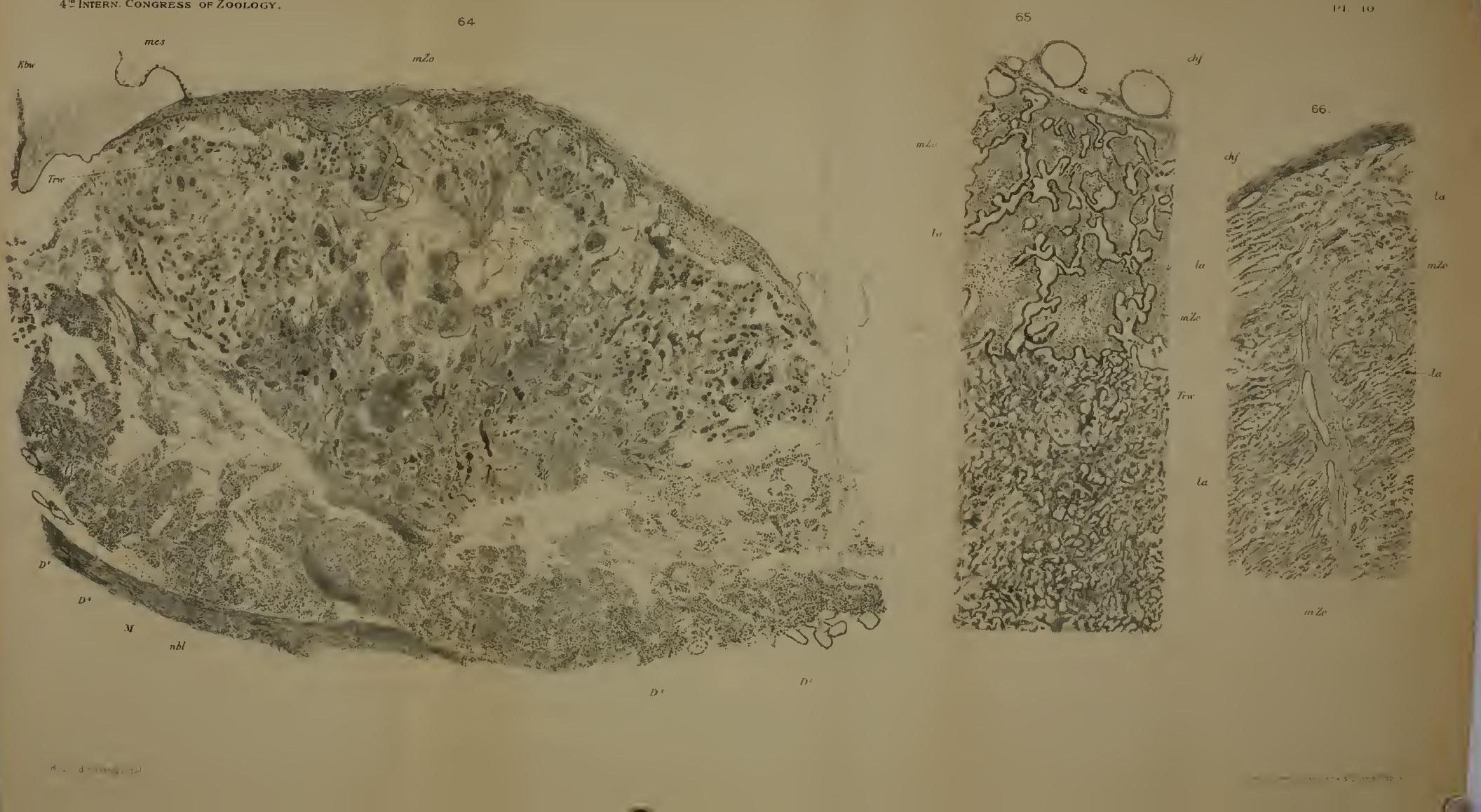
(n) C.

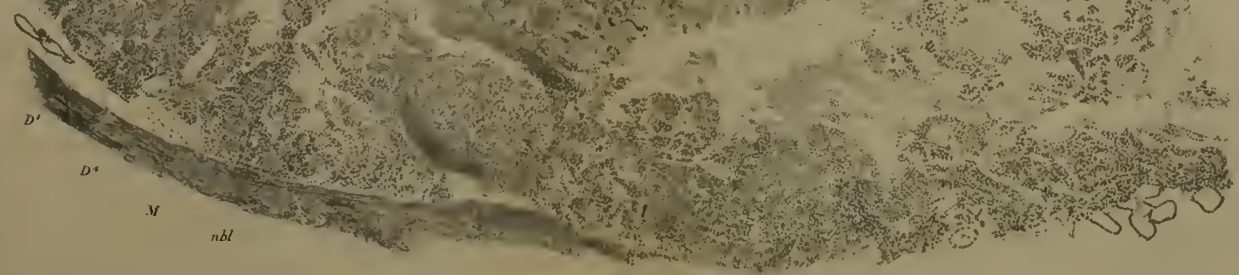

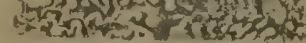





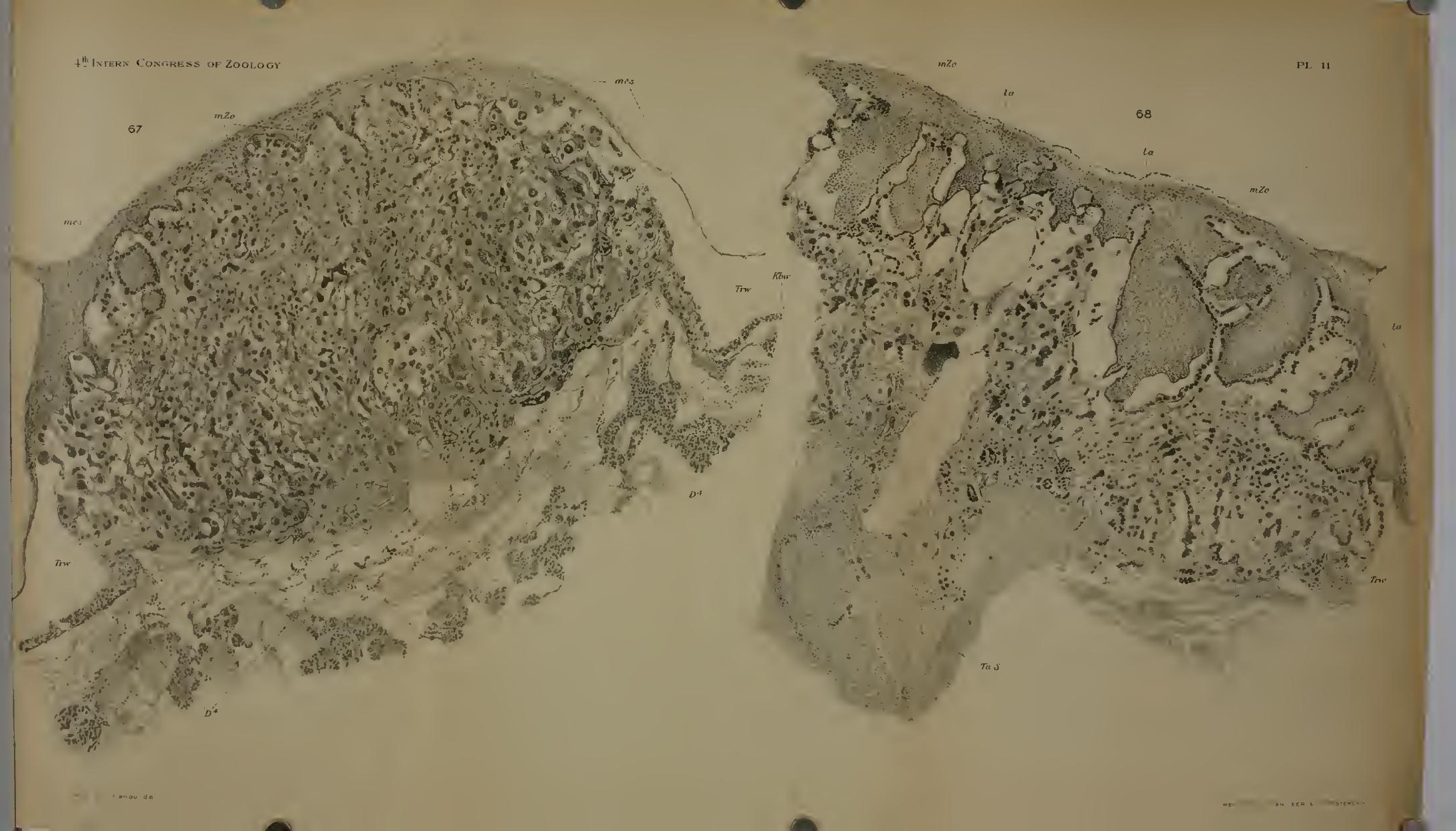





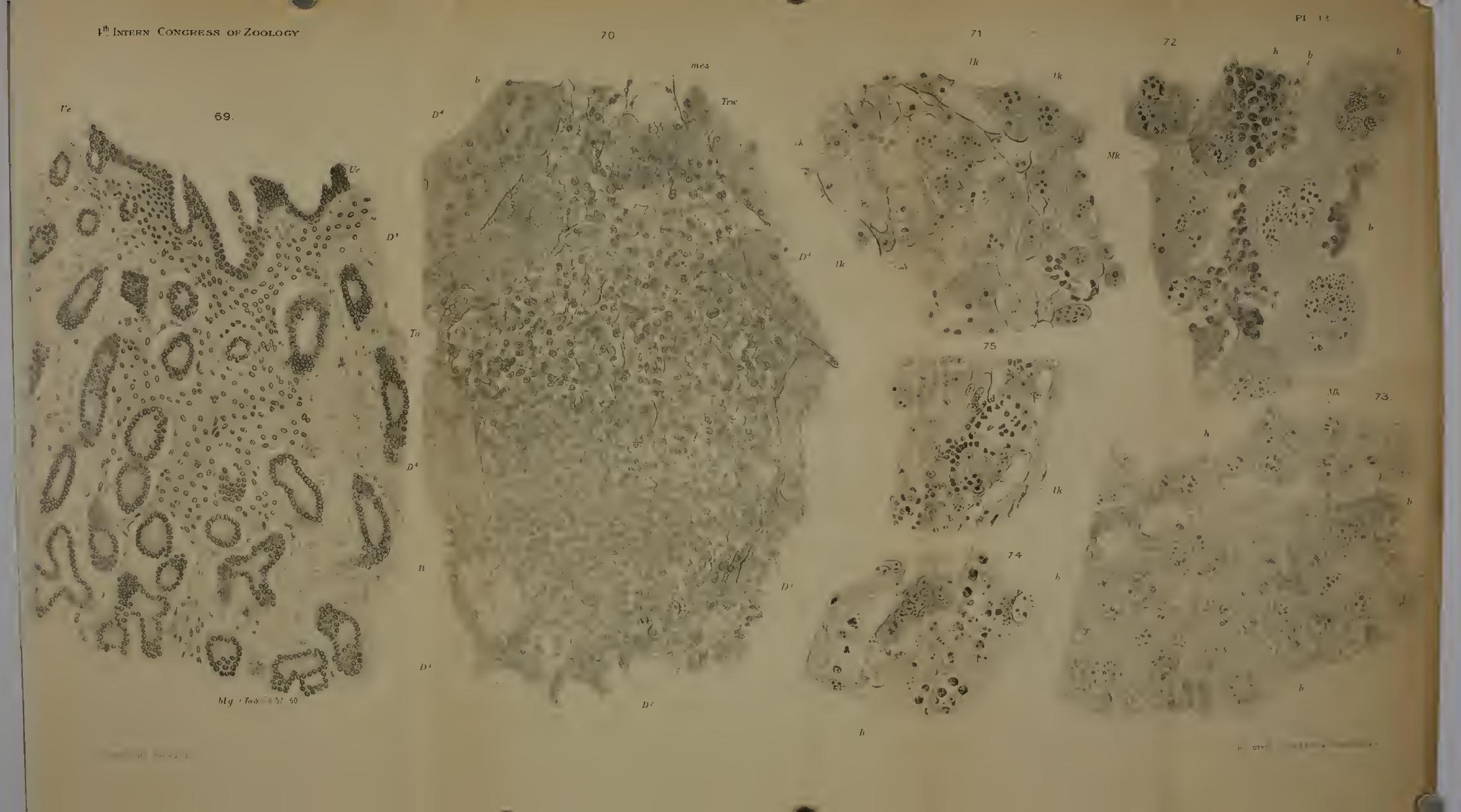


A

$\left\{\begin{array}{l}0 \\ 0+3 \\ 0 \\ 0\end{array}\right.$

ros d

10

$(1,0,0$

2. 0

b) 000

io 515

e 5

iin. 2

sitangact

2.1. 
$4^{\text {Hh }}$ INTERN CONGRess of ZnoLoGy.

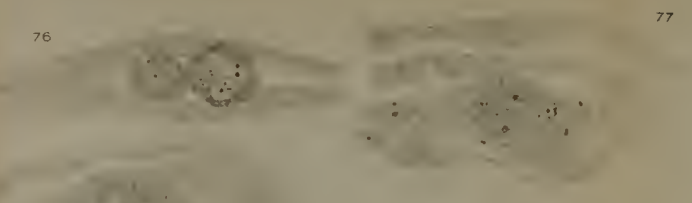

\section{$(3)$}

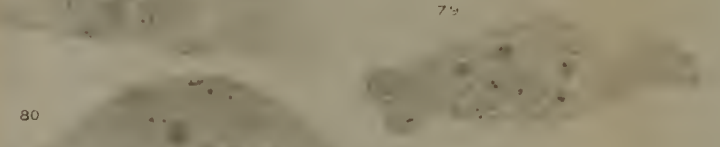

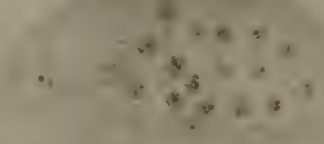

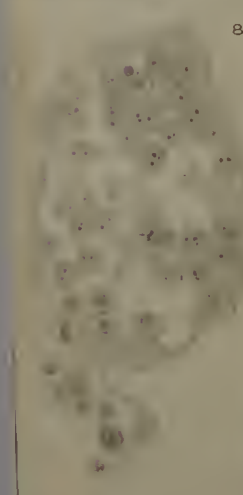
$\vartheta$

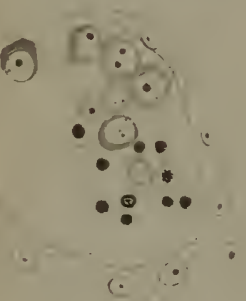

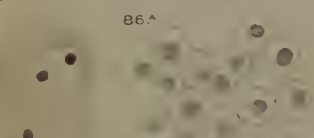
${ }_{1}^{83}$

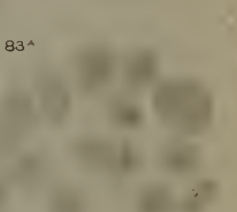

82

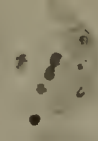

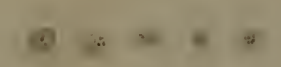

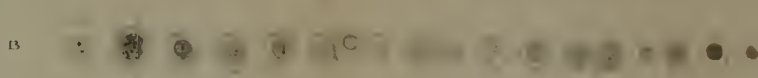

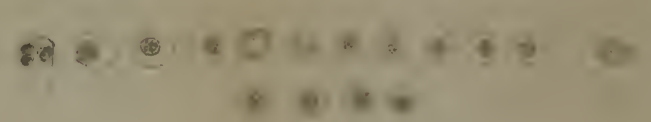

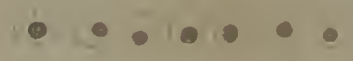

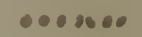

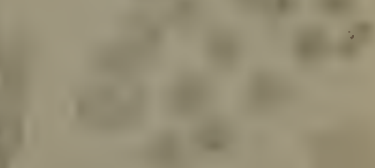

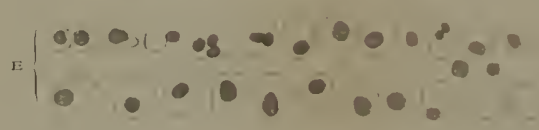

$\rightarrow-1$

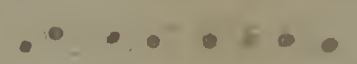

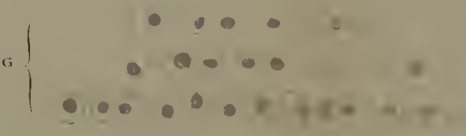

pre is

88

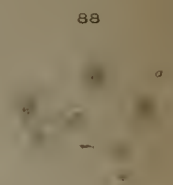

$$
\therefore \because \therefore
$$

$\therefore \therefore$

- 4 89.

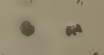

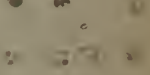

$\therefore \quad 7 \quad 3$

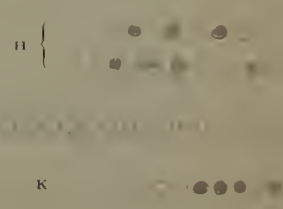

90

$\therefore \therefore \therefore \therefore \cdots$ 


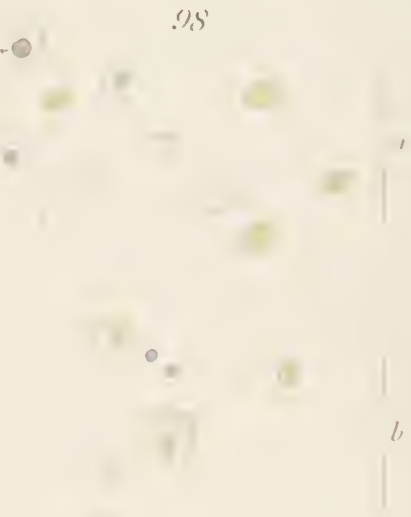

$7(9$.
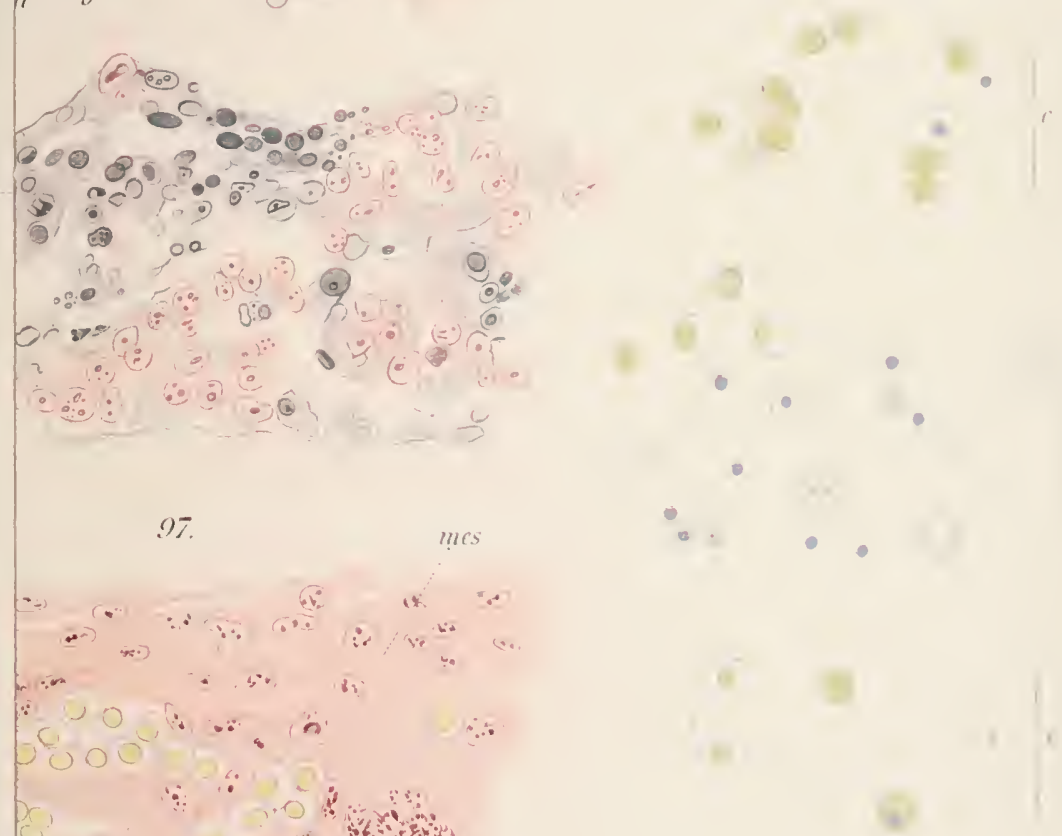

ty

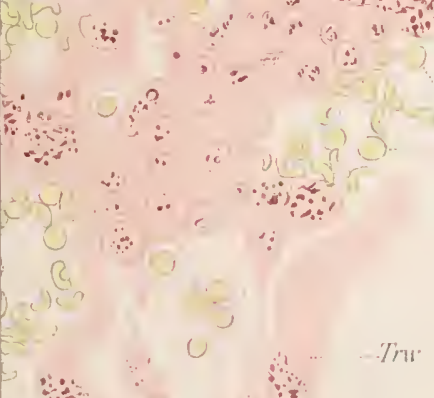

$\because \because \because \quad \because \quad \because$

Tru 
4h Intern Congres: a: Zoology
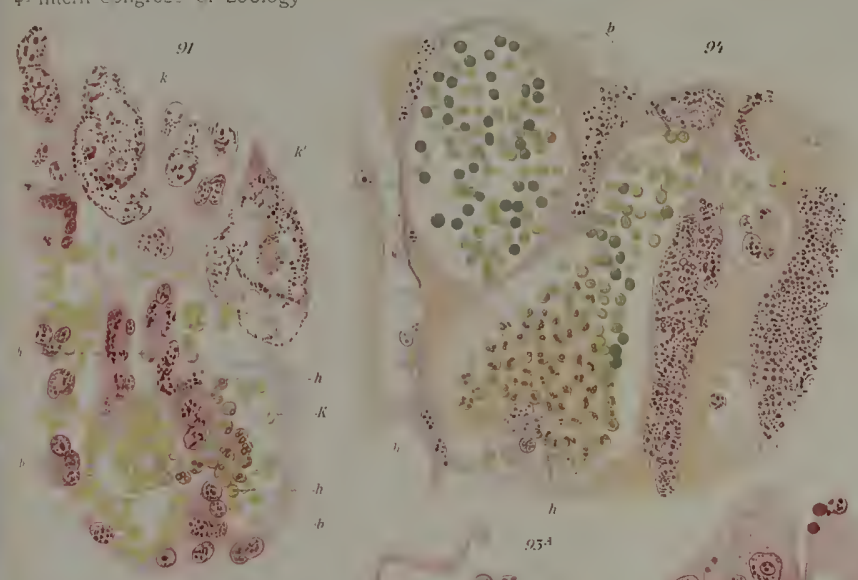

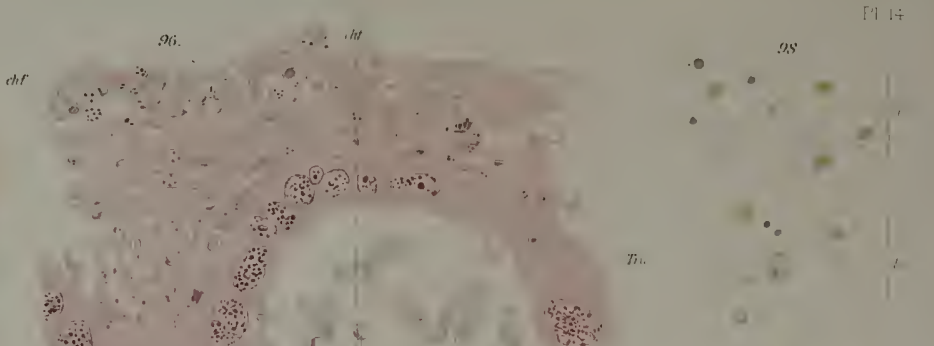

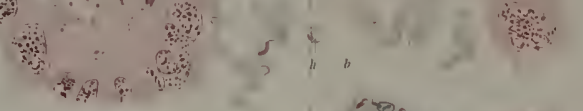
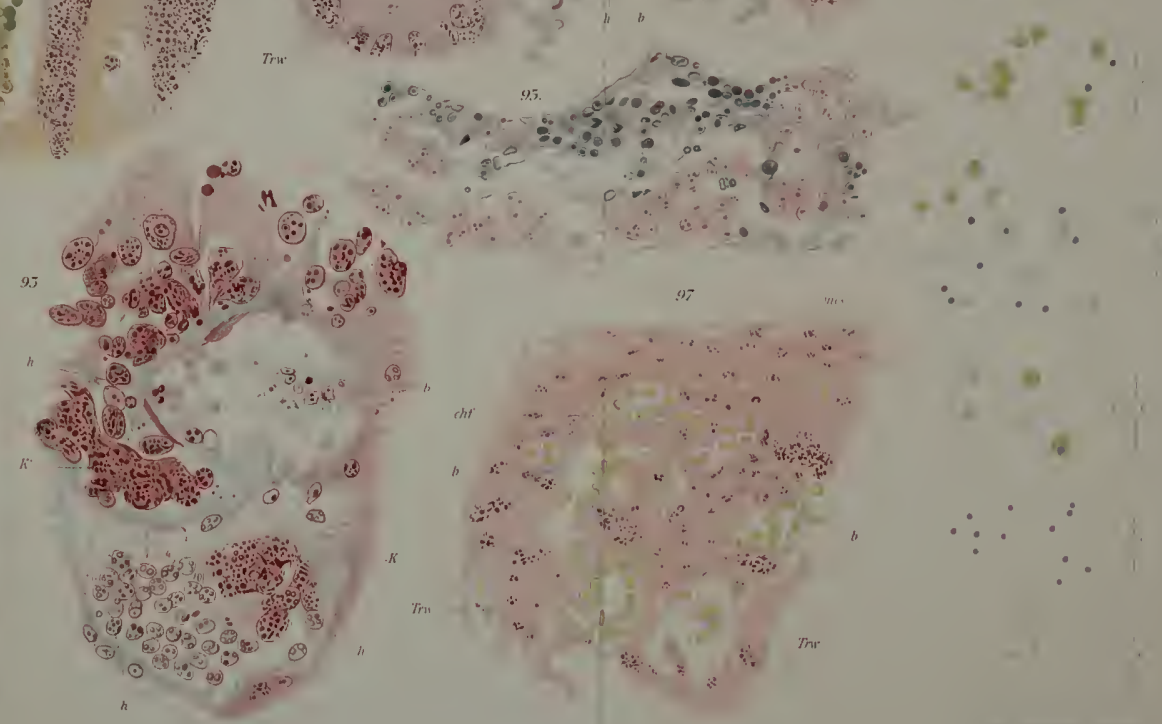

$+4 \cdot$

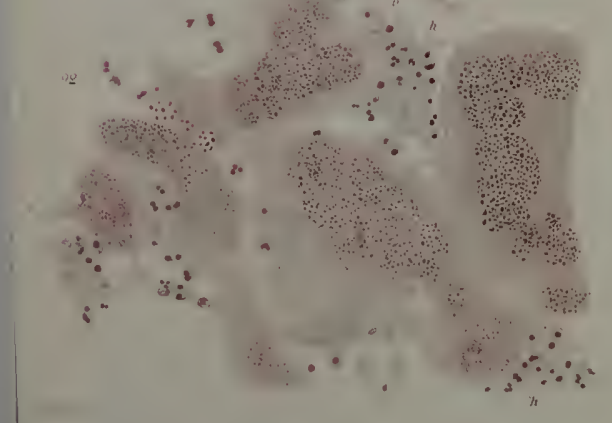

$\therefore \quad$.

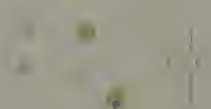

$\therefore \quad \therefore$

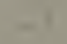




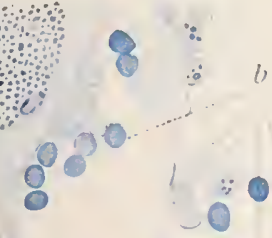

(2) 00

$80.8,-8=0$

$8 \cdot-80$

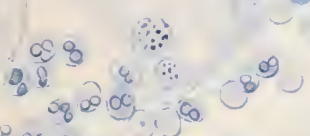

o. 2000 a

010

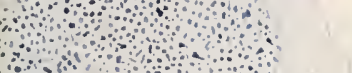

$\therefore \cdots$

and

an

and

wll

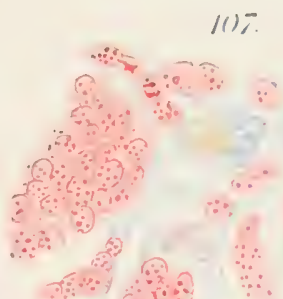

$\because \because$ ans

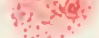

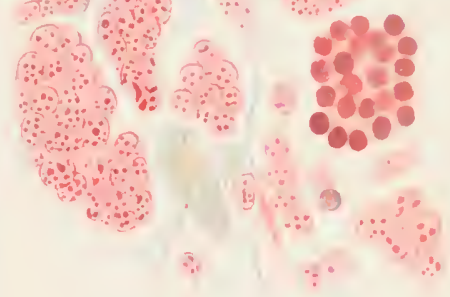
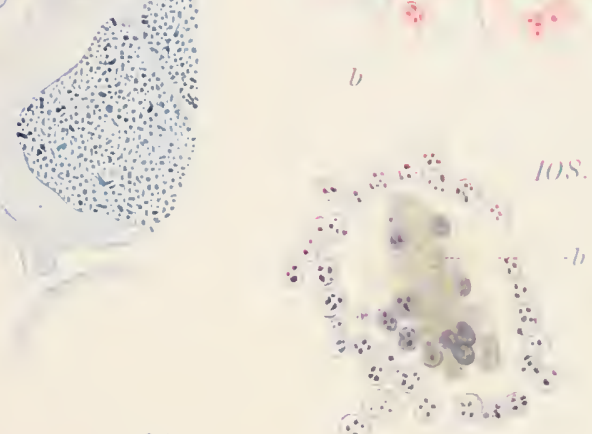

109

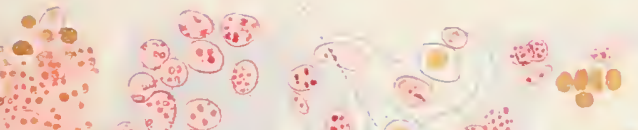
$\because \because \frac{0}{30}$

$\therefore$ (b)

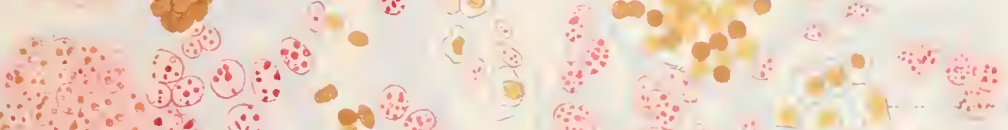

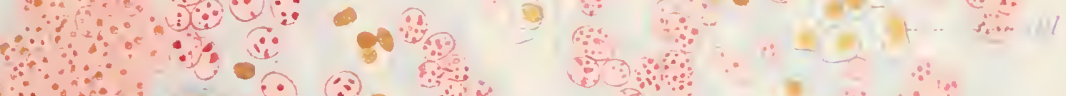

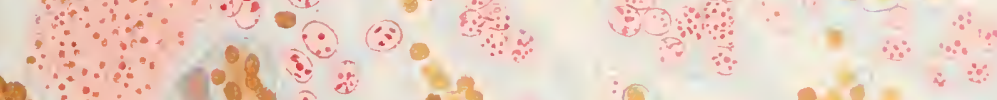

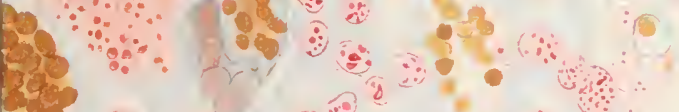
(1) to

$\sqrt{9}$ réo ivis or Q3,

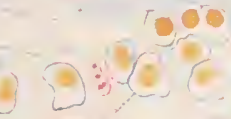

all 


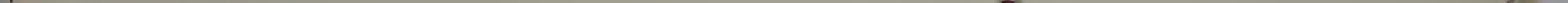






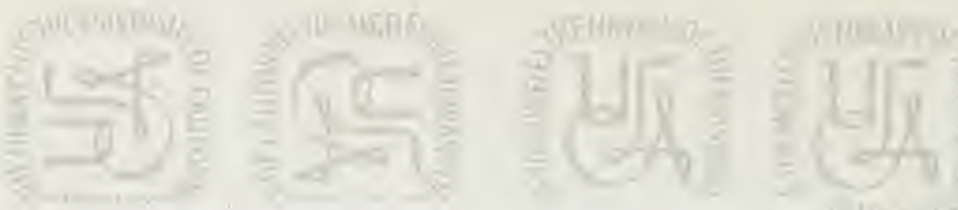

University of California

SOUTHERN REGIONAL LIBRARY FACILITY 405 Hilgard Avenue, Los Angeles, CA 90024-1388

Return this material to the library from which it was borrowed.

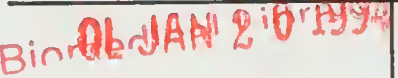

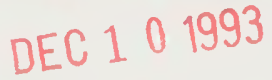

HEULIVLU

inilis
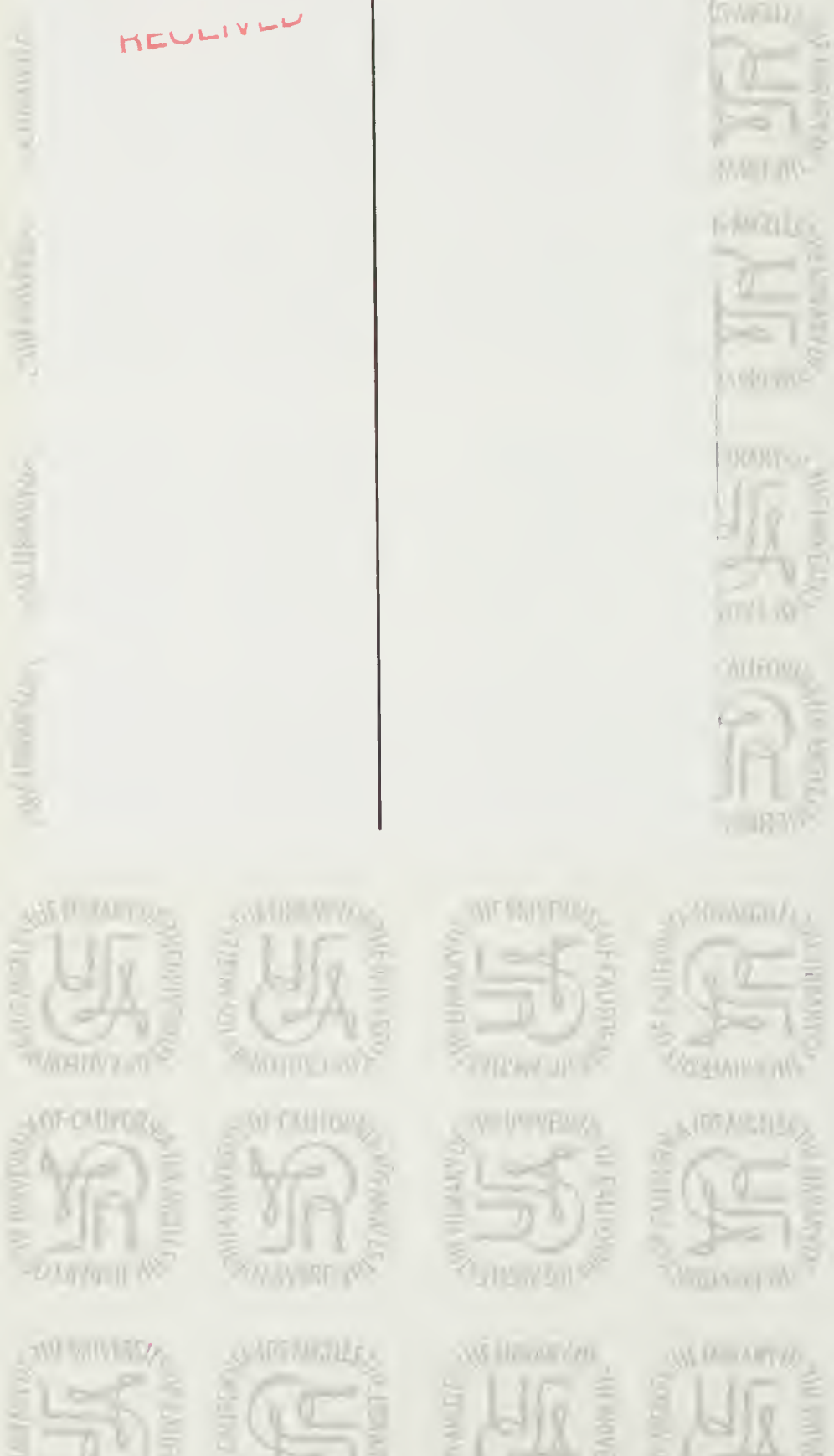

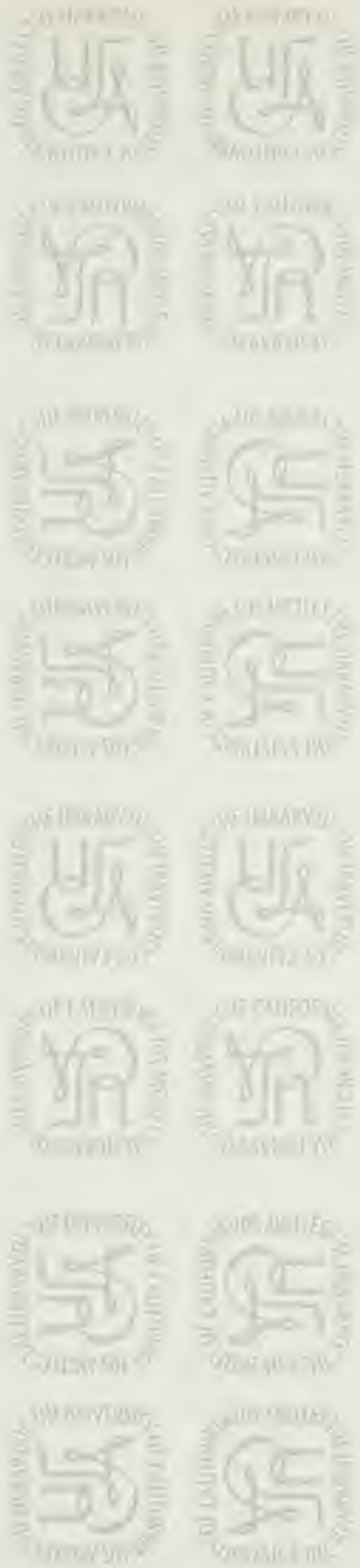
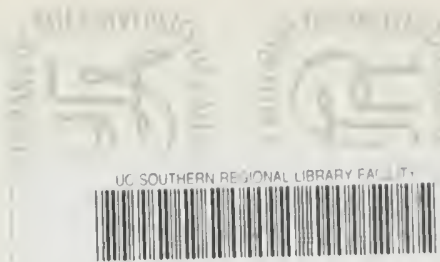

A 000293427
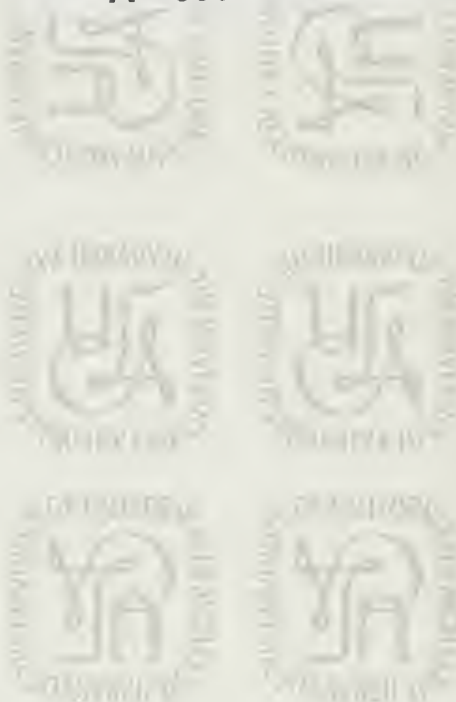

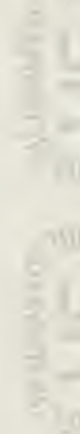
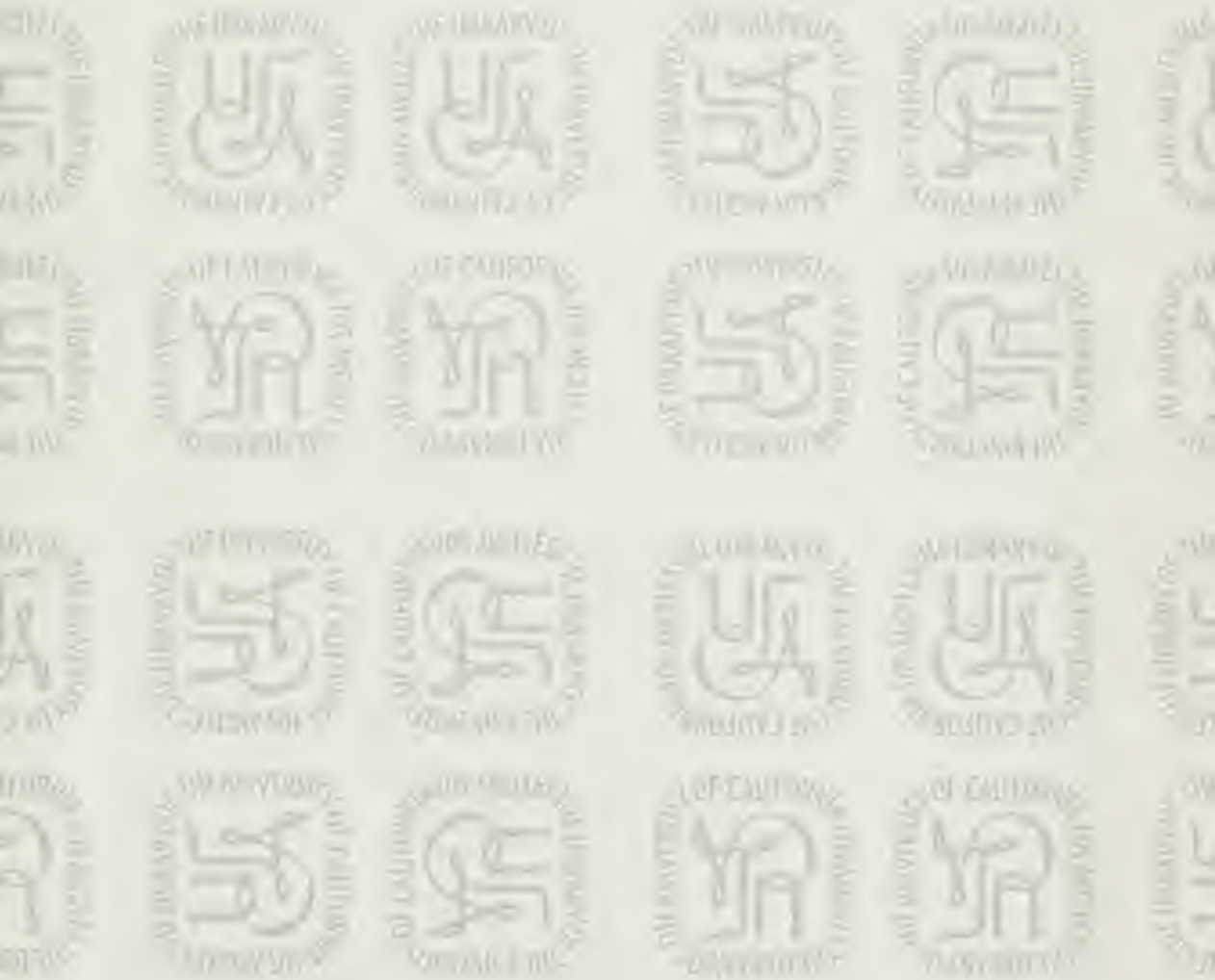

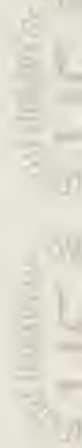




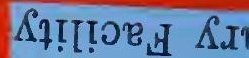

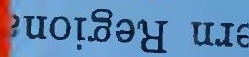

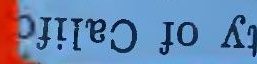

